\title{
AS ROCHAS GRANITÓIDES DO COMPLEXO GRANITICO CUNHAPORANGA, PARANÁ: ASPECTOS GEOLÓGICOS, GEOFÍSICOS, GEOQUÍMICOS E MINERALÓGICOS
}

\author{
GILSON BURIGO GUIMARÃES
}

Orientador: Prof. Dr. Horstpeter Herberto Gustavo José Ulbrich

TESE DE DOUTORAMENTO

COMISSÃO JULGADORA

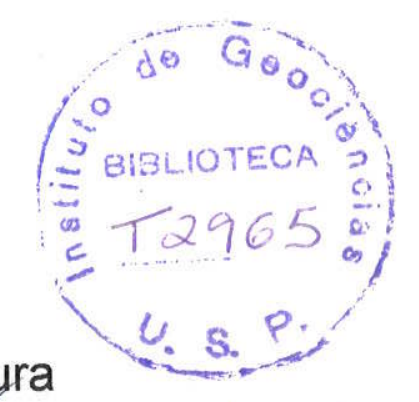

Nome

Presidente: Prof. Dr. Horstpeter H.G. José Ulbrich

Examinadores: Prof. Dr. Lauro Valentim Stoll Nardi

Prof. Dr. Reinhardt Adolfo Fuck

Prof. Dr. Roberto Dall'Agnol

Prof. Dr. Valdecir de Assis Janasi

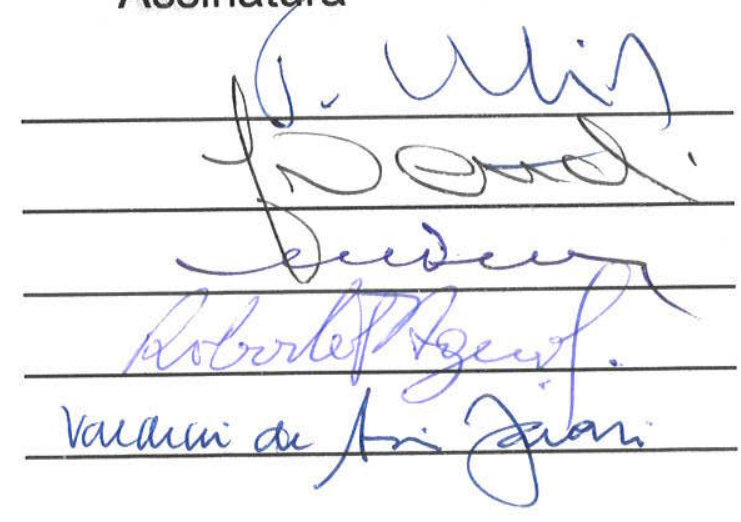

$$
\begin{aligned}
& \text { SÃO PAULO } \\
& 2000
\end{aligned}
$$




\section{AS ROCHAS GRANITÓIDES DO COMPLEXO GRANÍTICO CUNHAPORANGA, PARANÁ: ASPECTOS GEOLÓGICOS, GEOFÍSICOS, GEOQUIIMICOS E MINERALÓGICOS}

Gilson Burigo Guimarães

Orientador: Prof. Dr. Horstpeter H. G. J. Ulbrich
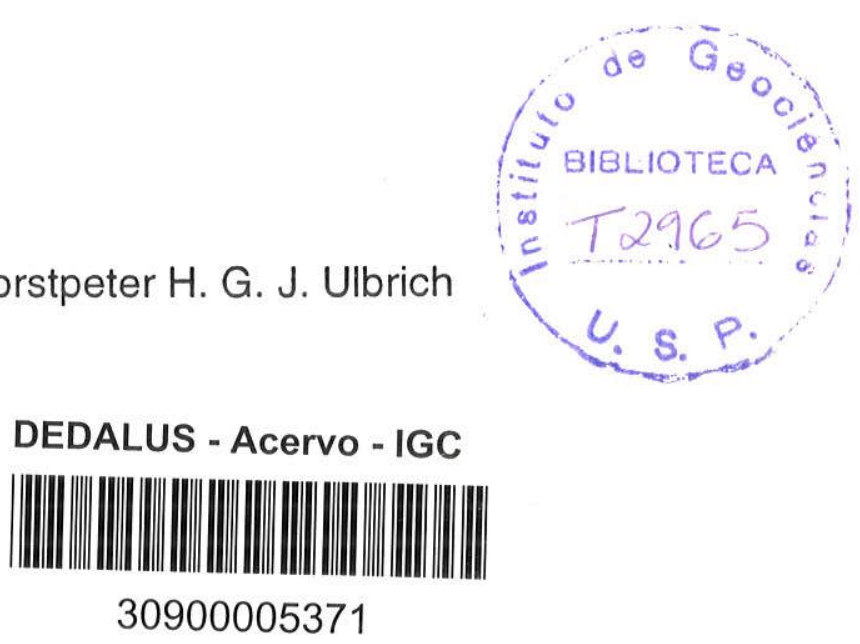

TESE DE DOUTORAMENTO

Programa de Pós-Graduação em Mineralogia e Petrologia

SÃO PAULO

2000 
Para os Guimarães, Aguilares, Burigos, Cruzes, Hrabovskys, Backs, Rúbios e Lopes, Ailys, Petersens, Prazeres, Hararas, Enrichs e demais irmãos de coração que, durante todos estes anos, através do sorriso ou do silêncio, da lágrima ou de um conselho, sempre estiveram ao meu lado, incentivando-me 


\section{SUMÁRIO}

DEDICATÓRIA

SUMÁRIO

ii

ÍNDICE DE FIGURAS vii

ÍNDICE DE TABELAS $\quad x$

ÍNDICE DE PRANCHAS FOTOGRÁFICAS $\quad x i$

RESUMO $\quad$ Xv

ABSTRACT xvii

AGRADECIMENTOS xix

CAPÍTULO 1: INTRODUÇÃO

1.1 Apresentação do tema 1

1.2 Localização da área e acessos 2

1.3 Aspectos fisiográficos 5

$\begin{array}{ll}1.4 \text { Objetivos } & 7\end{array}$

1.5 Metodologia $\quad 8$

1.5.1 Trabalhos de campo 18

$\begin{array}{ll}\text { 1.5.2 Mapa de compilação } & 10\end{array}$

$\begin{array}{ll}\text { 1.5.3 Geofísica } & 11\end{array}$

1.5.4 Descrição petrográfica e modas 13

1.5.5 Química mineral $\quad 15$

$\begin{array}{ll}\text { 1.5.6 Geoquímica de rochas } & 16\end{array}$

CAPÍTULO 2: O COMPLEXO GRANÍTICO CUNHAPORANGA E O CONTEXTO GEOLÓGICO REGIONAL 20

2.1 Síntese dos trabalhos anteriores sobre o Complexo Cunhaporanga $\quad 20$

2.1.1 Trabalhos anteriores à década de $60 \quad 22$

2.1.2 Trabalhos do período 1960-1970 25

2.1.3 Trabalhos do período 1970-1980 28 
2.1.4 Trabalhos do período 1980-1989 33

2.1.5 Trabalhos posteriores a $1989 \quad 38$

2.1.6 0 Complexo Granítico Cunhaporanga como unidade litoestratigráfica $\quad 42$

2.2 Outras unidades geológicas da região $\quad 44$

2.2.1 Grupo Itaiacoca $\quad 44$

2.2.1.1 "Quartzito Serra das Pedras" e congêneres 44

2.2.2 Complexo Granítico Três Córregos 45

$\begin{array}{ll}\text { 2.2.3 Grupo Castro } & 46\end{array}$

2.2.4 Bacia do Paraná 446

$\begin{array}{ll}2.2 .5 \text { Aluviões } & 47\end{array}$

2.3 Mapa geológico de compilação da região do Complexo Cunhaporanga 48

CAPÍTULO 3: O PROJETO AEROGEOFÍSICO SERRA DO MAR SUL NA REGIÃO DO COMPLEXO CUNHAPORANGA

CAPÍTULO 4: AS UNIDADES LITOESTRATIGRÁFICAS DO COMPLEXO GRANÍTICO CUNHAPORANGA 57

4.1 Unidades metamórficas do Complexo Cunhaporanga 59

4.1.1 Quartzito Serra das Pedras (NPcqsp) 59

4.1.2 Outras rochas metamórficas internas ao Complexo (NPcq e NPcrm) 61

4.2 Domínios Petrográficos da porção S/SE do Complexo 62

4.2.1 Domínio Abapã-Santa Quitéria (NPcasq) 63

4.2.2 Domínio Serra Abaixo-Alagados (NPcsaa) 64

4.2.3 Domínio Jotuba-Pitangui (NPcjp) $\quad 65$

4.2.4 Domínio Santa Rita (NPcsr) $\quad 67$

$\begin{array}{ll}\text { 4.2.5 Pórfiros (NPcpf) } & 68\end{array}$

4.2.5.1 Pórfiros intrusivos em granitóides do Complexo 68

4.2.5.2 Pórfiros intrusivos no Grupo Itaiacoca $\quad 69$

4.3 Domínios Petrográficos da porção centro-norte do Complexo $\quad 71$

4.3.1 Domínio Piraí do Sul (NPcp) 
4.3.2 Domínios Biscaias-Boa Vista (NPcbbv), Espigão Alto (NPcea) e Paredão da Santa (NPcps)

4.3.3 Domínio Espalha Brasa (NPceb)

4.3.4 Domínio Passo da Anta-Boa Esperança (NPcpac)

77

4.3.5 Domínio Arroio das Pedrinhas (NPcap)

78

4.3.5 Domínio Varginha (NPcv) 79

4.4 Domínios Petrográficos da porção NE do Complexo 81

4.4.1 Domínio Ouro Verde-Patrimônio Santo Antônio (NPcov) 81

4.4.2 Domínio Limeira (NPcl) 83

4.4.3 Domínio Francisco Simas-Vila Branca (NPcsvb) 85

4.4.3.1 Serra do Jacuzal 86

4.4.3.2 Estação Francisco Simas 87

4.4.3.3 Serra do Macaco-Dr. Ulysses

4.4.4 Granito São Domingos (NPcsd)

4.5 Granito Serra do Carambeí $\quad 88$

4.5.1 Álcali-feldspato granitos (NPcsc ${ }_{1}$ )

4.5.2 Fácies de borda ( $\left.\mathrm{NPcsc}_{2}\right) \quad 90$

4.6 Granito Joaquim Murtinho (NPcjm) 91

4.7 Setores indiferenciados (NPc) 92

4.8 Contato com as unidades adjacentes $\quad 93$

4.8.1 Grupo Itaiacoca $\quad 93$

4.8.2 Grupo Castro $\quad 96$

4.8.3 Formação Furnas $\quad 96$

CAPÍTULO 5: QUIMMICA MINERAL DAS ROCHAS GRANITÓIDES 109

$\begin{array}{ll}5.1 \text { Plagioclásio } & 109\end{array}$

5.2 Feldspato alcalino $\quad 112$

5.3 Piroxênio 112

$\begin{array}{ll}5.4 \text { Anfibólio } & 114\end{array}$

$\begin{array}{ll}5.5 \text { Biotita } & 117\end{array}$

$\begin{array}{ll}5.6 \text { Muscovita } & 119\end{array}$

5.7 Silicatos secundários de Ca e Al $\quad 119$ 
CAPÍTULO 6: GEOQUÍMICA DAS ROCHAS GRANITÓIDES

6.1 Caracterização geoquímica dos granitóides

6.1.1 Diagramas de Harker

6.1.2 Diagramas de variação multi-elementos ("aranhogramas")

6.1.3 Diagramas ACNK vs ANK

6.2 A evolução dos granitóides Cunhaporanga por cristalização fracionada

6.2.1 Diagramas de variação: elementos maiores

6.2.2 Diagramas de variação: elementos menores e traços 181

6.2.3 Aranhogramas e a diferenciação magmática 183

6.2.4 A origem dos muscovita-biotita granitóides

6.2.5 As linhagens geoquímicas-petrogenéticas nos granitóides do Complexo Cunhaporanga

6.3 O posicionamento dos dados geoquímicos em diagramas de caracterização geotectônica

6.3.1 Situação geotectônica do Complexo Cunhaporanga: informações geológicas

6.3.2 Situação geotectônica do Complexo Cunhaporanga: diagramas de discriminação

6.4 Geotermobarometria

\section{ANEXOS}

1 MAPA GEOLÓGICO DE COMPILAÇÃO DA REGIÃO DO COMPLEXO GRANÍTICO CUNHAPORANGA encarte 


\section{GRANÍTICO CUNHAPORANGA}

encarte

4 The airborne gamma-ray spectrometric survey of the Aerogeophysical Project Serra do Mar Sul in the region of the Cunhaporanga Granitic Complex, Paraná, southern Brazil

5 The airborne Aerogeophysical Project Serra do Mar Sul in the region of the Cunhaporanga Granitic Complex, Paraná, southern Brazil: analyses of the magnetometric data

6 Prehnita e outros silicatos secundários de Ca e Al em rochas granitóides do Complexo Granítico Cunhaporanga (PR)

7 Equações utilizadas para as estimativas de pressão $(P)$ e temperatura (T) do item 6.4, do Capítulo 6 


\section{ÍNDICE DE FIGURAS}

Figura 1.1: Localização da área de estudo

Figura 1.2: Toponímia e principais vias de acesso da área estudada

Figura 1.3: Localização da área estudada em relação às fohas topográficas 1: 100.00 e $1: 50.000$

Figura 2.1: O Complexo Granítico Cunhaporanga e seu contexto geológico regional

Figura 3.1: Mapa de localização do Projeto Aerogeofísico Serra do Mar Sul (PSMS)

Figura 3.2: Mapa das linhas de vôo do trecho do PSMS considerado neste estudo

Figura 3.3: Localização dos pontos de amostragem geofísica terrestre na região da Serra do Carambeí

Figura 4.1: Diagrama modal QAP para o conjunto das rochas granitóides do Complexo Cunhaporanga

Figura 4.2: Diagrama QAP com contagens modais para granitóides da porção S/SE do Complexo Cunhaporanga

Figura 5.1: Variação composicional de cristais de plagioclásio para vários tipos de granitóides do Complexo Cunhaporanga

Figura 5.2: Variação composicional de cristais de feldspato potássico para os diferentes tipos de granitóides do Complexo Cunhaporanga

Figura 5.3: Diagrama classificatório para análises de clinopiroxênios do Complexo Cunhaporanga

Figura 5.4: Diagramas $\mathrm{Si} X \boldsymbol{m g}^{*}$ e $(\mathrm{Na}+\mathrm{K})$ versus $\boldsymbol{m g}^{*}$ para anfibólios do Complexo Cunhaporanga

Figura 5.5: Variação composicional de cristais de biotita nos diferentes tipos de granitóides do Complexo Cunhaporanga

Figura 5.6: Variação composicional de cristais de muscovita para granitóides do Complexo Cunhaporanga

Figura 5.7: Diagrama Ps vs $\mathrm{Fe}_{2} \mathrm{O}_{3}$ para epidotos de rochas granitóides 
do Complexo Cunhaporanga

Figura 5.8: Teor médio de $\mathrm{Ba}$ nos diferentes tipos de granitóides do Complexo us porcentagem média de BaO dos feldspatos potássicos

Figura 6.1A: Diagramas de Harker (elementos maiores) para rochas do Complexo Cunhaporanga

Figura 6.1B: Diagramas de Harker para rochas do Complexo Cunhaporanga

Figura 6.1C: Diagramas de Harker (elementos traços) para rochas do Complexo Cunhaporanga

Figura 6.2A: Nomenclatura das rochas granitóides do Complexo Cunhaporanga (seg. Cox et al. 1979)

Figura 6.2B: Nomenclatura das rochas granitóides do Complexo Cunhaporanga (seg. Le Maitre et al. 1989)

Figura 6.2C: Nomenclatura das rochas granitóides do Complexo Cunhaporanga (seg. Middlemost 1994)

Figura 6.3: Diagramas $\mathrm{SiO}_{2}$ vs $\left(\mathrm{Na}_{2} \mathrm{O}+\mathrm{K}_{2} \mathrm{O}\right), \mathrm{K}_{2} \mathrm{O}$ e $\mathrm{CaO}$ para granitóides do Complexo Cunhaporanga

Figura 6.4: Comportamento diferenciado das rochas dos Domínios Petrográficos da porção S/SE do Complexo

Figura 6.5: Diagramas multi-elementos, normalizados em relação a um basalto de cadeia meso-oceânica

Figura 6.6: Diagramas $A / C N K \times A / N K$ para os diferentes tipos granitóides do Complexo

Figura 6.7: Diagrama multi-elementos, normalizado em relação a um basalto de cadeia meso-oceânica, para enclaves do Complexo Cunhaporanga

Figura 6.8: Diagramas $\mathrm{Zr}+\mathrm{Ce}+\mathrm{Nb}+\mathrm{Y}$ vs $10^{4} \mathrm{Ga} / \mathrm{Al}$ e $\left(\mathrm{K}_{2} \mathrm{O}+\mathrm{Na}_{2} \mathrm{O}\right) / \mathrm{CaO}$ e $\mathrm{Zr}+\mathrm{Ce}+\mathrm{Y}$ vs $\mathrm{Rb} / \mathrm{Ba}$

Figura 6.9: Diagramas discriminantes $R_{1} \times R_{2}$ para granitóides do Complexo Cunhaporanga

Figura 6.10: Diagramas discriminantes $(\mathrm{Y}+\mathrm{Nb})$ vs $\mathrm{Rb}$ e $\mathrm{Y}$ vs $\mathrm{Nb}$ para rochas do Complexo Cunhaporanga 
Figura 6.11: Diagramas $\mathrm{Y} / \mathrm{Nb}$ vs $\mathrm{Rb} / \mathrm{Nb}, \mathrm{Y} / \mathrm{Nb}$ vs $\mathrm{Sc} / \mathrm{Nb}, \mathrm{Nb}-\mathrm{Y}-\mathrm{Ce}$ e $\mathrm{Nb}-$ $\mathrm{Y}-\left(3^{*} \mathrm{Ga}\right)$ para rochas do Complexo Cunhaporanga

Figura 6.12: Índice $M$ de Watson \& Harrison (1983) para as rochas do Complexo Cunhaporanga 


\section{ÍNDICE DE TABELAS}

Tabela 3.1: Dados de gamaespectrometria terrestre e susceptibilidade magnética da região da Serra do Carambeí

Tabela 4.1: Modas de rochas granitóides do Complexo Cunhaporanga 106-108

Tabela 5.1: Relação dos minerais analisados em microssonda eletrônica

$125-126$

Tabela 5.2: Resultados analíticos e cálculos de fórmula estrutural (32 O) para cristais de plagioclásio do Complexo Cunhaporanga

$127-138$

Tabela 5.3: Resultados analíticos e cálculos de fórmula estrutural ( 32 O) para cristais de feldspato potássico do Complexo Cunhaporanga

$139-146$

Tabela 5.4: Valores referentes aos teores de $\mathrm{Ba}$ e da molécula $A b$ dos FK dos diferentes tipos granitóides do Complexo

Tabela 5.5: Resultados analíticos e cálculos de fórmula estrutural (6 O) para piroxênios do Complexo Cunhaporanga

Tabela 5.6: Resultados analíticos e cálculos de fórmula estrutural ( 23 O) para cristais de anfibólio do Complexo Cunhaporanga

$149-153$

Tabela 5.7: Resultados analíticos e cálculos de fórmula estrutural (22 O) para cristais de biotita do Complexo Cunhaporanga $154-160$

Tabela 5.8: Resultados analíticos e cálculos de fórmula estrutural (22 O) para cristais de muscovita do Complexo Cunhaporanga

Tabela 6.1: Teores para os elementos maiores, menores e traços para amostras de diferentes tipos granitóides do Complexo

203-209

Tabela 6.2: Detalhes sobre as amostras utilizadas nos diagramas multi-elementos da Figura 6.5

Tabela 6.3: Estimativas de pressão e temperatura para rochas do Complexo Cunhaporanga 


\section{ÍNDICE DE PRANCHAS}

PRANCHA 1

Foto 1A: Canyon do Rio Itararé, na divisa PR-SP

Foto 2A: Cachoeira do Corisco, afluente do Rio Itararé

Foto 3A: Serra das Furnas na região de Joaquim Murtinho

Fotos 4A e 5A: Relevo arrasado da bacia do Rio lapó, região de Joaquim Murtinho

Foto 6A: Serra das Antas entre São Domingos e Patrimônio Santo Antônio

PRANCHA 2

98

Foto 2A: Bandamento composicional em metarenitos/metarcósios do "Quartzito Serra das Pedras" (JM-22)

Foto 2B: Mica-quartzo xisto da região do Arroio das Pedrinhas (JM-109B)

Foto 2C: Fácies de borda do Domínio Serra Abaixo-Alagados (SC-68)

Foto 2D: Fácies de borda do Domínio Serra Abaixo-Alagados (SC-74)

Foto 2E: Dacito pórfiro com esferulitos de feldspato alcalino e quartzo (SC-51)

PRANCHA 3

Foto 3A: Estrutura de fluxo magmático no pórfiro de Mato Limpo, com orientação de anfibólio e imbricação de plagioclásio (SC-74B)

Foto 3B: Pórfiro intrusivo em metadolomitos do Grupo Itaiacoca, com fenocristais de quartzo deformados (SC-65)

Fotos 3C e 3D: Granitóide do Domínio Piraí do Sul, com prehnita inclusa em biotita e com textura micrográfica (MSP-1)

Foto 3E: Granitóide do Domínio Piraí do Sul com textura micrográfica (MSP-A)

PRANCHA 4

Fotos 4A e 4B: Enclaves dioríticos em granitóides do ponto PS-92

Fotos 4C e 4D: Cristais zonados de plagioclásio, com núcleos de labradorita, em granitóides do Domínio Espigão Alto (JGA-42B)

Foto 4E: Turmalina deutérico-hidrotermal de um muscovita biotita granitóide do 
Domínio Arroio das Pedrinhas (JM-124)

Foto 4F: Muscovita primária (?) em granitóide do Domínio Arroio das Pedrinhas $(\mathrm{JM}-111 \mathrm{~A})$

PRANCHA 5

Foto 5A: Muscovita secundária em plagioclásio de titanita biotita granitóide do Domínio Varginha (PS-47)

Foto 5B: Xenólito quartzítico foliado em granitóide do ponto IT-97 (Domínio Ouro Verde-Patrimônio Santo Antônio)

Fotos 5C e D: Epidoto primário (?) com orlas de epidoto secundário em pórfiro do Domínio Ouro Verde-Patrimônio Santo Antônio (IT-96)

PRANCHA 6 - Cristais de epidoto primário bordejando allanita em rochas do 102 Domínio Limeira

Fotos 6A e 6B: IT-10

Fotos 6C, 6D e 6F: IT-50b

Foto 6E: IT-58

PRANCHA 7

103

Foto 7A: Textura pan-xenomórfica em granitóide do Domínio Francisco SimasVila Branca (PS-130)

Foto 7B: Biotita intersticial do Granito Serra do Carambeí, com inclusões de material argiloso e quartzo (JGA-23 I)

Foto 7C: Feldspatos mesopertíticos do Granito Serra do Carambeí (JGA-23 I)

Foto 7D: Fraturas preenchidas com hematita no Granito Joaquim Murtinho (JM-96)

Foto 7E: Feldspatos mesopertíticos do Granito Joaquim Murtinho (JM-70B)

Foto 7F: Textura de substituição de mica primária no Granito Joaquim Murtinho (JM-96E)

PRANCHA 8

Foto 8A: Muscovita e fluorita secundárias do Granito Joaquim Murtinho (JM- 
97B)

Foto 8B: Intercrescimento micrográfico no Granito Joaquim Murtinho (JM-106)

Foto 8C: Silicificação e porfiroblastos de tremolita em metadolomito do Grupo Itaiacoca (ITA-1-110)

Foto 8D: Andalusita quiastolítica em metapelito do Grupo Itaiacoca (ITA-0-25)

Fotos 8E e 8F: Porfiroblasto de andalusita em metapelito do Grupo Itaiacoca (ITA-0-25)

PRANCHA 9

Fotos 9A e 9B: Porfiroblastos de estaurolita em metapelito grafitoso do Grupo Itaiacoca (PS-123)

Foto 9C: Porfiroblastos de muscovita em metapelito do Grupo Itaiacoca (IT-22)

Fotos 9D e 9E: Metadolomito do Grupo Itaiacoca com silicificação e neoformação de turmalina (IT-16)

PRANCHA 10

Foto 10A: Cristal zonado de plagioclásio em granitóide do Domínio Piraí do Sul (JM-20)

Foto 10B: Cristal zonado de plagioclásio em granitóide do Domínio AbapãSanta Quitéria (PS-78)

Foto 10C: Cristal zonado de plagioclásio em granitóide do Domínio Serra Abaixo-Alagados (SC-77)

Foto 10D: Hornblenda com núcleo reliquiar de clinopiroxênio em rocha do Domínio Espigão Alto (PS-92)

Fotos 10E e 10F: Hornblenda com núcleo reliquiar de clinopiroxênio em rocha do Domínio Serra Abaixo-Alagados (SC-77)

PRANCHA 11

Foto 11A: Núcleo de composição granítica incluso em enclave diorítico do Domínio Espigão Alto (PS-92a)

Foto 11B: Prehnita com hábito "bow-tie" associada a cloritas (Domínio Piraí do Sul, JM-20) 
Fotos 11C e 11D: Cristais de prehnita alongada/esferulítica em biotita (Domínio Abapã-Santa Quitéria, ITA-2-100)

Foto 11E: Agregados de hidrogranada interlamelares à biotita (Domínio Serra Abaixo-Alagados, SC-77)

Foto 11F: Agregados de pumpellyita inclusos em biotita de granitóide do Domínio Arroio das Pedrinhas (JM-46)

* Fotomicrografias 


\section{RESUMO}

As rochas granitóides do Complexo Granítico Cunhaporanga, uma unidade litoestratigráfica neoproterozóica do Cinturão Ribeira no estado do Paraná, foram estudadas através de diversas ferramentas: mapeamento geológico, caracterização petrográfica, interpretação de mapas aerogeofísicos (gamaespectrometria e magnetometria), geoquímica de rochas (elementos maiores, menores e alguns traços) e química mineral (principalmente feldspatos, anfibólios e micas), além de uma avaliação crítica de trabalhos anteriores a respeito do Complexo.

Apesar das limitações do Projeto Aerogeofísico Serra do Mar Sul, os padrões geofísicos revelados após o tratamento de seus dados permitiram reconhecer com relativa segurança os grandes traços geológicos da região em que se insere o Complexo Cunhaporanga.

Os trabalhos petrográficos e de campo conduziram à delimitação de áreas de maior ocorrência de certos tipos granitóides no Complexo. Estas áreas englobam em parte unidades já formalmente definidas (por exemplo, os Granitos Joaquim Murtinho e Serra do Carambeí) e, principalmente, unidades aqui denominadas informalmente de Domínios Petrográficos.

Foram reconhecidas duas linhagens "cálcio-alcalinas" de alto potássio, em parte com afinidades shoshoníticas, formadas principalmente por monzogranitos a granodioritos com titanita-hornblenda-biotita, titanita-biotita ou apenas biotita (similares aos tipos "l" da literatura). Uma outra linhagem, "alasquítica", seria representada pelos Granitos Serra do Carambeí $\Theta$ Joaquim Murtinho, corpos tardios constituídos por álcalifeldspato granitos muito semelhantes a granitos do tipo "A". Granitóides com muscovita primária localizados próximos ao contato com 0 Grupo Itaiacoca provavelmente seriam resultantes da assimilação parcial dos metassedimentos encaixantes. 
O contato entre as rochas granitóides do Complexo e o Grupo Itaiacoca, ao longo de toda sua extensão, é de natureza intrusiva. Cálculos com geotermobarometria, além de evidências geológicas, definem baixas pressões de colocação para estes granitóides, da ordem de 2 a 4 kbar para os tipos "cálcioalcalinos" e de menos de 2 kbar para os tipos alasquíticos. Este nível de colocação próximo à superfície proporcionou moderada a intensa atividade deutérico-hidrotermal sobre as rochas granitóides, exemplificado no caso das linhagens "cálcio-alcalinas" pelo desenvolvimento marcante de Ca-Al silicatos secundários (prehnita, hidrogranada, epidoto, pumpellyita). 


\section{ABSTRACT}

The granitoid rocks of the Cunhaporanga Granitic Complex, a Neoproterozoic lithostratigraphic unit of the Ribeira Fold Belt in Paraná state (southern Brazil), was studied by means of several tools: geological mapping, petrographic characterization, interpretation of airborne gamma-ray spectrometric and magnetometric maps, lithogeochemical data (major, minor, and some trace elements) and mineral chemistry (mainly feldspars, amphiboles, and micas), besides a critical evaluation of previous work related to the Complex.

Despite the limitations of the Aerogeophysical Project Serra do Mar Sul, the geophysical patterns outline with relative confidence the main geological features of the Cunhaporanga Complex.

The petrographic and field work defined areas of predominance of certain granitoid types in the Complex. These areas include some formally defined units (for example, the Joaquim Murtinho and Serra do Carambei Granites), but mainly informal units here denominated Petrographic Domains.

Two high-K "calc-alkaline" series, partly with shoshonitic affinities, were recognized. These are made up mainly by monzogranites and granodiorites with sphene-hornblende-biotite, sphene-biotite or only biotite (similar to the "l" type of the literature). Another magmatic series ("alaskitic") is represented by the Serra do Carambei and Joaquim Murtinho Granites, late intrusions constituted by alkali-feldspar granites similar to A-type rocks. Granitoid rocks with primary muscovite, located close to the contact with the Itaiacoca Group, are probably the result of partial assimilation of the country-rock metasediments.

The contact between the granitoid rocks of the Complex and the Itaiacoca Group is always intrusive. Calculations with geothermobarometry, besides geological evidence, point to a shallow level of emplacement for these granitoids (2-4 kbar for the 
"calc-alkaline" types and $<2 \mathrm{kbar}$ for the alaskitic types). This near-surface level of emplacement provided moderate to intense deuteric-hydrotermal activity on the granitoids rocks, exemplified in the "calc-alkaline" series by pronounced development of secondary $\mathrm{Ca}$-Al silicates (prehnite, hydrogarnet, epidote, pumpellyite). 


\section{AGRADECIMENTOS}

Diversas pessoas e instituições estiveram envolvidas na realização desta tese $e$ a elas externo meus agradecimentos:

- Ao Prof. Dr. Horstpeter H. G. J. Ulbrich pelo apoio, orientação, dedicação e exemplo de postura científica.

- À CAPES pela bolsa de doutoramento dentro do Programa de Incentivo à Capacitação Docente (PICD).

- À FAPESP pelo auxílio financeiro para a execução das atividades de campo e laboratoriais.

- À Universidade de São Paulo, ao Instituto de Geociências, ao antigo Departamento de Mineralogia e Petrologia (DMP), ao atual Departamento de Mineralogia e Geotectônica (GMG) e ao Programa de Mineralogia e Petrologia pela oportunidade de desfrutar de excelente infra-estrutura e de conviver com um corpo técnicoadministrativo qualificado e sempre solícito.

- À Universidade Estadual de Ponta Grossa pela liberação das minhas atividades docentes durante a maior parte do período de realização do doutoramento. Em especial aos colegas do Departamento de Geociências, que cubriram minha ausência, foram compreensivos com a dilatação de meu cronograma $e$ constantemente me estimularam. Um "obrigado" duplamente especial aos Profs. Borsato, Eraldo, Tavares, Godoy, Mário Sérgio, Madalozo, Leonel, Sílvia, Cicilian e Adílson, além dos técnicos Paulo e Márcia (PROPESP).

- À Prof . a Dr. a Eleonora M. G. Vasconcellos (UFPr), à MSc. Renata P. X. Moro e ao Geol. Vicente Pinheiro Júnior por terem me conduzido em uma visita de 
reconhecimento geológico ao Grupo Castro, durante a fase de seleção do tema a ser desenvolvido no doutorado.

- Aos funcionários da biblioteca do IG-USP por facilitar o acesso ao seu invejável acervo de obras. Também agradeço às bibliotecárias Eliane da UFPr e Marlene da MINEROPAR, as quais tornaram possivel o alcance da maior parte das "figurinhas difíceis" da coleção sobre o Complexo Cunhaporanga.

- Ao MSc. Sílvio T. Hiruma do Instituto Geológico-SMA pelo acesso à obra de 1916 de Euzébio P. de Oliveira.

- Ao Geol. Gilberto A. Kaulfuss por permitir utilizar e modificar sua adaptação da figura referente à geologia do leste paranaense (Figura 2.1 deste trabalho).

- Ao Dr. Amos Salvador (University of Texas at Austin) pelas sugestões e esclarecimentos no tocante aos procedimentos de nomenclatura estratigráfica adotados neste trabalho.

- Aos amigos Chico (Dr. Francisco J. F. Ferreira), Max (Maximilian Forlin), Valdir (MSc. Francisco V. da Silva) e Rodoílton (MSc. Rodoílton Stevanato), do Laboratório de Pesquisas em Geofísica Aplicada da UFPr, por terem cedido inúmeras horas de seu tempo e por compartilharem comigo seus conhecimentos em geofísica e informática.

- Ao Geol. Leandro M. Donatti pela cessão de farto material bibliográfico relacionado ao tema "geofísica" e também por seus comentários sobre a geologia do Complexo na região de Ouro Verde-Patrimônio Santo Antônio e arredores.

- À Geol. Lucelene Martins pelas instruções sobre a utilização do susceptibilímetro, bem como por diversas discussões sobre o tema "granitos", principalmente geotermobarometria. 
- Aos alunos da disciplina de Mapeamento Geológico do Curso de Geologia da Universidade de São Paulo (ano de 1997), aos Profs. Drs. Miguel A. S. Basei, Oswaldo Siga Jr., Ginaldo A. da C. Campanha, José Manoel dos Reis Neto, além de técnicos e monitores, pela oportunidade de trabalharmos em conjunto na Faixa Itaiacoca na região entre Abapã e Socavão e de discutirmos inúmeras vezes o significado geológico das associações litológicas identificadas e das suas relações com o Complexo Cunhaporanga. Também sou grato por ter podido utilizar os relatórios, mapas e lâminas petrográficas relacionados a estas atividades de mapeamento.

- Aos geólogos Hélcio J. dos Prazeres Filho e Gaston Enrich pela entusiástica participação em algumas das etapas de campo. Ao Hélcio agradeço também as inúmeras vezes em que compartilhamos informações sobre a geologia do Complexo e unidades vizinhas e ao Gaston as várias "dicas" sobre química mineral e informática (Minpet, Excel, etc.).

- Aos Srs. Cláudio Hopp, Luiz Cláudio Nogueira, Paulo Molinaro e Paulo Augusto Morgato, do Setor de Laminação, pela confecção de (muitas) lâminas petrográficas.

- Ao Prof. Dr. Gergely Szabó e à técnica Angélica Morente ao auxílio na utilização dos equipamentos do Laboratório de Óptica do GMG. Ao Prof. Gergely agradeço também as oportunidades em que se dispôs a analisar meticulosamente lâminas petrográficas do Complexo e do Grupo Itaiacoca.

- Ao MSc. Flávio M. S. de Carvalho pela determinação de minerais por difração de Raios X.

- À MSc. Sandra Andrade por auxílios "geoquímicos" diversos: na execução de ensaios colorimétricos em fatias de rochas, na obtenção de dados analíticos via metodologia ICP-AES e do conseqüente tratamento destes dados. 
- Ao Prof. Dr. Sílvio R. F. Vlach pelo apoio na obtenção e interpretação de resultados de química mineral, especialmente no que se refere à paragênese de silicatos secundários de Ca-Al e geotermobarometria. Valiosas também foram suas sugestões com respeito à divisão do Complexo em sub-unidades.

- Ao Quim. Marcos Masueto e à técnica Rosiane Damião da Silva (Aninha) pela preparação das lâminas de microssonda. Ao Marcos também pelo acompanhamento (por vezes até de madrugada) dos trabalhos de obtenção dos dados analíticos.

- À grande amiga MSc. Rosana P. Lopes pelos conselhos sobre química mineral e informática e por ter me alertado sobre algumas deficiências do Programa Minpet, principalmente no que se refere ao recálculo das fórmulas estruturais de minerais com muito flúor (neste caso também cedendo uma planilha Excel "prontinha" para ser usada).

- Ao MSc. Ossama Harara por diversas discussões relativas à petrogênese de rochas graníticas (de granitos tipo-A a epidoto magmático).

- Ao técnico José Paulo Sertek pela presteza e dedicação em ensinar os diferentes procedimentos de preparação de amostras para análise geoquímica.

- Ao Fis. Paulo Mori pela obtenção de resultados analíticos via Fluorescência de Raios X.

- Aos técnicos Ricardo Cadernete e Marinês Lopes da Silva, do Laboratório de Química e Plasma ICP-AES, pela preparação de soluções analíticas dosadas neste mesmo laboratório.

- Ao Geol. João Henrique Larizzatti pelo espírito de cooperação, ao preparar 4 amostras para análise geoquímica durante o Curso de Análise Instrumental. 
- Ao Prof. Dr. Valdecir de A. Janasi pelo apoio irrestrito para a realização deste trabalho, tendo contribuído na abordagem de tópicos como comportamento magnetométrico, petrogênese e geotermobarometria de rochas granitóides e subdivisão e representação em mapa das unidades do Complexo. Além disso agradeço seu empenho, junto com os demais membros do Programa de Mineralogia e Petrologia, para a viabilização da confecção dos volumes finais desta tese.

- Ao Prof. Dr. Lauro V. S. Nardi por se dispor a examinar o material referente ao Complexo (lâminas, amostras de mão, mapas, diagramas geoquímicos, etc.) e debater sobre seu significado.

- Ao Prof. Dr. Caetano Juliani pelas discussões referentes à geotermobarometria e processos de alteração hidrotermal e pelo acesso a seu "arsenal" informático.

- Ao MSc. Klaus J. Petersen Júnior pelo auxílio informático e na confecção de ilustrações (sem sua ajuda não haveriam as pranchas fotográficas desta tese !).

- Ao técnico Reynaldo P. Castellon por ter comprometido horas de seu descanso ajudado-me na obtenção de ilustrações e mapas.

- Aos Srs. Edmir de Oliveira, Claudionor Barboza, Dalton M. da Silva, José Gonçalves e Henrique Martins da Seção de Gráfica pela preparação e montagem dos volumes finais da tese.

- Aos funcionários das seções de pós-graduação Ana Paula Cabanal, Magali F. Rizzo e Tadeu Gaggiano por solucionar diversas questões burocrático-formais.

- Aos colegas de pós-graduação (novos ou antigos), a rica experiência de conviver com vocês. Da B1 a B7: Lucy, Jaime, Edir, Peter, Gustavo (Torrinha), Raquel, Dionísio, Chodur, Fernando, Geysa, Fernando Ordóñez, Lucelene, Guilherme, Gustavo (Troglô), Marco, Rosana, Klaus, Carmen, Gandini, Ângela, Mirian, Sandra, 
lede, Annabel. Também Leandro, Boggiani, Ana Lúcia, Ossama, Picanço, Werner, Cláudia (Kaú), Cris, Mauro, Cláudio, Cláudia Varnier, Jeane e, com certeza, muitos outros.

- À toda minha família, que não se importou em encontrar um "por quê" para as minhas escolhas, proporcionando todas as condições para que eu desse andamento à minha empreitada.

- À tante Lea von Hrabovsky por mais de uma década de acolhimento de mãe.

- Às turmas da Barreirinha, Guaraqueçaba, Jardim das Américas, Rebouças e Forquilhinha. Espero provar pra vocês que eu não sou apenas uma lenda.

- Aos meus filhos Bruno, Paula e Rodrigo que foram obrigados a ceder seu precioso tempo de convívio comigo e mesmo assim não apagaram, em nenhum instante, o brilhante sorriso que carregam.

- À Yara, que praticamente foi uma esposa-viúva nestes anos e teve de assumir sozinha um sem número de responsabilidades. 


\section{CAPÍTULO 1}

\section{INTRODUÇÃO}

\subsection{Apresentação do tema}

Os batólitos graníticos alongados são manifestações ígneas das mais notáveis, tanto pela participação direta na construção de crosta continental como por sua importância como indicadores tectônicos. Entretanto, modelos geológicos compatíveis com a gênese destas associações de rochas ainda carecem de boas descrições de casos específicos, sejam de exemplos localizados em terrenos antigos ou recentes, sejam em situações geotectônicas de justaposição de placas continental e oceânica ou então exclusivamente continentais.

No embasamento cristalino dos estados do Sul e Sudeste brasileiros batólitos graníticos aparecem como feições características, ocupando áreas que variam desde modestos $300 \mathrm{~km}^{2}$ (e. g., os maciços Morungaba ou Cantareira, em São Paulo) até dimensões enormes, como as mostradas pelos Complexos Cunhaporanga no Paraná $\left(\sim 3000 \mathrm{~km}^{2}\right)$ e Três Córregos no Paraná e em São Paulo $\left(>4000 \mathrm{~km}^{2}\right)$. As formas são variadas, desde as alongadas e claramente orientadas nas direções regionais predominantes, até as mais equidimensionais, sendo a evolução geológica destes batólitos claramente complexa.

O estudo de um desses "complexos batóliticos" converte-se em tarefa íngreme, principalmente pela multiplicidade de tipos ígneos e pelo próprio tamanho do alvo de pesquisa. A escolha pelo Complexo Cunhaporanga deveu-se ao pequeno volume de informações mais detalhadas a seu respeito e por seu acesso relativamente fácil, além de se estar previamente familiarizado com seu contexto geológico (Guimarães 1995). A desvantagem, junto com a dimensão avantajada da unidade, é que vários de seus setores têm baixo número de afloramentos, quase sempre muito intemperizados. 
Procurou-se investigar o Complexo Granítico Cunhaporanga ao longo de toda sua área de exposição, utilizando-se para tanto mapas aerogeofísicos e fotografias aéreas, observações diretas em campo, lâminas petrográficas, análises químicas em rocha-total e em minerais específicos, além de uma avaliação crítica da bibliografia existente.

\subsection{Localização da área e acessos}

A área estudada situa-se no centro-leste do estado do Paraná (Figura 1.1), ao longo de um eixo unindo Ponta Grossa à divisa com o estado de São Paulo, na altura de Itararé. Esta área ocupa diversos setores dos municípios de Castro, Piraí do Sul, Jaguariaíva, Sengés, Doutor Ulysses, Carambei e Ponta Grossa.

O acesso a partir de Curitiba faz-se através da BR-376 até Ponta Grossa (118 $\mathrm{km}$ ), seguindo-se por mais $21 \mathrm{~km}$ pela PR-151, em direção a Itararé, até a cidade de Castro. Esta rodovia corta a área no trecho que liga a cidade de Carambeí a Jaguariaíva, passando por Castro e Piraí do Sul, sendo praticamente a única via pavimentada da região.

Vindo da cidade de São Paulo, o melhor caminho é pela Rodovia Castelo Branco (SP-280) até o quilômetro 124, passando-se à rodovia SP-127 em direção a Capão Bonito. Daí segue-se pela SP-258, totalizando-se perto de $350 \mathrm{~km}$ desde a capital até a chegada em Itararé (situada a aproximadamente $15 \mathrm{~km}$ do extremo nordeste da área).

A região é servida por uma quantidade razoável de vias não pavimentadas, cujo trânsito é severamente comprometido em épocas de chuvas prolongadas (Figura 1.2). São elas a PR-090 (Estrada do Cerne), que vem de Curitiba, passa por Abapã e segue para Piraí do Sul, a PR-092, que liga Jaguariaíva a Cerro Azul, passando por Doutor Ulysses, além de diversas estradas municipais de menor ou maior qualidade. Destas destacam-se a Carambeí-Catanduva de Fora-Alagados (em pavimentação), CastroSanta Rita, Castro-Socavão-Santa Quitéria, Santa Quitéria-Estrada do Cerne, Piraí do 


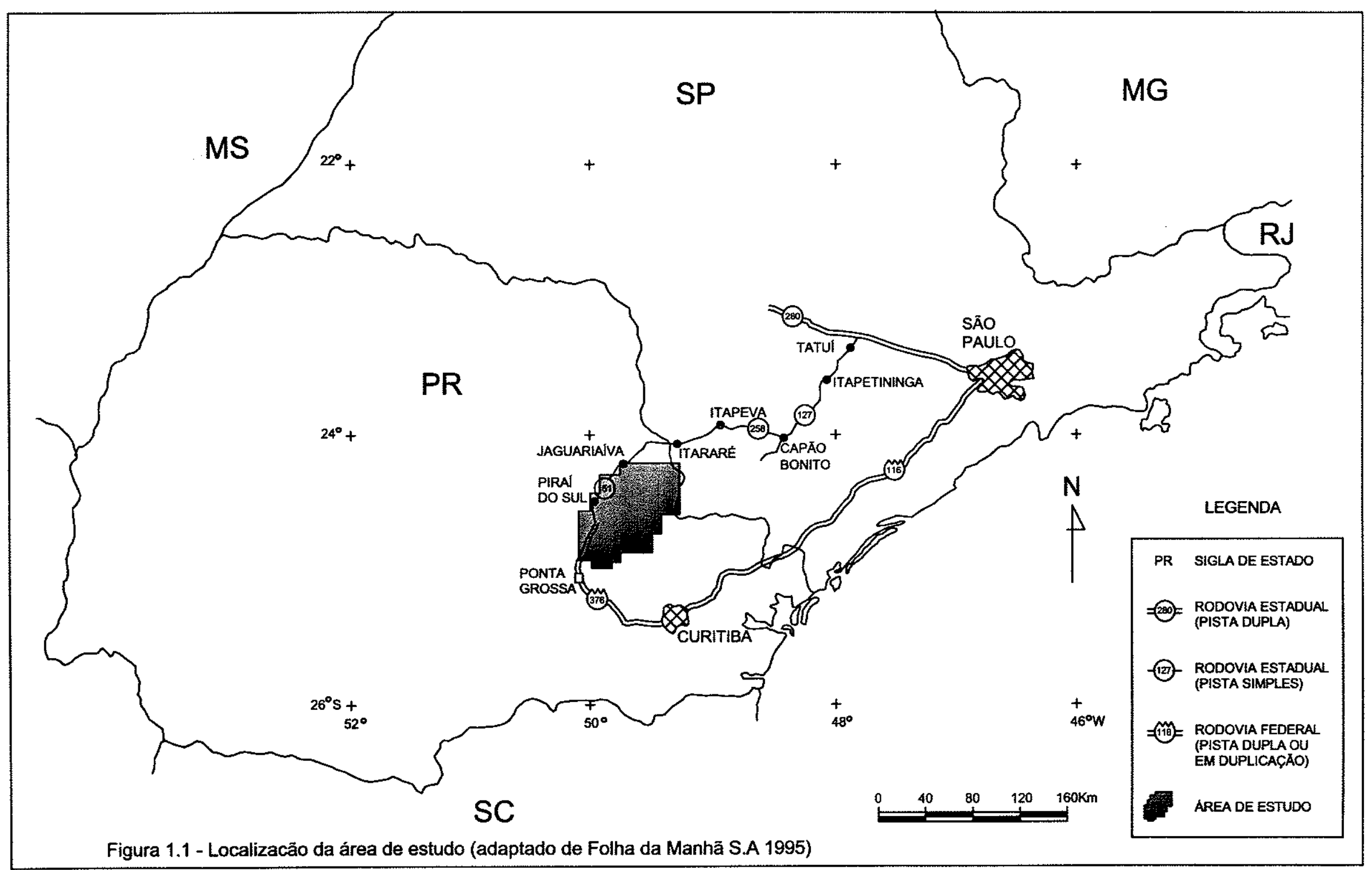




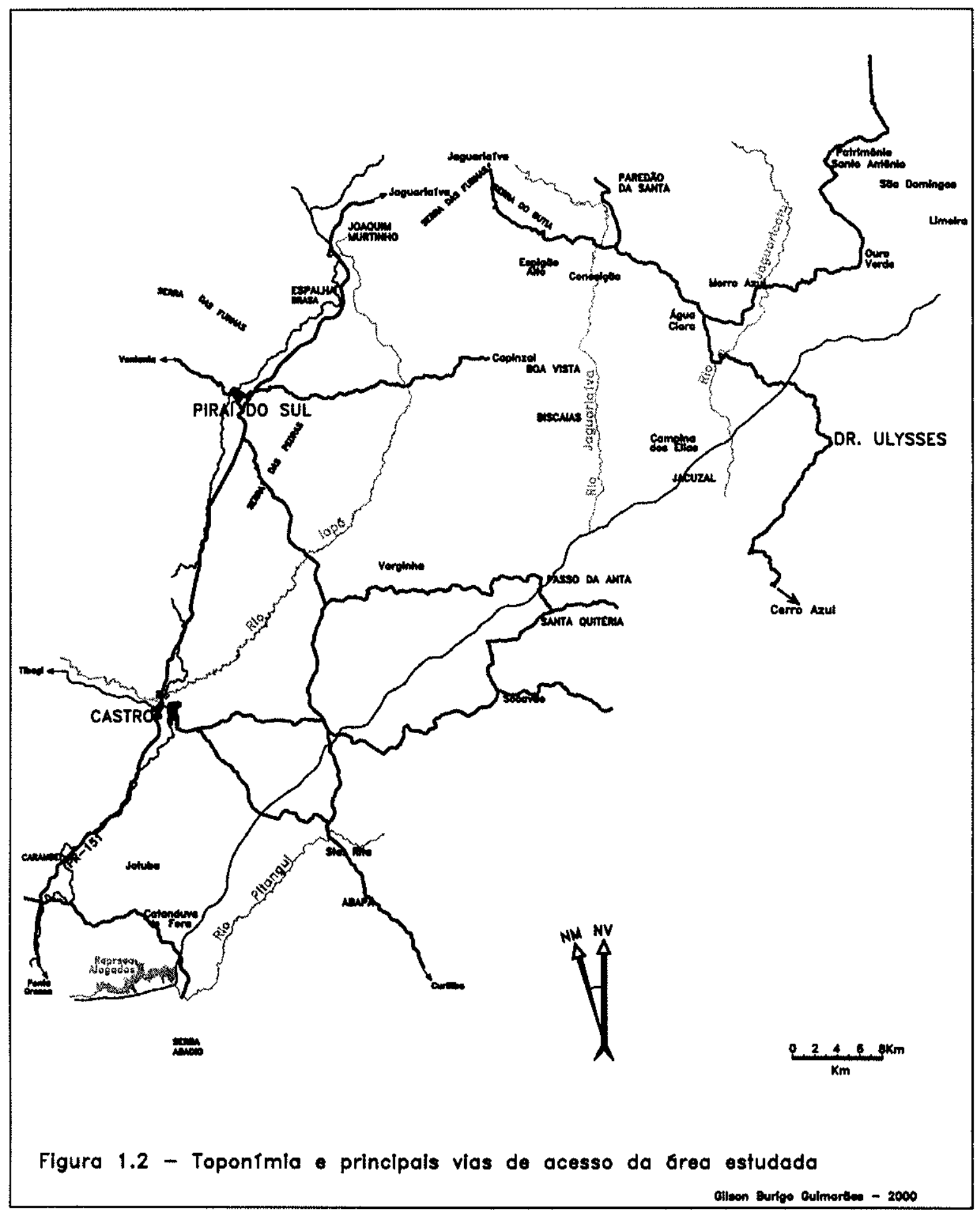


Sul-Fundão-Capinzal (parcialmente asfaltada), Jaguariaíva-Serra do Butiá-Conceição, PR-092-Morro Azul-Ouro Verde e Serra do Corisco-Patrimônio Santo Antônio-Ouro Verde.

\subsection{Aspectos fisiográficos}

O Complexo Granítico Cunhaporanga localiza-se no extremo noroeste do primeiro planalto paranaense, bordejado tanto a sudoeste como a norte pela estrutura regional conhecida por "Escarpa Devoniana". Esta caracteriza-se por um típico relevo em "cuesta", com desníveis da ordem de até 200 a $250 \mathrm{~m}$. Junto a ela são também comuns os vales encaixados de rios resseqüentes, formando "canyons", como no caso dos Rios Jaguariaíva, Jaguaricatu e Itararé (Fotos 1A e 1B).

Composta por arenitos devonianos da Formação Furnas, a escarpa recebe diversas denominações locais, tais como Serra da Janela (entre os vales dos Rios Itararé e Jaguaricatu), Serra Boa Esperança (entre os Rios Jaguaricatu e Jaguariaíva), Serra das Furnas (do Rio Jaguariaíva à região de Joaquim Murtinho; Foto 1C) ou Serra de Itaiacoca (próximo à localidade homônima). A altitude máxima de $1275 \mathrm{~m}$ é alcançada nas cercanias de Joaquim Murtinho.

Dentro da área do Complexo Cunhaporanga as principais bacias hidrográficas existentes (lapó, Pitangui, Jaguariaíva e Jaguaricatu) possuem características de relevo próprias.

O setor ocupado pela bacia do Rio lapó, no centro do Complexo, tem um nítido condicionamento litológico. As áreas com substrato granítico proporcionam um relevo com topografia suave, solos espessos, raras exposições de rochas e extensas várzeas (Fotos 1D e 1E). Já quando predominam os metarenitos, como no caso da Serra das Pedras, passa-se a uma topografia mais acidentada, com afloramentos freqüentes e solos pouco desenvolvidos. 
Enquanto as cotas alcançadas em terrenos graníticos da bacia do Rio lapó dificilmente fogem do intervalo entre 1050 e $970 \mathrm{~m}$, na Serra das Pedras os valores são normalmente iguais ou superiores a $1100 \mathrm{~m}$, com um máximo de $1359 \mathrm{~m}$.

$\mathrm{Na}$ bacia do Rio Pitangui, ao sul, tornam-se mais comuns os afloramentos de rochas graníticas, em especial na Serra do Carambeí (altitude máxima $1050 \mathrm{~m}$ ). Esta é constituída por um granito quartzoso de granulação grossa ("Granito Serra do Carambeí"), sendo comuns os solos litólicos, além de lajes junto às encostas.

O relevo ao norte do Complexo mostra-se significativamente mais movimentado que em sua porção central. Ao longo das bacias hidrográficas dos Rios Jaguariaíva e Jaguaricatu observa-se uma topografia moderadamente a muito ondulada. Isto devese tanto à ocorrência de áreas com grandes matacões de rochas graníticas como à presença de domínios constituídos por metassedimentos, em especial metarenitos (responsáveis por várias elevações com altitudes entre 1200 e $1300 \mathrm{~m}$ ).

"Cerros" e "serras" tornam-se freqüentes, destacando-se a Serra do Butiá (995 m), a Serra Boa Esperança (1317 m), a Serra das Antas (1190 m; Foto 1F), a Serra Paranapiacaba (1319 m), o Cerro Chato (1232 m), assim como elevações sem denominação, tais como as existentes ao redor da Campina dos Elias (cotas máximas de 1244 e $1328 \mathrm{~m}$ ).

O rio mais importante da área é o lapó, que nasce junto às escarpas da Serra das Furnas, em Joaquim Murtinho. Controlado estruturalmente pelas duas principais direções regionais (NE-SW e NW-SE), orienta-se dominantemente para sudoeste no trecho em que corre sobre o Complexo Cunhaporanga. A partir da cidade de Castro passa a um rumo noroeste, prosseguindo até adentrar no segundo planalto paranaense em direção ao Rio Tibagi.

Seus principais afluentes na região do Complexo (Ribeirão Cunhaporanga, Rio Taquara, etc.) são todos da margem esquerda. Já em terrenos do Grupo Castro os maiores tributários (Rios Piraí e Piraí-Mirim) desembocam na margem direita do lapó, estando também encaixados em estruturas NE-SW. 
Outros rios de destaque são Jaguariaíva, da Barra, Lanças, Jaguaricatu e Caçador no norte do Complexo, além de Pitangui e Jotuba na porção sul.

\subsection{Objetivos}

A principal intenção deste trabalho é a de levantar o maior número possível de dados geológicos (petrográficos, geoquímicos, geofísicos, etc.) referentes ao Complexo Granítico Cunhaporanga. O passo seguinte, procurando-se ser fiel ao grau de profundidade dos dados obtidos, é o de interpretá-los. Esta ênfase na descrição devese ao baixo volume de dados existentes sobre o pré-cambriano paranaense, freqüentemente resultando em interpretações pouco consistentes (ver discussão em Guimarães 1995).

Assim, os principais objetivos deste estudo são:

- Produzir um mapa geológico de compilação do Complexo Granítico Cunhaporanga e unidades adjacentes, na escala 1: 150.000;

- Interpretar os dados gamaespectrométricos e magnetométricos do levantamento aerogeofísico Serra do Mar Sul na área do Complexo Cunhaporanga;

- Caracterizar petrograficamente os tipos litológicos que compõem o Complexo;

- Estabelecer a natureza das relações de contato do Complexo com as unidades geológicas adjacentes;

- Produzir um mapa geológico do Complexo Granítico Cunhaporanga, na escala 1: 150.000 , em que estejam discriminadas áreas de predomínio de determinados tipos petrográficos; 
- Caracterizar quimicamente algumas fases minerais componentes de rochas granitóides e estimar parâmetros físico-químicos como pressão e temperatura de formação das rochas;

- Caracterizar geoquimicamente os tipos granitóides existentes no Complexo Cunhaporanga e interpretar os resultados obtidos;

- Sugerir possiveis mecanismos petrogenéticos-geotectônicos que sejam compatíveis com os dados obtidos e que permitam enquadrar o Complexo Granítico Cunhaporanga no contexto geológico regional.

\subsection{Metodologia}

\subsubsection{Trabalhos de campo}

Para os trabalhos de campo foram empregadas como referências as seguintes folhas topográficas: Ouro Verde, Vila Branca, Campina dos Elias, Piraí do Sul, Castro, Abapã, Socavão, Ponta Grossa e Itaiacoca, todas na escala 1:50.000, além da Folha Jaguariaíva 1:100.000 (Figura 1.3). Com exceção das folhas Ouro Verde e Jaguariaíva, mais recentes (1975 e 1981) e editadas pelo IBGE, os demais mapas são antigos (décadas de 50 e 60) e foram produzidos pelo Serviço Geográfico do Exército. Além destes, utilizou-se também um conjunto de fotografias aéreas na escala 1:70.000, datadas do ano de 1963 (USAF, Força Aérea Americana).

Apesar do considerável lapso de tempo entre a edição das cartas topográficas e dos trabalhos de campo, não houve problemas sérios de localização, pois a malha viária atual permaneceu praticamente inalterada nos últimos 40 anos ou mais.

Adicionalmente a orientação em campo foi facilitada pelo uso de um aparelho Ensign GPS TM, da marca Trimble. Este mostrou-se perfeitamente adequado à escala de trabalho (mapeamento e execução de perfis regionais em 1:50.000 - 1:100.000), 
com erros de posicionamento quase sempre inferiores a 100 metros (normalmente menores que 50 metros).

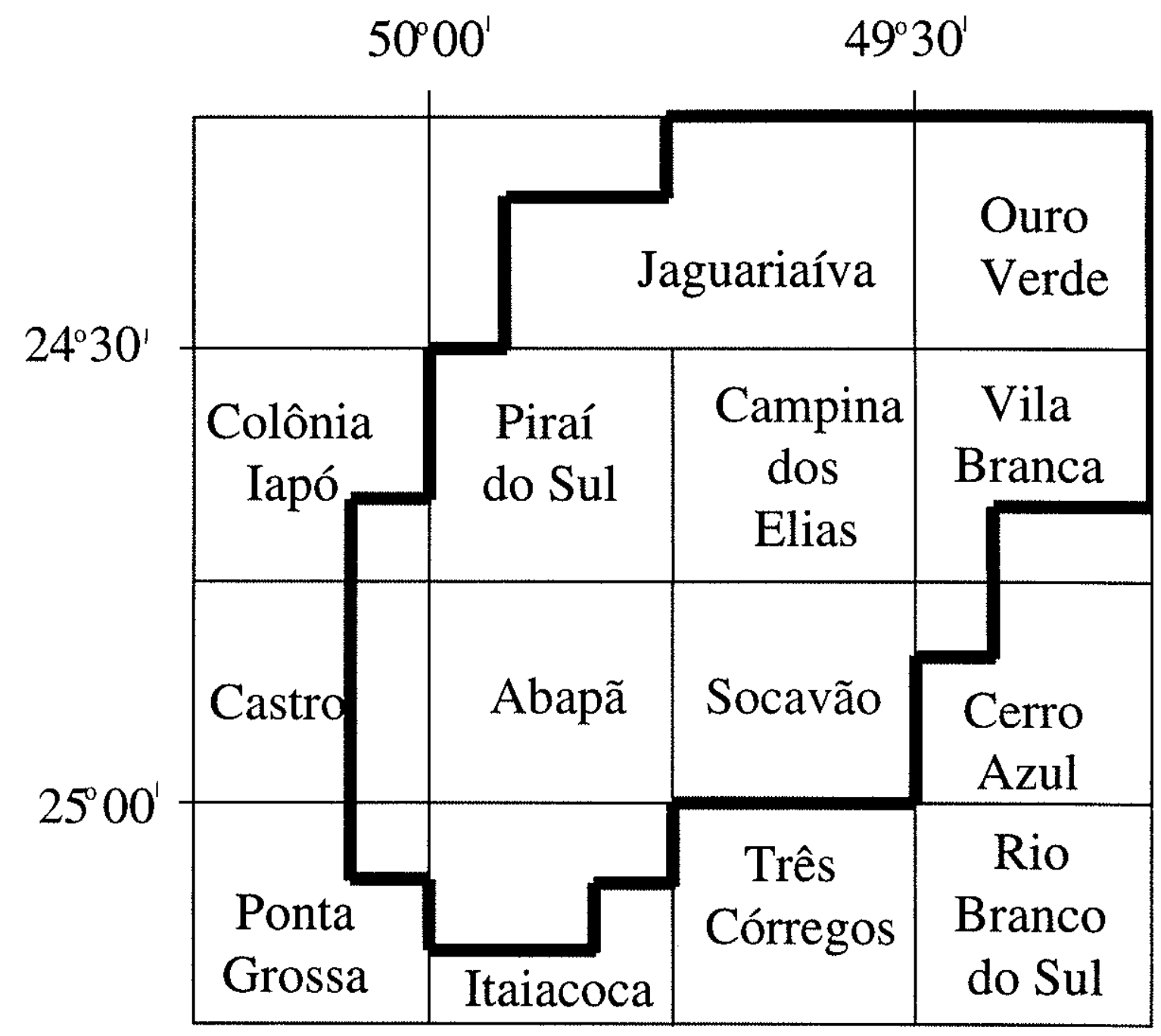

Figura 1.3: Localização da área estudada em relação às folhas topográficas 1: 100.000 (Jaguariaíva) e 1:50.000 (demais), editadas pelo IBGE (Jaguariaíva e Ouro Verde) e Serviço Geográfico do Exército (demais).

Os trabalhos de mapeamento geológico e de coleta de amostras seguiram as diretrizes convencionais para terrenos de rochas ígneas e metamórficas (ver Ulbrich 1984; Vlach 1985; Clarke 1992). Por conta da distribuição desigual de exposições adequadas, precárias principalmente na porção central do Complexo, o controle de campo foi mais efetivo para as regiões sul (Carambeí a Abapã) e norte (Joaquim 
Murtinho, Capinzal e Ouro Verde), conforme pode ser visto no mapa de pontos (Anexo 2). Apenas alguns dos pontos descritos por Guimarães (1995), na região de Joaquim Murtinho, estão representados no mapa de pontos do Anexo 2, especialmente aqueles com referências ao longo deste texto ou então de onde provêm amostras com análises geoquímicas.

\subsubsection{Mapa de compilação}

As bases para a tarefa de compilação foram os mapas da Comissão da Carta Geológica do Paraná (CCGP 1966, 1970 a,b, etc.) e do Projeto Leste do Paraná (CPRM $1977 \mathrm{a}, \mathrm{b}$, etc.). Apesar de terem mais de 20 ou até mesmo 30 anos, estes trabalhos ainda conservam seu valor como referência (comparar com mapas regionais, como de Biondi et al. 1989). Informações algo mais detalhadas puderam ser incorporadas a partir dos mapeamentos executados nas regiões de Carambeí (PintoCoelho 1986), Patrimônio São Domingos (Soares et al. 1987) e Joaquim Murtinho (Guimarães 1995).

As bases utilizadas têm predominantemente escalas de 1:70.000 (da Comissão da Carta) ou 1:100.000 (CPRM). Assim, para a confecão do mapa de compilação (Anexo 1), utilizaram-se efetivamente:

Porção centro-norte do Complexo: Folhas Joaquim Murtinho, Jaguariaíva-Sul e Serra das Antas (CCGP 1970; 1:70.000), Folha Pirai do Sul (CPRM 1977; 1:100.000) e Guimarães (1995; 1:50.000);

Porção nordeste do Complexo: Folhas Cerro Azul (CPRM 1977; 1:100.000), Varzeão (CCGP 1970; 1:70.000), Ribas (1981; 1:250.000) e Donatti (1997; 1:25.000);

Porção sul/sudeste do Complexo: Folhas Campo Largo, Piraí do Sul (ambas 1:100.000) e Ponta Grossa (1:50.000; as três da CPRM 1977), Castro (CCGP $1966 ; 1: 50.000)$ e Pinto-Coelho (1986; 1:25.000). 
Nesta etapa digitalizaram-se os dados existentes nos mapas acima referidos, sendo que os arquivos gerados foram tratados nos softwares AutoCAD R12 e R14 (Autodesk, Inc.) De modo a que não fossem introduzidas distorções adicionais às existentes nos trabalhos originais, optou-se pela impressão de uma versão em escala $1: 150.000$.

\subsubsection{Geofísica}

O objetivo principal da análise dos dados do Projeto Aerogeofísico Serra do Mar Sul (PSMS) foi o de confrontá-los com as informações geológicas disponíveis para o Complexo Granítico Cunhaporanga e áreas vizinhas. Para tanto foram necessários os seguintes passos: delimitação da área do PSMS a ser investigada; processamento dos dados geofísicos, geológicos e de posicionamento através do software GEOSOFT ${ }^{\text {MM }}$ (tamanho de célula $500 \times 500 \mathrm{~m}$, através do método de interpolação da curvatura mínima); confronto de arquivos geológicos digitais específicos (e. g., contorno das rochas graníticas) com os grids geofísicos; $e$, finalmente, impressão de mapas geofísico-geológicos (escalas 1: 250.000 a 1: 500.000).

De acordo com Silva (1994) e Silva \& Mantovani (1994), a fase de aquisição dos dados do PSMS teve uma série de incorreções. Um exemplo é a presença de valores negativos para as contagens dos canais de Th, $\mathrm{U}$ e K. Durante o tratamento dos dados contornou-se este problema através da introdução de um incremento ("shiff") para o conjunto de valores de cada canal específico, de modo que a menor contagem em cada canal passou a ser de $1 \mathrm{cps}$. Tendo em vista este procedimento, bem como problemas adicionais nos canais de $\mathrm{KeU}$ (ver adiante), optou-se pela não utilização de mapas de razões de elementos (Th/K, U/K e U/Th), particularmente úteis na deteç̧ão de alvos favoráveis à pesquisa mineral.

O primeiro processamento pelo software mostrava padrões muito acentuados na direção N30W, paralelos à direção do vôo, nos canais do $\mathrm{K}$ e do $U$ (causados por "stripping" e/ou remoção inadequada do radônio atmosférico). A aplicação de um filtro cosseno direcional de grau 6 sobre os grids originais eliminou/minimizou estes padrões, 
destacando ao mesmo tempo os valores presentes na direção ortogonal (método da "decorrugação"; para maiores informações e exemplos, ver Minty et al. 1997).

Durante o processamento dos dados magnetométricos efetuou-se a remoção da influência do enxame de diques máficos do Arco de Ponta Grossa. Constituídos predominantemente por diabásios de filiação toleíítica, portanto ricos em magnetita, estas rochas são responsáveis pelas anomalias lineares de direção NW-SE visiveis no grid original do campo magnético residual.

De modo a que fosse possivel visualizar-se as respostas magnéticas dos demais conjuntos litológicos, tornou-se interessante remover os padrões produzidos por estes diques. Tal procedimento consistiu no uso de um filtro cosseno direcional (grau 6) segundo a direção predominante (N50W) do enxame.

A escolha de um grau 6 para as operações acima visou evitar um incremento exagerado dos padrões magnéticos nas direções ortogonais, tal como ocorreu quando foram empregadas filtragens de grau 2 ou 1.

A seguir executou-se a operação conhecida como "redução ao pólo", a qual procura remover as assimetrias das anomalias magnéticas devidas a efeitos de indução. Este processo consiste em transformar as anomalias para o modo como elas apareceriam caso estivessem situadas exatamente sobre o pólo magnético. A "redução ao pólo" é particularmente indicada para regiões do globo cuja inclinação magnética situe-se entre $50^{\circ}$ e $20^{\circ}$, como é o caso da área estudada (inclinação de $-31^{\circ}$ na época do levantamento).

Por último, adicionou-se a técnica de imageamento conhecida por "iluminação". Sua principal virtude consiste em realçar detalhes sutis dos padrões, os quais dificilmente são identificados sem o uso deste procedimento.

Nos mapas com iluminação produzem-se sombras tais como as que seriam formadas caso existisse um ou mais "sóis" iluminando a área de interesse. No caso 
estudado optou-se por um "sol" posicionado a NW, pois a estruturação regional dominante é NE-SW.

O maior defeito da técnica, omitir feições lineares apontadas para este "sol", possui pouca relevância no caso em particular. Isto se dá porque a maior parte das estruturas NW-SE foi removida ou suavizada pelas filtragens direcionais acima mencionadas.

Os grids produzidos após os tratamentos descritos foram impressos tanto como imagens coloridas como imagens em diferentes tons de cinza. As imagens em cores são muito úteis na visualização global dos contornos e das amplitudes relativas das anomalias, ao passo que os grids em tons de cinza prestam-se ao reconhecimento de detalhes mais sutis, particularmente feições lineares.

As medidas de susceptibilidade magnética foram obtidas com um magnetômetro portátil modelo KT-9 da Exploranium, no modo de operação denominado "pin-mode". Cada leitura individual é conseguida apertando-se o pino de borracha do aparelho contra a amostra. Este procedimento é repetido pelo menos 20 vezes, em pontos diferentes da mesma amostra; o valor médio representa a susceptibilidade magnética $\boldsymbol{k}$ da amostra. O modelo da Exploranium dá resultados com uma precisão de cerca de 1 $\times 10^{-3}$ unidades SI.

Durante o levantamento geofísico terrestre na região da Serra do Carambeí foi utilizado um espectrômetro/cintilômetro diferencial, modelo GRS-500, da Scintrex, com cristal de $\mathrm{Nal}$ ativado por tálio (volume de $124 \mathrm{~cm}^{3}$ ). As leituras, efetuadas sem a correção do "background" e com tempo de integração de $10 \mathrm{~s}$, tiveram as seguintes janelas de detecção: contagem total $>0,08 \mathrm{MeV}\left(1^{a^{a}}\right.$ janela) e $>0,40 \mathrm{MeV}\left(2^{\mathrm{a}}\right.$ janela), potássio 1,35 a 1,59 MeV, urânio 1,65 a 1,67 MeV, tório 2,45 a 2,79 MeV.

\subsubsection{Descrição petrográfica e modas}

As descrições de lâminas petrográficas de rochas do Complexo (mais de 180) foram realizadas com microscópio petrográfico Zeiss-Axioplan, dando-se atenção à 
identificação dos minerais e suas relações texturais. Em paralelo foram examinadas amostras das unidades vizinhas, com especial ênfase para aquelas pertencentes à Faixa Itaiacoca (ver Prazeres et al. 1998).

As contagens modais para as rochas granitóides, em número de 50 , foram executadas integralmente ao microscópio apenas quando as mesmas apresentavamse com textura equigranular fina ou média (máximo de aproximadamente $5 \mathrm{~mm}$ ). Nestes casos empregou-se a metodologia descrita por Chayes (1949), contando-se entre 1300 e 2000 pontos por lâminas.

Para as rochas porfiriticas (ou inequigranulares com matriz média a grossa), efetuou-se a estimativa de sua composição através da contagem de grãos em fatias centimétricas de rocha, as quais foram previamente submetidas ao ensaio de coloração seletiva para feldspatos alcalinos (solução ativa de cobaltinitrito de sódio, responsável pelo tingimento de amarelo do feldspato potássico). Após este procedimento, executou-se a contagem de 4 minerais ou conjuntos de minerais (quartzo, feldspato potássico, plagioclásio e o conjunto dos minerais máficos) com o auxílio de uma malha regular impressa em folha transparente (espaçamento das linhas de $4 \mathrm{~mm}$; número de pontos entre 1000 e 1200). A proporção entre os diferentes minerais máficos (anfibólio, biotita, titanita, etc.) foi obtida ao microscópio, em lâmina petrográfica, de forma idêntica às estimativas para rochas equigranulares (neste caso, foram contados 1000 pontos).

O exame ao microscópio das rochas granitóides levou a uma classificação em 7 tipos petrográficos, empregada principalmente na discussão dos dados geoquímicos: titanita anfibólio biotita granitóides (abreviados, nas tabelas e figuras, como tit anf bio), titanita biotita granitóides (tit bio), biotita granitóides (sem titanita; bio), muscovita biotita granitóides (muscovita considerada primária; mu bio), álcalifeldspato granitos ("alasquíticos"; af granito), granitóides pórfiros com anfibólio (anf porf) e granitóides pórfiros com biotita (sem anfibólio; bio porf). Alguns dos pórfiros possuem matriz fina a afanítica e portanto são, antes que granitóides, dacito e riolito pórfiros. Porém, em vista da similaridade composicional, foram agrupados na categoria dos granitóides pórfiros. Adicionalmente, todos estes tipos (especialmente 
titanita anfibólio biotita e titanita biotita granitóides) foram discriminados em porfiríticos e equigranulares.

\subsubsection{Química mineral}

A primeira etapa para a obtenção de dados de química mineral com microssonda eletrônica é a realização de lâminas especiais para o equipamento, cuidadosamente polidas. A seguir são examinadas ao microscópio, sem cobertura, para a definição das áreas e dos minerais que serão analisados. Posteriormente a lâmina recebe uma cobertura de grafite em câmara de vácuo.

O equipamento analítico presente no IG-USP é uma microssonda Jeol, modelo JXA-8600S, com cinco espectrômetros, três com cristais PET/LiF e os outros dois com cristais STE/TAP e TAP/PET, aparelhada ainda com sistema EDS da NORAN e automatizada com o sistema NORAN-Voyager 4. A redução de dados, com correções dos efeitos de drift, dead-time e matriz é realizada pelo software PROZA, assim como o cálculo para porcentagem em peso dos óxidos e proporções catiônicas (para uma referência geral sobre estes procedimentos de correção, ver Bastin et al. 1984).

Nas análises de rotina, as condições são de $15 \mathrm{KV}$ e $20 \mathrm{nA}$ para a voltagem de aceleração e para a corrente do feixe eletrônico. O diâmetro do feixe para as análises quantitativas pela via WDS é variável: 1 a 5 micra para anfibólios, piroxênios, biotitas e outros; 10 micra para feldspatos. O tempo de contagem é de $20 \mathrm{~s}$ para os elementos mais abundantes e de até $60 \mathrm{~s}$ para alguns dos elementos traços. Os erros relativos nas determinações de óxidos são da ordem de $1 \%$ para os elementos abundantes, mas podem chegar a até 20 ou $30 \%$ nos casos de teores muito reduzidos.

As condições de operação durante a rotina análítica são calibradas por meio da leitura periódica de alguns padrōes, variáveis conforme as fases analisadas. Para as da presente pesquisa, foram os seguintes: Albita Amelia para $\mathrm{Na}$; microclínio para Si e $\mathrm{K}$; anortita sintética para $\mathrm{Ca}$ e $\mathrm{Al}$; diopsídio sintético para $\mathrm{Ca}, \mathrm{Mg}$ e $\mathrm{Si}$ em minerais máficos; hornblenda Arenal para $\mathrm{Al}$ (minerais máficos); olivina-Mn para $\mathrm{Fe}$ e $\mathrm{Mn}$; rutilo 
sintético para Ti; fluorita e apatita sintética para $\mathrm{F} \mathrm{e} \mathrm{Cl}$ em silicatos; Ba-plagioclásio para Ba.

O tratamento dos dados químicos foi efetuado com o auxílio do programa Minpet 2.02, de autoria de Linda R. Richard e, em parte, com planilhas do programa Excel 97 (Microsoft $\circledast$ ).

\subsubsection{Geoquímica de rochas}

Para as determinações geoquímicas de elementos maiores, menores e traços os pós de rocha foram obtidos após a limpeza da amostra para a retirada de partes alteradas e/ou descoloridas e/ou dos veios e moagem em britador de mandíbula de ferro.

Nas rochas equigranulares foram britados volumes de rocha de aproximadamente 1000 vezes o tamanho médio dos cristais (ou seja, equivalentes ao cubo de $10 \mathrm{u} \times 10 \mathrm{u} \times 10 \mathrm{u}$, onde $\mathrm{u}$ é o tamanho médio citado). A redução da granulometria foi realizada até tamanhos de partículas iguais ou menores a poucos $\mathrm{mm}$. A seguir, foi separado com quarteador um volume de $\sim 100 \mathrm{ml}$ para moagem em moinho de anéis de carbeto de $W$, do tipo Pulverisette, da Fritsch. Ao final a quantidade de pó obtida, com tamanho de partícula $\leq 200$ mesh, era em geral superior aos $100 \mathrm{~g}$.

Nas rochas inequigranulares, foram britadas quantidades significativamente superiores de material, tentando obter uma brita que fosse representativa. O procedimento de separação com quarteador e de moagem foi então similar ao descrito para as rochas equigranulares.

Para as determinações dos elementos maiores, menores e de alguns traços, com ICP-AES, foram pesadas alíquotas do pó moído de $\pm 2 \mathrm{~g}$ em cadinhos de porcelana e então colocadas em estufa a $100^{\circ} \mathrm{C}$ (determinação de $\mathrm{H}_{2} \mathrm{O}^{\circ}$ ). Uma alíquota desse pó, de $0,2500 \pm 0,0001 \mathrm{~g}$, foi colocada em cadinho de porcelana com 
$0,7500 \pm 0,0003 \mathrm{~g}$ de mistura de tetraborato e metaborato de $\mathrm{Li}$. Após mistura, colocou-se o pó em cadinho de grafite, levando-se à mufla a $1000^{\circ} \mathrm{C}$ para a fusão alcalina. Após 20 minutos, a pérola fundida foi despejada em béquer com $150 \mathrm{ml}$ de solução acidulada $e$ o vidro resultante dissolvido com ajuda de um bastão magnético em placa agitadora. A solução foi levada até $250 \mathrm{ml}$ em balão volumétrico e, a seguir, filtrada em filtro rápido. Este procedimento é realizado imediatamente após a fusão, para impedir a precipitação de sílica e outros elementos. A permanência de $\mathrm{Zr}$ na solução é assegurada com a adição, no balão, de algumas gotas de HF $48 \%$. A perda ao fogo é realizada ( $>1 \mathrm{~g}$ de pó), em cadinho de porcelana e em mufla à $1000^{\circ} \mathrm{C}$.

A determinação dos elementos maiores, menores e dos traços analisados com ICP-AES foi realizada com um equipamento ARL 3410 seqüencial, com a utilização de uma reta de calibração construída com padrões internacionais de rochas e minerais (CRM e RM, "certified reference materials" e "reference materials"), com coeficiente de correlação para a reta de calibração igual ou superior a 0,9997. A rotina utilizada é a seguinte: a) leitura dos padrões; b) primeira leitura de um padrão "in-house", $\mathrm{CD}_{1}$, que servirá de controle para correções de "driff" instrumental; c) leitura das amostras $A m_{1}$, $A m_{2}, .$. até $\mathrm{Am}_{10}$ como máximo; d) leitura do primeiro branco $\mathrm{Br}_{1} ;$ e) segunda leitura do controle, $\mathrm{CD}_{2}$; f) leitura das amostras $\mathrm{Am}_{11}$, etc.; g) segunda leitura do branco, $\mathrm{Br}_{2}$; e assim sucessivamente.

Para controle da qualidade dos resultados é intercalada, até duas vezes, uma amostra de um padrão internacional, ou de 2 padrões, que são analisadas da mesma maneira como o são as amostras-problemas. Os resultados obtidos (em Kcounts por segundo) são submetidos à correção por "drift", utilizando como referência as medições $C D_{1}, C D_{2}$, etc. versus o tempo das medições. Este procedimento, adaptado daquele utilizado no Imperial College de Londres (analista: Peter Watkins), permite a obtenção de dados de qualidade. Os erros para os elementos maiores são da ordem de $1 \%$ relativo, podendo por vezes atingir $2 \%$. Para os elementos menores e os traços, os erros são superiores, tipicamente $\leq 5 \%$, mas podem atingir $10 \%$, especialmente quando os valores são muito baixos e estão perto dos limites de detecção. Uma 
discussão mais detalhada sobre todos estes aspectos é encontrada em Janasi et al. (1995).

As determinações químicas com fluorescência de raios $X(F R X)$, em pastilhas de pó prensado, utilizam $7,00 \pm 0,005 \mathrm{~g}$ de pó de rocha, previamente secado a $60^{\circ} \mathrm{C}$, que é misturado e homogeneizado em saco de plástico com resina microgranular da Hoechst ("wax") como agente ligante. A pastilha é compactada em prensa Herzog por 60 s à pressão de 3 Kbar.

As determinações analíticas são realizadas no equipamento de fluorescência Philips, modelo PW-2400, com tubo de Rh, metodologia WDS e detectores de fluxo de Ar e/ou de cintilação de $\mathrm{Nal}$ e/ou de $\mathrm{Xe}$, contando ainda com 7 cristais analisadores diferentes. As curvas de calibração utilizam mais de 36 padrões internacionais de referência para rochas, solos e minerais, permitindo a determinação dos elementos maiores e menores e de 29 elementos traços, entre eles $\mathrm{S}, \mathrm{F}$ e $\mathrm{Cl}$. Os erros analíticos são da ordem de 5 a $10 \%$ para a maioria dos resultados, dependendo do elemento e dos teores; naturalmente, incrementam-se nas vizinhanças dos limites de detecção (para maiores detalhes, consultar Mori et al. 1999).

Para o presente estudo foram utilizados os resultados de ICP-AES para os elementos maiores e menores e dos seguintes traços: $\mathrm{Sr}, \mathrm{Ba}, \mathrm{Y}, \mathrm{V}, \mathrm{Zr}, \mathrm{Zn}$; os elementos Sc, Cr, Ni, Ga, Rb, Nb, La, Ce, Nd, Th, U e F foram determinados por FRX. Como no caso dos dados de química mineral, a composição das rochas foi tratada com o auxílio do programa Minpet 2.02. 


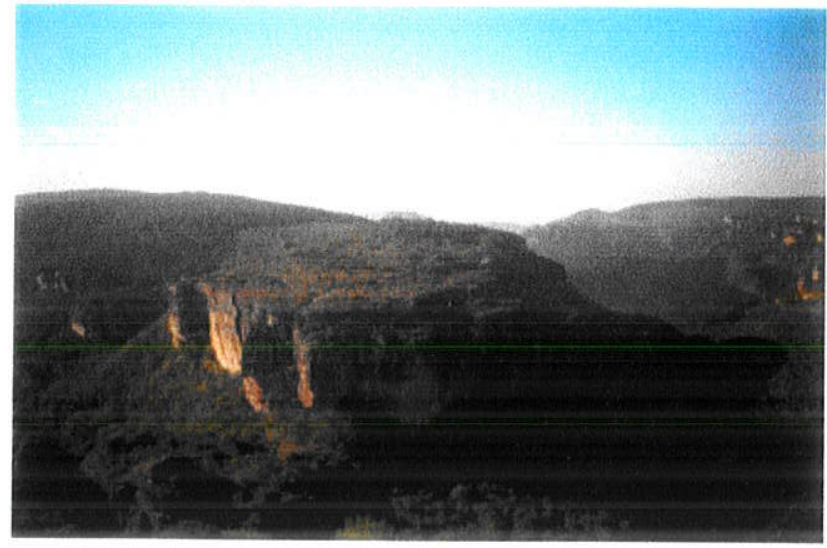

(A)

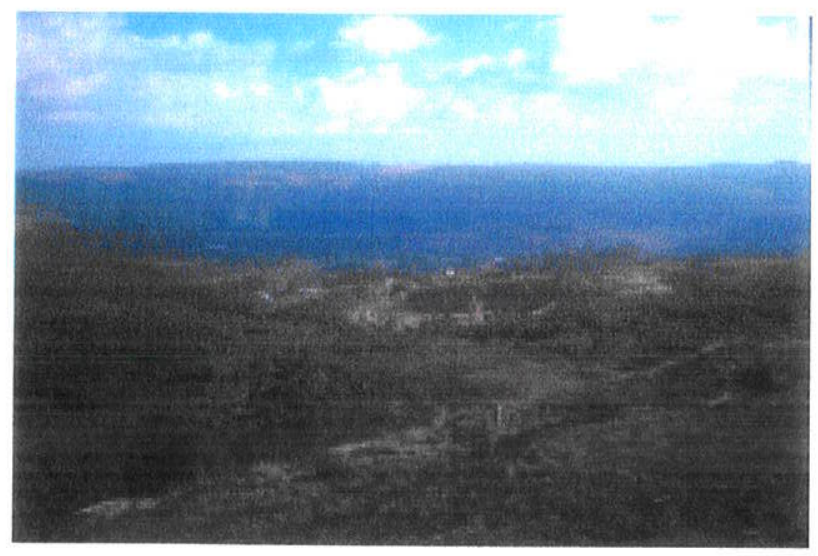

(C)

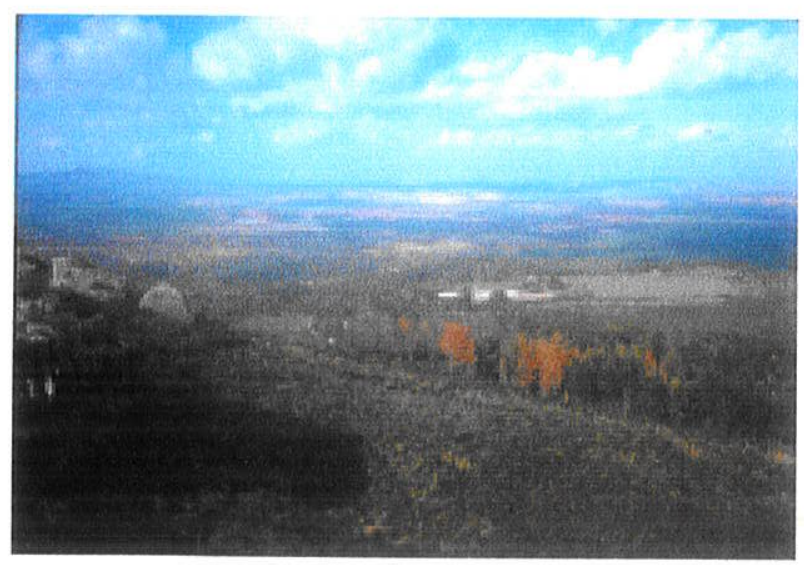

(E)

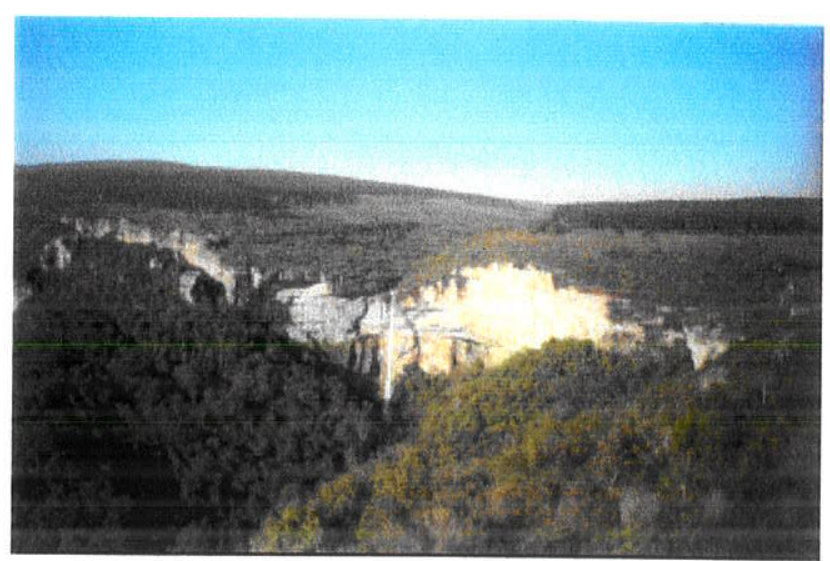

(B)

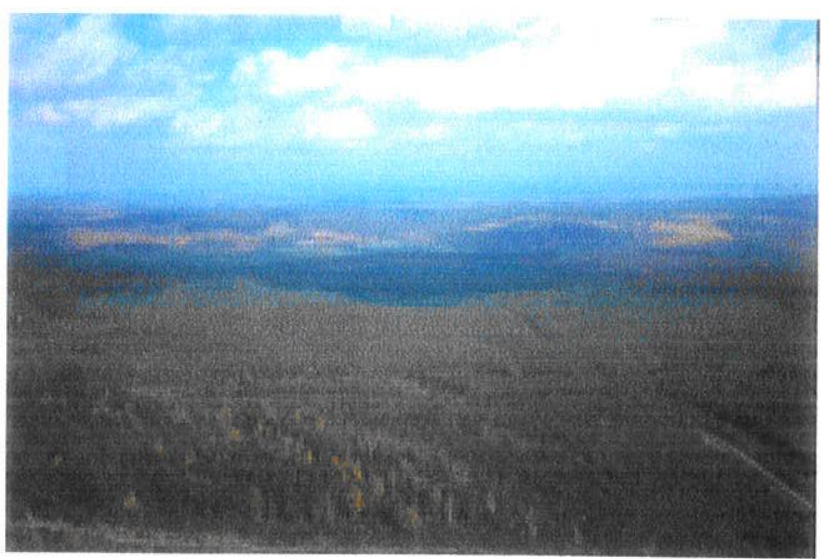

(D)

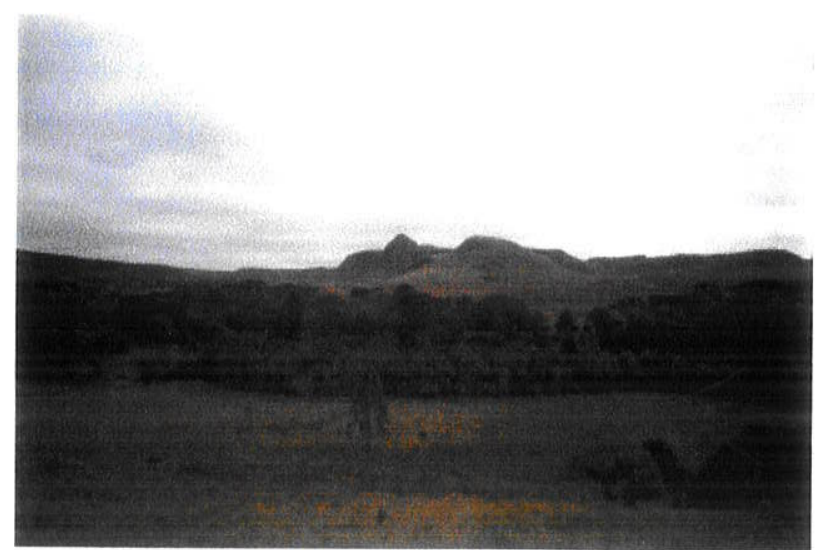

(F)

PRANCHA 1 - (A) Canyon do Rio Itararé, na divisa PR-SP. (B) Cachoeira do Corisco, afluente do Rio Itararé (contato entre o Arenito Furnas e metadolomitos do Grupo Itaiacoca). (C) Serra das Furnas na região de Joaquim Murtinho (contato entre o Arenito Furnas e o Granito Joaquim Murtinho; no centro da foto pedreira do ponto JM-97). (D) e (E) Relevo arrasado da bacia do Rio lapó, na região de Joaquim Murtinho (em (E) blocos do Arenito Furnas). (F) Vista da Serra das Antas (metarenitos/metarcósios), entre São Domingos e Patrimônio Santo Antônio. 


\section{CAPÍTULO 2}

\section{O COMPLEXO GRANÍTICO CUNHAPORANGA E O CONTEXTO GEOLÓGICO REGIONAL}

Este capítulo traz uma breve descrição das unidades geológicas que acompanham o Complexo Granítico Cunhaporanga, uma abordagem crítica dos trabalhos publicados a respeito do Complexo e um mapa geológico de compilação da região em que ele se insere (Anexo 1).

As entidades geológicas reconhecidas na área do presente estudo podem ser reunidas em unidades pertencentes à Faixa Dobrada Ribeira (Hasui et al. 1975), unidades fanerozóicas da Bacia do Paraná e aluviões cenozóicos relacionados à bacia hidrográfica do Rio lapó (Figura 2.1). Dentro da Faixa (ou Cinturão) Ribeira, o Complexo Granítico Cunhaporanga corresponderia a um dos vários batólitos graníticos gerados ao final do Neoproterozóico, durante o Ciclo Brasiliano.

A Zona de Cisalhamento Itapirapuã (ZCl; CPRM 1977c), de direção predominantemente N40E, divide localmente o Cinturão Ribeira em dois blocos tectônicos. O bloco a sudeste da $\mathrm{ZCl}$ está constituído principalmente pelas intrusões do Complexo Três Córregos, encontrando-se ainda no seu interior faixas de rochas supracrustais metamorfizadas em grau baixo a médio (e. g., rochas da Formação Água Clara). O bloco a noroeste é ocupado pelo Grupo Itaiacoca, em contato intrusivo com o Complexo Cunhaporanga, além do Grupo Castro.

\subsection{Síntese dos trabalhos anteriores sobre o Complexo Cunhaporanga}

Neste item optou-se por apresentar em fases cronológicas de conhecimento aquelas contribuições que, de algum modo, permitem uma melhor compreensão dos 


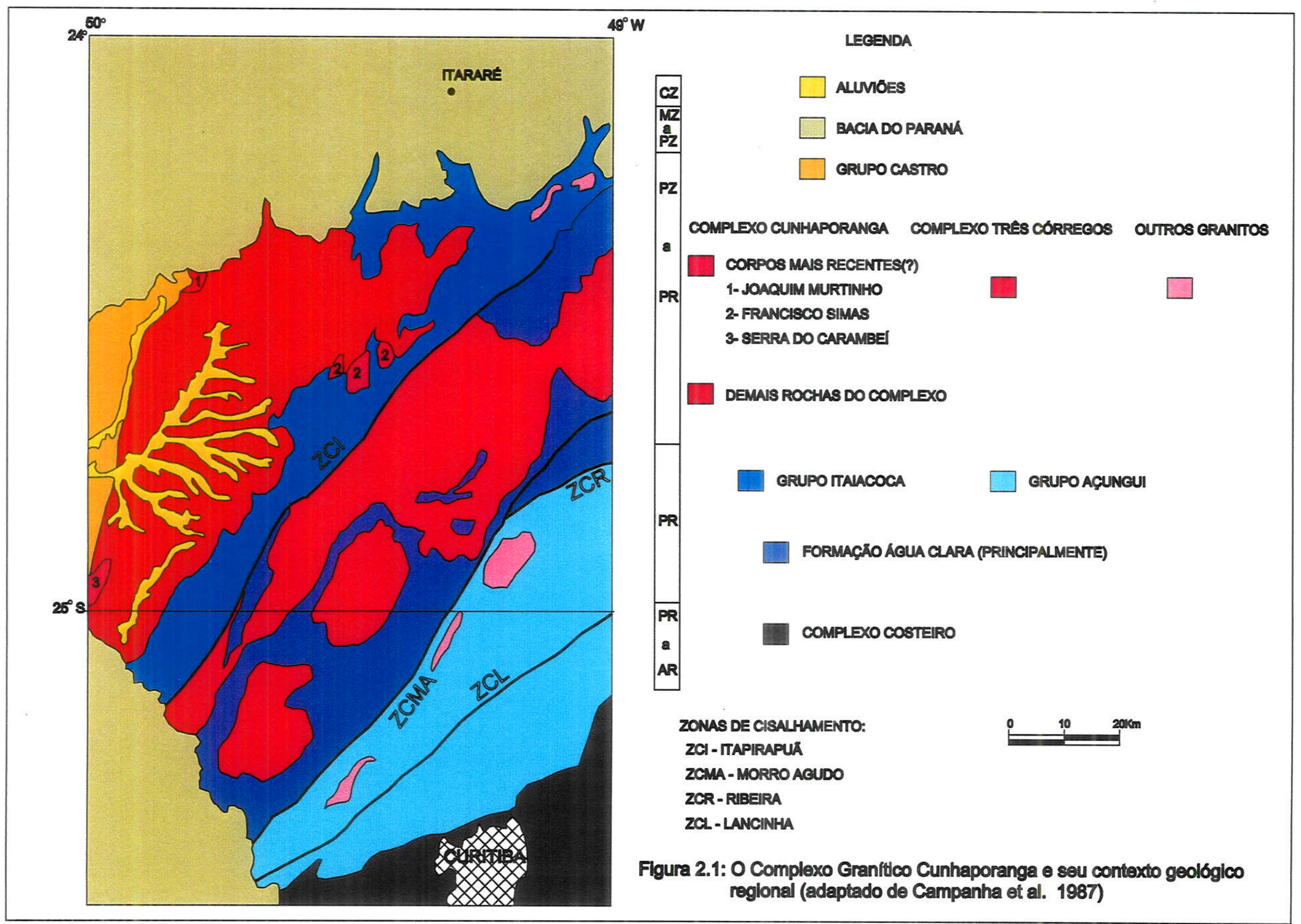


diferentes aspectos do Complexo Granítico Cunhaporanga. Deve-se ressaltar que poucas foram dirigidas especificamente ao estudo do Complexo, sendo que a maior parte dos registros refere-se a avaliações geológicas regionais.

Os trabalhos mais importantes para o entendimento de quem é o Complexo Cunhaporanga, de quanta diversidade litológica ele comporta e de quais são suas relações com as unidades vizinhas, foram executados pela Comissão da Carta Geológica do Paraná (CCGP), pela Companhia de Pesquisa de Recursos Minerais (CPRM) e pela Minerais do Paraná S. A. (MINEROPAR). CCGP, CPRM e MINEROPAR atuaram de forma mais intensa durante períodos específicos, de modo que as fases discriminadas a seguir recebem nomes vinculados diretamente a elas.

\subsubsection{Trabalhos anteriores à década de 60 (Fase pré-Comissão da Carta Geológica do Paraná)}

- Oliveira $(1916,1927)$

Provavelmente as primeiras citações sobre a ocorrência de granitos na área do Complexo foram efetuadas por Oliveira $(1916,1927)$. Este autor teria identificado rochas graníticas nos seguintes locais (ver mapa de pontos do Anexo 2 para localização): na fazenda de Cunhaporanga (a qual se estenderia "em rumo oeste-leste desde Yapó até as cabeceiras do rio Turvo, affluente da margem esquerda do Ribeira de Iguape"; Oliveira 1916, p. 80); na fazenda do Tabor (entre o Ribeirão do Meio e o Rio Jaguariaíva); em Joaquim Murtinho; na região dos cursos superiores dos Rios Jaguariaíva e Jaguaricatu; na "serra de Manoel Grande" (Serra de Paranapiacaba); além do trecho a partir da "serra do Varjão" (cerro Varzeão) até Cerro Azul (neste caso possivelmente rochas do Complexo Granítico Três Córregos).

Oliveira (1916) apontou dificuldades em se definir a constituição geológica na área da fazenda Cunhaporanga, tendo em vista o elevado grau de intemperismo observado: "O seu sub-sólo é difficilmente accessivel a investigações geologicas, mas parece-nos que nas proximidades do Yapó a rocha dominante é porphyro 
metamorphico de Castro e para leste, salvo em tres pontos, não existe rocha exposta, estando todas altamente decompostas e cobertas por um espesso deposito de terra argillosa vermelha que attinge até 15 metros de espessura." (Oliveira 1916, p. 81).

Entretanto, analisando os freqüentes cortes naturais ocasionados por escorregamentos e vossorocas, além de raros "blocos espheroidaes de decomposição concentrica", propôs a denominação de "granito de Cunhaporanga" para uma rocha constituída por "quartzo, orthose em grandes crystaes roseos, um mineral preto esverdeado muito menos decomposto que a orthose e mica em pequena quantidade" (Oliveira 1916, p. 81). No trabalho de 1927 este mineral preto-esverdeado foi identificado como sendo hornblenda.

Ao examinar-se os textos de Oliveira $(1916,1927)$ já é possivel antever uma diversidade faciológica das rochas granitóides. Assim, além de um hornblenda granito porfirítico na região da fazenda Cunhaporanga, haveria um "granito de granulação grossa" (Oliveira 1916, p. 81) em cortes de ferrovia próximo a localidade de Joaquim Murtinho (correspondendo ao Granito Joaquim Murtinho; ver Guimarães 1995). Já nas cabeceiras dos rios Jaguariaiva e Jaguaricatu existiriam granitos compostos "de quartzo grosseiro, mica biotita em placas hexagonaes e orthose", com "crystaes porphyroides de orthose (...) em todas as amostras examinadas." (Oliveira 1927, p. 22 23).

- Bigarella (1947)

Ao executar um perfil de reconhecimento entre Cerro Azul e Jaguariaiva (ver Anexo 2 para localização), Bigarella (1947) identificou dois domínios com granitos porfiríticos e um com granito de granulação fina. Os granitos porfiríticos seriam visíveis nos trechos entre Cerro Azul e a serra do Varzeão e da localidade de Cadeado até a serra do Butiá. No primeiro caso corresponderiam a granitóides do Complexo Três Córregos, enquanto no segundo pertenceriam ao Complexo Cunhaporanga. O granito fino (Granito Francisco Simas, ver adiante) seria observado desde a serra de Paranapiacaba até Cadeado. 
Metassedimentos classificados como da série Açungui (aqui tratados, em parte, como pertencentes ao Grupo Itaiacoca; ver item 2.2.1 adiante) estariam dispostos entre a Serra de Paranapiacaba e Varzeão, na localidade de Cadeado ou como "roof pendants" nos granitos porfiríticos do trecho mais a sul (Cerro Azul-Varzeão).

Apesar de não verificar as relações entre o granito fino e as rochas dolomíticas da série Açungui, Bigarella (1947) considerou os metassedimentos como "algonqueanos" (proterozóicos) e os granitos como posteriores ("post-algonqueanos").

- Almeida (1957)

A idéia de que o Complexo Cunhaporanga abrigaria rochas mais antigas e de grau metamórfico mais elevado que as do Grupo Açungui (e. g., Fuck et al. 1967 a), surgiu com o trabalho de Almeida (1957). Este autor considerou como não intrusivos no Açungui os granitos existentes junto às nascentes dos Rios Jaguariaíva, Jaguaricatu e do Ribeirão da Onça (sudeste de Castro).

Nas Serras da "Água Branca" (cabeceiras do Rio Jaguaricatu) e da "Avenca" (Serra do Avencal, entre Varzeão e Dr. Ulysses), ainda segundo Almeida (1957), aflorariam "granitos rosados, não porfíricos, associados a gnaisses e biotita-xistos" (Almeida 1957, p. 65), supostamente do Complexo Cristalino Brasileiro.

É interessante assinalar alguns pontos sobre o trabalho de Almeida (1957): apesar de incluir os granitos existentes nas cabeceiras do ribeirão da Onça no embasamento do Açungui, o autor não apresentou nenhuma descrição específica da região; b) os motivos para considerar-se o granito da serra da Avenca como não intrusivo não estão explícitos; c) o autor aparentemente não considerou a hipótese de que os tais "gnaisses e biotita-xistos" pudessem também pertencer ao Grupo Açungui, diferindo dos demais "metassedimentos da região, que em geral não ultrapassaram a zona da clorita" (Almeida 1957, p. 66) por influência termal dos referidos granitos. 


\subsubsection{Trabalhos do período 1960-1970 (Fase da Comissão da Carta Geológica do Paraná)}

Os primeiros trabalhos de mapeamento geológico sistemático do pré-cambriano paranaense foram aqueles conduzidos pela Comissão da Carta Geológica do Paraná (CCGP). As publicações iniciais de suas atividades consistiram na compilação de levantamentos aerofotogeológicos e geofísicos, realizados pela Prospec S. A., em 1954, para o Departamento Nacional da Produção Mineral. Destas, apenas a Folha Geológica do Varzeão (CCGP 1965) contém rochas granitóides consideradas atualmente como pertencentes ao Complexo Cunhaporanga, sendo referidas na legenda do mapa como "Intrusivas Ácidas" do tipo "gnaiss-granito".

Durante a segunda metade da década de 60 e início da de 70 foram várias as contribuições da CCGP (com destaque para o clássico trabalho Geologia do PréDevoniano e intrusivas subseqüentes da porção oriental do Estado do Paraná, de Bigarella et al. 1967). Infelizmente muitos dos mapas geológicos editados não estão acompanhados de um texto explicativo.

O Complexo, ou mais freqüentemente neste caso Granito Cunhaporanga, aparece nos seguintes trabalhos da CCGP: nas Folhas Geológicas de Abapã (CCGP 1966 a), Castro (CCGP 1966 b), Piraí do Sul (CCGP 1966 c), Jaguariaíva-Sul (CCGP 1970 a), Joaquim Murtinho (CCGP 1970 b), Serra das Antas (CCGP 1970 c) e Varzeão (CCGP 1970 d) e nos textos de Fuck (1967), Fuck (inédito), Trein (inédito), Fuck et al. (1967 a), Fuck et al. (1967 b) e de Muratori et al. (1970).

Por desconhecimento dos estudos pioneiros de Oliveira $(1916,1927)$ quando da impressão das Folhas de Abapã, Castro e Piraí do Sul, a CCGP (1966 a, b, c) utilizou a denominação Granito Castrolanda ao invés de Cunhaporanga. Este erro foi devidamente assinalado em publicações posteriores (Fuck 1967; Fuck et al. 1967 a).

As descrições mais detalhadas do Complexo Cunhaporanga apresentadas pela CCGP, basicamente de sua porção sul, encontram-se em Fuck (1967), Fuck et al (1967 a) e Trein (inédito). 
A CCGP propôs ainda a denominação de Granito Serra do Carambeí (e. g., Fuck 1967) e Granito Joaquim Murtinho (CCGP 1970 b) para dois corpos graníticos "alasquíticos" inscritos no Complexo Cunhaporanga. Estas unidades situam-se junto ao contato com o Grupo Castro, a primeira ao sul e a segunda ao norte.

O Granito Joaquim Murtinho teve uma caracterização superficial e deficiente por parte da CCGP (ver discussão mais detalhada em Guimarães 1995), resumindo-se à sua representação cartográfica na folha homônima (CCGP 1970 b) e breves comentários por parte de Muratori et al. (1970).

- Fuck (1967)

Ao relatar a geologia da Folha Abapã (ver localização na Figura 1.3), Fuck (1967) deixou claro (com riqueza ímpar de detalhes) que o termo "granito" Cunhaporanga possui um significado amplo. Este autor reconheceu uma marcante variação textural, estrutural e composicional das rochas granitóides, sendo mais comum "o granito porfiróide a biotita, com hornblenda subordinada" (Fuck 1967, p. 14), predominantemente isótropo. Outros termos presentes seriam hornblenda biotita granodioritos e, mais raramente, quartzomonzonitos e "rochas que tendem a dioritos" (Fuck 1967, p. 10).

Fiel às idéias "transformistas" de geração de corpos graníticos, ainda em voga nos anos 60, Fuck (1967) interpretou muscovita xistos e quartzitos inscritos no Complexo (e. g., nas localidades de Maracanã e Colônia Terra Nova ou compondo a Serra das Pedras), como remanescentes do processo de migmatização que teria formado o Granito Cunhaporanga. Epibolitos e embrechitos associados serviriam de suporte a este modelo genético. Entretanto, como será visto adiante, não existem rochas metamórficas de grau médio a alto no interior do Complexo (ou seja, verdadeiros gnaisses e migmatitos).

Ainda segundo Fuck (1967), nos locais em que o contato com as rochas do Grupo Açungui não se dá por falha não teriam sido observados sinais de metamorfismo 
de contato (apesar de descrever "asbestos tremolíticos" (Fuck 1967, p. 11) em metadolomitos da região de Taquaral). Deste modo o Granito Cunhaporanga não seria intrusivo, devendo portanto ser considerado mais antigo que o Grupo Açungui (concordando com Almeida 1957).

- Trein (inédito)

Dentro da área da Folha Itaiacoca (ver Figura 1.3) o Complexo Cunhaporanga ocupa uma parcela menor de seu quadrante noroeste (região de Serra Abaixo até o Rio Pitangui). Aqui Trein (inédito) destacou a ausência da textura porfiróide relatada por Fuck (1967), identificando exclusivamente rochas equigranulares médias a grossas, cinzas ou róseas. Discriminadas como pertencentes ao Granito Castrolanda (ver observação acima), estas rochas teriam teores de hornblenda superiores ao de biotita e "casos em que o quartzo entra em baixas porcentagens" (Trein inédito, p. 15).

De modo semelhante ao que se vê na descrição de Fuck (1967), Trein (inédito) parece relutante em admitir a existência de sinais de metamorfismo de contato do Complexo Cunhaporanga sobre rochas do Grupo Açungui. Um bom exemplo está no caso dos xistos, metarcósios e quartzitos com biotita na Serra Areias (próximo ao contato com o Complexo), onde o autor expressou que "a compreensão do fenômeno (grau metamórfico mais elevado) é mais difícil' (Trein, inédito, p. 28) em comparação aos "roof-pendants" inclusos no Complexo Três Córregos.

\section{- Fuck (inédito)}

Ao contrário do que havia sido apontado para as regiões de Abapã e Itaiacoca, os trabalhos da CCGP (Fuck inédito) nas Folhas de Campina dos Elias (por vezes denominada como Folha Jaguaricatu) e Socavão (ver Figura 1.3) identificaram relações intrusivas entre os granitóides do Complexo e suas encaixantes. Xistos e gnaisses ("resultantes do metamorfismo de contato dos granitos sôbre os filitos"; Fuck inédito, p. 4), mármores dolomíticos grosseiros com talco, tremolita centimétrica e serpentina, além de filões pegmatóides, ocorreriam desde Socavão até Campina dos Elias. 
Ao longo deste trecho os granitóides seriam equivalentes aos descritos por Fuck (1967) na Folha Abapã. No entanto, na região de Campina dos Elias-Lagoa, Fuck (inédito) citou a presença de um "corpo granítico, intrusivo tanto nos metassedimentos quanto no Granito Cunhaporanga" (Fuck, inédito, p. 5A e 6), constituído por rochas equigranulares claras, de granulação média a grossa, com pouca biotita.

- Fuck et al. (1967 a)

Reunindo as informações levantadas pelos diversos mapeamentos conduzidos pela CCGP acima citados, Fuck et al. (1967 a) trouxeram uma síntese do conhecimento acerca do Complexo Cunhaporanga. Quanto às relações de contato com suas encaixantes, descreveram-no como tendo "uma dualidade de caracteres, mostrando ao mesmo tempo, feições de granito circunscrito (intrusivo) tardi a postcinemático, e de granito difuso (anatéctico, sincinemático), sendo, portanto, um granito de tipo intermediário" (Fuck et al. 1967 a, p. 194).

Fuck (1967) e Fuck et al. (1967 a) chamaram a atenção para diferenças composicionais e texturais marcantes entre o Granito Cunhaporanga e o Granito Serra do Carambeí, destacando-se para este último granulação média, coloração rósea, biotita como máfico predominante $(\leq 5 \%)$ e teor de feldspato potássico sempre superior ao de plagioclásio. As relações de contato "não puderam ser claramente evidenciadas" (Fuck et al. 1967 a, p. 195), pois as mesmas ora seriam tectônicas ora pareceriam ser transicionais.

\subsubsection{Trabalhos do período 1970-1980 (Fase da Companhia de Pesquisa de Recursos Minerais)}

Logo após o encerramento das atividades da CCGP, a tarefa de obtenção de dados geológicos na área do embasamento paranaense foi conduzida quase exclusivamente pela Companhia de Pesquisa de Recursos Minerais (CPRM). No que diz respeito ao Complexo Cunhaporanga, são de interesse os seguintes projetos: Projeto Sudeste do Estado de São Paulo - SUDELPA (CPRM 1972 a, b; Kaefer \& 
Cunha 1974), Projeto Aerogeofísico Serra do Mar Sul (ver Capítulo 3) e o Projeto Leste do Estado Paraná (CPRM 1977 a, b, c, e). A partir destes trabalhos tornou-se mais comum o emprego de "Complexo" ao invés de "Granito" (ver discussão no item 2.1.6).

Antes da divulgação dos trabalhos da CPRM, foram colocados a público, durante $\circ 25^{\circ}$ Congresso Brasileiro de Geologia, os resultados dos mapeamentos executados pela PROTEC (Projetos Técnicos e Obras de Engenharia Ltda.) na região do Vale do Ribeira (Gomes et al. 1971 a, b). Esta empresa, contratada pelo DNPM durante a execução do Projeto Ribeira, individualizou do restante do Complexo Cunhaporanga o Granito Vila Branca, posteriormente denominado de Granito Francisco Simas (e. g., Ribas 1981).

- $\operatorname{CPRM}(1972 a, b)$

Durante o levantamento da geologia da Folha de Itararé (1:250.000) na região entre Varzeão (Dr. Ulysses) e Ouro Verde, a CPRM (1972 a) relatou o predomínio de granitóides equigranulares grosseiros, apenas localmente porfiríticos. Estes seriam principalmente granodioritos e quartzomonzonitos (em menor proporção granitos), com biotita como o mineral máfico mais abundante e hornblenda, muscovita, fluorita, zircão, allanita, dentre outros, como acessórios.

A afirmação de que haveria uma quantidade expressiva de rochas quartzomonzoníticas deve ser encarada com cautela. Aparentemente o significado do termo "quartzomonzonito" no relatório da CPRM não é o mesmo daquele sugerido por Streckeisen (1976). Com efeito, na definição dada por Le Maitre et al. (1989) para "quartzo monzonito", existe o comentário de que este termo foi utilizado, no passado, para designar rochas de composição monzogranítica. Este seria o caso da amostra JP-481a, classificada como um quartzomonzonito pela CPRM (1972 b) e que na realidade é um monzogranito rico em quartzo (Figura 2.2). 


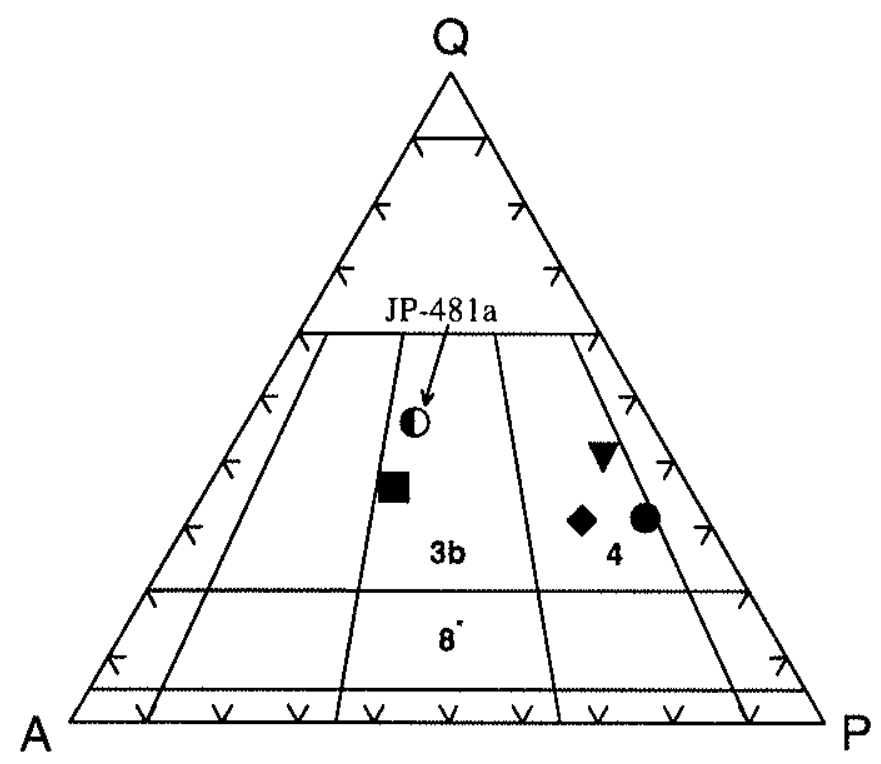

Figura 2.2: Diagrama modal QAP para rochas granitóides do Complexo Cunhaporanga da região de Varzeão, construído a partir de análises modais presentes em CPRM (1972 b). Campos 3b, 4 e $\mathbf{8}^{*}$, correspondem aos campos dos monzogranitos, granodioritos e quartzomonzonitos, segundo Streckeisen (1976).

Similaridade petrográfica e proximidade com o Complexo Granítico Três Córregos, por vezes distante menos de $5 \mathrm{~km}$, levaram a CPRM (1972 a) a imaginar uma conexão em profundidade com o Complexo Cunhaporanga. Hoje sabe-se que este tipo de conjectura é temerária, uma vez que os Complexos estão em terrenos separados pela Zona de Cisalhamento Itapirapuã (CPRM 1977 c) e portanto não evoluíram necessariamente de maneira sincrônica.

Os Granitos Vila Branca (PROTEC 1969, in CPRM 1972 a; Gomes et al. 1971 a, b) e Joaquim Murtinho (CCGP 1970 d) foram considerados no relatório da CPRM (1972 a) como "variações petrográficas do Granito Cunhaporanga" (CPRM 1972 a, p. 79), o que, para os autores do estudo em questão, serviria de justificativa para que as unidades deixassem de ser individualizadas. Apesar do critério empregado ser questionável, é fato que ao menos o emprego do termo "Granito Joaquim Murtinho" nesta região é inadequado (ver discussão em Guimarães 1995). 
- Kaefer \& Cunha (1974)

Provavelmente com o objetivo de melhor compreender o panorama geológico do território paulista, a CPRM estendeu o Projeto SUDELPA para o estado do Paraná, mais especificamente para o terço oriental da Folha Castro (1:250.000). O setor estudado englobou quase totalmente a área de ocorrência do Complexo Cunhaporanga (Kaefer \& Cunha 1974).

As observações de Kaefer \& Cunha (1974) não deixam dúvidas sobre a natureza intrusiva do contato das rochas granitóides com os metassedimentos do Grupo Açungui (Faixa Itaiacoca). Além de interpretarem lentes quartzíticas inscritas no Complexo como restos-de-teto, descreveram diopsídio-flogopita mármores, diopsídiotremolita mármores e quiastolita xistos nas regiões de Abapã e Lageado e em cortes de ferrovia "no nordeste da Quadrícula de Piraí do Sul" (Kaefer \& Cunha 1974, p. 196), ou seja, na região de Campina dos Elias-Jacuzal. Apenas localmente haveriam contatos por falha.

Assim como outros autores (e. g., Fuck 1967), Kaefer \& Cunha (1974) chamaram a atenção para a variedade de texturas e colorações dos granitóides do Complexo, ressaltando o predomínio de rochas cinza-rosadas porfiríticas. A única unidade granítica discriminada do restante do Complexo Cunhaporanga foi o Granito Serra do Carambeí, não sendo feita nenhuma menção a outras unidades, como por exemplo, o Granito Joaquim Murtinho.

- Gomes et al. (1975 a, b)

Os primeiros resultados de análises químicas de rochas granitóides do Complexo Cunhaporanga foram publicados por Gomes et al. (1975 a, b). A julgar pelo mapa de localização, as duas amostras investigadas foram coletadas próximo à Canastrão, na Folha Ouro Verde (ver Anexo 2 e Figura 1.3).

Tomando por base um conjunto de análises quimicas para diversas rochas ígneas publicado por Nockolds (1954), Gomes et al. (1975 a) consideraram o 
Complexo Cunhaporanga (assim como Três Córregos e Itaoca) como "sendo de natureza adamellítica" (Gomes et al. 1975 a, p. 129). No artigo de Nockolds (1954), adamellitos seriam rochas plutônicas com teores de quartzo superior a $10 \%$ e feldspato potássico entre 60 e $40 \%$ do total dos feldspatos.

Valores de $\mathrm{Na}_{2} \mathrm{O}$ sistematicamente superiores aos dos adamellitos de Nockolds (1954) foram apontados pelos autores. Antes de indicar uma particularidade geoquímica da região, este padrão possivelmente seria decorrente da imprecisão do método analítico utilizado (absorção atômica).

- $\operatorname{CPRM}(1977 c, d)$

No relatório referente ao mapa geológico da Folha Piraí do Sul, escala 1:100.000 (CPRM 1977 c), a descrição do Complexo Cunhaporanga é basicamente semelhante às apresentadas por Fuck et al. (1967 a) e Kaefer \& Cunha (1974). Já no que diz respeito às relações entre as rochas graníticas e os metamorfitos, sejam do Grupo Açungui ou das rochas inscritas no Complexo, os autores não demonstraram convicção. A despeito de considerarem o Complexo como "sintectônico com remobilizações tarditectônicas" (CPRM 1977 c, p. 65), em algumas passagens deixaram em aberto a possibilidade que o Complexo tivesse servido de embasamento para rochas do Grupo Açungui: "uma série de circunstâncias fazem plausíveis várias outras conjecturas, (como) estar em presença do Complexo Cristalino, base do Grupo Açungui" (CPRM 1977 c; p. 66).

Uma idade $\mathrm{Rb}-\mathrm{Sr}$ (rocha total) para o Granito Serra do Carambeí, interpretado como intrusivo no Complexo Cunhaporanga, teria indicado o valor de $543 \pm 25 \mathrm{Ma}$. Este valor possivelmente precisaria ser reavaliado com o uso das constantes de decaimento propostas por Steiger \& Jager (1977). A amostra (IL-295 b), coletada na localidade de Catanduva de Fora (CPRM 1977 d), provém do ponto aqui denominado como SC-29 (ver mapa de pontos, Anexo 2).

Apesar do texto não fazer menção a determinações geocronológicas em outros granitóides do Complexo Cunhaporanga, consta da ficha do afloramento IL-299 
(equivalente ao ponto PS-18; ver mapa de pontos, Anexo 2) uma idade K-Ar em biotita de $603 \pm 42 \mathrm{Ma}$ (CPRM 1977 d).

\subsubsection{Trabalhos do período 1980-1989 (Fase da Minerais do Paraná S. A)}

No que se refere a atividades de mapeamento geológico regional no embasamento paranaense, viveu-se durante a década de 80 o período de máxima atividade da Minerais do Paraná S. A. (MINEROPAR). Para a área aqui analisada destacam-se o relatório de Ribas (1981) sobre todo o Complexo Cunhaporanga e os estudos conduzidos no Granito Serra do Carambeí (Santos \& Felipe 1980; PintoCoelho 1986; Pinto-Coelho \& Marini 1986; Pinto-Coelho 1987; Pinto-Coelho 1988; Pinto-Coelho \& Siedlecki 1988; Pinto-Coelho et al. 1988).

- Santos \& Felipe (1980)

Dentro do Projeto Granitos da MINEROPAR, o Granito Serra do Carambeí foi uma das unidades cujo potencial metalogenético foi investigado (Santos \& Felipe 1980). A caracterização geológica do maciço baseou-se em dados de superfície e na descrição de testemunhos de sondagem $(2047 \mathrm{~m})$, os quais foram obtidos pela Comissão Nacional de Energia Nuclear (CNEN) no início da década de 70 , em convênio com a CPRM .

Estas perfurações foram executadas no setor sudoeste do granito, entre Sítio Grande e o Rio Moquém (ver Anexo 2). Ao final do relatório, Santos \& Felipe (1980) concluíram que tratava-se de um alvo com baixo interesse econômico.

Segundo este estudo as rochas do Complexo Cunhaporanga na região "variam dos termos granodiorito gnáissico a biotita-hornblenda tonalito, biotita granito a hornblenda-quartzo monzodiorito" (Santos \& Felipe 1980, p. 12), estando em contato com o Granito Serra do Carambeí através de um sistema de falhamentos ortogonais.

A natureza intrusiva do Granito Serra do Carambeí estaria evidenciada por xenólitos de outros granitos do Complexo Cunhaporanga, coletados na pedreira J. 
Cardoso (ponto SC-29; ver mapa de pontos, Anexo 2). Estes xenólitos seriam de uma rocha descrita como um "granito porfiróide constituído de megacristais de feldspato branco, de até $10 \mathrm{~cm}$ de aresta" (Santos \& Felipe 1980, p. 9).

- Ribas (1981)

Dentro da estratégia da MINEROPAR de caracterização petrográfica e ecônomica dos granitos paranaenses, o Complexo Granítico Cunhaporanga foi alvo de um estudo de reconhecimento regional no início dos anos 80 (Ribas 1981).

O trabalho de Ribas (1981) tem o mérito de conter a única tentativa de discriminação em mapa dos tipos petrográficos de todo o Complexo Cunhaporanga. Um primeiro mapa separa as rochas de acordo com critérios texturais, enquanto que o outro traz divisões em termos de composição modal.

No entanto há uma severa restrição aos procedimentos de obtenção das modas, as quais serviram de base para a construção do segundo mapa. Além dos valores terem sido meramente estimados (não foram feitas contagens como as propostas por Chayes 1949), para as rochas com fenocristais os números obtidos corresponderiam apenas aos das composições das matrizes. Este procedimento torna-se mais crítico se for lembrado que, segundo o autor, estes litotipos seriam os mais representativos do Complexo.

Ao contrário do que está registrado em trabalhos como o de Kaefer \& Cunha (1974), os contatos do Complexo Cunhaporanga com o Grupo Itaiacoca foram considerados como predominantemente por falhas, excetuando-se o setor nordeste da área.

Os Granitos Serra do Carambeí, Joaquim Murtinho e Francisco Simas foram interpretados como tardi a pós-tectônicos e tratados a parte do restante do Complexo. Correlacionáveis a estas unidades seriam também alguns diques e stocks micrograníticos das localidades de Caçador, Capinzal e Sertãozinho (ver Anexo 2). 
Segundo Ribas (1981), estes diques não estariam confinados aos limites do Complexo Cunhaporanga, havendo também aqueles que cortariam rochas do Grupo Itaiacoca.

Entre as três unidades acima citadas, o Granito Francisco Simas foi quem recebeu maior atenção no relatório de Ribas (1981). Para este autor esta unidade afloraria como "três apófises graníticas em meio a metassedimentos da Formação Itaiacoca, na região entre as localidades de Vila Branca (hoje Dr. Ulysses) e Campina dos Elias" (Ribas 1981, sem paginação).

Das três "apófises graníticas" citadas, foi para aquela situada mais a leste que a PROTEC (1969 in CPRM 1972 a) propôs a denominação de Granito Vila Branca. No entanto, o texto de Ribas (1981) não traz explicações sobre os motivos que o levaram a utilizar a denominação "Francisco Simas" em lugar de "Vila Branca". Na verdade não está claro nem mesmo quem teria empregado pela primeira vez o nome "Francisco Simas".

O Granito Francisco Simas seria constituído por monzogranitos a granodioritos equigranulares grosseiros, cinza-esbranquiçados a róseo-avermelhados, com biotita, clorita e titanita como minerais máficos principais, além de fluorita e muscovita como acessórios comuns. O granito ainda estaria acompanhado por uma importante fase de atividade tardi-magmática, registrada na forma de pegmatitos, hematitização e, localmente, greisenização (Ribas 1981).

- Pinto-Coelho (1986)

Apesar da sugestão de Santos \& Felipe (1980) de que o Granito Serra do Carambeí seria pouco interessante do ponto de vista econômico, a existência de setores radioanômalos na borda sudoeste do corpo estimularam Pinto-Coelho (1986) a uma avaliação mais pormenorizada da unidade.

A dissertação da autora foi desdobrada subseqüentemente em diversos trabalhos. Em Pinto-Coelho \& Marini (1986) tem-se uma comparação entre os padrões de elementos terras-raras do Granito Serra do Carambeí e os de diques "riolíticos" nele 
intrusivos, de um riolito do Grupo Castro e também de uma amostra denominada de fácies porfiróide do Complexo Granítico Cunhaporanga (coletada na região do Rincão do Cafequi, próximo ao ponto SC-30; ver mapa de pontos, Anexo 2).

Dentre as principais conclusões dos autores, destacam-se: a) ० Granito Serra do Carambeí e o Complexo Granítico Cunhaporanga teriam se originado por "processos genéticos e evolutivos distintos" (Pinto-Coelho \& Marini 1986, p. 1317); b) haveria uma "consangüinidade entre o Granito Serra do Carambeí e os "riolitos" associados" (Pinto-Coelho \& Marini 1986, p. 1317); c) seria improvável que os riolitos do Grupo Castro fossem co-genéticos ao Granito Serra do Carambeí ou às rochas "riolíticas" a ele vinculadas.

No entanto deve-se ressalvar que a última das três afirmações de Pinto-Coelho \& Marini (1986) não encontra respaldo nos padrões de distribuição de elementos terras-raras de riolitos analisados por Moro (1993).

A caracterização petrográfica e petroquímica do Granito Serra do Carambeí, neste último caso discutindo o comportamento de elementos maiores e traços além dos elementos terras-raras, foi dada em Pinto-Coelho (1987). A autora chamou a atenção para a homogeneidade faciológica da unidade (ver também Fuck et al. 1967a e Santos \& Felipe 1980) e as diferenças entre os resultados analíticos obtidos em rochas coletadas na superfície, de aspecto inalterado, quando comparados aos de testemunhos de sondagem (ver discussão mais detalhada em Pinto-Coelho 1988). O caráter alcalino identificado nos dados litoquímicos também foi apurado no estudo tipológico de zircão destas rochas (Pinto-Coelho et al. 1988).

A distribuição de elementos radioativos no Granito Serra do Carambeí e nos diques "riolíticos" foi abordada por Pinto-Coelho \& Siedlecki (1988). Este trabalho considerou a maior parte do urânio destas rochas como do tipo solúvel, ou seja, concentrado ao longo de planos de fratura e/ou clivagem mineral, ou ainda ao longo das superfícies de contato entre os minerais essenciais. Os teores de urânio fixo (retido na estrutura de minerais como, por exemplo, zircão) corresponderiam a 
aproximadamente $32 \%$ no caso do Granito Serra do Carambeí e $41 \%$ para os diques "riolíticos".

- Soares et al. (1987)

Ao descreverem a geologia do Grupo Itaiacoca na região de Palmeirinha de Baixo ao Bairro São Domingos, junto à divisa Paraná-São Paulo, Soares et al. (1987) relataram a presença de um corpo granítico de composição adamelítica, por eles denominado de Granito São Domingos. Este mesmo conjunto litológico foi tratado posteriormente como uma fácies do Complexo Granítico Cunhaporanga (Souza 1990; ver adiante).

Esta unidade foi subdividida em quatro zonas $(\gamma 1$ a $\gamma 4)$, distinguidas entre si pela intensidade na alteração hidrotermal, crescente de SW para NE. Os contatos com rochas consideradas como pertencentes à Formação Água Clara seriam "na maior parte tectônicos e localmente intrusivos" (Soares et al. 1987, p. 251).

- Biondi et al. (1989)

Uma boa prova do empenho da MINEROPAR em contribuir para o avanço do conhecimento da Geologia do Paraná está materializada nos mapas geológicos por ela produzidos. A despeito de diversas críticas que possam ser feitas aos produtos finais (os mapas), a empresa merece o aplauso por ter ocupado uma lacuna na tarefa de execução de levantamentos ou compilações geológicas nesta parte do país.

Como uma espécie de marco a simbolizar uma mudança na filosofia de atuação da empresa, deixando-se para trás um período em que houve uma maior ênfase em prospecção e no reconhecimento geológico regional, Biondi et al. (1989) publicaram o Mapa Geológico do Estado do Paraná, na escala 1: 650.000.

$\mathrm{Na}$ legenda deste mapa o magmatismo ácido brasiliano é agrupado em uma "Suíte granítica-cornubianítica brasiliana" de idade proterozóica/paleozóica, formada por cinco categorias: Migmatitos e Granitos de anatexia brasilianos; Granitos 
porfiríticos (Três Córregos e Cunhaporanga); Granitos alaskitos (Serra do Carambeí e Joaquim Murtinho); Granitos/Sieno-granitos (Cerne, Francisco Simas, São Domingos, etc., além de corpos sem denominação); Granitos subalcalinos e alcalinos (Graciosa, Marumbi, Agudos, etc. e outros corpos sem nome).

$\mathrm{Na}$ área do Complexo Granítico Cunhaporanga apenas a categoria dos Granitos subalcalinos e alcalinos não está representada, predominando a simbologia reservada aos Granitos porfiríticos. Além dos Granitos Serra do Carambeí, Joaquim Murtinho e Francisco Simas, foram individualizados na região entre Capinzal e Sertão de Cima domínios sem nome específico (norte do Complexo; ver mapa de pontos, no Anexo 2, para localização). Este conjunto de domínios havia sido designado por Fritzsons Jr. \& Biondi (1983), com base nos trabalhos de Ribas (1981), como "Cunhaporanga (equigranular 1)" (Fritzsons Jr. \& Biondi 1983, p. 283).

O setor "Cunhaporanga (equigranular 2)" (Fritzsons Jr. \& Biondi 1983, p. 283) foi chamado por Biondi et al. (1989) de Granito São Domingos. Entretanto, considerandose o mapa geológico de Soares et al. (1987), apenas uma pequena parcela deste setor seria correspondente à unidade São Domingos.

Dentre outros pontos interessantes, no mapa de Biondi et al. (1989) ० Complexo Cunhaporanga não faz contato a leste exclusivamente com o Grupo Itaiacoca. Na região entre Passo das Antas e Campina dos Elias, assim como no norte-nordeste do Complexo, o mapa simboliza a presença de rochas da Formação Água Clara, considerada como de idade mesoproterozóica e pertencente ao Grupo Setuva.

\subsubsection{Trabalhos posteriores a 1989 (Fase atual)}

Na década de 90 o Complexo Granítico Cunhaporanga passou a ser investigado quase exclusivamente por pesquisadores ligados a universidades (e. g., Souza 1990; Wernick et al. 1990 a, b; Reis Neto 1994; Guimarães 1995; Guimarães \& Ulbrich 1999). As ferramentas de estudo foram variadas, incluindo mapeamento faciológico (Guimarães 1995), geoquímica das rochas granitóides (Wernick et al. 1990 a, b; Reis Neto 1994; Guimarães \& Ulbrich 1999), geologia isotópica/geocronologia (Reis Neto 
1994), tipologia de zircões (Wernick et al. 1990 a) e aerogeofísica (Guimarães et al. $1997 \mathrm{a}, \mathrm{b})$.

- Souza (1990)

Souza (1990) mapeou uma região na divisa dos estados do Paraná e São Paulo, ao sul de Itararé, onde as principais unidades geológicas encontradas foram o Grupo Itaiacoca e os Complexos Cunhaporanga e Três Córregos.

Este autor subdividiu o Complexo Cunhaporanga em fácies Ouro Verde e São Domingos, intrusivas em metassedimentos do Grupo Itaiacoca. Uma das evidências de metamorfismo de contato seriam porfiroblastos de andaluzita em quartzo-muscovitabiotita xistos (ponto 5 de Souza 1990; situado na estrada Ouro Verde-Pinhalzinho, entre os pontos IT-8 e IT-9; ver mapa de pontos, Anexo 2).

É difícil saber qual a composição modal das fácies granitóides, pois a tabela em que são descritas suas características principais é, no mínimo, confusa (Tabela 9 de Souza 1990, p. 162).

Um muscovita-biotita gnaisse coletado junto a confluência dos córregos Taquaruçu e Ribeirãozinho (próximo ao ponto IT-58; ver mapa de pontos, Anexo 2), considerado como um enclave no Complexo, foi datado pelo método $\mathrm{Rb}-\mathrm{Sr}$ em rocha total. Apesar do bom alinhamento das análises no diagrama isocrônico (5 pontos, com MSWD $=0,693014)$, o espalhamento foi baixo, resultando em um erro elevado. $A$ idade de $642 \pm 78 \mathrm{Ma}\left(\mathrm{R}_{0}=0,74302\right)$ foi interpretada como de "rejuvenescimento do enclave, provocado pela intrusão do granito que o contém" (Souza 1990, p. 164).

- Wernick et al. (1990 a, b)

Wernick et al. (1990 a, b) apresentaram um conjunto de dados geológicos, petrográficos, químicos e de tipologia de zircão dos Complexos Cunhaporanga e Três Córregos, a partir dos quais efetuaram uma série de considerações petrológicas e geotectônicas. No caso do Complexo Cunhaporanga os autores reportaram a 
execução de 29 análises geoquímicas por fluorescência de raios X. Mas, infelizmente, não localizaram os pontos de coleta das amostras estudadas.

Uma parte expressiva das descrições geológicas e petrográficas de Wernick et al. (1990 b) para o Complexo Cunhaporanga, assim como dos padrões geoquímicos vistos nas figuras de seu texto, coincide com o que está exposto nos Capítulos 4 e 6 desta tese. Nestes capítulos serão exploradas algumas das semelhanças e diferenças observadas.

Wernick et al. (1990 b) concluíram que seus dados apontariam "um caráter mais aluminoso e geneticamente mais raso para o complexo Cunhaporanga e uma maior participação de material mantélico na gênese do complexo Três Córregos" (Wernick et al. 1990 b, p. 74).

Assumindo que os Complexos seriam aproximadamente sincrônicos e desenvolvidos em um ambiente de arco magmático, aderiram à idéia de Soares (1987), na qual esta região comportaria "uma paleozona de subducção cuja sutura estaria situada por debaixo da Bacia do Paraná e cujo mergulho seria para SE' (Wernick et al. 1990 b, p. 82).

- Reis Neto (1994)

Com base em um conjunto diversificado de dados (geológicos, petrográficos, geoquímicos, isotópicos e geocronológicos), Reis Neto (1994) procurou reconstruir a história geológica da Faixa Itaiacoca e dos Complexos graníticos adjacentes (Cunhaporanga e Três Córregos).

No que diz respeito ao Complexo Cunhaporanga, este autor reconheceu a existência de três grupos litológicos: rochas gnáissicas (denominadas informalmente como Gnaisses Piraí do Sul), graníticas e riolíticas. Os "gnaisses" seriam equivalentes às rochas de grau metamórfico mais elevado descritas por Fuck (1967) ao redor do "Quartzito Serra das Pedras". Já os "riolitos" seriam rochas de aspecto subvulcânico, intrusivas tanto nos granitos do Complexo como em metadolomitos da Faixa Itaiacoca. 
O número de amostras provenientes do Complexo e efetivamente estudadas por Reis Neto (1994) foi baixo, consistindo em um "gnaisse" (equivalente ao ponto PS-5; ver mapa de pontos, Anexo 2), dois "granitos" (PS-19 e PS-21) e dois "riolitos" (ITA-072/PS-103 e ITA-4-115).

Dos métodos geocronológicos/isotópicos empregados por Reis Neto $(\mathrm{Rb}-\mathrm{Sr}, \mathrm{Pb}$ $\mathrm{Pb}$ e $\mathrm{Sm}-\mathrm{Nd}$, todos em rocha-total), provavelmente apenas no caso do $\mathrm{Sm}-\mathrm{Nd}$ os dados do Complexo têm uma interpretação geológica mais imediata ( $\varepsilon \mathrm{Nd}$ como indicador petrogenético). As idades $\mathrm{Rb}-\mathrm{Sr}$ têm sempre algum tipo de problema, ou erros elevados (e. g, $617 \pm 406 \mathrm{Ma}$ para as rochas granítcas do ponto aqui denominado como PS-21) ou então foram obtidas em rochas com evidências significativas de processos tardi-magmáticos (como para os "gnaisses").

No modelo geotectônico proposto por Reis Neto (1994) os Complexos Três Córregos e Cunhaporanga representariam "as raizes de dois arcos magmáticos gerados (...) durante o Ciclo Brasiliano" (Reis Neto 1994, p. 235), cada qual em um bloco continental diferente.

- Guimarães (1995)

Ao estudar a área representada na Folha Geológica Joaquim Murtinho (CCGP 1970 b) pelo granito homônimo, assim como as unidades geológicas adjacentes, Guimarães (1995) subdividiu as rochas granitóides do Complexo Cunhaporanga em cinco associações de fácies.

Guimarães (1995) discutiu também as deficiências na proposição da unidade "Granito Joaquim Murtinho" por parte da Comissão da Carta Geológica do Paraná, sugerindo reservar a denominação formal apenas às rochas pertencentes às associações de fácies $N$ e (ver Guimarães \& Ulbrich 1996).

Considerando aspectos petrográficos e geológicos, Guimarães (1995) encontrou semelhanças por parte do Granito Joaquim Murtinho com os granitos tipo-A da 
literatura (e. g., Collins et al. 1982). Já no caso das rochas da associação de fácies /, haveria equivalência com granitos do tipo-I de Chappell \& White (1974).

\section{- Guimarães et al. (1997 a, b)}

Observações preliminares a respeito do comportamento magnetométrico e gamaespectrométrico do Complexo Cunhaporanga e adjacências foram trazidas por Guimarães et al. (1997 a, b). Estes autores chamaram a atenção para o grande potencial do Projeto Aerogeofísico Serra do Mar Sul como ferramenta de auxílio no mapeamento geológico regional, mesmo tendo em vista as limitações específicas deste levantamento geofísico (ver discussões sobre os problemas do projeto em Silva 1994 e Silva \& Mantovani 1994). Os padrões identificados serão discutidos com mais profundidade no Capítulo 3 e nos Anexos 4 e 5 .

\section{- Guimarães \& Ulbrich (1999)}

De modo equivalente ao que foi feito para os dados geofísicos, Guimarães \& Ulbrich (1999) trouxeram algumas considerações iniciais sobre a geoquímica das rochas granitóides do Complexo Cunhaporanga. Uma caracterização mais detalhada poderá ser encontrada no Capítulo 6 (ver adiante).

\subsubsection{O Complexo Granítico Cunhaporanga como unidade litoestratigráfica}

Tomando-se por base o que está exposto nas normas de nomenclatura estratigráfica brasileira e internacional (Comissão Especial de Nomenclatura Estratigráfica 1986; Salvador 1987, 1988, 1994), o conjunto de rochas "Cunhaporanga" atende os princípos básicos para ser enquadrada como uma unidade da classe litoestratigráfica.

Apesar de alguns autores considerarem aceitável o uso de "formação", "grupo" ou "membro" para rochas ígneas intrusivas não estratificadas (ver comentário em Salvador 1987), a maior parte da comunidade geocientífica prefere evitar esta prática. Alternativamente sugerem-se termos litológicos mais simples ("gabro", "granito", etc.) e 
que indiquem o tipo de rocha predominante. Para situações em que exista uma marcante heterogeneidade composicional, ou em que as relações estratigráficas entre diferentes tipos litológicos estejam precariamente estabelecidas, aconselha-se usar o termo "complexo". A última versão do Guia Estratigráfico Internacional (Salvador 1994) rejeita "suíte" como unidade litoestratigráfica formal (ver discussão em Bateman 1988 e réplica em Salvador 1988), em contraposição ao que prevê o Código Brasileiro de Nomenclatura Estratigráfica (Comissão Especial de Nomenclatura Estratigráfica 1986).

Como a unidade Cunhaporanga comporta uma grande diversidade composicional, textural e estrutural de rochas graníticas, além de mega-enclaves de rochas metamórficas, parece plenamente justificável que se empregue a designação formal "Complexo Granítico" ao invés de "Granito". No entanto é difícil determinar quem foram os autores responsáveis por esta modificação, podendo-se apenas trazer um histórico com os trabalhos que primeiro usaram a denominação "complexo".

Fuck (1967) utilizou a expressão "complexo granítico" (com letras minúsculas) aparentemente sem uma conotação de nomenclatura de unidade litoestratigráfica, reservando para este fim o termo "Granito" (letra maiúscula): "De um modo geral, as rochas do complexo granítico Cunhaporanga são isótropas, isto é, não apresentam propriedades direcionais. (...) Ao contrário do Granito Cunhaporanga, o Granito Serra do Carambei aflora com grande facilidade." (Fuck 1967, p. 14-15).

A CPRM (1972 a), ao discutir as rochas graníticas da região entre Varzeão e Ouro Verde, as incluíram no item "Complexo Granítico Cunhaporanga". Apesar disto, ao longo do texto, fizeram uso das palavras "Granito" e "Batólito", mas não de "Complexo": "O Granito Cunhaporanga aflora na extremidade oeste da folha (...) aparente passagem gradual de rochas graníticas do Batólito Cunhaporanga para migmatitos (...)" (CPRM 1972 a, p. 78 e 80). Comportamento semelhante pode ser encontrado em Kaefer \& Cunha (1974), porém com os termos "granito", "batólito" e "complexo" grafados em letra minúscula. 
Já nos mapas e relatórios do Projeto Leste do Paraná (e. g., CPRM 1977, b, c) a denominação "Complexo Granítico Cunhaporanga" é a única utilizada, estabelecendo um procedimento que passou a ser seguido por grande parte dos autores subseqüentes (e. g., Ribas 1981; Pinto-Coelho 1986; Guimarães 1995).

\subsection{Outras unidades geológicas da região}

\subsubsection{Grupo Itaiacoca}

Entre os Complexos Graníticos Cunhaporanga e Três Córregos ocorre um espesso pacote redobrado de rochas de baixo grau metamórfico, alongado na direção N40E (Figura 2.1). O conjunto, por vezes considerado como integrante do Grupo/Série Açungui (e. g., Bigarella 1947), foi denominado por Almeida (1956, 1957) como Formação Itaiacoca e, após mapeamentos adicionais na parte meridional do estado de São Paulo, como Grupo Itaiacoca (IPT 1985). Mais recentemente, tem-se empregado a designação informal de Faixa Itaiacoca para este conjunto (e. g., Reis Neto 1994).

São reconhecidos ao longo da faixa metassedimentos carbonáticos (normalmente dolomíticos), pelíticos e psamíticos (metarcósios e metarenitos), além de rochas metavulcânicas (metatraquitos a metabasaltos) e meta-subvulcânicas (principalmente metadiabásios) (Soares et al. 1987; Souza 1990; Prazeres et al. 1998). O metamorfismo foi pouco intenso, atingindo apenas a zona da clorita da fácies xisto verde, sendo comuns estruturas primárias reliquiares (estromatólitos, estratificações cruzadas, amígdalas, etc.).

\subsubsection{1 "Quartzito Serra das Pedras" e congêneres}

O "Quartzito Serra das Pedras" (Muratori inédito in Fuck 1967) é constituído por metarcósios e metarenitos quartzosos, de granulação média a grossa, com grandes quantidades de material caulinítico intercalado (metatufitos alterados ?). A denominação aplica-se às rochas aflorantes num grande "teto-pendente" sobre as 
rochas graníticas do Complexo Cunhaporanga (Kaefer e Cunha 1974; Guimarães 1995), situando-se próximo ao contato com a bacia do Grupo Castro.

Ao longo de todo o Complexo Cunhaporanga, mas em especial em sua porção nordeste, observam-se várias exposições de rochas "quartzíticas" semelhantes ao "Quartzito Serra das Pedras", provavelmente a ele correlatas. Segundo Soares et al. (1987), esta correlação se estenderia aos demais corpos de metarcósios existentes dentro do Grupo Itaiacoca.

\subsubsection{Complexo Granítico Três Córregos}

Localizado no leste do Paraná e adentrando no sul de São Paulo como uma faixa de orientação NE-SW, o Complexo Três Córregos (Fuck 1966; CPRM 1972 a) constitui uma massa batolítica de aproximadamente $3700 \mathrm{~km}^{2}$ (Figura 2.1). No Paraná, seu limite a oeste com rochas do Grupo Itaiacoca é essencialmente tectônico (ZCl), enquanto que a leste pode justapor-se à Formação Água Clara e ao Grupo Açungui, tectonicamente ou de forma intrusiva. Assim como o Complexo Cunhaporanga, é recoberto a sudoeste e nordeste pela Bacia do Paraná.

Predominam rochas granitóides cálcio-alcalinas variadas, geralmente porfiríticas, entremeadas por grandes porções de rochas encaixantes na forma de "restos-de-teto" (Fuck et al. 1967 b).

Os parâmetros geoquímicos e petrográficos, aliados às idades $\mathrm{Rb}-\mathrm{Sr}$ e $\mathrm{K}-\mathrm{Ar}$ obtidas por Gimenez Filho (1993) no estado de São Paulo, levaram-no a propor a existência de um "arco magmático Três Córregos" durante o período de $650 \mathrm{Ma}$ e 800 $\mathrm{Ma}$, com manifestações pós-tectônicas entre $560 \mathrm{Ma}$ e $600 \mathrm{Ma}$. Reis Neto (1994) identificou no estado do Paraná unidades similares às encontradas em São Paulo, com as idades radiométricas correspondendo, em geral, às referidas por Gimenez Filho (1993).

$\mathrm{Na}$ região considerada neste estudo, as rochas encaixantes do Complexo Três Córregos, presentes como "tetos-pendentes", pertencem à Formação Água Clara 
(Marini et al. 1967 b). Ela diferencia-se do Grupo Itaiacoca pelo grau metamórfico mais elevado (fácies xisto verde alta a anfibolito) e por uma maior complexidade estrutural. Os principais litotipos observados são rochas cálcio-silicáticas (meta-margas), muscovita granada-xistos, anfibolitos e quartzitos.

\subsubsection{Grupo Castro}

O Grupo Castro (Trein \& Fuck 1967) situa-se no extremo noroeste da área de embasamento da Bacia do Paraná, ocupando aproximadamente $740 \mathrm{~km}^{2}$ (Figura 2.1). A unidade, a oeste, é recoberta discordantemente pelos sedimentos da Formação Furnas; a leste, apresenta contatos discordantes intrusivos, em parte tectônicos, com o Complexo Cunhaporanga.

Moro (1993) reconheceu quatro associações no Grupo: a vulcânica intermediária-ácida, a sedimentar inferior (em parte, considerada contemporânea à primeira), a sedimentar superior e uma associação vulcânica ácida.

As unidades vulcânicas são constituidas por riolitos, andesitos e rochas piroclásticas diversas. As rochas sedimentares são essencialmente clásticas, imaturas, de deposição continental (conglomerados, arcósios, siltitos e lamitos).

Classificada como uma molassa do final do Ciclo Brasiliano, a bacia do Grupo Castro ainda é pouco conhecida geocronologicamente. Cordani et. al. (inédito) relataram uma idade de $543 \pm 12 \mathrm{Ma}$ obtida a partir de zircões de riolitos (U-Pb pelo método SHRIMP). Esta determinação diverge significativamente das obtidas por Moro (1993), pelo método $\mathrm{Rb}-\mathrm{Sr}$ (rocha-total em riolitos), com valores entre $440 \mathrm{Ma}$ e 470 Ma.

\subsubsection{Bacia do Paraná}

A Bacia do Paraná está representada na área de estudo pela Formação Furnas (Siluriano-Devoniano; Figura 2.1) e por diques máficos correlatos à Formação Serra Geral (Jurássico-Cretáceo). 
Com base em trabalhos de campo e também da análise de perfis de raios-gama de poços estratigráficos, Assine (1996) propôs a subdivisão da Formação Furnas em três membros, organizados da base para o topo em: a) unidade I, caracterizada por valores baixos de radioatividade, constituída predominantemente por arenitos médios a muito grossos, feldspáticos e/ou caulínicos, ocorrendo também arenitos conglomeráticos e conglomerados quartzosos; b) unidade II, com respostas radiométricas mais elevadas, formada por arenitos finos a grossos, mas principalmente médios, que podem gradar lateralmente para siltitos e/ou folhelhos ricos em muscovita. Mostra ainda intercalações de siltitos argilosos de alguns centímetros a dois metros de espessura, responsáveis pelo padrão serrilhado dos perfis (vários picos de alta intensidade); c) unidade III, com respostas radiométricas muito baixas, formada por arenitos médios a muito grossos, com lentes conglomeráticas e escassos níveis sílticoargilosos (exceto em direção ao topo).

Os diques, normalmente com espessuras centimétricas a decamétricas e orientação preferencial N40-60W, são compostos por diabásios equigranulares finos a médios (Marini et al. 1967a) ou, em menores proporções, dioritos e quartzo monzodioritos (Prazeres et al. 1998).

\subsubsection{Aluviōes}

Ao longo das drenagens do Rio lapó e seus afluentes, sedimentos ocupam extensas planícies aluviais, parcialmente cobertas por água; segundo Ribas (1981), seriam constituídos por material areno-argiloso a turfáceo.

Topograficamente acima dos depósitos de várzea (mas próximos a eles), ocorre um conjunto de sedimentos assentados em discordância angular sobre o Grupo Castro (Almeida 1952; Coutinho 1955). Trata-se de material pouco consolidado, descrito por Trein \& Fuck (1967) como arenitos e arcósios grossos com matriz argilosa, além de conglomerados e níveis de argilas plásticas. Foram correlacionados por Almeida (1952) e Coutinho (1955) aos sedimentos cenozóicos das Bacias de Curitiba e São Paulo (Formação Piraquara de Coimbra et al. 1996 ?). 


\subsection{Mapa geológico de compilação da região do Complexo Cunhaporanga}

Com o objetivo de identificar a área de distribuição do que se convencionou denominar Complexo Granítico Cunhaporanga, produziu-se um mapa geológico de compilação na escala 1:150.000 (Anexo 1).

A maioria dos traços geológicos corresponde ao que está representado nos mapas da Comissão da Carta Geológica do Paraná (CCGP 1970 a, b, c, d) e do Projeto Leste do Paraná da CPRM (CPRM 1977 a, b, c, d). Isto porque a maior parte dos trabalhos posteriores, com algumas exceções (e. g., Pinto-Coelho 1986; Guimarães 1995), utilizaram-se destes mesmos mapas como base (e. g., Biondi et al. 1989), às vezes introduzindo distorções ao invés de corrigílas. 


\section{CAPÍTULO 3}

\section{O PROJETO AEROGEOFÍSICO SERRA DO MAR SUL NA REGIÃo DO COMPLEXO CUNHAPORANGA}

O Projeto Aerogeofísico Serra do Mar Sul (PSMS) corresponde a um levantamento gamaespectrométrico e magnetométrico executado na década de 70 para a CPRM (Companhia de Pesquisa de Recursos Minerais). A área de cobertura $\left(50.000 \mathrm{~km}^{2}\right)$ abrange a maior parte do embasamento cristalino paranaense e catarinense, alcançando também, a noroeste, os afloramentos do Grupo Castro e de uma pequena parte das rochas adjacentes da Bacia do Paraná (Figura 3.1). O setor do PSMS que interessa para esta pesquisa aparece discriminado na Figura 3.2 (ver também os Anexos 4 e 5). Infelizmente uma parte significativa da área ocupada pelo Complexo Cunhaporanga ficou de fora deste levantamento.

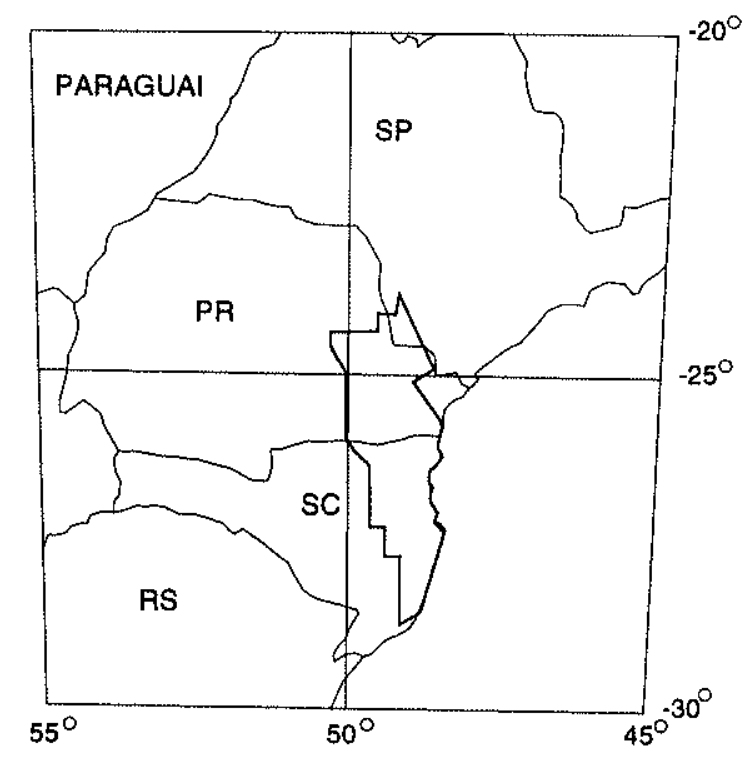

Figura 3.1: Mapa de localização do Projeto Aerogeofísico Serra do Mar Sul (PSMS). Fonte:http://www.cprm.gov.br/aero/1000/aero1000.htm. 
O projeto tem as seguintes características principais (Silva \& Mantovani 1994): espaçamento entre as linhas de vôo de 750 a $1250 \mathrm{~m}$ (localmente sobreposições ou afastamentos $>2 \mathrm{~km}$ ); altura média de vôo de $158 \mathrm{~m}$, variando entre 80 a mais de 300 $\mathrm{m}$; direção das linhas de vôo $\mathrm{N} 30 \mathrm{~W}$ (não exatamente ortogonal à estruturação geológica dominante na área estudada, que é N 30-45 E); canais de contagem utilizados: total $(\mathrm{CT})$, potássio $(\mathrm{K})$, urânio $(\mathrm{U})$, tório $(\mathrm{Th})$ e campo magnético. As janelas de detecção selecionadas foram as seguintes: contagem total 1,00-2,90 MeV, K 1,351,65 MeV, U 1,65-2,30 MeV $\odot$ Th 2,30-2,90 MeV, algo diferentes das recomendadas pela IAEA (1991).

Silva \& Mantovani (1994) chamaram a atenção para diversas restrições aos dados deste projeto. São elas: variações no espaçamento entre as linhas de vôo (responsáveis pelas lacunas observadas nos grids geofísicos; Figura 3.2); imprecisões nas coordenadas UTM dos registros dos vôos (localmente superiores a $4 \mathrm{~km}$ ); oscilações nas alturas de vôo; e emprego nas aeronaves de cristais gamaespectrométricos com volumes diferentes.

$\mathrm{Na}$ prática, os dados levantados pelo PSMS constituem dois levantamentos diferentes, pois foram obtidos a partir de duas bases, Curitiba (altitude $\sim 900 \mathrm{~m}$ ) e Florianópolis $(\sim 10 \mathrm{~m})$ (Silva \& Mantovani 1994).

O espaçamento entre as linhas de vôo, em geral superior aos $750 \mathrm{~m}$ neste projeto, não permite que os mapas produzidos com estes dados possam ser analisados em escalas inferiores a 1:250.000. Horsfall (1997), por exemplo, sugeriu espaçamento entre 400 e $500 \mathrm{~m}$ para mapeamentos na escala de 1:100.000, em regiões de rochas cristalinas.

Finalmente, os resultados gamaespectrométricos no PSMS são apresentados apenas em contagens por unidade de tempo (cps), impossibilitando as comparações com os padrões observados em outras áreas de constituição geológica similar, nas quais os dados aparecem lançados em ppm (eU, eTh) e \% (K). Aguarda-se para breve o tratamento de dados absolutos referentes ao PSMS (Misener et al.1997), convertidos através da técnica de back-calibration (ver Grasty et al. 1997). 


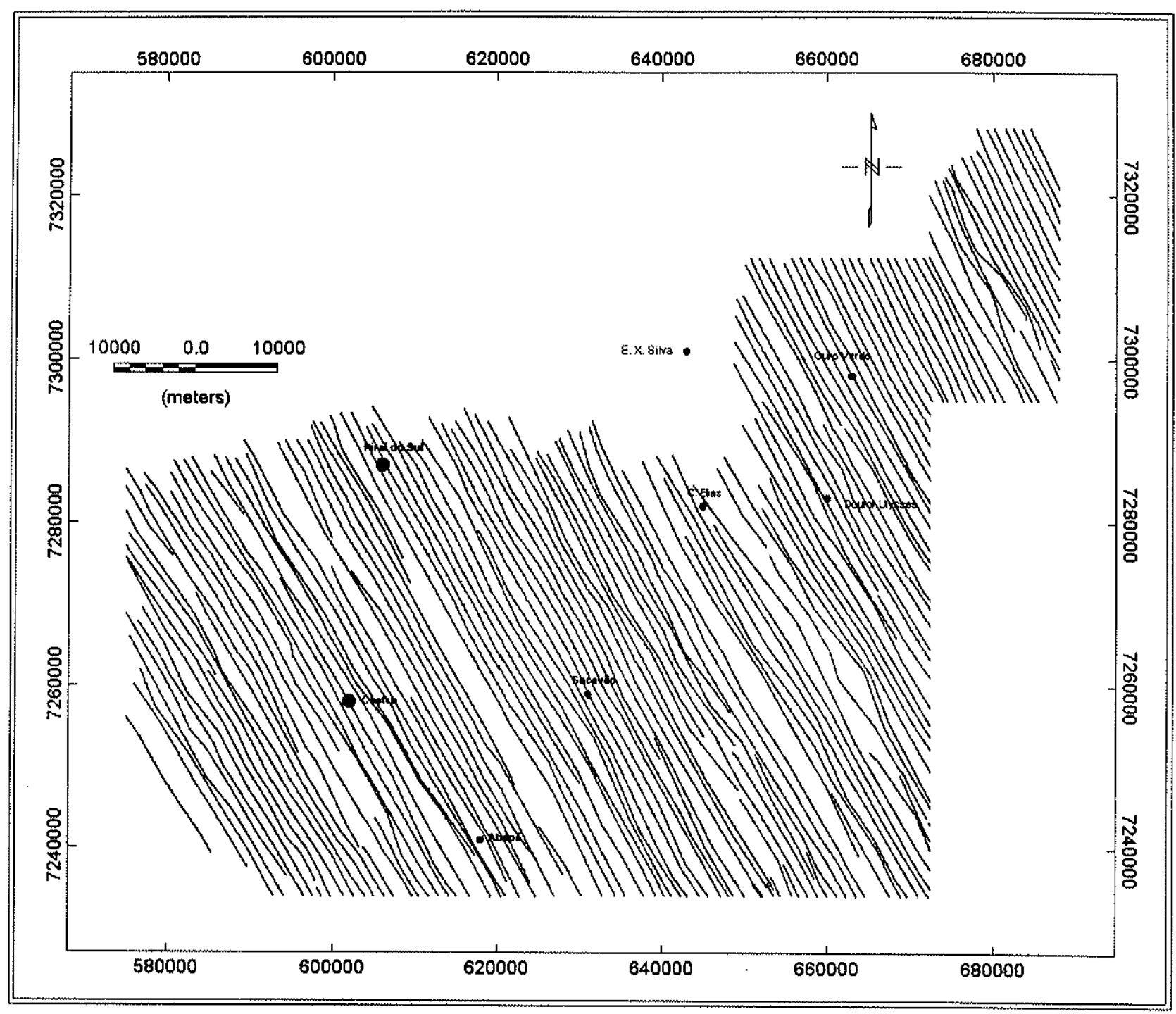

Figura 3.2: Mapa das linhas de vôo do trecho do PSMS considerado neste estudo.

No Anexo 4 tem-se uma discussão dos padrões gamaespectrométricos identificados na região do Complexo Cunhaporanga e unidades vizinhas. Enquanto os canais de CT (principalmente) e Th mostraram um elevado poder de discriminação dos atributos geológicos, os canais de $\mathrm{U}$ e $\mathrm{K}$ trouxeram resultados por vezes espúrios, não correlacionáveis com dados da geologia de superfície. 
Na região da Serra do Carambeí, por exemplo, pode-se perceber facilmente que os dados do canal do $\mathrm{K}$ têm problemas. Aqui afloram lajes do Granito Serra do Carambeí, de composição alasquítica (4-4,5\% $\mathrm{K}_{2} \mathrm{O}$; ver Capítulo 6), onde se esperariam altas respostas para estel canal específico. Entretanto o que se tem é um padrão quase homogêneo de baixos valores, sem contraste com as rochas adjacentes (e. g., com os arenitos pobres em $\mathrm{K}$ da Formação Furnas).

Além disso, caso o "grid" geofísico do K fosse considerado integralmente válido, seria necessário admitir que na região do Granito São Sebastião (Complexo Três Córregos) existiriam granitóides com pelo menos o dobro de $\mathrm{K}_{2} \mathrm{O}$ do que o Granito Serra do Carambeí (ver Figura 6 do Anexo 4), o que não corresponde à realidade (Hélcio J. Prazeres Filho, comunicação verbal).

Dados de um perfil geofísico terrestre conduzido nesta área (Figura 3.3; Tabela 3.1) confirmam que os valores de K não são baixos para o Granito Serra do Carambeí. Na Tabela 3.1, a coluna "Observações" faz referências a pontos localizados no Anexo 2 e a anomalias geofísicas investigadas pela CNEN (Companhia Nacional de Energia Nuclear) no início da década de 70 (ver Pinto-Coelho 1986).

Pinto-Coelho \& Siedlecki (1988) afirmaram que aproximadamente $32 \%$ do urânio presente no Granito Serra do Carambeí seria do tipo "fixo", ou seja, estaria retido na estrutura cristalina de minerais como zircão, enquanto que o restante seria do tipo "solúvel". Estas proporções entre os tipos de urânio aparentemente são confirmadas pelos dados do levantamento gamaespectrométrico terrestre. As leituras efetuadas em pontos onde existe apenas o solo de alteração deste granito (radiação gama proveniente apenas dos minerais resistentes ao intemperismo) corresponderam a \pm $30 \%$ dos valores obtidos em rochas inalteradas (comparar os pontos 10 e 15, solos, com o ponto 14, rocha sã, da Tabela 3.1).

Com respeito aos padrões espectrométricos para as diferentes unidades geológicas, pode-se dizer que: 


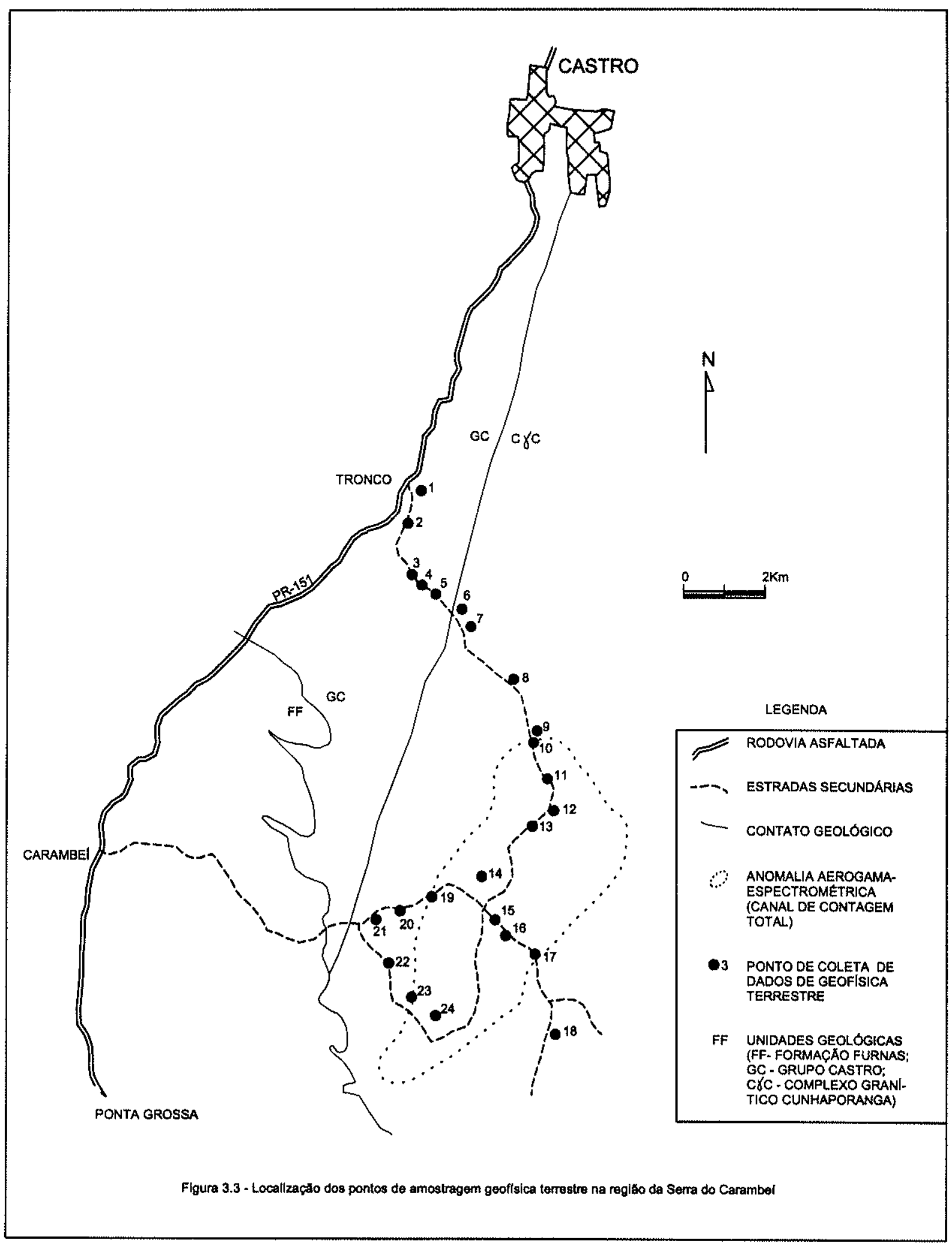


a) a maioria das intrusões do Complexo Cunhaporanga apresentam valores bastante altos de Th e $U$ e mais baixos de CT e K. Valores mais altos na CT são identificados para o Granito Serra do Carambeí (cf., por exemplo, Santos \& Felipe 1980, Pinto-Coelho 1986; ver Figura 3.3);

b) o contraste entre os canais é menor no Complexo Três Córregos, que pode ser dividido em dois domínios, um adjacente à Faixa Itaiacoca e outro mais ao sul, correspondendo à localização do Granito São Sebastião;

c) mega-enclaves em ambos os Complexos (Grupo Itaiacoca, Formação Água Clara) são facilmente identificados por contagens mais baixas que as dos granitos (em todos os canais);

d) a resposta significativamente mais alta no canal do Th para o Complexo Cunhaporanga, em comparação ao Complexo Três Córregos (principalmente na região do Granito São Sebastião), deve-se provavelmente mais a diferenças no grau de intemperismo das duas regiões do que a uma diversidade litológica (o Th é menos móvel durante os processos de meteorização das rochas; comparar as razões $T h / U$ de rochas sãs e solos delas derivados na Tabela 3.1);

e) a Faixa Itaiacoca é mostrada, em todos os mapas, como uma região com contagens baixas a moderadas;

f) o Grupo Castro aparece com padrão espectrométrico complexo, fortemente controlado por sua constituição litológica;

g) o arenito Furnas possui respostas geralmente baixas;

h) os depósitos aluviais da bacia hidrográfica do Rio lapó se destacam como faixas de valores muito baixos nos mapas de $K, T h, U$ e CT.

De maneira equivalente à gamaespectrometria, os dados magnetométricos coletados pelo PSMS estão discutidos no Anexo 5. Com o objetivo de se auxiliar a 
interpretação dos padrões aerogeofísicos, procedeu-se a leitura da susceptibilidade magnética $\boldsymbol{k}$ de amostras de granitóides do Complexo Cunhaporanga, rochas do Grupo Castro e alguns quartzitos, xistos e gnaisses.

Dos mapas produzidos, aquele correspondente ao campo magnético residual reduzido ao Pólo é o que permite o reconhecimento das grandes unidades geológicas da região (Figura 5 do Anexo 5).

Granitóides cálcio-alcalinos (com altos valores de $\boldsymbol{k}$ ) predominam nos dois complexos graníticos. Entretanto, os mapas mostram padrões irregulares para essas unidades, em parte por redução dos teores originais de magnetita (influência da alteração superficial e deutérico-hidrotermal e freqüente cataclase; ver Capítulo 5 e Anexo 6).

Na região entre Socavão e Abapã tem-se baixas respostas no mapa do campo magnético reduzido ao Pólo (Figura 5, Anexo 5). Como as amostras de granitóides desta área, péssima em afloramentos, têm elevadas leituras de susceptibilidade magnética, é possível que as rochas metassedimentares predominem sobre os granitos cálcio-alcalinos neste trecho do Complexo (Domínio Abapã-Santa Quitéria, ver Capítulo 4).

A Faixa Itaiacoca é representada principalmente por um conjunto alongado de anomalias negativas. $\mathrm{Na}$ sua parte meridional, um padrão convoluto identifica a presença de metavulcânicas dobradas.

O Grupo Castro reproduz, em parte, o padrão irregular do embasamento, sugerindo que a sua espessura pode ser menor que a estimada. Já o arenito Furnas e os depósitos aluvionares do Rio lapó não são registrados nestes mapas. 
Tabela 3.1: Dados de gamaespectrometria terrestre (contagem total, potássio, urânio e tório, em cps) e susceptibilidade magnética $\boldsymbol{k}$ (em unidades SI) da regiāo da Serra do Carambeí. CT 1 e CT 2: contagens totais (com diferentes janelas de detecção).

\begin{tabular}{|c|c|c|c|c|c|c|c|c|}
\hline Ponto & CT 1 & $\mathrm{CT} 2$ & $\mathrm{~K}$ & $\mathrm{U}$ & Th & $\mathrm{Th} / \mathrm{U}$ & $\boldsymbol{k}$ & Observaçōes \\
\hline 1 & 212,4 & 58,1 & 3,4 & 1,4 & 1,5 & 1,07 & 2,32 & solo \\
\hline 2 & 278,2 & 78,8 & 5,3 & 2,1 & 2,2 & 1,05 & 2,28 & solo \\
\hline 3 & 367,5 & 102,6 & 6,2 & 4,2 & 1,8 & 0,43 & 0,49 & riolito alterado (SC-18) \\
\hline 4 & 377,2 & 117,0 & 8,2 & 5,0 & 2,3 & 0,46 & 0,53 & riolito (SC-19) \\
\hline 5 & 119,8 & 33,6 & 2,0 & 1,1 & 0,8 & 0,73 & 11,4 & solo de andesito (SC-20) \\
\hline 6 & 389,7 & 131,0 & 10,5 & 7,9 & 1,4 & 0,18 & 1,21 & Cunhaporanga cataclasado (SC-21) \\
\hline \multirow[t]{2}{*}{7} & 134,5 & 30,6 & 2,0 & 1,5 & 0,5 & 0,33 & 0,12 & quartzito (SC-22) (xenólito $n 10^{1} \mathrm{~m}$ ) \\
\hline & 258,6 & 75,4 & 4,0 & 2,6 & 1,3 & 0,50 & 0,80 & solo de granitos (Cunhaporanga) \\
\hline 8 & 348,6 & 109,1 & 8,5 & 4,6 & 1,3 & 0,28 & 20,2 & blocos de granodiorito foliado (SC-23) \\
\hline 9 & 312,0 & 83,3 & 5,1 & 2,9 & 2,0 & 0,69 & 9,44 & solo com contribuição aluvionar \\
\hline 10 & 414,3 & 112,5 & 5,7 & 3,1 & 2,9 & 0,94 & 5,91 & $\begin{array}{c}\text { solo } \\
\end{array}$ \\
\hline 11 & 910,3 & 245,9 & 14,8 & 6,7 & 5,4 & 0,81 & 0,07 & Carambeí alterado (SC-9) \\
\hline 12 & 548,2 & 160,7 & 11,1 & 6,4 & 2,3 & 0,36 & $-0,07$ & laje do Carambeí alterado (SC-8) \\
\hline \multirow{3}{*}{13} & 386,4 & 99,5 & 6,0 & 3,4 & 1,8 & 0,53 & - & \multirow{2}{*}{$\begin{array}{l}\text { cava para remoção de argila, } \\
\text { com solo de cor negra }\end{array}$} \\
\hline & 420,8 & 108,1 & 5,5 & 2,8 & 2,2 & 0,79 & - & \\
\hline & 393,7 & 101,8 & 5,9 & 2,8 & 2,3 & 0,82 & $-0,01$ & porção de argila mais branca e c/ Qz $\beta$ \\
\hline \multirow{3}{*}{14} & 794,0 & 229,8 & 14,5 & 10,3 & 4,4 & 0,43 & 0,07 & \multirow{3}{*}{$\begin{array}{c}\text { leituras em rocha fresca } \\
\text { de uma pedreira do Carambeí } \\
\text { (SC-3) }\end{array}$} \\
\hline & 831,7 & 238,0 & 17,6 & 9,9 & 4,7 & 0,47 & 0,08 & \\
\hline & 762,8 & 218,8 & 16,6 & 9,9 & 3,5 & 0,35 & - & \\
\hline 15 & 445,6 & 117,5 & 7,3 & 2,8 & 2,9 & 1,04 & 1,54 & solo \\
\hline 16 & 508,9 & 137,8 & 8,8 & 4,3 & 3,1 & 0,72 & 1,29 & solo (limite entre horizontes A e B) \\
\hline 17 & 727,4 & 197,4 & 10,9 & 5,7 & 4,7 & 0,82 & 2,86 & Carambeí muito alterado \\
\hline 18 & 265,7 & 66,1 & 3,9 & 2,0 & 1,2 & 0,60 & 0,47 & rocha alterada (fácies de borda Carambeí ?) \\
\hline \multirow[t]{2}{*}{19} & 712,6 & 216,8 & 12,3 & 6,8 & 5,3 & 0,78 & 1,12 & solo marrom-avermelhado (horizonte B) \\
\hline & 1392,4 & 420,6 & 25,8 & 12,1 & 8,9 & 0,74 & 0,22 & $\begin{array}{l}\text { material argiloso cinza-esverdeado } \\
\text { (anomalia AN-3 da CNEN) }\end{array}$ \\
\hline 20 & 149,6 & 39,3 & 2,2 & 1,5 & 0,6 & 0,40 & 24,8 & solo (dique mesozóico?) \\
\hline 21 & 336,0 & 99,3 & 6,1 & 5,2 & 1,7 & 0,33 & 0,28 & solo \\
\hline 22 & 309,2 & 91,8 & 6,8 & 4,0 & 1,1 & 0,28 & 0,84 & $\begin{array}{ll} & \text { solo } \\
\end{array}$ \\
\hline \multirow[t]{2}{*}{23} & 2267,4 & 753,7 & 53,0 & 22,7 & 16,7 & 0,74 & 0,06 & "diques riolíticos" (AN-4 da CNEN) \\
\hline & 716,2 & 202,7 & 14,0 & 8,0 & 4,0 & 0,50 & 0,15 & Carambeí alterado \\
\hline 24 & 641,4 & 176,6 & 11,5 & 7,5 & 3,0 & 0,40 & $-0,00$ & lajes do Carambeí \\
\hline
\end{tabular}




\section{CAPÍTULO 4}

\section{A. \\ AS UNIDADES LITOESTRATIGRÁFICAS DO COMPLEXO GRANÍTICO CUNHAPORANGA}

Neste capitulo será feita uma descrição das principais feições petrográficas das rochas do Complexo Cunhaporanga, em especial de seus diferentes tipos granitóides. Estes, para os quais também são apresentados dados modais (Figura 4.1; Tabela 4.1), aparecem no mapa geológico do Anexo 3 como unidades litoestratigráficas formais (Granitos Serra do Carambeí, Joaquim Murtinho e São Domingos) e informais (os Domínios Petrográficos).

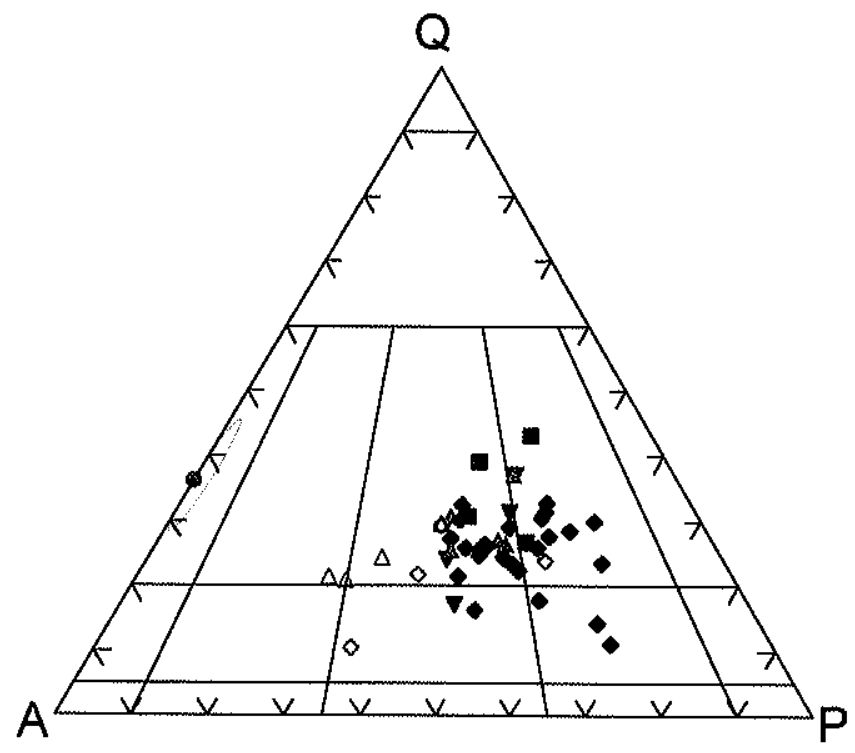

Figura 4.1: Diagrama modal QAP (Streckeisen 1976) para o conjunto das rochas granitóides do Complexo Cunhaporanga. Símbolos cheios para rochas equigranulares, vazios para porfiríticas: losangos para titanita anfibólio biotita granitóides, triângulos para titanita biotita granitóides, triângulos invertidos para biotita granitóides, quadrados para muscovita biotita granitóides, círculo para álcali-feldspato granitos (área pontilhada define as composições estimadas visualmente para outras amostras dos Granitos Serra do Carambeí e Joaquim Murtinho). 
Uma ampla gama de rochas granitóides foi identificada, em sintonia com 0 quadro delineado para a unidade no Capítulo 2. Parte das observações prévias foram confirmadas (e. g., predomínio de granodioritos a monzogranitos equigranulares, ricos em hornblenda, no extremo SW do Complexo, tal como em Trein, documento inédito), enquanto outras tiveram de ser revistas (e. g., ausência de rochas gnáissicomigmatíticas no interior do Complexo).

Um exemplo de trabalho com aspectos apenas parcialmente confirmados com os dados aqui levantados é o de Wernick et al. (1990 b; ver também Capítulos 6 e 7). Apesar de concordar-se com as linhas gerais da minuciosa descrição petrográfica apresentada, algumas diferenças devem ser assinaladas:

a) enclaves surmicáceos não predominam sobre os enclaves microgranulares intermediários a básicos;

b) apesar da relativa subjetividade dos termos "placóide" e "prismático" quando da descrição do hábito cristalino do feldspato potássico, os fenocristais de microclínio/ortoclásio das rochas porfiríticas a inequigranulares do Complexo são principalmente prismáticos;

c) septos maiores das rochas encaixantes não são raros, como verifica-se na porção nordeste do Complexo ou na região da Serra das Pedras.

A opção de se evitar, no momento, a utilização exclusiva de termos formais prende-se a dois pontos principais: compreensão insuficiente das relações entre as diferentes unidades e dúvidas sobre a área efetivamente ocupada pelas mesmas. A baixa densidade de informações (como é o caso em trechos arrasados e profundamente intemperizados) e o caráter aparentemente gradual das mudanças litológicas entre alguns dos domínios são algumas das dificuldades encontradas.

Esta reticência quanto à nomenclatura das unidades do Complexo deve-se também à necessidade de se desestimular a proliferação de nomes que, uma vez ampliado o nível de conhecimento da unidade, podem revelar-se inadequados. 
Tome-se como exemplo o "Domínio Petrográfico Abapã-Santa Quitéria". Com o que foi levantado até o momento, parece existir neste setor um predomínio de rochas de composição granodiorítica, aparentemente respaldando o emprego de um nome formal como "Granodiorito X". No entanto, com o detalhamento dos trabalhos de campo e de laboratório, pode-se vir a concluir que metassedimentos, na forma de mega-enclaves, sejam a litologia dominante (ver comentários sobre os padrões aeromagnetométricos no Capítulo 3). Assim, "Complexo X" poderia ser mais indicado que "Granodiorito X".

Ainda neste mesmo domínio, estudos adicionais poderiam indicar que monzogranitos ocorrem em maior quantidade que granodioritos, motivando a que se redefinisse o "Granodiorito X" como "Granito X". Mas, como é freqüente acontecer quando autores diferentes da proposta inicial estão envolvidos, não seria surpresa se surgisse um "Granito $\underline{Y}$ " em substituição ao " $\underline{\text { ". }}$

A situação descrita acima está longe de ser fictícia, como percebe-se nos casos das unidades "Granito Joaquim Murtinho" (ver discussão em Guimarães 1995) e "Francisco Simas-Vila Branca" (ver item 4.4.3, adiante), apenas para ficar com exemplos restritos ao Complexo Cunhaporanga.

\subsection{Unidades metamórficas do Complexo Cunhaporanga}

\subsubsection{Quartzito Serra das Pedras (NPcqsp)}

O "Quartzito Serra das Pedras" (Muratori inédito in Fuck 1967) é a única unidade litoestratigráfica metamórfica do Complexo Cunhaporanga que possui nome, apesar de não ter sido rigorosamente formalizada. Constitui-se de metarenitos e metarcósios esbranquiçados e friáveis (com grãos recristalizados médios a grossos), freqüentemente dispostos em camadas tabulares centimétricas a métricas (Foto 2A), possivelmente refletindo $O$ antigo acamamento sedimentar (descrições mais detalhadas em Fuck 1967 e Guimarães 1995). 
Muscovita e minerais opacos (magnetita normalmente convertida em óxidos e hidróxidos de ferro) podem, localmente, ocorrer em quantidades mais expressivas. Em alguns casos a maior presença de muscovita resulta em verdadeiros muscovita(feldspato)-quartzo xistos e, mais raramente, muscovita xistos.

Ao contrário do que afirmaram diversos autores (e. g., Fuck 1967; Fuck et al. 1967 b; Reis Neto 1994), não existem rochas gnáissicas típicas ou migmatitos acompanhando o "Quartzito Serra das Pedras". Nos locais assinalados em mapa para estas rochas, como em Biondi et al. (1989), caracterizados por uma péssima qualidade dos afloramentos, foram identificados unicamente granitos, metarenitos ou xistos. O "Gnaisse Piraí do Sul" de Reis Neto (1994), por exemplo, constitui-se exclusivamente por rochas magmáticas ligeiramente foliadas (granitos a dioritos) e desprovidas de bandamento gnáissico. Rochas xistosas profundamente intemperizadas, com material quartzo-feldspático intercalado (possivelmente apófises graníticas), foram descritas como migmatitos por Fuck (1967).

A natureza intrusiva do contato entre o "Quartzito Serra das Pedras" e as rochas ígneas do Complexo não é percebida imediatamente em campo. Isto deve-se principalmente ao elevado grau de alteração das rochas situadas nesta região (cf. também Fuck 1967; Kaefer \& Cunha 1974; CPRM 1977 c). Outro aspecto desfavorável é a própria constituição mineralógica dos metarenitos e metarcósios (quartzo \pm feldspato potássico), inadequada para o desenvolvimento de paragêneses típicas de metamorfismo de contato.

No entanto a ocorrência de apófises graníticas e fraturas preenchidas com argilominerais, orientadas em diversas direções (algumas com turmalina centimétrica associada; ponto PS-88 no Anexo 2), são claros sinais de que o "Quartzito Serra das Pedras" comportou-se como encaixante das rochas graníticas do Complexo. A julgar pelo padrão aeromagnetométrico discutido no Anexo 5 , esta unidade não teria uma espessura significativa, favorecendo então a interpretação de que se trata de um grande teto-pendente sobre as rochas graníticas do Complexo (Kaefer \& Cunha 1974; Guimarães 1995). 


\subsubsection{Outras rochas metamórficas internas ao Complexo (NPcq e NPcrm)}

Junto com o "Quartzito Serra das Pedras" ocorrem inúmeros outros corpos de rochas metamórficas no Complexo Cunhaporanga. Com dimensões variadas (ver Anexo 1), são constituídos por metarenitos e metarcósios $(N P c q)$ e, em menor proporção, xistos (Foto 2B) e metadolomitos (NPcrm). O predomínio de rochas metapsamíticas em detrimento de outros tipos metamórficos (metapelitos, metavulcânicas ou metadolomitos) deve ser encarado com reservas, pois pode apenas significar uma maior resistência destas rochas quartzosas aos procesos intempéricos e erosivos. Assim como visto no item anterior, não existem os migmatitos e gnaisses típicos representados próximos às localidades de Maracanã-Colônia Terra Nova, Eduardo Xavier da Silva-Água Clara e São Domingos-Limeira (ver os mapas de CCGP 1966 a 1970 a, b, c; CPRM 1977 c; Biondi et al. 1989).

Petrograficamente, os metarenitos e metarcósios são idênticos ao "Quartzito Serra das Pedras" (cf. Fuck et al. 1967 b). Já os gnaisses e migmatitos referidos em trabalhos anteriores são principalmente metarenitos que gradam para muscovitaquartzo xistos (e. g., JGA-12 e 13) ou metassiltitos e metarcósios impuros recristalizados por metamorfismo de contato (e. g., IT-38, 39, 50, 58, dentre outros).

O grau de recristalização metamórfica destes litotipos, encaixantes das rochas granitóides, é variável. Em alguns xistos a intensidade do metamorfismo chegou a permitir a formação de finas palhetas de sillimanita (JM-109). Por outro lado, certos metarenitos quase não parecem rochas metamórficas, preservando estruturas sedimentares tais como estratificações cruzadas de pequeno a médio porte (IT-106).

As possibilidades de que o "Quartzito Serra das Pedras" e os demais corpos metapsamíticos situados no Complexo fossem correlacionáveis entre si e, ainda, de que este conjunto pudesse equivaler a alguma das subunidades do Grupo Itaiacoca, serão exploradas no item 4.7.1 (ver adiante). 


\subsection{Domínios Petrográficos da porção S/SE do Complexo}

Com exceção de trechos restritos ocupados por um biotita granito foliado (Domínio Santa Rita) ou pelo Granito Serra do Carambeí (tratado separadamente no item 4.5), a parte meridional do Complexo caracteriza-se por um predomínio de anfibólio biotita granodioritos a monzogranitos (Figura 4.2). Os critérios utilizados para distinguir estas últimas rochas no mapa geológico do Anexo 3 (Domínios Abapã-Santa Quitéria, Serra Abaixo-Alagados e Jotuba-Pitangui) foram eminentemente texturais e estruturais. Pórfiros como corpos de pequenas dimensões, isolados do Complexo mas provavelmente relacionados às suas rochas, são comuns em meio aos litotipos do Grupo Itaiacoca.

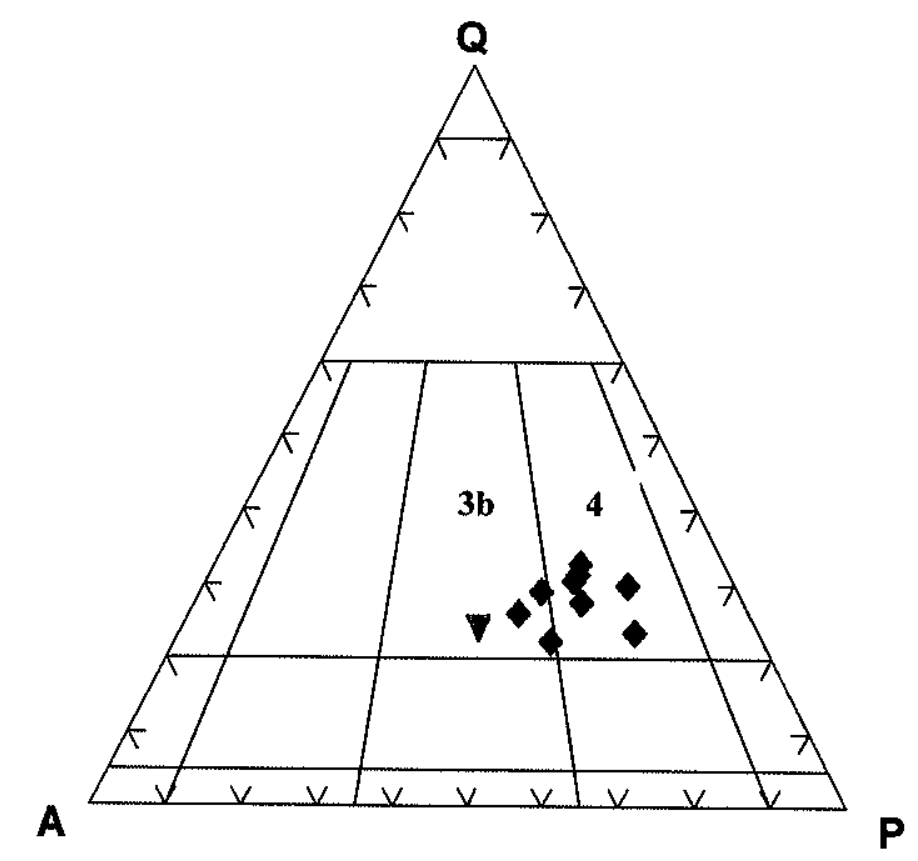

Figura 4.2: Diagrama QAP (Streckeisen 1976) com contagens modais para granitóides da porção S/SE do Complexo Cunhaporanga (ver Tabela 4.1). Losangos para titanita anfibólio biotita granitóides dos Domínios Serra Abaixo-Alagados e Abapã-Santa Quitéria, triângulo invertido para biotita granitóide do Domínio Santa Rita. Campo 3b para monzogranitos e campo 4 para granodioritos. 


\subsubsection{Domínio Abapã-Santa Quitéria (NPcasq)}

No trecho que vai desde um pouco ao sudoeste de Abapã (Taquaral) até Santa Quitéria, passando por Socavão, são vistos blocos de granitóides sempre com boa quantidade de anfibólio e com textura inequigranular a porfirítica, onde os fenocristais de feldspato potássico dificilmente ultrapassam 1,5 a $2 \mathrm{~cm}$.

$\mathrm{Na}$ região imediatamente junto ao contato com rochas do Grupo Itaiacoca, entre Taquaral e Retiro (e. g., ITA-2-100; PS-23 ?), são identificados granitóides portadores de texturas do tipo "borda de resfriamento de corpo ígneo". Em outras palavras, com texturas de granulação mais fina, indicativas de terem se formado em ambientes com elevado contraste térmico entre o magma formador destas rochas e suas encaixantes.

Petrografia macroscópica. Os granitóides são acinzentados, com índice de cor normalmente entre 10 e 15 , mas podendo oscilar entre 7 a 25. A cor varia do cinzamédio para o escuro nas amostras de Lajeado a Taquaral (e. g., PS-21, SC-49) e do médio para o claro de Butiazal a Santa Quitéria (e. g., PS-54, PS-78). Quase sempre levemente foliados (eventualmente maciços ou então moderadamente foliados), são em geral inequigranulares, com fenocristais de feldspato potássico com 1 a $1,5 \mathrm{~cm}$.

As rochas aqui interpretadas como de uma fácies de borda do Domínio AbapãSanta Quitéria são cinza-escuras a cinza-esverdeadas (róseas quando alteradas), com 5 a $7 \%$ de fenocristais máficos. A matriz é afanítica a fina, com microfenocristais milimétricos de plagioclásio, anfibólio (ambos alcançando até $\sim 5 \mathrm{~mm}$ ) e biotita nas rochas granodioríticas, além de quartzo bipiramidal (com até $1 \mathrm{~cm}$ de diâmetro) e feldspato potássico centimétrico nos monzogranitos.

Enclaves microgranulares, dioríticos ou com a mesma composição dos granitóides, são comuns em todas as rochas deste domínio, havendo em menores proporções xenólitos de metassedimentos.

Petrografia microscópica. As composições modais concentram-se principalmente no campo granodiorítico, sendo os monzogranitos e 
quartzomonzodioritos subordinados (estes últimos reconhecidos em alguns afloramentos).

As rochas tidas aqui como "fácies de borda" mostram uma paragênese formada por plagioclásio (com zonação muito destacada), anfibólio, biotita, quartzo, feldspato potássico (às vezes só na matriz) e titanita primária. Magnetita, apatita e zircão são vistos em quantidades subordinadas.

O anfibólio com freqüência está totalmente substituído por clorita, carbonato, titanita, quartzo e opacos, ou parcialmente convertido em biotita. Esta pode ter alguma cloritização, além de freqüente acomodação interlamelar de Ca-Al silicatos secundários como prehnita e epidoto. Os cristais maiores de quartzo possuem hábito bipiramidal, embaiamento das faces e inclusões arredondadas da matriz.

Os minerais descritos acima são os mesmos observados nas rochas de granulação mais grossa, com algumas diferenças texturais (e. g., o plagioclásio possui zoneamento muito mais intenso na fácies de borda). Até mesmo a associação de minerais de $\mathrm{Ca}-\mathrm{Al}$ secundários (prehnita e outros) está presente.

\subsubsection{Domínio Serra Abaixo-Alagados (NPcsaa)}

Tomando-se o rumo sudoeste, a partir do Domínio Abapã-Santa Quitéria, chegase à região de Serra Abaixo e sul da represa dos Alagados, onde predominam rochas francamente equigranulares (tal como observado por Trein, documento inédito). No limite entre estes domínios tem-se rochas fortemente porfiríticas, que passam gradualmente, em direção a Serra Abaixo, para litotipos de mesma composição porém equigranulares médios, havendo também termos intermediários inequigranulares (ponto SC-75). Está área está destacada no mapa do Anexo 3 por um padrão hachurado. No ponto SC-74 identifica-se um dique de espessura indefinida, ocupado por um dacito pórfiro (ver item 4.2 .5 adiante).

Petrografia macroscópica. Na região do Arroio Moinho a Mato Limpo (e. g., SC$68, \mathrm{SC}-74)$ os granitóides são maciços e fortemente porfiríticos, com matriz fina a 
afanítica. Os fenocristais são euedrais e centimétricos de feldspato potássico $(3-9 \mathrm{~cm}$; porém em quantidade reduzida), milimétricos de plagioclásio e quartzo (ambos 3-10 $\mathrm{mm}$; Fotos 2C e 2D), anfibólio (até $5 \mathrm{~mm}$ ), biotita e titanita $(2-3 \mathrm{~mm}$ ).

Esta zona, caracterizada por forte contraste textural entre fenocristais e matriz, indica resfriamento rápido do magma durante sua colocação. Como a passagem para as áreas ocupadas por rochas equigranulares não está acompanhada por mudanças mineralógicas, tanto os termos porfiríticos (fácies de borda) como os equigranulares (fácies interna) provavelmente integrariam um mesmo corpo magmático. Pequenos enclaves microgranulares dioríticos e essencialmente biotíticos ("surmicáceos") são comuns nestas rochas.

Petrografia microscópica. Os monzogranitos a granodioritos são constituídos por plagioclásio idiomórfico fortemente zonado (núcleos de labradorita cálcica), feldspato potássico, quartzo (estes dois intersticiais ao plagioclásio), anfibólio (com núcleos de clinopiroxênio), biotita e titanita. Os minerais acessórios são apatita, zircão e opacos (magnetita em grande quantidade). Sericitização parcial de plagioclásio, cloritização da biotita e prehnita/pumpellyita intercalados a cristais de biotita são as principais texturas secundárias destes granitóides.

\subsubsection{Domínio Jotuba-Pitangui (NPcjp)}

As rochas granitóides deste domínio são fortemente porfiríticas (fenocristais de feldspato potássico $\geq 3 \mathrm{~cm}$ ), tendo ao seu lado, localmente, afloramentos de metarenitos/metarcósios com claros sinais de que representam mega-xenólitos envolvidos pelas rochas magmáticas (e. g., SC-22, SC-53).

A estrutura dos granitóides pode ser maciça, como entre Rincão do Cafequi e Ronca-Porco (e. g., SC-64) ou foliada a fortemente foliada (eventualmente com aspecto gnáissico), como no trecho Campina do Jotuba-Capoeira de Dentro (e. g., SC-23) ou próximo ao Rio Pitangui, entre Lago e o Arroio Sebastião (e. g., SC-45). 
Granitóides deformados, em conjunto com afloramentos ocasionais de metassedimentos da região de São Sebastião-Maracanã-Terra Nova, foram descritos como migmatitos embrechíticos por Fuck (1967), dentre outros. No entanto a deformação tem caráter localizado, provavelmente associada a zonas de cisalhamento internas ao Complexo.

Segue-se aqui a mesma interpretação dada por Santos \& Felipe (1980), que fizeram a seguinte afirmação sobre a região ocupada pelos migmatitos descritos por Fuck (1967): "Essa faixa mostra uma transição gradativa para um granito de textura granoporfiroblástica, bem orientado, que por sua vez transiciona para um granito porfiróide, sem orientação. Não é correto, portanto, separar essa fácies gnáissica, distinguindo-a como unidade à parte do Cunhaporanga" (Santos \& Felipe 1980, p. 910).

Em alguns pontos, em blocos, identificam-se corpos tabulares de anfibólio biotita granitóides equigranulares ( 6 a $30 \mathrm{~cm}$ de espessura), intrusivos nas rochas porfiríticas (e. g., SC-45, SC-46; diques ou estruturas ígneas?). Não é possivel determinar se existe conexão com uma outra ocorrência isolada de um anfibólio biotita granodiorito foliado, próxima à Maracanã (SC-79).

O contato destas rochas equigranulares com as porfiríticas é marcado por uma estreita faixa milimétrica/centimétrica, de cor branca, constítuída essencialmente por quartzo e feldspatos, aparentemente gradacional para a fácies equigranular.

Os monzogranitos a granodioritos (porfiríticos ou equigranulares) têm coloração acinzentada e índice de cor superior a 10 , não raro $\geq 20$. Diques aplíticos com biotita granitos equigranulares médios, de textura gráfica e índice de cor $\leq 5$, são ocasionais neste domínio.

Petrografia microscópica. Os granodioritos ao norte do Granito Serra do Carambeí mostram anfibólio, feldspatos, quartzo, titanita e grandes cristais zonados de allanita orientados, com foliação bem definida (origem magmática ?) e deformados (e. g., SC-23). O plagioclásio está quase integralmente sericitizado e a biotita totalmente 
substituída por clorita, com prehnita e raro epidoto interlamelar. Estas rochas possuem texturas cataclásticas (cristais fragmentados) e fraturas com preenchimento de quartzo e clorita, possivelmente ligadas a um metamorfismo dinâmico em fácies xisto verde, zona da clorita.

Algumas rochas foliadas (região de São Sebastião a Maracanã) possuem forte recristalização dos minerais primários, adquirindo aspecto metamórfico (cristais subedrais/anedrais, orientados). Entretanto diversas feições meso- (e. g., bordas de resfriamento no contato entre fácies distintas) e microscópicas confirmam a origem magmática destas rochas. Plagioclásio zonado, mirmequitas no contato entre feldspato potássico e plagioclásio, titanitas euedrais no centro de glomérulos de minerais máficos (subedrais/anedrais fora dos glomérulos), são algumas texturas formadas durante os estágios ígneos destas rochas.

As condições de metamorfismo a que teriam sido submetidos estes granitóides são difíceis de determinar, pois não está claramente definido quais seriam os melhores critérios de discriminação entre minerais reliquiares e neoformados. A prehnita, por exemplo, confinada à biotita, tanto pode ter sido gerada antes como após a atuação dos esforços responsáveis pela foliação existente nestes granitóides.

\subsubsection{Domínio Santa Rita (NPcsr)}

Ao longo da Estrada do Cerne, no trecho entre Capão Alto e o Rio Pitangui, temse diversas exposições de um biotita monzogranito foliado, especialmente próximo a Santa Rita (PS-18, PS-19). Além deste tipo granitóide são identificadas também rochas hololeucocráticas, interpretadas por Fuck (1967) como ocupando diques, os quais seriam correlacionáveis às rochas vulcânicas ácidas do Grupo Castro.

Petrografia macroscópica. Os biotita granitos estão sempre foliados, com orientação da biotita e, em menor proporção, dos minerais félsicos. Vênulas e aplitos quartzo-feldspáticos de dimensão milimétrica-centimétrica são muito comuns. 
A textura é equigranular fina a média (raros cristais maiores de feldspato potássico) e a cor branco-acinzentada a rósea, com índice de cor entre 5 e 7 ou ainda menor. São freqüentes os enclaves decimétricos profundamente alterados de um material rico em biotita, granulação média, por vezes foliado, com fenocristais centimétricos de feldspato argilizado. Localmente este material está empobrecido em quartzo, além de ser cortado por diversos aplitos, em parte confinados aos enclaves.

Em cortes da Estrada do Cerne, como nos pontos PS-16 e PS-17, observa-se uma rocha fortemente intemperizada, de cor castanho-clara a marrom. Com índice de cor em torno de zero, seus únicos minerais máficos são raros grãos acinzentados de brilho metálico e de reduzida dimensão (magnetita ?). Maciça, com fraturas e vênulas ocasionais, possui granulação muito fina a média, com eventuais microfenocristais milimétricos de feldspato, localmente com uma fina borda de alteração.

Petrografia microscópica. Com textura hipidiomórfica equigranular e foliação bem marcada, os monzogranitos foliados são constituídos por oligoclásio (com grande quantidade de mirmequitas), feldspato potássico (muitas inclusões de plagioclásio), quartzo e biotita, além de poucos opacos, clorita, zircão e apatita.

O elevado grau de intemperismo das rochas hololeucocráticas dificulta sobremaneira sua observação ao microscópio. São identificadas estreitas orlas de intercrescimento micrográfico nos feldspatos, carbonatos em vênulas ou substituindo feldspatos, além de clorita e muscovita disseminadas. A presença de raros grãos de titanita idiomórfica (profundamente alterada) poderia indicar uma correlação destes litotipos com outros granitóides cálcio-alcalinos da região.

\subsubsection{Pórfiros (NPcpf)}

\subsubsection{Pórfiros intrusivos em granitóides do Complexo}

Blocos de dacito- (a traquiandesito) pórfiros foram identificados em apenas dois pontos: na região de São Sebastião, junto a granitóides foliados do Domínio JotubaPitangui (SC-51) e em Mato Limpo, no Domínio Serra Abaixo-Alagados (SC-74). 
Petrografia macroscópica. A geometria do corpo que abriga o pórfiro de São Sebastião não pôde ser definida em campo, enquanto que em Mato Limpo o pórfiro muito provavelmente ocupa um dique de espessura indeterminada. Tratam-se de rochas cinza-esverdeadas, com foliação leve (SC-51) a marcada (SC-74), com matriz de granulação muito fina a afanítica. Os microfenocristais são subedrais/euedrais, orientados, de plagioclásio (1-6 mm), anfibólio (1-3 mm; localmente acicular), além de biotita $(\leq 1 \mathrm{~mm})$.

Petrografia microscópica. Ambas as rochas (dacitos a traquiandesitos pórfiros) possuem uma matriz muito fina, constituída por quartzo, feldspatos e minerais máficos. Os fenocristais de plagioclásio são idiomórficos, com forte zonação e sericitização (muitas vezes em setores preferenciais). Os cristais maiores de anfibólio podem estar parcial ou totalmente convertidos em biotita e opacos, além de abrigarem fraturas com clorita. A biotita está parcialmente cloritizada e com inclusões de Ca-Al silicatos secundários (e. g., pumpellyita e epidoto), ao passo que as seções basais revelam um número elevado de inclusões aciculares (rutilo ?), configurando uma textura sagenítica Os acessórios incluem magnetita euedral, apatita acicular e zircão.

Como diferenças entre os dois pórfiros pode-se citar: titanita em maior quantidade e melhor formada (subedral) no pórfiro de Mato Limpo; agregados circulares (diâmetro $\leq 1 \mathrm{~mm}$ ), fibro-radiados, de feldspato alcalino e quartzo na rocha de São Sebastião (Foto 2E); estrutura de fluxo magmático (Foto 3A), com rotação de fenocristais e sombras de pressão a eles associadas (propiciando aumento da granulação da matriz quartzo-feldspática) no corpo de Mato Limpo.

\subsubsection{Pórfiros intrusivos no Grupo Itaiacoca}

$\mathrm{Na}$ Faixa Itaiacoca, especialmente nas proximidades com o Complexo Cunhaporanga, são freqüentes pequenos corpos de granitóides pórfiros (os "riolitos" de Reis Neto 1994), de geometria nem sempre determinada (diques e/ou "plugs" ?). Estas rochas normalmente estão muito alteradas, sendo muitas vezes reconhecidas pela associação de argilas caulíniticas e pequenos cristais de quartzo, em contraste com as rochas encaixantes (metadolomitos, metarcósios, filitos, etc.). 
Petrografia macroscópica. Rochas menos alteradas, como na Pedreira Irapuru (ITA-0-72/PS-103), atestam a existência de biotita, anfibólio e titanita em pelo menos alguns dos corpos intrusivos na Faixa Itaiacoca. Estes pórfiros em particular são róseos, com índice de cor igual ou superior a 10 , maciços e de matriz muito fina a afanítica. Os fenocristais euedrais têm em média 1 a $3 \mathrm{~mm}$, alcançando até $5 \mathrm{~mm}$ para os minerais máficos e $8 \mathrm{~mm}$ para os feldspatos. No entanto, são mais comuns os pórfiros aparentemente desprovidos de minerais máficos (e. g., SC-65B; influência de transformações tardi-magmáticas ou um tipo petrográfico diferente ?).

Petrografia microscópica. Nos pórfiros em que a paragênese primária pôde ser determinada, as fases minerais são plagioclásio, anfibólio, biotita, quartzo, feldspato potássico (às vezes só na matriz ?) e titanita. Apatita e zircão ocorrem em quantidades subordinadas. Os cristais maiores de quartzo possuem hábito bipiramidal, embaiamento das faces e inclusões arredondadas da matriz. Textura esferulítica, com quartzo e feldspatos, pode ser vista ocasionalmente.

Anfibólio e biotita com freqüência estão totalmente cloritizados, ao passo que sericita, argilominerais e, mais raramente, epidoto, substituem (parcial ou totalmente) os feldspatos da matriz e dos fenocristais.

Chama a atenção o fato de que muitos destes pórfiros possuem claros sinais de deformação, especialmente na forma de recristalização do quartzo. Os fenocristais deste mineral podem estar convertidos em sub-grãos com extinção ondulante ou mesmo com recuperação cristalina plena (Foto 3B). O mais provável é que estas rochas possuam estas feições por estarem próximas à Falha do Uirapuru (Prazeres et al. 1998), um lineamento de orientação NE-SW confinado à Faixa Itaiacoca. Este falhamento possivelmente foi reativado intermitentemente ao longo do tempo geológico, pois no mapa da CCGP (1966 a) aparece deslocando um dique de microdiorito mesozóico. 


\subsection{Domínios Petrográficos da porção centro-norte do Complexo}

De modo similar ao que acontece ao sul, existe também um contraste marcante entre o padrão de afloramentos das duas principais bacias hidrográficas presentes no centro e norte do Complexo. Em certas áreas ocupadas pelo Rio lapó e seus afluentes, especialmente na região central, pode-se andar por vários quilômetros sem que se veja um único bloco de rocha granitóide. Já na bacia do Rio Jaguariaíva o relevo mais movimentado proporciona um número um pouco maior de exposições, quase exclusivamente na forma de blocos e matacões.

Apesar da precariedade do controle de campo, conduzindo a limites algo arbitrários entre os domínios, é possivel estabelecer alguns traços gerais sobre os granitóides da porção centro-norte do Complexo Cunhaporanga:

a) a faixa contígua aos metassedimentos do Grupo Itaiacoca (de Campina dos Elias a Eduardo Xavier da Silva) concentra uma quantidade significativa de biotita \pm muscovita granitos/granodioritos;

b) rochas dioríticas a quartzomonzodioríticas são raras, mas um pouco mais freqüentes próximo ao "Quartzito Serra das Pedras";

c) os teores de anfibólio nem sempre são tão expressivos como na porção meridional do Complexo, podendo mesmo ser nulos, como na região de Varginha;

d) salvo por estruturas cataclásticas e foliações de fluxo magmático em pontos restritos, as rochas são predominantemente maciças;

e) manifestações magmáticas "não cálcio-alcalinas", como o Granito Joaquim Murtinho (tratado a parte no item 4.6), são subordinadas.

Mesmo sendo irrelevante tecer considerações genéticas quando da proposição de unidades litoestratigráficas, parece clara a existência de um "trend" evolutivo ligando os domínios petrográficos deste trecho do Complexo. Assim, os termos mais primitivos do Domínio Piraí do Sul (maior proporção de dioritos e quartzomonzodioritos) passam a anfibólio biotita monzogranitos dos Domínios Espigão Alto e Biscaias-Boa Vista (diferentes entre si na textura), que por sua vez dão lugar aos biotita monzogranitos do Domínio Paredão da Santa. Já os muscovita biotita granitos/granodioritos do Domínio 
Passo da Anta-Água Clara provavelmente correspondem ao resultado da interação entre os granitóides acima e litotipos do Grupo Itaiacoca. Os biotita granitos porfiríticos do Domínio Varginha (tardios ?) podem ou não relacionar-se aos granitóides restantes.

\subsubsection{Domínio Piraí do Sul (NPcp)}

O Domínio Piraí do Sul, confinado principalmente entre o vale do Rio lapó e o contato com o Grupo Castro, possui exposições apenas ocasionais de rochas granitóides. Estas incluem os "Gnaisses Piraí do Sul" de Reis Neto (1994) e parte da Associação de Fácies I de Guimarães (1995), principalmente os litotipos menos evoluídos da subfácies las (biotita hornblenda monzogranitos, granodioritos e quartomonzodioritos). Apófises quartzo-feldspáticas, fraturas de orientação caótica preenchidas por caulim + muscovita \pm turmalina, além de muscovita centimétrica nos metarenitos/metarcósios do "Quartzito Serra das Pedras", indicam a natureza intrusiva destes granitóides.

Petrografia macroscópica. As rochas existentes na região de Santo André pertencem à Associação de Fácies I de Guimarães (1995) e caracterizam-se por uma estrutura predominantemente maciça e textura equigranular média (fácies $/ a$ ), sendo menos comuns os tipos porfiríticos com matriz média a grossa (fácies $l b e / c$ ). De coloração acinzentada e creme (cor dos fenocristais de feldspato potássico), possuem índice de cor entre 7 e 20 (eventualmente superior) e classificam-se como monzogranitos, granodioritos e quartzo-monzodioritos. Enclaves microgranulares, dioríticos ou com a mesma composição dos granitóides, são relativamente freqüentes.

As rochas visíveis junto à Estrada do Cerne (e. g., PS-1, PS-5), dioritos a monzogranitos acinzentados, são essencialmente similares às descritas próximo a Santo André, diferindo apenas em detalhes (e. g., cristais ocasionais de quartzo arredondado em PS-7). Dioritos coletados próximo ao Ribeirão Guabiroba (PS-32) chamam a atenção pela grande quantidade de cristais euedrais milimétricos de titanita $(2-3 \%$ da rocha). 
Petrografia microscópica. Estas rochas são hipidiomórficas equigranulares a porfiríticas, tendo uma paragênese primária dada por oligoclásio-andesina (freqüentemente com forte zonação), feldspato potássico, quartzo, anfibólio (com núcleos ocasionais de clinopiroxênio), biotita e titanita. Os acessórios são apatita, zircão, allanita e minerais opacos (principalmente magnetita). Quase sempre estas rochas mostram alterações tardi-magmáticas de intensidade baixa a moderada. As transformações incluem principalmente sericitização parcial de plagioclásio e cloritização da biotita, sendo que esta costumeiramente abriga cristais interlamelares de prehnita.

Os dioritos a monzogranitos do ponto PS-5 foram denominados por Reis Neto (1994) como Gnaisses Piraí do Sul, em parte pela presença de discreta foliação magmática e das paragêneses tardi-magmáticas (e. g., clorita + prehnita + epidoto, interlamelares à biotita; sericitização dos plagioclásios; etc.). Cristais ripiformes de plagioclásio zonado, parcialmente corroídos e envolvidos por arranjos granofíricos de quartzo e feldspato alcalino, podem sugerir mistura parcial entre magmas (Fotos $3 \mathrm{C}$, 3D e 3E).

As principais texturas primárias destas rochas são: matriz hipidiomórfica; plagioclásio em agregados (synneusis); zonação por vezes marcante dos plagioclásios (identificada tanto por extinção como por alteração diferencial); anfibólio, allanita e titanita euedrais; inclusões orientadas de plagioclásio e minerais máficos em cristais maiores de feldspato potássico.

Sinais de forte alteração hidrotermal são identificados nas rochas dioríticas do ponto PS-32, próximo ao contato com o "Quartzito Serra das Pedras". Esta manifestase pela presença expressiva de muscovita, substituindo a biotita (junto com epidoto) ou preenchendo vênulas irregulares. 


\subsubsection{Domínios Biscaias-Boa Vista (NPcbbv), Espigão Alto (NPcea) e Paredão da Santa (NPCPS)}

As rochas que compõem o segmento setentrional do Complexo são principalmente biotita monzogranitos inequigranulares com algum anfibólio (equivalendo às rochas da Associação de Fácies I de Guimarães 1995, principalmente os litotipos da subfácies laM.

Em alguns trechos, entretanto, foge-se deste padrão, seja com granitóides fortemente porfiríticos (feldspato potássico) ou então pela ausência de rochas com anfibólio. Apesar do controle de campo algo precário, procurou-se individualizar no mapa geológico do Anexo 3 as áreas correspondentes a cada uma das variantes petrográficas mencionadas (respectivamente Domínios Espigão Alto, Biscaias-Boa Vista e Paredão da Santa).

As relações de idade entre os hornblenda biotita granitóides equigranulares e porfiríticos não puderam ser determinadas conclusivamente em campo. Já os biotita granitóides podem aparecer em diques intrusivos nas rochas porfiríticas (e. g., JGA32).

Próximo ao limite entre os Domínios Biscaias-Boa Vista e Varginha (Rio do Tigre; PS-36), observam-se blocos de um biotita granitóide de aspecto pórfiro. A sua forma de ocorrência não permite estabelecer se está disposta como dique, "plug", etc., ou mesmo configurando a fácies de borda de um corpo maior (ver descrição de situação semelhante para rochas do Domínio Varginha, item 4.3.6).

O quadro inverso (hornblenda granitóide porfirítico intrusivo em biotita granito equigranular) é mais raro, mas é observado no ponto PS-68. Mas neste caso o biotita granito encontra-se foliado, possuindo um aspecto semelhante ao das rochas do Domínio Santa Rita (ver item 4.2.4). A distância, aliada à baixa densidade de afloramentos, não estimula que estas rochas sejam consideradas seguramente correlatas. 
Petrografia macroscópica. As rochas porfiríticas com anfibólio são maciças, de matriz média e fenocristais de feldspato potássico da ordem de 1-1,5 cm (e. g., PS-36) ou mais comumente $3-5 \mathrm{~cm}$ (excepcionalmente $7-8 \mathrm{~cm}$; e. g., PS-67, PS-68), tendo índice de cor 10 a 15, ocasionalmente 20. Os teores de anfibólio dos tipos equigranulares quase sempre são baixos, de modo similar ao que foi discutido por Guimarães (1995) para as rochas da subfácies laN. Enclaves dioríticos são eventuais (e. g., PS-92; Fotos 4A e 4B).

Os "pórfiros" do Rio do Tigre são branco-amarelados, por intemperismo, tendo índice de cor entre 15 e 25. Localmente as rochas possuem uma proporção mais elevada de fenocristais de feldspato, o que confere um índice de cor mais baixo, entre 3 e 5. Maciças a levemente foliadas, possuem matriz fina com fenocristais euedrais milimétricos (raramente centimétricos) de feldspato potássico, plagioclásio, biotita e quartzo.

Logo abaixo da represa da fábrica de papel Cachoeira (JGA-21) observa-se um dique de microgranito ( $5 \mathrm{~m}$ de espessura) intrusivo em um hornblenda biotita granito. A rocha possui cor cinza-rosada (ocre-amarelada quando intemperizada), com índice de cor próximo a zero. A textura é porfirítica, com microfenocristais de quartzo (arredondados, com diâmetro máximo de $\sim 1,5 \mathrm{~mm}$ ), feldspato rosado (subedral/euedral, de 1 a $3 \mathrm{~mm}$ ) e minerais máficos esverdeados alongados (máximo de $2 \mathrm{~mm}$ ). A matriz é fina a muito fina.

Petrografia microscópica. As principais texturas primárias das rochas dos Domínios Biscaias-Boa Vista, Espigão Alto e Paredão da Santa são: matriz hipidiomórfica; plagioclásio em agregados (synneusis); zonação por vezes marcante dos plagioclásios (identificada tanto por extinção como por alteração diferencial; Fotos 2C e 2D); anfibólio, allanita e titanita euedrais; inclusões orientadas de plagioclásio e minerais máficos em cristais maiores de feldspato potássico. A medida em que reduzse a porcentagem de anfibólio (acompanhada da elevação dos teores de quartzo), percebe-se uma acentuada tendência ao idiomorfismo por parte da biotita e da titanita. 
Os "pórfiros" do Rio do Tigre (monzogranitos a granodioritos) mostram domínios com proporções bem variadas de biotita, orientada segundo uma foliação provavelmente de origem magmática. Sinais de alteração deutérica-hidrotermal são apenas discretos (e. g., cloritização da biotita é quase nula). As principais texturas primárias destas rochas são: matriz hipidiomórfica; titanita subedral; inclusões orientadas (plagioclásio e minerais máficos) em cristais maiores de feldspato potássico.

Os fenocristais de quartzo do microgranito hololeucocrático da fábrica Cachoeira (JGA-21) são subedrais/euedrais, muitas vezes com uma fina orla de intercrescimento micrográfico, enquanto que os de feldspato estão intensamente alterados (para argilas, sericita e carbonatos), tornando-se difícil a determinação do tipo de feldspato presente. $\mathrm{Na}$ matriz, além de finos cristais anedrais de quartzo e de feldspatos, há também pequenos cristais anedrais de biotita (?) verde, zircão, carbonatos e fluorita (esta também em cavidades dentro de fenocristais de feldspato).

\subsubsection{Domínio Espalha Brasa (NPceb)}

Próximo ao contato com o Grupo Castro, entre Piraí do Sul e Joaquim Murtinho (região de Espalha Brasa no mapa da CCGP 1970 b), Guimarães (1995) separou um conjunto de granitóides cataclásticos, denominados na ocasião como Associação de Fácies III.

Petrografia macroscópica. Estas rochas têm índice de cor entre 5 e 7 e coloração avermelhada, decorrente de alterações intempérica e deutérica. A estrutura varia desde maciça com fraturas até cataclástica, com fluorita preenchendo estas fraturas ou ocorrendo disseminada. De textura inequigranular a porfirítica, possuem fenocristais de feldspato potássico alcançando entre 3 e $4 \mathrm{~cm}$, enquanto que a matriz varia de afanítica a fanerítica média-grossa.

Petrografia microscópica. Os monzogranitos a granodioritos destacam-se pela deformação cataclástica, com forte cominuição dos minerais, além das vênulas com argilominerais e fluorita. A biotita, quase integralmente cloritizada, é o principal mineral máfico (anfibólio está ausente). 


\subsubsection{Domínio Passo da Anta-Boa Esperança (NPcpac)}

Seguindo-se para leste/nordeste a partir dos domínios setentrionais anteriores, tem-se uma faixa que se estende desde Passo da Anta até Boa Esperança. Nela são encontrados granitóides com biotita ou biotita + muscovita intercalados a metassedimentos, freqüentemente com apófises graníticas de aspecto pegmatóide e com muscovita. Apesar dos granitóides da Associação de Fácies II de Guimarães (1995), na região de Joaquim Murtinho, serem essencialmente similares às rochas deste domínio, são tratados em separado (ver item 4.3.5). No entanto não se descarta a possibilidade de que possam fazer parte de uma mesma unidade, parcialmente encoberta pela Bacia do Paraná.

Petrografia macroscópica. As rochas granitóides em que existe o predomínio de biotita são cinza-ciaras (índice de cor 5; branco-amareladas quando intemperizadas), enquanto que as com muscovita e biotita têm coloração cinza-avermelhada (índice de cor $\leq 2$ ). Maciças (e. g., JGA-10, JGA-14) ou foliadas (e. g., PS-44, PS-57), são normalmente equigranulares finas a médias, podendo comportar ocasionalmente domínios de granulação grossa a muito grossa. Esporadicamente vêem-se pequenos enclaves biotíticos alongados paralelamente à foliação do granitóide hospedeiro.

Petrografia microscópica. Os granitóides (monzogranitos a granodioritos) possuem oligoclásio (raramente zonado), feldspato potássico (freqüentes inclusões de quartzo arredondado, especialmente nos muscovita biotita granitos), quartzo, biotita parcialmente cloritizada e muscovita. Em alguns casos allanita ou titanita são acessórios, em conjunto com apatita, zircão e opacos. As texturas são panxenomórficas $\theta$ tanto a biotita como os minerais félsicos podem dispor-se orientados, definindo uma foliação (magmática?).

A muscovita ocorre associada à biotita (intercalada e, por vezes, radiada), isolada (subedral) ou substituindo feldspato (preenchendo fraturas).

Minerais opacos podem aparecer em boas quantidades nestas rochas, apresentando-se subedrais a euedrais (hábito quadrangular: magnetita e pirita ?). Esta 
observação ratifica os valores relativamente altos de susceptibilidade magnética para alguns destes litotipos $(\boldsymbol{k} \sim 6,5$ unidades S.I.).

\subsubsection{Domínio Arroio das Pedrinhas (NPcap)}

Os granitóides a base de biotita e biotita + muscovita existentes nas proximidades das nascentes do Arroio das Pedrinhas, junto ao sopé da escarpa do Furnas, são nitidamente distintos dos (anfibólio) biotita monzogranitos predominantes na região de Joaquim Murtinho. Denominados por Guimarães (1995) como Associação de Fácies II, são aqui rebatizados como Domínio Arroio das Pedrinhas.

Petrografia macroscópica. Os biotita granitos (fácies lla de Guimarães 1995) são cinzentos, com índice de cor entre 5 e 15 e textura equigranular média. Maciços a levemente foliados, possuem freqüentes enclaves biotíticos e, mais raramente, xenólitos quartzosos.

Os muscovita biotita granitos (fácies //b de Guimarães 1995) aparecem em quantidades significativamente menores, distinguindo-se por sua coloração rósea (índice de cor inferior a 5). Texturalmente são equigranulares finos a médios.

Petrografia microscópica. A paragênese primária dos biotita granitóides (monzogranitos, granodioritos e quartzomonzonitos) constitui-se de oligoclásioandesina subedral, feldspato potássico (com inclusões arredondadas de quartzo comuns), quartzo, biotita e, raramente, titanita. Zircão, apatita, allanita e opacos aparecem como acessórios. Predomina a textura hipidiomórfica equigranular a inequigranular.

Alterações tardi-magmáticas são observadas, porém pouco intensas. Estas incluem sericitização do plagioclásio, além de cloritas, argilas e hidróxidos de ferro interlamelares à biotita, freqüentemente acompanhadas de diminutos cristais de pumpellyita esferulítica ou prehnita. 
As rochas com muscovita mostram composições modais enriquecidas em quartzo (assimilação de metassedimentos ?), textura xenomórfica equigranular a inequigranular e uma paragênese primária com plagioclásio, feldspato potássico (ambos com grande número de inclusões arredondadas de quartzo), muscovita $\theta$ biotita parcialmente cloritizada. Os acessórios mais importantes são turmalina (fortemente pleocróica; Foto 4E), opacos (pirita, dentre outros) e zircão.

A muscovita ocorre tanto isolada como associada a feldspatos e biotita, desde xenomórfica até idiomórfica (Foto 4F). Localmente há filmes de biotita intercalados aos planos de clivagem de cristais euedrais de muscovita.

\subsubsection{Domínio Varginha (NPcv)}

As informações nesta porção do Complexo são muito restritas, resumindo-se a matacões isolados nas encostas dos Ribeirões do Anselmo (e. g., PS-46 e 47) e Cunhaporanga (PS-66), na região de Varginha. As rochas identificadas são predominantemente biotita granitos porfiríticos, além de uma ocorrência isolada de um granitóide de aspecto pórfiro (PS-48).

Estes "pórfiros" foram observados num local em que também existem os tipos porfiríticos dominantes. Além de espacialmente ligadas, estas litologias apresentam as mesmas fases minerais (até mesmo allanitas fortemente zonadas), o que pode levar a duas suposições: ou os "pórfiros" representam uma fácies de borda de um corpo principal, formado pelos biotita granitos porfiríticos, ou são manifestações recorrentes do mesmo líquido magmático responsável pela cristalização de ambos os tipos petrográficos.

Petrografia macroscópica. Os biotita granitos são inequigranulares a porfiríticos, matriz média a grossa, com fenocristais de feldspato potássico normalmente entre 1-2 $\mathrm{cm}$ (excepcionalmente $3 \mathrm{~cm}$ ). Maciças a levemente foliadas, têm coloração ora acinzentada, ora creme-esbranquiçadas, onde 0 índice de cor normalmente situa-se entre 5 e $10 \mathrm{ou}$, eventualmente, ainda menos. Enclaves microgranulares dioríticos, de diâmetro milimétrico a centimétrico, são comuns. 
Os "pórfiros" são maciços e encontram-se pouco alterados, tendo coloração cinza e índice de cor entre 5 e 7 . Os fenocristais são euedrais milimétricos (raramente centimétricos), de feldspato potássico, plagioclásio, biotita e quartzo, reconhecendo-se na matriz (granulação fina a média) titanitas euedrais com até $2 \mathrm{~mm}$.

Petrografia microscópica. Os biotita monzo- a sienogranitos (?) sofreram modificações de caráter hidrotermal de intensidade desde branda até elevada. Estas alterações manifestam-se como muscovitização dos feldspatos e da biotita, cloritização da biotita, presença de carbonatos intersticiais ou derivados de plagioclásio e, mais raramente, fluorita associada às cloritas.

Determinações modais macroscópicas, efetuadas em fatias de rocha submetidas a ensaio de coloração seletiva dos feldspatos, indicaram composições ricas em feldspato potássico (PS-47). No entanto, após exame ao microscópio, percebeu-se que a quantidade deste mineral fora superestimada em decorrência da forte muscovitização do plagioclásio (o ensaio tinge fases minerais ricas em potássio, o que acaba também por ocorrer com os grãos de plagioclásio com muita muscovita; Foto 5A).

As principais texturas primárias destas rochas são: matriz hipidiomórfica; intercrescimentos micrográficos nas orlas dos feldspatos potássicos; forte zonação dos plagioclásios (tanto por extinção como por alteração diferencial); allanita e titanita euedrais (esta última em quantidades às vezes bem reduzidas); inclusões orientadas de plagioclásio e minerais máficos em cristais maiores de feldspato potássico.

A textura da matriz dos "pórfiros" (rochas monzograníticas ?) é xenomórfica granular, sendo os microfenocristais de feldspato potássico subedrais/anedrais (com muitas inclusões de plagioclásio, quartzo, apatita e biotita) e os de plagioclásio euedrais a subedrais, com forte zonação. 


\subsection{Domínios Petrográficos da porção NE do Complexo}

O setor nordeste do Complexo Cunhaporanga tem uma proporção entre metassedimentos e rochas granitóides tão elevada que, sem exagero, também poderia ser descrito como um "segmento do Grupo Itaiacoca caracterizado por elevado número de intrusões graníticas" (ver também o item 4.7.1, adiante). A faixa de metassedimentos orientada N-S, que passa por E. X. da Silva, Água Clara e prossegue em direção à Campina dos Elias, praticamente separa os granitóides discutidos neste item do restante do Complexo.

\subsubsection{Domínio Ouro Verde-Patrimônio Santo Antônio (NPcov)}

Este domínio petrográfico é composto por um núcleo maior de forma ovalada (balizado pelas localidades de Patrimônio Santo Antônio, Ouro Verde, Campina do Morro Azul $\Theta$ Bairro da Roseira), que aparece com destaque em mapas aerogamaespectrométricos (Anexo 4), além de pequenas áreas a oeste e sudoeste. Quase totalmente circundado por rochas do Grupo Itaiacoca, nele são comuns matacões métricos a decamétricos de rochas granitóides.

A constituição litológica deste domínio é quase homogênea e é dada por um biotita monzo- a sienogranito porfirítico que adquire, em direção ao contato com as encaixantes, uma textura equigranular fina. Em um único ponto (IT-96) foi identificado um pórfiro de composição monzogranítica a granodiorítica.

Petrografia macroscópica. O principal tipo petrográfico é um granitóide maciço, onde sua textura é seriada, desde uma matriz de granulação média até fenocristais centimétricos de feldspato potássico (normalmente $1-3 \mathrm{~cm}$ ) e de plagioclásio $(1 \mathrm{~cm}$ ). Localmente são visíveis cristais arredondados de quartzo (forma quase bipiramidal). Biotita e titanita euedral são os minerais máficos, conferindo um índice de cor geralmente entre 10 e 15 , sendo a cor geral da rocha algo creme-acinzentada. 
Entre os enclaves, pouco freqüentes, predominam aqueles de composição mineralógica semelhante a deste granitóide. Aqueles essencialmente ricos em biotita (xistos recristalizados ?) e quartzosos são mais raros (xenólitos de quartzitos; Foto 5B).

O contato oeste das rochas granitóides (Cerrado da Roseira; e. g., IT-101 e 104) caracteriza-se pela alternância de metassedimentos (principalmente quartzitos) com um granito quase sempre muito alterado e maciço. Sua granulação é fina, com raros cristais maiores de feldspato potássico $(<5 \mathrm{~mm})$. O índice de cor é da ordem de 7 a 10, sendo a cor geral da rocha cinzenta. Enclaves de composição similar ao do próprio granitóide (apenas mais ricos em biotita e titanita) podem estar presentes.

No ponto IT-96, em meio aos biotita granitóides porfiríticos, existe uma quantidade reduzida de blocos de um granitóide cinzento, maciço e com textura porfirítica e matriz fina a muito fina (com titanita). Os fenocristais milimétricos euedrais são de biotita e plagioclásio, mais raramente de anfibólio e feldspato potássico (cristais maiores).

Petrografia microscópica. Nos monzo- a sienogranitos reconhecem-se plagioclásio intensamente zonado, quartzo (cristais maiores com formato arredondado; recristalização a partir de xenólitos de metarenitos ?), feldspato potássico (fenocristais são localmente zonados e com muitas inclusões ordenadas de plagioclásio), biotita e titanita (esta por vezes abundante). Os acessórios principais são allanita, opacos (magnetita e ilmenita), apatita e zircão. A textura é hipidiomórfica equigranular (Cerrado da Roseira) ou porfirítica com matriz hipidiomórfica granular.

Sericitização moderada do plagioclásio, leve cloritização da biotita, prehnita e granada interlamelares à biotita são feições secundárias comuns. É difícil indicar se a muscovita destas rochas (associada a feldspatos, biotita/clorita ou isolada) é primária ou secundária.

O pórfiro assemelha-se, quanto à composição mineralógica, aos anfibólio biotita monzogranitos (a granodioritos) do Domínio Petrográfico Limeira (ver adiante). Tem como associação de minerais primários: plagioclásio euedral (com zonação muitíssimo 
marcada), anfibólio subedral/anedral (parcialmente convertido em biotita, dentre outros), biotita idiomórfica/sub-idiomórfica, quartzo, feldspato potássico (como intercrescimento micrográfico que circunda fenocristais de plagioclásio ou na matriz), titanita e epidoto, além de minerais como zircão, apatita e magnetita (isolados ou agregados).

De forma similar ao que ocorre para as rochas do domínio Limeira, também há diferenças marcantes de pleocroísmo entre o epidoto tido como primário e aquele seguramente secundário. O primeiro possui cores suaves (incolor a amarelo bem claro), enquanto o segundo as tem intensas, variando entre incolor, amarelo e amareloesverdeado (Fotos 5C e 5D).

Alterações tardi-magmáticas (brandas a moderadas) incluem sericitização do plagioclásio, cloritização da biotita e inclusões de titanita, epidoto, hidrogranada, prehnita e pumpellyita na biotita.

\subsubsection{Domínio Limeira (NPcl)}

Entre o Bairro São Domingos e Ouro Verde, nas proximidades da confluência dos córregos Taquaruçu e Ribeirãozinho, estendendo-se em direção ao Bairro da Limeira, ocorre uma sucessão de blocos de rochas granitóides, acompanhados de blocos de muscovita biotita quartzitos (até quartzo muscovita biotita xistos) e quartzo muscovita biotita gnaisses finos (o gnaisse datado pelo método Rb-Sr por Souza 1990, foi coletado neste domínio; ver item 2.1.5, Capítulo 2).

Os granitóides, além de terem produzido metamorfismo termal e hidrotermalismo sobre os metassedimentos, apresentam sinais sugestivos de que as rochas encaixantes tenham sido parcialmente assimiladas. Isto manifesta-se através da transição entre tipos essencialmente ígneos de um lado e metamórficos do outro, com uma ampla gama de termos com composição intermediária, identificados por diferenças texturais e na proporção de quartzo e minerais máficos. 
Assim, no trecho referido, tem-se biotita granitos e muscovita biotita granitos com colorações claras e índice de cor entre 0 e 15. Maciças a foliadas, podem ser desde afaníticas a faneríticas finas a muito grossas (pegmatóides) ou até mesmo porfiríticas (matriz fina com fenocristais milimétricos de quartzo, feldspato e biotita). Não foi possivel definir em campo qual seria o granitóide original, totalmente desprovido dos efeitos da assimilação (e. g., biotita granitos do Domínio Ouro VerdePatrimônio Santo Antônio ? Granito São Domingos ?).

Junto às rochas descritas acima, ao menos em três pontos (IT-10, 50 e 58), foram vistos também matacões isolados de anfibólio biotita monzogranitos a granodioritos. Contudo, não foi possível determinar a natureza de suas relações com os outros tipos ígneos (seriam enclaves ? materiais preservados durante a assimilação das encaixantes ?). Estes tipos com anfibólio são rochas acinzentadas, com índice de cor entre 10 e 15 (eventualmente maiores). A estrutura é principalmente maciça (localmente com cataclase, planos preenchidos com epidoto e forte cloritização) e a textura é inequigranular média, com fenocristais euedrais de feldspato potássico (1-1,5 $\mathrm{cm}$ ).

Enclaves microgranulares claros (de composição granítica, apenas com granulação fina) e "biotíticos", além de xenólitos de quartzitos, todos de dimensões centimétricas, podem estar presentes.

Petrografia microscópica. Os granitóides com biotita e biotita + muscovita citados acima têm composições essencialmente graníticas, ora com mais feldspato potássico, ora mais plagioclásio. A textura predominante é quase sempre panxenomórfica granular, com a muscovita aparecendo isolada (subedral) ou associada a biotita/clorita. Raros cristais de titanita euedral (muito alterados) indicam que o tipo de granitóide que interagiu com os metassedimentos também possuía esta fase mineral.

Os minerais primários dos granitóides com anfibólio incluem também plagioclásio (com forte zonação), quartzo, feldspato potássico (eventualmente zonado e com inclusões ordenadas, principalmente de plagioclásio), biotita e titanita (por vezes 
zonada). Entre os acessórios, além de zircão, magnetita e apatita, destacam-se ainda allanita e epidoto.

O epidoto, considerado primário, aparece ou bordejando cristais idiomórficos fortemente zonados de allanita (Fotos da Prancha 6), ou como cristais euedrais/subedrais isolados ou ainda associados a outros minerais máficos. Ao contrário do epidoto secundário, que também existe nestas rochas, seu pleocroísmo é tênue.

Estes monzogranitos a granodioritos têm uma trama mineral hipidiomórfica granular, com glomérulos dos minerais máficos e ocasionalmente cristais agrupados de plagioclásio (em synneusis).

Modificações dos minerais precoces incluem: cloritização desde baixa a intensa da biotita; presença de epidoto, prehnita e pumpellyita, intercalados aos cristais de biotita; bordas de epidoto secundário sobre epidoto primário; sericitização moderada a elevada do plagioclásio.

\subsubsection{Domínio Francisco Simas-Vila Branca (NPcsvb)}

Os trechos correspondentes a este domínio, no mapa do Anexo 3, são os mesmos agrupados por Ribas (1981) sob a denominação de Granito Francisco Simas. Eles situam-se, da Campina dos Elias em direção a Dr. Ulysses, na região da Serra do Jacuzal, na região das cabeceiras dos rios Teixeira e Jaguaricatu e entre a Serra do Macaco e Caetanos.

Trata-se de uma porção do Complexo com grande quantidade de septos do Grupo Itaiacoca, em geral com sinais de metamorfismo de contato e/ou assimilação. A presença expressiva de metassedimentos deve responder pela ausência de granitóides com anfibólio e do predomínio de granitóides com biotita e biotita + muscovita.

Preferiu-se utilizar uma denominação informal ao invés daquela proposta por Ribas (1981) por dois motivos. Primeiramente, apesar de não se ter uma compreensão 
adequada sobre quais são os granitóides existentes nos três trechos citados acima, os dados aqui trazidos indicam que eles podem ser diferentes entre si. Em segundo lugar, porque o nome Vila Branca já foi utilizado anteriormente (PROTEC 1969, in CPRM 1972 a; Gomes et al. 1971 a, b) e, portanto, é prioritário.

\subsubsection{Serra do Jacuzal}

Na Serra do Jacuzal, ao sul da Campina dos Elias, tem-se um grande número de blocos e matacões de um granitóide cinza-acastanhado, muitos deles com diâmetros decamétricos (PS-63). Seu contato com metassedimentos pelíticos e psamíticos é nitidamente intrusivo (recristalização e neoformação de minerais nas rochas encaixantes; apófises com muscovita e textura pegmatóide; PS-61, 62, 64 e 65).

Petrografia macroscópica. Estas rochas têm índice de cor entre 5 e 7 e uma textura inequigranular seriada, variando sua granulometria entre 2 e $13 \mathrm{~mm}$, normalmente de 5 a $8 \mathrm{~mm}$. A biotita quase sempre é pequena, podendo constituir agregados alongados com até $4 \mathrm{~mm}$. Titanita e pirita euedrais são comuns. $A$ estrutura é foliada, com orientação dos minerais félsicos e máficos, assim como de pequenos enclaves ricos em biotita.

Petrografia microscópica. Estes granodioritos a monzogranitos possuem oligoclásio, quartzo, feldspato potássico, biotita e titanita como principais minerais, em geral orientados segundo uma foliação provavelmente magmática. Em quantidades subordinadas ocorrem apatita, opacos (magnetita, pirita), allanita (cristais pequenos e zonados) e zircão.

A textura é inequigranular, com cristais maiores subedrais em uma matriz xenomórfica. O plagioclásio, com muitas mirmequitas, não tem zonação marcada. Glomérulos alongados de minerais máficos (biotita, titanita e opacos) são comuns. 
Cloritização da biotita é restrita, enquanto que parte dos grãos de plagioclásio estão sericitizados ou substituídos por cristais maiores de muscovita e, mais raramente, carbonatos.

\subsubsection{Estação Francisco Simas}

Petrografia macroscópica. Na região das cabeceiras do Rio Jaguaricatu, entre o Rio Teixeira e a estação ferroviária de Francisco Simas, tem-se rochas cinza-claras quando sãs, equigranulares médias e com índice de cor inferior a 5. São maciças, com porções localizadas em que a foliação é bem definida. Veios pegmatóides com muscovita são muito comuns, dispondo-se em direções diversas e de modo discordante à foliação do granito encaixante, quando a mesma está presente. Destaca-se a cor intensamente negra da "biotita" destes granitóides.

Petrografia microscópica. Os sieno- a monzogranitos (Foto 7A) possuem oligoclásio (raramente zonado), feldspato potássico (freqüentes inclusões de quartzo arredondado), quartzo e biotita fortemente cloritizada e/ou substituída por muscovita e hidróxidos de ferro. Fluorita pode aparecer em pequenas quantidades. As texturas são panxenomórficas e eventualmente identifica-se uma foliação (magmática?), definida pela orientação de "biotita" e minerais félsicos.

\subsubsection{Serra do Macaco-Dr. Ulysses}

Este trecho, praticamente não investigado neste trabalho, provavelmente abriga parte das rochas incluídas na unidade Vila Branca pela PROTEC (Gomes et. al. 1971 a, b; CPRM 1972 a). Os poucos locais analisados permitiram visualizar uma freqüente imbricação entre metassedimentos e rochas granitóides.

\subsubsection{Granito São Domingos (NPcsd)}

Concordando com o que Soares et al. (1987) comentaram sobre o Granito São Domingos, a cobertura vegetal (na forma de reflorestamento com Pinus sp.) e o 
intemperismo dificultam o reconhecimento dos tipos petrográficos presentes, suas relações com as unidades adjacentes, além da própria extensão do corpo ígneo.

As informações levantadas durante as etapas de campo ainda são insuficientes para confirmar ou rejeitar o panorama descrito por Soares et al. (1987), ou seja, de que a unidade se apresentaria zonada, com um aumento progressivo da intensidade da alteração hidrotermal de SW para NE. Também é prematuro estabelecer correlações com os granitóides vizinhos (e. g., do Domínio Petrográfico Ouro Verde-Patrimônio Santo Antônio).

Das quatro zonas em que se subdividiria o Granito São Domingos, foram descritos pontos localizados apenas nas porções discriminadas como " $\gamma 1$ " e " $\gamma 2$ " no mapa geológico de Soares et al. (1987). O " $\gamma$ 1" (e. g., IT-46 e 52) é um biotita granito com índice de cor variável (freqüentemente entre 7 e 10), textura equigranular/inequigranular média a grossa, podendo estar ligeiramente foliado.

Já o " $\gamma 2$ " caracteriza-se por uma marcante variação textural (afanítico com cristais majores de quartzo bipiramidal até equigranular grosso), coloração róseoavermelhada e um índice de cor normalmente inferior a 3 (biotita cloritizada). Em lajes do ponto IT-43 são comuns veios de quartzo de orientação N65-80E, com pouco ou nenhum feldspato, acompanhados por vezes de sulfetos oxidados. Os veios podem estar escalonados ao longo de fraturas paralelas e localmente adelgaçados (no entanto a espessura dificilmente ultrapassa os $5 \mathrm{~cm}$ ). Neste ponto também foram identificadas fluorita e galena disseminadas no granito.

\subsection{Granito Serra do Carambeí}

Com bom número de exposições, principalmente como lajes de rocha friável, o Granito Serra do Carambeí (Fuck 1967) dispõe-se como um corpo alongado segundo N30E, no extremo sudoeste do Complexo. Rochas relativamente frescas são encontradas apenas em algumas pedreiras na região de Catanduva de Fora. 
Exceto por raros diques com rochas "riolíticas" (os elvans de Pinto-Coelho 1986), costuma-se descrever o Granito Serra do Carambeí como tendo um único tipo petrográfico, tanto em termos texturais como composicionais (cf. Santos \& Felipe 1980; Pinto-Coelho 1986). No entanto, isto só é verdadeiro se for considerada exclusivamente a área radioanômala da Figura 3 do Anexo 4, ou seja, onde há uma forte anomalia positiva no canal da contagem total do levantamento aerogamaespectrométrico do PSMS.

Como já foi abordado por outros autores (e. g., Fuck 1967), a região que marca o contato entre as rochas do Granito Serra do Carambeí e suas encaixantes (outros granitóides do Complexo) é pobre em afloramentos. Este fato fez com que Fuck (1967) e Fuck et al. (1967 a) aventassem a possibilidade de uma passagem transicional entre os álcali-feldspato granitos e os granitóides cálcio-alcalinos circunjacentes. Pontos descritos nesta região de contato $\left(\mathrm{SC}-4^{+}, 5,6,11\right.$ e 12; ver Anexo 2) sugerem a existência de uma fácies de borda no Granito Serra do Carambeí, algo distinta dos "alasquitos" característicos da unidade.

\subsection{1 Álcali-feldspato granitos (NPcsc $)_{1}$ )}

Petrografia macroscópica. Estas rochas são normalmente avermelhadas ou amareladas quando alteradas, variando entre róseo e cinza quando frescas. $O$ índice de cor dificilmente ultrapassa 3 , sendo biotita $e$ hematita os minerais máficos predominantes. A textura é equigranular fina a grossa, localmente com pegmatitos quartzo-feldspáticos. Hematita, fluorita e sulfetos (pirita, galena, etc.) são comuns, disseminados ou ocupando fraturas.

Petrografia microscópica. Muito semelhantes aos álcali-feldspato granitos do Granito Joaquim Murtinho, diferem principalmente pela menor intensidade das deformações rúpteis e das alterações tardi-magmáticas. A biotita é xenomórfica (Foto 7B) e intersticial ao quartzo e ao feldspato mesopertítico (Foto 7C), podendo estar pouco ou intensamente alterada (argilominerais, opacos, clorita e muscovita) e com inclusões lenticulares de quartzo. Os zircões são relativamente grandes e de seção 
basal quadrangular, freqüentemente acompanhados por opacos e material de aspecto ferruginoso.

Ao contrário do que descreveram Pinto-Coelho \& Siedlecki (1988), em nenhuma das lâminas estudadas foram identificadas allanita ou titanita, esta última considerada pelas autoras como um mineral acessório comum nestas rochas.

\subsubsection{Fácies de borda ( $\left.\mathrm{NPCs}_{2}\right)$}

Petrografia macroscópica. Nos pontos SC-11 e 12, ao norte do Rio Jotuba, temse rochas moderada a intensamente alteradas de coloração variada (tons acinzentados, alaranjados e marrom-esverdeados). $O$ índice de cor oscila entre 5 e 10 , sendo o principal mineral máfico a biotita. Texturalmente são rochas bem heterogêneas, alternando porções equigranulares médias a grossas com porfiríticas de matriz fina. Neste último caso, os fenocristais euedrais podem ser de feldspato potássico ( $\geq 2 \mathrm{~cm}$; predominantes), plagioclásio, biotita (até $1 \mathrm{~cm}$ ) e quartzo (cor branca a azulada).

Seu aspecto macroscópico geral é totalmente distinto tanto dos álcali-feldspato granitos como dos hornblenda granodioritos foliados, estes visíveis a partir dos pontos SC-13 e SC-14.

No contato sul do Granito Serra do Carambeí (pontos SC-4 ${ }^{+}$, SC-5 e SC-6), cortes de estrada mostram rochas profundamente intemperizadas. Estas possuem aspecto similar ao observado nas porções alteradas das exposições localizadas ao norte, acima descritas (SC-11 e 12).

Petrografia microscópica. Apesar de profundamente alterados, os feldspatos provavelmente são mesopertíticos, com finas orlas de intercrescimento micrográfico (semelhantes às existentes nos sienitos/quartzo sienitos da fácies $V b$ do Granito Joaquim Murtinho; ver Guimarães 1995). Os minerais máficos primários podem estar totalmente substituídos por argilominerais e opacos alongados paralelamente às clivagens do hospedeiro (biotita). Uma matriz de granulação fina possui pequenos 
cristais tardios de biotita (parcialmente cloritizada), quartzo, opacos, feldspato e fluorita. Entretanto, contrariamente ao que se vê nos álcali-feldspato granitos, esta matriz tem uma boa quantidade de pequenos cristais euedrais de apatita e subedrais/anedrais de titanita (normalmente com muita ilmenita).

\subsection{Granito Joaquim Murtinho (NPcjm)}

O Granito Joaquim Murtinho (Guimarães 1995; Guimarães \& Ulbrich 1996) é um corpo ígneo intrusivo com menos de $10 \mathrm{~km}^{2}$ de superfície aflorante, limitado por falhas normais (no contato com o Grupo Castro ou com outros granitóides do Complexo Cunhaporanga) ou então recoberto discordantemente pelos arenitos da Formação Furnas. Localizado na região de Joaquim Murtinho (divisa dos municípios de Piraí do Sul e Jaguariaíva), está exposto na forma de lajes em encostas ou em pedreiras ao lado da PR-151 e da ferrovia Ponta Grossa-Itararé (Foto 1C).

Petrografia macroscópica. Os álcali-feldspato granitos da Associação de Fácies IV de Guimarães (1995) representam o Granito Joaquim Murtinho típico. São rochas com intensidade variada de cataclase, muitas vezes com os planos de fratura preenchidos por hematita (Foto 7D), fluorita e/ou sulfetos (pirita, calcopirita, galena, etc.). Localmente com cavidades miarolíticas milimétricas, possuem textura equigranular afanítica a muito grossa (ocasionalmente são observados "pods" pegmatóides de quartzo e feldspato).

$O$ índice de cor é sempre muito baixo, sendo a hematita o mineral máfico predominante. Além de ocorrer em fraturas, aparece também em substituição a minerais primários (provavelmente biotita). As cores das rochas variam entre 0 marrom-avermelhado (mais freqüente) e diversos tons de cinza-esverdeado, dependendo da cor dos feldspatos.

De ocorrência mais restrita, os sienitos/quartzo sienitos da fácies $V b$ (Associação V), normalmente intensamente intemperizados, têm coloração amarelo 
rosada e índice de cor superior a 10 (principalmente minerais opacos). Maciços, são inequigranulares a porfiríticos, com matriz afanítica a fanerítica média.

Petrografia microscópica. Os minerais primários dos álcali-feldspato granitos são mesopertita (Foto 7E), quartzo e biotita (atualmente completamente substituída por argilominerais e óxidos/hidróxidos de ferro), com cristais quadrangulares de zircão (zonados e parcialmente metamictizados) como acessórios.

As feições microscópicas de maior destaque são a deformação cataclástica e as transformações deutérico-hidrotermais (Fotos 7E e 7F). Estas são responsáveis pela modificação parcial (mesopertita) ou total (biotita ?) de parte dos minerais precoces, reconhecendo-se processos de albitização, muscovitização, argilização e substituição por óxidos/hidróxidos de ferro (hematitização). Carbonatos, sulfetos e fluorita (Foto 8A) disseminados, em fraturas ou nos miárolos, também são de origem secundária.

Tanto os álcali-feldspato granitos leucocráticos ("alasquitos") como as rochas sieníticas possuem texturas típicas de rochas subvulcânicas: feldspato mesopertítico (granitos "hypersolvus"), intercrescimento micrográfico (Foto 8B), quartzo bipiramidal com engolfamentos nas bordas e cavidades miarolíticas.

\subsection{Setores indiferenciados (NPc)}

$\mathrm{Na}$ porção nordeste $e$ central do Complexo algumas áreas permanecem indiferenciadas (ver Anexo 3). Isto se deve principalmente ao volume insuficiente de informações sobre os tipos petrográficos destes trechos. No entanto os granitóides identificados, quase sempre muito alterados, costumam ser ou biotita ( \pm muscovita) granitos finos a médios (e. g., IT-7 e 8), ou biotita granitos inequigranulares a porfiríticos (e. g., IT-21 e 23). 


\subsection{Contato com as unidades adjacentes}

Deixando-se de lado as rochas do enxame de diques do Arco de Ponta Grossa, os sedimentos cenozóicos da bacia hidrográfica do Rio lapó e os depósitos de tálus associados à Escarpa Devoniana, o Complexo Granítico Cunhaporanga faz contato com três unidades geológicas: o Grupo Itaiacoca, o Grupo Castro e a Formação Furnas.

A afirmação de Wernick et al. (1990 b) de que " $A$ sucessão litológica interna, bem como a geometria dos seus contatos regionais, indica que ambos os complexos (Cunhaporanga e Três Córregos) estão adernados para SE" (Wernick et al. 1990 b, p. 68) parece pouco consistente. No que se refere ao Complexo Cunhaporanga, não foram encontradas bases sólidas em observações petrográficas, no arranjo dos possíveis corpos ígneos, nem no padrão do contato com as unidade vizinhas. Como as relações entre os diferentes tipos magmáticos, ou destes com suas encaixantes, dificilmente são vistas em campo (falta de afloramentos; recobrimento por unidades mais novas; etc.), não é possível determinar com segurança se os contatos são planares ou não e para qual quadrante mergulham.

\subsubsection{Grupo Itaiacoca}

Como pôde ser visto no Capítulo 2, a natureza do contato Cunhaporanga/ltaiacoca foi descrita de diversas maneiras, conforme os autores que estudaram a região.

Somando-se as observações diretas de campo com o que aparece em trabalhos como os de Fuck (inédito), Kaefer \& Cunha (1974), Souza (1990), Wernick et al. (1990 b) e Prazeres et al. (1998), pode-se afirmar, inequivocamente, que o contato entre o Complexo Cunhaporanga e as rochas do Grupo Itaiacoca é intrusivo ao longo de toda sua extensão.

As evidências aqui levantadas que demonstram este caráter intrusivo, são: 
a) granitóides do Complexo, situados nas proximidades da região de contato, podem aparecer com texturas indicativas de resfriamento rápido (e. g., ITA-2-100);

b) o grau metamórfico das rochas da Faixa Itaiacoca intensifica-se a medida que se examinam rochas próximas do contato com os granitóides. Biotita (e. g., IT-38, IT50) e granada (PS-59, PS-102, PS-123) em metassedimentos clásticos e tremolita (e. g., PS-49, PS-50; SC-65) em metadolomitos (Foto 8C) estão ausentes em domínios mais afastados do Complexo;

c) presença de porfiroblastos tardi-tectônicos (em relação à última fase de deformação do metamorfismo regional) de andalusita (e. g., PS-102, ITA-0-25, ITA-2-3; Fotos 8D, 8E e 8F), estaurolita (PS-123; Fotos 9A e 9B) e muscovita (e. g., IT-22; Foto 9C) em metapelitos;

d) metapelitos com texturas nodulosas (PS-22, IT-22);

e) metassomatismo das rochas encaixantes, em especial de metadolomitos (e. g., silicificação, ITA-1-110; turmalinas centimétricas, IT-16; Fotos 9D e 9E);

f) zonas métricas de transição entre rochas granitóides e metarcósios e metassiltitos, com termos intermediários de composição híbrida, indicando ter havido assimilação das rochas encaixantes por parte do magma granítico (e. g., IT-41, IT-54-55; PS122);

g) apófises graníticas intrusivas nos metassedimentos, freqüentemente de aspecto pegmatóide (com muscovita centimétrica e, mais raramente, com turmalina; e. g., (T-49);

h) ao longo de perfis executados nas regiões de Água Clara, Campina dos Elias, Dr. Ulysses e Ouro Verde, é comum a alternância de afloramentos de rochas graníticas e de metassedimentos ("stoping" ?), em especial de metarenitos/metarcósios (o exame dos mapas geológicos destas áreas já antecipa este padrão).

Este último tópico remete à questão dos inúmeros corpos de metassedimentos inclusos no Complexo, na forma de mega-enclaves ou tabiques, situados junto ao contato com as rochas da faixa ou mais afastados, como o "Quartzito Serra das Pedras". Seriam eles entidades geológicas pertencentes ao Grupo Itaiacoca?

No caso de corpos localizados próximo à Faixa, como nas regiões de Passo das Antas, Campina dos Elias, Eduardo Xavier da Silva ou mesmo outros pontos isolados 
(e. g., PS-24, PS-99), não há motivos para que a resposta não seja afirmativa. Existe similaridade petrográfica e estrutural entre os metassedimentos situados no Complexo e os externos a ele, proximidade geográfica (quando não continuidade lateral), além dos inúmeros indicadores de contato intrusivo apontados acima.

Quanto às rochas inclusas no Complexo, mais afastadas do contato ("Quartzito Serra das Pedras"; SC-15, SC-69; JM-111, etc.), também há semelhança petrográfica e estrutural (Soares et al. 1987), sendo que a distância da faixa não é suficientemente exagerada para inibir o estabelecimento de correlações.

No entanto é ainda prematuro afirmar que todos os corpos de metarenitos e metarcósios existentes no Complexo e no Grupo Itaiacoca pertençam a uma única formação geológica. Do lado externo ao Complexo ainda se faz necessário definir se os metarcósios do sul do Grupo Itaiacoca (Seqüência Abapã de Trein et al. 1985) são correlacionáveis aos que existem mais ao norte (Formações Bairro da Estiva e Serra dos Macacos, de Souza 1990).

Já os metarenitos e metarcósios do Complexo são virtualmente indistinguíveis uns dos outros, quer sejam provenientes da Serra das Pedras, Serra das Antas (estes considerados como integrantes da Formação Bairro da Estiva por Souza 1990) ou das regiōes de Eduardo Xavier da Silva, Campina dos Elias ou Dr. Ulysses.

Rochas pertencentes à Formação Água Clara estariam ausentes do bloco tectônico em que se situam o Grupo Itaiacoca e o Complexo Cunhaporanga, sendo encontradas exclusivamente a sudeste da Zona de Cisalhamento Itapirapuã. Assim, seguindo a mesma interpretação de Souza (1990), as rochas descritas por Soares et al. (1987) como integrantes da Formação Água Clara (região do Bairro São Domingos; ver localização no Anexo 2), devem corresponder também a litologias do Grupo Itaiacoca, porém com grau metamórfico mais alto por influência das intrusões graníticas. 


\subsubsection{Grupo Castro}

Como descrito por Trein \& Fuck (1967), o contato entre o Grupo Castro e o Complexo Cunhaporanga é principalmente tectônico, com apenas alguns trechos próximo a Piraí do Sul em que são observadas discordâncias erosivas (Guimarães 1995). O principal lineamento que justapõe as duas unidades, com orientação N20E e que se estende desde a localidade de Tirania $(\sim 16 \mathrm{~km}$ a NNE de Castro) até desaparecer por sob a bacia do Paraná, ao sul, foi classificado por Moro (1993) como uma "falha com rejeito de mergulho oblíquo lateral direito" (Moro 1993, legenda do mapa geológico, Anexo I).

Este falhamento pôde ser identificado nos pontos SC-21 e SC-52. No primeiro observa-se um granitóide fortemente cataclasado, com cloritização dos minerais máficos e epidoto em fraturas. No segundo tem-se uma rocha aparentemente riolítica, intensamente cataclasada e hidrotermalizada, com inúmeros veios/vênulas de quartzo e argilas. Níveis de hematita, provavelmente selando fraturas, podem alcançar vários centímetros de espessura. A alteração supérgena/hidrotermal é também responsável por belas drusas de quartzo e crostas botrioidais/globulares de goethita.

Mais para o norte do Complexo os contatos Cunhaporanga/Castro voltam a ser tectônicos. A falha de orientação N-S que faz o limite entre o Granito Joaquim Murtinho e conglomerados do Grupo Castro possui um caráter distensional, tal como indica um pequeno enxame de diques paralelos ao falhamento. Compostos por granitóides pórfiros, estes corpos têm espessura decimétrica a métrica.

\subsubsection{Formação Furnas}

O Complexo Granítico Cunhaporanga encontra-se recoberto discordantemente por rochas pertencentes à Bacia do Paraná, tanto em seu extremo sudoeste (região de Itaiacoca a Alagados) como ao norte-nordeste (de Joaquim Murtinho à Serra da Janela). Exceto por ocorrências localizadas da Formação lapó (e. g., em Alagados; Assine 1996) e de soleiras de diabásio correlatas à Formação Serra Geral (e. g., 
próximo ao canyon do Rio Jaguariaíva; CCGP 1970 a), o contato se dá com os arenitos da Formação Furnas.

Normalmente simples de ser reconhecida, a passagem das rochas do Complexo para as da Bacia deve ser examinada com cuidado na região do Cerrado da Roseira. Nela aparecem metarenitos pertencentes ao Complexo, por vezes muito pouco deformados (IT-106), com mergulhos suaves $\left(\leq 20^{\circ}\right)$ e com estratificações cruzadas que, numa primeira análise, podem lembrar as do arenito Furnas. 


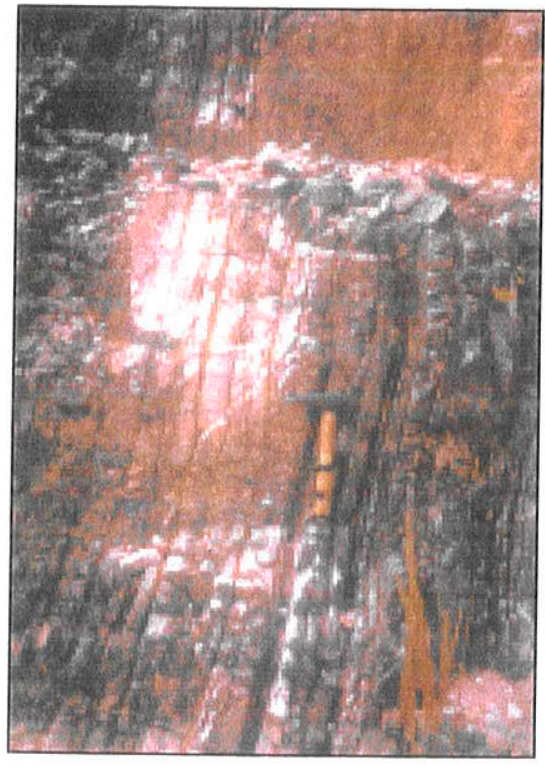

(A)

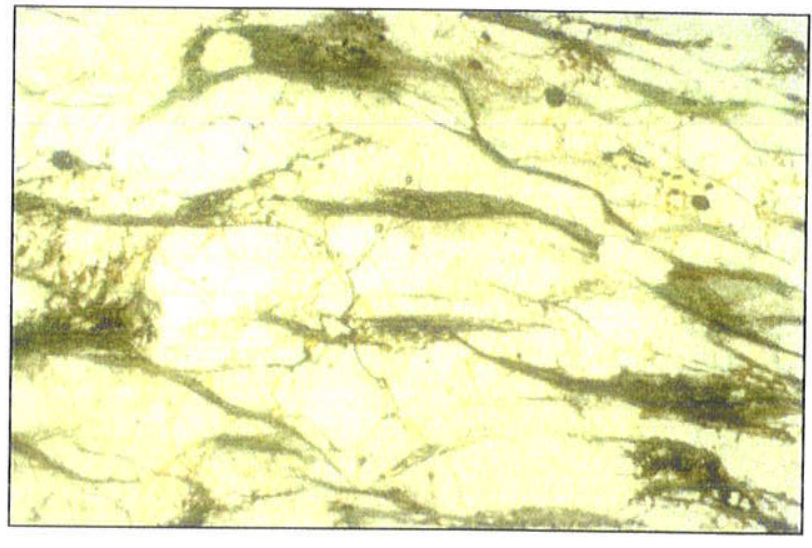

(B)

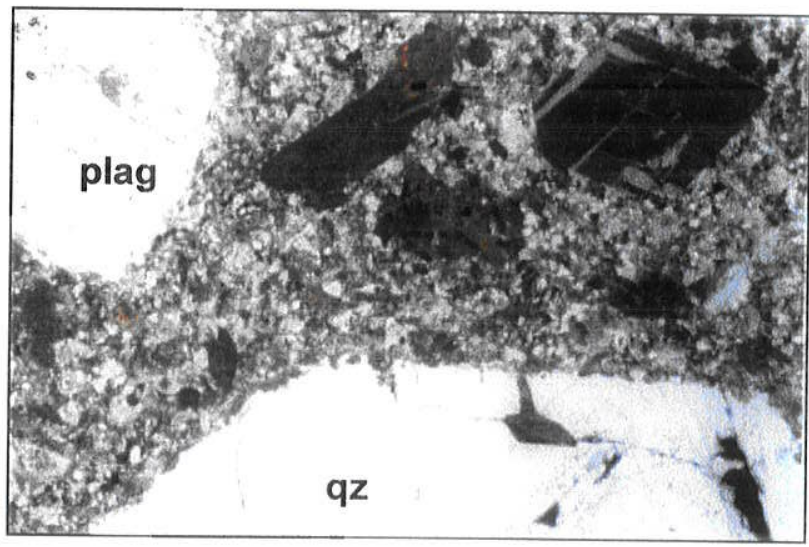

(C)

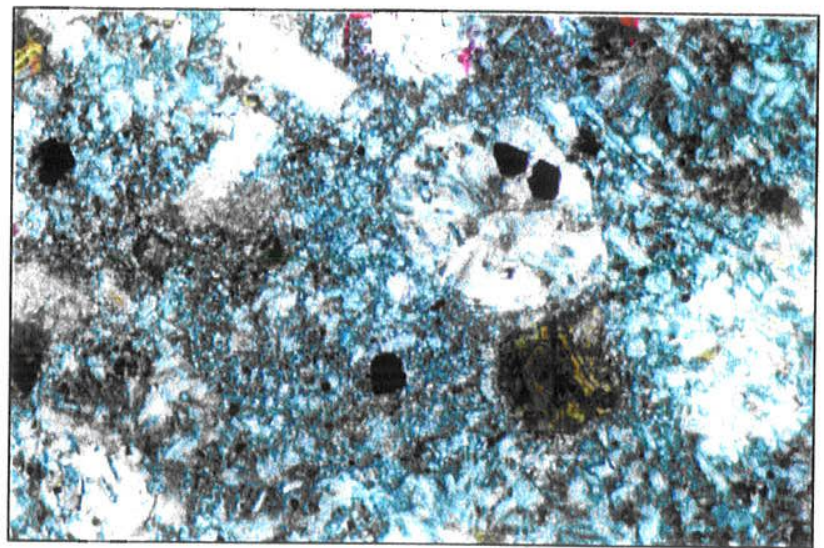

(E)

PRANCHA 2 - (A) Bandamento composicional em metarenitos/metarcósios do "Quartzito Serra das Pedras" (ponto JM-22 de Guimarães 1995). (B) Mica-quartzo xisto da região do Arroio das Pedrinhas (JM-109B; aumento 25X; luz plano-polarizada (//)). (C) e (D) Fácies de borda do Domínio Serra Abaixo-Alagados; em (C) destaque para o fenocristal de quartzo (qz) e a matriz de granulação fina (SC-68; aumento 6,25X; polarizadores cruzados (\#)); em (D) fenocristal zonado de plagioclásio (SC-74; aumento 6,25X; \#). (E) Dacito pórfiro com esferulitos de feldspato alcalino e quartzo (SC-51; aumento 25X; \#). plag: plagioclásio. 


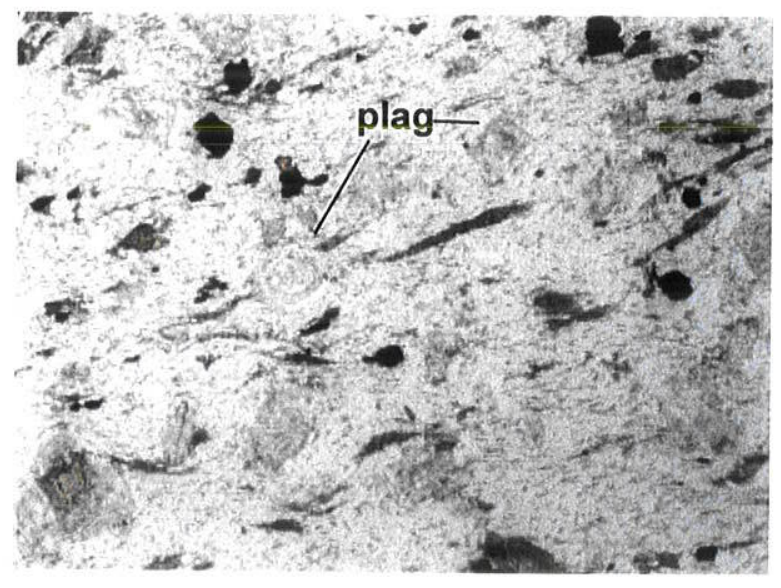

(A)

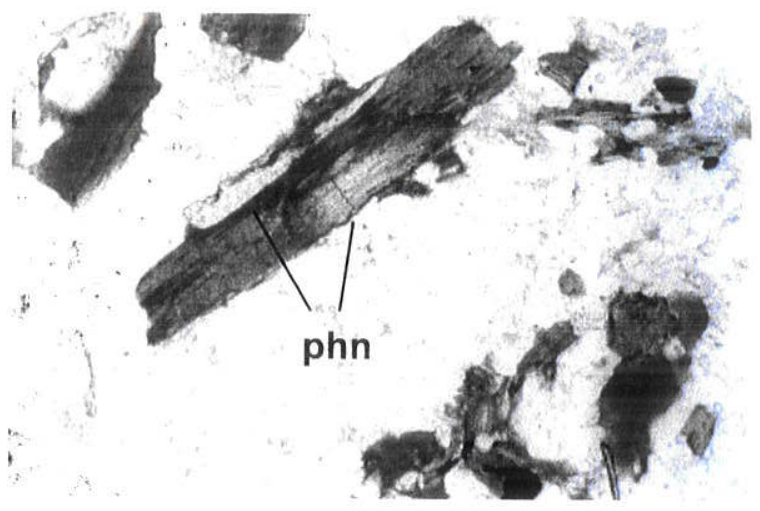

(C)

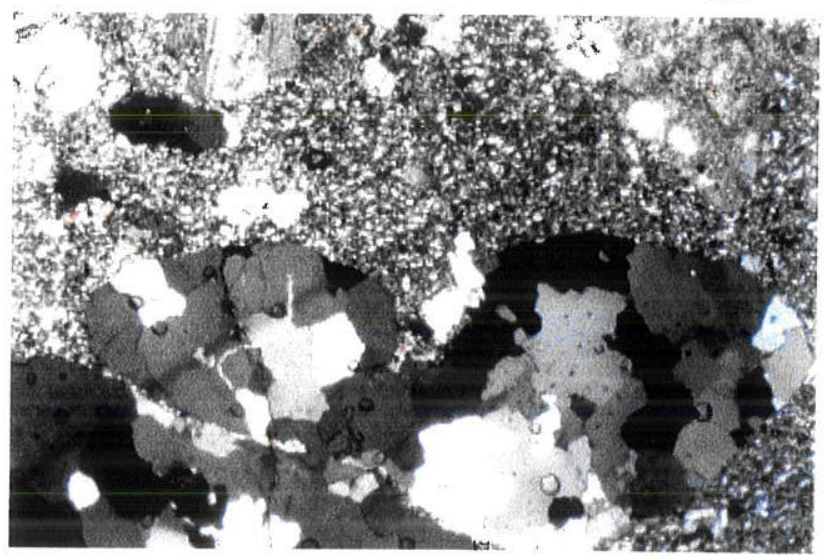

(B)

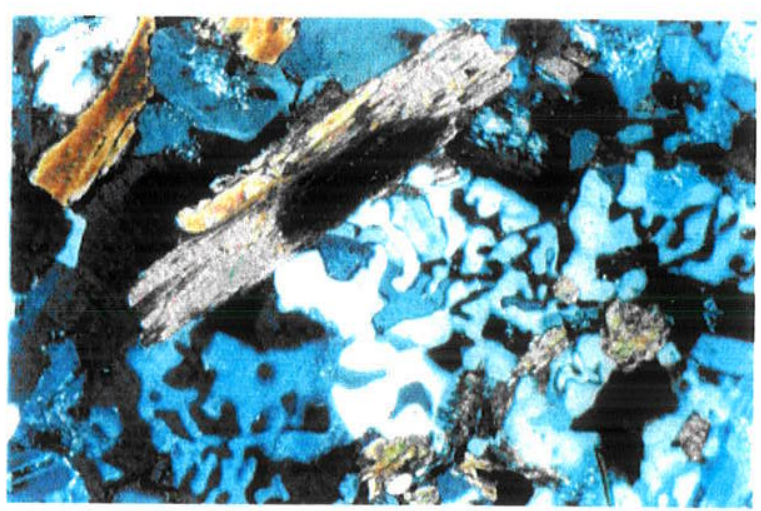

(D)

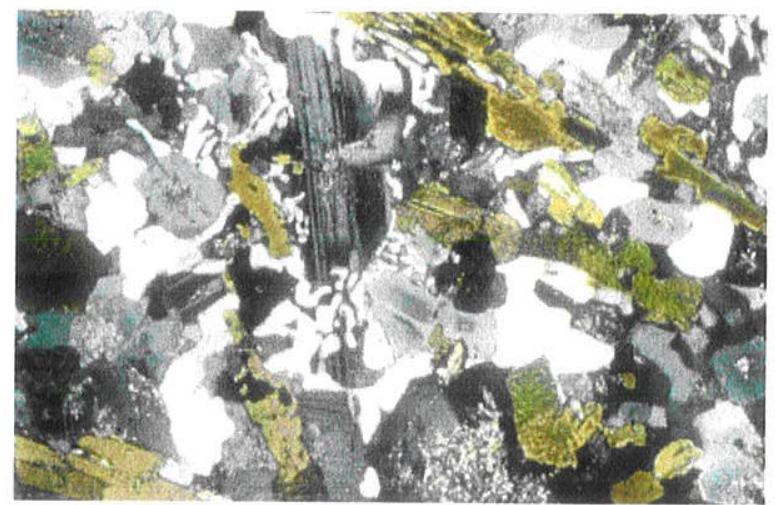

(E)

PRANCHA 3 - (A) Estrutura de fluxo magmático no pórfiro de Mato Limpo, com orientação de anfibólio e imbricação de plagioclásio (plag) euedral (SC-74B; aumento 6,25X; //). (B) Pórfiro intrusivo em metadolomitos do Grupo Itaiacoca, com fenocristais de quartzo deformados (SC65; aumento 6,25X; \#). (C), (D) e (E): Rochas granitóides do ponto PS-5, Domínio Piraí do Sul (mesmo ponto de coleta do "Gnaisse Piraí do Sul" de Reis Neto 1994). Observar a textura granofírica em (D) e (E), além de prehnita (phn) interlamelar à biotita em (C) e (D) (C e D, MSP-1, aumento 25X; // e \#; E, MSP-A, aumento 6,25X; \#). 


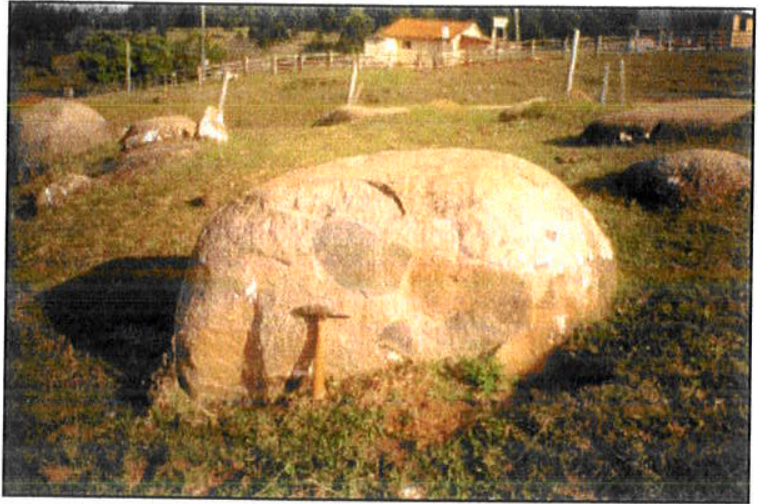

(A)

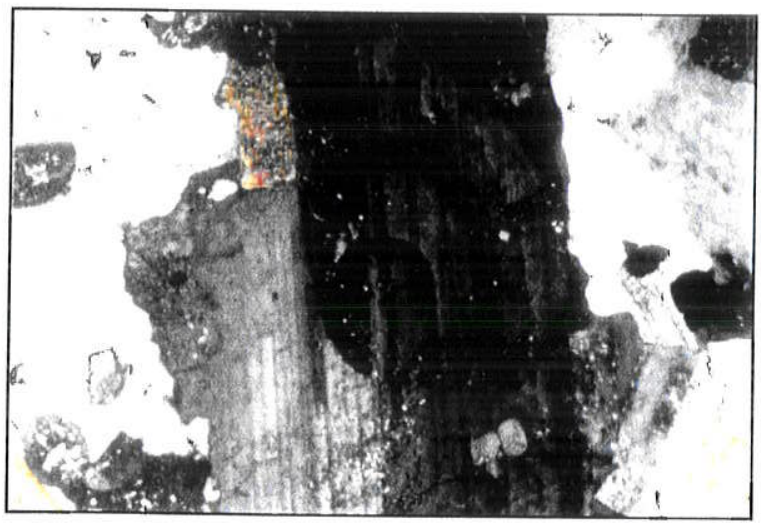

(C)

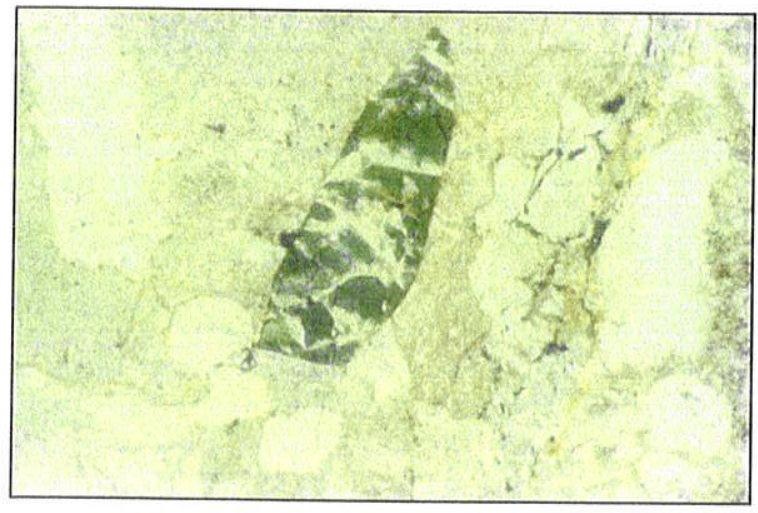

(E)

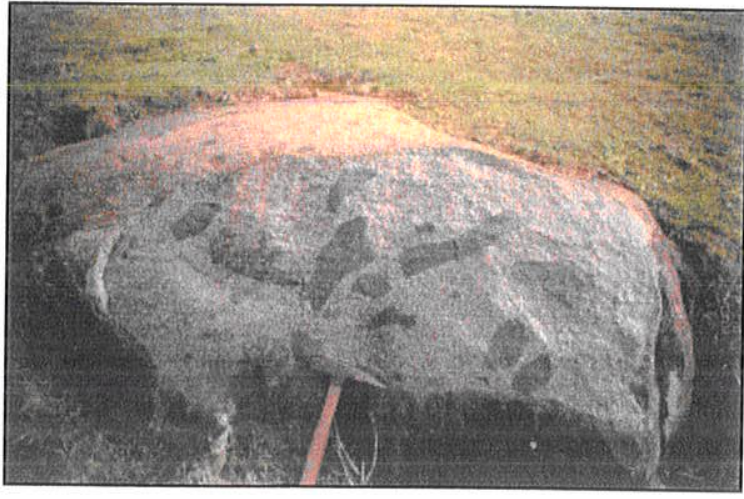

(B)

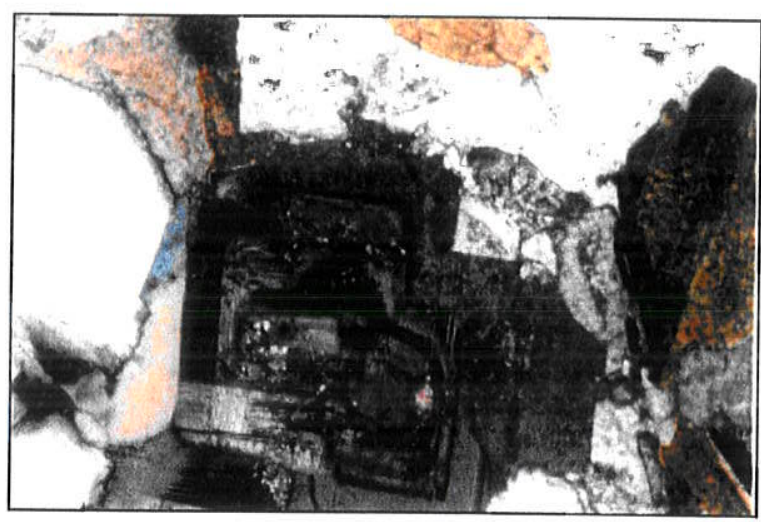

(D)

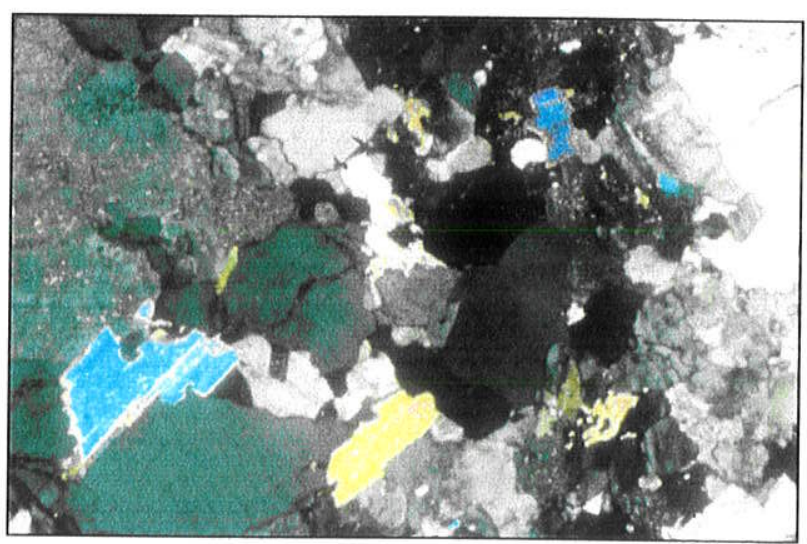

(F)

PRANCHA 4 - (A) e (B): Enclaves dioríticos em granitóides do ponto PS-92 (limite entre os Domínios Piraí do Sul e Espigão Alto). (C) e (D) Cristais zonados de plagioclásio, com núcleos arredondados de labradorita, em granitóides do Domínio Espigão Alto (JGA-42B; aumento 25X; \#). (E) Turmalina deutérico-hidrotermal, parcialmente sericitizada, de um muscovita biotita granitóide do Domínio Arroio das Pedrinhas (JM-124, aumento 25X; /). (F) Muscovita primária (?) em granitóide do Domínio Arroio das Pedrinhas (JM-111A, aumento 12,5X; \#). 


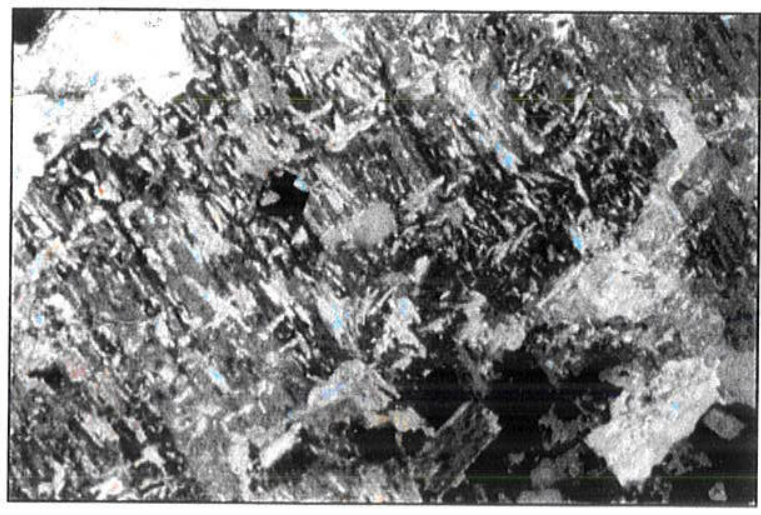

(A)

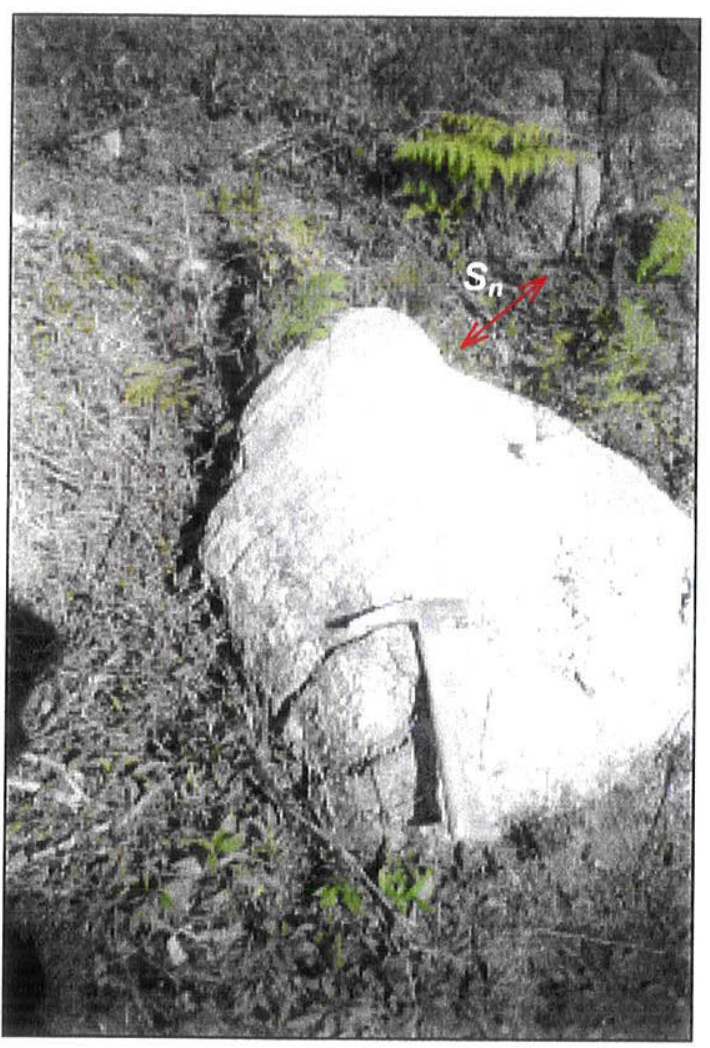

(C)

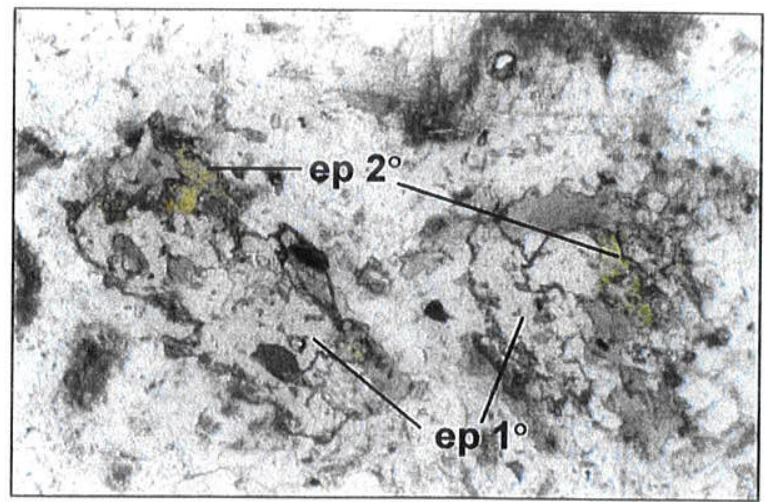

(D)

(B)

PRANCHA 5 - (A) Muscovita secundária em plagioclásio de titanita biotita granitóide do Domínio Varginha (PS-47, aumento 12,5X; \#). (B) Xenólito quartzítico foliado $\left(\boldsymbol{S}_{n}\right)$ em granitóide do ponto IT-97 (Domínio Ouro Verde-Patrimônio Santo Antônio). (C) e (D) Cristais de epidoto considerado primário (ep $1^{\circ}$ ), com orlas de epidoto secundário (ep $2^{\circ}$ ), em granitóide pórfiro com anfibólio do Domínio Ouro Verde-Patrimônio Santo Antônio (IT-96; aumento 50X em C e 25X em D; /). 


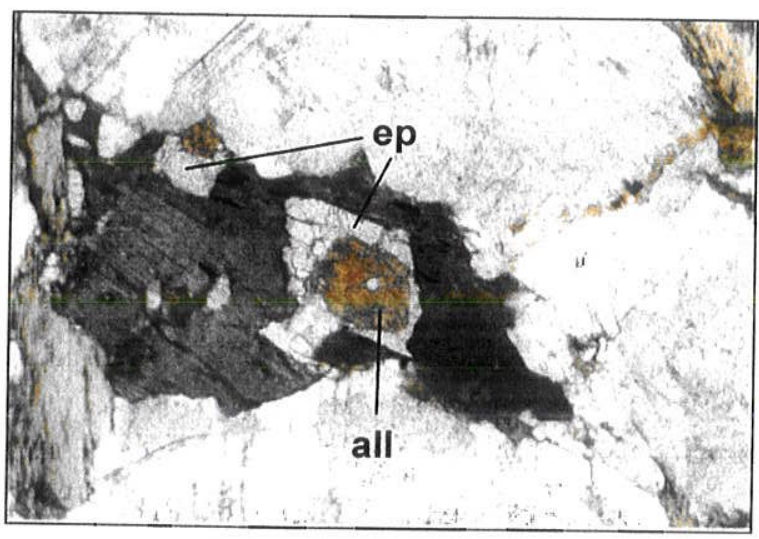

(A)

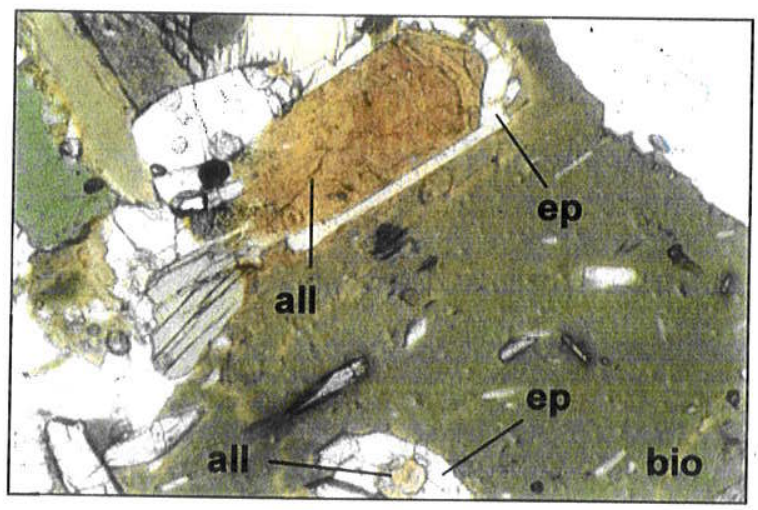

(C)

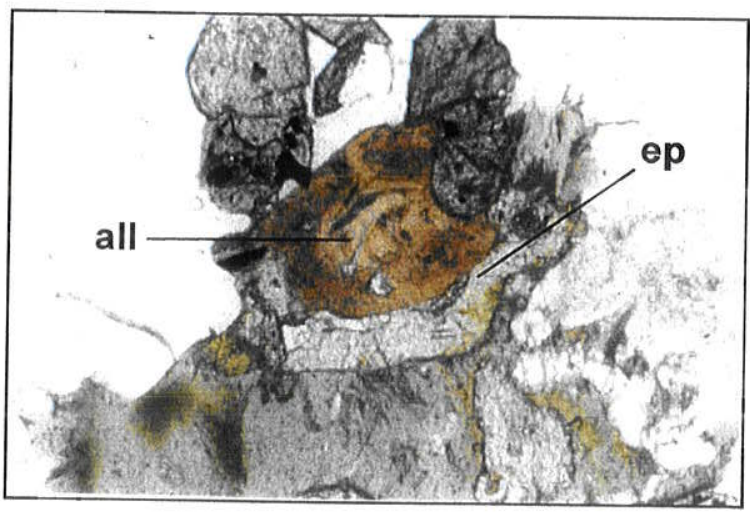

(E)

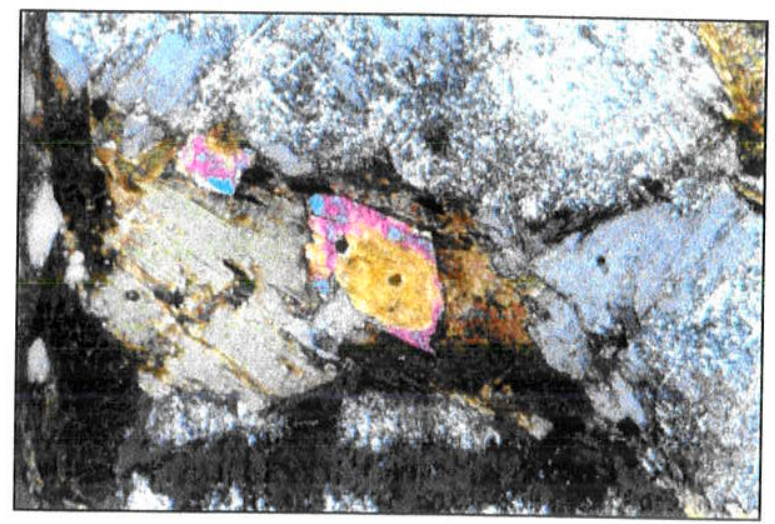

(B)

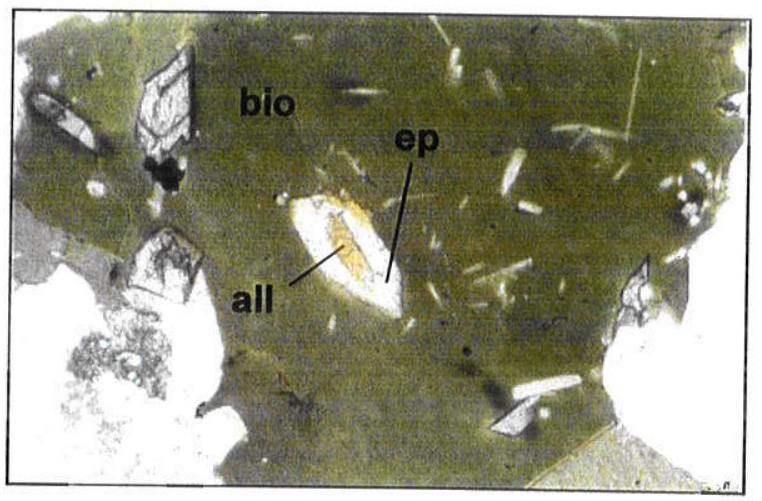

(D)

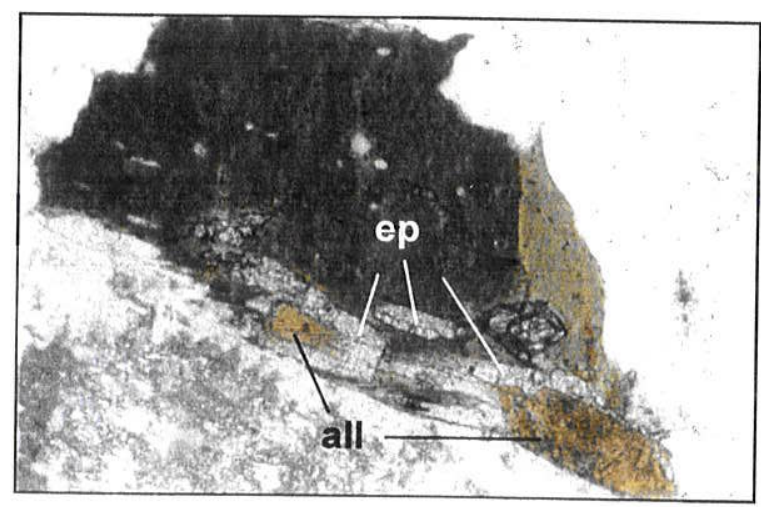

(F)

PRANCHA 6 - Cristais de epidoto (ep) primário bordejando allanita (all), freqüentemente zonada, em monzogranitos a granodioritos do Domínio Limeira. bio: biotita. Fotos com aumento 25X. (A) e (B) amostra IT-10; (C), (D) e (F) amostra IT-50b; (E) amostra IT-58. Em (B) foto com polarizadores cruzados; demais com luz plano-polarizada. 


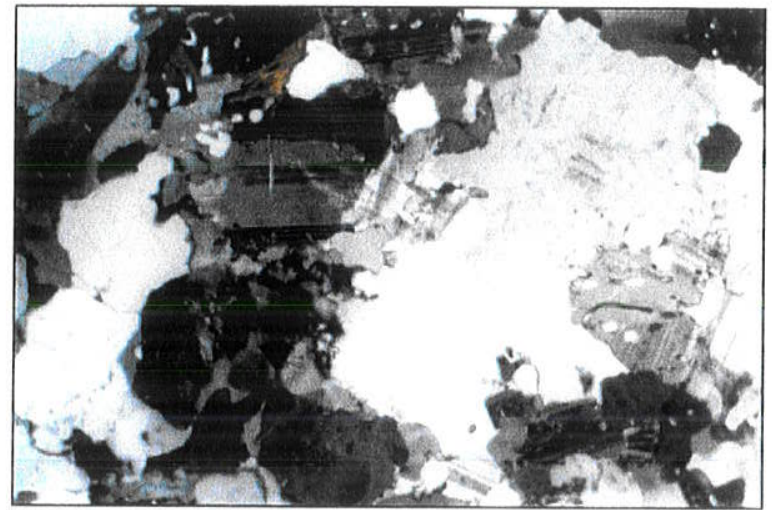

(A)

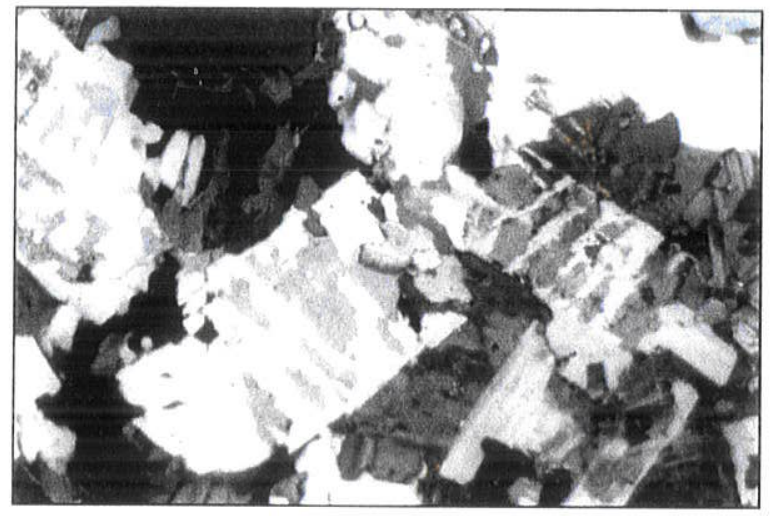

(C)

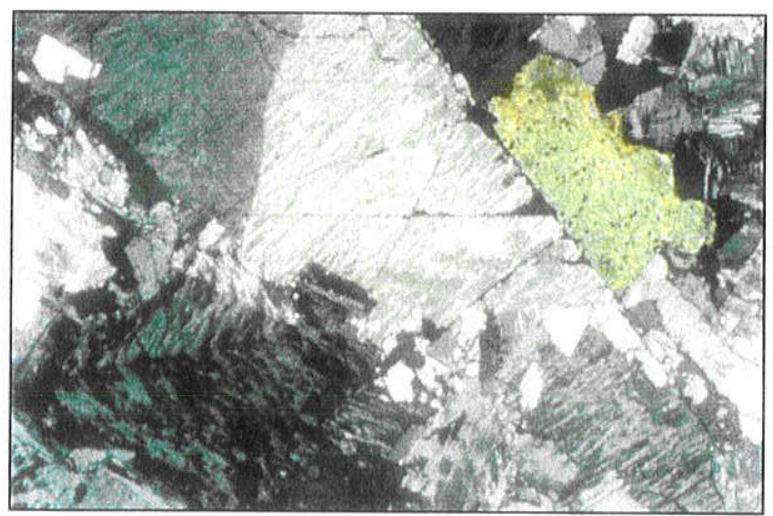

(E)

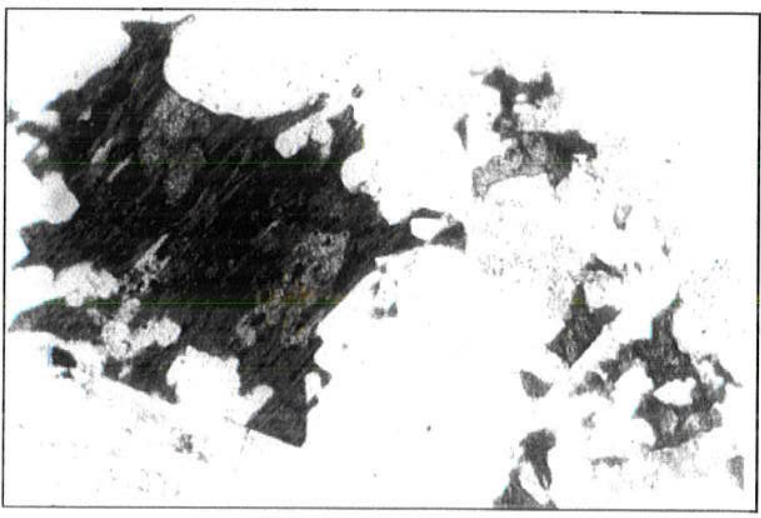

(B)

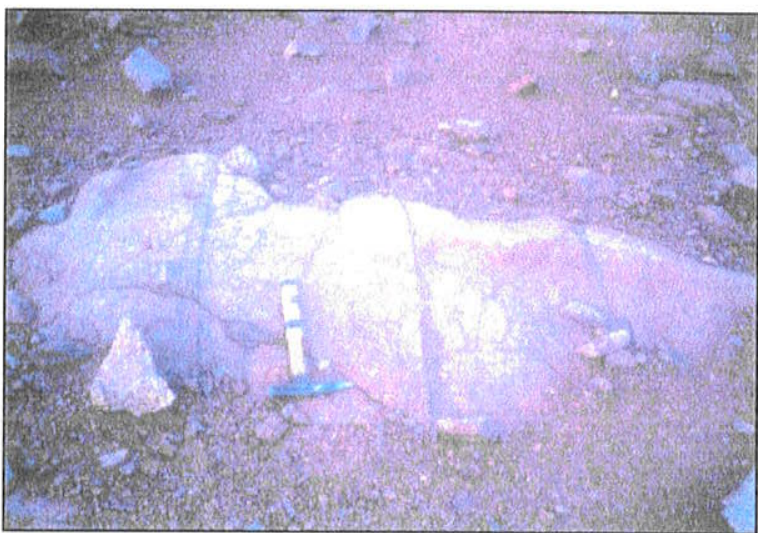

(D)

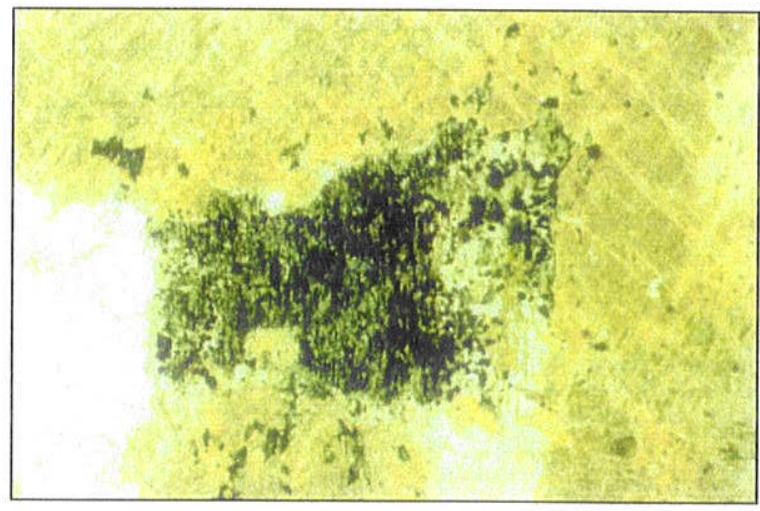

(F)

PRANCHA 7 - (A) Textura pan-xenomórfica em granitóide do Domínio Francisco Simas-Vila Branca (PS-130; aumento 12,5X; \#). (B) Cristais intersticiais de biotita (annita) do Granito Serra do Carambeí, com inclusões de material argiloso e quartzo (JGA-23 I; aumento 25X; /1). (C) Feldspatos mesopertíticos do Granito Serra do Carambeí (JGA-23 I; aumento 25X; /I). (D) Planos de fratura, em bloco do Granito Joaquim Murtinho, preenchidos por hematita (ponto JM-96). (E) Feldspatos mesopertíticos do Granito Joaquim Murtinho, com cavidade preenchida por argilominerais e sericita (JM-70B; aumento 6,25X; \#). (F) Textura de substituição de mica primária por opacos e argilominerais no Granito Joaquim Murtinho (JM-96E; aumento 12,5X; //). 


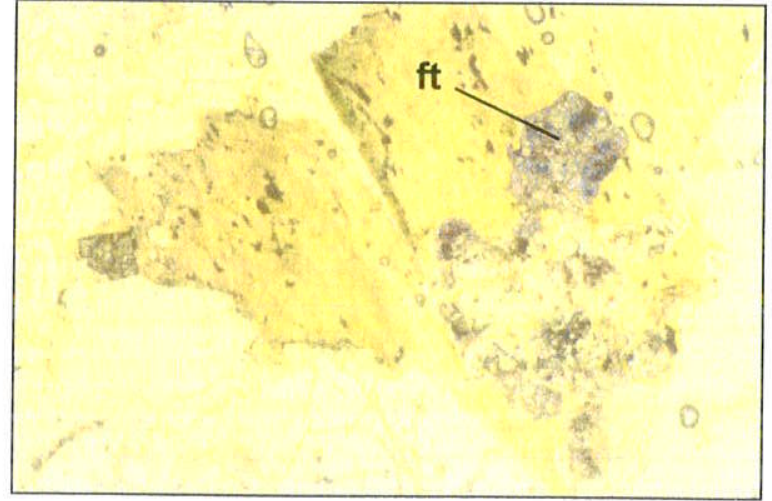

(A)

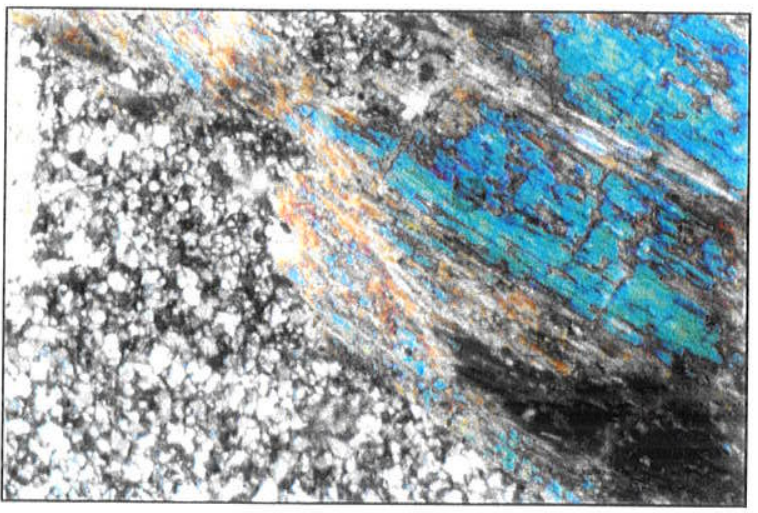

(C)

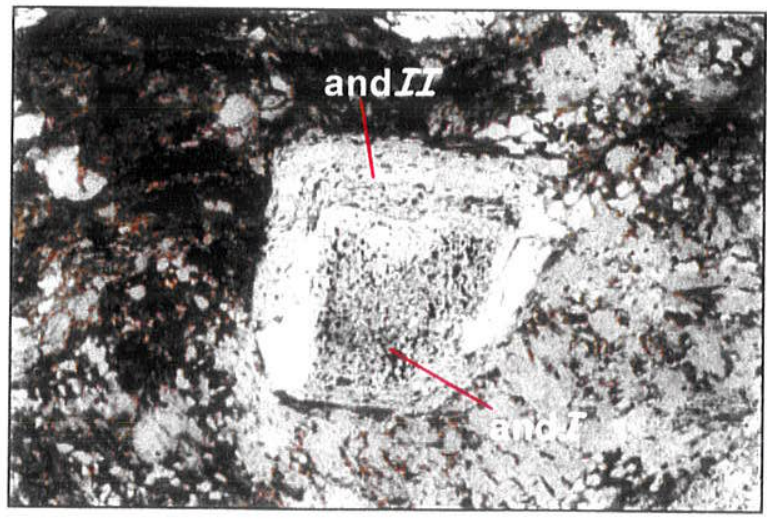

(E)

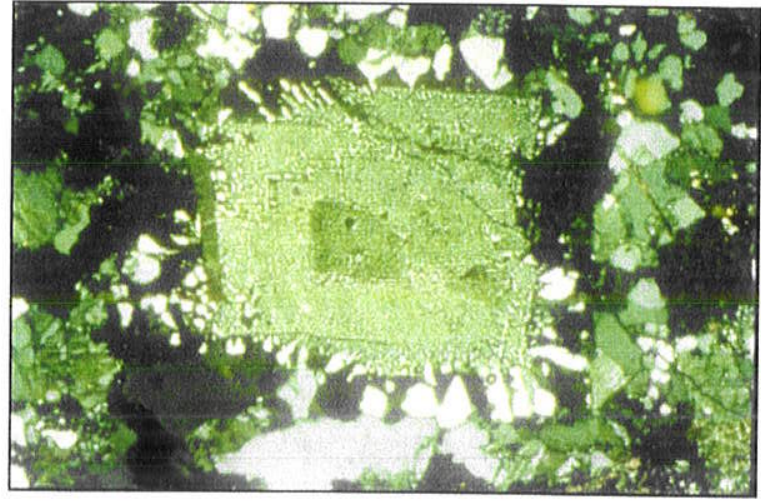

(B)

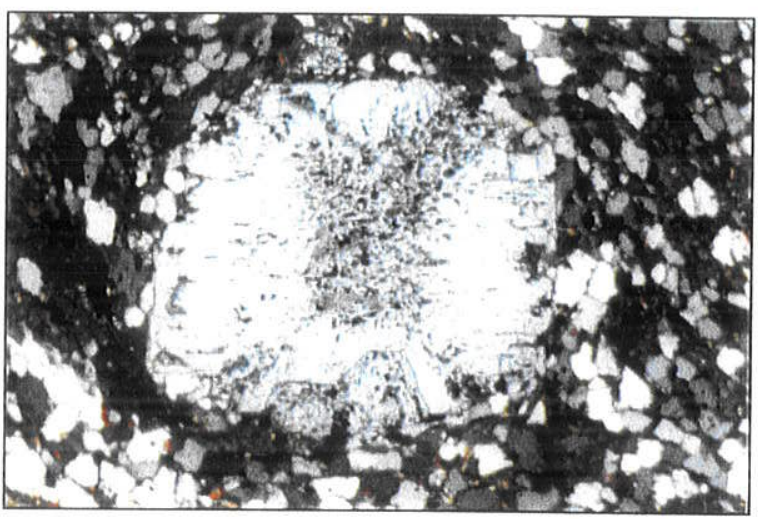

(D)

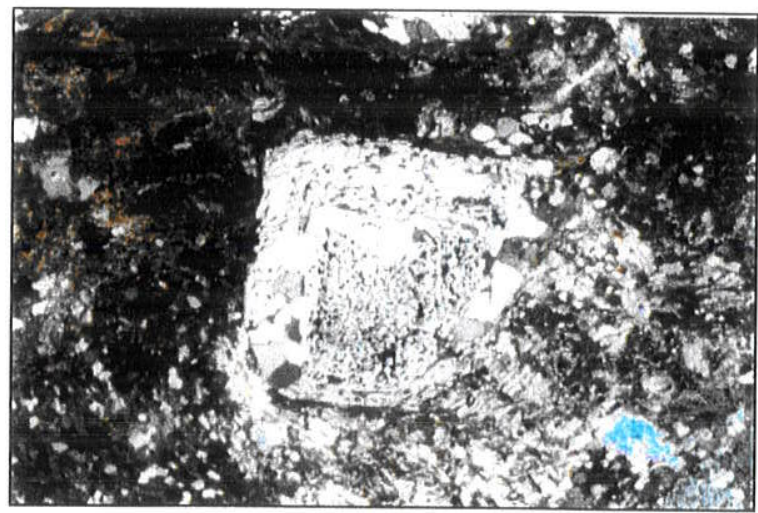

(F)

PRANCHA 8 - (A) Muscovita e fluorita (ft) secundárias do Granito Joaquim Murtinho (JM-97B; aumento 25X; //). (B) Intercrescimento micrográfico em rocha quartzo-sienítica do Granito Joaquim Murtinho (JM-106; aumento 12,5X; \#). (C) Silicificação e porfiroblastos de tremolita em metadolomito do Grupo Itaiacoca (ITA-1-110; aumento 25X; \#). (D) Andalusita quiastolítica em metapelito do Grupo Itaiacoca (ITA-0-25; aumento 25X; \#). (E) e (F) Porfiroblasto de andalusita em metapelito do Grupo Itaiacoca (ITA-0-25; aumento 25X; // e \#). Observar: existência de 2 gerações de andalusita (and $I$ e andII; dois episódios intrusivos ?); quartzo provavelmente cristalizado em sombra de pressão préandII. 


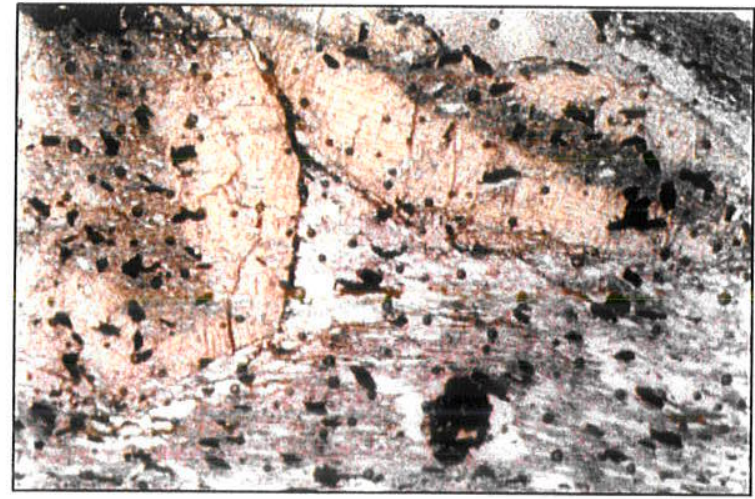

(A)

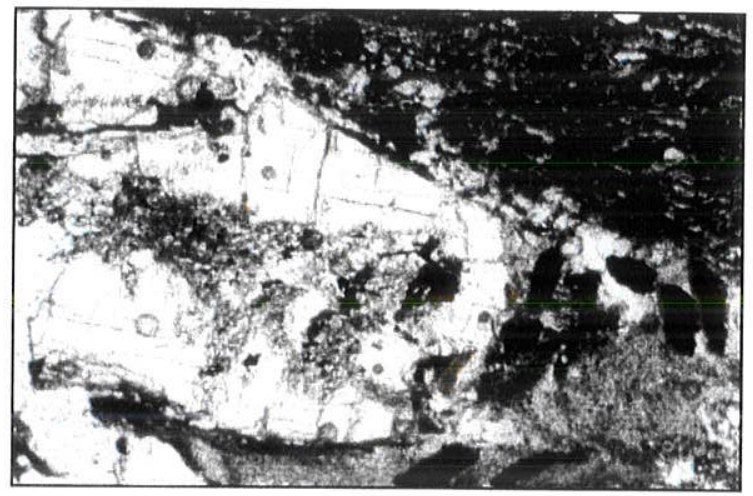

(B)

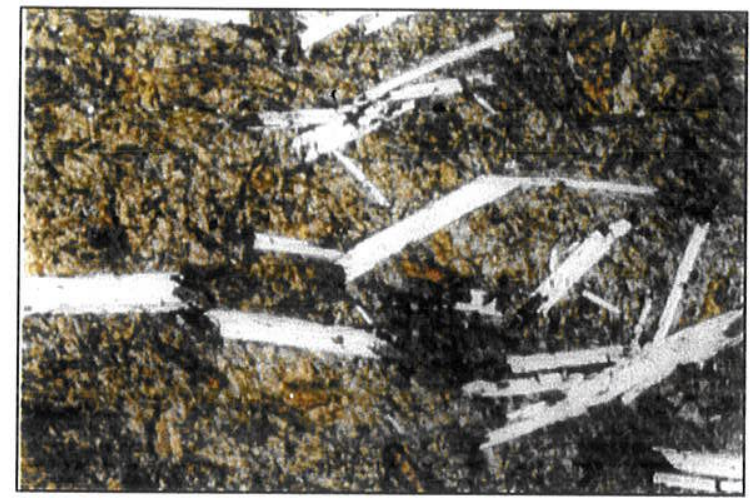

(C)

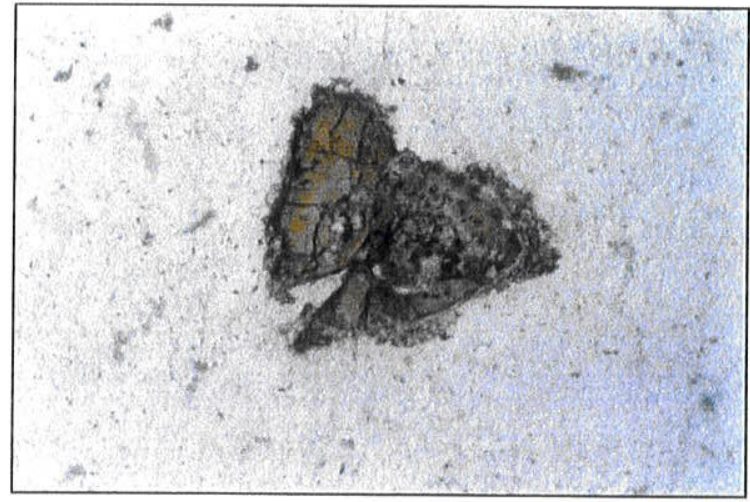

(D)

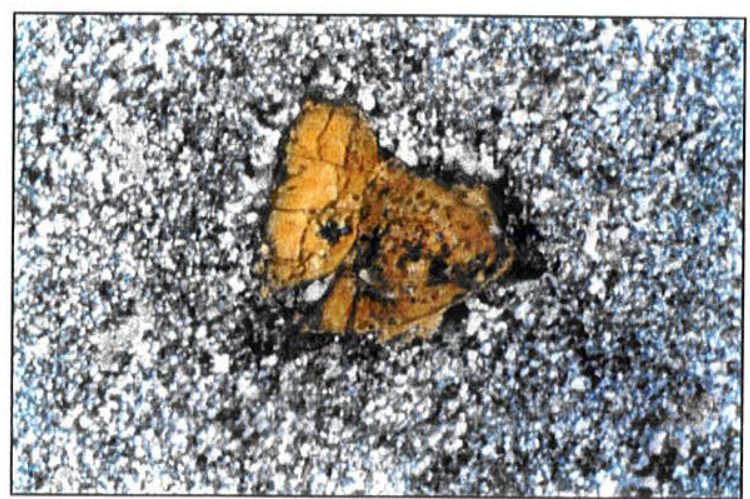

(E)

PRANCHA 9 - (A) e (B) Porfiroblastos de estaurolita em metapelito grafitoso do Grupo Itaiacoca (PS-123; aumento 12,5X em A e 25X em B; /). (C) Porfiroblastos de muscovita em metapelito do Grupo Itaiacoca (IT-22; aumento 6,25X; //). (D) e (E) Metassomatismo em metadolomito do Grupo Itaiacoca, evidenciado por forte silicificação e neoformação de turmalina (IT-16; aumento 12,5X; // e \#). 
Tabela 4.1: Modas de rochas granitóides do Complexo Cunhaporanga

\begin{tabular}{|c|c|c|c|c|c|c|c|c|c|c|c|c|c|c|c|c|c|c|c|}
\hline \multicolumn{20}{|c|}{$\begin{array}{c}\text { Dominios Petrográficos da porção S/SE do Complexo } \\
\text { DOMÍNIO ABAPÂ-SANTA QUITÉRIA }\end{array}$} \\
\hline Amostra & Qz & FK & Plag & Anf & Bio & Clo & $\mathrm{Mu}$ & Opa & Tit & $\mathrm{Ap}$ & $\mathrm{Zr}$ & All & Ep & Phn & $\mathrm{Ft}$ & $\mathbf{Q}$ & A & $\mathbf{P}$ & $M$ \\
\hline PS-21 & 23,6 & 16,0 & 37,4 & 6,9 & 12,7 & - & - & 0,6 & 1,5 & 0,7 & tr. & tr. & tr. & 0,4 & - & 30,6 & 20,8 & 48,6 & 22,8 \\
\hline PS-54 & 19,0 & 13,1 & 48,5 & 5,1 & 11,0 & 0,5 & $=$ & 0,4 & 2,0 & 0,4 & tr. & tr. & tr. & tr. & - & 23,6 & 16,3 & 60,2 & 19,4 \\
\hline PS-76 & 24,4 & 14,3 & 36,0 & 6,8 & 15,0 & 0,3 & tr. & 1,1 & 1,3 & 0,5 & tr. & tr. & tr. & tr. & - & 32,7 & 19,1 & 48,2 & 25,0 \\
\hline PS-78 & 25,8 & 12,1 & 48,3 & 4,7 & 6,5 & 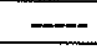 & - & 0,9 & 0,8 & 0,3 & tr. & $=$ & $=$ & 0,4 & $=$ & 29,9 & 14,0 & 56,0 & 13,6 \\
\hline PS-79 & 23,2 & 17,8 & 42,9 & $5,0^{\circ}$ & 6,6 & 0,7 & $=$ & 1,5 & 1,2 & 0,9 & tr. & tr. & - & tr. & 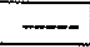 & 27,7 & 21,2 & 51,1 & 15,9 \\
\hline ITA-4-36 & 19,3 & 24,0 & 42,8 & 4,9 & $\cdots$ & 5,2 & $=$ & 1,0 & 0,8 & 0,7 & tr. & tr. & tr. & 1,2 & $\ldots$ & 22,4 & 27,9 & 49,7 & 13,8 \\
\hline \multicolumn{20}{|c|}{ DOMINIO SERRA ABAIXO-ALAGADOS } \\
\hline Amostra & $\mathrm{Qz}$ & FK & Plag & Anf & Bio & $\mathrm{Clo}$ & $\mathrm{Mu}$ & Opa & Tit & $\mathrm{Ap}$ & $\mathrm{Zr}$ & All & Ep & Phn & $\mathrm{Ft}$ & $\mathbf{Q}$ & A & $\mathbf{P}$ & $\mathbf{M}$ \\
\hline SC-34 & 23,9 & 21,2 & 36,9 & $6,6^{\mathrm{c}}$ & 6,2 & 0,9 & - & 2,2 & 1,2 & 0,4 & tr. & - & - & 0,6 & - & 29,1 & 25,9 & 45,0 & 18,1 \\
\hline SC-77* & 22,6 & 26,3 & 37,8 & $4,3^{c}$ & 5,8 & 0,5 & $\ldots$ & 1,2 & 0,5 & 0,5 & tr. & & $\underline{-}$ & 0,5 & $\ldots$ & 26,1 & 30,3 & 43,6 & 13,3 \\
\hline \multicolumn{20}{|c|}{ DOMINIO JOTUBA-PITANGUI } \\
\hline Amostra & $\mathrm{Qz}$ & FK & Plag & Anf & Bio & Clo & $\mathrm{Mu}$ & Opa & Tit & $A p$ & $\mathrm{Zr}$ & All & $\mathrm{Ep}$ & Phn & $\mathrm{Ft}$ & $\mathbf{Q}$ & $A$ & $\mathbf{P}$ & M \\
\hline SC-79 & 23,9 & 15,2 & 37,3 & 7,3 & 14,0 & 0,5 & $-\infty$ & tr. & 1,5 & tr. & tr. & tr. & - & 0,3 & - & 31,3 & 19,9 & 48,8 & 23,6 \\
\hline \multicolumn{20}{|c|}{ DOMINIO SANTA RITA } \\
\hline Amostra & $\mathrm{Qz}$ & FK & Plag & Anf & Bio & Clo & $\mathrm{Mu}$ & Opa & Tit & Ap & $\mathrm{Zr}$ & All & $\mathrm{Ep}$ & Phn & $\mathrm{Ft}$ & $\mathbf{Q}$ & A & $\mathbf{P}$ & $\mathbf{M}$ \\
\hline \multirow{3}{*}{\multicolumn{20}{|c|}{$\begin{array}{c}\text { Domínios Petrográficos da porçáo centro-norte do Complexo } \\
\text { DOMíNIO PIRAI DO SUL }\end{array}$}} \\
\hline & & & & & & & & & & & & & & & & & & & \\
\hline & & & & & & & & & & & & & & & & & & & \\
\hline $\begin{array}{l}\text { Amosta } \\
\text { JM-10E }\end{array}$ & $\frac{Q z}{200}$ & FK & Plag & Anf & Bio & Clo & $\mathrm{Mu}$ & Opa & Tit & $A p$ & $\mathrm{Zr}$ & All & $E p$ & Phn & $\mathrm{Ft}$ & $\mathbf{Q}$ & A & $\mathbf{P}$ & $M$ \\
\hline JM-19B & $\frac{20,0}{80}$ & 25,9 & 36,0 & $6,0^{c}$ & 9,9 & 0,6 & - & 1,0 & 0,4 & tr. & tr. & - & - & tr. & - & 24,4 & 31,6 & 44,0 & 17,9 \\
\hline $\mathrm{JM}-20$ & $\frac{8,9}{187}$ & 17,2 & 54,4 & $3,3^{\mathrm{c}}$ & - & 2,5 & $\cdots$ & 8,0 & tr. & 0,5 & tr. & - & 5,2 & tr. & $-\infty$ & 11,1 & 21,4 & 67,6 & 19,5 \\
\hline $\mathrm{JM}-27^{\star}$ & $\frac{78,1}{12,5}$ & $\frac{31,6}{201}$ & 36,8 & 4,2 & tr. & 5,9 & tr. & 0,8 & tr. & 0,3 & tr. & 0,5 & tr. & 0,9 & 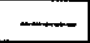 & 21,5 & 36,3 & 42,3 & 12,6 \\
\hline JM-31 & $\begin{array}{l}12,0 \\
19,2\end{array}$ & $\frac{28,1}{201}$ & 35,9 & $9,6^{\mathrm{C}}$ & 7,1 & 2,5 & $=$ & 1,8 & 0,5 & 0,6 & tr. & -- & 0,6 & 0,9 & - & 16,3 & 36,7 & 46,9 & 23,6 \\
\hline \multirow{2}{*}{\multicolumn{20}{|c|}{ DOMINIO BISCAIAS-BOA VISTA }} \\
\hline Amostra & $\mathrm{Qz}$ & & & & & & & & & & & & & & & & & & \\
\hline JGA-33 & 18.7 & 35,4 & & & Dio & $C_{10}$ & $\mathrm{Mu}$ & Opa & Tit & $A p$ & $\mathrm{Zr}$ & All & Ep & Phn & $\mathrm{Ft}$ & Q & A & $\mathbf{P}$ & M \\
\hline JGA-34 & 26,7 & 31,4 & 327 & $\frac{0,6}{\mathrm{tr}}$ & 3,4 & 0,8 & - & 1,6 & 1,7 & 0,4 & tr. & tr. & tr. & 0,4 & $\cdots$ & 21,9 & 41,5 & 36,5 & 11,0 \\
\hline JGA-35 & 10,5 & 15,9 & 476 & & 0,1 & 0,3 & - & 1,0 & 0,8 & tr. & tr. & tr. & - & tr. & - & 29,4 & 34,6 & 36,0 & 8,8 \\
\hline JGA-41 & 8.6 & 45.2 & $\frac{110}{270}$ & $\frac{9,2}{13}$ & - & 7,8 & tr. & 3,5 & 3,5 & 1,0 & tr. & - & tr. & 0,5 & -- & 14,2 & 21,5 & 64,3 & 25,5 \\
\hline \multirow{2}{*}{\multicolumn{20}{|c|}{ DOMINIO ESPIGÄO ALTO }} \\
\hline Amostra & $\mathrm{Qz}$ & FK & Plag & Anf & Bio & & & & & & & & & & & & & & \\
\hline PS-96A & 21,3 & 26,4 & 35,9 & 1,4 & 10,5 & tr. & - & 2,0 & 1,4 & $\frac{\pi}{0.5}$ & $\frac{2 t}{t r}$ & All & Exp & Phn & $\mathrm{Ft}$ & $\mathbf{Q}$ & A & $P$ & $\mathbf{M}$ \\
\hline & & & & & & & & & & & & tr. & - & tr. & - & 25,5 & 31,6 & 42,9 & 15,8 \\
\hline
\end{tabular}


Tabela 4.1 (cont.): Modas de rochas granitóides do Complexo Cunhaporanga

\begin{tabular}{|c|c|c|c|c|c|c|c|c|c|c|c|c|c|c|c|c|c|c|c|}
\hline \multicolumn{20}{|c|}{ DOMINIO ESPIGĀO ALTO (cont.) } \\
\hline Amostra & $\mathrm{Qz}$ & FK & Plag & Anf & Bio & Clo & $\mathrm{Mu}$ & Opa & Tit & $A p$ & $\mathrm{Zr}$ & All & Ep & Phn & $\mathrm{Ft}$ & $\mathbf{Q}$ & $\mathbf{A}$ & $\mathbf{P}$ & $M$ \\
\hline $\mathrm{JM}-35$ & 22,0 & 20,3 & 43,1 & $3,4^{\mathrm{c}}$ & 9,0 & 0,7 & - & 0,7 & tr. & 0,5 & tr. & - & tr. & 0,3 & $=$ & 25,8 & 23,8 & 50,5 & 14,6 \\
\hline $\mathrm{JM}-39$ & 29,9 & 28,0 & 34,4 & 0,5 & 2,5 & 2,7 & $=$ & 0,9 & 0,5 & 0,3 & tr. & tr. & $=$ & 0,4 & - & 32,4 & 30,3 & 37,3 & 7,8 \\
\hline $\mathrm{JM}-40 \mathrm{~B}$ & 27,4 & 29,0 & 34,7 & tr. & 5,5 & 0,8 & tr. & 1,5 & $=$ & 0,3 & tr. & tr. & tr. & 0,3 & 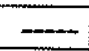 & 30,1 & 31,8 & 38,1 & 8,4 \\
\hline JM-63B & 22,0 & 25,3 & 35,9 & $2,4^{\mathrm{c}}$ & 9,5 & 1,2 & $=$ & 1,5 & 1,3 & 0,8 & tr. & tr. & tr. & tr. & tr. & 26,4 & 30,4 & 43,2 & 16,7 \\
\hline JM-72 & 21,5 & 21,2 & 47,1 & tr. & 3,2 & 2,2 & $=$ & 2,8 & 1,1 & tr. & tr. & - & 0,4 & 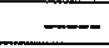 & $=$ & 23,9 & 23,6 & 52,4 & 9,7 \\
\hline $\mathrm{JM}-75$ & 23,8 & 30,7 & 37,9 & tr. & 4,7 & 0,8 & 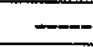 & 1,0 & 0,4 & 0,5 & tr. & tr. & tr. & tr. & 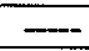 & 25,8 & 33,2 & 41,0 & 7,4 \\
\hline JM-76 & 24,5 & 25,6 & 40,4 & - & 1,9 & 6,0 & $=$ & 0,9 & tr. & 0,5 & tr. & tr. & tr. & 0,3 & - & 27,1 & 28,3 & 44,6 & 9,6 \\
\hline JM-137 * & 25,6 & 16,4 & 48,4 & tr. & 5,8 & 1,3 & - & 1,0 & 1,0 & tr. & tr. & tr. & tr. & tr. & $\cdots$ & 28,3 & 18,1 & 53,5 & 10,0 \\
\hline JGA-4C & 23,9 & 23,8 & 38,5 & 0,9 & 8,9 & tr. & $=$ & 1,5 & 0,9 & 0,6 & tr. & $=$ & - & 1,0 & $=$ & 27,7 & 27,6 & 44,7 & 13,8 \\
\hline JGA-42A & 30,3 & 32,2 & 36,1 & - & 0,3 & 0,5 & tr. & 0,3 & tr. & tr. & tr. & tr. & $\overline{-}$ & - & - & 30,7 & 32,7 & 36,6 & 1,1 \\
\hline JGA-42B & 14,8 & 22,8 & 45,4 & 2,5 & 9,6 & 0,3 & - & 1,4 & 2,7 & 0,4 & tr. & tr. & tr. & $=$ & $=$ & 17,8 & 27,5 & 54,7 & 16,9 \\
\hline JGA-43 * & 20,3 & 23,8 & 38,6 & 6,0 & 6,5 & 0,7 & $\underline{-}$ & 1,5 & 1,2 & 0,8 & tr. & - & tr. & 0,5 & - & 24,5 & 28,8 & 46,7 & 17,2 \\
\hline \multicolumn{20}{|c|}{ DOMINIO PAREDÄO DA SANTA } \\
\hline Amostra & $\mathrm{Qz}$ & FK & Plag & Anf & Bio & Clo & Mu & Opa & Tit & $\mathrm{Ap}$ & $\mathrm{Zr}$ & All & Ep & $\mathrm{Phn}$ & $\mathrm{Ft}$ & $\mathbf{Q}$ & $\mathbf{A}$ & $\mathbf{P}$ & $\mathbf{M}$ \\
\hline JGA-1 & 24,3 & 30,6 & 33,8 & tr. & 8,1 & 0,3 & - & 1,3 & 0,8 & 0,5 & tr. & - & 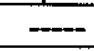 & tr. & - & 27,4 & 34,5 & 38,1 & 11,0 \\
\hline JGA-44 & 24,2 & 25,2 & 42,0 & - & 5,5 & 0,6 & tr. & 1,5 & tr. & 0,8 & tr. & - & - & $\cdots$ & - & 26,5 & 27,6 & 46,0 & 8,4 \\
\hline \multicolumn{20}{|c|}{ DOMINIO PASSO DA ANTA-ÁGUA CLARA } \\
\hline Amostra & $\mathrm{Qz}$ & FK & Plag & Anf & Bio & Clo & $\mathrm{Mu}$ & Opa & Tit & $\mathrm{Ap}$ & $\mathrm{Zr}$ & All & $E p$ & Phn & $\mathrm{Ft}$ & $\mathbf{Q}$ & A & $\mathbf{P}$ & $M$ \\
\hline JGA-14 & 25,6 & 23,7 & 46,3 & - & 0,9 & 1,4 & $1,2^{p}$ & 0,8 & - & 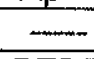 & tr. & - & - & - & - & 26,8 & 24,8 & 48,4 & 3,1 \\
\hline \multicolumn{20}{|c|}{ DOMÍNIO ARROIO DAS PEDRINHAS } \\
\hline Amostra & $\mathrm{Qz}$ & FK & Plag & Anf & Bio & Clo & $\mathrm{Mu}$ & Opa & Tit & $A p$ & $\mathrm{Zr}$ & All & Ep & Phn & $\mathrm{Ft}$ & $\mathbf{Q}$ & A & $\mathbf{P}$ & M \\
\hline JM-46 * & 32,6 & 18,6 & 36,8 & $\ldots$ & 5,7 & 4,5 & - & 1,1 & 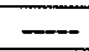 & tr. & tr. & tr. & tr. & 0,3 & 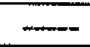 & 37,0 & 21,1 & 41,8 & 11,6 \\
\hline $\mathrm{JM}-111 \mathrm{~A}^{\mathrm{a}}$ & 41,8 & 15,4 & 39,3 & 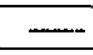 & 0,3 & tr. & $3,0^{p}$ & tr. & - & $\ldots$ & tr. & $\cdots$ & - & - & - & 43,3 & 16,0 & 40,7 & 0,3 \\
\hline $\mathrm{JM}-111 \mathrm{~B}$ & 16,3 & 36,7 & 41,3 & $=$ & 3,6 & 0,5 & 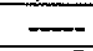 & 1,0 & $\ldots$ & 0,3 & tr. & tr. & - & 0,3 & - & 17,3 & 38,9 & 43,8 & 5,7 \\
\hline $\mathrm{JM}-124^{\mathrm{B}}$ & 33,2 & 21,0 & 30,6 & 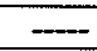 & 1,5 & 2,4 & $9,2^{p}$ & 1,2 & $=$ & $\cdots$ & tr. & - & - & + & - & 39,2 & 24,8 & 36,1 & 5,1 \\
\hline $\mathrm{JM}-128 \mathrm{~A}$ & 23,8 & 32,7 & 36,1 & $=$ & 5,1 & 0,5 & - & 0,9 & 0,5 & tr. & tr. & tr. & $=$ & tr. & - & 25,7 & 35,3 & 39,0 & 7,0 \\
\hline JM-136 & 27,3 & 21,4 & 38,4 & - & 9,7 & tr. & tr. & 2,5 & $\ldots$ & 0,3 & tr. & tr. & - & tr. & 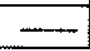 & 31,3 & 24,6 & 44,1 & 12,5 \\
\hline \multicolumn{20}{|c|}{ DOMINIO VARGINHA } \\
\hline Amostra & $\mathrm{Qz}$ & FK & Plag & Anf & Bio & Clo & $\mathrm{Mu}$ & Opa & Tit & $A p$ & $\mathrm{Zr}$ & All & Ep & Phn & $\mathrm{Ft}$ & $\mathbf{Q}$ & $\mathbf{A}$ & $\mathbf{P}$ & $M$ \\
\hline PS-47* & 19,9 & 49,1 & 23,2 & ב-ב & 3,0 & 0,8 & 2,3 & 0,9 & tr. & tr. & tr. & $-\infty$ & - & $\ldots$ & $=$ & 21,6 & 53,3 & 25,2 & 5,1 \\
\hline \multicolumn{20}{|c|}{$\begin{array}{l}\text { Domínios Petrográficos da porção NE do Complexo } \\
\text { DOMÍNIO OURO VERDE-PATRIMÓNIO SANTO ANTÓNIO }\end{array}$} \\
\hline Amostra & $\mathrm{Qz}$ & FK & Plag & Anf & Bio & $\mathrm{Clo}$ & $\mathrm{Mu}$ & Opa & Tit & Ap & $\mathrm{Zr}$ & All & Ep & Phn & $\mathrm{Ft}$ & $\mathbf{Q}$ & $\mathbf{A}$ & $\mathbf{P}$ & $M$ \\
\hline IT-3 & 22,3 & 36,6 & 27,9 & - & 8,4 & 0,6 & 0,3 & 1,2 & 1,7 & 0,6 & tr. & tr. & - & tr. & $\ldots$ & 25,7 & 42,2 & 32,1 & 12,8 \\
\hline
\end{tabular}


Tabela 4.1 (cont.): Modas de rochas granitóides do Complexo Cunhaporanga

\begin{tabular}{|c|c|c|c|c|c|c|c|c|c|c|c|c|c|c|c|c|c|c|c|}
\hline \multicolumn{20}{|c|}{ DOMINIO OURO VERDE-PATRIMÓNIO SANTO ANTÓNIO (cont) } \\
\hline Amostra & Qz & FK & Plag & Anf & Bio & $\mathrm{Clo}$ & $\mathrm{Mu}$ & Opa & Tit & Ap & $\mathrm{Zr}$ & All & Ep & Phn & $\mathrm{Ft}$ & $\mathbf{Q}$ & A & $\mathbf{P}$ & $\mathbf{M}$ \\
\hline IT-4 & 19,2 & 47,5 & 25,6 & - & 5,9 & tr. & tr. & 0,4 & 0,9 & 0,3 & tr. & tr. & - & - & $\ldots$ & 20,8 & 51,5 & 27,7 & 7,5 \\
\hline IT-11 & 25,7 & 30,1 & 31,1 & - & 6,7 & 2,2 & tr. & 2,2 & 1,7 & 0,3 & tr. & tr. & $\underline{-}$ & $-\ldots$ & 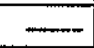 & 29,6 & 34,6 & 35,8 & 13,1 \\
\hline IT-97 & 21,4 & 39,4 & 27,0 & $\underline{\square}$ & 6,4 & tr. & tr. & 0,8 & 0,8 & 0,5 & tr. & tr. & - & $\ldots$ & - & 24,4 & 44,9 & 30,8 & 8.5 \\
\hline \multicolumn{20}{|c|}{ DOMINIO FRANCISCO SIMAS-VILA BRANCA } \\
\hline Amostra & Qz & FK & Plag & Anf & Bio & $\mathrm{Clo}$ & $\mathrm{Mu}$ & Opa & Tit & Ap & $\mathrm{Zr}$ & All & Ep & $\mathrm{Phn}$ & Ft & $\mathbf{Q}$ & $\mathbf{A}$ & $\mathbf{P}$ & $\mathbf{M}$ \\
\hline PS-63* & 34,8 & 20,0 & 39,1 & - & 3,5 & 1,0 & tr. & tr. & 1,1 & tr. & tr. & tr. & - & -- & $\ldots$ & 37,1 & 21,3 & 41,6 & 5,6 \\
\hline PS-130 & 30,4 & 29,9 & 38,2 & $=$ & $=$ & 1,4 & tr. ${ }^{p}$ & tr. & $\ldots$ & tr. & tr. & $\overline{-}$ & - & $=$ & $\ldots$ & 30,9 & 30,4 & 38,8 & 1,4 \\
\hline \multicolumn{20}{|c|}{ Granito Serra do Carambeí } \\
\hline Amostra & Qz & FK & Plag & Anf & Bio & Clo & $\mathrm{Mu}$ & Opa & Tit & Ap & $\mathrm{Zr}$ & All & Ep & Phn & Ft & $\mathbf{Q}$ & $\mathbf{A}$ & $\mathbf{P}$ & $\mathbf{M}$ \\
\hline JGA-231 & 35,2 & $M s p$ & 61,7 & - & 1,3 & - & tr. & 1,1 & - & - & tr. & - & 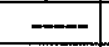 & - & 0,8 & 36,3 & 63,7 & 0,0 & 2,4 \\
\hline $\mathrm{SC}-3^{\mathrm{d}}$ & 35,2 & $M s p$ & 61,8 & $=$ & 1,6 & - & tr. & 0,8 & 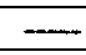 & $=$ & tr. & $\ldots$ & $=$ & - & tr. & 36,3 & 63,7 & 0,0 & 2,9 \\
\hline
\end{tabular}

Abreviaturas e símbolos: Qz - quartzo; FK - feldspato potássico; Msp - mesopertita; Plag - plagioclásio; Anf - anfibólio; Bio biotita; Clo - clorita; Mu - muscovita; Opa - opacos; Tit - titanita; Ap - apatita; Zr - zircão; All - allanita; Ep - epidoto; Phn prehnita (inclui também pumpellyita e granada); Ft - fluorita; $\mathbf{Q}, \mathbf{A}, \mathbf{P}$ - porcentagens de quartzo, feldspato alcalino e plagioclásio no diagrama QAP de Streckeisen (1976); $\mathbf{M}$ - índice de cor; tr, - teores inferiores a $0,3 \%$; ---- mineral ausente; *: traços de carbonato secundário; a: traços de turmalina; b: $0,9 \%$ de turmalina; $\mathbf{c}$ : núcleos de clinopiroxênio; d: $0,5 \%$ de material não identificado interlamelar à biotita; p: primário. 


\section{CAPÍTULO 5}

\section{QUÍMICA MINERAL DAS ROCHAS GRANITÓIDES}

Neste capítulo são apresentados os resultados de química mineral das rochas granitóides, obtidos por meio da microssonda eletrônica (Tabela 5.1). As determinações analíticas, bem como as proporções catiônicas e a composição em termos de "end members", são mostradas nas Tabelas 5.2 (plagioclásios), 5.3 (feldspatos potássicos), 5.5 (piroxênios), 5.6 (anfibólios), 5.7 (biotitas) e 5.8 (muscovitas). No Anexo 6 são feitos comentários sobre a química da associação de minerais de $\mathrm{Ca}-\mathrm{Al}$ secundários, característica de boa parte dos granitóides do Complexo,

Os resultados estão agrupados de acordo com a divisão litoestratigráfica proposta no Capítulo 4 e por tipo de granitóide: titanita anfibólio biotita granitóides, titanita biotita granitóides, biotita granitóides (sem titanita), muscovita biotita granitóides (muscovita considerada primária), álcali-feldspato granitos ("alasquitos" dos Granitos Serra do Carambeí e Joaquim Murtinho), granitóides pórfiros com anfibólio e granitóides pórfiros com biotita (sem anfibólio). O número restrito e desigual de análises para cada unidade litoestratigráfica do Complexo faz com que uma discussão centrada em variantes petrográficas seja mais elucidativa, reservandose comentários adicionais para os casos em que a procedência geográfica seja fator determinante.

\subsection{Plagioclásio}

Os plagioclásios dos granitóides do Complexo são na maioria das vezes zonados, a composicão variando conforme o tipo de rocha analisado (Fotos 10A, 10B e 10C). Os titanita anfibólio biotita granitóides, mais primitivos, têm zonalidades por 
vezes mais marcadas, encontrando-se núcleos de labradorita que passam, irregular ou oscilatoriamente, para zonas intermediárias com labradorita-andesina, até as bordas com oligoclásio (ver Figura 5.1A, C; Tabela 5.2; nas Figuras, N é núcleo, B é borda, enquanto a seta indica o caminho da cristalização). No entanto, com mais freqüência, as diferenças na composição das porções centrais e marginais dos cristais não é elevada (e. g., o plagioclásio $b$ de PS-21 varia entre $A n_{31}$ e $A n_{24}$; a composição do cristal $b$ de JGA-4c fica entre $A n_{36}$ e $A n_{27}$, Figura 5.1A).

Os tipos com biotita e com titanita-biotita (desconsiderando-se o enclave PS-76a) mostram núcleos e bordas quase sempre dentro do intervalo composicional do oligoclásio $\left(A n_{30}\right.$ até $\left.A n_{15}\right)$, sendo algo mais sódicos nos muscovita biotita granitóides $\left(\sim \mathrm{An}_{10-15}\right)$. O plagioclásio observado nas lamelas pertíticas dos álcali-feldspato granitos é albítico (Figura 5.1C; Tabela 5.2).

Nos pórfiros com anfibólio repete-se o comportamento dos granitóides mais primitivos, com fenocristais de plagioclásio fortemente zonados (núcleos até mesmo de bytownita, com $A n_{74} ;$ Figura $5.1 \mathrm{C}$ ). Já no pórfiro apenas com biotita (PS-48) a composição do núcleo é menos cálcica $\left(\mathrm{An}_{35}\right.$; Figura 5.1B).

As proporções moleculares do componente potássico são baixas, em média Or $=1,7$. Valores entre 3,0 e 5,0 foram obtidos apenas em titanita anfibólio biotita granitóides e titanita biotita granitóides.

Os núcleos de labradorita (mais raramente bytownita), nas rochas mais primitivas, são freqüentemente arredondados e mais alterados que as bordas (e. g., Foto 10C). Uma das interpretações é que se tratam de "restitos" do protolito (anfibolítico-gábrico, granulítico básico, etc.), do qual derivariam por fusão parcial os respectivos magmas. Deve ser lembrado, entretanto, que sob altas pressões de água, o diagrama do plagioclásio achata-se bastante, fazendo com que apenas alguns graus de diferença de temperatura sejam suficientes para proporcionar a cristalização da andesina ou oligoclásio, no lugar da labradorita (e. g., White 1992). 


\section{PLAGIOCLÁSIOS DO COMPLEXO GRANÍTICO CUNHAPORANGA}
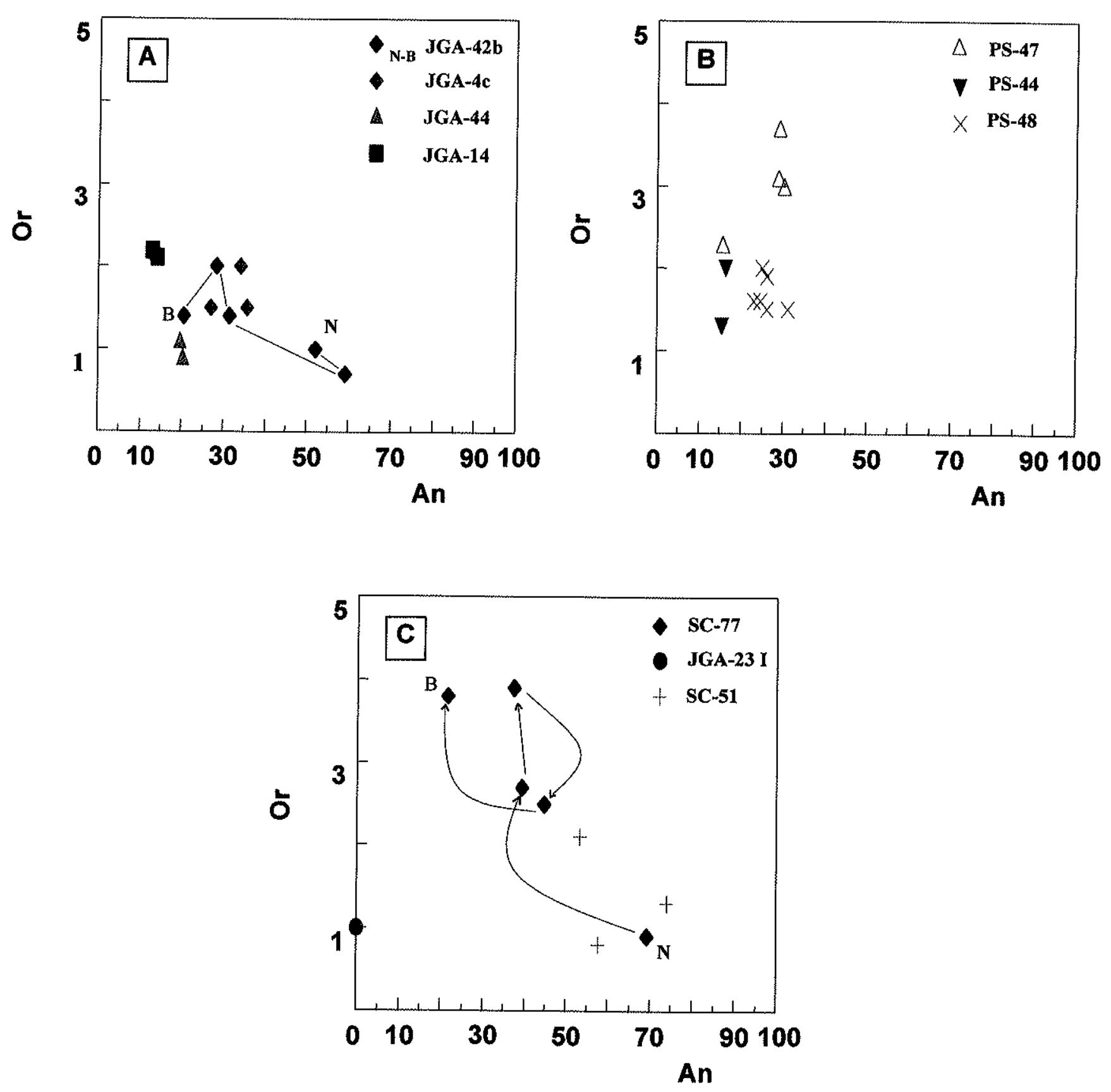

Figura 5.1: Variação composicional de cristais de plagioclásio (moléculas de anortita - An - e ortoclásio - Or) para vários tipos de granitóides do Complexo Cunhaporanga. N-B: análises realizadas do núcleo em direção à borda de um cristal. Símbolos cheios para rochas equigranulares, vazios para porfiríticas: losangos para titanita anfibólio biotita granitóides, triângulos para titanita biotita granitóides, triângulos invertidos para biotita granitóides, quadrados para muscovita biotita granitóides, círculos para álcali-feldspato granitos, cruzes para granitóides pórfiros com anfibólio e letra X para granitóides pórfiros com biotita. 


\subsection{Feldspato alcalino}

Os resultados para os feldspatos potássicos aparecem lançados na Tabela $5.3 \mathrm{e}$ ilustrados na Figura 5.2. Chamam a atenção os teores elevados de $\mathrm{Ba}$ (ver Tabela 5.4), superiores a $2 \% \mathrm{BaO}$ nas rochas mais primitivas. Estas apresentam não só os maiores teores de $\mathrm{Ba}$, como também a maior variação em termos de conteúdo do elemento (Figura 5.2). Teores cada vez menores aparecem nas rochas progressivamente mais evoluídas, sendo que nos álcali-feldspato granitos e nos granitos com muscovita-biotita não ultrapassam $0,25 \%$ de $\mathrm{BaO}$ (ver também o padrão de distribuição dos teores médios de cada tipo petrográfico vs o teor médio de Ba das rochas, Figura 5.8).

As abundâncias de $\mathrm{CaO}$ são sempre muito baixas, em média com proporção molecular de An inferior a 0,2. As variações, em termos dos "end members" $A b$-Or, são também mais dilatadas nas rochas primitivas, diminuindo nos tipos com biotita e com muscovita-biotita (Tabela 5.4).

Nos álcali-feldspato granitos (Granitos Serra do Carambeí e Joaquim Murtinho) tem-se tipicamente mesopertitas, com composicões de feldspatos recristalizados (Or > $93 \%$ ), fruto evidentemente da exsolução de fases albíticas (ver item 5.1). A composição original do feldspato alcalino é estimada em torno do intervalo $A b_{40}-\mathrm{Or}_{60}$ a $A b_{50}-\mathrm{Or}_{50}$ (ver descrições petrográficas nos itens 4.5 e 4.6 do Capítulo 4).

\subsection{Piroxênio}

Muitas das rochas mais primitivas provavelmente tiveram o piroxênio como fase precoce durante sua trajetória de cristalização. No entanto, este mineral quase sempre deve ter sido reabsorvido pelo magma através de reações peritécticas, com formação progressiva de anfibólio. Relitos de piroxênio no centro de hornblendas, testemunhando estas reações descontínuas, são encontrados em titanita anfibólio biotita granitóides dos Domínios Petrográficos Serra Abaixo-Alagados (e. g., diopsídio 
FELDSPATOS POTÁSSICOS DO COMPLEXO GRANÍTICO CUNHAPORANGA
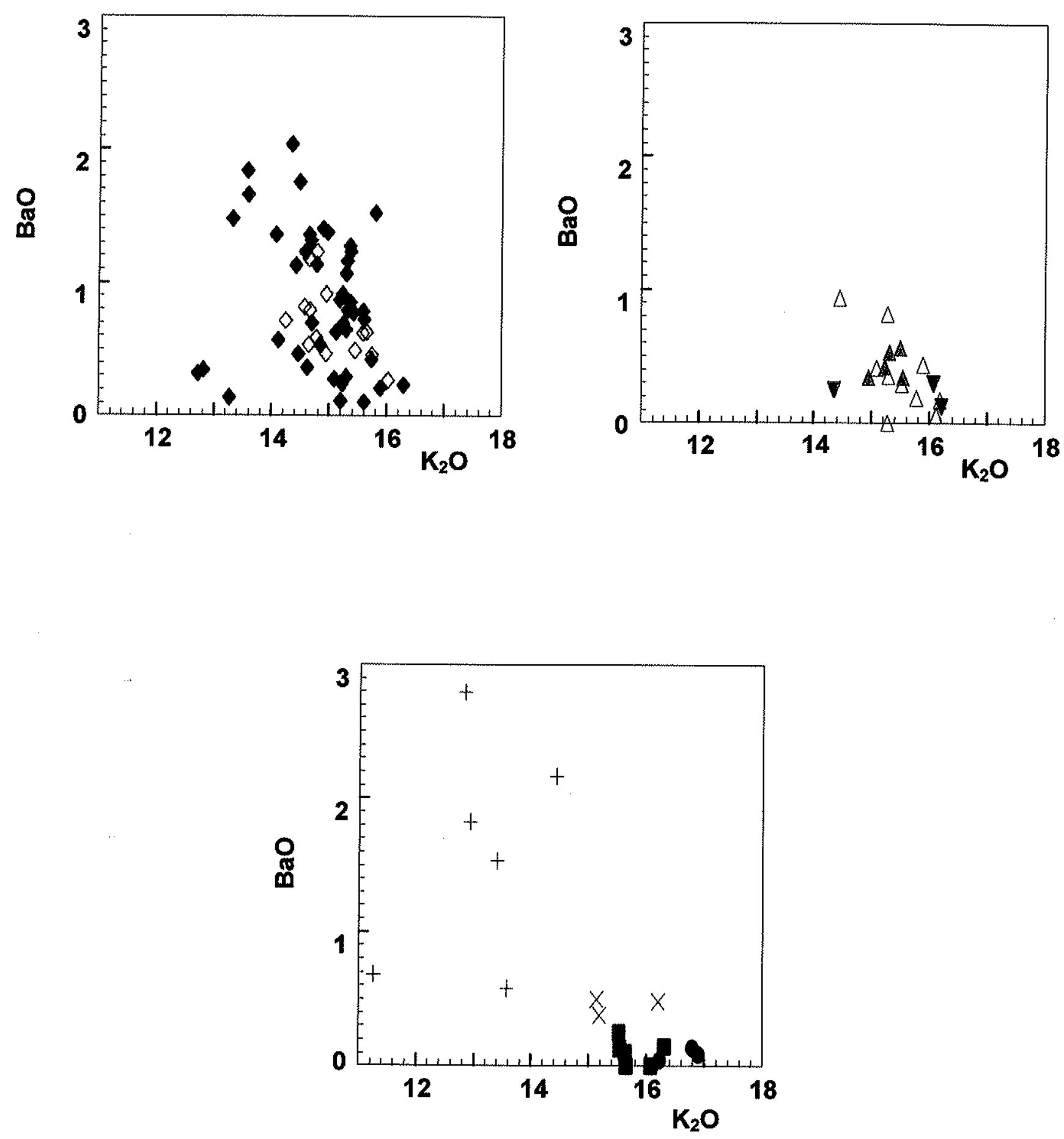

Figura 5.2: Variação composicional de cristais de feldspato potássico $\left(\mathrm{K}_{2} \mathrm{O} X\right.$ $\mathrm{BaO}$ ) para os diferentes tipos de granitóides do Complexo Cunhaporanga (símbolos como na Figura 5.1). Valores nos diagramas em porcentagem de óxidos. 
em SC-77; ver Tabela 5.5 e Figura 5.3), Abapã-Santa Quitéria, Piraí do Sul e, em menor proporção, Espigão Alto (Fotos 10D, 10E e 10F).

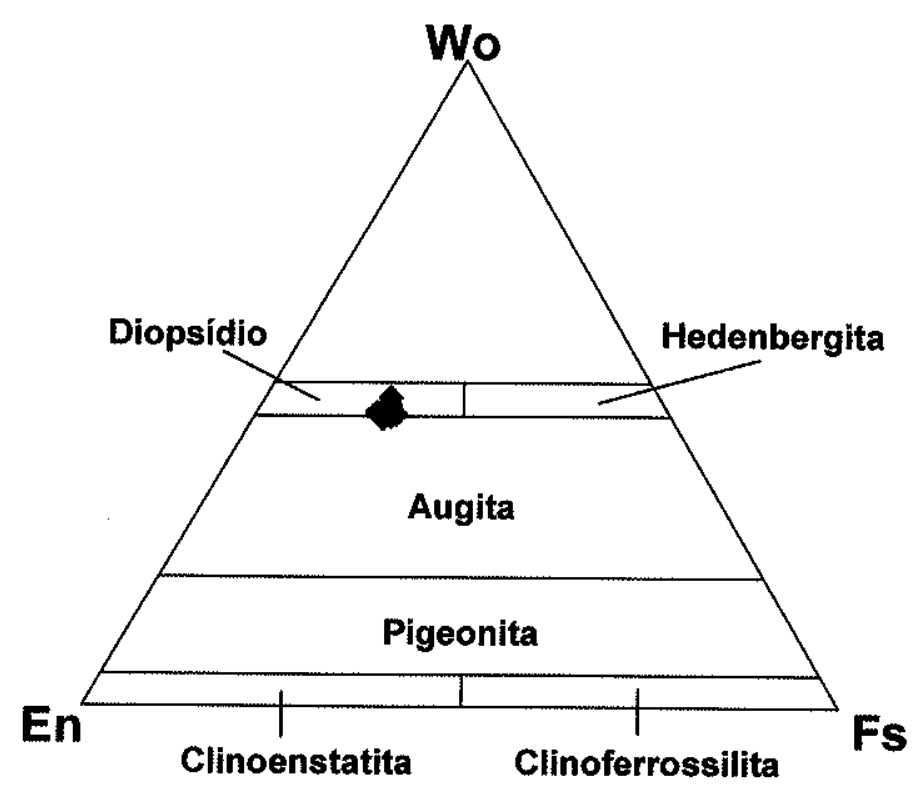

Figura 5.3: Diagrama classificatório para análises de clinopiroxênios do Complexo Cunhaporanga. Wo, En e Fs correspondem respectivamente às proporções moleculares de wolastonita, enstatita e ferrossilita.

Piroxênios são também identificados em alguns dos enclaves dioríticos inclusos em granitóides do Complexo, como na região de Jararaca, em Piraí do Sul, onde ocorre a transição entre os Domínios Piraí do Sul e Espigão Alto. Neste caso são novamente do tipo diopsídio $\left(\boldsymbol{m g}^{*} \sim 0,70\right.$; PS-92a; Tabela 5.5 e Figura 5.3), porém com composição um pouco menos magnesiana do que os do Domínio Serra AbaixoAlagados $\left(m g^{\#} \sim 0,78\right)$. Esta diferença na relação $\mathrm{Mg} / \mathrm{Fe}$ é coerente com os teores da molécula de An para os plagioclásios coexistentes (ver Tabela 5.2).

\subsection{Anfibólio}

Na Tabela 5.6, são lançadas as análises dos anfibólios encontrados nos tipos com titanita-anfibólio-biotita e nos pórfiros com anfibólio. A amplitude da variação 
composicional pode ser visualizada nos diagramas de $\mathrm{Si}$ (Figura 5.4A) e $(\mathrm{Na}+\mathrm{K}$; Figura 5.4B) versus o número $\mathrm{mg}^{*}$. De acordo com a classificação de Leake et al. (1997), predominam magnésio-hornblendas, em menor proporção magnésiohastingsitas e hastingsitas, enquanto edenitas e tschermakitas são ainda mais restritas (Figuras $5.4 \mathrm{C}$ e D).

Chamam a atenção os anfibólios dos pórfiros de São Sebastião (SC-51), que se afastam da tendência mostrada pelas rochas mais primitivas com titanita-anfibóliobiotita (Figura 5.4A). Geoquimicamente, estes dois tipos petrográficos são muito parecidos (ver Capítulo 6), com os pórfiros representando magmas equivalentes aos dos titanita-anfibólio-biotita granitóides, mas certamente resfriados de maneira rápida. Como a proporção catiônica de Si do anfibólio nada mais é do que uma representação indireta dos teores de $A I^{N}$ (este, um conhecido indicador geotermobarométrico), o deslocamento do alinhamento principal deve refletir diferenças nas condições de cristalização: temperaturas diferentes e, muito provavelmente, pressões menores para os pórfiros e maiores para os granitóides com titanita-anfibólio-biotita (ver item 6.4).

Apesar do baixo número de análises, pode-se distinguir dois alinhamentos grosseiramente paralelos na Figura 5.4B (desconsiderando-se os pórfiros de São Sebastião). Entretanto é difícil dimensionar (se é que existe) o significado geológico do trend definido pelos anfibólios das amostras PS-92a (enclave), JGA-43b (enclave; autólito?) e IT-50b (blocos soltos: enclaves ?) (e. g., estariam relacionados a rochas dos estágios precoces do magmatismo ?). As três amostras citadas não são representativas do contexto geológico em que estão inseridas. Enquanto PS-92a é um enclave diorítico, JGA-43b foi coletada em blocos de hornblenda quartzo monzodioritos (autólitos ?) subordinados a hornblenda biotita monzogranitos e biotita monzogranitos predominantes. Já IT-50b é um granodiorito cujas relações com os biotita granitos do Domínio Limeira não puderam ser perfeitamente estabelecidas em campo, podendo mesmo tratar-se de enclaves (ver comentários no item 4.4.2 do Capítulo 4). 


\section{ANFIBÓLIOS DO COMPLEXO GRANÍTICO CUNHAPORANGA}
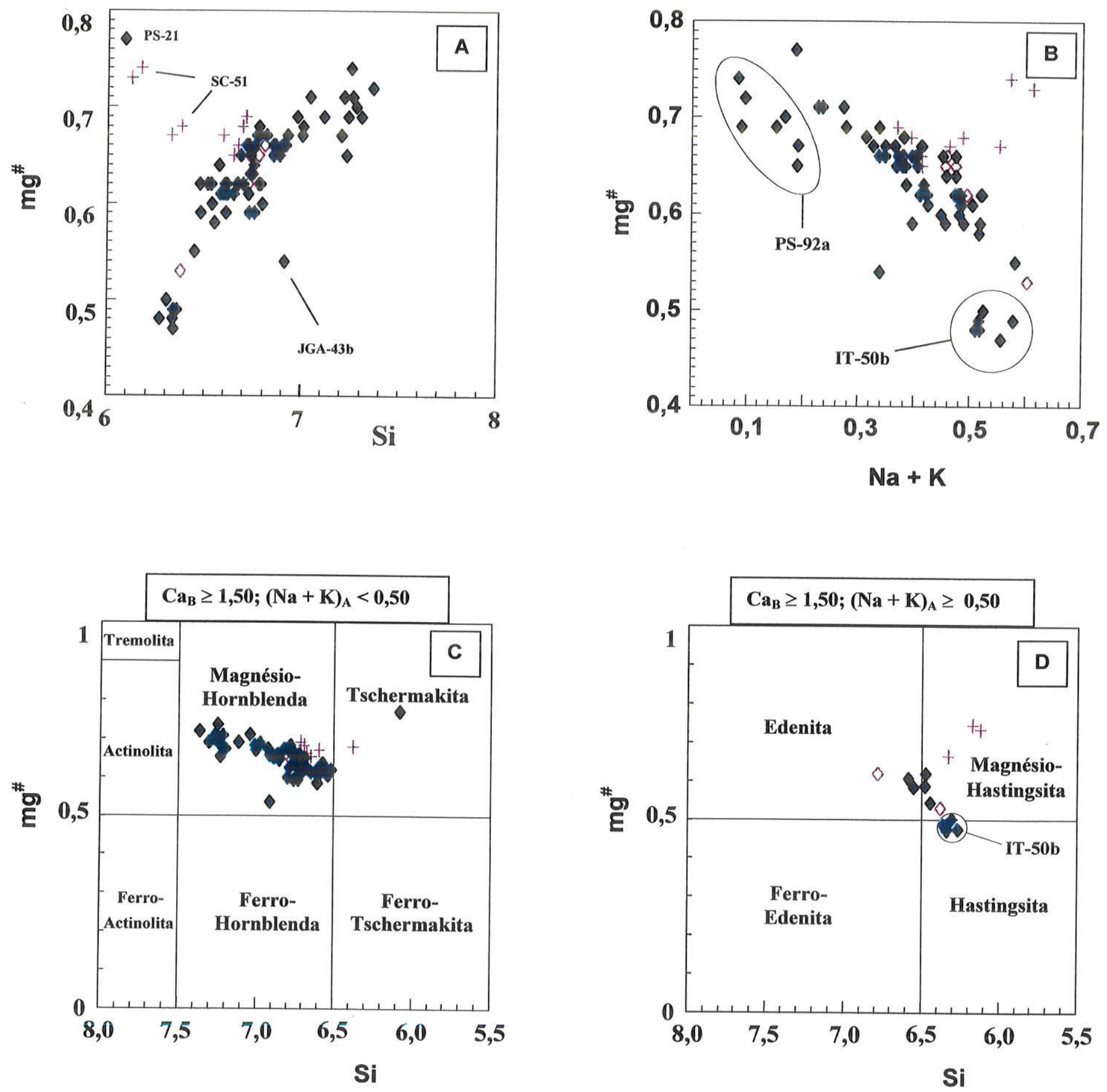

Figura 5.4: Diagramas $\mathrm{Si} X m g^{\#}\left(\mathrm{~A}, \mathrm{C}\right.$ e $\mathrm{D} ; \mathrm{mg}^{\#}=\mathrm{Mg} /\left(\mathrm{Mg}+\mathrm{Fe}^{+2}\right.$, valores das fórmulas estruturais) e ( $\mathrm{Na}+\mathrm{K})$ versus $\mathbf{m g}^{\#}(\mathrm{~B})$ para anfibólios do Complexo Cunhaporanga. Em C e D classificação dos anfibólios segundo Leake et al. (1997); $\mathrm{Ca}_{\mathrm{B}}=$ cálcio na posição estrutural $\mathrm{B}$ e $(\mathrm{Na}+\mathrm{K})_{\mathrm{A}}$ = sódio e potássio na posição estrutural $\mathrm{A}$. 


\subsection{Biotita}

$\mathrm{Na}$ Tabela 5.7, aparece o conjunto de análises das biotitas dos granitóides do Complexo (Figura 5.5A). Com exceção principalmente de IT-50b (Domínio Limeira), as biotitas dos titanita anfibólio biotita granitóides possuem um espalhamento relativamente bem definido (Figuras 5.5B e D). Como no caso dos anfibólios, as biotitas do granodiorito IT-50b têm um comportamento distinto dos demais exemplares deste tipo petrográfico (e. g., $\boldsymbol{m g}^{*}$ mais baixo; ver item 5.4 acima).

O espalhamento dos pontos na Figura 5.5B assemelha-se ao que surge dos dados da Figura 5.5C, retirando-se os muscovita biotita granitos e os álcali-feldspato granitos.

As biotitas mais "aluminosas" $\left(\mathrm{Al}_{2} \mathrm{O}_{3}>16 \%\right)$ estão quase sempre em rochas situadas em regiões com fortes indícios de assimilação parcial dos metassedimentos. encaixantes (Domínio Passo da Anta-Água Clara: JGA-14 e PS-44; Domínio Francisco Simas-Vila Branca: PS-63). A composição particular destas biotitas reforça a hipótese de que a assimilação de rochas encaixantes deve ser fator importante na geração dos muscovita biotita granitóides (ver Capítulo 6).

Os álcali-feldspato granitos (Granito Serra do Carambeí) aparecem com annitas, devido ao teor quase nulo de $\mathrm{MgO}$ destas rochas (ver Capítulo 6), uma característica comum a granitóides do tipo "A" (e. g., Collins et al. 1982). A confirmação destas mesmas composições para o Granito Joaquim Murtinho é difícil, tendo em vista o elevado grau de alteração de suas micas primárias.

Segundo Patiño Douce (1993), quanto mais elevada a temperatura, mais facilmente se cristalizam micas enriquecidas em titânio. Sendo assim, não surpreende que os maiores teores de Ti na Figura 5.5D tenham sido obtidos nas amostras PS-92a, PS-93a $\theta$ SC-77, todas com composições $\theta$ texturas indicativas de altas temperaturas (ver Capítulos 4 e 6). As duas últimas são monzogranitos a granodioritos com relictos de piroxênio e núcleos de plagioclásio cálcico (e. g., $\mathrm{An}_{69}$ em SC-77). Já a amostra PS-92a corresponde a um enclave diorítico com núcleos milimétricos arredondados de 


\section{BIOTITAS DO COMPLEXO GRANÍTICO CUNHAPORANGA}
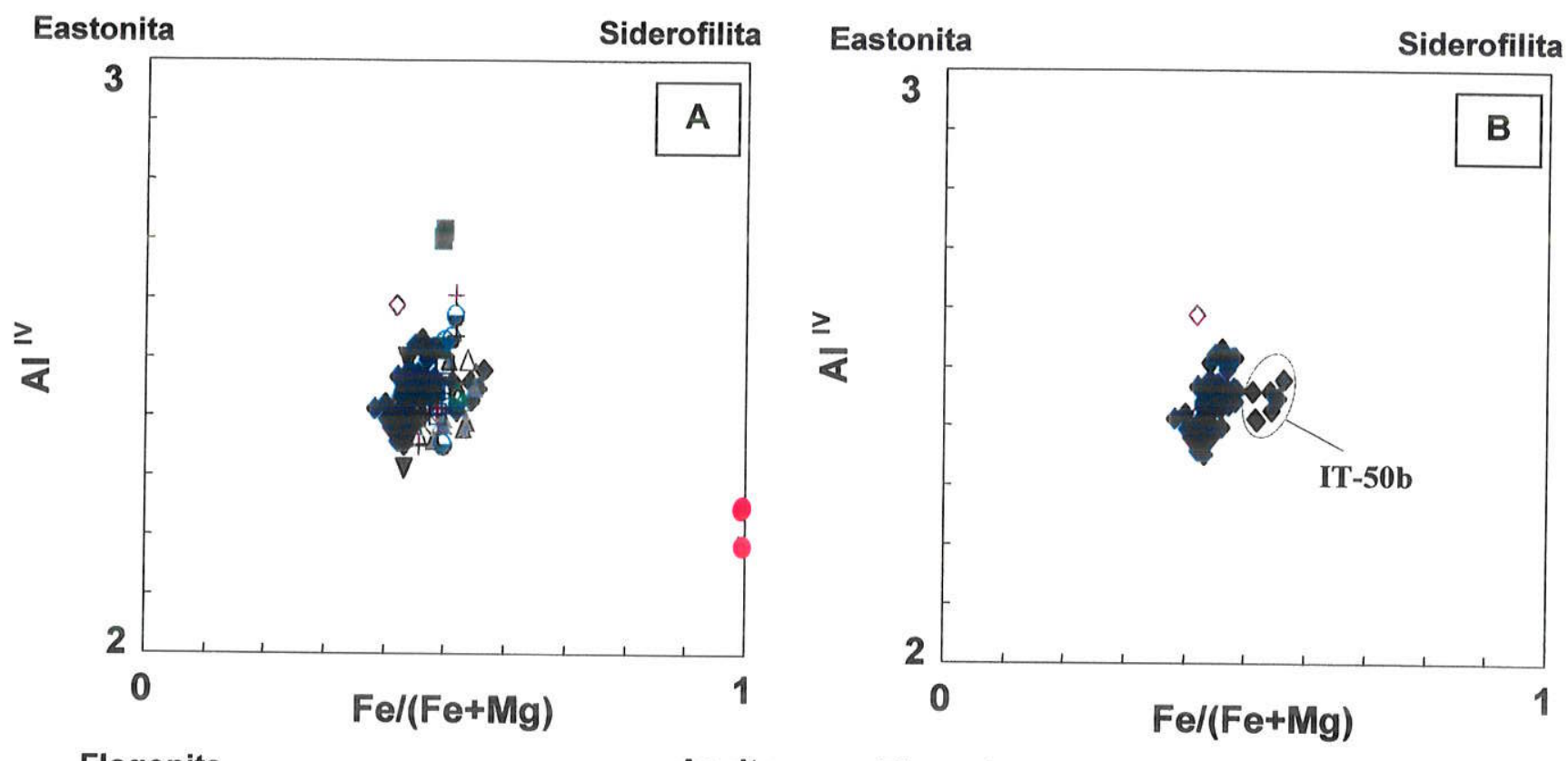

Flogopita

Annita

Flogopita

Annita
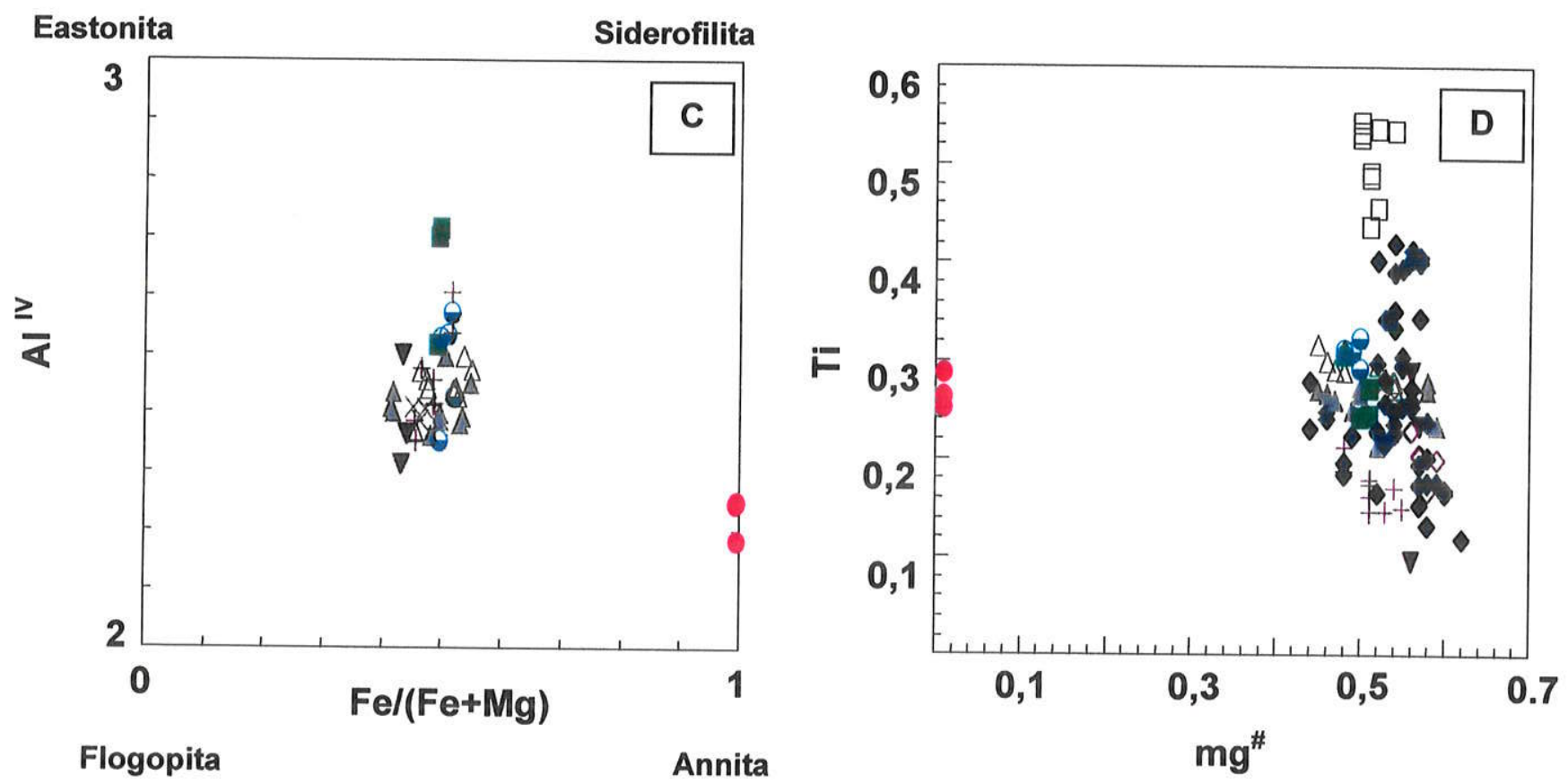

Flogopita

Annita

Figura 5.5: Variação composicional de cristais de biotita nos diferentes tipos de granitóides do Complexo Cunhaporanga (A, B e C, $\mathrm{Fe} /(\mathrm{Fe}+\mathrm{Mg})$ vs Al ${ }^{\mathrm{IV}}$; D, $\mathbf{m g}^{\#}$ vs Ti). Em A e $\mathbf{D}$ todas as análises; em $\mathbf{B}$ apenas os titanita anfibólio biotita granitóides; em $\mathbf{C}$ os demais tipos petrográficos (círculo semi-preenchido para o enclave em PS-46). Em D, quadrados vazados para PS-92a. Demais símbolos como na Figura 5.1. Valores das fórmulas estruturais. 
composição granítica (os maiores teores de $\mathrm{Ti}$ estão nas biotitas alongadas destes núcleos; Foto 11A).

\subsection{Muscovita}

Os muscovita biotita granitóides não são um tipo petrográfico quantitativamente expressivo no Complexo. Adicionalmente, quase sempre aparecem como rochas fortemente intemperizadas, o que dificulta a obtenção de material apropriado para investigação analítica.

$\mathrm{Na}$ Tabela 5.8 tem-se alguns resultados analíticos para muscovitas primárias (JGA-14 e PS-130) e secundárias (PS-66 e JM-97) de granitóides do Complexo, sendo que a variação composicional destes minerais pode ser percebida nas Figuras $5.6 \mathbf{A}$ e B.

O caráter mais aluminoso das biotitas dos Domínios Passo das Antas-Água Clara e Francisco Simas-Vila Branca é também observado para suas muscovitas (Tabela 5.8). Isto vai novamente de encontro à interpretação de que as rochas do Grupo Itaiacoca tenham influenciado a composição dos muscovita biotita granitóides.

As diferenças químicas entre as rochas do Granito Joaquim Murtinho ( $\mathrm{MgO} / \mathrm{Fe}_{2} \mathrm{O}_{3}{ }^{\top}$ entre 0,01 e 0,06; ver Capítulo 6) e as do Domínio Varginha $\left(\mathrm{MgO} / \mathrm{Fe}_{2} \mathrm{O}_{3}{ }^{\top}\right.$ $\sim 0,29$ ), aparecem também na composição das muscovitas deutérico-hidrotermais $\left({\boldsymbol{~} \boldsymbol{g}^{*}}^{*}\right.$ 0,14 e 0,45, respectivamente; Figura 5.6B). No caso das muscovitas de PS-66 (Domínio Varginha), é nítida a relação com as biotitas das quais elas são derivadas (biotitas primárias com $\boldsymbol{m} \boldsymbol{g}^{\#} \sim 0,47$ ).

\subsection{Silicatos secundários de Ca e Al}

$\mathrm{Na}$ época em que foi realizada a descrição das rochas granitóides do Complexo na região de Joaquim Murtinho, despertou a atenção um conjunto de minerais 


\section{MUSCOVITAS DO COMPLEXO GRANÍTICO CUNHAPORANGA}
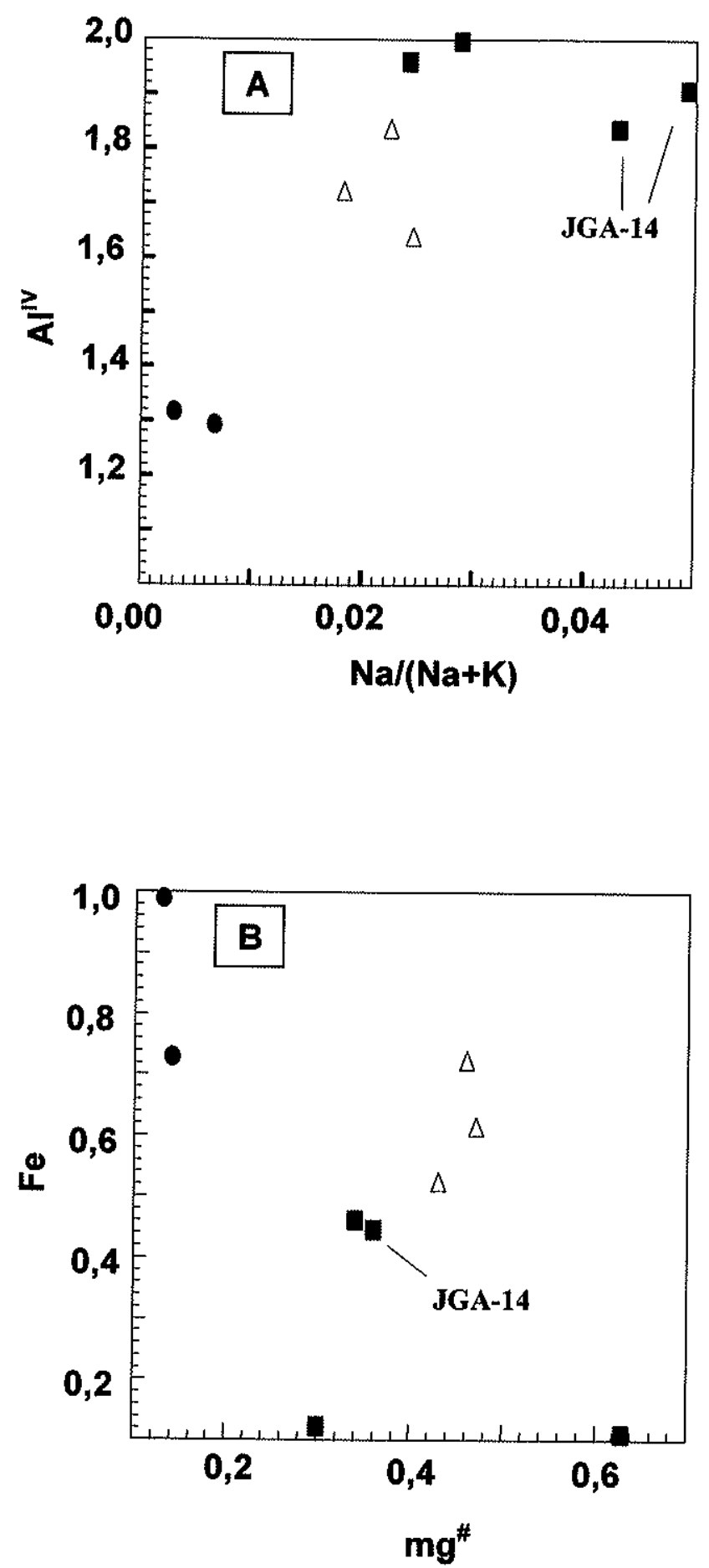

Figura 5.6: Variação composicional de cristais de muscovita para granitóides do Complexo Cunhaporanga (símbolos como na Figura 5.1). Em A, Na/(Na $+\mathrm{K}$ ) vs Allv; em B, $\boldsymbol{m} \boldsymbol{g}^{\#}$ vs $\mathrm{Fe}$. Valores das fórmulas estruturais. 
secundários de $\mathrm{Ca}$ e Al intercrescidos em biotita (ou em clorita dela derivada; Guimarães 1995; Guimarães \& Ulbrich 1996). A ampliação da área de estudo para todo o Complexo só fez perceber que este não era um fenômeno localizado, identificando-se os mesmos minerais em unidades do Complexo situadas do extremo NE (e. g., Domínio Limeira) até os setores mais ao sul (e. g., Domínio Serra AbaixoAlagados). No Anexo 6 tem-se uma versão preliminar da discussão sobre os aspectos químico-mineralógicos desta associação mineral, bem como do seu significado geológico.

Os principais pontos a destacar sobre os Ca-Al silicatos secundários são:

a) os granitóides hospedeiros destes minerais (pórfiros inclusive) têm normalmente > $2 \% \mathrm{CaO}$, não se encontrando $\mathrm{Ca}-\mathrm{Al}$ silicatos secundários em rochas mais evoluídas (empobrecidas em $\mathrm{Ca}$ ), como os muscovita biotita granitóides ou os álcali-feldspato granitos das unidades Joaquim Murtinho e Serra do Carambeí;

b) mais importante do que o teor de $\mathrm{CaO}$ da rocha é a sua relação atômica $\mathrm{Ca} / \mathrm{Al}$. Exemplos dos minerais aqui discutidos estão sempre presentes em rochas com $\mathrm{Ca} / \mathrm{Al}>$ 0,25 e sempre ausentes se essa relação, na rocha, é menor que 0,21. Rochas com $\mathrm{Ca} / \mathrm{Al}$ entre estes valores podem ou não ter $\mathrm{Ca}-\mathrm{Al}$ silicatos secundários;

c) a maior parte dos granitóides mais ricos em $\mathrm{Ca}$ apresentam $\mathrm{Ca}-\mathrm{Al}$ silicatos secundários, com $\mathrm{Fe}^{3+}$ predominante sobre $\mathrm{Fe}^{2+}$. São eles prehnita $(\sim 5,3 \%$ $\mathrm{Fe}_{2} \mathrm{O}_{3}{ }^{\top}$ ), hidrogranada (granditas com até $\sim 1,6 \% \mathrm{~F}$ ), pumpellyita $\left(\sim 14,9 \% \mathrm{FeO}^{\top}\right.$ ) e epidoto $\left(\sim 21,5 \% \mathrm{Fe}_{2} \mathrm{O}_{3}{ }^{\top}\right)$. Estes minerais podem aparecer como grãos isolados ou intercrescidos com biotita e/ou clorita (Fotos 11B-F);

d) os epidotos secundários diferem daqueles considerados primários, situados nos Domínios Limeira e Ouro Verde-Patrimônio Santo-Antônio, tanto nas propriedades ópticas e texturais (ver Capítulo 4) como nas químicas (Figura 5.7). As diferenças nos valores da molécula Ps são equivalentes aos apresentados por Tulloch (1979); 
e) os Ca-Al silicatos secundários devem ter se originado em condições equivalentes as descritas para o metamorfismo de carga, a partir de reações em que tomaram parte o $\mathrm{Ca}$, o $\mathrm{Al}$ e $\circ \mathrm{Fe}^{3+}$ da biotita e do plagioclásio;

f) estas reações provavelmente aconteceram durante 0 resfriamento das rochas granitóides próximo da superfície ( $\mathrm{T}<300^{\circ} \mathrm{C}, \mathrm{P} \sim 2-3 \mathrm{kbar}$ ), sob condições de elevada fugacidade de $\mathrm{H}_{2} \mathrm{O}$ e $\mathrm{O}_{2}$ e com quantidades insignificantes de $\mathrm{CO}_{2}$.

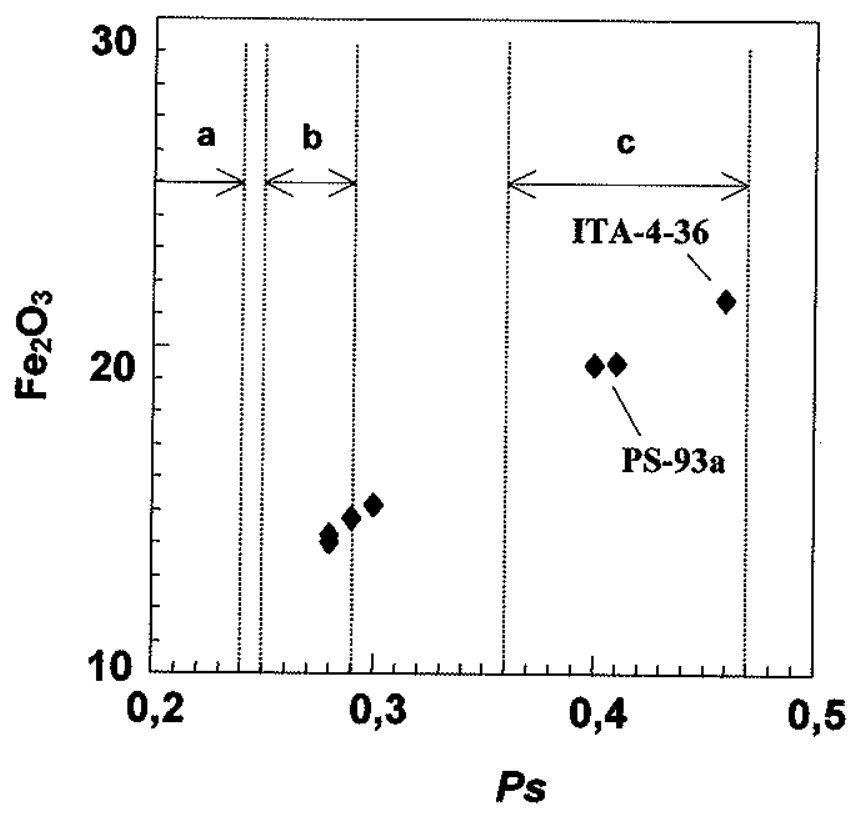

Figura 5.7: Diagrama $P s$ vs $\mathrm{Fe}_{2} \mathrm{O}_{3}$ para epidotos de rochas granitóides do Complexo Cunhaporanga. Ps é a proporção da molécula pistacita nos epidotos: $P \boldsymbol{s}=$ $\mathrm{Fe}^{3+} /\left(\mathrm{Fe}^{3+}+\mathrm{Al}\right)$. As composições dos epidotos estudados por Tulloch (1979) permitiram delimitar os campos $\mathbf{a}, \mathbf{b}$ e $\mathbf{c}$, onde em a situam-se os epidotos formados da alteração de plagioclásio (limite inferior, $P s=0$ ), em b os epidotos primários e em c os epidotos secundários associados à biotitas. ITA-4-36 e PS-93a são, respectivamente, análises para epidotos secundários dos Domínios Abapã-Santa Quitéria e Espigão Alto. Demais pontos para epidotos primários. 


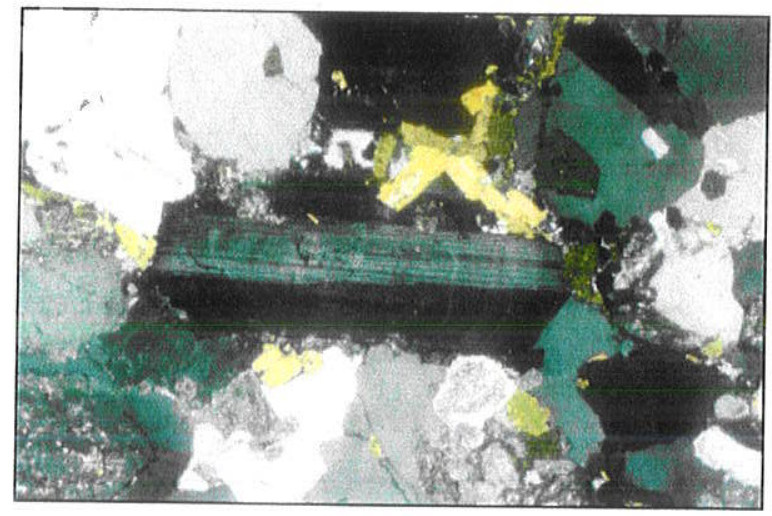

(A)

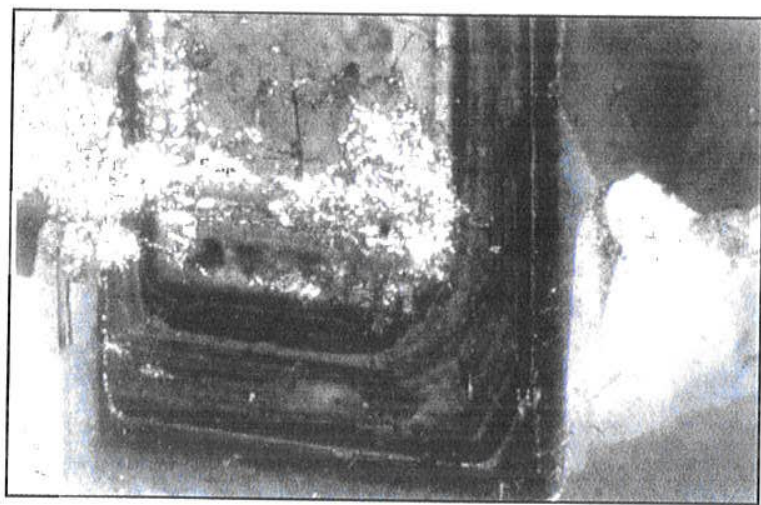

(C)

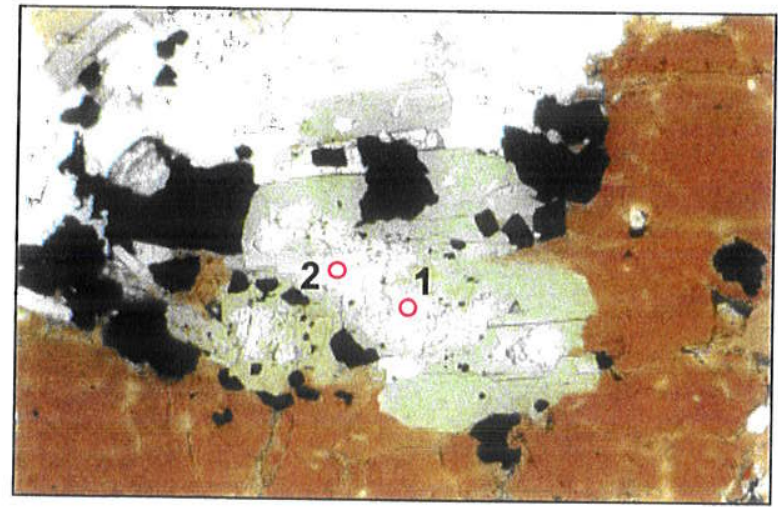

(E)

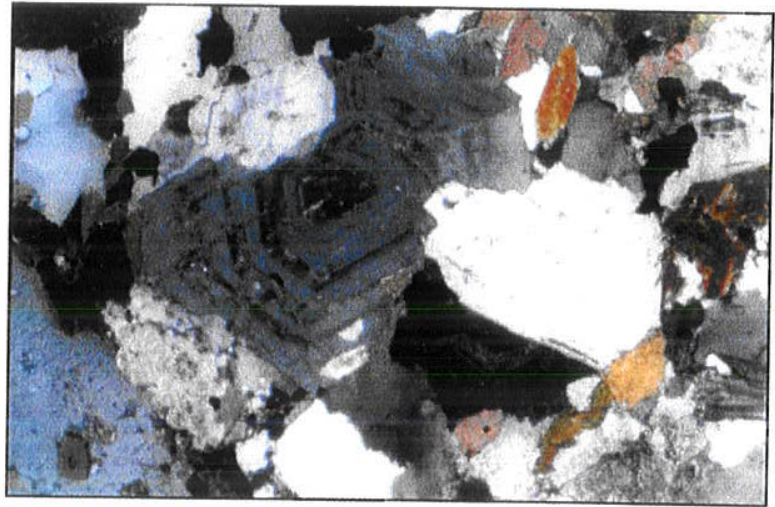

(B)

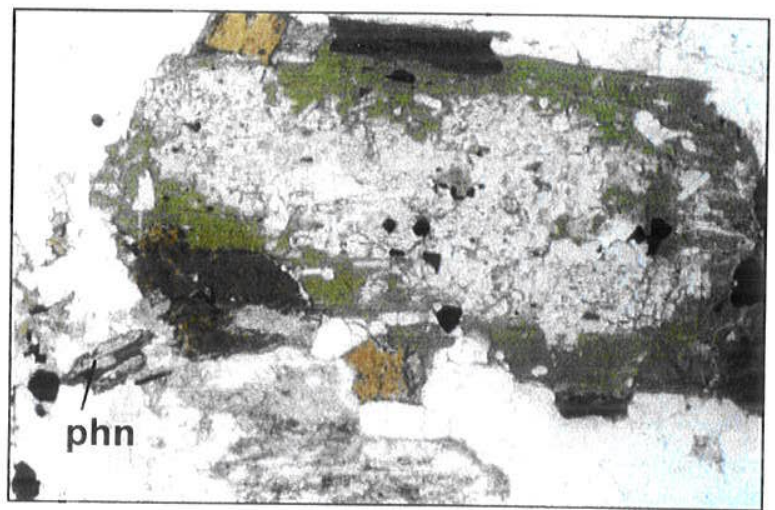

(D)

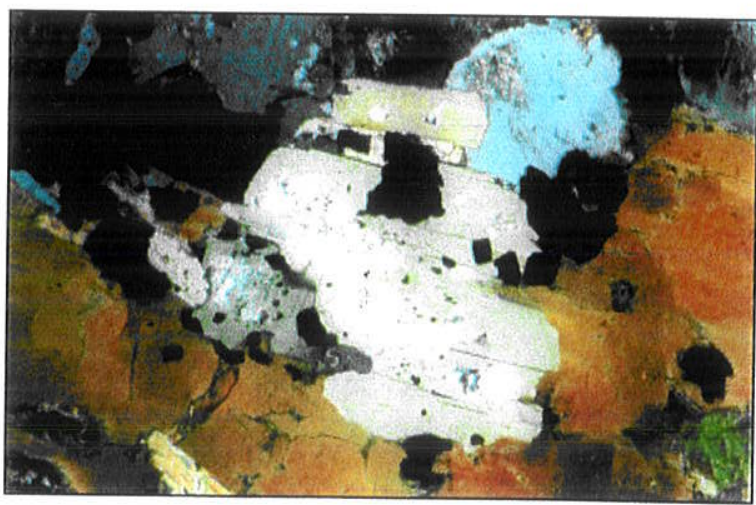

(F)

PRANCHA 10 - (A), (B) e (C): Cristais zonados de plagioclásio em titanita anfibólio biotita granitóides dos Domínios Piraí do Sul (JM-20; aumento 6,25X; \#), Abapã-Santa Quitéria (PS78; aumento 6,25X; \#) e Serra Abaixo-Alagados (SC-77; aumento 25X; \#). Notar o núcleo arredondado de labradorita em C. (D), (E) e (F): Hornblendas com núcleos reliquiares de clinopiroxênio em rochas dos Domínios Espigão Alto (PS-92; aumento 12,5X; /n) e Serra Abaixo-Alagados (SC-77; aumento 25X; // e \#). 1 e 2 em E correspondem aos pontos de análise em microssonda (ver Tabela 5.5). phn: prehnita. 


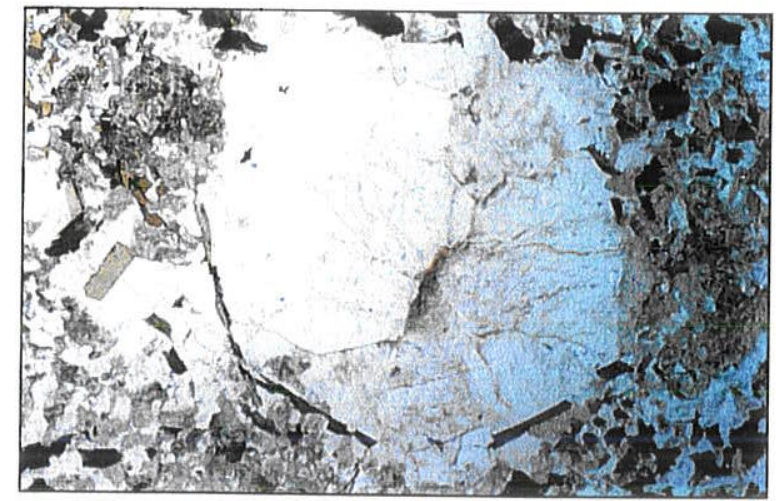

(A)

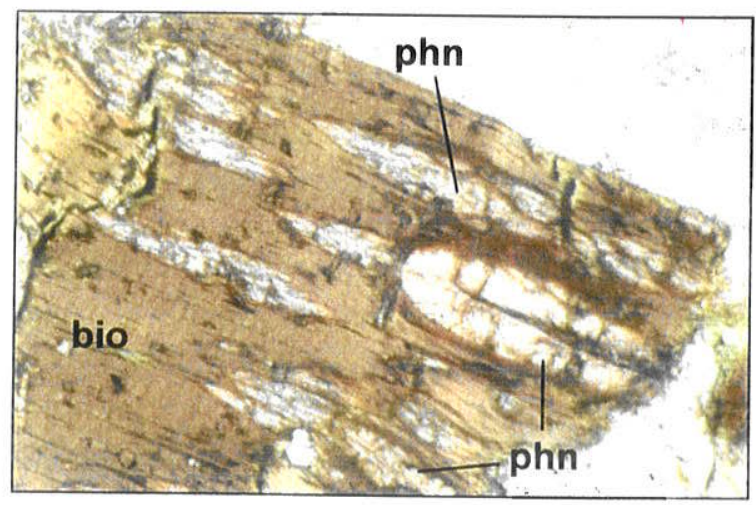

(C)

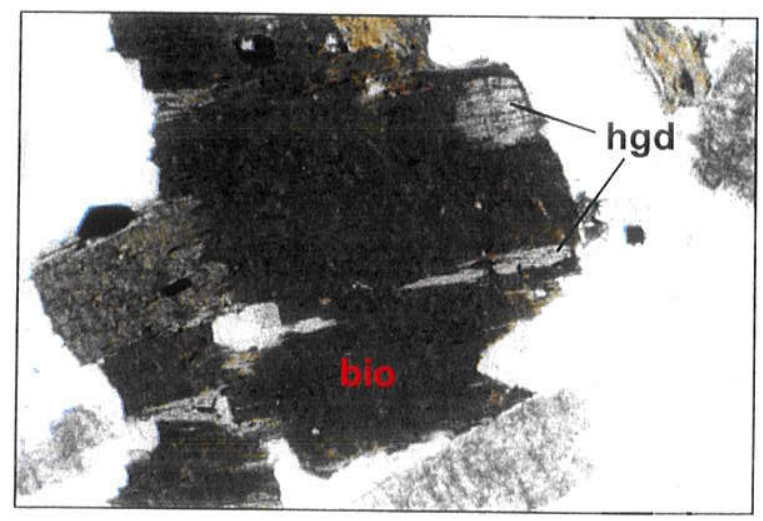

(E)

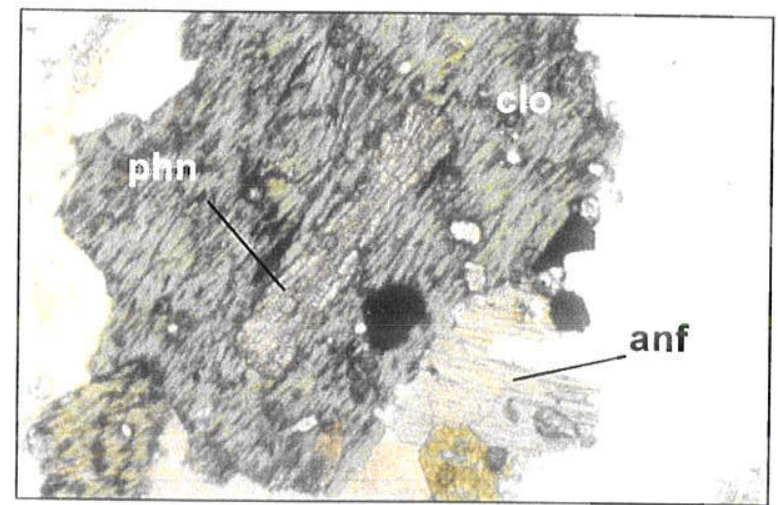

(B)

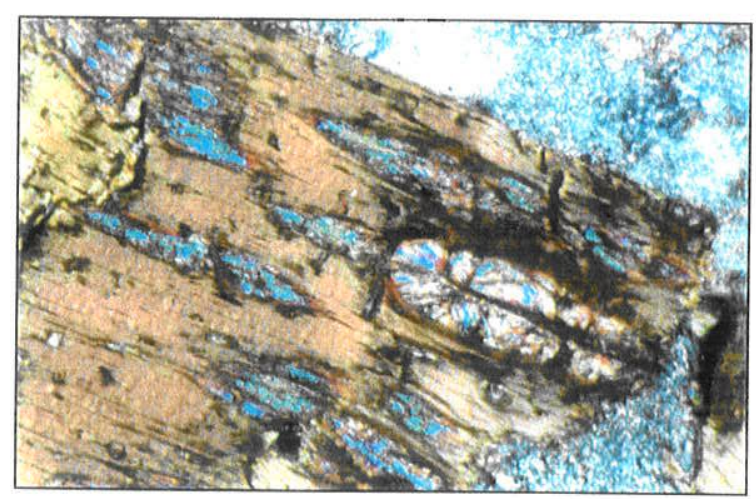

(D)

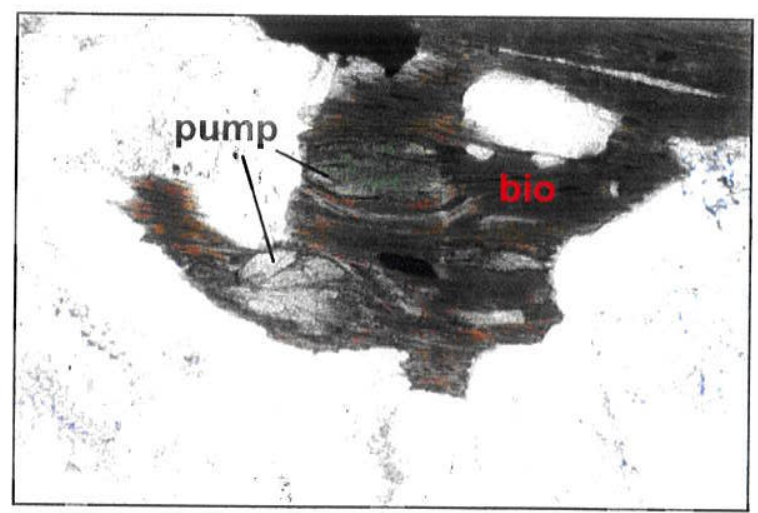

(F)

PRANCHA 11 - (A) Núcleo arredondado, de composição granítica, incluso em enclave diorítico do Domínio Espigão Alto (PS-92a; aumento 6,25X; //; ver Fotos 4A e 4B). Observar hábito alongado e disposição concêntrica da biotita deste núcleo. (B) Prehnita (phn) com hábito "bow-tie" associada a cloritas (clo) de alteração de biotita (Domínio Piraí do Sul, JM-20; aumento 25X; /). (C) e (D) Cristais de prehnita alongada ou esferulítica, inclusos em biotita (bio) (Domínio Abapã-Santa Quitéria, ITA-2100; aumento 25X; // e \#). (E) Agregados irregulares a lenticulares de hidrogranada (hgd) interlamelares à biotita (Domínio Serra Abaixo-Alagados, SC-77; aumento 25X; //). (F) Agregados de pumpellyita (pump) fortemente pleocróica inclusos em biotita de um biotita granitóide do Domínio Arroio das Pedrinhas (JM-46; aumento 50X; //). anf: anfibólio. 
Tabela 5.1: Relação dos minerais analisados em microssonda eletrônica, discriminados segundo a subdivisão em unidades litoestratigráficas do Complexo Granítico Cunhaporanga (ver Anexos 2 e 3).

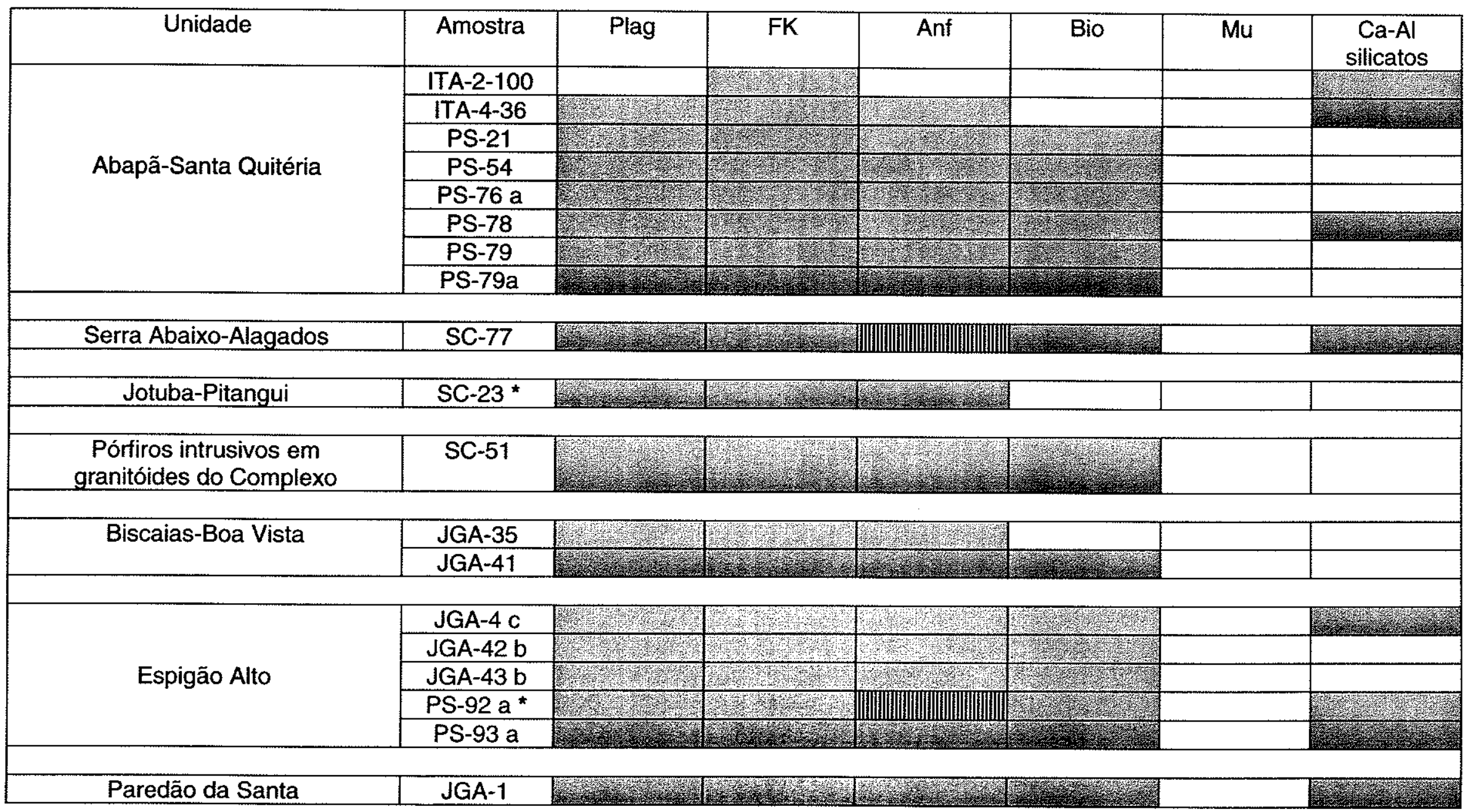


Tabela 5.1 (cont.): Relação dos minerais analisados em microssonda eletrônica, discriminados segundo a subdivisão em unidades litoestratigráficas do Complexo Granítico Cunhaporanga (ver Anexos 2 e 3).

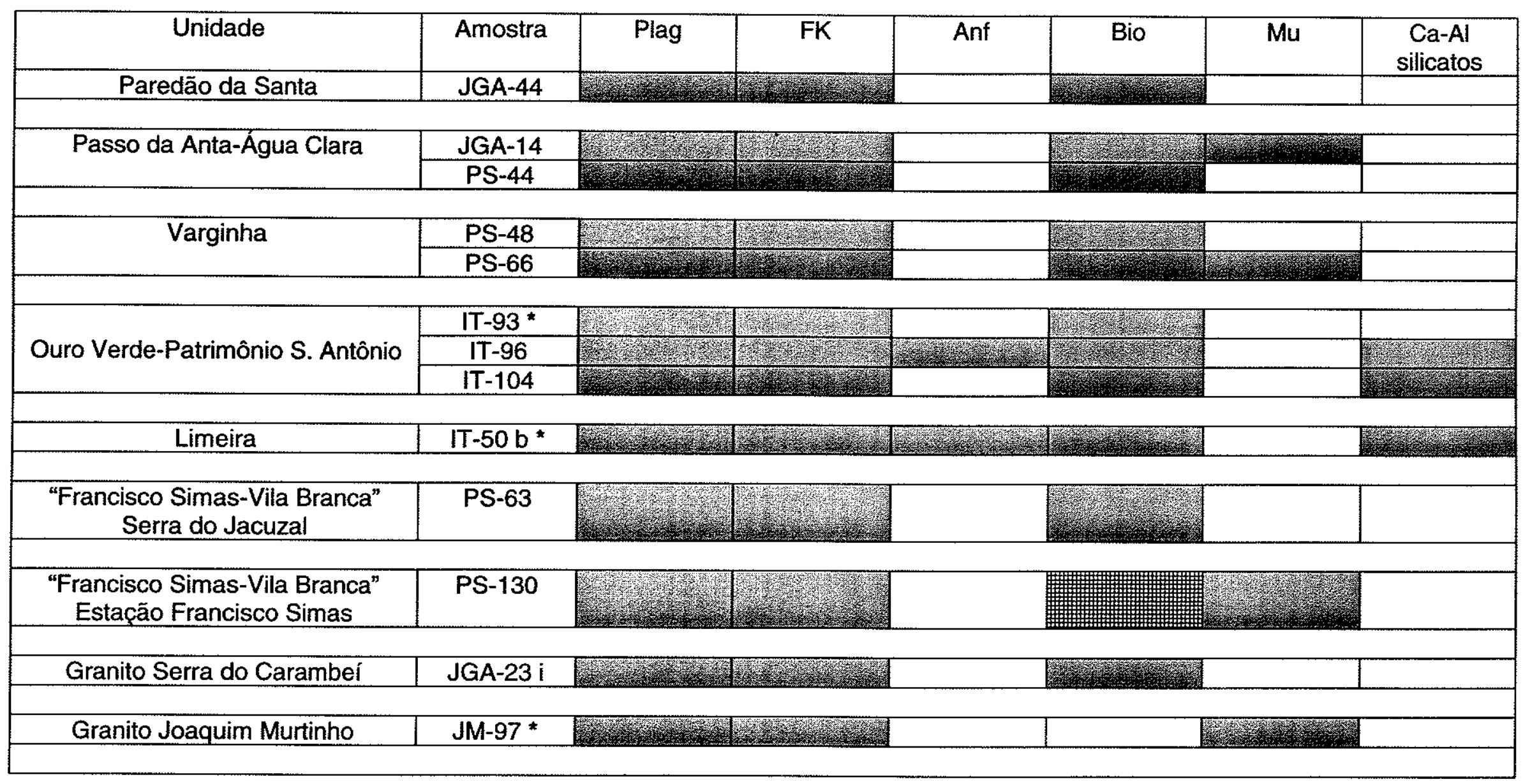

Observações e abreviaturas: Plag - plagioclásio; FK - feldspato potássico; Anf - anfibólio; Bio - biotita; Mu - muscovita; Ca-Al silicatos silicatos principalmente secundários de Ca e Al (prehnita, pumpellyita, granada e/ou epidoto); * - amostras sem análise litoquímica; hachuras verticais em Anf - inclui também análises de clinopiroxênio; padrão quadriculado em Bio - biotita cloritizada. 
Tabela 5.2: Resultados analíticos e cálculos de fórmula estrutural (32 O) para cristais de plagioclásio do Complexo Granítico Cunhaporanga.

\begin{tabular}{|c|c|c|c|c|c|c|c|c|c|c|c|c|c|c|c|c|c|}
\hline & \multicolumn{17}{|c|}{ Domínios Petrográficos da porção S/SE do Complexo } \\
\hline & \multicolumn{17}{|c|}{ DOMÍNIO ABAPÃ-SANTA QUITÉRIA } \\
\hline & \multicolumn{17}{|c|}{ tit anf bio } \\
\hline & \multicolumn{4}{|c|}{ ITA-4-36 } & \multicolumn{11}{|c|}{ PS-21 } & \multicolumn{2}{|c|}{ PS-54 } \\
\hline Local & $\mathrm{b}_{\mathrm{a}}$ & $\mathbf{n}_{\mathrm{a}}$ & $\mathrm{b}_{\mathrm{b}}$ & $\mathrm{n}_{\mathrm{b}}$ & $\mathrm{b}_{\mathrm{a}}$ & $i_{a} 1$ & $i_{a} 2$ & $\mathrm{i}_{\mathrm{a}} 3$ & $\mathrm{n}_{\mathrm{a}}$ & $\mathrm{b}_{\mathrm{b}} 1$ & $b_{b} 2$ & $i_{b} 1$ & $i_{b} 2$ & $i_{b} 3$ & $\mathrm{n}_{\mathrm{b}}$ & $i_{a}$ & $b_{b}$ \\
\hline $\mathrm{SiO}_{2}$ & 63,42 & 62,32 & 62,64 & 60,58 & 61,73 & 60,53 & 60,86 & 58,71 & 60,05 & 61,72 & 61,47 & 61,66 & 61,05 & 60,37 & 60,21 & 60,59 & 64,14 \\
\hline $\mathrm{Al}_{2} \mathrm{O}_{3}$ & 22,31 & 23,33 & 23,08 & 24,52 & 23,43 & 24,39 & 23,85 & 25,60 & 24,78 & 23,52 & 23,44 & 23,38 & 24,02 & 24,63 & 24,53 & 24,22 & 22,22 \\
\hline $\mathrm{Fe}_{2} \mathrm{O}_{3}$ & 0,13 & 0,05 & 0,07 & 0,11 & 0,08 & 0,14 & 0,17 & 0,17 & 0,14 & 0,12 & 0,16 & 0,08 & 0,11 & 0,17 & 0,09 & 0,19 & 0,14 \\
\hline $\mathrm{CaO}$ & 3,54 & 4,58 & 4,46 & 5,99 & 5,01 & 5,82 & 5,61 & 7,25 & 6,31 & 4,90 & 4,96 & 4,94 & 5,72 & 6,00 & 6,12 & 5,66 & 3,50 \\
\hline SrO & 0,02 & 0,11 & 0,12 & 0,22 & 0,16 & 0,22 & 0,15 & 0,23 & 0,18 & 0,14 & 0,16 & 0,15 & 0,24 & 0,14 & 0,18 & 0,18 & 0,03 \\
\hline $\mathrm{BaO}$ & 0,00 & 0,00 & 0,01 & 0,10 & 0,00 & 0,01 & 0,04 & 0,00 & 0,00 & 0,00 & 0,00 & 0,00 & 0,00 & 0,02 & 0,00 & 0,00 & 0,00 \\
\hline $\mathrm{Na}_{2} \mathrm{O}$ & 9,46 & 8,91 & 8,97 & 8,09 & 8,48 & 7,99 & 8,04 & 7,25 & 7,81 & 8,83 & 8,71 & 8,90 & 8,16 & 8,08 & 7,93 & 8,22 & 9,48 \\
\hline $\mathrm{K}_{2} \mathrm{O}$ & 0,25 & 0,23 & 0,16 & 0,16 & 0,33 & 0,38 & 0,43 & 0,24 & 0,35 & 0,23 & 0,28 & 0,28 & 0,29 & 0,32 & 0,22 & 0,31 & 0,31 \\
\hline Total & 99,13 & 99,53 & 99,51 & 99,77 & 99,22 & 99,48 & 99,15 & 99,45 & 99,62 & 99,46 & 99,18 & 99,39 & 99,59 & 99,73 & 99,27 & 99,37 & 99,82 \\
\hline \multicolumn{18}{|c|}{$O=32$} \\
\hline $\mathrm{Si}$ & 11,302 & 11,097 & 11,148 & 10,819 & 11,044 & 10,839 & 10,924 & 10,557 & 10,751 & 11,020 & 11,014 & 11,027 & 10,911 & 10,790 & 10,801 & 10,859 & 11,347 \\
\hline $\mathrm{Al}$ & 4,682 & 4,893 & 4,837 & 5,158 & 4,936 & 5,143 & 5,042 & 5,421 & 5,226 & 4,947 & 4,946 & 4,923 & 5,054 & 5,185 & 5,183 & 5,112 & 4,628 \\
\hline $\mathrm{Fe}^{3+}$ & 0,018 & 0,006 & 0,009 & 0,015 & 0,011 & 0,019 & 0,023 & 0,024 & 0,019 & 0,016 & 0,022 & 0,011 & 0,015 & 0,023 & 0,012 & 0,026 & 0,019 \\
\hline$Z$ & 16,002 & 15,996 & 15,994 & 15,992 & 15,991 & 16,001 & 15,989 & 16,002 & 15,996 & 15,983 & 15,982 & 15,961 & 15,980 & 15,998 & 15,996 & 15,997 & 15,994 \\
\hline $\mathrm{Ca}$ & 0,675 & 0,873 & 0,851 & 1,146 & 0,959 & 1,117 & 1,080 & 1,397 & 1,210 & 0,937 & 0,953 & 0,947 & 1,096 & 1,149 & 1,176 & 1,086 & 0,664 \\
\hline $\mathrm{Sr}$ & 0,002 & 0,012 & 0,012 & 0,023 & 0,016 & 0,023 & 0,016 & 0,024 & 0,018 & 0,015 & 0,017 & 0,015 & 0,024 & 0,014 & 0,019 & 0,018 & 0,003 \\
\hline $\mathrm{Ba}$ & 0,000 & 0,000 & 0,000 & 0,007 & 0,000 & 0,001 & 0,003 & 0,000 & 0,000 & 0,000 & 0,000 & 0,000 & 0,000 & 0,001 & 0,000 & 0,000 & 0,000 \\
\hline $\mathrm{Na}$ & 3,268 & 3,078 & 3,095 & 2,802 & 2,941 & 2,775 & 2,799 & 2,527 & 2,710 & 3,059 & 3,025 & 3,087 & 2,829 & 2,801 & 2,757 & 2,855 & 3,252 \\
\hline $\mathrm{K}$ & 0,056 & 0,053 & 0,036 & 0,036 & 0,075 & 0,086 & 0,098 & 0,056 & 0,080 & 0,053 & 0,064 & 0,065 & 0,066 & 0,072 & 0,049 & 0,072 & 0,070 \\
\hline $\boldsymbol{X}$ & 4,001 & 4,016 & 3,994 & 4,014 & 3,991 & 4,002 & 3,996 & 4,004 & 4,018 & 4,064 & 4,059 & 4,114 & 4,015 & 4,037 & 4,001 & 4,031 & 3,989 \\
\hline$\Sigma$ & 20,003 & 20,012 & 19,988 & 20,006 & 19,982 & 20,003 & 19,985 & 20,006 & 20,014 & 20,047 & 20,041 & 20,075 & 19,995 & 20,035 & 19,997 & 20,028 & 19,983 \\
\hline \multicolumn{18}{|c|}{ Proporçōes moleculares } \\
\hline $\mathrm{Ab}$ & 80,8 & 75,8 & 76,7 & 69,1 & 72,8 & 68,5 & 69,1 & 62,1 & 66,4 & 74,4 & 73,7 & 74,2 & 69,7 & 68,4 & 67,9 & 69,9 & 80,7 \\
\hline An & 17,7 & 22,8 & 22,4 & 30,0 & 25,2 & 29,2 & 28,3 & 36,4 & 31,5 & 24,2 & 24,6 & 24,1 & 28,6 & 29,7 & 30,8 & 28,2 & 17,5 \\
\hline Or & 1,5 & 1,4 & 0,9 & 0,9 & 2,0 & 2,2 & 2,6 & 1,5 & 2,1 & 1,4 & 1,7 & 1,7 & 1,7 & 1,9 & 1,3 & 1,9 & 1,8 \\
\hline
\end{tabular}


Tabela 5.2 (cont.): Resultados analíticos e cálculos de fórmula estrutural (32 O) para cristais de plagioclásio do Complexo Granítico Cunhaporanga.

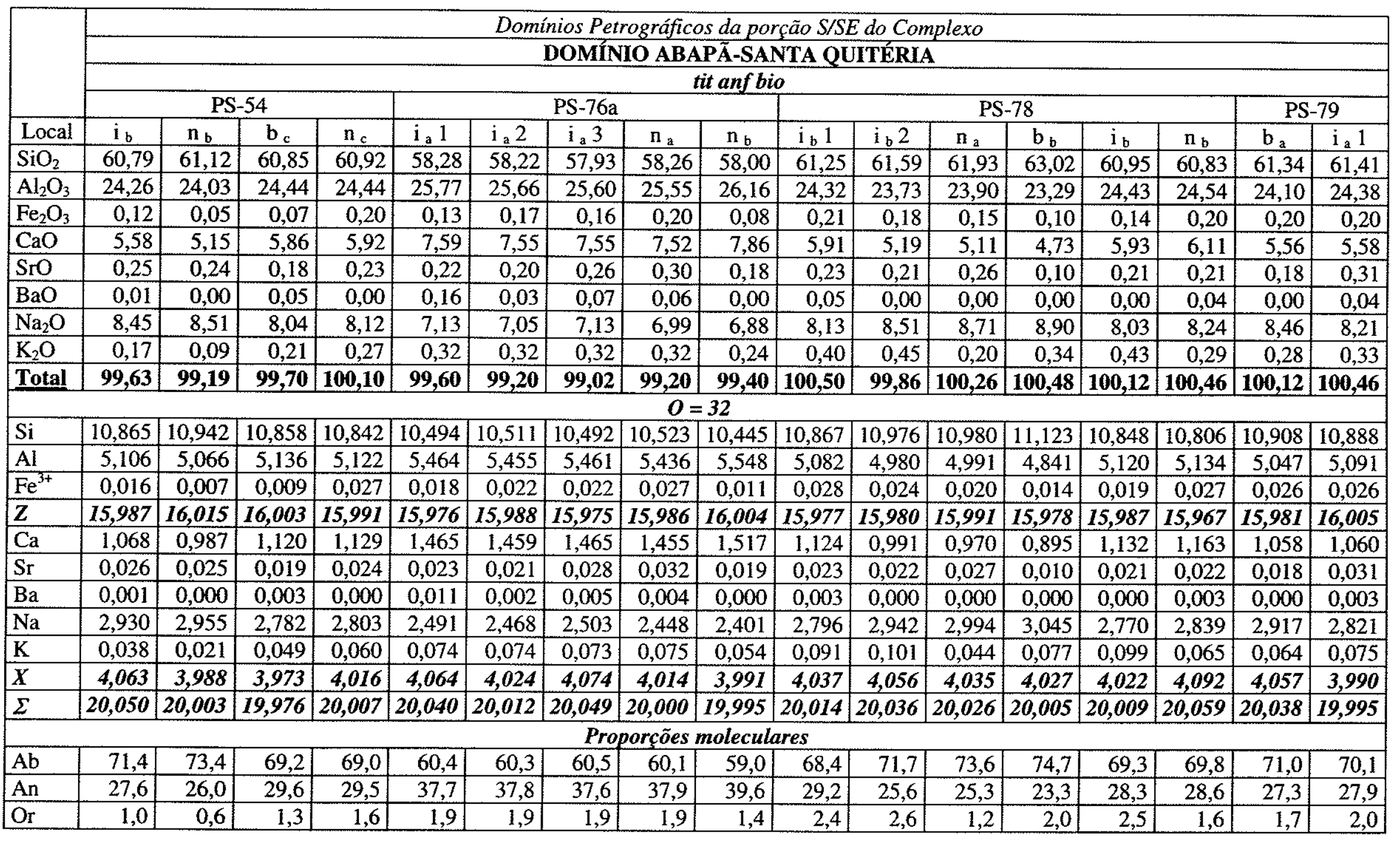


Tabela 5.2 (cont.): Resultados analíticos e cálculos de fórmula estrutural (32 O) para cristais de plagioclásio do Complexo Granítico Cunhaporanga.

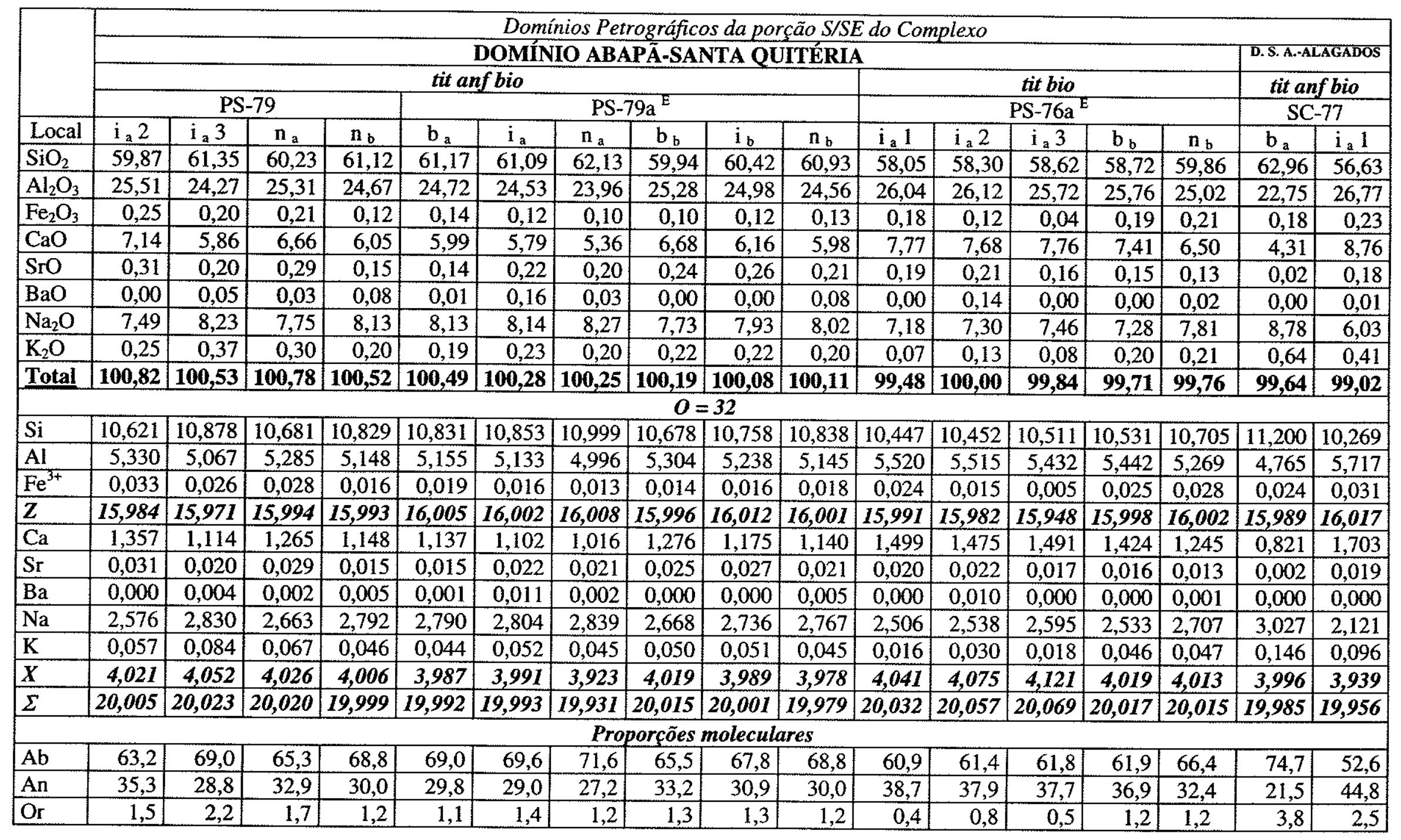


Tabela 5.2 (cont.): Resultados analíticos e cálculos de fórmula estrutural (32 O) para cristais de plagioclásio do Complexo Granítico Cunhaporanga.

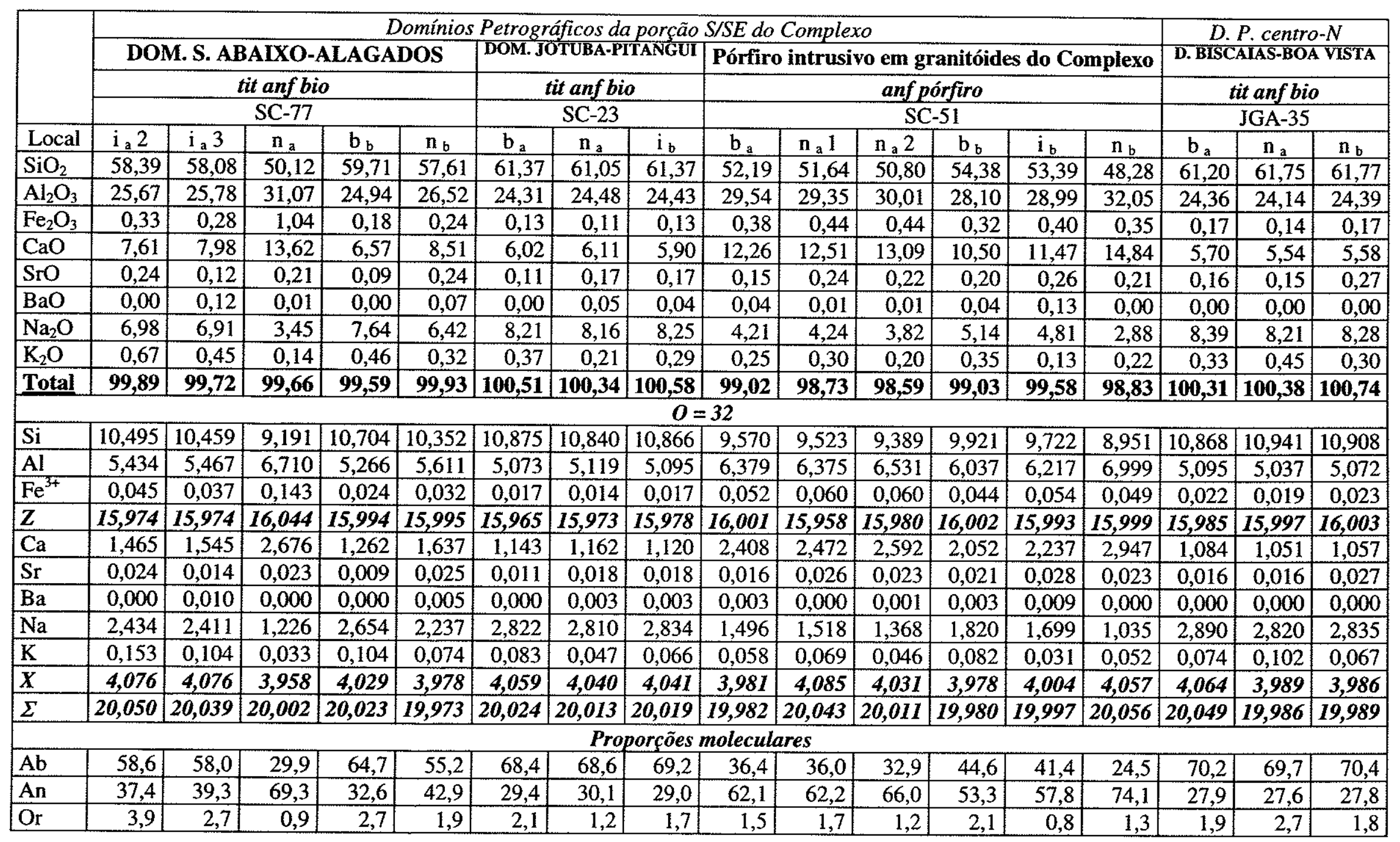


Tabela 5.2 (cont.): Resultados analíticos e cálculos de fórmula estrutural (32 O) para cristais de plagioclásio do Complexo Granítico Cunhaporanga.

\begin{tabular}{|c|c|c|c|c|c|c|c|c|c|c|c|c|c|c|c|c|c|}
\hline & \multicolumn{17}{|c|}{ Domínios Petrográficos da porçāo centro- $N$ do Complexo } \\
\hline & & & & DOMI & ÍNIO BI & ISCAIAS & S-BOA I & VISTA & & & & \multirow{2}{*}{\multicolumn{6}{|c|}{\begin{tabular}{|c|} 
DOMÍNIO ESPIGÃO ALTO \\
tit anf bio \\
\end{tabular}}} \\
\hline & \multicolumn{11}{|c|}{ tit anf bio } & & & & & & \\
\hline & \multicolumn{9}{|c|}{ JGA-41 } & \multicolumn{2}{|c|}{ PS-36 } & \multicolumn{5}{|c|}{ JGA-4c } & JGA-17 \\
\hline Local & $\mathrm{b}_{\mathrm{a}}$ & $\mathrm{i}_{\mathrm{a}} 1$ & $i_{\mathrm{a}} 2$ & $\mathrm{n}_{\mathrm{a}}$ & $\mathrm{b}_{\mathrm{b}}$ & $i_{b} 1$ & $i_{\mathrm{b}} 2$ & $\mathrm{n}_{\mathrm{b}}$ & $\mathbf{n}_{c}$ & $\mathrm{~b}$ & $\mathrm{i}$ & $\mathrm{b}_{\mathrm{a}}$ & $\mathrm{n}_{\mathrm{a}}$ & $\mathrm{b}_{\mathrm{b}}$ & $i_{b} 1$ & $\mathrm{n}_{\mathrm{b}}$ & $\mathrm{i}_{\mathrm{a}}$ \\
\hline $\mathrm{SiO}_{2}$ & 62,14 & 60,52 & 61,82 & 60,66 & 61,96 & 62,38 & 62,15 & 60,62 & 61,71 & 62,04 & 61,81 & 60,32 & 60,89 & 61,12 & 59,06 & 58,76 & 63,46 \\
\hline $\mathrm{Al}_{2} \mathrm{O}_{3}$ & 23,51 & 24,21 & 23,25 & 24,06 & 23,69 & 23,34 & 23,20 & 24,13 & 23,33 & 23,71 & 23,72 & 23,85 & 23,80 & 23,92 & 25,38 & 25,43 & 22,66 \\
\hline $\mathrm{Fe}_{2} \mathrm{O}_{3}$ & 0,21 & 0,17 & 0,22 & 0,18 & 0,18 & 0,18 & 0,19 & 0,23 & 0,15 & 0,15 & 0,18 & 0,20 & 0,13 & 0,15 & 0,19 & 0,17 & 0,10 \\
\hline $\mathrm{CaO}$ & 4,87 & 5,82 & 4,95 & 5,67 & 5,01 & 5,01 & 4,70 & 5,92 & 5,10 & 5,11 & 5,29 & 5,66 & 5,57 & 5,45 & 6,97 & 7,32 & 3,58 \\
\hline $\mathrm{SrO}$ & 0,16 & 0,15 & 0,08 & 0,12 & 0,13 & 0,11 & 0,06 & 0,10 & 0,15 & 0,08 & 0,10 & 0,08 & 0,07 & 0,06 & 0,12 & 0,11 & 0,04 \\
\hline $\mathrm{BaO}$ & 0,02 & 0,00 & 0,10 & 0,15 & 0,19 & 0,19 & 0,03 & 0,00 & 0,02 & 0,00 & 0,05 & 0,10 & 0,00 & 0,00 & 0,08 & 0,12 & 0,04 \\
\hline $\mathrm{Na}_{2} \mathrm{O}$ & 8,55 & 8,18 & 8,42 & 7,90 & 8,75 & 8,60 & 8,70 & 8,07 & 8,83 & 8,58 & 8,42 & 8,50 & 8,34 & 8,36 & 7,58 & 7,48 & 9,52 \\
\hline $\mathrm{K}_{2} \mathrm{O}$ & 0,43 & 0,48 & 0,61 & 0,64 & 0,43 & 0,46 & 0,53 & 0,50 & 0,27 & $\begin{array}{l}0,35 \\
\end{array}$ & 0,42 & 0,40 & 0,54 & 0,25 & 0,34 & 0,25 & 0,22 \\
\hline Total & 99,89 & 99,53 & 99,45 & 99,38 & 100,34 & 100,27 & 99,56 & 99,57 & 99,56 & 100,02 & 99,99 & 99,11 & 99,34 & 99,31 & 99,72 & 99,64 & 99,62 \\
\hline \multicolumn{18}{|c|}{$O=32$} \\
\hline $\mathrm{Si}$ & 11,050 & 10,843 & 11,055 & 10,885 & 10,998 & 11,068 & 11,087 & 10,855 & 11,023 & 11,015 & 10,992 & 10,863 & 10,919 & 10,936 & 10,597 & 10,562 & 11,259 \\
\hline $\mathrm{Al}$ & 4,922 & 5,108 & 4,897 & 5,084 & 4,951 & 4,876 & 4,875 & 5,088 & 4,908 & 4,957 & 4,967 & 5,059 & 5,025 & 5,040 & 5,363 & 5,383 & 4,735 \\
\hline $\mathrm{Fe}^{3+}$ & 0,028 & 0,023 & 0,030 & 0,024 & 0,024 & 0,024 & 0,026 & 0,032 & 0,020 & 0,020 & 0,024 & 0,026 & 0,018 & 0,020 & 0,026 & 0,022 & 0,014 \\
\hline$Z$ & 16,000 & 15,974 & 15,982 & 15,993 & 15,973 & 15,968 & 15,988 & 15,975 & 15,951 & 15,992 & 15,983 & 15,948 & 15,962 & 15,996 & 15,986 & 15,967 & 16,008 \\
\hline $\mathrm{Ca}$ & 0,927 & 1,117 & 0,948 & 1,091 & 0,953 & 0,952 & 0,899 & 1,136 & 0,976 & 0,971 & 1,008 & 1,093 & 1,070 & 1,044 & \begin{tabular}{|l|}
1,339 \\
\end{tabular} & \begin{tabular}{|l|}
1,409 \\
\end{tabular} & 0,681 \\
\hline $\mathrm{Sr}$ & 0,017 & 0,015 & 0,008 & 0,012 & 0,013 & 0,011 & 0,006 & 0,010 & 0,015 & 0,008 & 0,011 & 0,009 & 0,007 & 0,006 & 0,013 & 0,011 & 0,004 \\
\hline $\mathrm{Ba}$ & 0,001 & 0,000 & 0,007 & 0,010 & 0,013 & 0,013 & 0,002 & 0,000 & 0,002 & 0,000 & 0,003 & 0,007 & 0,000 & 0,000 & 0,005 & 0,008 & 0,003 \\
\hline $\mathrm{Na}$ & 2,949 & 2,841 & 2,921 & 2,749 & 3,012 & 2,958 & 3,002 & 2,800 & 3,059 & 2,955 & 2,903 & 2,970 & 2,901 & 2,901 & 2,637 & 2,606 & 3,276 \\
\hline $\mathrm{K}$ & 0,097 & 0,110 & 0,140 & 0,146 & 0,097 & 0,105 & 0,121 & 0,115 & 0,062 & 0,080 & 0,096 & 0,092 & 0,124 & 0,058 & 0,077 & 0,058 & 0,049 \\
\hline $\boldsymbol{X}$ & 3,991 & 4,083 & 4,024 & 4,008 & 4,088 & 4,039 & 4,030 & 4,061 & 4,114 & 4,014 & 4,021 & 4,171 & 4,102 & 4,009 & 4,071 & 4,092 & 4,013 \\
\hline$\Sigma$ & 19,991 & 20,057 & 20,006 & 20,001 & 20,061 & 20,007 & 20,018 & 20,036 & 20,065 & 20,006 & 20,004 & 20,119 & 20,064 & 20,005 & 20,057 & 20,059 & 20,021 \\
\hline \multicolumn{18}{|c|}{ Proporçöes moleculares } \\
\hline $\mathrm{Ab}$ & 73,1 & 68,6 & 71,7 & 67,7 & 73,0 & 72,5 & 73,5 & 67,8 & 73,5 & 72,6 & 71,2 & 70,3 & 69,6 & 71,3 & 63,7 & 62,6 & 80,9 \\
\hline $\mathrm{An}$ & 24,4 & 28,6 & 24,7 & 28,5 & 24,5 & 24,8 & 23,3 & 29,2 & 24,9 & 25,3 & 26,3 & 27,4 & 27,2 & 27,2 & 34,3 & 35,9 & 17,8 \\
\hline $\mathrm{Or}$ & 2,5 & 2,8 & 3,7 & 3,8 & 2,5 & 2,7 & 3,1 & 3,0 & 1,6 & 2,1 & 2,5 & 2,3 & 3,1 & 1,5 & 2,0 & 1,5 & 1,3 \\
\hline
\end{tabular}


Tabela 5.2 (cont.): Resultados analíticos e cálculos de fórmula estrutural $(32 \mathrm{O})$ para cristais de plagioclásio do Complexo Granítico Cunhaporanga.

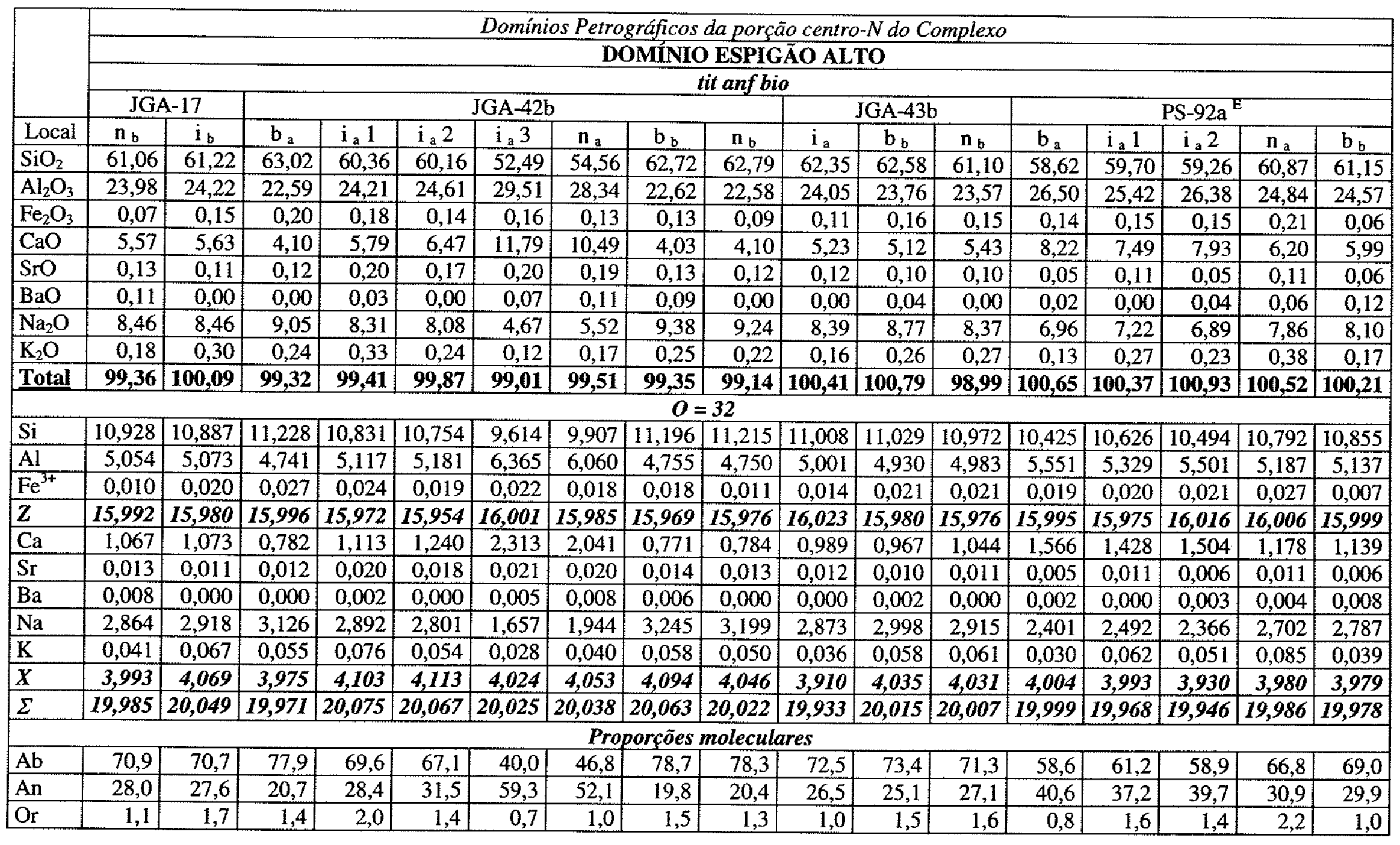


Tabela 5.2 (cont.): Resultados analíticos e cálculos de fórmula estrutural ( 32 O) para cristais de plagioclásio do Complexo Granítico Cunhaporanga.

\begin{tabular}{|c|c|c|c|c|c|c|c|c|c|c|c|c|c|c|c|c|c|}
\hline \multirow[b]{5}{*}{ Local } & \multicolumn{17}{|c|}{ Domínios Petrográficos da porção centro- $N$ do Complexo } \\
\hline & \multicolumn{9}{|c|}{ DOMÍNIO ESPIGÃO ALTO } & \multicolumn{5}{|c|}{ DOMÍNIO PAREDÃO DA SANTA } & \multirow{2}{*}{\multicolumn{3}{|c|}{$\begin{array}{c}\text { D.P.DA ANTA-A.CLARA } \\
\text { mu bio } \\
\end{array}$}} \\
\hline & \multicolumn{9}{|c|}{ tit anf bio } & \multirow{2}{*}{\multicolumn{2}{|c|}{\begin{tabular}{|c|} 
tit anf bio \\
JGA-1
\end{tabular}}} & \multirow{2}{*}{\multicolumn{3}{|c|}{\begin{tabular}{|c|} 
tit bio \\
JGA-44 \\
\end{tabular}}} & & & \\
\hline & PS.92aE & & & & PS & $-93 a$ & & & & & & & & & \multicolumn{3}{|c|}{ JGA-14 } \\
\hline & $\mathrm{n}_{\mathrm{b}}$ & $\mathrm{b}_{\mathrm{a}}$ & $\mathrm{i}_{\mathrm{a}} 1$ & $\mathrm{i}_{\mathrm{a}} 2$ & $\mathrm{n}_{\mathrm{a}} 1$ & $\mathrm{n}_{\mathrm{a}} 2$ & $\mathbf{b}_{\mathrm{b}}$ & $i_{b}$ & $n_{b}$ & $\mathrm{~b}$ & $\mathrm{n}$ & $\mathbf{n}_{\mathrm{a}}$ & $\mathrm{b}_{\mathrm{b}}$ & $\mathbf{n}_{\mathrm{b}}$ & $\mathrm{b}_{\mathrm{a}}$ & $\mathbf{n}_{\mathrm{a}}$ & $\mathrm{b}_{\mathrm{b}}$ \\
\hline $\mathrm{SiO}_{2}$ & 60,74 & 62,11 & 61,07 & 58,67 & 59,20 & 58,52 & 62,58 & 59,63 & 59,57 & 63,23 & 61,48 & 63,25 & 63,09 & 63,23 & 65,11 & 65,60 & 64,86 \\
\hline $\mathrm{Al}_{2} \mathrm{O}_{3}$ & 24,67 & 23,54 & 24,64 & 25,66 & 25,76 & 25,94 & 23,62 & 25,36 & 25,36 & 22,85 & 23,56 & 22,67 & 23,01 & 22,67 & 21,66 & 21,69 & 22,08 \\
\hline $\mathrm{Fe}_{2} \mathrm{O}_{3}$ & 0,17 & 0,18 & 0,19 & 0,17 & 0,05 & 0,10 & 0,21 & 0,14 & 0,17 & 0,17 & 0,19 & 0,08 & 0,09 & 0,08 & 0,05 & 0,03 & 0,11 \\
\hline $\mathrm{CaO}$ & 6,33 & 5,19 & 6,10 & 7,42 & 7,55 & 7,80 & 4,87 & 6,82 & 6,92 & 4,00 & 5,13 & 3,98 & 4,12 &, 02 & 2,56 &, 33 & 2,87 \\
\hline SrO & 0,02 & 0,03 & 0,03 & 0,05 & 0,13 & 0,13 & 0,06 & 0,02 & 0,06 & 0,00 & 0,10 & 0,02 & 0,06 &, 02 & 0,00 & 0,00 & 0,00 \\
\hline $\mathrm{BaO}$ & 0,01 & 0,01 & 0,00 & 0,07 & 0,22 & 0,031 & 0,01 & 0,04 & 0,00 & 0,02 & 0,05 & 0,00 & 0,07 & 15 & 0,00 & 0,00 & 0,01 \\
\hline $\mathrm{Na}_{2} \mathrm{O}$ & 7,98 & 8,44 & 8,01 & 7,24 & 6,98 & 6,91 & 8,65 & 7,53 & 7,37 & 9,06 & 8,52 & 9,35 & 9,32 & 9,45 & 10,19 & 10,39 & 9,94 \\
\hline $\mathrm{K}_{2} \mathrm{O}$ & 0,14 & 0,31 & 0,28 & 0,32 & 0,35 & 0,26 & 0,31 & 0,29 & 0,26 & 0,43 & 0,29 & 0,28 & 0,16 & 0,19 & 0,34 & 0,34 & 0,36 \\
\hline Total & 100,06 & 99,80 & 100,32 & 99,59 & 100,25 & 99,69 & 100,30 & 99,82 & 99,70 & 99,76 & 99,32 & 99,63 & 99,92 & 99,81 & 99,91 & 100,38 & 100,23 \\
\hline \multicolumn{18}{|c|}{$O=32$} \\
\hline $\mathrm{Si}$ & 10,803 & 11,042 & 10,832 & 10,540 & 10,569 & 10,500 & 11,065 & 10,656 & 10,654 & 11,216 & 11,001 & 11,232 & 11,180 & 11,223 & 11,485 & 11,510 & 11,414 \\
\hline $\mathrm{Al}$ & 5,168 & 4,928 & 5,147 & 5,428 & 5,415 & 5,482 & 4,918 & 5,337 & 5,341 & 4,773 & 4,964 & 4,741 & \begin{tabular}{|l|}
4,801 \\
\end{tabular} & 4,739 & 4,500 & 4,482 & 4,576 \\
\hline $\mathrm{Fe}^{3+}$ & 0,023 & 0,024 & 0,025 & 0,022 & 0,007 & 0,014 & 0,027 & 0,019 & 0,023 & 0,023 & 0,025 & 0,011 & \begin{tabular}{|l|}
0,013 \\
\end{tabular} & 0,010 & 0,006 & 0,004 & 0,014 \\
\hline$\underline{Z}$ & 15,994 & 15,994 & 16,004 & 15,990 & 15,991 & 15,996 & 16,010 & 16,012 & 16,018 & 16,012 & 15,990 & 15,984 & 15,994 & 15,972 & 15,991 & 15,996 & 16,004 \\
\hline $\mathrm{Ca}$ & 1,205 & \begin{tabular}{|l}
0,988 \\
\end{tabular} & 1,160 & 1,428 & 1,444 & 1,500 & 0,922 & 1,305 & 1,325 & 0,760 & \begin{tabular}{|l|}
0,983 \\
\end{tabular} & 0,757 & \begin{tabular}{|l|}
0,782 \\
\end{tabular} & 0,764 & 0,485 & \begin{tabular}{|l|}
0,439 \\
\end{tabular} & 0,542 \\
\hline $\mathrm{Sr}$ & 0,002 & 0,003 & 0,003 & 0,005 & 0,014 & 0,014 & 0,006 & 0,002 & 0,006 & 0,000 & 0,010 & 0,002 & 0,007 & 0,002 & 0,000 & 0,000 & 0,000 \\
\hline $\mathrm{Ba}$ & 0,001 & 0,001 & 0,000 & 0,005 & 0,015 & 0,002 & 0,000 & 0,003 & 0,000 & 0,001 & 0,003 & 0,000 & 0,005 & 0,011 & 0,000 & 0,000 & 0,001 \\
\hline $\mathrm{Na}$ & 2,752 & 2,909 & 2,754 & 2,523 & 2,417 & 2,404 & 2,964 & 2,607 & 2,554 & 3,116 & 2,976 & 3,220 & 3,201 & 3,251 & 3,485 & 3,534 & 3,391 \\
\hline $\mathrm{K}$ & 0,032 & 0,070 & 0,064 & 0,073 & 0,079 & 0,060 & 0,071 & 0,067 & 0,059 & 0,096 & 0,066 & 0,064 & 0,036 & 0,042 & 0,075 & 0,075 & 0,081 \\
\hline$X$ & 3,992 & 3,971 & 3,981 & 4,034 & 3,969 & 3,980 & 3,963 & 3,984 & 3,944 & 3,973 & 4,017 & 4,043 & 4,031 & 4,070 & 4,045 & 4,048 & 4,015 \\
\hline$\Sigma$ & 19,986 & 19,965 & 19,985 & 20,024 & 19,960 & 19,976 & 19,973 & 19,996 & 19,962 & 19,985 & 20,007 & 20,027 & 20,025 & 20,042 & 20,036 & 20,044 & 20,019 \\
\hline \multicolumn{18}{|c|}{ Proporçōes moleculares } \\
\hline $\mathrm{Ab}$ & 67,7 & 72,2 & 68,0 & 61,3 & 59,9 & 59,2 & 73,8 & 64,2 & 63,5 & 77,4 & 72,6 & 78,7 & 78,7 & 79,2 & 85,4 & 86,6 & 83,7 \\
\hline An & 31,5 & 26,0 & 30,4 & 36,8 & 38,0 & 39,2 & 24,3 & 34,1 & 35,0 & 20,0 & 25,6 & 19,6 & 20,4 & 19,7 & 12,6 & 11,4 & 14,2 \\
\hline Or & 0,9 & 1,8 & 1,7 & 1,9 & 2,1 & 1,6 & 1,9 & 1,7 & 1,5 & 2,5 & 1,7 & 1,7 & 0,9 & 1,1 & 2,0 & 2,0 & 2,1 \\
\hline
\end{tabular}


Tabela 5.2 (cont.): Resultados analíticos e cálculos de fórmula estrutural (32 O) para cristais de plagioclásio do Complexo Granítico Cunhaporanga.

\begin{tabular}{|c|c|c|c|c|c|c|c|c|c|c|c|c|c|c|c|c|c|}
\hline \multirow[b]{5}{*}{ Local } & \multicolumn{17}{|c|}{ Domínios Petrográficos da porção centro- $N$ do Complexo } \\
\hline & \multicolumn{3}{|c|}{ D.P.DA ANTA-A.CLARA } & \multirow{2}{*}{\multicolumn{14}{|c|}{$\begin{array}{c}\text { DOMÍNIO VARGINHA } \\
\text { tit bio }\end{array}$}} \\
\hline & \multirow{2}{*}{\begin{tabular}{|l|} 
mu bio \\
JGA-14 \\
\end{tabular}} & \multirow{2}{*}{\multicolumn{2}{|c|}{$\begin{array}{c}\text { bio } \\
\text { PS-44 } \\
\end{array}$}} & \multicolumn{6}{|c|}{ tit bio } & & & & & & & & \\
\hline & & & & \multicolumn{4}{|c|}{ PS-46 } & \multicolumn{2}{|c|}{ PS- $46^{\mathrm{E}}$} & \multicolumn{6}{|c|}{ PS-47 } & \multicolumn{2}{|c|}{ PS-66 } \\
\hline & $\mathrm{n}_{\mathrm{b}}$ & $\mathrm{n}_{\mathrm{a}}$ & $\mathbf{b}_{\mathbf{b}}$ & $b_{a}$ & $\mathrm{i}_{\mathrm{a}} 1$ & $\mathrm{i}_{\mathrm{a}} 2$ & $\mathbf{n}_{\mathrm{a}}$ & $\mathrm{b}_{\mathrm{b}}$ & $\mathrm{n}_{\mathrm{b}}$ & $\mathrm{b}_{\mathrm{a}}$ & $i_{a} 1$ & $i_{\mathrm{a}} 2$ & $\mathrm{n}_{\mathrm{a}} 1$ & $\mathrm{n}_{\mathrm{a}} 2$ & $\mathbf{n}_{\mathrm{b}}$ & $\mathrm{b}_{\mathrm{a}}$ & $\mathbf{n}_{\mathrm{a}}$ \\
\hline $\mathrm{SiO}_{2}$ & 65,04 & 64,58 & 63,83 & 60,63 & 60,40 & 61,53 & 60,64 & 63,59 & 61,05 & 64,47 & 60,75 & 60,55 & 60,17 & 60,61 & 60,71 & 64,46 & 63,45 \\
\hline $\mathrm{Al}_{2} \mathrm{O}_{3}$ & 21,66 & 22,08 & 22,28 & 24,46 & 24,69 & 24,10 & 24,46 & 22,32 & 24,04 & 21,86 & 24,21 & 24,35 & 24,45 & 24,25 & 24,04 & 22,15 & 22,55 \\
\hline $\mathrm{Fe}_{2} \mathrm{O}_{3}$ & 0,02 & 0,01 & 0,06 & 0,21 & 0,17 & 0,21 & 0,21 & 0,20 & 0,13 & 0,16 & 0,18 & 0,17 & 0,26 & 0,19 & 0,18 & 0,12 & 0,12 \\
\hline $\mathrm{CaO}$ & 2,62 & 3,15 & 3,33 & 5,94 & 6,30 & 5,65 & 5,94 & 3,66 & 5,76 & 3,15 & 5,84 & 5,87 & 6,07 & 5,77 & 5,73 & 3,08 & 3,95 \\
\hline SrO & 0,00 & 0,01 & 0,05 & 0,05 & 0,08 & 0,16 & 0,05 & 0,00 & 0,08 & 0,00 & 0,01 & 0,06 & 0,07 & 0,05 & 0,07 & 0,00 & 0,00 \\
\hline $\mathrm{BaO}$ & 0,05 & 0,04 & 0,00 & 0,06 & 0,00 & 0,00 & 0,06 & 0,00 & 0,14 & 0,00 & 0,07 & 0,03 & 0,04 & 0,06 & 0,05 & 0,09 & 0,00 \\
\hline $\mathrm{Na}_{2} \mathrm{O}$ & 9,97 & 9,99 & 9,68 & 7,95 & 8,01 & 7,93 & 7,95 & 9,52 & 8,13 & 9,63 & 8,06 & 7,91 & 7,90 & 8,16 & 8,27 & 9,90 & 9,40 \\
\hline $\mathrm{K}_{2} \mathrm{O}$ & 0,38 & 0,23 & 0,34 & 0,35 & 0,35 & 0,81 & 0,35 & 0,26 & 0,24 & 0,39 & 0,53 & 0,62 & 0,51 & 0,49 & 0,30 & $\begin{array}{l}0,30 \\
\end{array}$ & 0,46 \\
\hline Total & 99,74 & 100,09 & 99,57 & 99,65 & 100,00 & 100,39 & 99,66 & 99,55 & 99,57 & 99,66 & 99,65 & 99,56 & 99,47 & 99,58 & 99,35 & 100,10 & 99,93 \\
\hline \multicolumn{18}{|c|}{$O=32$} \\
\hline $\mathrm{Si}$ & 11,490 & 11,389 & 11,327 & 10,833 & 10,772 & 10,923 & 10,877 & 11,293 & 10,910 & 11,415 & 10,863 & 10,840 & 10,793 & 10,848 & 10,880 & 11,375 & 11,246 \\
\hline $\mathrm{Al}$ & 4,507 & 4,586 & 4,657 & 5,148 & 5,185 & 5,038 & 5,062 & 4,669 & 5,058 & 4,558 & 5,098 & 5,134 & 5,164 & 5,112 & 5,075 & 4,602 & 4,706 \\
\hline $\mathrm{Fe}^{3+}$ & 0,002 & 0,001 & 0,008 & 0,028 & 0,023 & 0,028 & 0,024 & 0,027 & 0,017 & 0,021 & 0,024 & 0,023 & 0,035 & 0,026 & 0,025 & 0,016 & 0,016 \\
\hline$Z$ & 15,999 & 15,976 & 15,992 & 16,009 & 15,980 & 15,989 & 15,963 & 15,989 & 15,986 & 15,994 & 15,985 & 15,997 & 15,992 & 15,986 & 15,980 & 15,993 & 15,968 \\
\hline $\mathrm{Ca}$ & 0,496 & 0,596 & 0,632 & 1,136 & 1,204 & 1,075 & 1,140 & 0,696 & 1,103 & 0,597 & 1,119 & 1,125 & 1,167 & 1,107 & 1,101 & 0,582 & 0,750 \\
\hline $\mathrm{Sr}$ & 0,000 & 0,001 & 0,005 & 0,005 & 0,008 & 0,016 & 0,009 & 0,000 & 0,008 & 0,000 & 0,001 & 0,006 & 0,008 & 0,006 & 0,008 & 0,000 & 0,000 \\
\hline $\mathrm{Ba}$ & 0,004 & 0,003 & 0,000 & 0,004 & 0,000 & 0,000 & 0,002 & 0,000 & 0,010 & 0,000 & 0,005 & 0,002 & 0,003 & 0,004 & 0,003 & 0,006 & 0,000 \\
\hline $\mathrm{Na}$ & 3,414 & 3,416 & 3,331 & 2,756 & 2,768 & 2,730 & 2,791 & 3,278 & 2,817 & 3,305 & 2,796 & 2,744 & 2,746 & 2,833 & 2,874 & 3,389 & 3,231 \\
\hline $\mathrm{K}$ & 0,085 & 0,052 & 0,077 & 0,080 & 0,080 & 0,183 & 0,125 & 0,058 & 0,055 & 0,088 & 0,121 & 0,142 & 0,116 & 0,111 & 0,068 & 0,067 & 0,103 \\
\hline$X$ & 3,999 & 4,068 & 4,045 & 3,981 & 4,060 & 4,004 & 4,067 & 4,032 & 3,993 & 3,990 & 4,042 & 4,019 & 4,040 & 4,061 & 4,054 & 4,044 & 4,084 \\
\hline$\Sigma$ & 19,998 & 20,044 & 20,037 & 19,990 & 20,040 & 19,993 & 20,030 & 20,021 & 19,979 & 19,984 & 20,027 & 20,016 & 20,032 & 20,047 & 20,034 & 20,037 & 20,052 \\
\hline \multicolumn{18}{|c|}{ Proporçōes moleculares } \\
\hline $\mathrm{Ab}$ & 84,7 & 83,3 & 81,6 & 68,1 & 67,0 & 67,2 & 67,5 & 80,4 & 69,6 & 82,0 & 68,0 & 67,1 & 66,9 & 68,7 & 69,8 & 83,1 & 78,1 \\
\hline An & 13,1 & 15,4 & 16,4 & 29,8 & 30,9 & 28,1 & 29,3 & 18,1 & 28,9 & 15,7 & 28,9 & 29,2 & 30,2 & 28,5 & 28,4 & 15,1 & 19,2 \\
\hline Or & 2,2 & 1,3 & 2,0 & 2,1 & 2,1 & 4,8 & 3,2 & 1,5 & 1,4 & 2,3 & 3,1 & 3,7 & 3,0 & 2,9 & 1,8 & 1,7 & 2,6 \\
\hline
\end{tabular}


Tabela 5.2 (cont.): Resultados analíticos e cálculos de fórmula estrutural (32 O) para cristais de plagioclásio do Complexo Granítico Cunhaporanga.

\begin{tabular}{|c|c|c|c|c|c|c|c|c|c|c|c|c|c|c|c|c|c|}
\hline \multirow[b]{5}{*}{ Local } & \multicolumn{11}{|c|}{ Domínios Petrográficos da porção centro- $N$ do Complexo } & \multirow{3}{*}{\multicolumn{6}{|c|}{$\begin{array}{c}\text { Dom. Petrogr. da porção NE do Complexo } \\
\text { DOM. OURO VERDE-P. SANTO ANTÔNIO } \\
\text { tit bio }\end{array}$}} \\
\hline & \multicolumn{11}{|c|}{ DOMÍNIO VARGINHA } & & & & & & \\
\hline & \multirow{2}{*}{\multicolumn{4}{|c|}{$\begin{array}{l}\text { tit bio } \\
\text { PS-66 } \\
\end{array}$}} & \multicolumn{7}{|c|}{ bio pórfiro } & & & & & & \\
\hline & & & & & & & & PS-48 & & & & \multicolumn{6}{|c|}{ IT-93 } \\
\hline & $b_{b}$ & $i_{b} 1$ & $i_{b} 2$ & $\mathrm{n}_{\mathrm{b}}$ & $\mathrm{b}_{\mathrm{a}}$ & $\mathrm{i}_{\mathrm{a}} 1$ & $\mathrm{i}_{\mathrm{a}} 2$ & $i_{\mathrm{a}} 3$ & $\mathrm{i}_{\mathrm{a}} 4$ & $\mathbf{n}_{\mathbf{a}}$ & $\mathrm{n}_{\mathrm{b}}$ & $b_{a}$ & $i_{a} 1$ & $\mathrm{i}_{\mathrm{a}} 2$ & $b_{b}$ & $i_{b}$ & $\mathrm{n}_{\mathrm{b}} 1$ \\
\hline $\mathrm{SiO}_{2}$ & 63,01 & 59,90 & 60,71 & 61,18 & 62,46 & 61,53 & 61,36 & 61,92 & 59,95 & 61,28 & 59,04 & 63,47 & 62,05 & 62,03 & 64,61 & 63,09 & 65,39 \\
\hline $\mathrm{Al}_{2} \mathrm{O}_{3}$ & 22,74 & 24,64 & 24,13 & 24,02 & 23,53 & 23,34 & 23,74 & 23,46 & 24,86 & 24,08 & 25,34 & 22,22 & 23,21 & 23,19 & 21,57 & 22,82 & 21,11 \\
\hline $\mathrm{Fe}_{2} \mathrm{O}_{3}$ & 0,18 & 0,26 & 0,15 & 0,27 & 0,10 & 0,18 & 0,08 & 0,12 & 0,14 & 0,07 & 0,08 & 0,04 & 0,26 & 0,18 & 0,08 & 0,13 & 0,14 \\
\hline $\mathrm{CaO}$ & 3,85 & 6,39 & 5,78 & 5,65 & 4,67 & 5,13 & 5,18 & 4,88 & 6,23 & 5,26 & 7,05 & 3,48 & 4,51 & 4,81 & 3,04 & 4,19 & 2,40 \\
\hline $\mathrm{SrO}$ & 0,00 & 0,07 & 0,05 & 0,05 & 0,00 & 0,08 & 0,11 & 0,12 & 0,15 & 0,11 & 0,14 & 0,08 & 0,08 & 0,06 & 0,01 & 0,01 & 0,05 \\
\hline $\mathrm{BaO}$ & 0,00 & 0,11 & 0,02 & 0,07 & 0,00 & 0,00 & 0,16 & 0,07 & 0,12 & 0,05 & 0,01 & 0,05 & 0,06 & 0,05 & 0,08 & 0,00 & 0,03 \\
\hline $\mathrm{Na}_{2} \mathrm{O}$ & 9,32 & 7,80 & 8,31 & 8,41 & 8,92 & 8,75 & 8,38 & 8,54 & 7,91 & 8,46 & 7,39 & 9,41 & 8,57 & 8,54 & 9,60 & 9,00 & 9,95 \\
\hline $\mathrm{K}_{2} \mathrm{O}$ & 0,35 & 0,34 & 0,27 & 0,34 & 0,27 & 0,34 & 0,32 & 0,27 & 0,25 & 0,25 & 0,30 & 0,24 & 0,32 & 0,26 & 0,26 & 0,14 & 0,25 \\
\hline Total & 99,45 & 99,51 & 99,42 & 99,99 & 99,95 & 99,35 & 99,33 & 99,38 & 99,61 & 99,56 & 99,35 & 98,98 & 99,05 & 99,11 & 99,24 & 99,38 & 99,32 \\
\hline \multicolumn{18}{|c|}{$O=32$} \\
\hline $\mathrm{Si}$ & 11,214 & 10,746 & 10,871 & 10,900 & 11,076 & 11,014 & 10,982 & 11,055 & 10,739 & 10,938 & 10,615 & 11,325 & 11,102 & 11,095 & 11,473 & 11,217 & 11,580 \\
\hline $\mathrm{Al}$ & 4,766 & 5,207 & 5,087 & 5,038 & 4,913 & 4,920 & 5,004 & 4,932 & 5,244 & 5,061 & 5,366 & \begin{tabular}{|l|}
4,669 \\
\end{tabular} & \begin{tabular}{|l|}
4,890 \\
\end{tabular} & 4,884 & 4,510 & 4,777 & 4,404 \\
\hline $\mathrm{Fe}^{3+}$ & 0,024 & 0,035 & 0,020 & 0,037 & 0,013 & 0,024 & 0,011 & 0,016 & 0,018 & 0,009 & 0,011 & 0,006 & 0,035 & 0,024 & 0,010 & 0,018 & 0,019 \\
\hline$Z$ & 16,004 & 15,988 & 15,978 & 15,975 & 16,002 & 15,958 & 15,997 & 16,003 & 16,001 & 16,008 & 15,992 & 16,000 & 16,027 & 16,003 & 15,993 & 16,012 & 16,003 \\
\hline $\mathrm{Ca}$ & 0,734 & 1,227 & 1,109 & 1,079 & 0,888 & \begin{tabular}{|l|}
0,984 \\
\end{tabular} & \begin{tabular}{|l|}
0,993 \\
\end{tabular} & 0,934 & 1,195 & 1,005 & 1,358 & 0,665 & \begin{tabular}{|l|}
0,865 \\
\end{tabular} & \begin{tabular}{|l|}
0,922 \\
\end{tabular} & 0,578 & \begin{tabular}{|l|}
0,799 \\
\end{tabular} & 0,455 \\
\hline $\mathrm{Sr}$ & 0,000 & 0,007 & 0,005 & 0,005 & 0,000 & 0,008 & 0,011 & 0,012 & 0,015 & 0,011 & 0,015 & 0,009 & 0,008 & 0,006 & 0,001 & 0,001 & 0,005 \\
\hline $\mathrm{Ba}$ & 0,000 & 0,008 & 0,001 & 0,005 & 0,000 & 0,000 & 0,011 & 0,005 & 0,008 & 0,003 & 0,001 & 0,003 & 0,004 & 0,004 & 0,005 & 0,000 & 0,002 \\
\hline $\mathrm{Na}$ & 3,216 & 2,713 & 2,887 & 2,903 & 3,068 & 3,037 & 2,909 & 2,958 & 2,748 & 2,926 & 2,575 & 3,254 & 2,973 & 2,960 & 3,306 & 3,102 & 3,418 \\
\hline $\mathrm{K}$ & 0,079 & 0,079 & 0,061 & 0,077 & 0,061 & 0,077 & 0,073 & 0,061 & 0,056 & 0,056 & 0,069 & 0,053 & 0,073 & 0,060 & 0,059 & 0,033 & 0,056 \\
\hline $\boldsymbol{X}$ & 4,029 & 4,034 & 4,063 & 4,069 & 4,017 & 4,106 & 3,997 & 3,970 & 4,022 & 4,001 & 4,018 & 3,984 & 3,923 & 3,952 & 3,949 & 3,935 & 3,936 \\
\hline$\Sigma$ & 20,033 & 20,022 & 20,041 & 20,044 & 20,019 & 20,064 & 19,994 & 19,973 & 20,023 & 20,009 & 20,010 & 19,984 & 19,950 & 19,955 & 19,942 & 19,947 & 19,939 \\
\hline \multicolumn{18}{|c|}{ Proporçöes moleculares } \\
\hline $\mathrm{Ab}$ & 78,9 & 66,2 & 69,9 & 70,3 & 75,3 & 73,0 & 72,0 & 73,7 & 67,4 & 72,2 & 63,0 & 81,0 & 74,9 & 74,0 & 83,0 & 77,9 & 86,3 \\
\hline An & 19,1 & 31,8 & 28,5 & 27,7 & 23,1 & 25,1 & 26,1 & 24,7 & 31,1 & 26,3 & 35,2 & 17,6 & 23,1 & 24,4 & 15,4 & 21,3 & 12,2 \\
\hline Or & 2,1 & 2,0 & 1,6 & 2,0 & 1,6 & 2,0 & 1,9 & 1,6 & 1,5 & 1,5 & 1,8 & 1,4 & 1,9 & 1,6 & 1,6 & 0,9 & 1,5 \\
\hline
\end{tabular}


Tabela 5.2 (cont.): Resultados analíticos e cálculos de fórmula estrutural ( $32 \mathrm{O}$ ) para cristais de plagioclásio do Complexo Granítico Cunhaporanga.

\begin{tabular}{|c|c|c|c|c|c|c|c|c|c|c|c|c|c|c|c|}
\hline \multirow[b]{5}{*}{ Local } & \multicolumn{15}{|c|}{ Domínios Petrográficos da porção NE do Complexo } \\
\hline & \multicolumn{15}{|c|}{ DOMÍNIO OURO VERDE-PATRIMÔNIO SANTO ANTÔNIO } \\
\hline & \multicolumn{8}{|c|}{ tit bio } & \multirow{2}{*}{\multicolumn{7}{|c|}{\begin{tabular}{|c|} 
anf pórfiro \\
IT-96
\end{tabular}}} \\
\hline & IT-93 & \multicolumn{7}{|c|}{$\mathrm{TT}-104$} & & & & & & & \\
\hline & $\mathrm{n}_{\mathrm{b}} 2$ & $\mathrm{~b}_{\mathbf{a}}$ & $i_{\mathrm{a}} 1$ & $i_{a} 2$ & $b_{b} 1$ & $b_{\mathrm{b}} 2$ & $\mathrm{i}_{\mathrm{b}}$ & $\mathrm{n}_{\mathrm{b}}$ & $b_{a}$ & $\mathrm{i}_{\mathrm{a}} \mathrm{l}$ & $\mathrm{n}_{\mathrm{a}} 1$ & $n_{\mathrm{a}} 2$ & $\mathrm{~b}_{\mathrm{b}}$ & $i_{b}$ & $\mathrm{n}_{\mathrm{b}}$ \\
\hline$\overline{\mathrm{SiO}_{2}}$ & 64,49 & 64,50 & 63,94 & 63,86 & 65,38 & 65,06 & 64,06 & 63,86 & 63,98 & 60,42 & 58,31 & 57,76 & 58,20 & 63,09 & 54,51 \\
\hline $\mathrm{Al}_{2} \mathrm{O}_{3}$ & 22,02 & 22,25 & 22,52 & 22,72 & 21,98 & 22,08 & 22,50 & 22,34 & 22,26 & 24,57 & 25,78 & 26,18 & 25,58 & 22,82 & 27,85 \\
\hline $\mathrm{Fe}_{2} \mathrm{O}_{3}$ & 0,13 & 0,18 & 0,07 & 0,06 & 0,06 & 0,08 & 0,11 & 0,09 & 0,09 & 0,14 & 0,20 & 0,14 & 0,43 & 0,13 & 0,43 \\
\hline $\mathrm{CaO}$ & 3,18 & 3,36 & 3,72 & 3,90 & 3,05 & 3,14 & 3,80 & 3,59 & 3,58 & 6,44 & 7,79 & 8,17 & 7,54 & 4,19 & 10,36 \\
\hline SrO & 0,05 & 0,07 & 0,06 & 0,08 & 0,06 & 0,06 & 0,06 & 0,04 & 0,03 & 0,08 & 0,12 & 0,10 & 0,19 & 0,01 & 0,20 \\
\hline $\mathrm{BaO}$ & 0,00 & 0,04 & 0,00 & 0,03 & 0,00 & 0,09 & 0,06 & 0,07 & 0,00 & 0,00 & 0,09 & 0,13 & 0,09 & 0,00 & 0,00 \\
\hline $\mathrm{Na}_{2} \mathrm{O}$ & 9,60 & 9,60 & 9,38 & 9,27 & 9,77 & 9,69 & 9,38 & 9,29 & 9,47 & 7,72 & 6,93 & 6,65 & 6,97 & 9,00 & 5,39 \\
\hline $\mathrm{K}_{2} \mathrm{O}$ & 0,20 & 0,20 & 0,25 & 0,24 & 0,24 & 0,25 & 0,25 & 0,24 & 0,14 & 0,13 & 0,18 & 0,33 & 0,15 & 0,14 & 0,08 \\
\hline Total & 99,67 & 100,19 & 99,93 & 100,15 & 100,54 & 100,45 & 100,23 & 99,51 & 99,54 & 99,51 & 99,40 & 99,46 & 99,15 & 99,38 & 98,83 \\
\hline \multicolumn{16}{|c|}{$O=32$} \\
\hline $\mathrm{Si}$ & 11,406 & 11,363 & \begin{tabular}{|l|}
11,301 \\
\end{tabular} & 11,269 & 11,456 & 11,424 & 11,299 & 11,330 & 11,340 & 10,803 & 10,500 & 10,414 & 10,510 & 11,217 & 9,953 \\
\hline $\mathrm{Al}$ & 4,586 & 4,617 & 4,687 & 4,721 & 4,535 & 4,566 & 4,674 & 4,667 & 4,647 & 5,174 & 5,467 & 5,559 & 5,441 & 4,777 & 5,989 \\
\hline $\mathrm{Fe}^{3+}$ & 0,018 & 0,024 & 0,010 & 0,008 & 0,008 & 0,010 & 0,015 & 0,012 & 0,011 & 0,019 & 0,027 & 0,019 & 0,059 & 0,018 & 0,059 \\
\hline$Z$ & 16,010 & 16,004 & 15,998 & 15,998 & 15,999 & 16,000 & 15,988 & 16,009 & 15,998 & 15,996 & 15,994 & 15,992 & 16,010 & 16,012 & 16,001 \\
\hline $\mathrm{Ca}$ & 0,602 & \begin{tabular}{|l}
0,633 \\
\end{tabular} & \begin{tabular}{|l}
0,704 \\
\end{tabular} & 0,738 & 0,572 & \begin{tabular}{|r|}
0,592 \\
\end{tabular} & 0,719 & 0,682 & \begin{tabular}{|l|l|}
0,679 \\
\end{tabular} & \begin{tabular}{|l|}
1,234 \\
\end{tabular} & 1,503 & 1,579 & 1,459 & 0,799 & \begin{tabular}{|l|}
2,027 \\
\end{tabular} \\
\hline $\mathrm{Sr}$ & 0,005 & 0,007 & 0,006 & 0,008 & 0,006 & 0,006 & 0,006 & 0,004 & 0,003 & 0,009 & 0,013 & 0,010 & 0,020 & 0,001 & 0,021 \\
\hline $\mathrm{Ba}$ & 0,000 & 0,002 & 0,000 & 0,002 & 0,000 & 0,006 & 0,004 & 0,005 & 0,000 & 0,000 & 0,006 & 0,009 & 0,006 & 0,000 & 0,000 \\
\hline $\mathrm{Na}$ & 3,291 & 3,280 & 3,213 & 3,171 & 3,320 & 3,298 & 3,207 & 3,194 & 3,255 & 2,677 & 2,419 & 2,324 & 2,441 & 3,102 & 1,909 \\
\hline $\mathrm{K}$ & 0,044 & 0,046 & 0,057 & 0,053 & 0,054 & 0,055 & 0,057 & 0,055 & 0,031 & 0,029 & 0,040 & 0,076 & 0,035 & 0,033 & 0,019 \\
\hline $\bar{X}$ & 3,942 & 3,968 & 3,980 & 3,972 & 3,952 & 3,957 & 3,993 & 3,940 & 3,968 & 3,949 & 3,981 & 3,998 & 3,961 & 3,935 & 3,976 \\
\hline$\Sigma$ & 19,952 & 19,978 & 19,978 & 19,970 & 19,951 & 19,957 & 19,981 & 19,949 & 19,966 & 19,945 & 19,975 & 19,990 & 19,971 & 19,947 & 19,977 \\
\hline \multicolumn{16}{|c|}{ Proporções moleculares } \\
\hline $\mathrm{Ab}$ & 82,8 & 82,0 & 79,9 & 79,1 & 83,3 & 82,8 & 79,6 & 80,3 & 81,2 & 66,6 & 59,6 & 57,0 & 60,6 & 77,9 & 46,8 \\
\hline An & 16,1 & 16,8 & 18,6 & 19,5 & 15,2 & 15,8 & 18,9 & 18,2 & 18,0 & 32,6 & 39,3 & 41,1 & 38,5 & 21,3 & 52,7 \\
\hline Or & 1,2 & 1,2 & 1,5 & 1,4 & 1,5 & 1,5 & 1,5 & 1,5 & 0,8 & 0,8 & 1,0 & 2,0 & 0,9 & 0,9 & 0,5 \\
\hline
\end{tabular}


Tabela 5.2 (cont.): Resultados analíticos e cálculos de fórmula estrutural (32 O) para cristais de plagioclásio do Complexo Granítico Cunhaporanga.

\begin{tabular}{|c|c|c|c|c|c|c|c|c|c|c|c|c|c|c|}
\hline & \multicolumn{14}{|c|}{ Domínios Petrográficos da porção NE do Complexo } \\
\hline & \multirow{2}{*}{\multicolumn{7}{|c|}{\begin{tabular}{|l|} 
DOMÍNIO LIMEIRA \\
tit anf bio
\end{tabular}}} & \multicolumn{7}{|c|}{ DOM. FRANCISCO SIMAS-VILA BRANCA } \\
\hline & & & & & & & & \multirow{2}{*}{\multicolumn{4}{|c|}{$\begin{array}{l}\text { tit bio } \\
\text { PS-63 }\end{array}$}} & \multirow{2}{*}{\multicolumn{3}{|c|}{$\frac{m u \text { bio }}{\text { PS-130 }}$}} \\
\hline & \multicolumn{7}{|c|}{$\mathrm{IT}-50 \mathrm{~b}$} & & & & & & & \\
\hline Local & $\mathrm{b}_{\mathrm{a}}$ & $\mathrm{i}_{\mathrm{a}}$ & $n_{a} 1$ & $\mathrm{n}_{\mathrm{a}} 2$ & $\mathrm{~b}_{\mathrm{b}} 1$ & $\mathrm{~b}_{\mathrm{b}} 2$ & $n_{b}$ & $\mathrm{~b}_{\mathrm{a}}$ & $\mathrm{n}_{\mathrm{a}} 1$ & $\mathrm{n}_{\mathrm{a}} 2$ & $\mathrm{n}_{\mathrm{b}}$ & $\mathrm{b}_{\mathrm{a}}$ & $\mathbf{n}_{\mathrm{a}}$ & $b_{b}$ \\
\hline $\mathrm{SiO}_{2}$ & 62,52 & 62,36 & 62,90 & 63,54 & 61,80 & 62,18 & 62,74 & 63,15 & 63,24 & 67,08 & 63,76 & 65,61 & 64,92 & 65,06 \\
\hline $\mathrm{Al}_{2} \mathrm{O}_{3}$ & 23,21 & 23,17 & 22,74 & 22,60 & 23,63 & 23,08 & 22,88 & 22,66 & 22,44 & 20,25 & 22,59 & 21,75 & 21,60 & 21,50 \\
\hline $\mathrm{Fe}_{2} \mathrm{O}_{3}$ & 0,19 & 0,08 & 0,21 & 0,22 & 0,08 & 0,12 & 0,19 & 0,03 & 0,07 & 0,00 & 0,08 & 0,00 & 0,02 & 0,09 \\
\hline $\mathrm{CaO}$ & 4,75 & 4,72 & 4,42 & 4,01 & 5,10 & 4,73 & 4,29 & 3,94 & 3,86 & 1,01 & 3,55 & 2,69 & 2,67 & 2,78 \\
\hline $\mathrm{SrO}$ & 0,04 & 0,10 & 0,07 & 0,06 & 0,08 & 0,06 & 0,12 & 0,10 & 0,05 & 0,11 & 0,04 & 0,00 & 0,00 & 0,00 \\
\hline $\mathrm{BaO}$ & 0,00 & 0,05 & 0,06 & 0,10 & 0,02 & 0,07 & 0,00 & 0,05 & 0,01 & 0,00 & 0,04 & 0,11 & 0,00 & 0,00 \\
\hline $\mathrm{Na}_{2} \mathrm{O}$ & 8,71 & 8,56 & 8,77 & 9,17 & 8,27 & 8,54 & 8,77 & 9,55 & 9,41 & 11,40 & 9,70 & 10,17 & 10,05 & 10,05 \\
\hline $\mathrm{K}_{2} \mathrm{O}$ & 0,22 & 0,21 & 0,31 & 0,45 & 0,22 & 0,27 & 0,28 & 0,14 & 0,17 & 0,09 & 0,22 & \begin{tabular}{|r|}
0,20 \\
\end{tabular} & 0,34 & 0,30 \\
\hline Total & 99,64 & 99,25 & 99,48 & 100,16 & 99,21 & 99,04 & 99,27 & 99,62 & 99,25 & 99,94 & 99,98 & 100,53 & 99,60 & 99,78 \\
\hline \multicolumn{15}{|c|}{$O=32$} \\
\hline $\mathrm{Si}$ & 11,115 & 11,126 & 11,198 & 11,243 & 11,038 & 11,124 & 11,185 & 11,223 & 11,265 & 11,780 & 11,276 & 11,499 & 11,485 & 11,493 \\
\hline $\mathrm{Al}$ & 4,859 & 4,869 & 4,768 & 4,710 & 4,971 & 4,862 & 4,804 & 4,743 & 4,706 & 4,188 & 4,705 & 4,489 & 4,500 & 4,473 \\
\hline $\mathrm{Fe}^{3+}$ & 0,026 & 0,010 & 0,028 & 0,030 & 0,011 & 0,016 & 0,025 & 0,004 & 0,010 & 0,000 & 0,010 & 0,000 & 0,003 & 0,012 \\
\hline $\boldsymbol{Z}$ & 16,000 & 16,005 & 15,994 & 15,983 & 16,020 & 16,002 & 16,014 & 15,970 & 15,981 & 15,968 & 15,991 & 15,988 & 15,988 & 15,987 \\
\hline $\mathrm{Ca}$ & 0,905 & 0,903 & 0,842 & 0,760 & 0,976 & 0,906 & 0,819 & 0,750 & \begin{tabular}{|l|}
0,737 \\
\end{tabular} & 0,189 & \begin{tabular}{|l|}
0,673 \\
\end{tabular} & 0,504 & 0,506 & 0,525 \\
\hline $\mathrm{Sr}$ & 0,004 & 0,010 & 0,007 & 0,007 & 0,008 & 0,006 & 0,012 & 0,011 & 0,006 & 0,011 & 0,005 & 0,000 & 0,000 & 0,000 \\
\hline $\mathrm{Ba}$ & 0,000 & 0,003 & 0,004 & 0,007 & 0,001 & 0,005 & 0,000 & 0,004 & 0,001 & 0,000 & 0,002 & 0,007 & 0,000 & 0,000 \\
\hline $\mathrm{Na}$ & 3,003 & 2,961 & 3,029 & 3,147 & 2,865 & 2,961 & 3,032 & 3,292 & 3,249 & 3,882 & 3,325 & 3,455 & 3,448 & 3,442 \\
\hline $\mathrm{K}$ & 0,049 & 0,048 & 0,071 & 0,102 & 0,050 & 0,061 & 0,065 & 0,032 & 0,038 & 0,019 & 0,050 & 0,044 & 0,077 & 0,068 \\
\hline $\boldsymbol{X}$ & 3,961 & 3,925 & 3,953 & 4,023 & 3,900 & 3,939 & 3,928 & 4,089 & 4,031 & 4,101 & 4,055 & 4,010 & 4,031 & 4,035 \\
\hline$\Sigma$ & 19,961 & 19,930 & 19,947 & 20,006 & 19,920 & 19,941 & 19,942 & 20,059 & 20,012 & 20,069 & 20,046 & 19,998 & 20,019 & 20,013 \\
\hline \multicolumn{15}{|c|}{ Proporções moleculares } \\
\hline $\mathrm{Ab}$ & 74,8 & 74,6 & 75,8 & 77,5 & 72,4 & 74,3 & 76,4 & 79,9 & 79,8 & 94,6 & 81,2 & 85,6 & 84,8 & 85,6 \\
\hline An & 23,9 & 24,1 & 22,4 & 19,8 & 26,2 & 24,1 & 21,9 & 19,3 & 19,2 & 4,9 & 17,5 & 13,3 & 13,2 & 13,3 \\
\hline Or & 1,3 & 1,3 & 1,9 & 2,7 & 1,4 & 1,6 & 1,7 & 0,8 & 1,0 & 0,5 & 1,3 & 1,2 & 2,0 & 1,2 \\
\hline
\end{tabular}


Tabela 5.2 (cont.): Resultados analíticos e cálculos de fórmula estrutural (32 O) para cristais de plagioclásio do Complexo Granítico Cunhaporanga.

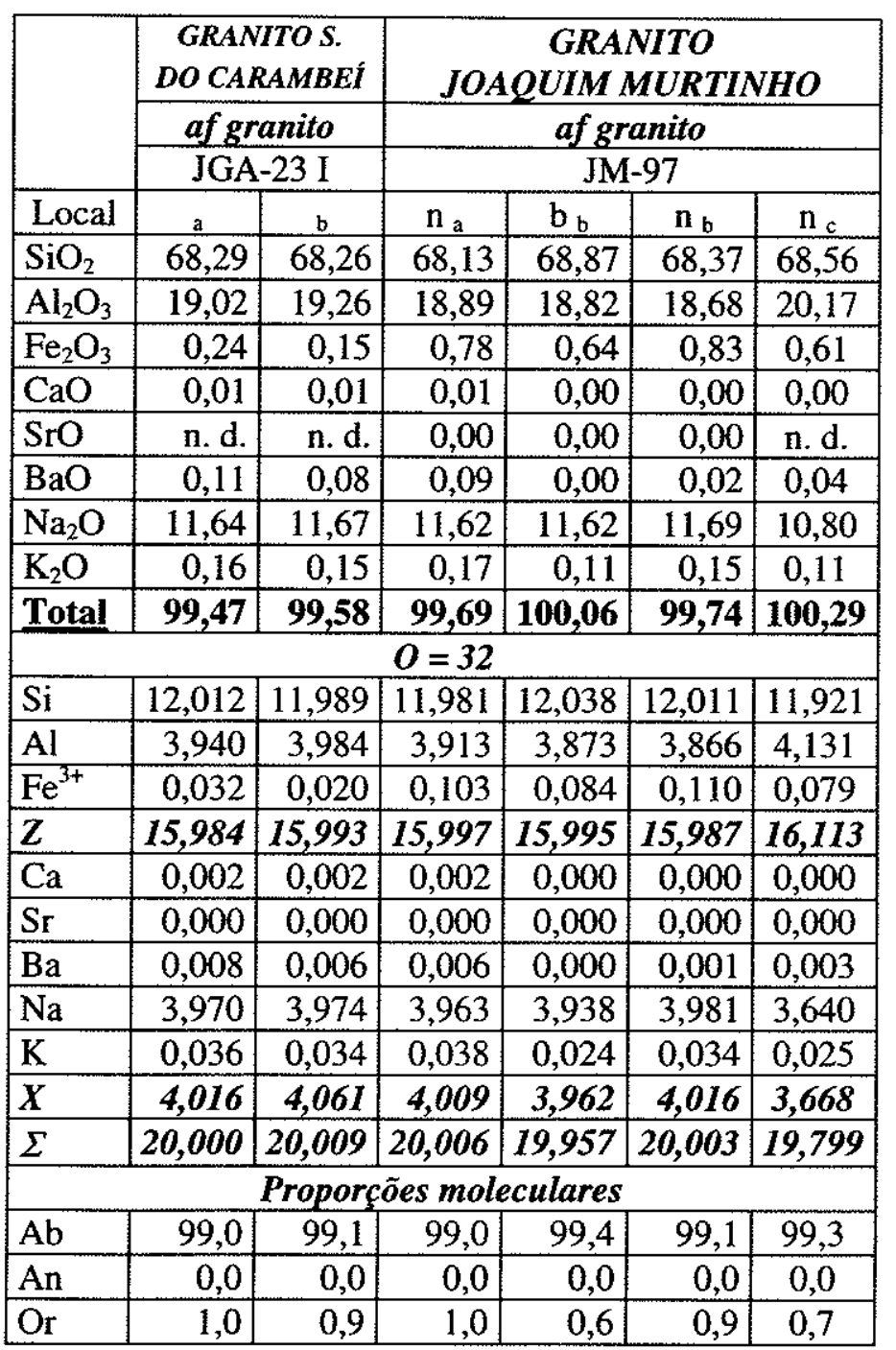

Observações: Amostras com textura porfirítica estão sublinhadas; "E" identifica amostra de enclave. No "Local", "b", "i" e " $n$ " representam respectivamente borda, posição intermediária e núcleo do mineral; os índices "a", "b" e "c" relacionam-se a diferentes grãos da mesma amostra; os números "1", "2" e "3" marcam análises em locais diferentes de um mesmo grão. "n. d." - nāo determinado. 
Tabela 5.3: Resultados analíticos e cálculos de fórmula estrutural $(32 \mathrm{O})$ para cristais de feldspato potássico do Complexo Granítico Cunhaporanga.

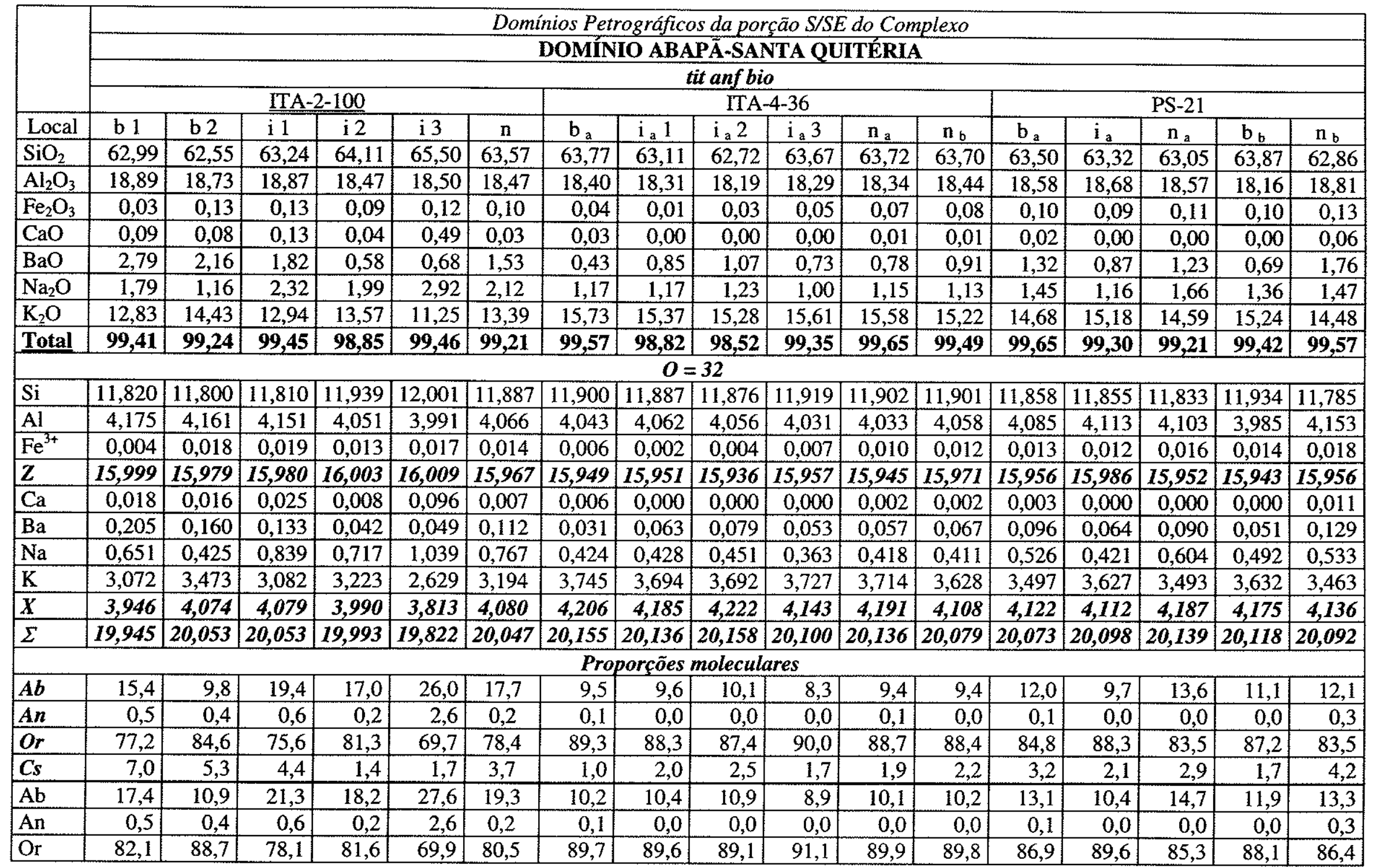


Tabela 5.3 (cont.): Resultados analíticos e cálculos de fórmula estrutural (32 O) para cristais de feldspato potássico do Complexo Cunhaporanga.

\begin{tabular}{|c|c|c|c|c|c|c|c|c|c|c|c|c|c|c|c|c|c|}
\hline & \multicolumn{17}{|c|}{ Domínios Petrográficos da porção S/SE do Complexo } \\
\hline & \multicolumn{15}{|c|}{ DOMÍNIO ABAPÃ-SANTA QUITÉRIA } & \multirow{3}{*}{\multicolumn{2}{|c|}{\begin{tabular}{|c} 
D. S. A.ALAGADOS \\
tit anf bio \\
SC-77 \\
\end{tabular}}} \\
\hline & \multicolumn{15}{|c|}{ tit anf bio } & & \\
\hline & \multicolumn{3}{|c|}{ PS-54 } & \multicolumn{2}{|c|}{ PS-76a } & \multicolumn{3}{|c|}{ PS-78 } & \multicolumn{4}{|c|}{ PS-79 } & \multicolumn{3}{|c|}{ PS-79a ${ }^{E}$} & & \\
\hline & $\mathrm{i}_{\mathrm{a}}$ & $\mathrm{b}_{\mathrm{b}}$ & $\mathbf{n}_{\mathrm{b}}$ & $\mathrm{b}$ & $\mathrm{n}$ & $\mathrm{n}_{\mathrm{a}}$ & $b_{b}$ & $\mathrm{n}_{\mathrm{b}}$ & $b_{a}$ & $\mathbf{n}_{\mathbf{a}}$ & $\mathrm{b}_{\mathrm{b}}$ & $n_{b}$ & $b_{a}$ & $\mathrm{~b}_{\mathrm{b}}$ & $\mathrm{n}_{\mathrm{b}}$ & & $i_{b}$ \\
\hline $\mathrm{SiO}_{2}$ & 64,21 & 64,62 & 63,34 & 63,26 & 63,38 & 64,37 & 64,83 & 63,50 & 64,35 & 63,13 & 64,03 & 63,75 & 63,35 & 64,44 & 63,86 & 65,30 & 65,66 \\
\hline $\mathrm{Al}_{2} \mathrm{O}_{3}$ & 18,16 & 18,50 & 18,63 & 18,52 & 19,06 & 18,43 & 18,23 & 18,21 & 18,34 & 18,85 & & 18,70 & 18,85 & 18,50 & 18,66 & 18,64 & 18,57 \\
\hline $\mathrm{Fe}_{2} \mathrm{O}_{3}$ & 0,03 & 0,08 & 0,04 & 0,01 & 0,10 & 0,10 & 0,10 & 0,04 & 0,03 & 0,11 & 0,06 & 0,15 & 0,05 & 0,02 & 0,13 & 0,10 & 0,11 \\
\hline $\mathrm{CaO}$ & 0,00 & 0,00 & 0,00 & 0,00 & 0,53 & 0,0 & 0,00 & 0,00 & 0,00 & 0,01 & & 0,00 & 0,00 & 0,00 & 0,01 & 0,11 & 0,09 \\
\hline $\mathrm{BaO}$ & 0,23 & 0 & 1,23 & 1,16 & 1,48 & 0,65 & 0,27 & 0,78 & 0,11 & 2,04 & & 1,40 & 1,52 & 0,8 & 1, & 0,32 & 0,35 \\
\hline $\mathrm{Na}_{2} \mathrm{O}$ & 0,78 & 1,04 & & 1,13 & 2,24 & 1,17 & 1,38 & 1,07 & 1,13 & 1,47 & & 1,3 & 0,51 & 0,8 & & 3,40 & 2,88 \\
\hline $\mathrm{K}_{2} \mathrm{O}$ & 16,29 & 15,88 & 15,37 & 15,31 & 13,32 & 15,29 & 15,09 & 15,42 & 15,61 & 14,34 & 14,83 & 14,89 & 15,79 & 15,32 & 14,96 & 12,73 & 12,83 \\
\hline Total & 99,70 & 100,33 & 99,72 & 99,40 & 100,11 & 100,01 & 99,90 & 99,02 & 99,57 & 99,95 & 99,36 & 100,27 & 100,07 & 99,95 & & & 100,49 \\
\hline \multicolumn{18}{|c|}{$O=32$} \\
\hline $\mathrm{Si}$ & 11,960 & 11,935 & 11,851 & 11,866 & 11,765 & 11,936 & 11,987 & 11,923 & 11,954 & 11,807 & 11,929 & 11,853 & 11,838 & 11,952 & 11,8 & 11,919 & 11,973 \\
\hline $\mathrm{Al}$ & 3,983 & 4,024 & 4,105 & 4,092 & 4,167 & 4,025 & 3,969 & 4,028 & 4,013 & 4,151 & 4,0 & 4,094 & 4,148 & 4,040 & 4,0 & 4,006 & 3,988 \\
\hline $\mathrm{Fe}^{3+}$ & 0,005 & 0,012 & 0,005 & 0,001 & 0,014 & 0,013 & 0,013 & 0,006 & 0,005 & 0,016 & 0,008 & 0,021 & 0,007 & 0,003 & 0,018 & 0,014 & 0,015 \\
\hline$Z$ & 15,948 & 15,971 & 15,961 & 15,959 & 15,946 & 15,974 & 15,969 & 15,957 & 15,972 & 15,974 & 15,964 & 15,968 & 15,993 & 15,995 & 15,976 & 15,939 & 15,976 \\
\hline $\mathrm{Ca}$ & 0,000 & 0,000 & 0,000 & 0,000 & \begin{tabular}{|l|}
0,106 \\
\end{tabular} & \begin{tabular}{|l|}
0,000 \\
\end{tabular} & 0,000 & 0,000 & 0,000 & \begin{tabular}{|c|}
0,003 \\
\end{tabular} & 0,004 & 0,000 & 0,000 & 0,000 & & \begin{tabular}{|l|}
0,021 \\
\end{tabular} & 0,018 \\
\hline $\mathrm{Ba}$ & 017 & 015 &, 090 & 0,085 & 0,107 & 0,047 & 020 & & 0,008 & 149 & & 0,102 & 0,1 & 0,058 & & 0,023 & 0,025 \\
\hline $\mathrm{Na}$ & 0,282 & 0,371 & 401 & 0,411 & 0,807 & 0,420 & 0,495 & 0,3 & 0,405 & 532 & 0,555 & 0,496 & 0,183 & 0,313 & & 1,203 & 1,019 \\
\hline $\mathbf{K}$ & 3,870 & 3,742 & 3,670 & 3,663 & 3,155 & 3,618 & 3,558 & 3,693 & 3,699 & 3,422 & 3,525 & 3,531 & 3,763 & 3,626 & 3,548 & 2,963 & 2,984 \\
\hline $\boldsymbol{X}$ & 4,169 & 4,128 & 4,161 & 4,159 & 4,175 & 4,085 & 4,073 & 4,139 & 4,112 & 4,106 & 4,123 & 4,129 & 4,058 & 3,997 & 4,084 & 4,210 & 4,046 \\
\hline$\Sigma$ & 20,117 & 20,099 & 20,122 & 20,118 & 20,121 & 20,059 & 20,042 & 20,096 & 20,084 & 20,080 & 20,087 & 20,097 & 20,051 & 19,992 & 20,060 & 20,149 & 20,022 \\
\hline \multicolumn{18}{|c|}{ Proporções moleculares } \\
\hline$A b$ & 6,4 & 8,5 & 9 & 9,3 & 18,3 & 9,7 & 11,5 & 8,9 & 9,3 & 12,2 & 12,7 & 11,3 & 4,2 & 7,4 & 10,0 & 27,3 & 24,0 \\
\hline An & 0,0 & 0,0 & 0,0 & 0,0 & 2,6 & 0,0 & 0,0 & 0,0 & 0,0 & 0,1 & 0,1 & 0,0 & 0,0 & 0,0 & 0,0 & 0,5 & 0,5 \\
\hline Or & 93,1 & 91,0 & 88,0 & 87,9 & 75,7 & 88,8 & 87,8 & 89,3 & 90,4 & 82,9 & 85,9 & 85,4 & 92,1 & 90,7 & 86,7 & 71,4 & 74,7 \\
\hline$C s$ & 0,6 & 0,5 & 2,9 & 2,8 & 3,5 & 1,6 & 0,7 & 1,9 & 0,3 & 4,9 & 1,3 & 3,3 & 3,7 & 1,9 & 3,3 & 0,8 & 0,8 \\
\hline $\mathrm{Ab}$ & 6,8 & 9,0 & 9,9 & 10,1 & 19,8 & 10,4 & 12,2 & 9,5 & 9,9 & 13,4 & 13,6 & 12,3 & 4,6 & 7,9 & 10,9 & 28,7 & 25,3 \\
\hline An & 0,0 & 0,0 & 0,0 & 0,0 & 2,6 & 0,0 & 0,0 & 0,0 & 0,0 & 0,1 & 0,1 & 0,0 & 0,0 & 0,0 & 0,0 & 0,5 & 0,4 \\
\hline $\mathrm{Or}$ & 93,2 & 91,0 & 91,0 & 89,9 & 77,6 & 89,6 & 87,8 & 90,5 & 90,1 & 86,5 & 86,3 & 87,7 & 95,4 & 92,1 & 89,1 & 70,8 & 74,2 \\
\hline
\end{tabular}


Tabela 5.3 (cont.): Resultados analíticos e cálculos de fórmula estrutural (32 O) para cristais de feldspato potássico do Complexo Cunhaporanga.

\begin{tabular}{|c|c|c|c|c|c|c|c|c|c|c|c|c|c|c|c|c|}
\hline \multirow[b]{5}{*}{ Local } & \multirow{2}{*}{\multicolumn{3}{|c|}{\begin{tabular}{|c|} 
D.P. S/SE Complexo \\
DOM.JOTUBA-PITANGUI \\
\end{tabular}}} & \multicolumn{13}{|c|}{ Domínios Petrográficos da porşão centro- $N$ do Complexo } \\
\hline & & & & \multirow{2}{*}{\multicolumn{13}{|c|}{$\begin{array}{c}\text { DOMINIO BISCAIAS-BOA VISTA } \\
\text { tit anf bio }\end{array}$}} \\
\hline & \multicolumn{3}{|c|}{ tit anf bio } & & & & & & & & & & & & & \\
\hline & \multicolumn{3}{|c|}{ SC-23 } & \multicolumn{3}{|c|}{ JGA-35 } & \multicolumn{6}{|c|}{$\underline{\mathrm{JGA}-41}$} & \multicolumn{4}{|c|}{$\underline{\text { PS-36 }}$} \\
\hline & $\mathrm{b}$ & $\mathrm{i}$ & $\mathrm{n}$ & $\mathrm{b}_{\mathrm{a}}$ & $\mathrm{n}_{\mathrm{a}}$ & $\mathbf{n}_{\mathrm{b}}$ & $\mathrm{b}_{\mathrm{a}}$ & $\mathrm{n}_{\mathrm{a}}$ & $\mathrm{b}_{\mathrm{b}}$ & $i_{b} 1$ & $i_{b} 2$ & $\mathrm{n}_{\mathrm{b}}$ & $b_{a}$ & $\mathrm{i}_{\mathrm{a}}$ & $\mathrm{n}_{\mathrm{a}}$ & $\mathbf{n}_{\mathrm{b}}$ \\
\hline $\mathrm{SiO}_{2}$ & 64,01 & 63,73 & 64,46 & 63,38 & 64,10 & 63,79 & 63,60 & 63,41 & 64,18 & 63,90 & 63,80 & 63,91 & 64,23 & 64,45 & 63,83 & 63,90 \\
\hline $\mathrm{Al}_{2} \mathrm{O}_{3}$ & 18,24 & 18,61 & 18,41 & 18,46 & 18,55 & 18,61 & 18,33 & 18,51 & 18,51 & 18,51 & 18,14 & 18,27 & 18,23 & 18,62 & 18,67 & 18,33 \\
\hline $\mathrm{Fe}_{2} \mathrm{O}_{3}$ & 0,05 & 0,08 & 0,07 & 0,08 & 0,10 & 0,03 & 0,08 & 0,09 & 0,15 & 0,09 & 0,15 & 0,07 & 0,09 & 0,04 & 0,06 & 0,08 \\
\hline $\mathrm{CaO}$ & 0,02 & 0,05 & 0,01 & 0,05 & 0,02 & 0,01 & 0,03 & 0,09 & 0,02 & 0,07 & 0,00 & 0,06 & 0,00 & 0,03 & 0,06 & 0,07 \\
\hline $\mathrm{BaO}$ & 0,79 & 1,18 & 0,47 & 1,36 & 1,13 & 1,14 & 0,62 & 0,91 & 0,49 & 0,71 & 0,63 & 0,59 & 0,27 & 0,53 & 0,82 & 0,46 \\
\hline $\mathrm{Na}_{2} \mathrm{O}$ & 1,46 & 1,58 & 1,44 & 1,45 & 1,36 & 1,17 & 1,10 & 1,49 & 1,25 & 1,94 & 1,03 & 1,63 & 0,92 & 1,94 & 1,68 & 1,04 \\
\hline $\mathrm{K}_{2} \mathrm{O}$ & 14,67 & 14,65 & 14,94 & 14,66 & 14,42 & 14,78 & 15,59 & 14,95 & 15,44 & 14,24 & 15,65 & 14,78 & 16,02 & 14,65 & 14,57 & 15,74 \\
\hline Total & 99,24 & 99,88 & 99,80 & 99,44 & 99,68 & 99,53 & 99,35 & 99,45 & 100,04 & 99,46 & 99,40 & 99,31 & 99,76 & 100,26 & 99,69 & 99,62 \\
\hline \multicolumn{17}{|c|}{$O=32$} \\
\hline Si & 11,948 & 11,868 & 11,946 & 11,868 & 11,919 & 11,900 & 11,902 & 11,854 & 11,897 & 11,888 & 11,934 & 11,924 & 11,949 & 11,896 & 11,873 & 11,910 \\
\hline $\mathrm{Al}$ & 4,008 & 4,081 & 4,018 & 4,071 & 4,062 & 4,088 & 4,040 & 4,076 & 4,041 & 4,055 & 3,996 & 4,014 & 3,994 & 4,048 & 4,088 & 4,023 \\
\hline $\mathrm{Fe}^{3+}$ & 0,008 & 0,010 & 0,010 & 0,012 & 0,014 & 0,004 & 0,011 & 0,012 & 0,021 & 0,013 & 0,021 & 0,010 & 0,012 & 0,005 & 0,008 & 0,011 \\
\hline$\underline{Z}$ & 15,964 & 15,959 & 15,974 & 15,951 & 15,995 & 15,992 & 15,953 & 15,942 & 15,959 & 15,956 & 15,951 & 15,948 & 15,955 & 15,949 & 15,969 & 15,944 \\
\hline $\mathrm{Ca}$ & 0,005 & 0,010 & 0,003 & 0,009 & 0,005 & 0,002 & 0,007 & 0,017 & 0,004 & 0,014 & 0,000 & 0,011 & 0,000 & 0,005 & 0,012 & 0,013 \\
\hline $\mathrm{Ba}$ & 0,058 & 0,086 & 0,034 & 0,095 & 0,082 & 0,083 & 0,046 & 0,067 & 0,036 & 0,052 & 0,046 & 0,043 & 0,020 & 0,038 & 0,060 & 0,033 \\
\hline $\mathrm{Na}$ & 0,528 & 0,572 & 0,516 & 0,526 & 0,492 & 0,424 & 0,398 & 0,540 & 0,450 & 0,698 & 0,374 & 0,591 & 0,330 & 0,694 & 0,607 & 0,375 \\
\hline $\mathrm{K}$ & 3,493 & 3,479 & 3,532 & 3,501 & 3,420 & 3,517 & 3,721 & 3,564 & 3,652 & 3,380 & 3,734 & 3,518 & 3,802 & 3,449 & 3,457 & 3,743 \\
\hline$\underline{X}$ & 4,084 & 4,147 & 4,085 & 4,135 & 3,999 & 4,026 & 4,172 & 4,188 & 4,142 & 4,144 & 4,154 & 4,163 & 4,152 & 4,186 & 4,136 & 4,164 \\
\hline$\Sigma$ & 20,048 & 20,106 & 20,059 & 20,086 & 19,994 & 20,018 & 20,125 & 20,130 & 20,101 & 20,100 & 20,105 & 20,111 & 20,107 & 20,135 & 20,105 & 20,108 \\
\hline \multicolumn{17}{|c|}{ Proporções moleculares } \\
\hline$A b$ & 12,2 & 13,0 & 12,0 & 12,0 & 11,6 & 9,9 & 9,0 & 12,2 & 10,3 & 16,0 & 8,5 & 13,4 & 7,5 & 15,7 & 13,9 & 8,5 \\
\hline$A n$ & 0,1 & 0,2 & 0,1 & 0,2 & 0,1 & 0,1 & 0,2 & 0,4 & 0,1 & 0,4 & 0,0 & 0,3 & 0,0 & 0,1 & 0,3 & 0,3 \\
\hline Or & 85,8 & 84,0 & 86,9 & 84,6 & 85,5 & 87,3 & 89,3 & 85,3 & 88,5 & 82,0 & 90,0 & 84,9 & 91,9 & 82,9 & 83,9 & 90,1 \\
\hline$C s$ & 1,9 & 2,8 & 1,1 & 3,2 & 2,8 & 2,8 & 1,5 & 2,2 & 1,2 & 1,7 & 1,5 & 1,4 & 0,6 & 1,3 & 2,0 & 1,1 \\
\hline$\overline{A b}$ & 13,1 & 14,1 & 12,7 & 13,0 & 12,6 & 10,8 & 9,6 & 13,1 & 11,0 & 17,1 & 9,1 & 14,3 & 8,0 & 16,7 & 14,9 & 9,1 \\
\hline $\mathrm{An}$ & 0,1 & 0,2 & 0,1 & 0,2 & 0,1 & 0,1 & 0,2 & 0,4 & 0,1 & 0,3 & 0,0 & 0,3 & 0,0 & 0,1 & 0,3 & 0,3 \\
\hline Or & 86,8 & 85,7 & 87,2 & 86,7 & 87,3 & 89,2 & 90,2 & 86,5 & 88,9 & 82,6 & 90,9 & 85,4 & 92,0 & 83,1 & 84,8 & 90,6 \\
\hline
\end{tabular}


Tabela 5.3 (cont.): Resultados analíticos e cálculos de fórmula estrutural $(32 \mathrm{O})$ para cristais de feldspato potássico do Complexo Cunhaporanga.

\begin{tabular}{|c|c|c|c|c|c|c|c|c|c|c|c|c|c|c|c|c|c|}
\hline & \multicolumn{17}{|c|}{ Domínios Petrográficos da porção centro- $N$ do Complexo } \\
\hline & \multicolumn{17}{|c|}{ DOMÍNIO ESPIGÃO ALTO } \\
\hline & \multicolumn{17}{|c|}{ tit anf bio } \\
\hline & \multicolumn{3}{|c|}{ JGA-4c } & \multicolumn{3}{|c|}{ JGA-17 } & JGA-42b & \multicolumn{3}{|c|}{$\mathrm{JGA}-43 \mathrm{~b}$} & \multicolumn{4}{|c|}{ PS-92a ${ }^{E}$} & \multicolumn{3}{|c|}{ PS-93a } \\
\hline Local & $\mathrm{b}_{\mathrm{a}}$ & $\mathrm{n}_{\mathrm{a}}$ & $\mathbf{n}_{b}$ & $b_{a}$ & $\mathrm{i}_{\mathrm{a}}$ & $i_{b}$ & $\mathrm{n}$ & $n_{a} 1$ & $n_{\mathrm{a}} 2$ & $\mathrm{n}_{\mathrm{b}}$ & $\mathrm{b}_{\mathrm{a}}$ & $\mathrm{n}_{\mathrm{a}}$ & $\mathbf{b}_{\mathrm{b}}$ & $\mathrm{n}_{\mathrm{b}}$ & $\mathrm{b}_{\mathrm{a}}$ & $\mathrm{n}_{\mathrm{a}}$ & $\mathrm{b}_{\mathrm{b}}$ \\
\hline $\mathrm{SiO}_{2}$ & 64,43 & 64,16 & 64,63 & 65,35 & 64,24 & 63,32 & 62,95 & 64,26 & 63,88 & 64,17 & 65,08 & 64,68 & 65,27 & 65,42 & 64,29 & 64,67 & 64,97 \\
\hline $\mathrm{Al}_{2} \mathrm{O}_{3}$ & 18,37 & 18,43 & 18,22 & 18,23 & 18,20 & 18,59 & 18,72 & 18,58 & 18,78 & 18,52 & 18,51 & 18,50 & 18,36 & 18,54 & 18,08 & 18,26 & 18,22 \\
\hline $\mathrm{Fe}_{2} \mathrm{O}_{3}$ & 0,09 & 0,12 & 0,08 & 0,11 & 0,08 & 0,10 & 0,08 & 0,04 & 0,09 & 0,06 & 0,18 & 0,08 & 0,20 & 0,08 & 0,13 & 0,10 & 0,02 \\
\hline $\mathrm{CaO}$ & 0,05 & 0,04 & 0,00 & 0,00 & 0,02 & 0,01 & 0,08 & 0,00 & 0,06 & 0,01 & 0,01 & 0,11 & 0,02 & 0,07 & 0,03 & 0,06 & 0,01 \\
\hline $\mathrm{BaO}$ & 0,36 & 0,46 & 0,11 & 0,14 & 0,30 & 1,27 & 1,84 & 0,63 & 1,36 & 0,70 & 0,62 & 0,51 & 0,54 & 0,71 & 0,27 & 0,20 & 0,10 \\
\hline $\mathrm{Na}_{2} \mathrm{O}$ & 1,37 & 1,51 & 1,05 & 2,72 & 1,48 & 1,05 & 1,78 & 1,23 & 1,76 & 1,57 & 0,99 & 1,35 & 1,94 & 2,31 & 0,74 & 1,24 & 0,79 \\
\hline $\mathrm{K}_{2} \mathrm{O}$ & 14,62 & 14,46 & 15,20 & 13,28 & 15,30 & 15,36 & 13,57 & 15,12 & 14,07 & 14,70 & 15,02 & 14,50 & 14,01 & 13,16 & 15,49 & 14,63 & 15,48 \\
\hline Total & 99,29 & 99,18 & 99,29 & 99,83 & 99,62 & 99,70 & 99,02 & 99,86 & 100,00 & 99,73 & 100,40 & 99,72 & 100,33 & 100,28 & 99,04 & 99,15 & 99,59 \\
\hline \multicolumn{18}{|c|}{$O=32$} \\
\hline $\mathrm{Si}$ & 11,966 & 11,940 & 12,000 & 12,001 & 11,946 & 11,850 & \begin{tabular}{|l|}
1,830 \\
\end{tabular} & 11,916 & 11,858 & 11,915 & 11,978 & 11,962 & 11,985 & 11,984 & 12,000 & 12,003 & 12,027 \\
\hline $\mathrm{Al}$ & 4,018 & 4,038 & 3,984 & 3,942 & 3,985 & 4,098 & 4,142 & 4,058 & 4,106 & 4,050 & 4,011 & 4,029 & 3,971 & 3,999 & 3,974 & 3,991 & 3,971 \\
\hline $\mathrm{Fe}^{3+}$ & 0,012 & 0,017 & 0,011 & 0,015 & 0,012 & 0,014 & 0,011 & 0,005 & \begin{tabular}{|l|}
0,012 \\
\end{tabular} & 0,009 & 0,025 & 0,011 & 0,027 & 0,012 & 0,019 & \begin{tabular}{|l|}
0,014 \\
\end{tabular} & 0,003 \\
\hline$Z$ & 15,996 & 15,996 & 15,995 & 15,958 & 15,943 & 15,962 & 15,983 & 15,979 & 15,977 & 15,974 & 16,014 & 16,002 & 15,983 & 15,995 & 15,993 & 16,008 & 16,001 \\
\hline $\mathrm{Ca}$ & 0,010 & 0,008 & 0,000 & 0,000 & 0,003 & 0,001 & \begin{tabular}{|l|}
0,016 \\
\end{tabular} & 0,000 & \begin{tabular}{|l|}
0,012 \\
\end{tabular} & 0,002 & 0,002 & 0,021 & 0,004 & 0,013 & 0,006 & 0,011 & 0,002 \\
\hline $\mathrm{Ba}$ & 0,026 & 0,034 & 0,008 & 0,010 & 0,022 & 0,093 & 0,136 & 0,046 & 0,099 & 0,051 & 0,045 & 0,037 & 0,039 & 0,051 & 0,020 & 0,014 & 0,007 \\
\hline $\mathrm{Na}$ & 0,492 & 0,545 & 0,379 & 0,968 & 0,532 & 0,382 & 0,650 & 0,443 & 0,634 & 0,565 & 0,352 & 0,483 & 0,689 & 0,819 & 0,269 & 0,447 & 0,284 \\
\hline$\underline{K}$ & 3,464 & 3,432 & 3,601 & 3,111 & 3,629 & 3,666 & 3,253 & 3,577 & 3,333 & 3,483 & 3,526 & 3,421 & 3,281 & 3,075 & 3,689 & 3,464 & 3,657 \\
\hline $\boldsymbol{X}$ & 3,992 & 4,019 & 3,988 & 4,089 & 4,186 & 4,142 & 4,055 & 4,066 & 4,078 & 4,101 & 3,925 & 3,962 & 4,013 & 3,958 & 3,984 & 3,936 & 3,950 \\
\hline$\Sigma$ & 19,988 & 20,015 & 19,983 & 20,047 & 20,129 & 20,104 & 20,038 & 20,045 & 20,055 & 20,075 & 19,939 & 19,964 & 19,996 & 19,953 & 19,977 & 19,944 & 19,951 \\
\hline \multicolumn{18}{|c|}{ Proporçōes moleculares } \\
\hline$A b$ & 11,7 & 12,8 & 9,0 & 22,6 & 12,0 & 8,7 & 15,1 & 10,3 & 14,6 & 13,0 & 8,5 & 11,5 & 16,3 & 19,7 & 6,4 & 10,8 & 6,8 \\
\hline$A n$ & 0,2 & 0,2 & 0,0 & 0,0 & 0,1 & 0,0 & 0,4 & 0,0 & 0,3 & 0,1 & 0,1 & 0,6 & 0,1 & 0,3 & 0,1 & 0,3 & 0,1 \\
\hline Or & 87,2 & 85,8 & 90,7 & 77,1 & 87,2 & 88,3 & 80,0 & 88,2 & 81,8 & 85,3 & 90,0 & 86,7 & 82,3 & 78,3 & 92,8 & 88,5 & 92,9 \\
\hline Cs & 0,9 & 1,2 & 0,3 & 0,3 & 0,7 & 3,0 & 4,5 & 1,5 & 3,3 & 1,7 & 1,5 & 1,3 & 1,3 & 1,7 & 0,7 & 0,5 & 0,2 \\
\hline$A b$ & 12,4 & 13,7 & 9,5 & 23,7 & 12,8 & 9,4 & 16,6 & 11,0 & 15,9 & 14,0 & 9,1 & 12,3 & 17,3 & 21,0 & 6,8 & 11,4 & 7,2 \\
\hline An & 0,3 & 0,2 & 0,0 & 0,0 & 0,1 & 0,0 & 0,4 & 0,0 & 0,3 & 0,0 & 0,1 & 0,5 & 0,1 & 0,3 & 0,2 & 0,3 & 0,1 \\
\hline Or & 87,3 & 86,1 & 90,5 & 76,3 & 87,2 & 90,5 & 83,0 & 89,0 & 83,8 & 86,0 & 90,9 & 87,2 & 82,6 & 78,7 & 93,1 & 88,3 & 92,7 \\
\hline
\end{tabular}


Tabela 5.3 (cont.): Resultados analíticos e cálculos de fórmula estrutural (32 O) para cristais de feldspato potássico do Complexo Cunhaporanga.

\begin{tabular}{|c|c|c|c|c|c|c|c|c|c|c|c|c|c|c|c|c|c|}
\hline & \multicolumn{17}{|c|}{ Domínios Petrográficos da porção centro- $N$ do Complexo } \\
\hline & \multirow{3}{*}{\multicolumn{5}{|c|}{$\begin{array}{c}\text { DOMINIO ESPIGĀO ALTO } \\
\text { tit anf bio } \\
\text { PS-93a }\end{array}$}} & \multicolumn{7}{|c|}{ DOMINIO PAREDÃO DA SANTA } & \multicolumn{5}{|c|}{ DOM. P. DA ANTA-ÁGUA CLARA } \\
\hline & & & & & & \multicolumn{3}{|c|}{ tit anf bio } & \multirow{2}{*}{\multicolumn{4}{|c|}{\begin{tabular}{|c|} 
tit bio \\
JGA-44 \\
\end{tabular}}} & \multirow{2}{*}{\multicolumn{3}{|c|}{\begin{tabular}{|l} 
mu bio \\
JGA-14
\end{tabular}}} & \multirow{2}{*}{\multicolumn{2}{|c|}{\begin{tabular}{|c|} 
bio \\
PS-44 \\
\end{tabular}}} \\
\hline & & & & & & \multicolumn{3}{|c|}{ JGA-1 } & & & & & & & & & \\
\hline Local & $i_{b} 1$ & $i_{b} 2$ & $i_{b} 3$ & $\mathrm{n}_{\mathrm{b}} 1$ & $n_{b} 2$ & $\mathrm{i}_{\mathrm{a}}$ & $\mathbf{b}_{\mathbf{b}}$ & $i_{b}$ & $b_{a}$ & $\mathrm{i}_{\mathrm{a}}$ & $\mathbf{n}_{\mathrm{a}}$ & $\mathrm{n}_{\mathrm{b}}$ & $\mathrm{n}_{\mathrm{a}}$ & $i_{b}$ & $\mathbf{n}_{\mathrm{b}}$ & $\mathrm{n}_{\mathbf{a}}$ & $\mathbf{b}_{\mathrm{b}}$ \\
\hline $\mathrm{SiO}_{2}$ & 65,22 & 63,67 & 62,61 & 62,29 & 64,52 & 63,21 & 64,21 & 63,74 & 63,66 & 64,08 & 63,92 & 63,89 & 63,62 & 64,41 & 64,57 & 63,65 & 64,06 \\
\hline $\mathrm{Al}_{2} \mathrm{O}_{3}$ & 18,47 & 18,20 & 18,95 & 19,10 & 18,38 & 18,75 & 18,24 & 18,49 & 18,26 & 18,16 & 18,35 & 18,31 & 18,35 & 18,32 & 18,48 & 18,10 & 18,14 \\
\hline $\mathrm{Fe}_{2} \mathrm{O}_{3}$ & 0,00 & 0,11 & 0,08 & 0,04 & 0,04 & 0,08 & 0,09 & 0,08 & 0,12 & 0,06 & 0,04 & 0,04 & 0,01 & 0,00 & 0,07 & 0,05 & 0,05 \\
\hline $\mathrm{CaO}$ & 0,05 & 0,39 & 0,03 & 0,07 & 0,00 & 0,09 & 0,05 & 0,06 & 0,00 & 0,04 & 0,02 & 0,00 & 0,00 & 0,01 & 0,01 & 0,00 &, 00 \\
\hline $\mathrm{BaO}$ & 0,46 & 1,13 & 2,52 & 2,81 & 1,25 & 1,66 & 0,24 & 0,57 & 0,57 & 0,53 & 0,35 & 0,35 & 0,00 & 0,00 & 0,10 & 0,31 &, 13 \\
\hline $\mathrm{Na}_{2} \mathrm{O}$ & 1,55 & 1,31 & 1,74 & 2,17 & 1,51 & 2,06 & 1,50 & 2,17 & 1,13 & 1,41 & 1,39 & 1,12 & 1,02 & 1,14 & 1,29 & 0,80 & 0,73 \\
\hline $\mathrm{K}_{2} \mathrm{O}$ & 14,51 & 14,51 & 13,17 & 12,53 & 14,04 & 13,58 & 15,23 & 14,11 & 15,49 & 15,31 & 14,95 & 15,54 & 16,07 & 15,65 & 15,63 & 16,07 & 16,22 \\
\hline Total & 100,27 & 99,31 & 99,11 & 99,00 & 99,74 & 99,43 & 99,56 & 99,22 & 99,23 & 99,59 & 99,02 & 99,25 & 99,07 & 99,53 & 100,15 & 98,98 & 99,33 \\
\hline \multicolumn{18}{|c|}{$O=32$} \\
\hline $\mathrm{Si}$ & 11,988 & 11,913 & 11,790 & 11,748 & 11,970 & 11,820 & 11,937 & 11,882 & 11,917 & 11,935 & 11,935 & 11,927 & 11,905 & 11,961 & 11,932 & 11,945 & 11,963 \\
\hline $\mathrm{Al}$ & 3,999 & 4,011 & 4,203 & 4,242 & 4,015 & 4,129 & 3,993 & 4,060 & 4,025 & 3,983 & 4,035 & 4,024 & 4,046 & 4,005 & 4,022 & 4,000 & 3,990 \\
\hline $\mathrm{Fe}^{3+}$ & 0,000 & 0,015 & 0,011 & 0,006 & 0,006 & 0,011 & 0,013 & 0,012 & 0,017 & 0,009 & 0,005 & 0,005 & 0,002 & 0,000 & 0,009 & 0,008 & 0,007 \\
\hline $\mathbf{Z}$ & 15,987 & 15,939 & 16,004 & 15,996 & 15,991 & 15,960 & 15,943 & 15,954 & 15,959 & 15,927 & 15,975 & 15,956 & 15,957 & 15,966 & 15,963 & 15,953 & 15,960 \\
\hline $\mathrm{Ca}$ & 0,010 & 0,078 & 0,007 & 0,015 & 0,000 & 0,017 & 0,009 & 0,012 & 0,000 & 0,007 & 0,004 & 0,000 & 0,000 & 0,001 & 0,001 & 0,000 & 0,000 \\
\hline $\mathrm{Ba}$ & 0,033 & 0,083 & 0,186 & 0,207 & 0,091 & 0,121 & 0,018 & 0,041 & 0,041 & 0,039 & 0,026 & 0,025 & 0,000 & 0,000 & 0,007 & 0,023 & 0,010 \\
\hline $\mathrm{Na}$ & 0,551 & 0,474 & 0,635 & 0,793 & 0,544 & 0,747 & 0,541 & 0,783 & 0,410 & 0,510 & 0,503 & 0,404 & 0,370 & 0,412 & 0,463 & 0,293 & 0,263 \\
\hline $\mathrm{K}$ & 3,403 & 3,463 & 3,165 & 3,014 & 3,323 & 3,240 & 3,612 & 3,356 & 3,699 & 3,638 & 3,562 & 3,700 & 3,839 & 3,708 & 3,684 & 3,848 & 3,864 \\
\hline $\boldsymbol{X}$ & 3,997 & 4,098 & 3,993 & 4,029 & 3,958 & 4,125 & 4,180 & 4,192 & 4,150 & 4,194 & 4,095 & 4,129 & 4,209 & 4,121 & 4,155 & 4,164 & 4,137 \\
\hline$\Sigma$ & 19,984 & 20,037 & 19,997 & 20,025 & 19,949 & 20,085 & 20,123 & 20,146 & 20,109 & 20,121 & 20,070 & 20,085 & 20,166 & 20,087 & 20,118 & 20,117 & 20,097 \\
\hline \multicolumn{18}{|c|}{ Proporções moleculares } \\
\hline$A b$ & 13,1 & 10,9 & 14,9 & 18,4 & 13,0 & 17,1 & 12,3 & 17,7 & 9,3 & 11,5 & 11,6 & 9,2 & 8,3 & 9,5 & 10,6 & 6,6 & 6,0 \\
\hline$A n$ & 0,3 & 1,9 & 0,2 & 0,4 & 0,0 & 0,4 & 0,2 & 0,3 & 0,0 & 0,2 & 0,1 & 0,0 & 0,0 & 0,0 & 0,0 & 0,0 & 0,0 \\
\hline Or & 85,6 & 84,5 & 78,7 & 74,3 & 84,0 & 78,6 & 86,9 & 80,6 & 89,3 & 87,1 & 87,4 & 89,9 & 91,7 & 90,5 & 89,2 & 92,6 & 93,7 \\
\hline$C s$ & 1,1 & 2,7 & 6,2 & 6,9 & 3,1 & 4,0 & 0,6 & 1,3 & 1,4 & 1,3 & 0,8 & 0,8 & 0,0 & 0,0 & 0,2 & 0,7 & 0,3 \\
\hline $\mathrm{Ab}$ & 13,9 & 11,8 & 16,7 & 20,7 & 14,1 & 18,7 & 13,0 & 18,9 & 10,0 & 12,3 & 12,4 & 9,8 & 8,8 & 10,0 & 11,2 & 7,1 & 6,4 \\
\hline An & 0,3 & 1,9 & 0,2 & 0,4 & 0,0 & 0,4 & 0,2 & 0,3 & 0,0 & 0,2 & 0,1 & 0,0 & 0,0 & 0,0 & 0,0 & 0,0 & 0,0 \\
\hline Or & 85,8 & 86,3 & 83,1 & 78,9 & 85,9 & 80,9 & 86,8 & 80,8 & 90,0 & 87,6 & 87,5 & 90,2 & 91,2 & 90,0 & 88,8 & 92,9 & 93,6 \\
\hline
\end{tabular}


Tabela 5.3 (cont.): Resultados analíticos e cálculos de fórmula estrutural (32 O) para cristais de feldspato potássico do Complexo Cunhaporanga.

\begin{tabular}{|c|c|c|c|c|c|c|c|c|c|c|c|c|c|c|c|c|c|}
\hline & \multicolumn{14}{|c|}{ Domínios Petrográficos da porçäo centro- $N$ do Complexo } & \multirow{2}{*}{\multicolumn{3}{|c|}{$\begin{array}{c}\text { Dom. P. NE Complexo } \\
\text { D. O. V.-P. S. ANTÔNIO }\end{array}$}} \\
\hline & \multirow{3}{*}{\begin{tabular}{|c|}
$\begin{array}{c}\text { D.P.A.A. } \\
\text { C. }\end{array}$ \\
bio \\
PS.
\end{tabular}} & \multicolumn{13}{|c|}{ DOMININO VARGINHA } & & & \\
\hline & & \multicolumn{10}{|c|}{ tit bio } & \multicolumn{3}{|c|}{ bio pórfiro } & \multirow{2}{*}{\multicolumn{3}{|c|}{$\begin{array}{l}\text { tit bio } \\
\text { IT-93 }\end{array}$}} \\
\hline & & \multicolumn{3}{|c|}{ PS 46} & \multicolumn{2}{|c|}{ PS-47 } & \multicolumn{5}{|c|}{ PS-66 } & \multicolumn{3}{|c|}{ PS-48 } & & & \\
\hline Local & $\mathrm{n}_{\mathrm{b}}$ & & $\mathrm{b}_{\mathrm{b}}$ & $i_{b}$ & b & $\mathrm{n}$ & $\mathrm{b}_{\mathrm{a}}$ & $\mathrm{n}_{\mathrm{a}} 1$ & $\mathrm{n}_{\mathrm{a}} 2$ & $b_{b}$ & $n_{b}$ & $\mathrm{~b}_{\mathrm{a}}$ & $\mathrm{n}_{\mathrm{a}}$ & $\mathbf{n}_{\mathrm{b}}$ & $b_{a}$ & $\mathrm{n}_{\mathrm{a}} \mathrm{l}$ & $\mathrm{n}_{\mathrm{a}} 2$ \\
\hline $\mathrm{SiO}_{2}$ & 64,23 & 63,81 & 64,12 & 63,64 & 63,83 & 64,58 & 64,55 & 64,50 & 63,13 & 64,56 & 63,87 & 63,77 & 63,80 & 63,97 & 65,08 & 64,54 & 64,74 \\
\hline $\mathrm{Al}_{2} \mathrm{O}_{3}$ & 18,21 & 18,63 & 18,24 & 18,26 & 18,26 & 18,33 & 18,18 & 18,20 & 18,12 & 18,34 & 18,41 & 18,20 & 18,29 & 18,34 & 18,38 & 18,47 & 18,40 \\
\hline $\mathrm{Fe}_{2} \mathrm{O}_{3}$ & 0,06 & 0,07 & 0,09 & 0,09 & 0,08 & 0,08 & 0,10 & 0,15 & 0,12 & 0,08 & 0,05 & 0,08 & 0,07 & 0,02 & 0,14 & 0,04 & 0,07 \\
\hline $\mathrm{CaO}$ & 0,00 & 0,06 & 0,03 & 0,05 & 0,02 & 0,00 & 0,01 & 0,00 & 0,04 & 0,00 & 0,07 & 0,02 & 0,01 & 0,0 & 0,00 & 0,00 & 0,00 \\
\hline $\mathrm{BaO}$ & 0,25 & 0,94 & 0,18 & 0,82 & 0,42 & 0,30 & 0,00 & 0,19 & 0,44 & 0,06 & 0,36 & 0,50 & 0,49 & 0,38 & 0,10 & 0,05 & 1,28 \\
\hline $\mathrm{Na}_{2} \mathrm{O}$ & 2,00 & 1,60 & 0,93 & 1,38 & 1,28 & 0,81 & 1,57 & 1,23 & 0,99 & 0,92 & 1,34 & 1,31 & 0,90 & 1,4 & 1,05 & 0,91 & 1,22 \\
\hline $\mathrm{K}_{2} \mathrm{O}$ & 14,36 & 14,44 & 16,18 & 15,28 & 15,09 & 15,52 & 15,27 & 15,77 & 15,89 & 16,12 & 15,29 & 15,14 & 16,20 & 15,19 & 15,39 & 15,54 & 14,78 \\
\hline Total & 99,11 & 99,55 & 99,77 & 99,52 & 98,98 & 99,62 & 99,68 & 100,04 & 98,73 & 100,08 & 99,39 & 99,02 & 99,76 & 99,41 & & 99,54 & 100,67 \\
\hline \multicolumn{18}{|c|}{$O=32$} \\
\hline $\mathrm{Si}$ & 11,955 & 11,883 & 11,934 & 11,901 & 11,938 & 11,982 & 11,965 & 11,953 & 11,901 & 11,953 & 11,909 & 11,937 & 11,910 & 11,923 & 11,990 & 11,966 & \begin{tabular}{|l|l}
11,948 \\
\end{tabular} \\
\hline $\mathrm{Al}$ & 3,991 & 4,086 & 3,999 & 4,020 & 4,021 & 4,006 & 3,969 & 3,971 & 4,023 & 3,998 & 4,042 & 4,011 & 4,021 & 4,026 & 3,988 & 4,033 & 4,025 \\
\hline $\mathrm{Fe}^{3+}$ & 0,008 & 0,009 & 0,013 & 0,012 & 0,012 & 0,012 & \begin{tabular}{|l|}
0,013 \\
\end{tabular} & 0,021 & 0,017 & 0,011 & 0,007 & 0,011 & 0,009 & 0,002 & 0,019 & 0,005 & 0,009 \\
\hline $\bar{Z}$ & 15,954 & 15,978 & 15,946 & 15,933 & 15,971 & 16,000 & 15,947 & 15,945 & 15,941 & 15,962 & 15,958 & 15,959 & 15,940 & 15,951 & 15,997 & 16,004 & 15,982 \\
\hline $\mathrm{Ca}$ & 0,000 & 0,012 & 0,006 & 0,010 & 0,005 & 0,000 & $0,002 \mid$ & 0,000 & 0,007 & 0,000 & 0,015 & 0,004 & 0,002 & 0,010 & 0,000 & 0,000 & 0,000 \\
\hline $\mathrm{Ba}$ & 0,018 & 0,069 & 0,013 & 0,060 & 0,031 & 0,021 & 0,000 & 0,014 & 0,033 & 0,005 & 0,026 & 0,037 & 0,036 & 0,028 & 0,007 & 0,004 & 0,093 \\
\hline $\mathrm{Na}$ & 0,721 & 0,578 & 0,336 & 0,501 & 0,464 & 0,291 & 0,564 & 0,441 & 0,362 & 0,331 & 0,486 & 0,476 & 0,326 & 0,527 & 0,374 & 0,328 & 0,435 \\
\hline $\mathrm{K}$ & 3,409 & 3,430 & 3,842 & 3,644 & 3,601 & 3,674 & 3,612 & 3,728 & 3,822 & 3,806 & 3,637 & 3,616 & 3,859 & 3,611 & 3,618 & 3,675 & 3,476 \\
\hline $\boldsymbol{X}$ & 4,148 & 4,089 & 4,197 & 4,215 & 4,101 & 3,986 & 4,178 & 4,183 & 4,224 & 4,142 & 4,164 & 4,133 & 4,223 & 4,176 & 3,999 & 4,007 & 4,004 \\
\hline$\Sigma$ & 20,102 & 20,067 & 20,143 & 20,148 & 20,072 & 19,986 & 20,125 & 20,128 & 20,165 & 20,104 & 20,122 & 20,092 & 20,168 & 20,127 & 19,996 & 20,011 & 19,986 \\
\hline \multicolumn{18}{|c|}{ Proporçôes moleculares } \\
\hline$A b$ & 16,5 & 13,3 & 7,6 & 11,2 & 10,7 & 6,9 & 12,8 & 10,0 & 8,1 & 7,6 & 11,0 & 10,9 & 7,3 & 11,9 & 8,9 & 7,8 & 10,2 \\
\hline $\boldsymbol{A n}$ & 0,0 & 0,3 & 0,2 & 0,3 & 0,1 & 0,0 & 0,1 & 0,0 & 0,2 & 0,0 & 0,4 & 0,1 & 0,0 & 0,2 & 0,0 & 0,0 & 0,0 \\
\hline Or & 82,9 & 84,1 & 91,9 & 86,6 & 88,2 & 92,4 & 87,1 & 89,6 & 90,7 & 92,3 & 87,8 & 87,8 & 91,6 & 86,9 & 90,9 & 92,1 & 86,7 \\
\hline$C s$ & 0,6 & 2,3 & 0,4 & 1,9 & 1,0 & 0,7 & 0,0 & 0,4 & 1,0 & 0,2 & 0,9 & 1,2 & 1,1 & 0,9 & 0,2 & 0,1 & 3,1 \\
\hline $\mathrm{Ab}$ & 17,5 & 14,4 & 8,0 & 12,1 & 11,4 & 7,3 & 13,5 & 10,6 & 8,6 & 8,0 & 11,7 & 11,6 & 7,8 & 12,7 & 9,4 & 8,2 & 11,1 \\
\hline An & 0,0 & 0,3 & 0,1 & 0,2 & 0,1 & 0,0 & 0,0 & 0,0 & 0,2 & 0,0 & 0,4 & 0,1 & 0,0 & 0,2 & 0,0 & 0,0 & 0,0 \\
\hline Or & 82,5 & 85,3 & 91,8 & 87,7 & 88,5 & 92,7 & 86,5 & 89,4 & 91,2 & 92,0 & 87,9 & 88,3 & 92,2 & 87,1 & 90,6 & 91,3 & 88,9 \\
\hline
\end{tabular}


Tabela 5.3 (cont.): Resultados analíticos e cálculos de fórmula estrutural (32 O) para cristais de feldspato potássico do Complexo Cunhaporanga.

\begin{tabular}{|c|c|c|c|c|c|c|c|c|c|c|c|c|c|c|c|c|}
\hline & \multicolumn{16}{|c|}{ Domínios Petrográficos da porção $N E$ do Complexo } \\
\hline & \multicolumn{16}{|c|}{ DOMÍNIO OURO VERDE-PATRIMÔNIO SANTO ANTÔNIO } \\
\hline & \multicolumn{14}{|c|}{ tit bio } & \multirow{2}{*}{\multicolumn{2}{|c|}{$\begin{array}{c}\text { anf pórfiro } \\
\text { IT-96 }\end{array}$}} \\
\hline & \multicolumn{5}{|c|}{ IT-93 } & \multicolumn{9}{|c|}{ IT-104 } & & \\
\hline Local & $b_{b}$ & $i_{b} 1$ & $i_{b} 2$ & $i_{b} 3$ & $i_{b} 4$ & $b_{a}$ & $\mathbf{i}_{\mathbf{a}}$ & $\mathrm{n}_{\mathrm{a}} 1$ & $\mathrm{n}_{\mathrm{a}} 2$ & $b_{b}$ & $i_{b} 1$ & $i_{b} 2$ & $i_{b} 3$ & $i_{b} 4$ & $\mathrm{~b}_{\mathrm{a}}$ & $\mathbf{n}_{\mathrm{a}}$ \\
\hline $\mathrm{SiO}_{2}$ & 64,80 & 64,72 & 64,73 & 64,61 & 65,26 & 64,50 & 64,83 & 63,88 & 64,16 & 64,88 & 64,69 & 64,78 & 64,26 & 63,85 & 64,99 & 65,28 \\
\hline $\mathrm{Al}_{2} \mathrm{O}_{3}$ & 18,53 & 18,55 & 18,62 & 18,71 & 18,48 & 18,04 & 18,27 & 18,83 & 18,54 & 18,50 & 18,32 & 18,52 & 18,59 & 18,61 & 18,47 & 17,94 \\
\hline $\mathrm{Fe}_{2} \mathrm{O}_{3}$ & 0,07 & 0,07 & 0,07 & 0,08 & 0,00 & 0,00 & 0,08 & 0,01 & 0,06 & 0,06 & 0,02 & 0,11 & 0,06 & 0,11 & 0,05 & 0,17 \\
\hline $\mathrm{CaO}$ & 0,00 & 0,00 & 0,02 & 0,00 & 0,00 & 0,00 & 0,00 & 0,06 & 0,05 & 0,00 & 0,00 & 0,02 & 0,03 & 0,00 & 0,00 & 0,00 \\
\hline $\mathrm{BaO}$ & 1,28 & 0,98 & 0,90 & 1,20 & 0,32 & 0,33 & 0,31 & 1,49 & 1,12 & 0,14 & 0,23 & 0,64 & 0,95 & 0,97 & 0,17 & 0,22 \\
\hline $\mathrm{Na}_{2} \mathrm{O}$ & 1,22 & 1,09 & 1,34 & 1,09 & 1,10 & 1,01 & 1,28 & 1,33 & 1,25 & 1,10 & 1,22 & 1,27 & 1,30 & 1,38 & 0,45 & 0,39 \\
\hline $\mathrm{K}_{2} \mathrm{O}$ & 14,78 & 14,48 & 14,84 & 15,24 & 15,91 & 15,20 & 14,71 & 14,04 & 14,34 & 14,94 & 15,07 & 14,79 & 14,51 & 14,46 & 15,91 & 16,14 \\
\hline Total & 100,67 & 100,23 & 100,16 & 100,54 & 100,40 & 99,07 & 99,47 & 99,64 & 99,51 & 99,63 & 99,54 & 100,12 & 99,71 & 99,39 & 100,03 & 110,14 \\
\hline \multicolumn{17}{|c|}{$O=32$} \\
\hline $\mathrm{Si}$ & 11,948 & 11,957 & 11,948 & 11,924 & 11,994 & 12,020 & 12,006 & 11,887 & 11,935 & 11,987 & 11,989 & $\mid 11,958$ & 11,928 & 11,901 & 11,998 & 12,058 \\
\hline $\mathrm{Al}$ & 4,025 & 4,035 & 4,046 & 4,067 & 4,001 & 3,960 & 3,985 & 4,127 & 4,061 & 4,025 & 3,998 & 4,025 & 4,064 & 4,085 & 4,015 & 3,903 \\
\hline $\mathrm{Fe}^{3+}$ & 0,009 & 0,010 & 0,010 & 0,012 & 0,000 & 0,000 & 0,011 & 0,002 & 0,009 & 0,009 & 0,003 & 0,015 & 0,008 & 0,015 & 0,006 & 0,024 \\
\hline$Z$ & 15,982 & 16,002 & 16,004 & 16,003 & 15,995 & 15,980 & 16,002 & 16,016 & 16,005 & 16,021 & 15,990 & 15,998 & 16,000 & 16,001 & 16,019 & 15,985 \\
\hline $\mathrm{Ca}$ & 0,000 & 0,000 & 0,004 & 0,000 & 0,000 & 0,000 & 0,000 & 0,011 & 0,011 & 0,000 & 0,000 & 0,004 & 0,006 & 0,000 & 0,000 & 0,000 \\
\hline $\mathrm{Ba}$ & 0,093 & 0,071 & 0,065 & 0,086 & 0,023 & 0,024 & 0,022 & 0,109 & 0,082 & 0,010 & 0,016 & 0,046 & 0,069 & 0,071 & 0,012 & 0,016 \\
\hline $\mathrm{Na}$ & 0,435 & 0,389 & 0,479 & 0,391 & 0,390 & 0,366 & 0,458 & 0,480 & 0,450 & 0,393 & 0,437 & 0,455 & 0,469 & 0,499 & 0,162 & 0,139 \\
\hline $\mathrm{K}$ & 3,476 & 3,495 & 3,409 & 3,495 & 3,574 & 3,613 & 3,476 & 3,333 & 3,402 & 3,522 & 3,562 & 3,482 & 3,437 & 3,439 & 3,746 & 3,804 \\
\hline$X$ & 4,004 & 3,955 & 3,957 & 3,972 & 3,987 & 4,003 & 3,956 & 3,933 & 3,945 & 3,925 & 4,015 & 3,987 & 3,981 & 4,009 & 3,920 & 3,959 \\
\hline$\Sigma$ & 19,986 & 19,957 & 19,961 & 19,975 & 19,982 & 19,983 & 19,958 & 19,949 & 19,950 & 19,946 & 20,005 & 19,985 & 19,981 & 20,010 & 19,939 & 19,944 \\
\hline \multicolumn{17}{|c|}{ Proporçôes moleculares } \\
\hline$A b$ & 10,2 & 9,3 & 11,4 & 9,3 & 9,3 & 8,6 & 11,0 & 11,5 & 10,7 & 9,5 & 10,3 & 10,8 & 11,1 & 11,7 & 3,9 & 3,3 \\
\hline$A n$ & 0,0 & 0,0 & 0,1 & 0,0 & 0,0 & 0,0 & 0,0 & 0,3 & 0,3 & 0,0 & 0,0 & 0,1 & 0,2 & 0,0 & 0,0 & 0,0 \\
\hline Or & 86,7 & 88,3 & 86,3 & 87,8 & 90,0 & 90,6 & 88,3 & 84,5 & 86,2 & 90,2 & 89,1 & 87,6 & 86,4 & 85,9 & 95,7 & 96,2 \\
\hline$C s$ & 3,1 & 2,4 & 2,2 & 2,9 & 0,8 & 0,8 & 0,8 & 3,7 & 2,8 & 0,4 & 0,6 & 1,6 & 2,4 & 2,4 & 0,4 & 0,5 \\
\hline $\mathrm{Ab}$ & 11,1 & 10,0 & 12,3 & 10,1 & 9,8 & 9,2 & 11,6 & 12,6 & 11,6 & 10,0 & 10,9 & 11,5 & 12,0 & 12,7 & 4,1 & 3,5 \\
\hline An & 0,0 & 0,0 & 0,1 & 0,0 & 0,0 & 0,0 & 0,0 & 0,3 & 0,3 & 0,0 & 0,0 & 0,1 & 0,2 & 0,0 & 0,0 & 0,0 \\
\hline Or & 88,9 & 90,0 & 87,6 & 89,9 & 90,2 & 90,8 & 88,4 & 87,2 & 88,1 & 90,0 & 89,1 & 88,4 & 87,9 & 87,3 & 95,9 & 96,5 \\
\hline
\end{tabular}


Tabela 5.3 (cont.): Resultados analíticos e cálculos de fórmula estrutural (32 O) para cristais de feldspato potássico do Complexo Cunhaporanga.

\begin{tabular}{|c|c|c|c|c|c|c|c|c|c|c|c|c|c|c|c|}
\hline & \multicolumn{11}{|c|}{ Domínios Petrográficos da porção NE do Complexo } & \multirow{3}{*}{\multicolumn{2}{|c|}{$\begin{array}{c}\text { GRANITO S. } \\
\text { DO CARAMBEÍ } \\
\text { af granito }\end{array}$}} & \multirow{2}{*}{\multicolumn{2}{|c|}{$\begin{array}{l}\text { GRANITO J. } \\
\text { MURTINHO }\end{array}$}} \\
\hline & \multirow{2}{*}{\multicolumn{2}{|c|}{$\begin{array}{c}\text { D.O.V.-P.S.A. } \\
\text { anf pórfiro }\end{array}$}} & \multirow{2}{*}{\multicolumn{5}{|c|}{$\begin{array}{c}\text { DOMÍNIO LIMEIRA } \\
\text { tit anf bio }\end{array}$}} & \multicolumn{4}{|c|}{ D. FR. SIMAS-V. BRANCA } & & & & \\
\hline & & & & & & & & tit bio & & mu bio & & & & afgr & anito \\
\hline & \multicolumn{2}{|c|}{ IT-96 } & \multicolumn{5}{|c|}{ IT-50b } & PS-63 & \multicolumn{3}{|c|}{ PS-130 } & \multicolumn{2}{|c|}{ JGA-23 I } & \multicolumn{2}{|c|}{ JM-97 } \\
\hline Local & $\mathrm{b}_{\mathrm{b}} \mathbf{1}$ & $b_{b} 2$ & $i_{a} 1$ & $\mathrm{i}_{\mathrm{a}} 2$ & $\mathrm{n}_{\mathrm{a}}$ & $b_{b}$ & $\mathbf{n}_{\mathbf{b}}$ & $\mathrm{n}$ & $b_{a}$ & $b_{b}$ & $n_{b}$ & $i_{a}$ & $\mathbf{i}_{\mathrm{b}}$ & $i_{a}$ & $i_{b}$ \\
\hline $\mathrm{SiO}_{2}$ & 64,08 & 65,61 & 64,56 & 64,88 & 64,06 & 64,50 & 63,73 & 63,83 & 64,38 & 64,52 & 63,96 & 64,30 & 63,66 & 63,96 & 63,95 \\
\hline $\mathrm{Al}_{2} \mathrm{O}_{3}$ & 18,52 & 18,25 & 18,52 & 18,52 & 18,57 & 18,73 & 19,01 & 18,35 & 18,38 & 18,14 & 18,21 & 17,89 & 17,91 & 17,72 & 17,98 \\
\hline $\mathrm{Fe}_{2} \mathrm{O}_{3}$ & 0,00 & 0,12 & 0,00 & 0,04 & 0,07 & 0,07 & 0,00 & 0,08 & 0,04 & 0,03 & 0,00 & 0,23 & 0,25 & 0,44 & 0,32 \\
\hline $\mathrm{CaO}$ & 0,02 & 0,00 & 0,02 & 0,05 & 0,01 & 0,00 & 0,00 & 0,01 & 0,00 & 0,01 & 0,00 & 0,00 & 0,00 & 0,00 & 0,00 \\
\hline $\mathrm{BaO}$ & 0,32 & 0,00 & 0,73 & 0,70 & 1,04 & 1,10 & 1,99 & 0,42 & 0,15 & 0,25 & 0,13 & 0,04 & 0,09 & 0,00 & 0,14 \\
\hline $\mathrm{Na}_{2} \mathrm{O}$ & 0,66 & 0,59 & 1,30 & 1,77 & 1,02 & 1,11 & 1,13 & 1,11 & 0,92 & 1,10 & 1,39 & 0,66 & 0,17 & 0,79 & 0,30 \\
\hline $\mathrm{K}_{2} \mathrm{O}$ & 15,63 & 16,08 & 14,35 & 13,87 & 15,09 & 14,98 & 14,46 & 15,23 & 16,30 & 15,53 & 15,54 & 16,23 & 16,90 & 16,11 & 16,80 \\
\hline Total & 99,21 & 100,64 & 99,48 & $\mathbf{9 9 , 8 3}$ & 99,85 & 100,48 & 100,32 & 99,03 & 100,17 & 99,58 & 99,23 & 99,35 & $\mathbf{9 8 , 9 8}$ & 99,02 & 99,49 \\
\hline \multicolumn{16}{|c|}{$O=32$} \\
\hline$\underline{\mathrm{Si}}$ & 11,946 & 12,035 & 11,970 & 11,971 & 11,914 & 11,913 & 11,844 & 11,932 & 11,928 & 11,987 & 11,940 & 11,993 & 11,960 & 11,981 & 11,959 \\
\hline $\mathrm{Al}$ & 4,066 & 3,943 & 4,043 & 4,023 & 4,067 & 4,073 & 4,161 & 4,041 & 4,010 & 3,968 & 4,002 & 3,929 & 3,964 & 3,908 & 3,960 \\
\hline $\mathrm{Fe}^{3+}$ & 0,000 & 0,017 & 0,000 & 0,006 & 0,010 & 0,010 & 0,000 & 0,011 & 0,005 & 0,005 & 0,000 & 0,033 & 0,035 & 0,062 & 0,045 \\
\hline$Z$ & 16,012 & 15,995 & 16,013 & 16,000 & 15,991 & 15,996 & 16,005 & 15,984 & 15,943 & 15,960 & 15,942 & 15,955 & 15,959 & 15,951 & 15,964 \\
\hline $\mathrm{Ca}$ & 0,003 & 0,000 & 0,005 & 0,009 & 0,002 & 0,000 & 0,000 & 0,002 & 0,000 & 0,002 & 0,000 & 0,000 & 0,000 & 0,000 & 0,000 \\
\hline $\mathrm{Ba}$ & 0,023 & 0,000 & 0,053 & 0,050 & 0,075 & 0,079 & 0,145 & 0,031 & 0,011 & 0,018 & 0,010 & 0,003 & 0,007 & 0,000 & 0,010 \\
\hline $\mathrm{Na}$ & 0,237 & 0,208 & 0,467 & 0,634 & 0,368 & 0,398 & 0,408 & 0,402 & 0,331 & 0,396 & 0,502 & 0,238 & 0,062 & 0,286 & 0,109 \\
\hline K & 3,716 & 3,763 & 3,394 & 3,265 & 3,579 & 3,530 & 3,429 & 3,633 & 3,853 & 3,680 & 3,702 & 3,862 & 4,051 & 3,849 & 4,008 \\
\hline$\underline{X}$ & 3,979 & 3,971 & 3,919 & 3,958 & 4,024 & 4,007 & 3,982 & 4,068 & 4,195 & 4,096 & 4,214 & 4,103 & 4,120 & 4,135 & 4,127 \\
\hline$\Sigma$ & 19,991 & 19,966 & 19,932 & 19,958 & 20,015 & 20,003 & 19,987 & 20,052 & 20,138 & 20,056 & 20,156 & 20,058 & 20,079 & 20,086 & 20,091 \\
\hline \multicolumn{16}{|c|}{ Proporções moleculares } \\
\hline$A b$ & 5,6 & 5,0 & 11,3 & 15,2 & 8,6 & 9,3 & 9,6 & 9,3 & 7,5 & 9,2 & 11,3 & 5,5 & 1,4 & 6,5 & 2,5 \\
\hline $\boldsymbol{A n}$ & 0,1 & 0,0 & 0,1 & 0,2 & 0,1 & 0,0 & 0,0 & 0,1 & 0,0 & 0,0 & 0,0 & 0,0 & 0,0 & 0,0 & 0,0 \\
\hline Or & 93,5 & 95,1 & 86,8 & 82,9 & 88,8 & 88,0 & 85,6 & 89,6 & 92,2 & 90,2 & 88,4 & 94,4 & 98,4 & 93,5 & 97,2 \\
\hline Cs & 0,8 & 0,0 & 1,8 & 1,7 & 2,5 & 2,7 & 4,9 & 1,0 & 0,4 & 0,6 & 0,3 & 0,1 & 0,2 & 0,0 & 0,3 \\
\hline $\mathrm{Ab}$ & 6,0 & 5,2 & 12,1 & 16,2 & 9,3 & 10,1 & 10,6 & 10,0 & 7,9 & 9,7 & 11,9 & 5,8 & 1,5 & 6,9 & 2,6 \\
\hline An & 0,1 & 0,0 & 0,1 & 0,2 & 0,1 & 0,0 & 0,0 & 0,0 & 0,0 & 0,0 & 0,0 & 0,0 & 0,0 & 0,0 & 0,0 \\
\hline Or & 93,9 & 94,8 & 87,8 & 83,5 & 90,6 & 89,9 & 89,4 & 90,0 & 92,1 & 90,2 & 88,1 & 94,2 & 98,5 & 93,1 & 97,4 \\
\hline
\end{tabular}

Observações: As proporções moleculares $\boldsymbol{A b}, \boldsymbol{A n}, \boldsymbol{O r}$ e $\boldsymbol{C s}$ foram calculadas considerando-se a existência da molécula de celsiana $\left(\mathrm{BaAl}_{2} \mathrm{Si}_{2} \mathrm{O}_{8}\right)$, ao contrário do cálculo efetuado para Ab, An e Or. Demais observaçōes, ver Tabela 5.2. 
Tabela 5.4: Valores referentes aos teores de $\mathrm{Ba}$ (porcentagem de $\mathrm{BaO}$, teores em ppm e proporção da molécula celsiana, $C s$ ) e da molécula $A b$ dos feldspatos potássicos (FK) dos diferentes tipos granitóides do Complexo (inclusive teores de Ba, em ppm, para estas rochas). $N=$ número de análises de FK para cada tipo de rocha; $n=$ número de análises para cada litotipo.

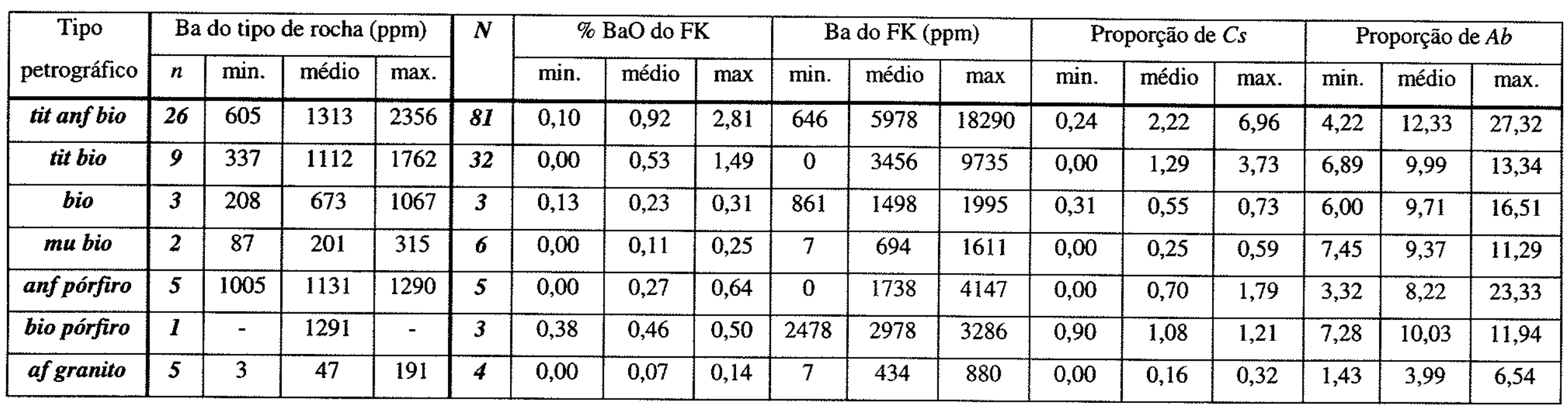

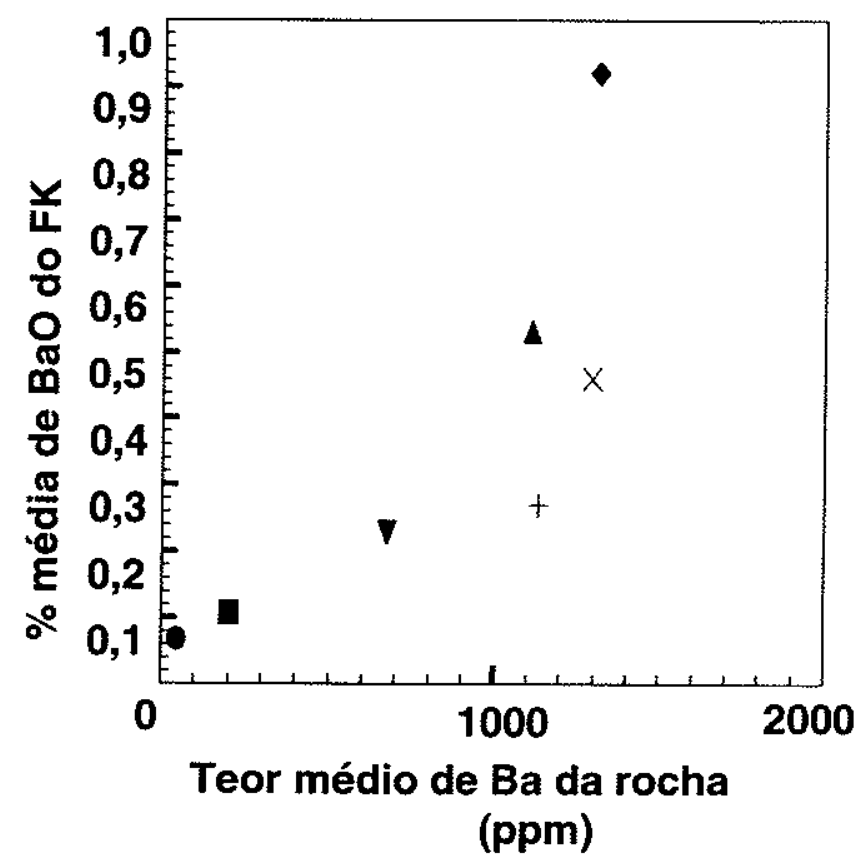

Figura 5.8: Teor médio de $\mathrm{Ba}(\mathrm{ppm})$ nos diferentes tipos de granitóides do Complexo vs porcentagem média de $\mathrm{BaO}$ dos feldspatos potássicos destes mesmos litotipos (símbolos como na Figura 5.1).

(ppm) 
Tabela 5.5: Resultados analíticos e cálculos de fórmula estrutural $(6 \mathrm{O})$ para piroxênios do Complexo Granítico Cunhaporanga.

\begin{tabular}{|c|c|c|c|c|c|c|c|c|}
\hline & \multicolumn{2}{|c|}{ SC-77 } & \multicolumn{6}{|c|}{ PS-92a ${ }^{\mathrm{E}}$} \\
\hline Local & n 1 & n 2 & $\mathrm{~b}_{\mathrm{a}}$ & $i_{a}$ & $\mathrm{n}_{\mathrm{a}}$ & $b_{b}$ & $\mathrm{n}_{\mathrm{b}} 1$ & $n_{b} 2$ \\
\hline $\mathrm{SiO}_{2}$ & 52,26 & 51,73 & 53,05 & 53,04 & 53,18 & 52,95 & 52,87 & 52,48 \\
\hline $\mathrm{TiO}_{2}$ & 0,14 & 0,31 & 0,13 & 0,03 & 0,03 & 0,08 & 0,10 & 0,10 \\
\hline $\mathrm{Al}_{2} \mathrm{O}_{3}$ & 1,48 & 2,21 & 0,55 & 0,42 & 0,44 & 0,55 & 0,60 & 0,79 \\
\hline $\mathrm{FeO}^{\mathrm{T}}$ & 9,46 & 9,96 & 10,84 & 10,26 & 9,74 & 10,29 & 10,26 & 11,11 \\
\hline $\mathrm{MnO}$ & 0,64 & 0,64 & 0,33 & 0,37 & 0,42 & 0,41 & 0,48 & 0,46 \\
\hline $\mathrm{MgO}$ & 13,75 & 13,32 & 13,09 & 13,26 & 12,49 & 12,73 & 12,87 & 12,63 \\
\hline $\mathrm{CaO}$ & 22,49 & 21,68 & 21,91 & 22,29 & 23,21 & 22,71 & 22,20 & 21,87 \\
\hline $\mathrm{Na}_{2} \mathrm{O}$ & 0,46 & 0,57 & 0,36 & 0,28 & 0,27 & 0,26 & 0,31 & 0,32 \\
\hline $\mathrm{K}_{2} \mathrm{O}$ & 0,05 & 0,05 & 0,00 & 0,02 & 0,00 & 0,00 & 0,00 & 0,00 \\
\hline Total & 100,72 & 100,45 & 100,27 & 99,96 & 99,79 & 99,99 & 99,68 & 99,76 \\
\hline \multicolumn{9}{|c|}{$O=6$} \\
\hline $\mathrm{Si}$ & 1,934 & 1,922 & 1,986 & 1,989 & 2,002 & 1,990 & 1,991 & 1,980 \\
\hline & 0,064 & 0,078 & 0,014 & 0,011 & 0,000 & 0,010 & 0,009 & 0,020 \\
\hline $\mathrm{Fe}^{3+} \mathrm{T}$ & 0,002 & 0,000 & 0,000 & 0,000 & 0,000 & 0,000 & 0,000 & 0,000 \\
\hline $\mathrm{Al}{ }^{\mathrm{MI}}$ & 0,000 & 0,018 & 0,010 & 0,008 & 0,020 & 0,015 & 0,018 & 0,015 \\
\hline $\mathrm{Ti}{ }^{\mathrm{MI}}$ & 0,004 & 0,009 & 0,004 & 0,001 & 0,001 & 0,002 & 0,003 & 0,003 \\
\hline $\mathrm{Fe}^{3+\mathrm{MI}}$ & 0,093 & 0,085 & 0,022 & 0,022 & 0,000 & 0,009 & 0,008 & 0,024 \\
\hline $\mathrm{Fe}^{2+\mathrm{MI}}$ & 0,144 & 0,150 & 0,233 & 0,228 & 0,278 & 0,261 & 0,249 & 0,249 \\
\hline $\mathrm{Mg}^{\mathrm{MI}}$ & 0,758 & 0,738 & 0,731 & 0,741 & 0,701 & 0,713 & 0,722 & 0,710 \\
\hline $\mathrm{Fe}^{2+\mathrm{M} 2}$ & 0,053 & 0,074 & 0,084 & 0,072 & 0,028 & 0,054 & 0,066 & 0,078 \\
\hline $\mathrm{Mn}^{\mathrm{M} 2}$ & 0,020 & 0,020 & 0,010 & 0,012 & 0,013 & 0,013 & 0,015 & 0,015 \\
\hline $\mathrm{Ca}{ }^{\mathrm{M} 2}$ & 0,892 & 0,863 & 0,879 & 0,896 & 0,936 & 0,915 & 0,896 & 0,884 \\
\hline $\mathrm{Na}{ }^{\mathrm{M} 2}$ & 0,033 & 0,041 & 0,026 & 0,020 & 0,020 & 0,019 & 0,023 & 0,024 \\
\hline $\mathrm{K}^{\mathrm{M} 2}$ & 0,002 & 0,002 & 0,000 & 0,001 & 0,000 & 0,000 & 0,000 & 0,000 \\
\hline$\Sigma^{T-M 2}$ & 3,998 & 3,998 & 4,000 & 3,999 & 4,000 & 4,000 & 4,000 & 4,000 \\
\hline$m g^{\#}$ & 0,79 & 0,77 & 0,70 & 0,71 & 0,70 & 0,69 & 0,70 & 0,68 \\
\hline
\end{tabular}

Observaçōes: Análises efetuadas em piroxênios situados em um núcleo de anfibólio (cristal "a" da amostra SC-77, um titanita anfibólio biotita granitóide; Tabela 5.6) e em um enclave diorítico (PS-92a). Os símbolos M1, M2 e T referem-se às posiçōes cristalográficas da fórmula padrão do piroxênio $(\mathrm{M} 2, \mathrm{M} 1) \mathrm{TO}_{3} \cdot \mathrm{FeO}^{\mathrm{T}}$ tal como obtido na microssonda eletrônica; $\boldsymbol{m g}{ }^{\#}=\mathrm{Mg} /\left(\mathrm{Mg}+\mathrm{Fe}^{2+}\right)$. Demais observações, ver Tabela 5.2. 
Tabela 5.6: Resultados analíticos e cálculos de fórmula estrutural $(23 \mathrm{O})$ para cristais de anfibólio do Complexo Granítico Cunhaporanga.

\begin{tabular}{|c|c|c|c|c|c|c|c|c|c|c|c|c|c|c|c|c|c|}
\hline \multirow[b]{4}{*}{ Local } & \multicolumn{17}{|c|}{ Dominios Petrográficos da porção S/SE do Complexo } \\
\hline & \multicolumn{17}{|c|}{ DOMINNIO ABAPÃ-SANTA QUITÉRIA } \\
\hline & \multicolumn{3}{|c|}{ ITA-4-36 } & \multicolumn{3}{|c|}{ PS-21 } & \multicolumn{4}{|c|}{ PS-54 } & \multicolumn{4}{|c|}{ PS-76a } & \multicolumn{3}{|c|}{ PS-78 } \\
\hline & $\mathrm{b}$ & $\mathrm{i}$ & $\mathbf{n}$ & $\mathrm{b}_{\mathrm{a}}$ & $\mathrm{n}_{\mathrm{a}}$ & $b_{b}$ & $\mathrm{~b}_{\mathrm{a}}$ & $\mathrm{n}_{\mathrm{a}}$ & $i_{b}$ & $\mathrm{n}_{b}$ & $\mathrm{~b}_{\mathrm{a}}$ & $\mathrm{n}_{\mathrm{a}}$ & $\mathrm{b}_{\mathrm{b}}$ & $\mathbf{n}_{b}$ & $\mathrm{~b}_{\mathrm{a}}$ & $b_{b}$ & $\mathbf{n}_{\mathrm{b}}$ \\
\hline $\mathrm{SiO}_{2}$ & 46,91 & 47,07 & 46,65 & 44,38 & 42,34 & 45,31 & 41,99 & 42,64 & 45,56 & 45,05 & 44,11 & 43,14 & 43,32 & 45,00 & 46,73 & 47,29 & 45,93 \\
\hline $\mathrm{TiO}_{2}$ & 0,86 & 0,62 & 0,72 & 0,50 & 0,57 & 0,71 & 0,89 & 0,95 & 0,77 & 52 & 0,86 & 0,88 & 0,97 & 1,14 & 0,80 & 0,79 & 1,08 \\
\hline $\mathrm{Al}_{2} \mathrm{O}_{3}$ & 7,27 & 7,42 & 7,55 & 9,53 & 15,67 & 8,85 & 10,82 & 10,32 & 8,01 & 8,63 & 9,72 & 10,16 & 9,52 & 8,45 & 7,58 & 7,19 & 8,30 \\
\hline $\mathrm{FeO}^{\mathrm{T}}$ & 15,62 & 15,72 & 15,94 & 17,37 & 15,36 & 16,62 & 19,27 & 18,82 & 17,19 & 17,95 & 17,46 & 17,91 & 17,62 & 17,06 & 16,31 & 15,91 & 16,70 \\
\hline $\mathrm{MnO}$ & 0,39 & 0,35 & 0,37 & 0,34 & 0,32 & 0,36 & 0,37 & 0,34 & 0,37 & 0,39 & 0,42 & 0,39 & 0,40 & 0,38 & 0,48 & 0,48 & 0,43 \\
\hline $\mathrm{MgO}$ & 12,68 & 12,68 & 12,32 & 11,41 & 10,82 & 11,85 & 9,25 & 9,69 & 11,35 & 10,78 & 10,47 & 10,39 & 10,47 & 11,38 & 12,29 & 12,62 & 11,83 \\
\hline $\mathrm{CaO}$ & 12,00 & 12,02 & 11,85 & 12,04 & 11,17 & 11,97 & 11,79 & 11,83 & 12,08 & 11,96 & 11,74 & 11,82 & 11,84 & 11,87 & 12,06 & 11,98 & 11,91 \\
\hline $\mathrm{Na}_{2} \mathrm{O}$ & 1 & & 1,18 & 1,23 & 1,09 & 1,19 & 1,44 & & 1,21 & & 1,27 & 1,31 & 30 & & 1,16 & 1,16 & 1,30 \\
\hline $\mathrm{K}_{2} \mathrm{O}$ & 0 & 0,8 & & 1,02 & 0,88 & 0,92 & 1,34 & 29 & 1,89 & 89 & 1,06 & 1,22 & 13 & 96 & 0,85 & 0,76 &, 92 \\
\hline$F$ & 0 & & & 0,24 & 0,30 & 0,15 & 0,13 & 0,06 & 0,05 & 18 & 0,17 & 0,14 & 1,11 & 0,06 & 0,15 & 0,34 & 0,24 \\
\hline $\mathrm{Cl}$ & 0 & 0,00 & 0 , & 0,03 & 0,02 & 0,02 & 0,06 & 0,06 & 0,02 & 0,03 & 0,07 & 0,03 & 0,09 & 0,10 & 0,02 & 0,03 & 0,02 \\
\hline Total & 97,90 & 98,06 & 97,76 & 98,07 & 98,54 & 97,95 & 97,35 & 97,41 & \begin{tabular}{|l}
97,49 \\
\end{tabular} & 97,47 & 97,35 & 97,38 & 96,76 & 97,60 & 98,41 & 98,55 & 98,66 \\
\hline \multicolumn{18}{|c|}{$O=23$} \\
\hline Si & 6,898 & 6,905 & 6,885 & 6,572 & 6,084 & 6,683 & 6,376 & 6,446 & 6,795 & 6,730 & 6,608 & 6,480 & 6,552 & 6,697 & 6,854 & 6,917 & 6,748 \\
\hline $\mathrm{Al}$ & 1,102 & 1,095 & 1,115 & 1,428 & 1,916 & 1,317 & 1,624 & 1,554 & 1,205 & 1,270 & 1,392 & 1,520 & 1,448 & 1,30 & 1,146 & 1,083 & 1,252 \\
\hline & 0,157 & 0,187 & 0,196 & 0,234 & 0,735 & 0,221 & 0,310 & 0,284 & 0,201 & 0,248 & 0,324 & 0,276 & 0,247 & 0,1 & 0,164 & 0,156 & 0,184 \\
\hline $\mathrm{Fe}^{3+\mathrm{C}}$ & 0,483 & 0,486 & 0,519 & 0,716 & 1,153 & 0,642 & 0,590 & 0,556 & 0,455 & 0,594 & 0,533 & 0,625 & 0,546 & 0,5 & 0,526 & 0,527 & 0,538 \\
\hline $\mathrm{Ti}{ }^{C}$ & 0,095 & 0,068 & 0,079 & 0,056 & 0,061 & 0,079 & 0,102 & 0,108 & 0,086 & 0,059 & 0,097 & 0,100 & 0,111 & 0,127 & 0,088 & 0,087 & 0,119 \\
\hline $\mathrm{Mg}^{\mathrm{C}}$ & 2,779 & 2,772 & 2,711 & 2,518 & 2,319 & 2,606 & 2,094 & 2,185 & 2,522 & 2,401 & 2,339 & 2,325 & 2,362 & 2,524 & 2,688 & 2,752 & 2,591 \\
\hline $\mathrm{Fe}^{2+\mathrm{C}}$ & 1,437 & 1,443 & 1,449 & 1,435 & 0,693 & 1,408 & 1,856 & 1,824 & 1,689 & 1,649 & 1,654 & 1,624 & 1,683 & 1,569 & 1,475 & 1,420 & 1,514 \\
\hline Mn C & 0,048 & 0,044 & 0,047 & 0,042 & 0,039 & 0,045 & 0,047 & 0,043 & 0,052 & 0,049 & 0,053 & 0,049 & 0,051 & 0,048 & 0,060 & 0,059 & 0,053 \\
\hline $\mathrm{Ca}{ }^{\mathrm{B}}$ & 1,891 & 1,889 & 1,874 & 1,910 & 1,720 & 1,891 & 1,918 & 1,917 & 1,989 & 1,914 & 1,885 & 1,902 & 1,918 & 1,893 & 1,896 & 1,878 & 1,874 \\
\hline $\mathrm{Na}$ & 0,109 & 0,111 & 0,126 & 0,090 & 0,280 & 0,109 & 0,082 & 0,083 & 0,047 & 0,086 & 0,115 & 0,098 & 0,082 & 0,107 & 0,104 & 0,122 & 0,126 \\
\hline $\mathrm{Ca}$ & 0,000 & 0,000 & 0,000 & 0,000 & 0,000 & 0,000 & 0,000 & 0,000 & 0,000 & 0,000 & 0,000 & 0,000 & 0,000 & 0,000 & 0,000 & 0,000 & 0,000 \\
\hline $\mathrm{Na}$ & 0,245 & 0,242 & 0,210 & 0,265 & 0,024 & 0,232 & 0,343 & 0,333 & 0,279 & 0,228 & 0,254 & 0,285 & 0,298 & 0,240 & 0,225 & 0,207 & 0,244 \\
\hline & 0,135 & 0,155 & 0,158 & 0,193 & 0,162 & 0,173 & 0,260 & 0,248 & 0,169 & 0,169 & 0,202 & 0,233 & 0,218 & 0,183 & 0,159 & 0,141 & 0,173 \\
\hline$\Sigma^{T \cdot A}$ & 15,380 & 15,397 & 15,368 & 15,457 & 15,186 & 15,405 & 15,603 & 15,581 & 15,448 & 15,397 & 15,456 & 15,518 & 15,516 & 15,423 & 15,384 & 15,349 & 15,417 \\
\hline Nome & & $\mathrm{Mg}-\mathrm{Hbl}$ & & $\mathrm{Mg}-\mathrm{Hbl}$ & Tsch & Mg-Hbl & $M g$. & & $M g-h$ & $\mathrm{Hbl}$ & $\mathbf{M g}-\mathrm{Hbl}$ & Mg-Hst & $E d n$ & $\mathrm{Mg}-\mathrm{Hbl}$ & & $\mathrm{Mg}-\mathrm{Hbl}$ & \\
\hline & 0,66 & 0,66 & 0,65 & 0,64 & 0,77 & 0,65 & 0,53 & 0,55 & 0,60 & 0,55 & 0,59 & 0,59 & 0,58 & 0,62 & 0,65 & 0,66 & 0,63 \\
\hline
\end{tabular}


Tabela 5.6 (cont.): Resultados analíticos e cálculos de fórmula estrutural $(23 \mathrm{O})$ para cristais de anfibólio do Complexo Granítico Cunhaporanga.

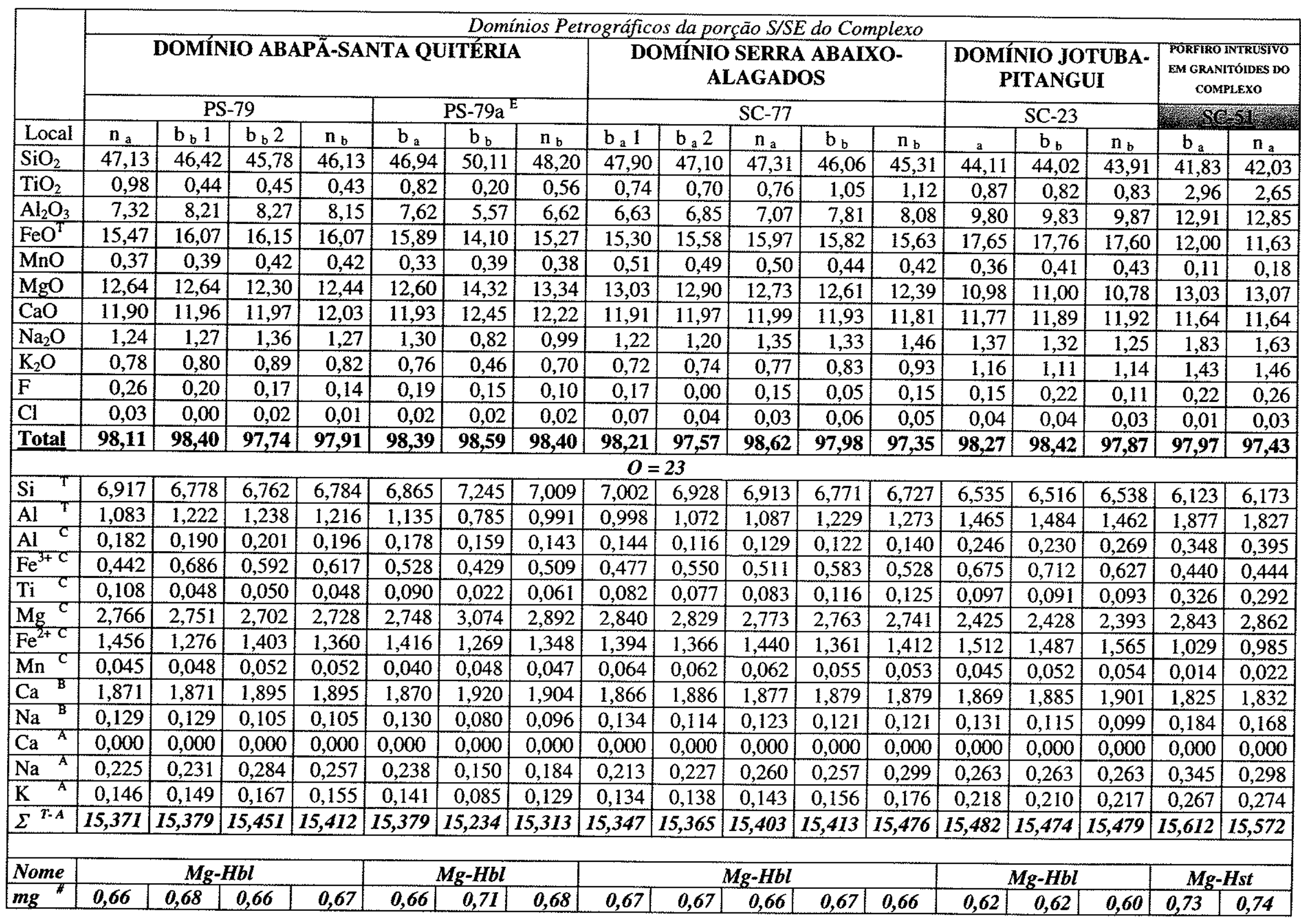


Tabela 5.6 (cont.): Resultados analíticos e cálculos de fórmula estrutural $(23 \mathrm{O})$ para cristais de anfibólio do Complexo Granítico Cunhaporanga.

\begin{tabular}{|c|c|c|c|c|c|c|c|c|c|c|c|c|c|c|c|c|c|}
\hline \multirow[b]{4}{*}{ Loc } & \multirow{3}{*}{\multicolumn{2}{|c|}{\begin{tabular}{|c}
$D, P, S / S E$ \\
$\begin{array}{c}\text { PORFIRO INTRUSIVO } \\
\text { EM GRANITÓIDES DO } \\
\text { COMPLEXO }\end{array}$ \\
SCST
\end{tabular}}} & \multicolumn{15}{|c|}{ Domínios Petrográficos da porçāo centro norte do Complexo } \\
\hline & & & \multicolumn{9}{|c|}{ DOMÍNIO BISCAIAS-BOA VISTA } & \multicolumn{6}{|c|}{ DOMÍNIO ESPIGÃO ALTO } \\
\hline & & & \multicolumn{3}{|c|}{ JGA-35 } & \multicolumn{3}{|c|}{ JGA-41 } & \multicolumn{3}{|c|}{ PS-36 } & \multicolumn{3}{|c|}{ JGA-4c } & \multicolumn{3}{|c|}{ JGA-17 } \\
\hline & $\mathrm{b}_{\mathrm{b}}$ & $\mathbf{n}_{\mathrm{b}}$ & $\mathrm{b}_{\mathrm{a}}$ & $\mathbf{n}_{\mathrm{a}}$ & $\mathrm{n}_{\mathrm{b}}$ & $\mathrm{n}_{\mathrm{a}}$ & $\mathrm{b}_{\mathrm{b}}$ & $\mathbf{n}_{\mathrm{b}}$ & $\mathrm{n}_{\mathrm{a}}$ & $\mathrm{b}_{\mathrm{b}}$ & $\mathrm{n}_{\mathrm{b}}$ & $\mathbf{n}_{\mathbf{a}}$ & $\mathbf{b}_{\mathrm{b}}$ & $\mathrm{n}_{\mathrm{b}}$ & $\mathrm{b}_{\mathrm{a}}$ & $\mathbf{n}_{\mathrm{a}}$ & $\mathrm{b}_{\mathrm{b}}$ \\
\hline $\mathrm{SiO}_{2}$ & 42,85 & 43,05 & 44,80 & 45,66 & 44,58 & 46,08 & 45,42 & 45,60 & 45,39 & 44,70 & 45,87 & 44,22 & 44,10 & 43,34 & 45,51 & 45,45 & 45,09 \\
\hline $\mathrm{TiO}_{2}$ & 1,81 & 1,85 & 0,79 & 0,75 & 0,60 & 0,82 & 0,99 & 0,91 & 0,90 & 0,74 & 0,90 & 1,28 & 1,19 & 1,36 & 0,82 & 0,95 & 0,75 \\
\hline $\mathrm{Al}_{2} \mathrm{O}_{3}$ & 11,25 & 10,50 & 9,38 & 8,68 & 9,34 & 7,54 & 8,45 & 8,18 & 8,22 & 8,86 & 7,90 & 9,13 & 9,02 & 9,53 & 8,47 & 8,11 & 8,06 \\
\hline $\mathrm{FeO}^{\mathrm{T}}$ & 15,23 & 15,44 & 17,18 & 16,73 & 17,51 & 15,90 & 16,73 & 16,24 & 16,00 & 16,87 & 16,24 & 17,09 & 17,48 & 17,56 & 17,09 & 16,14 & 17,49 \\
\hline $\mathrm{MnO}$ & 0,31 & 0,33 & 0,42 & 0,41 & 0,40 & 0,49 & 0,55 & 0,55 & 0,67 & 0,63 & 0,64 & 0,61 & 0,56 & 0,56 & 0,70 & 0,60 & 0,70 \\
\hline $\mathrm{MgO}$ & 11,78 & 11,89 & 11,33 & 11,64 & 11,25 & 12,55 & 11,57 & 11,74 & 12,02 & 11,26 & 12,09 & 11,01 & 10,98 & 10,91 & 11,37 & 11,93 & 11,00 \\
\hline $\mathrm{CaO}$ & 11,70 & 11,58 & 12,06 & 11,93 & 11,92 & 11,86 & 11,68 & 11,73 & 11,83 & 11,67 & 11,84 & 11,78 & 11,74 & 11,60 & 12,02 & 11,72 & 11,79 \\
\hline $\mathrm{Na}_{2} \mathrm{O}$ & 1,72 & 1,53 & 1,34 & 1,16 & 1,34 & 1,42 & 1,47 & 1,60 & 1,43 & 1,50 & 1,38 & 1,34 & 1,40 & 1,45 & 1,39 & 1,37 & 1,39 \\
\hline $\mathrm{K}_{2} \mathrm{O}$ & 1,11 & 1,10 & 1,02 & 0,90 & 1,07 & 0,93 & 1,10 & 1,0 & 0,96 & 1,03 & 0,99 & 1,1 & 1,16 & 1,29 & 0,97 & 1,12 & 1,01 \\
\hline$F$ & 0,15 & 0,02 & 0,25 & 0,19 & 0,19 & 0,31 & 0,23 & 0,14 & 0,38 & 0,40 & 0,40 & 0,2 & 0,32 & 0,24 & 0,18 & 0,24 & 0,21 \\
\hline $\mathrm{Cl}$ & 0,03 & 0,04 & 0,04 & 0,03 & 0,06 & 0,06 & 0,06 & 0,06 & 0,06 & 0,04 & 0,02 & 0,09 & 0,07 & 0,10 & 0,05 & 0,02 & 0,02 \\
\hline Total & 97,94 & 97,33 & 98,61 & 98,07 & 98,25 & 97,96 & 98,24 & 97,74 & 97,84 & 97,70 & 98,26 & 97,96 & 98,02 & 97,93 & 98,57 & 97,63 & 97,49 \\
\hline \multicolumn{18}{|c|}{$O=23$} \\
\hline $\mathrm{Si}$ & 6,328 & 6,380 & 6,614 & 6,735 & 6,603 & 6,808 & 6,724 & 6,778 & 6,735 & 6,670 & 6,777 & 6,596 & 6,584 & 6,475 & 6,727 & 6,753 & 6,756 \\
\hline $\mathrm{Al}$ & 1,672 & 1,620 & 1,386 & 1,265 & 1,397 & 1,192 & 1,276 & 1,222 & 1,265 & 1,330 & 1,223 & 1,404 & 1,416 & 1,525 & 1,273 & 1,247 & 1,244 \\
\hline $\mathrm{Al}{ }^{\mathrm{C}}$ & 0,285 & 0,213 & 0,245 & 0,243 & 0,231 & 0,120 & 0,196 & 0,210 & 0,171 & 0,227 & 0,150 & 0,200 & 0,169 & 0,152 & 0,202 & 0,171 & 0,179 \\
\hline $\mathrm{Fe}^{3+\mathrm{C}}$ & 0,582 & 0,667 & 0,575 & 0,584 & 0,664 & 0,554 & 0,524 & 0,420 & 0,539 & 0,578 & 0,546 & 0,552 & 0,596 & 0,690 & 0,500 & 0,524 & 0,516 \\
\hline & 0,201 & 0,213 & 0,087 & 0,084 & 0,067 & 0,091 & 0,110 & 0,102 & 0,100 & 0,083 & 0,099 & 0,143 & 0,134 & 0,152 & 0,091 & 0,107 & 0,084 \\
\hline $\mathrm{Mg}^{\mathrm{C}}$ & 2,594 & 2,667 & 2,494 & 2,559 & 2,484 & 2,763 & 2,554 & 2,600 & 2,660 & 2,505 & 2,664 & 2,448 & 2,444 & 2,431 & 2,506 & 2,641 & 2,456 \\
\hline $\mathrm{Fe}^{2+\mathrm{C}}$ & 1,300 & 1,206 & 1,546 & 1,480 & 1,505 & 1,411 & 1,547 & 1,599 & 1,446 & 1,527 & 1,460 & 1,580 & 1,586 & 1,503 & 1,613 & 1,481 & 1,676 \\
\hline $\mathrm{Mn} \mathrm{C}^{\mathrm{C}}$ & 0,039 & 0,026 & 0,052 & 0,051 & 0,050 & 0,062 & 0,068 & 0,069 & 0,084 & 0,080 & 0,080 & 0,077 & 0,071 & 0,071 & 0,088 & 0,076 & 0,089 \\
\hline $\mathrm{Ca}^{\mathrm{B}}$ & 1,851 & 1,839 & 1,907 & 1,886 & 1,891 & 1,878 & 1,853 & 1,868 & 1,880 & 1,865 & 1,873 & 1,882 & 1,879 & 1,856 & 1,904 & 1,866 & 1,893 \\
\hline $\mathrm{Na}$ & 0,149 & 0,161 & 0,093 & 0,114 & 0,109 & 0,122 & 0,147 & 0,132 & 0,120 & 0,135 & 0,127 & 0,118 & 0,121 & 0,144 & 0,096 & 0,134 & 0,107 \\
\hline $\mathrm{Ca}$ & 0,000 & 0,000 & 0,000 & 0,000 & 0,000 & 0,000 & 0,000 & 0,000 & 0,000 & 0,000 & 0,000 & 0,000 & 0,000 & 0,000 & 0,000 & 0,000 & 0,000 \\
\hline $\mathrm{Na}{ }^{A}$ & 0,343 & 0,279 & 0,292 & 0,216 & 0,275 & 0,283 & 0,275 & 0,330 & 0,293 & 0,299 & 0,269 & 0,268 & 0,284 & 0,276 & 0,302 & 0,261 & 0,296 \\
\hline & 0,209 & 0,208 & 0,192 & \begin{tabular}{|l|}
0,169 \\
\end{tabular} & 0,202 & 0,176 & 0,207 & 0,190 & 0,181 & 0,196 & 0,186 & 0,215 & 0,220 & 0,245 & 0,183 & 0,213 & 0,192 \\
\hline$\Sigma^{T \cdot A}$ & 15,552 & 15,487 & 15,484 & 15,385 & 15,477 & 15,459 & 15,482 & 15,520 & 15,474 & 15,495 & 15,455 & 15,483 & 15,505 & 15,521 & 15,485 & 15,474 & 15,488 \\
\hline Nome & Mg-Hst & Tsch & & $\mathrm{Mg}-\mathrm{Hbl}$ & & $M g-1$ & $\mathrm{Hbl}$ & $E d n$ & & $M g-H b l$ & & $\mathrm{Mg}-\mathrm{Hbl}$ & $E d n$ & Mg-Hst & & $M g-H b l$ & \\
\hline$m g$ & 0,67 & 0,68 & 0,62 & 0,63 & 0,62 & 0,66 & 0,62 & 0,62 & 0,65 & 0,62 & 0,65 & 0,61 & 0,61 & 0,62 & 0,61 & 0,64 & 0,59 \\
\hline
\end{tabular}


Tabela 5.6 (cont.): Resultados analíticos e cálculos de fórmula estrutural $(23 \mathrm{O})$ para cristais de anfibólio do Complexo Granítico Cunhaporanga.

\begin{tabular}{|c|c|c|c|c|c|c|c|c|c|c|c|c|c|c|c|c|c|}
\hline \multirow[b]{4}{*}{ Local } & \multicolumn{17}{|c|}{ Domínios Petrográficos da porçâa centro-norte do Complexo } \\
\hline & \multicolumn{17}{|c|}{ DOMÍNIO ESPIGÃO ALTO } \\
\hline & \multirow{2}{*}{$\frac{\mathrm{JGA}-17}{\mathrm{n}_{\mathrm{b}}}$} & \multicolumn{3}{|c|}{ JGA-42b } & \multicolumn{4}{|c|}{ JGA-43b } & \multicolumn{7}{|c|}{$P S-92 a^{E}$} & \multicolumn{2}{|c|}{ PS-93 } \\
\hline & & $\mathbf{n}_{\mathbf{a}}$ & $\mathrm{b}_{\mathrm{b}}$ & $\mathrm{n}_{\mathrm{b}}$ & $b_{a}$ & $\mathbf{n}_{\mathrm{a}}$ & $\mathrm{b}_{\mathrm{b}}$ & $n_{b}$ & $b_{a}$ & $\mathrm{n}_{\mathrm{a}}$ & $b_{b}$ & $\mathrm{n}_{\mathrm{b}}$ & $b_{c}$ & $n_{c} 1$ & $\mathrm{n}_{\mathrm{c}} 2$ & $\mathrm{~b}$ & $\mathrm{n}$ \\
\hline $\mathrm{SiO}_{2}$ & 44,80 & 45,48 & 46,60 & 46,21 & 46,28 & 46,09 & 44,58 & 45,97 & 51,02 & 50,32 & 49,47 & 50,20 & 50,20 & 49,26 & 49,63 & 44,61 & 44,48 \\
\hline $\mathrm{TiO}_{2}$ & 0,78 & 0,83 & 1,06 & 0,66 & 0,56 & 0,83 & 0,87 & 0,82 & 0,70 & 0,97 & 0,93 & 0,95 & 0,17 & 0,20 & 0,23 & 1,37 & 1,42 \\
\hline $\mathrm{Al}_{2} \mathrm{O}_{3}$ & 8,52 & 7,94 & 7,25 & 7,56 & 9,92 & 8,45 & 9,14 & 8,11 & 4,04 & 4,47 & 5,35 & 4,57 & 4,68 & 5,30 & 4,95 & 8,63 & 9,08 \\
\hline $\mathrm{FeO}^{\mathrm{T}}$ & 18,05 & 16,98 & 16,24 & 16,30 & 15,67 & 16,40 & 17,46 & 16,90 & 14,38 & 14,51 & 15,20 & 14,75 & 15,80 & 16,07 & 15,81 & 16,91 & 17,26 \\
\hline $\mathrm{MnO}$ & 0,67 & 0,50 & 0,55 & 0,57 & 0,56 & 0,52 & 0,58 & 0,54 & 0,28 & 0,32 & 0,24 & 0,33 & 0,30 & 0,24 & 0,28 & 0,45 & 0,35 \\
\hline $\mathrm{MgO}$ & 11,09 & 12,05 & 12,34 & 12,32 & 10,12 & 11,72 & 11,15 & 12,02 & 14,42 & 14,21 & 13,35 & 14,15 & 13,44 & 12,93 & 13,43 & 11,19 & 10,99 \\
\hline $\mathrm{CaO}$ & 11,74 & 11,96 & 11,86 & 11,83 & 13,72 & 12,01 & 11,99 & 11,91 & 11,67 & 12,07 & 11,75 & 11,24 & 11,85 & 12,15 & 12,04 & 11,42 & 11,38 \\
\hline $\mathrm{Na}_{2} \mathrm{O}$ & 1,52 & 1,22 & 1,11 & 1,15 & 0,80 & 1,24 & 1,36 & 1,21 & 0,79 & 0,79 & 0,95 & 0,92 & 0,68 & 0,78 & 0,77 & 1,39 & 1,51 \\
\hline $\mathrm{K}_{2} \mathrm{O}$ & 0,95 & 0,87 & 0,80 & 0,67 & 0,56 & 0,86 & 1,01 & 0,87 & 0,38 & 0,41 & 0,49 & 0,46 & 0,28 & 0,31 & 0,28 & 1,00 & 0,91 \\
\hline$F$ & 0,47 & 0,29 & 0,20 & 0,20 & 0,22 & 0,26 & 0,11 & 0,35 & 0,24 & 0,24 & 0,00 & 0,16 & 0,38 & 0,23 & 0,24 & 0,53 & 0,47 \\
\hline $\mathrm{Cl}$ & 0,02 & 0,01 & 0,02 & 0,01 & 0,02 & 0,03 & 0,04 & 0,04 & 0,04 & 0,01 & 0,03 & 0,02 & 0,02 & 0,03 & 0,04 & 0,03 & 0,04 \\
\hline Total & 98,61 & 98,11 & 98,02 & 97,47 & 98,42 & 98,41 & 98,28 & 98,75 & 97,95 & 98,31 & $\mathbf{9 7 , 7 7}$ & 97,76 & 97,79 & 97,49 & 97,71 & 97,53 & 97,88 \\
\hline \multicolumn{18}{|c|}{$O=23$} \\
\hline $\mathrm{Si}$ & 6,648 & 6,716 & 6,854 & 6,820 & 6,912 & 6,786 & 6,607 & 6,740 & 7,365 & 7,202 & 7,278 & 7,251 & 7,305 & 7,231 & 7,240 & 6,666 & 6,620 \\
\hline $\mathrm{Al}$ & 1,352 & 1,284 & 1,146 & 1,180 & 1,088 & 1,214 & 1,393 & 1,2601 & 0,635 & 0,798 & 0,722 & 0,749 & 0,695 & 0,769 & 0,760 & 1,334 & 1,380 \\
\hline & 0,136 & 0,096 & 0,110 & 0,134 & 0,656 & 0,251 & 0,202 & 0,187 & 0,052 & 0,119 & 0,039 & 0,028 & 0,107 & 0,147 & 0,090 & 0,185 & 0,211 \\
\hline $\mathrm{Fe}^{3+\mathrm{C}}$ & 0,692 & 0,705 & 0,597 & 0,703 & 0,000 & 0,473 & 0,611 & 0,691 & 0,532 & 0,450 & 0,434 & 0,692 & 0,613 & 0,478 & 0,585 & 0,593 & 0,612 \\
\hline & 0,087 & 0,092 & 0,117 & 0,073 & 0,063 & 0,092 & 0,097 & 0,028 & 0,076 & 0,102 & 0,105 & 0,104 & 0,019 & 0,022 & 0,025 & 0,154 & 0,159 \\
\hline $\mathrm{Mg}^{\mathrm{C}}$ & 2,453 & 2,652 & 2,707 & 2,710 & 2,253 & 2,572 & 2,464 & 2,686 & 3,102 & 2,898 & 3,063 & 3,047 & 2,915 & 2,829 & 2,922 & 2,492 & 2,438 \\
\hline $\mathrm{Fe}^{2+\mathrm{C}}$ & 1,548 & 1,392 & 1,400 & 1,309 & 1,957 & 1,546 & 1,554 & 1,386 & 1,204 & 1,401 & 1,320 & 1,089 & 1,310 & 1,494 & 1,343 & 1,520 & 1,536 \\
\hline $\mathrm{Mn}^{\mathrm{C}}$ & 0,084 & 0,062 & 0,069 & 0,071 & 0,071 & 0,065 & 0,073 & 0,067 & 0,034 & 0,030 & 0,038 & 0,040 & 0,037 & 0,030 & 0,035 & 0,056 & 0,044 \\
\hline & 1,867 & 1,893 & 1,869 & 1,871 & 2,000 & 1,894 & 1,904 & 1,871 & 1,804 & 1,833 & 1,870 & 1,740 & 1,848 & 1,911 & 1,882 & 1,828 & 1,815 \\
\hline $\mathrm{Na}$ & 0,133 & 0,107 & 0,131 & 0,129 & 0,000 & 0,106 & 0,096 & 0,129 & 0,196 & $\begin{array}{l}0,167 \\
\end{array}$ & 0,130 & 0,258 & 0,152 & 0,089 & 0,118 & 0,172 & 0,185 \\
\hline $\mathrm{Ca}$ & 0,000 & 0,000 & 0,000 & 0,000 & 0,195 & 0,000 & 0,000 & 0,000 & 0,000 & 0,000 & 0,000 & 0,000 & 0,000 & 0,000 & 0,000 & 0,000 & 0,000 \\
\hline $\mathrm{Na}{ }^{A}$ & 0,304 & 0,242 & 0,186 & 0,200 & 0,232 & 0,249 & 0,293 & 0,216 & 0,026 & 0,101 & 0,092 & 0,000 & 0,039 & 0,132 & 0,100 & 0,230 & 0,252 \\
\hline & 0,180 & 0,164 & 0,150 & 0,126 & 0,107 & 0,161 & 0,190 & 0,163 & 0,069 & \begin{tabular}{l|}
0,091 \\
\end{tabular} & 0,076 & 0,084 & 0,051 & 0,057 & 0,052 & 0,191 & 0,173 \\
\hline$\Sigma^{T-A}$ & 15,484 & 15,406 & 15,336 & 15,326 & 15,534 & 15,410 & 15,484 & 15,379 & 15,095 & 15,192 & 15,169 & 15,082 & 15,091 & 15,189 & 15,152 & 15,421 & 15,424 \\
\hline Nome & $\mathrm{Mg}-\mathrm{Hbl}$ & & $\mathrm{Mg}-\mathrm{Hbl}$ & & & $M g-1$ & $\mathrm{Hbl}$ & & & & & $\mathrm{Mg}-\mathrm{Hbl}$ & & & & $M g_{-}$ & $H b l$ \\
\hline$m g^{*}$ & 0,61 & 0,66 & 0,66 & 0,67 & 0,54 & 0,62 & 0,61 & 0,65 & 0,72 & 0,67 & 0,70 & \begin{tabular}{|l|}
0,74 \\
\end{tabular} & 0,69 & 0,65 & 0,69 & 0,62 & 0,61 \\
\hline
\end{tabular}


Tabela 5.6 (cont.): Resultados analíticos e cálculos de fórmula estrutural $(23 \mathrm{O})$ para cristais de anfibólio do Complexo Granítico Cunhaporanga.

\begin{tabular}{|c|c|c|c|c|c|c|c|c|c|c|c|c|c|c|c|}
\hline & \multirow{2}{*}{\multicolumn{4}{|c|}{$\begin{array}{c}\text { Dom, Petrogr, centro-norte } \\
\text { DOM, PAREDÃO DA SANTA }\end{array}$}} & \multicolumn{11}{|c|}{ Domínios Petrográficos da porçāo NE do Complexo } \\
\hline & & & & & \multicolumn{5}{|c|}{ DOM, O, VERDE-P, S, ANTÔNIO } & \multicolumn{6}{|c|}{\begin{tabular}{|c|} 
DOMINIO LIMEIRA \\
\end{tabular}} \\
\hline & \multicolumn{4}{|c|}{ JGA-1 } & \multicolumn{5}{|c|}{ IT-96 } & \multicolumn{6}{|c|}{ IT-50b } \\
\hline & $b_{a}$ & 2 & $0_{0}$ & $\mathrm{n}_{\mathrm{b}}$ & $\mathrm{b}_{\mathrm{a}}$ & $\mathrm{n}_{\mathrm{a}}$ & $\mathrm{b}_{\mathrm{b}}$ & $\mathbf{n}_{b}$ & $i_{c}$ & $\mathrm{~b}_{\mathrm{a}}$ & $\mathrm{n}_{\mathrm{a}}$ & $\mathrm{b}_{\mathrm{b}}$ & $\mathrm{n}_{\mathrm{b}}$ & $b_{c}$ & \\
\hline $\mathrm{iO}_{2}$ & 48,22 & 47,47 & 49,97 & 48,66 & 44,62 & 45,28 & 45,33 & 44,96 & 45,75 & 41,72 & 41,69 & 41,55 & 41,81 & & \\
\hline $\mathrm{TiO}_{2}$ & 0,66 & & & & 1,50 & 1,13 & & & 1,24 & 0,65 & 1,02 & & & 1,27 & \\
\hline & 5,72 & 6,07 & & & 9,18 & 8,54 & 8,51 & & 8,1 & 11,05 & 11,03 & & 10,82 & 1,21 & 11,0 \\
\hline & 15,33 & 16,07 & 14,64 & 15,46 & 15,21 & 15,62 & 16,26 & 15,94 & & & & & 20,86 & & 20,5 \\
\hline & & & & & 0,29 & 0,27 & 0,28 & 0,26 & & & & 0,2 & & & 2 \\
\hline & 45 & 92 & & & 12,34 & 12,38 & 12,20 & & & 7,85 & 7,92 & $\mathrm{I}, \mathrm{I}$ & 8,24 & & \\
\hline & 69 & 11,60 & & & 11,76 & 11,55 & 11,78 & & & 11,26 & & 11,2 & 11,25 & & 1, \\
\hline & & & & & 1,44 & 1,35 & 1,35 & & & & & 1,4 & & & \\
\hline & & & & & 1,00 & 0,95 & 0,91 & & & & & & & & \\
\hline & & & & & 0,40 & 0,41 & 0,43 & 19 & 2 & & & & & & \\
\hline & 01 & & & & 0,03 & & 0,05 & 0,02 & 0,03 & 0,02 & 0,03 & & & & \\
\hline otal &, 03 & 97,87 & & 98,05 & 97,77 & 97,51 & 98,34 & 97,65 & 98,09 & & & & & & \\
\hline \multicolumn{16}{|c|}{$O=23$} \\
\hline & 042 & & & & 6,597 & 6,693 & 6,672 & 6,649 & 6,712 & 6,336 & 6,339 & & 59 & & \\
\hline & 0,958 & 1,025 & & 384 & 1,403 & 1,307 & 1,328 & 1,351 & 1,288 & 1,664 & 1,661 & & & & 1,66 \\
\hline & 0,026 & 025 & & 81 & 0,197 & 0,180 & 0,148 & 0,194 & 0,115 & 0,313 & 0,314 & & 0,2 & & 0,32 \\
\hline & 0,686 & 684 & & 582 & 0,546 & 0,650 & 0,634 & 0,574 & 0,709 & 0,858 & 0,746 & & 0,6 & & 0,64 \\
\hline & 0,072 & 76 & & & 0,167 & 0,126 & 0,137 & 0,162 & 0,137 & 0,075 & & & & & 0,14 \\
\hline & 2,927 & 331 & & 907 & 2,720 & 2,729 & 2,678 & 2,641 & 2,766 & 1,777 & & & 1,8 & & 1,87 \\
\hline & 1,187 & 91 & & 1,309 & 1,335 & 1,281 & 1,368 & 1,398 & 1,232 & 1,949 & 2,0 & & 1,9 & & 1,97 \\
\hline & & & & & 0,036 & 0,034 & 0,035 & & 0,041 & 0,028 & & & 0,0 & & 0,03 \\
\hline & & & & & 1,862 & 1,829 & 1,858 & 1,846 & 1,822 & 1,832 & & & 1,832 & & 1,81 \\
\hline & & & & & 0,138 & 0,171 & 0,142 & 0,154 & 0,178 & 0,168 & & & 0,168 & & 0,18 \\
\hline & & & & & 0,000 & 0,000 & 0,000 & 0,000 & 0,000 & 0,000 & & & 0,000 & & 0,00 \\
\hline & 0,170 & & & & 0,275 & 0,216 & 0,243 & 0,223 & 0,194 & 0,240 & & 39 & 0,240 & & 0,29 \\
\hline & 0,103 & 0,119 & & 0,094 & 0,189 & 0,179 & 0,171 & 0,190 & 0,175 & 0,271 & 0,288 & 0,279 & 0,277 & & 0,28 \\
\hline$\sum^{T-A}$ & 15,273 & 15,337 & 15,227 & 15,277 & 15,464 & 15,395 & 15,415 & 15,413 & 15,369 & 15,511 & 15,556 & 15,518 & 15,516 & 15,525 & 15,57 \\
\hline & \multicolumn{4}{|c|}{$\mathrm{Mg}-\mathrm{H} b \mathrm{l}$} & \multicolumn{5}{|c|}{$\mathbf{M g}-\mathbf{H b l}$} & \multicolumn{4}{|c|}{ Hst } & Mg-Hst & Hist \\
\hline ng & 0,71 & 0,69 & 0,71 & 0,69 & 0,67 & 0,68 & 0,66 & 0,65 & 0,69 & 0,48 & 0,47 & 0,48 & 0,49 & 0,50 & \\
\hline
\end{tabular}

Observaçōes: Amostras são titanita anfibólio biotita granitóides, exceto $\mathrm{SC}-51$ (sombreado), um granitóide pórfiro com anfibólio. Os símbolos $\mathrm{A}, \mathrm{B}, \mathrm{C}$ e $\mathrm{T}$ referem-se às posições cristalográficas da fórmula padrão do anfibólio $\mathrm{AB}_{2} \mathrm{C}_{5} \mathrm{~T}_{8} \mathrm{O}_{22}(\mathrm{OH})_{2}$. Nomenclatura de acordo com Leake et al. (1997). FeO tal como obtido na microssonda eletrônica; $\boldsymbol{m g}{ }^{*}=\mathrm{Mg} /\left(\mathrm{Mg}+\mathrm{Fe}^{2+}\right)$. Demais observaçôes, ver Tabela 5.2. 
Tabela 5.7: Resultados analíticos e cálculos de fórmula estrutural (22 O) para cristais de biotita do Complexo Granítico Cunhaporanga.

\begin{tabular}{|c|c|c|c|c|c|c|c|c|c|c|c|c|c|c|c|c|c|}
\hline & \multicolumn{17}{|c|}{ Domínios Petrográficos da porçāo S/SE do Complexo } \\
\hline & \multicolumn{17}{|c|}{ DOMÍNIO ABAPÃ-SANTA QUITÉRIA } \\
\hline & \multicolumn{17}{|c|}{ tit anf bio } \\
\hline & \multicolumn{5}{|c|}{$\frac{\text { PS-21 }}{n_{b}}$} & \multicolumn{3}{|c|}{ PS-54 } & \multicolumn{2}{|c|}{ PS-76a } & \multicolumn{3}{|c|}{ PS-78 } & \multicolumn{3}{|c|}{ PS-79a } & \begin{tabular}{|l} 
PS. $79 \mathrm{a}^{\mathrm{E}}$ \\
\end{tabular} \\
\hline Local & $n_{a}$ & $b_{b}$ & $\mathrm{n}_{\mathrm{b}}$ & $b_{c}$ & $\mathbf{n}_{c}$ & $\mathrm{~b}_{\mathrm{a}}$ & $\mathbf{n}_{\mathbf{a}}$ & $b_{b}$ & $\mathrm{~b}$ & $\mathbf{n}$ & $b_{a}$ & $\mathrm{n}_{\mathrm{a}}$ & $i_{b}$ & & & & \\
\hline $\mathrm{SiO}_{2}$ & 37,05 & 36,76 & 37,44 & 37,18 & 37,23 & 36,77 & 36,46 & 35,97 & 36,94 & 36,76 & 37,51 & 37,56 & 37,82 & 37,50 & 37,28 & 37,54 & 37,73 \\
\hline $\mathrm{TiO}_{2}$ & 2,63 & 1,16 & 1,37 & 1,54 & 1,74 & 2,00 & 2,00 & 1,45 & 1,90 & 2,63 & 1,57 & 1,48 & 1,54 & 1,55 & 1,51 & 1,06 & 2,28 \\
\hline $\mathrm{Al}_{2} \mathrm{O}_{3}$ & 15,34 & 15,96 & 15,68 & 15,49 & 15,66 & 15,70 & 15,89 & 15,80 & 15,86 & 15,53 & 15,79 & 15,98 & 15,45 & 15,60 & 15,53 & 16,02 & 15,70 \\
\hline $\mathrm{Cr}_{2} \mathrm{O}_{3}$ & 0,03 & $\mathrm{n}, \mathrm{d}$, & $\mathrm{n}, \mathrm{d}$, & $\mathrm{n}, \mathrm{d}$, & $\mathrm{n}, \mathrm{d}$, & $\mathrm{n}, \mathrm{d}$, & $\mathrm{n}, \mathrm{d}$, & $\mathrm{n}, \mathrm{d}$, & $\mathrm{n}, \mathrm{d}$, & $\mathrm{n}, \mathrm{d}$, & $\mathrm{n}, \mathrm{d}$, & $\mathrm{n}, \mathrm{d}$, & $\mathrm{n}, \mathrm{d}$, & $\mathrm{n}, \mathrm{d}$, & 0,00 & 0,06 & $\mathrm{n}, \mathrm{d}$ \\
\hline $\mathrm{FeO}^{1}$ & 18,64 & 18,19 & 18,19 & 17,05 & 18,17 & 19,73 & 19,60 & 20,07 & 19,34 & 19,54 & 17,73 & 16,70 & 18,03 & 17,07 & 17,07 & 16,36 & 18,22 \\
\hline $\mathrm{MnO}$ & 0,24 & 0,28 & 0,25 & 0,20 & 0,21 & 0,24 & 0,26 & 0,28 & 0,30 & 0,26 & 0,31 & 0,34 & 0,30 & 0,38 & 0,29 & 0,30 & 0,26 \\
\hline $\mathrm{MgO}$ & 13,04 & 14,09 & 13,45 & 13,50 & 13,54 & 11,85 & 11,69 & 12,30 & 12,18 & 11,86 & 13,59 & 13,91 & 13,27 & 13,62 & 14,35 & 14,82 & 12,96 \\
\hline $\mathrm{BaO}$ & 0,24 & 0,07 & 0,07 & 0,16 & 0,15 & 0,25 & 0,09 & 0,21 & 0,12 & 0,13 & 0,14 & 0,13 & 0,12 & 0,19 & 0,00 & 0,19 & 0,13 \\
\hline $\mathrm{CaO}$ & 0,13 & 0,02 & 0,02 & 0,05 & 0,05 & 0,04 & 0,05 & 0,08 & 0,02 & 0,00 & 0,00 & 0,00 & 0,00 & 0,01 & 0,02 & 0,01 & 0,05 \\
\hline $\mathrm{Na}_{2} \mathrm{O}$ & 0,06 & 0,04 & 0,06 & 0,08 & 0,04 & 0,07 & 0,07 & 0,06 & 0,10 & 0,09 & 0,09 & 0,03 & 0,06 & 0,06 & 0,07 & 0,05 & 0,05 \\
\hline $\mathrm{K}_{2} \mathrm{O}$ & 9,38 & 8,97 & 9,60 & 9,89 & 9,89 & 9,79 & 9,67 & 9,46 & 9,81 & 9,92 & 9,75 & 9,77 & 9,93 & 9,97 & 9,49 & 9,61 & 9,97 \\
\hline $\mathrm{F}$ & 0,28 & 0,28 & 0,44 & 0,30 & 0,37 & 0,28 & 0,27 & 0,41 & 0,17 & 0,27 & 0,35 & 0,34 & 0,33 & 0,33 & 0,42 & 0,30 & 0,28 \\
\hline Total & 97,06 & 95,83 & 96,55 & 95,44 & 97,03 & 96,72 & 96,03 & 96,08 & 96,74 & 96,99 & 96,82 & 96,23 & 96,85 & 96,27 & 96,02 & 96,30 & 97,61 \\
\hline \multicolumn{18}{|c|}{$O=22$} \\
\hline Si & 5,539 & 5,532 & 5,602 & 5,618 & 5,559 & 5,558 & 5,539 & 5,484 & 5,564 & 5,537 & 5,593 & 5,605 & 5,647 & 5,619 & 5,579 & 5,588 & 5,594 \\
\hline $\mathrm{Al}^{\mathrm{N}}$ & 2,461 & 2,468 & 2,398 & 2,382 & 2,441 & 2,442 & 2,461 & 2,516 & 2,436 & 2,463 & 2,407 & 2,395 & 2,353 & 2,381 & 2,421 & 2,412 & 2,406 \\
\hline $\mathrm{Al}^{\mathrm{V}}$ & 0,242 & 0,363 & 0,367 & 0,377 & 0,315 & 0,355 & 0,385 & 0,323 & 0,380 & 0,294 & 0,368 & 0,416 & 0,366 & 0,374 & 0,319 & 0,398 & 0,339 \\
\hline $\mathrm{Ti}$ & 0,296 & 0,132 & 0,154 & 0,175 & 0,195 & 0,227 & 0,229 & 0,166 & 0,215 & 0,297 & 0,176 & 0,166 & 0,173 & 0,175 & 0,169 & 0,119 & 0,255 \\
\hline $\mathrm{Fe}^{2+}$ & 2,331 & 2,289 & 2,276 & 2,155 & 2,268 & 2,494 & 2,490 & 2,559 & 2,437 & 2,462 & 2,211 & 2,084 & 2,252 & 2,139 & 2,136 & 2,036 & 2,259 \\
\hline $\mathrm{Cr}$ & 0,003 & 0,000 & 0,000 & 0,000 & 0,000 & 0,000 & 0,000 & 0,000 & 0,000 & 0,000 & 0,000 & 0,000 & 0,000 & 0,000 & 0,000 & 0,007 & 0,000 \\
\hline $\mathrm{Mn}$ & 0,031 & 0,036 & 0,032 & 0,025 & 0,026 & 0,030 & 0,033 & 0,037 & 0,038 & 0,034 & 0,039 & 0,043 & 0,038 & 0,048 & 0,036 & 0,038 & 0,033 \\
\hline $\mathrm{Mg}$ & 2,905 & 3,160 & 3,000 & 3,041 & 3,013 & 2,668 & 2,647 & 2,794 & 2,735 & 2,663 & 3,020 & 3,094 & 2,952 & 3,041 & 3,200 & 3,287 & 2,865 \\
\hline $\mathrm{Ba}$ & 0,014 & 0,004 & 0,004 & 0,010 & 0,009 & 0,015 & 0,005 & 0,013 & 0,007 & 0,007 & 0,008 & 0,008 & 0,007 & 0,011 & 0,000 & 0,011 & 0,007 \\
\hline $\mathrm{Ca}$ & 0,021 & 0,004 & 0,003 & 0,008 & 0,008 & 0,007 & 0,008 & 0,013 & 0,003 & 0,000 & 0,000 & 0,000 & 0,000 & 0,002 & 0,004 & 0,001 & 0,007 \\
\hline $\mathrm{Na}$ & 0,019 & 0,013 & 0,016 & 0,024 & 0,012 & 0,021 & 0,021 & 0,018 & 0,029 & 0,026 & 0,026 & 0,007 & 0,018 & 0,018 & 0,021 & 0,016 & 0,013 \\
\hline $\mathrm{K}$ & 1,789 & 1,722 & 1,833 & 1,906 & 1,883 & 1,887 & 1,874 & 1,840 & 1,885 & 1,907 & 1,854 & 1,860 & 1,892 & 1,905 & 1,813 & 1,824 & 1,885 \\
\hline$\Sigma$ & 15,651 & 15,722 & 15,683 & 15,720 & 15,728 & 15,704 & 15,693 & 15,761 & 15,728 & 15,690 & 15,702 & 15,677 & 15,698 & 15,713 & 15,699 & 15,736 & 15,663 \\
\hline$m g$ & 0,55 & 0,58 & 0,57 & 0,59 & 0,57 & 0,52 & 0,52 & 0,52 & 0,53 & 0,52 & 0,58 & 0,60 & 0,57 & 0,59 & 0,60 & 0,62 & 0,56 \\
\hline
\end{tabular}


Tabela 5.7 (cont.): Resultados analíticos e cálculos de fórmula estrutural (22 O) para cristais de biotita do Complexo Granítico Cunhaporanga.

\begin{tabular}{|c|c|c|c|c|c|c|c|c|c|c|c|c|c|c|c|c|c|}
\hline & \multicolumn{10}{|c|}{ Domínios Petrográficos da porção $S / S E$ do Complexo } & \multicolumn{7}{|c|}{ Dom. Petrográficos da porçāo centro-norte do Complexo } \\
\hline & \multicolumn{5}{|c|}{$\begin{array}{l}\text { DOMÍNIO ABAPÃ-SANTA } \\
\text { QUITÉRIA }\end{array}$} & \multirow{3}{*}{\multicolumn{3}{|c|}{\begin{tabular}{|c|} 
DOMÍNIO SERRA \\
ABAIXO-ALAGADOS \\
tit anf bio \\
SC- 77 \\
\end{tabular}}} & \multirow{3}{*}{\multicolumn{2}{|c|}{\begin{tabular}{|c|}
$\begin{array}{c}\text { Pórfiro intrusivo } \\
\text { em granitóides } \\
\text { do Complexo }\end{array}$ \\
anf pórfiro \\
SC-51 \\
\end{tabular}}} & \multirow{2}{*}{\multicolumn{6}{|c|}{$\begin{array}{l}\text { DOMINNIO BISCAIAS-BOA VISTA } \\
\text { tit anf bio } \\
\end{array}$}} & \multirow{4}{*}{\begin{tabular}{|c|} 
D. E. \\
ALTO \\
ititanf bio \\
JGA-4c \\
b \\
\end{tabular}} \\
\hline & \multirow{2}{*}{\multicolumn{2}{|c|}{$\begin{array}{c}\text { tit anf bio } \\
\text { PS-79a }{ }^{\mathrm{E}}\end{array}$}} & \multirow{2}{*}{\multicolumn{3}{|c|}{$\frac{\text { tit bio }}{\text { PS-76a }{ }^{\mathrm{E}}}$}} & & & & & & & & & & & & \\
\hline & & & & & & & & & & & \multicolumn{3}{|c|}{ JGA-41 } & \multicolumn{3}{|c|}{$\underline{\text { PS-36 }}$} & \\
\hline & & $b_{b}$ & $b_{a}$ & 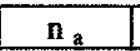 & $\mathrm{n}_{\mathrm{b}}$ & $b_{a}$ & & $\mathbf{n}_{\mathrm{b}}$ & \multicolumn{2}{|c|}{\begin{tabular}{l|l}
$\mathrm{b}$ & $\mathrm{n}$ \\
\end{tabular}} & $\mathrm{b}_{\mathrm{a}}$ & & & & $\overline{\mathrm{n}_{\mathrm{a}}}$ & & \\
\hline $\mathrm{SiO}_{2}$ & 37,91 & 37,71 & 36,00 & 35,79 & 36,10 & 36,97 & 36,35 & 36,12 & 35,73 & 35,16 & 35,51 & 36,69 & 37,39 & 37,58 & 37,49 & 37,46 & 36,95 \\
\hline $\mathrm{TiO}_{2}$ & 2,33 & 2,11 & 2,71 & 2,72 & 2,83 & 3,45 & 3,09 & 3,52 & 1,84 & 1,62 & 1,52 & 2,01 & 1,77 & 1,81 & 1,82 & 1,49 & 2,60 \\
\hline $\mathrm{Al}_{2} \mathrm{O}_{3}$ & 15,47 & 15,49 & 17,09 & 17,04 & 16,78 & 14,41 & 14,77 & 14,64 & 16,05 & 16,42 & 15,05 & 14,36 & & 14,94 & 14,74 & 14,94 & 14,53 \\
\hline $\mathrm{Cr}_{2} \mathrm{O}_{3}$ & & $\mathrm{n}, \mathrm{d}$, & $\mathrm{n}, \mathrm{d}$ & & & & $\mathrm{n}, \mathrm{d}$, & & $\mathrm{n}, \mathrm{d}$, & & $\mathrm{n}, \mathrm{d}$ & $\mathrm{n}, \mathrm{d}$, & $\mathrm{n}, \mathrm{d}$, & $\mathrm{n}, \mathrm{d}$, & $\mathrm{n}, \mathrm{d}$ & $\mathrm{n}, \mathrm{d}$ & $\mathrm{n}, \mathrm{d}$, \\
\hline $\mathrm{FeO}^{1}$ & 18,00 & 17,13 & 19,23 & 19,97 & 19,04 & 18,75 & 19,43 & 19,90 & 20,85 & 21,60 & 19,29 & 19,57 & 17,44 & 18,22 & 17,89 & 18,05 & 19,05 \\
\hline $\mathrm{MnO}$ & & 0,29 & 0,26 & & 0,33 & & 0,38 & & & & 0,44 & & & 0,54 & 0,51 & & 0,46 \\
\hline $\mathrm{MgC}$ & 89 & 13,25 & 10,35 & & 10,75 & 12,4 & 12,90 & & & & 15 , & & & & & & 13,05 \\
\hline $\mathrm{BaO}$ & & & & & & & 0,29 & & & & & & & & 08 & & 0,15 \\
\hline $\mathrm{CaO}$ & & & 3 & & & 0,0 & 0,04 & & & & & & & & 02 & & 0,02 \\
\hline $\mathrm{Na}_{2} \mathrm{O}$ & & & 05 & & & & 0,09 & & & & & & & & & & 0,10 \\
\hline $\mathrm{K}_{2}$ & 11 & 86 & 10,20 & & 10,02 & & 8,88 & & & & & & & 10,04 & 91 & & 9,17 \\
\hline $\bar{F}$ & & 0,21 & 10 & & & & 0,46 & & & & 0 & & & & & & 0,56 \\
\hline Total & 97,49 & 96,25 & 96,38 & 96,63 & 96,31 & 96,67 & 96,68 & 96,95 & 96,72 & & & & & & & & 96,64 \\
\hline \multicolumn{18}{|c|}{$O=22$} \\
\hline $\mathrm{Si}$ & 625 & 5,642 & 5,466 & 5,429 & 5,472 & 5,370 & 5,481 & 5,484 & 5,463 & 3,594 & 5,41 & & & 5,602 & 5,625 & & 5,561 \\
\hline $\mathrm{Al}^{\mathrm{N}}$ & 2,375 & 2,358 & 2,534 & 2,571 & 2,528 & 2,430 & 2,519 & 2,516 & 2,537 & 2,606 & 2,587 & 2,460 & 2,3 & 2,398 & 2,375 & 2,4 & 2,439 \\
\hline $\mathrm{Al}^{\mathrm{VI}}$ & & 374 & 0,526 & & 0,471 & & 0,107 & & & & & & & 0,227 & 0,232 & & 0,139 \\
\hline $\mathrm{Ti}$ & 260 & 238 & 309 & & 0,32 & 0,3 & 0,351 & & & 187 & 5 & & & 03 & & & 0,294 \\
\hline $\mathrm{Fe}^{2+}$ & 234 & 43 & 442 & & 414 & 363 & 2,450 & 527 & 7 & 71 & 99 & 71 & 2,1 & 2,271 & 2,245 & 49 & 2,398 \\
\hline $\mathrm{Cr}$ & 0,000 & 0,000 & 0,000 & & 0,000 & 0,0 & 0,000 & & & 50 & 0,05 & 00 & & 0,000 & 0,000 & & 0,000 \\
\hline Mn & 0,035 & 037 & 0,033 & & 0,043 & 0,0 & 0,048 & & & 0,0 & 0 & & & & & & 0,059 \\
\hline & & & & & & & 2,899 & & & & & & & & 3,020 & & 2,927 \\
\hline $\mathrm{Ba}$ & 0,006 & 0,007 & 022 & & & & 0,017 & & & 35 & 0,0 & & & 0,0 & 0,005 & & 0,009 \\
\hline $\mathrm{Ca}$ & 0,000 & 0,001 & 0,004 & 0,000 & 0,000 & 0,001 & 0,006 & 0,000 & 0,000 & 0,006 & 0,003 & 0,001 & & 0,003 & 0,003 & 01 & 0,003 \\
\hline $\mathrm{Na}$ & 0,015 & 0,019 & 0,014 & 0,025 & 0,020 & 0,032 & 0,027 & 0,039 & 0,024 & 0,020 & 0,025 & 0,022 & 0,026 & 0,019 & 0,024 & 0,026 & 0,028 \\
\hline $\mathrm{K}$ & 1,914 & 1,883 & 1,975 & 1,930 & 1,938 & 1,890 & 1,708 & 1,838 & 1,879 & 1,699 & 1,446 & 1,744 & 1,865 & 1,909 & 1,898 & 1,917 & 1,760 \\
\hline$\Sigma$ & 15,645 & 15,655 & 15,667 & 15,683 & 15,653 & 15,650 & 15,614 & 15,693 & 15,725 & 15,738 & 15,699 & 15,732 & 15,686 & 15,721 & 15,696 & 15,746 & 15,617 \\
\hline og & 0,56 & 0,58 & 0,49 & 0,48 & 0,50 & 0,54 & 0,54 & 0,52 & 0,48 & 0,48 & 0,58 & 0,56 & 0,59 & 0,57 & 0,57 & 0,58 & 0,55 \\
\hline
\end{tabular}


Tabela 5.7 (cont.): Resultados analíticos e cálculos de fórmula estrutural (22 O) para cristais de biotita do Complexo Granítico Cunhaporanga.

\begin{tabular}{|c|c|c|c|c|c|c|c|c|c|c|c|c|c|c|c|c|c|}
\hline \multirow[b]{5}{*}{ Local } & \multicolumn{17}{|c|}{ Domínios Petrográficos da porçāo centro-norte do Complexo } \\
\hline & \multicolumn{17}{|c|}{ DOMÍNIO ESPIGÃO ALTO } \\
\hline & \multicolumn{17}{|c|}{ tit anf bio } \\
\hline & \multicolumn{3}{|c|}{ JGA-4c } & \multicolumn{3}{|c|}{$\mathrm{JGA}-42 \mathrm{~b}$} & \multicolumn{4}{|c|}{ JGA-43b } & \multicolumn{7}{|c|}{ PS-92a ${ }^{E}$} \\
\hline & $\mathrm{n}_{\mathrm{a}} \mathrm{l}$ & $n_{a} 2$ & $\mathrm{n}_{\mathrm{b}}$ & $b_{a}$ & $\mathrm{n}_{\mathrm{a}}$ & $i_{b}$ & $b_{a}$ & $\mathrm{n}_{\mathrm{a}}$ & $b_{b}$ & $\mathbf{n}_{\mathrm{b}}$ & $\mathbf{b}_{\mathbf{a}}$ & $\mathrm{n}_{\mathrm{b}}$ & $b_{c}$ & & $b_{d}$ & $\mathrm{n}_{\mathrm{d}}$ & $\mathrm{b}_{\mathrm{e}}$ \\
\hline $\mathrm{SiO}_{2}$ & 36,00 & 36,76 & 36,06 & 36,88 & 35,33 & 37,04 & 37,01 & 37,33 & 37,46 & 37,71 & 37,16 & 36,73 & 36,77 & 36,34 & 37,27 & 37,14 & 36,92 \\
\hline $\mathrm{TiO}_{2}$ & 2,21 & 2,70 & 2,91 & 1,98 & 2,18 & 2,07 & 2,20 & 2,32 & 2,42 & 2,25 & 4,05 & 4,28 & 4,69 & 4,62 & 3,87 & 4,35 & 4,72 \\
\hline $\mathrm{Al}_{2} \mathrm{O}_{3}$ & 14,82 & 14,92 & 14,63 & 14,88 & 14,53 & 14,69 & 14,92 & 15,21 & 15,34 & 15,06 & 13,95 & 13,82 & 14,08 & 14,05 & 14,09 & 13,94 & 14,05 \\
\hline $\mathrm{Cr}_{2} \mathrm{O}_{3}$ & $\mathrm{n}, \mathrm{d}$, & $\mathrm{n}, \mathrm{d}$ & $\mathrm{n}, \mathrm{d}$, & $\mathrm{n}, \mathrm{d}$ & $\mathrm{n}, \mathrm{d}$, & $\mathrm{n}, \mathrm{d}$ & $\mathrm{n}, \mathrm{d}$ & $\mathrm{n}, \mathrm{d}$, & $\mathrm{n}, \mathrm{d}$, & $\mathrm{n}, \mathrm{d}$ & $\mathrm{n}, \mathrm{d}$, & $\mathrm{n}, \mathrm{d}$ & $\mathrm{n}, \mathrm{d}$ & $\mathrm{n}, \mathrm{d}$ & $\mathrm{n}, \mathrm{d}$ & $\mathrm{n}, \mathrm{d}$ & $\mathrm{n}, \mathrm{d}$ \\
\hline $\mathrm{FeO}^{\mathrm{T}}$ & 19,75 & 19,07 & 19,28 & 19,50 & 19,05 & 19,61 & 19,22 & 18,60 & 18,60 & 18,47 & 20,25 & 19,92 & 19,62 & 19,75 & 19,90 & 20,30 & 19,15 \\
\hline $\mathrm{MnO}$ & 0,50 & 0,53 & 0,46 & 0,39 & 0,35 & 0,36 & 0,36 & 0,33 & 0,36 & 0,45 & 0,14 & 0,18 & 0,15 & 0,17 & 0,19 & 0,13 & 0,17 \\
\hline $\mathrm{MgO}$ & 13,51 & 12,87 & 12,46 & 12,93 & 12,06 & 12,88 & 12,91 & 13,03 & 13,07 & 13,07 & 12,27 & 11,82 & 11,22 & 11,27 & 11,69 & 11,68 & 11,56 \\
\hline $\mathrm{BaO}$ & 0,00 & 0,07 & 0,00 & 0,34 & 0,56 & 0,31 & 0,13 & 0,03 & 0,06 & 0,11 & 0,25 & 0,11 & 0,54 & 0,74 & 0,04 & 0,28 & 0,25 \\
\hline $\mathrm{CaO}$ & 0,17 & 0,03 & 0,00 & 0,10 & 0,06 & 0,03 & 0,00 & 0,01 & 0,00 & 0,00 & 0,04 & 0,00 & 0,06 & 0,03 & 0,01 & 0,02 & 0,00 \\
\hline $\mathrm{Na}_{2} \mathrm{O}$ & 0,07 & 0,13 & 0,13 & 0,09 & 0,56 & 0,10 & 0,08 & 0,13 & 0,08 & 0,08 & 0,09 & 0,09 & 0,06 & 0,08 & 0,09 & 0,09 & 0,11 \\
\hline $\mathrm{K}_{2} \mathrm{O}$ & 7,87 & 9,20 & 9,33 & 9,35 & 8,26 & 8,99 & 9,81 & 9,85 & 9,73 & 9,72 & 9,47 & 9,46 & 9,48 & 9,35 & 9,50 & 9,42 & 9,30 \\
\hline$F$ & 0,44 & 0,45 & 0,60 & 0,28 & 0,25 & 0,28 & 0,46 & 0,41 & 0,33 & 0,37 & 0,34 & 0,32 & 0,35 & 0,50 & 0,57 & 0,19 & 0,16 \\
\hline Total & 95,34 & 96,73 & 95,86 & 96,71 & 93,18 & 96,36 & 97,08 & 97,25 & 97,45 & 97,28 & 98,00 & 96,72 & 97,01 & 96,90 & 97,20 & 97,52 & 96,38 \\
\hline \multicolumn{18}{|c|}{$O=22$} \\
\hline $\mathrm{Si}$ & 5,479 & 5,527 & 5,491 & 5,569 & 5,539 & 5,601 & 5,561 & 5,573 & 5,573 & 5,619 & 5,552 & 5,556 & 5,553 & 5,510 & 5,595 & 5,578 & 5,581 \\
\hline $\mathrm{Al}^{\mathrm{N}}$ & 2,521 & 2,473 & 2,509 & 2,431 & 2,461 & 2,399 & 2,439 & 2,427 & 2,427 & 2,381 & 2,448 & 2,444 & 2,447 & 2,490 & 2,405 & 2,422 & 2,419 \\
\hline $\mathrm{Al}^{\mathrm{v}}$ & 0,137 & 0,173 & 0,117 & 0,218 & 0,226 & 0,219 & 0,203 & 0,249 & 0,264 & 0,264 & 0,010 & 0,021 & 0,060 & 0,022 & 0,088 & 0,047 & 0,085 \\
\hline $\mathrm{Ti}$ & 0,253 & 0,305 & 0,333 & 0,225 & 0,257 & 0,235 & 0,248 & 0,260 & 0,271 & 0,252 & 0,455 & 0,486 & 0,532 & 0,527 & 0,437 & 0,491 & 0,536 \\
\hline $\mathrm{Fe}^{2+}$ & 2,513 & 2,398 & 2,456 & 2,463 & 2,498 & 2,480 & 2,415 & 2,322 & 2,314 & 2,302 & 2,530 & 2,520 & 2,478 & 2,504 & 2,498 & 2,550 & 2,420 \\
\hline $\mathrm{Cr}$ & 0,000 & 0,000 & 0,000 & 0,000 & 0,000 & 0,000 & 0,000 & 0,000 & 0,000 & 0,000 & 0,000 & 0,000 & 0,000 & 0,000 & 0,000 & 0,000 & 0,000 \\
\hline $\mathrm{Mn}$ & 0,064 & 0,068 & 0,060 & 0,049 & 0,046 & 0,046 & 0,045 & 0,041 & 0,046 & 0,056 & 0,018 & 0,023 & 0,020 & 0,022 & 0,024 & 0,017 & 0,022 \\
\hline $\mathrm{Mg}$ & 3,064 & 2,885 & 2,828 & 2,909 & 2,817 & 2,902 & 2,890 & 2,899 & 2,899 & 2,903 & 2,732 & 2,664 & 2,526 & 2,547 & 2,615 & 2,614 & 2,603 \\
\hline $\mathrm{Ba}$ & 0,000 & 0,004 & 0,000 & 0,020 & 0,034 & 0,018 & 0,008 & 0,002 & 0,003 & 0,006 & 0,014 & 0,006 & 0,032 & 0,044 & 0,003 & 0,016 & 0,015 \\
\hline $\mathrm{Ca}$ & 0,027 & 0,005 & 0,000 & 0,016 & 0,010 & 0,005 & 0,000 & 0,001 & 0,000 & 0,000 & 0,007 & 0,000 & 0,009 & 0,005 & 0,001 & 0,003 & 0,000 \\
\hline $\mathrm{Na}$ & 0,022 & 0,038 & 0,038 & 0,026 & 0,169 & 0,030 & 0,024 & 0,037 & 0,024 & 0,024 & 0,026 & 0,026 & 0,018 & 0,024 & 0,025 & 0,025 & 0,033 \\
\hline $\mathrm{K}$ & 1,529 & 1,765 & 1,813 & 1,801 & 1,651 & 1,734 & 1,881 & 1,875 & 1,847 & 1,848 & 1,805 & 1,825 & 1,827 & 1,809 & 1,819 & 1,805 & 1,793 \\
\hline$\Sigma$ & 15,609 & 15,641 & 15,645 & 15,727 & 15,708 & 15,669 & 15,714 & 15,689 & 15,668 & 15,655 & 15,599 & 15,573 & 15,501 & 15,504 & 15,508 & 15,567 & 15,507 \\
\hline & 0,55 & 0,55 & 0,54 & 0,54 & 0,53 & 0,54 & 0,54 & 0,56 & 0,56 & 0,56 & 0,52 & 0,51 & 0,50 & 0,50 & $0,5 I$ & 0,51 & 0,52 \\
\hline
\end{tabular}


Tabela 5.7 (cont.): Resultados analíticos e cálculos de fórmula estrutural (22 O) para cristais de biotita do Complexo Granítico Cunhaporanga.

\begin{tabular}{|c|c|c|c|c|c|c|c|c|c|c|c|c|c|c|c|c|c|}
\hline \multirow[b]{5}{*}{ Local } & \multicolumn{17}{|c|}{ Domínios Petrográficos da porção centro-norte do Complexo } \\
\hline & \multicolumn{9}{|c|}{ DOMÍNIO ESPIGÃO ALTO } & \multicolumn{6}{|c|}{ DOMÍNIO PAREDÄO DA SANTA } & \multirow{2}{*}{\multicolumn{2}{|c|}{$\begin{array}{c}\text { D. P. ANTA-Á. } \\
\text { CLARA } \\
\text { mu bio } \\
\end{array}$}} \\
\hline & \multicolumn{9}{|c|}{ tit anf bio } & \multirow{2}{*}{\multicolumn{3}{|c|}{$\frac{\text { titanf bio }}{\text { JGA-1 }}$}} & \multirow{2}{*}{\multicolumn{3}{|c|}{$\frac{\text { tit bio }}{\text { JGA-44 }}$}} & & \\
\hline & \multicolumn{2}{|c|}{ PS-92a ${ }^{E}$} & \multicolumn{7}{|c|}{ PS-93a } & & \multicolumn{2}{|c|}{ JGA-1 } & & & & \multicolumn{2}{|c|}{ JGA-14 } \\
\hline & $\mathrm{n}_{\mathrm{e}} 1$ & $\mathrm{n}_{\mathrm{c}} 2$ & $b_{a}$ & $\mathrm{n}_{\mathrm{a}}$ & $b_{b} 1$ & $b_{b} 2$ & $\mathrm{n}_{\mathrm{b}}$ & $\underline{b}_{c}$ & $n_{c}$ & & $b_{b}$ & $n_{b}$ & $\mathrm{~b}_{\mathrm{a}}$ & & & $\mathrm{b}_{\mathrm{a}}$ & \\
\hline $\mathrm{SiO}_{2}$ & 36,12 & 37,16 & 36,69 & 36,34 & 37,16 & 37,46 & 36,67 & 37,18 & 37,11 & 36,37 & 36,90 & 37,71 & 37,46 & 37,36 & 37,29 & 34,74 & 34,98 \\
\hline $\mathrm{TiO}_{2}$ & 4,74 & 4,74 & 3,57 & 3,71 & 3,56 & 3,60 & 3,66 & 3,05 & 3,50 & 3,01 & 2,48 & 1,79 & 2,08 & 2,49 & 2,39 & 2,12 & 2,15 \\
\hline $\mathrm{Al}_{2} \mathrm{O}_{3}$ & 13,96 & 13,71 & 14,06 & 14,31 & 13,85 & 13,70 & 14,21 & 14,35 & 14,33 & 14,83 & 14,49 & 14,11 & 14,79 & 14,78 & 15,19 & 18,92 & 18,88 \\
\hline $\mathrm{Cr}_{2} \mathrm{O}_{3}$ & $\mathrm{n}, \mathrm{d}$, & $\mathrm{n}, \mathrm{d}$ & 0,00 & $\mathrm{n}, \mathrm{d}$ & $\mathrm{n}, \mathrm{d}$, & $\mathrm{n}, \mathrm{d}$, & $\mathrm{n}, \mathrm{d}$, & $\mathrm{n}, \mathrm{d}$, & 0,00 & $\mathrm{n}, \mathrm{d}$ & $\mathrm{n}, \mathrm{d}$, & $\mathrm{n}, \mathrm{d}$ & $\mathrm{n}, \mathrm{d}$ & $\mathrm{n}, \mathrm{d}$ & $\mathrm{n}, \mathrm{d}$, & $\mathrm{n}, \mathrm{d}$ & $\mathrm{n}, \mathrm{d}$, \\
\hline $\mathrm{FeO}^{\mathrm{T}}$ & 19,55 & 18,63 & 18,22 & 19,15 & 17,91 & 17,82 & 18,67 & 18,27 & 18,32 & 19,31 & 19,49 & 18,38 & 17,24 & 17,42 & 16,83 & 18,90 & 18,61 \\
\hline $\mathrm{MnO}$ & 0,19 & 0,16 & 0,30 & 0,31 & 0,29 & 0,37 & 0,34 & 0,29 & 0,35 & 0,56 & 0,57 & 0,47 & 0,26 & 0,31 & & 0,62 & 0,66 \\
\hline $\mathrm{MgO}$ & 11,06 & 12,16 & 12,98 & 12,52 & 13,31 & 13,11 & 13,31 & 13,67 & 12,70 & 12,18 & 12,54 & 14,12 & 13,70 & 13,57 & 13,09 & 10,71 & 10,66 \\
\hline $\mathrm{BaO}$ & 1,93 & 0,25 & 0,19 & 1,10 & 0,15 & 0,28 & 0,10 & 0,00 & 0,23 & 0,66 & 0,53 & 0,12 & 0,05 & 0,15 & 0,01 & 0,00 & 0,12 \\
\hline $\mathrm{CaO}$ & 0,00 & 0,02 & 0,00 & 0,03 & 0,01 & 0,00 & 0,03 & 0,01 & 0,00 & 0,00 & 0,00 & 0,00 & 0,00 & 0,00 & 0,01 & 0,08 & 0,04 \\
\hline $\mathrm{Na}_{2} \mathrm{O}$ & 0,11 & 0,13 & 0,05 & 0,08 & 0,04 & 0,05 & 0,05 & 04 & 0,05 & 0,10 & 0,1 & & 0,09 & 0,12 & 0,08 & 0,08 & 0,04 \\
\hline $\mathrm{K}_{2} \mathrm{O}$ & 8,73 & 9,24 & 9,27 & 9,26 & 9,11 & 9,36 & 8,90 & 8,52 & 9,52 & 9,75 & 9,83 & 9,88 & 10,01 & 10,09 & 9,67 & 8,06 & 8,04 \\
\hline$F$ & 0,39 & 0,70 & 1,10 & 0,74 & 1,13 & 0,95 & 0,92 & 0,80 & 1,01 & 0,33 & 0,49 & 0,47 & 1,06 & 0,94 & 0,91 & 0,52 & 0,85 \\
\hline Total & 96,77 & 96,89 & 96,43 & 97,56 & 96,52 & 96,71 & 96,86 & 96,17 & 97,11 & 97,10 & 97,44 & 97,10 & 96,76 & 97,22 & 95,70 & 94,75 & 95,04 \\
\hline \multicolumn{18}{|c|}{$O=22$} \\
\hline $\mathrm{Si}$ & 5,515 & 5,570 & 5,520 & 5,471 & 5,564 & 5,608 & 5,490 & 5,566 & 5,547 & 5,505 & 5,561 & 5,643 & 5,590 & 5,564 & 5,599 & 5,287 & 5,300 \\
\hline $\mathrm{Al}^{\mathrm{N}}$ & 2,485 & 2,422 & 2,480 & 2,529 & 2,436 & 2,392 & 2,508 & 2,434 & 2,453 & 2,495 & 2,439 & 2,357 & 2,410 & 2,436 & 2,401 & 2,713 & 2,700 \\
\hline $\mathrm{Al}^{\mathrm{VI}}$ & 0,028 & 0,000 & 0,014 & & 0,008 & 0,02 & 0,000 & 0,097 & 0,072 & 0,151 & 0,135 & 0,132 & 0,192 & 0,157 & 0,289 & 0,682 & 0,673 \\
\hline $\mathrm{Ti}$ & 0,544 & 0,534 & 0,404 & 0,420 & 0,400 & 0,405 & 0,412 & 0,344 & 0,393 & 0,342 & 0,28 & 0,201 & 0,234 & 0,278 & 0,270 & 0,243 & 0,245 \\
\hline $\mathrm{Fe}^{2+}$ & 2,497 & 2,335 & 2,292 & 2,411 & 2,242 & 2,232 & 2,337 & 2,288 & 2,290 & 2,444 & 2,456 & 2,301 & 2,151 & 2,169 & 2,113 & 2,406 & 2,358 \\
\hline $\mathrm{Cr}$ & 0,000 & 0,000 & 0,000 & 0,000 & 0,000 & 0,000 & 0,000 & 0,000 & 0,000 & 0,000 & 0,000 & 0,000 & 0,000 & 0,000 & 0,000 & 0,000 & 0,000 \\
\hline $\mathrm{Mn}$ & 0,025 & 0,020 & 0,039 & 0,039 & 0,037 & 0,04 & 0,043 & 0,037 & 0,044 & 0,072 & 0,07 & 0,060 & 0,033 & 0,039 & 0,031 & 0,080 & 0,085 \\
\hline $\mathrm{Mg}$ & 2,516 & 2,716 & 2,909 & 2,810 & 2,971 & 2,925 & 2,968 & 3,049 & 2,830 & 2,747 & 2,815 & 3,149 & 3,045 & 3,011 & 2,929 & 2,430 & 2,408 \\
\hline $\mathrm{Ba}$ & 0,116 & 0,015 & 0,011 & 0,065 & 0,009 & 0,016 & 0,006 & 0,000 & 0,014 & 0,039 & 0,032 & 0,007 & 0,003 & 0,009 & 0,001 & 0,000 & 0,007 \\
\hline $\mathrm{Ca}$ & 0,000 & 0,004 & 0,000 & 0,005 & 0,002 & 0,000 & 0,005 & 0,001 & 0,000 & 0,000 & 0,000 & 0,000 & 0,000 & 0,000 & 0,001 & 0,013 & 0,007 \\
\hline $\mathrm{Na}$ & 0,032 & 0,036 & 0,015 & 0,024 & 0,013 & 0,015 & 0,014 & 0,012 & 0,014 & 0,029 & 0,032 & 0,014 & 0,027 & 0,034 & 0,022 & 0,023 & 0,011 \\
\hline $\mathrm{K}$ & 1,700 & 1,766 & 1,780 & 1,778 & 1,740 & 1,788 & 1,700 & 1,627 & 1,815 & 1,883 & 1,890 & 1,886 & 1,906 & 1,917 & 1,853 & 1,565 & 1,554 \\
\hline$\Sigma$ & 15,457 & 15,419 & 15,465 & 15,563 & 15,422 & 15,454 & 15,484 & 15,454 & 15,472 & 15,708 & 15,715 & 15,750 & \begin{tabular}{|l|l|}
15,592 \\
\end{tabular} & 15,615 & 15,507 & 15,441 & 15,348 \\
\hline 8. & 0,50 & 0,54 & 0,56 & 0,54 & 0,57 & 0,57 & 0,56 & 0,57 & 0,55 & 0,53 & 0,53 & $0, \mathbf{3}$ & 0,59 & 0,58 & 0,58 & 0,50 & 0.51 \\
\hline
\end{tabular}


Tabela 5.7 (cont.): Resultados analíticos e cálculos de fórmula estrutural (22 O) para cristais de biotita do Complexo Granítico Cunhaporanga.

\begin{tabular}{|c|c|c|c|c|c|c|c|c|c|c|c|c|c|c|c|c|c|}
\hline \multirow[b]{5}{*}{ Local } & \multicolumn{15}{|c|}{ Domínios Petrográficos da porção centro-norte do Complexo } & \multirow{3}{*}{\multicolumn{2}{|c|}{$\begin{array}{c}\text { D. P.NE } \\
\text { D. O. VERDE.-P } \\
\text { S. ANTONIO } \\
\text { tit bio }\end{array}$}} \\
\hline & \multicolumn{4}{|c|}{$\begin{array}{c}\text { DOMÍNIO PASSO DA. ANTA- } \\
\text { ÁGUA CLARA }\end{array}$} & \multicolumn{11}{|c|}{ DOMÍNIO VARGINHA } & & \\
\hline & \multirow{3}{*}{\begin{tabular}{|c|} 
mu bio \\
JGA-14 \\
$n_{b}$ \\
\end{tabular}} & \multirow{2}{*}{\multicolumn{3}{|c|}{$\begin{array}{c}\text { bio } \\
\text { PS-44 }\end{array}$}} & \multicolumn{8}{|c|}{ tit bio } & \multirow{2}{*}{\multicolumn{3}{|c|}{$\begin{array}{c}\text { bio pórfiro } \\
\text { PS-48 }\end{array}$}} & & \\
\hline & & & & & & PS-46 & & & $-46^{\mathrm{E}}$ & & PS-66 & & & & & \multicolumn{2}{|c|}{ IT -93} \\
\hline & & $\mathrm{n}_{\mathrm{a}}$ & $b_{b}$ & $\mathrm{n}_{\mathrm{b}}$ & $\mathrm{n}_{\mathrm{a}}$ & $\mathbf{b}_{\mathrm{b}}$ & $\mathrm{n}_{\mathrm{b}}$ & $\mathrm{b}$ & $\mathrm{n}$ & $\mathrm{b}_{\mathrm{a}}$ & $\mathrm{n}_{\mathrm{a}}$ & $\mathrm{n}_{\mathrm{b}}$ & $\mathrm{b}_{\mathrm{a}}$ & $\mathrm{n}_{\mathrm{a}}$ & & $b_{a}$ & $\mathrm{n}_{\mathrm{a}}$ \\
\hline $\mathrm{SiO}_{2}$ & 36,75 & 37,99 & 36,52 & 38,25 & 35,71 & 36,62 & 36,90 & 37,45 & 37,02 & 36,68 & 36,21 & 36,41 & 37,58 & 37,78 & 37,14 & 36,99 & 37,49 \\
\hline $\mathrm{TiO}_{2}$ & 2,42 & 2,59 & 0,85 & 2,09 & 2,58 & 2,68 & 2,75 & 2,57 & 2,70 & 2,55 & 2,76 & 2,51 & 2,05 & 2,35 & 2,47 & 2,41 & 2,54 \\
\hline $\mathrm{Al}_{2} \mathrm{O}_{3}$ & 18,21 & 16,24 & 16,41 & 16,07 & 14,65 & 14,40 & 14,53 & 14,19 & 14,41 & 14,95 & 15,00 & 14,75 & 14,62 & 14,40 & 14,56 & 14,85 & 14,96 \\
\hline $\mathrm{Cr}_{2} \mathrm{O}_{3}$ & $\mathrm{n}, \mathrm{d}$, & $\mathrm{n}, \mathrm{d}$ & $\mathrm{n}, \mathrm{d}$, & $\mathrm{n}, \mathrm{d}$, & $\mathrm{n}, \mathrm{d}$, & $\mathrm{n}, \mathrm{d}$, & $\mathrm{n}, \mathrm{d}$, & 0,05 & 0,00 & $\mathrm{n}, \mathrm{d}$, & $\mathrm{n}, \mathrm{d}$, & $\mathrm{n}, \mathrm{d}$, & $\mathrm{n}, \mathrm{d}$, & $\mathrm{n}, \mathrm{d}$, & $\mathrm{n}, \mathrm{d}$, & $\mathrm{n}, \mathrm{d}$, & $\mathrm{n}, \mathrm{d}$, \\
\hline $\mathrm{FeO}^{T}$ & 17,64 & 16,07 & 18,41 & 16,06 & 21,70 & 21,24 & 21,36 & 20,27 & 21,60 & 21,24 & 21,66 & 21,02 & 18,73 & 19,38 & 19,43 & 18,68 & 19,18 \\
\hline $\mathrm{MnO}$ & 0,63 & 0,17 & 0,19 & 0,19 & 0,53 & 0,49 & 0,48 & 0,50 & 0,59 & 0,32 & 0,42 & 0,43 & 0,43 & 0,42 & 0,39 & 0,27 & 0,29 \\
\hline $\mathrm{MgO}$ & 10,17 & 11,46 & 13,41 & 11,85 & 10,51 & 10,99 & 11,06 & 11,57 & 11,14 & 10,64 & 9,97 & 10,78 & 12,77 & 12,56 & 12,14 & 12,18 & 11,96 \\
\hline $\mathrm{BaO}$ & 0,07 & 0,53 & 0,00 & 0,10 & 0,49 & 0,10 & 0,00 & 0,12 & 0,10 & 0,07 & 0,66 & 0,03 & 0,04 & 0,01 & 0,22 & 0,34 & 0,55 \\
\hline $\mathrm{CaO}$ & 0,01 & 0,00 & 0,03 & 0,00 & 0,00 & 0,00 & 0,01 & 0, & & & & 0,00 & 0,00 & 0, & & 0,02 & 0,00 \\
\hline $\mathrm{Na}_{2} \mathrm{O}$ & 0,10 & 0,07 & 0,08 & 0,04 & 0,11 & 0,09 & 0,06 & 0,06 & 0,08 & 0,0 & 0,11 & 0,06 & 0,08 & 0,06 & 10 & 0,06 & 0,08 \\
\hline $\mathrm{K}_{2} \mathrm{O}$ & 10,06 & 10,13 & 7,93 & 10,45 & 9,89 & 9,89 & 10,03 & 9,92 & 9,90 & 9,99 & 9,87 & 10,10 & 10,27 & 10,24 & 10,09 & 9,44 & 9,74 \\
\hline $\mathrm{F}$ & 0,71 & 1,46 & 1,26 & 1,21 & 0,42 & 0,75 & 0,73 & 0,55 & 0,59 & 0,52 & 0,65 & 0,59 & 1,31 & 1,01 & 0,67 & 1,93 & 1,85 \\
\hline Total & 96,76 & 96,70 & 95,09 & 96,31 & 96,59 & 97,24 & 97,91 & 97,26 & \begin{tabular}{|r}
98,12 \\
\end{tabular} & 97,04 & 97,31 & 96,66 & 97,88 & 98,21 & 97,20 & 97,16 & 98,63 \\
\hline \multicolumn{18}{|c|}{$O=22$} \\
\hline $\mathrm{Si}$ & 5,483 & 5,636 & 5,502 & 5,687 & 5,504 & 5,560 & 5,561 & 5,648 & 5,574 & 5,572 & 5,527 & 5,558 & 5,591 & 5,614 & 5,593 & 5,531 & 5,543 \\
\hline $\mathrm{Al}^{\mathrm{N}}$ & 2,517 & 2,364 & 2,498 & 2,313 & 2,496 & 2,440 & 2,439 & 2,352 & 2,426 & 2,428 & 2,473 & 2,442 & 2,409 & 2,386 & 2,407 & 2,469 & 2,457 \\
\hline $\mathrm{Al}^{\mathrm{VI}}$ & 0,686 & 0,477 & 0,415 & 0,504 & 0,166 & 0,138 & 0,142 & 0,171 & 0,132 & 0,249 & 0,227 & 0,212 & 0,156 & 0,138 & 0,178 & 0,148 & 0,151 \\
\hline $\mathrm{Ti}$ & 0,272 & 0,289 & 0,097 & 0,234 & 0,299 & 0,306 & 0,311 & 0,292 & 0,306 & 0,291 & 0,317 & 0,289 & 0,229 & 0,2 & 0,2 & 0,271 & 0,282 \\
\hline $\mathrm{Fe}^{2+}$ & 2,201 & 1,994 & 2,319 & 1,996 & 2,798 & 2,697 & 2,692 & 2,558 & 2,720 & 2,698 & 2,766 & 2,683 & 2,331 & 2,409 & 2,447 & 2,336 & 2,372 \\
\hline $\mathrm{Cr}$ & 000 & 0,000 & 0,000 & 0,000 & 0,000 & 0,000 & 0,000 & 0,006 & 0,000 & 0,000 & 0,000 & 0,000 & 0,000 & 0,000 & 0,000 & 0,000 & 0,000 \\
\hline $\mathrm{Mn}$ & 0,079 & 0,021 & 0,024 & 0,024 & 0,069 & 0,063 & 0,061 & 0,064 & 0,075 & 0,042 & 0,054 & 0,055 & 0,054 & 0,053 & 0,049 & 0,034 & 0,037 \\
\hline $\mathrm{Mg}$ & 2,261 & 2,533 & 3,011 & 2,626 & 2,413 & 2,486 & 2,484 & 2,600 & 2,500 & 2,409 & 2,268 & 2,452 & 2,831 & 2,782 & 2,726 & 2,714 & 2,635 \\
\hline $\mathrm{Ba}$ & 0,004 & 0,031 & 0,000 & 0,006 & 0,030 & 0,006 & 0,000 & 0,007 & 0,006 & 0,004 & 0,039 & 0,002 & 0,003 & 0,001 & 0,013 & 0,020 & 0,032 \\
\hline $\mathrm{Ca}$ & 002 & 0,000 & 0,005 & 0,000 & 0,000 & 0,000 & 0,001 & 0,002 & 0,000 & 0,000 & 0,000 & 0,000 & 0,000 & 0,000 & 0,000 & 0,003 & 0,000 \\
\hline $\mathrm{Na}$ & 0,029 & 0,020 & 0,024 & 0,012 & 0,033 & 0,026 & 0,018 & 0,017 & 0,024 & 0,023 & 0,033 & 0,016 & 0,023 & 0,016 & 0,028 & 0,016 & 0,023 \\
\hline $\mathrm{K}$ & 1,914 & 1,918 & 1,525 & 1,982 & 1,945 & 1,915 & 1,928 & 1,908 & 1,901 & 1,936 & 1,922 & 1,967 & 1,950 & 1,942 & 1,938 & 1,801 & 1,838 \\
\hline$\Sigma$ & 15,447 & 15,282 & 15,419 & 15,384 & 15,753 & 15,637 & 15,638 & 15,626 & 15,664 & 15,652 & 15,626 & 15,675 & 15,576 & 15,602 & 15,659 & 15,343 & 15,369 \\
\hline$n g$ & 0,51 & 0,56 & 0,56 & 0,57 & 0,46 & 0,48 & 0,48 & 0,50 & 0,48 & 0,47 & 1,43 & 0,48 & 0,55 & 0,54 & 0,53 & 0,54 & 0,53 \\
\hline
\end{tabular}


Tabela 5.7 (cont.): Resultados analíticos e cálculos de fórmula estrutural $(22 \mathrm{O})$ para cristais de biotita do Complexo Granítico Cunhaporanga.

\begin{tabular}{|c|c|c|c|c|c|c|c|c|c|c|c|c|c|c|c|c|c|}
\hline & \multicolumn{17}{|c|}{ Domínios Petrográficos da porção $N E$ do Complexo } \\
\hline & \multicolumn{13}{|c|}{ DOMINIO OURO VERDE-PATRIMÔNIO SANTO ANTÔNIO } & \multirow{3}{*}{\multicolumn{4}{|c|}{$\begin{array}{c}\text { DOMÍNIO LIMEIRA } \\
\text { tit anf bio } \\
\text { IT-50b }\end{array}$}} \\
\hline & & & tit & & & & & & & & & & & & & & \\
\hline & \multicolumn{2}{|c|}{ IT-93 } & \multicolumn{4}{|c|}{ IT-104 } & \multicolumn{7}{|c|}{ IT -96} & & & & \\
\hline Local & $b_{b}$ & $\mathrm{n}_{\mathrm{b}}$ & & $\mathrm{n}_{\mathrm{a}}$ & $b_{b}$ & $n_{b}$ & $\mathbf{b}_{\mathbf{a}}$ & $\mathrm{n}_{\mathrm{a}}$ & $b_{b}$ & $\mathrm{n}_{\mathrm{b}} 1$ & $\mathrm{n}_{\mathrm{b}} 2$ & $b_{c}$ & $n_{c}$ & $\mathrm{~b}_{\mathrm{a}}$ & $\mathbf{n}_{\mathrm{a}}$ & $b_{b}$ & $\mathrm{n}_{\mathrm{b}} 1$ \\
\hline $\mathrm{SiO}_{2}$ & 37,84 & 37,18 & 37,69 & 36,43 & 37,35 & 37,54 & 36,58 & 36,80 & 36,41 & 36,99 & 36,66 & 37,23 & 37,68 & 36,60 & 36,11 & 36,84 & 36,94 \\
\hline $\mathrm{TiO}_{2}$ & 2,49 & 2,63 & 1,89 & 2,19 & 2,43 & 2,38 & 1,41 & 1,51 & 1,28 & 1,57 & 1,28 & 1,31 & 1,51 & 2,16 & 2,09 & 1,73 & 1,62 \\
\hline $\mathrm{Al}_{2} \mathrm{O}_{3}$ & 14,45 & 14,86 & 14,74 & 15,09 & 14,99 & 14,95 & 15,93 & 15,84 & 15,89 & 15,21 & 15,65 & 15,92 & 15,31 & 15,50 & 15,27 & 15,84 & 15,61 \\
\hline $\mathrm{Cr}_{2} \mathrm{O}_{3}$ & $\mathrm{n}, \mathrm{d}$ & $\mathrm{n}, \mathrm{d}$, & $\mathrm{n}, \mathrm{d}$, & $\mathrm{n}, \mathrm{d}$ & $\mathrm{n}, \mathrm{d}$ & $\mathrm{n}, \mathrm{d}$ & $\mathrm{n}, \mathrm{d}$, & $\mathrm{n}, \mathrm{d}$ & $\mathrm{n}, \mathrm{d}$ & $\mathrm{n}, \mathrm{d}$, & $\mathrm{n}, \mathrm{d}$ & $\mathrm{n}, \mathrm{d}$ & $\mathrm{n}, \mathrm{d}$, & $\mathrm{n}, \mathrm{d}$, & $\mathrm{n}, \mathrm{d}$, & $\mathrm{n}, \mathrm{d}$ & $\mathrm{n}, \mathrm{d}$, \\
\hline $\mathrm{FeO}^{\mathrm{T}}$ & 18,24 & 19,34 & 19,42 & 20,57 & 19,90 & 19,92 & 19,95 & 19,82 & 19,98 & 20,00 & 20,06 & 18,94 & 18,92 & 21,82 & 21,86 & 20,69 & 21,14 \\
\hline $\mathrm{MnO}$ & 0,24 & 0,31 & 0,34 & 0,36 & 0,38 & 0,29 & 0,29 & 0,31 & 0,28 & 0,25 & 0,32 & 0,26 & 0,32 & 0,17 & 0,17 & 0,18 & 0,19 \\
\hline $\mathrm{MgO}$ & 12,23 & 11,90 & 11,77 & 11,25 & 11,32 & 11,28 & 11,81 & 11,64 & 12,89 & 11,82 & 11,93 & 12,80 & 12,59 & 10,28 & 10,40 & 10,88 & 10,98 \\
\hline $\mathrm{BaO}$ & 0,00 & 0,29 & 0,03 & 0,81 & 0,16 & 0,18 & 0,86 & 0,63 & 0,07 & 0,05 & 0,25 & 0,00 & 0,03 & 0,14 & 0,00 & 0,15 & 0,07 \\
\hline $\mathrm{CaO}$ & 0,00 & 0,00 & 0,00 & 0,00 & 0,00 & 0,02 & 0,08 & 0,03 & 0,10 & 0,08 & 0,13 & 0,04 & 0,01 & 0,00 & 0,35 & 0,02 & 0,00 \\
\hline $\mathrm{Na}_{2} \mathrm{O}$ & 0,06 & 0,03 & 0,06 & 0,02 & 0,07 & 0,06 & 0,06 & 0,05 & 0,05 & 0,07 & 0,06 & 0,08 & 0,09 & 0,04 & 0,08 & 0,05 & 0,08 \\
\hline $\mathrm{K}_{2} \mathrm{O}$ & 9,44 & 9,76 & 9,38 & 9,26 & 9,54 & 9,52 & 8,96 & 9,21 & 7,84 & 9,24 & 8,86 & 8,38 & 9,43 & 9,64 & 9,52 & 9,40 & 9,55 \\
\hline $\mathrm{F}$ & 1,92 & 1,26 & 1,66 & 1,43 & 1,13 & 1,32 & 0,61 & 0,45 & 0,49 & 0,48 & 0,43 & 0,47 & 0,72 & 0,41 & $\begin{array}{l}0,49 \\
\end{array}$ & 0,63 & 0,68 \\
\hline Total & 96,92 & 97,56 & 96,97 & 97,40 & 97,27 & 97,43 & 96,54 & 96,30 & 95,29 & 95,78 & 95,63 & 95,44 & 96,61 & 96,75 & 96,33 & 96,39 & 96,86 \\
\hline \multicolumn{18}{|c|}{$O=22$} \\
\hline $\mathrm{Si}$ & 5,633 & 5,559 & 5,639 & 5,505 & 5,601 & 5,614 & 5,544 & 5,583 & \begin{tabular}{|l}
5,525 \\
\end{tabular} & 5,627 & 5,586 & 5,612 & 5,646 & 5,574 & 5,542 & 5,587 & 5,589 \\
\hline $\mathrm{Al}^{\mathrm{N}}$ & 2,367 & 2,441 & 2,361 & 2,495 & 2,399 & 2,386 & 2,456 & 2,417 & 2,475 & 2,373 & 2,414 & 2,388 & 2,354 & 2,426 & 2,458 & 2,413 & 2,411 \\
\hline $\mathrm{Al}^{\mathrm{VI}}$ & 0,169 & 0,179 & 0,239 & 0,193 & 0,252 & 0,250 & 0,391 & 0,416 & 0,369 & 0,354 & 0,397 & 0,442 & 0,349 & 0,357 & 0,304 & 0,419 & 0,374 \\
\hline $\mathrm{Ti}$ & 0,279 & 0,296 & 0,213 & 0,249 & 0,274 & 0,267 & 0,161 & 0,173 & 0,147 & 0,179 & 0,146 & 0,149 & 0,171 & 0,248 & 0,241 & 0,197 & 0,184 \\
\hline $\mathrm{Fe}^{2+}$ & 2,270 & 2,418 & 2,430 & 2,599 & 2,495 & 2,492 & 2,529 & 2,515 & 2,535 & 2,545 & 2,557 & 2,388 & 2,371 & 2,779 & 2,805 & 2,624 & 2,675 \\
\hline $\mathrm{Cr}$ & 0,000 & 0,000 & 0,000 & 0,000 & 0,000 & 0,000 & 0,000 & 0,000 & 0,000 & 0,000 & 0,000 & 0,000 & 0,000 & 0,000 & 0,000 & 0,000 & 0,000 \\
\hline $\mathrm{Mn}$ & 0,031 & 0,039 & 0,043 & 0,046 & 0,048 & 0,036 & 0,037 & 0,040 & 0,035 & 0,033 & 0,041 & 0,033 & 0,041 & 0,021 & 0,023 & 0,023 & 0,024 \\
\hline $\mathrm{Mg}$ & 2,714 & 2,653 & 2,625 & 2,532 & 2,529 & 2,514 & 2,669 & 2,633 & 2,915 & 2,679 & 2,710 & 2,876 & 2,811 & 2,333 & 2,379 & 2,459 & 2,477 \\
\hline $\mathrm{Ba}$ & 0,000 & 0,017 & 0,002 & 0,048 & 0,009 & 0,011 & 0,051 & 0,037 & 0,004 & 0,003 & 0,015 & 0,000 & 0,002 & 0,008 & 0,021 & 0,009 & 0,004 \\
\hline $\mathrm{Ca}$ & 0,000 & 0,000 & 0,000 & 0,000 & 0,000 & 0,003 & 0,013 & 0,005 & 0,016 & 0,014 & 0,022 & 0,007 & 0,002 & 0,000 & 0,000 & 0,004 & 0,000 \\
\hline $\mathrm{Na}$ & 0,018 & 0,008 & 0,017 & 0,005 & 0,022 & 0,017 & 0,019 & 0,015 & 0,016 & 0,021 & 0,019 & 0,025 & 0,027 & 0,013 & 0,023 & 0,013 & 0,023 \\
\hline $\mathrm{K}$ & 1,792 & 1,862 & 1,790 & 1,785 & 1,824 & 1,816 & 1,732 & 1,783 & 1,518 & 1,794 & 1,722 & 1,612 & 1,803 & 1,874 & 1,863 & 1,819 & 1,843 \\
\hline$\Sigma$ & 15,273 & 15,471 & 15,359 & 15,456 & 15,454 & 15,406 & 15,601 & 15,618 & 15,555 & 15,622 & 15,628 & 15,531 & 15,575 & 15,632 & 15,659 & 15,567 & 15,604 \\
\hline$m g^{\prime \prime}$ & 0,54 & 0,52 & 0,52 & 0,49 & 0,50 & 0,50 & 0,51 & 0,51 & 0,53| & 0,51 & $0,5 I$ & 0,55 & 0,54 & 0,46 & 0,46 & 0,48 & 0,48 \\
\hline
\end{tabular}


Tabela 5.7 (cont.): Resultados analíticos e cálculos de fórmula estrutural $(22 \mathrm{O})$ para cristais de biotita do Complexo Granítico Cunhaporanga.

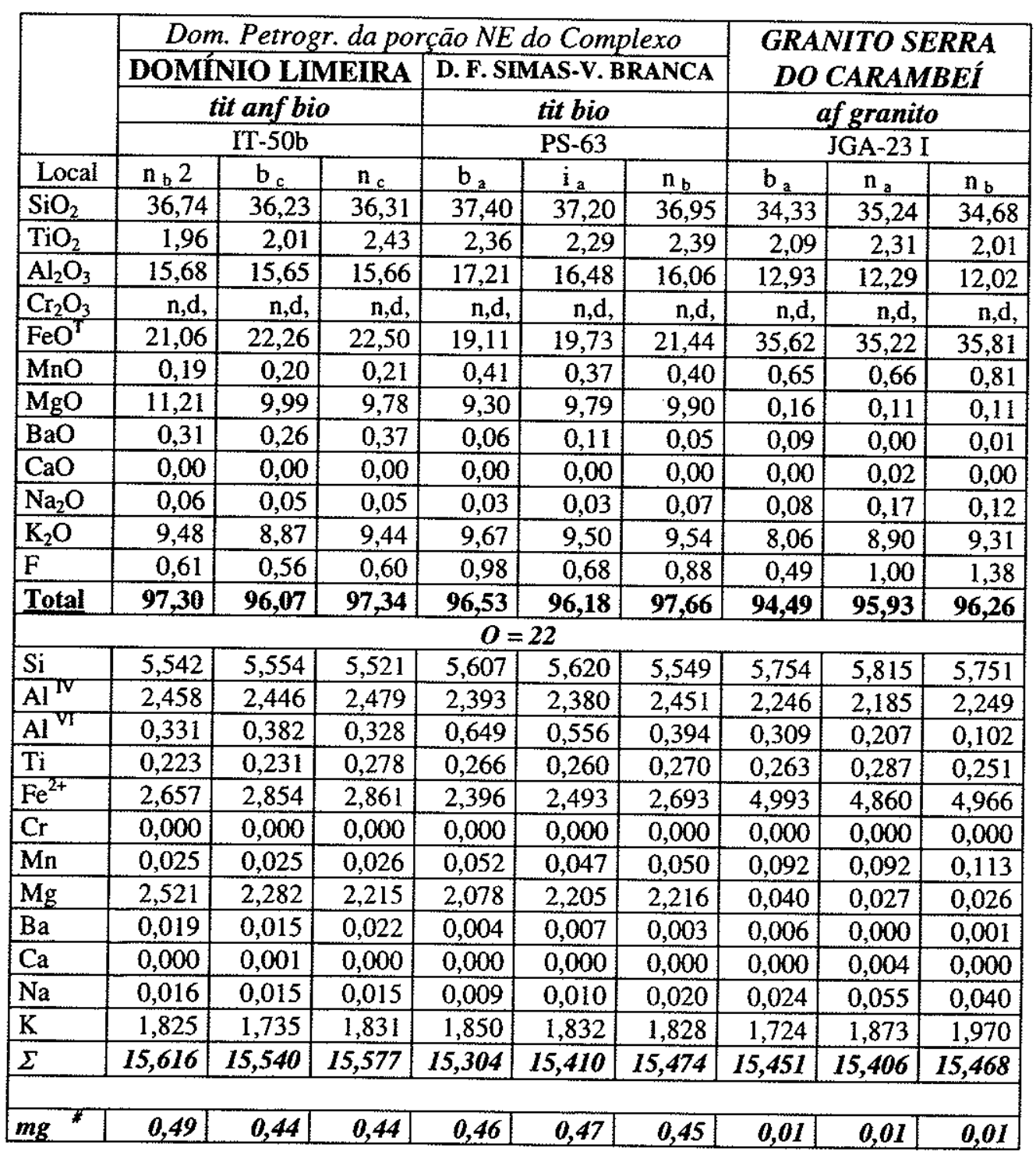

Observações: $\mathrm{FeO}^{\mathrm{T}}$ tal como obtido na microssonda eletrônica; $\boldsymbol{m g}{ }^{\#}=\mathrm{Mg} /\left(\mathrm{Mg}+\mathrm{Fe}^{2+}\right)$. Demais observações, ver Tabela 5.2. 
Tabela 5.8: Resultados analíticos e cálculos de fórmula estrutural $(22 \mathrm{O})$ para cristais de muscovita do Complexo Granítico Cunhaporanga.

\begin{tabular}{|c|c|c|c|c|c|c|c|c|c|}
\hline \multirow[b]{5}{*}{ Local } & \multicolumn{5}{|c|}{ Domínios Petrográficos da porçäo centro- $N$ do Complexo } & \multirow{2}{*}{\multicolumn{2}{|c|}{$\begin{array}{c}\text { D. P. NE Complexo } \\
\text { DOM. F. SIMAS-V. } \\
\text { BRANCA }\end{array}$}} & \multirow{2}{*}{\multicolumn{2}{|c|}{$\begin{array}{c}\text { Granito } \\
\text { Joaquim Murtinho }\end{array}$}} \\
\hline & \multicolumn{2}{|c|}{$\begin{array}{c}\text { DOM. P. DA ANTA- } \\
\text { ÁGUA CLARA }\end{array}$} & \multicolumn{3}{|c|}{ DOMÍNIO VARGINHA } & & & & \\
\hline & \multicolumn{2}{|c|}{ mu bio } & \multicolumn{3}{|c|}{ tit anf bio } & \multicolumn{2}{|c|}{ mu bio } & \multicolumn{2}{|c|}{ af granito } \\
\hline & \multicolumn{2}{|c|}{ JGA-14 } & \multicolumn{3}{|c|}{ PS-66 } & \multicolumn{2}{|c|}{ PS-130 } & \multicolumn{2}{|c|}{ JM-97 } \\
\hline & b 1 & b 2 & $\mathrm{~b}_{\mathrm{a}}$ & $\mathrm{n}_{\mathrm{a}}$ & $\mathrm{n}_{\mathrm{b}}$ & $\mathrm{b}$ & $\mathbf{n}$ & ${ }_{\mathrm{a}} 1$ & $\mathrm{a} 2$ \\
\hline $\mathrm{SiO}_{2}$ & 45,69 & 45,86 & 45,16 & 47,30 & 46,26 & 45,93 & 46,11 & 49,32 & 47,86 \\
\hline $\mathrm{TiO}_{2}$ & 0,47 & 0,81 & 0,57 & 0,17 & 0,39 & 0,38 & 0,18 & 0,17 & 0,32 \\
\hline $\mathrm{Al}_{2} \mathrm{O}_{3}$ & 34,09 & 32,95 & 29,90 & 30,83 & 29,87 & 37,92 & 37,07 & 28,77 & 26,13 \\
\hline $\mathrm{FeO}^{\mathrm{T}}$ & 4,14 & 3,96 & 6,35 & 4,67 & 5,42 & 1,13 & 1,02 & 6,44 & 8,45 \\
\hline $\mathrm{MnO}$ & 0,08 & 0,05 & 0,09 & 0,03 & 0,07 & 0,00 & 0,01 & 0,14 & 0,14 \\
\hline $\mathrm{MgO}$ & 1,18 & 1,25 & 2,98 & 1,98 & 2,72 & 0,27 & 0,97 & 0,60 & 0,71 \\
\hline $\mathrm{BaO}$ & 0,10 & 0,00 & 0,20 & 0,10 & 0,16 & 0,06 & 0,00 & 0,00 & 0,00 \\
\hline $\mathrm{CaO}$ & 0,03 & 0,03 & 0,00 & 0,00 & 0,00 & 0,00 & 0,00 & 0,11 & 0,07 \\
\hline $\mathrm{Na}_{2} \mathrm{O}$ & 0,37 & 0,32 & 0,17 & 0,18 & 0,14 & 0,22 & 0,19 & 0,02 & 0,05 \\
\hline $\mathrm{K}_{2} \mathrm{O}$ & 10,89 & 10,90 & 11,04 & 11,16 & 11,49 & 11,37 & 11,68 & 9,48 & 9,89 \\
\hline $\mathrm{F}$ & 0,12 & 0,17 & 0,25 & 0,15 & 0,34 & 0,07 & 0,19 & 0,22 & 0,33 \\
\hline Total & 97,14 & 96,30 & 96,71 & 96,56 & 96,86 & 97,34 & 97,42 & 95,28 & 93,95 \\
\hline \multicolumn{10}{|c|}{$O=22$} \\
\hline $\mathrm{Si}$ & 6,084 & 6,153 & 6,149 & 6,352 & 6,257 & 5,999 & 6,028 & 6,669 & 6,681 \\
\hline $\mathrm{Al}^{\mathrm{IV}}$ & 1,916 & 1,847 & 1,851 & 1,648 & 1,743 & 2,001 & 1,972 & 1,331 & 1,319 \\
\hline $\mathrm{Al}^{\mathrm{VI}}$ & 3,436 & 3,364 & 2,950 & 3,233 & 3,021 & 3,839 & 3,741 & 3,255 & 2,980 \\
\hline $\mathrm{Ti}$ & 0,047 & 0,081 & 0,059 & 0,017 & 0,040 & 0,037 & 0,018 & 0,017 & 0,034 \\
\hline $\mathrm{Fe}^{2+}$ & 0,461 & 0,445 & 0,723 & 0,525 & 0,613 & 0,123 & 0,111 & 0,729 & 0,987 \\
\hline $\mathrm{Mn}$ & 0,009 & 0,006 & 0,010 & 0,003 & 0,008 & 0,000 & 0,001 & 0,016 & 0,016 \\
\hline $\mathrm{Mg}$ & 0,234 & 0,250 & 0,605 & 0,396 & 0,548 & 0,053 & 0,189 & 0,122 & 0,147 \\
\hline $\mathrm{Ba}$ & 0,005 & 0,000 & 0,011 & 0,005 & 0,009 & 0,003 & 0,000 & 0,000 & 0,000 \\
\hline $\mathrm{Ca}$ & 0,004 & 0,004 & 0,000 & 0,000 & 0,000 & 0,000 & 0,000 & 0,016 & 0,010 \\
\hline $\mathrm{Na}$ & 0,096 & 0,084 & 0,044 & 0,048 & 0,037 & 0,056 & 0,048 & 0,005 & 0,012 \\
\hline $\mathrm{K}$ & 1,850 & 1,866 & 1,918 & 1,911 & 1,982 & 1,894 & 1,948 & 1,636 & 1,761 \\
\hline$\Sigma$ & 14,142 & 14,099 & 14,319 & 14,137 & 14,258 & 14,004 & 14,057 & 13,795 & 13,948 \\
\hline$m g^{\#}$ & 0,34 & 0,36 & 0,46 & 0,43 & 0,47 & 0,30 & 0,63 & 0,14 & 0,13 \\
\hline
\end{tabular}

Observações: $\mathrm{FeO}^{\mathrm{T}}$ tal como obtido na microssonda eletrônica; $\boldsymbol{m g}^{\#}=\mathrm{Mg} /\left(\mathrm{Mg}+\mathrm{Fe}^{2+}\right)$. Demais observações, ver Tabela 5.2. 


\section{CAPÍtULO 6}

\section{GEOQUÍMICA DAS ROCHAS GRANITÓIDES}

Neste capítulo serão apresentados os dados de geoquímica de rochas granitóides, com uma discussão sobre suas relações petrogenéticas. Os resultados de 51 análises, listados na Tabela 6.1 de acordo com a unidade litoestratigráfica e o tipo petrográfico, foram obtidos por meio de duas técnicas, a de ICP-AES (elementos maiores, menores e alguns traços) e fluorescência de raios $X$ (demais traços), conforme procedimentos discutidos no Capítulo 1 (item 1.5.6).

O conjunto de determinações analíticas mostra-se adequado para uma caracterização geoquímica geral do Complexo, além de permitir que se estabeleçam algumas observações sobre tipologia geoquímica, caminhos de evolução magmática e localização em diagramas de discriminação geotectônica.

O grau por vezes bastante marcado da alteração hidrotermal e/ou intempérica de muitos destes tipos petrográficos nem sempre propiciou a obtenção de amostras frescas. Isto explica, em parte, o número desigual de análises químicas para cada unidade litoestratigráfica do Complexo. Adicionalmente, a dificuldade de se processar algumas rochas fortemente porfiríticas (e. g., com fenocristais de feldspato potássico de até $9 \mathrm{~cm}$ ) interferiu na representatividade dessas variantes texturais no conjunto de amostras estudadas. 


\subsection{Caracterização geoquímica dos granitóides}

\subsubsection{Diagramas de Harker}

As Figuras 6.1A, $\mathrm{B}$ e $\mathrm{C}$, onde estão representados os dados integrados para os granitóides do Complexo, permitem uma avaliação global, identificando semelhanças e desvios do padrão geral.

Existe uma correlação negativa marcante entre $\mathrm{SiO}_{2}$ e os óxidos $\mathrm{Al}_{2} \mathrm{O}_{3}, \mathrm{CaO}$, $\mathrm{Fe}_{2} \mathrm{O}_{3}$ (total) e $\mathrm{MgO}$ (Figura 6.1A), também destacada por outros indicadores de evolução que foram testados (e. g., índice de diferenciação $D I$ vs óxidos; índice de Larsen, etc.). O mesmo comportamento ocorre em diagramas da maior parte dos elementos traços $\left(\mathrm{TiO}_{2}, \mathrm{P}_{2} \mathrm{O}_{5}\right.$; Figura 6.1B) e menores (Ba, Sr, V; Figura 6.1C). Os diagramas de variação identificam os álcali-feldspato granitos das unidades Carambeí e Joaquim Murtinho como rochas anômalas, pobres em $\mathrm{Al}_{2} \mathrm{O}_{3}, \mathrm{CaO}, \mathrm{MgO}, \mathrm{Ba}, \mathrm{Sr}$ e Ve enriquecidas em sílica (por vezes com mais de $76 \%$ de $\mathrm{SiO}_{2}$ ).

O decréscimo de $\mathrm{MgO}$ e $\mathrm{CaO}$ com o incremento da sílica é muito marcado, gerando-se algum espalhamento apenas nas rochas mais evoluídas; a amostra PS103, um pórfiro com anfibólio intrusivo no Grupo Itaiacoca, afasta-se da tendência geral pelo teor excessivo em $\mathrm{MgO}$ e reduzido em $\mathrm{CaO}$. O valor elevado em $\mathrm{CaO}(\sim 6,8 \%)$ para o diorito PS-32 do Domínio Piraí do Sul deve-se, em parte, à alteração deutérica (grande quantidade de epidoto + muscovita; ver item 4.3.1, Capítulo 4).

No gráfico com os resultados analíticos do $\mathrm{Fe}_{2} \mathrm{O}_{3}$ (total) está bem evidente a forte hematitização que caracteriza os Granitos Serra do Carambeí e Joaquim Murtinho, pois seus dados deslocam-se nitidamente da tendência principal.

As quantidades de álcalis de uma rocha (ou de um conjunto de rochas) freqüentemente são utilizadas com fins de nomenclatura e de enquadramento em séries magmáticas (e. g., Cox et al. 1979, Middlemost 1994). Apesar de proposto inicialmente para a nomenclatura de rochas vulcânicas, tem se procurado adaptar o 
COMPLEXO GRANÍTICO CUNHAPORANGA (geoquímica das rochas granitóides)
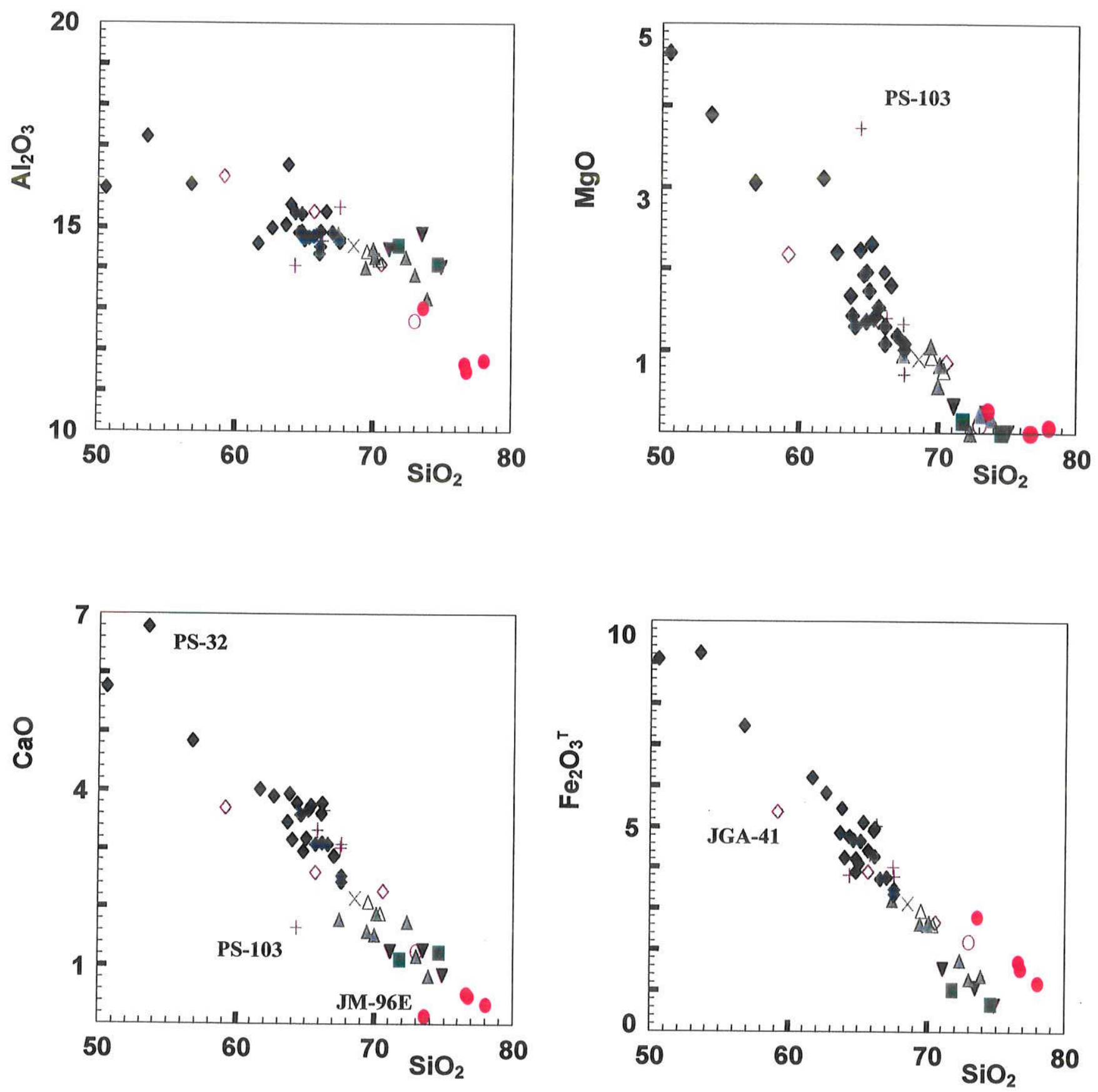

Figura 6.1A: Diagramas de Harker (elementos maiores) para rochas do Complexo Granítico Cunhaporanga (símbolos cheios para rochas equigranulares, vazios para porfiríticas): losangos para titanita anfibólio biotita granitóides, triângulos para titanita biotita granitóides, triângulos invertidos para biotita granitóides, quadrados para muscovita biotita granitóides, círculos para álcali-feldspato granitos, cruzes para granitóides pórfiros com anfibólio e letra $X$ para granitóide pórfiro com biotita. Nos diagramas, valores em porcentagem em peso de óxidos. 


\section{COMPLEXO GRANÍTICO CUNHAPORANGA (geoquímica das rochas granitóides)}
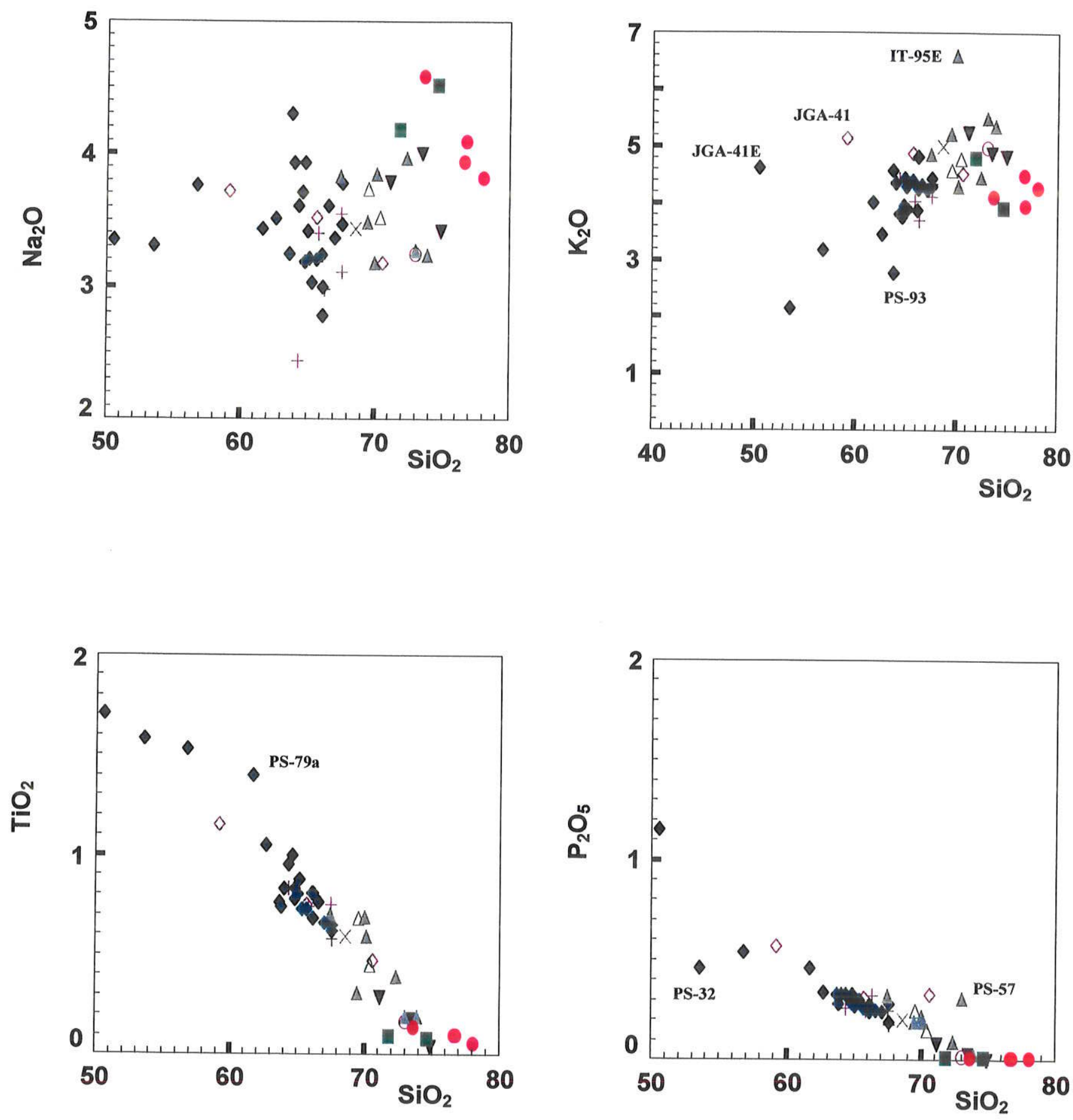

Figura 6.1B: Diagramas de Harker para rochas do Complexo Granítico Cunhaporanga (símbolos cheios para rochas equigranulares, vazios para porfiríticas): losangos para titanita anfibólio biotita granitóides, triângulos para titanita biotita granitóides, triângulos invertidos para biotita granitóides, quadrados para muscovita biotita granitóides, círculos para álcali-feldspato granitos, cruzes para granitóides pórfiros com anfibólio e letra X para granitóide pórfiro com biotita. Nos diagramas, valores em porcentagem em peso de óxidos. 
COMPLEXO GRANÍTICO CUNHAPORANGA (geoquímica das rochas granitóides)
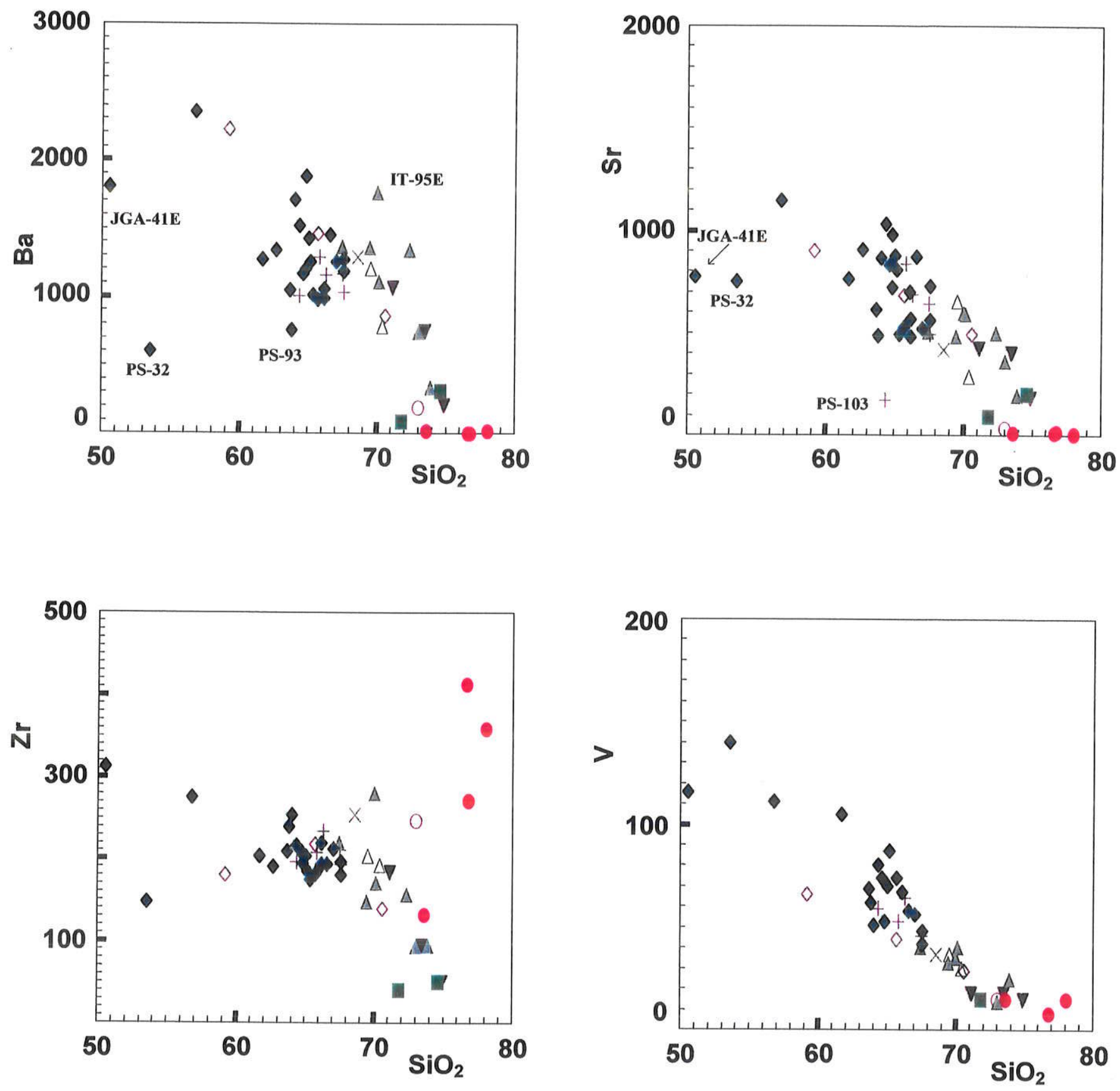

Figura 6.1C: Diagramas de Harker (elementos traços) para rochas do Complexo Granítico Cunhaporanga (símbolos cheios para rochas equigranulares, vazios para porfiríticas): losangos para titanita anfibólio biotita granitóides, triângulos para titanita biotita granitóides, triângulos invertidos para biotita granitóides, quadrados para muscovita biotita granitóides, círculos para álcali-feldspato granitos, cruzes para granitóides pórfiros com anfibólio e letra $\mathrm{X}$ para granitóide pórfiro com biotita. Nos diagramas, valores em ppm nas ordenadas e em porcentagem em peso nas abcissas. 
diagrama TAS ("total alkali-silica diagram") também para rochas plutônicas (Middlemost 1994).

As Figuras 6.2A, $\mathrm{B}$ e $\mathrm{C}$ mostram o posicionamento das rochas granitóides do Complexo em diferentes esquemas de nomenclatura que consideram os teores de $\mathrm{Na}_{2} \mathrm{O}$ e $\mathrm{K}_{2} \mathrm{O}$, onde os nomes dos campos foram adaptados dos termos originais para rochas vulcânicas (Figuras 6.2A e B), ou então seguiram a proposta de Middlemost (1994; Figura 6.2C). Tal como visto no Capítulo 4, a maior parte das análises distribuem-se nos campos reservados aos granitos e granodioritos.

Mesmo trazendo algumas vantagens (e. g., possibilidade de comparação com trabalhos que possuem análises químicas, mas não contagens modais), a adoção da nomenclatura de rochas granitóides com base em seus teores de álcalis tem restrições:

a) serve de desestímulo a um estudo petrográfico cuidadoso (macro- e microscópico);

b) o esquema atual, com base em contagens modais, tem larga aceitação;

c) a nomenclatura puramente química das rochas introduz ambiguidade, uma área que já é suficientemente problemática. Assim, nas Figuras $6.2 \mathrm{~B}$ e $\mathrm{C}$ um número relativamente alto de rochas ocupa o campo quartzomonzonítico, classificadas no diagrama QAP como monzogranitos ou granodioritos (motivo da diferença: índice de cor elevado destes litotipos, em especial pela presença significativa de biotita), enquanto que o enclave JGA-41E, rico em biotita, aparece no limite com o campo de rochas insaturadas e com feldspatóides (Figura 6.2C; motivo: alto teor de álcalis pela contribuição da biotita).

Os granitóides do Complexo Cunhaporanga, ainda no diagrama de $\mathrm{SiO}_{2}$ vs álcalis, dispõem-se preferencialmente como rochas sub-alcalinas (Figura 6.3 a); como exceções aparecem apenas três amostras que apresentaram, proporcionalmente à sílica, os maiores teores de $\mathrm{K}_{2} \mathrm{O}$ (ver Figura 6.1B). Estas rochas sub-alcalinas (Figuras $6.3 \mathrm{~b}$ e c) mostram um padrão comum a granitos cálcio-alcalinos de alto $\mathrm{K}$ (em parte shoshoníticos). Como já indicado em Guimarães (Figura 6, na página 26, 1995), o correto seria considerar os granitóides do Complexo como pertencentes a uma série magmática álcali-cálcica e não cálcio-alcalina (Figura 6.3 d). 
COMPLEXO GRANÍTICO CUNHAPORANGA (geoquímica das rochas granitóides)
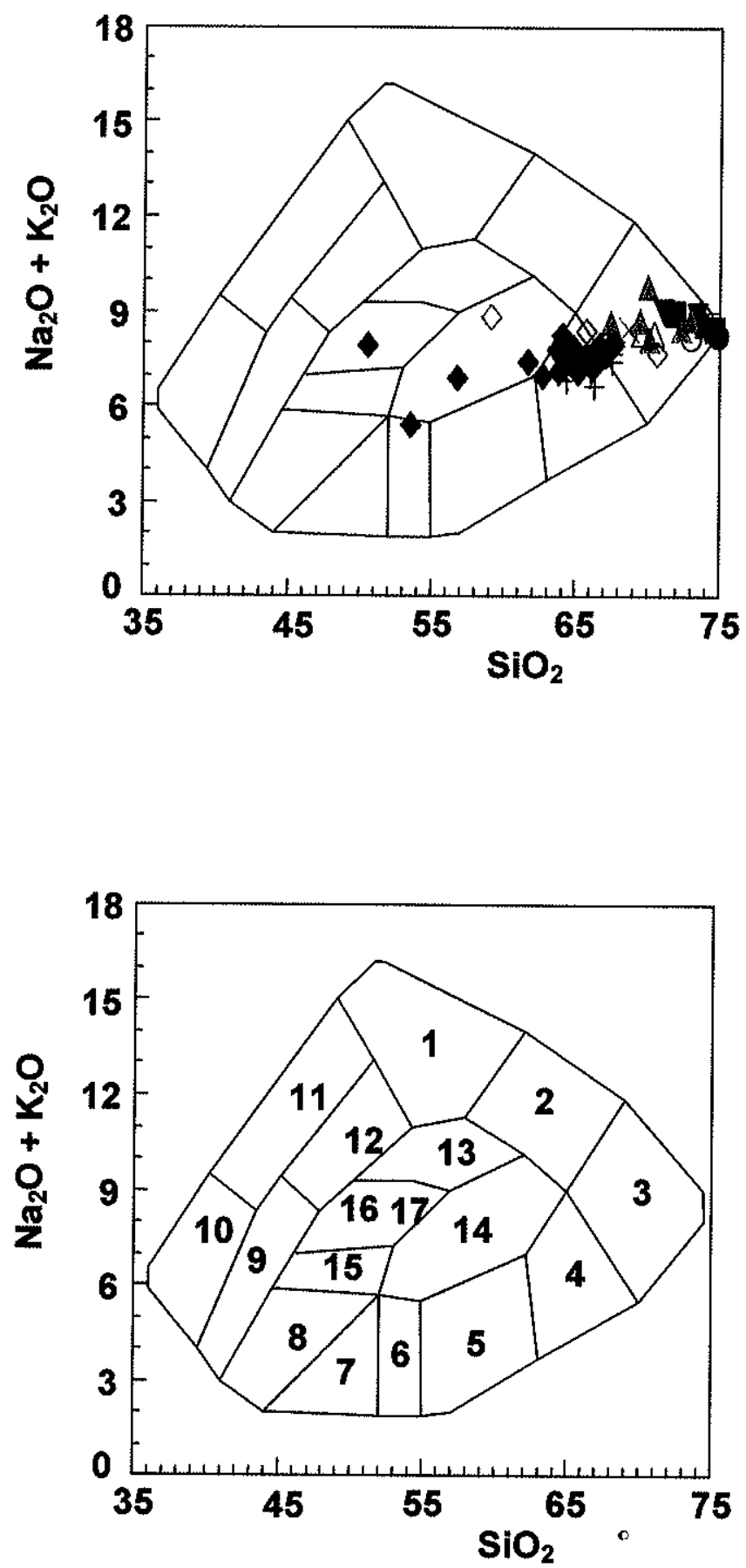

Figura 6.2A: Nomenclatura das rochas granitóides do Complexo Cunhaporanga. Campos correspondentes à nomenclatura proposta por Cox et al. (1979) para rochas vulcânicas, aqui adaptados: $\mathbf{3}$ - granitos; 4 - granodioritos; 5 dioritos; 6 - dioritos/gabros; 14 - monzodioritos; 17 -monzogabros. Símbolos como na Figura 6.1. Nos diagramas, valores em porcentagem em peso de óxidos. 
COMPLEXO GRANÍTICO CUNHAPORANGA (geoquímica das rochas granitóides)
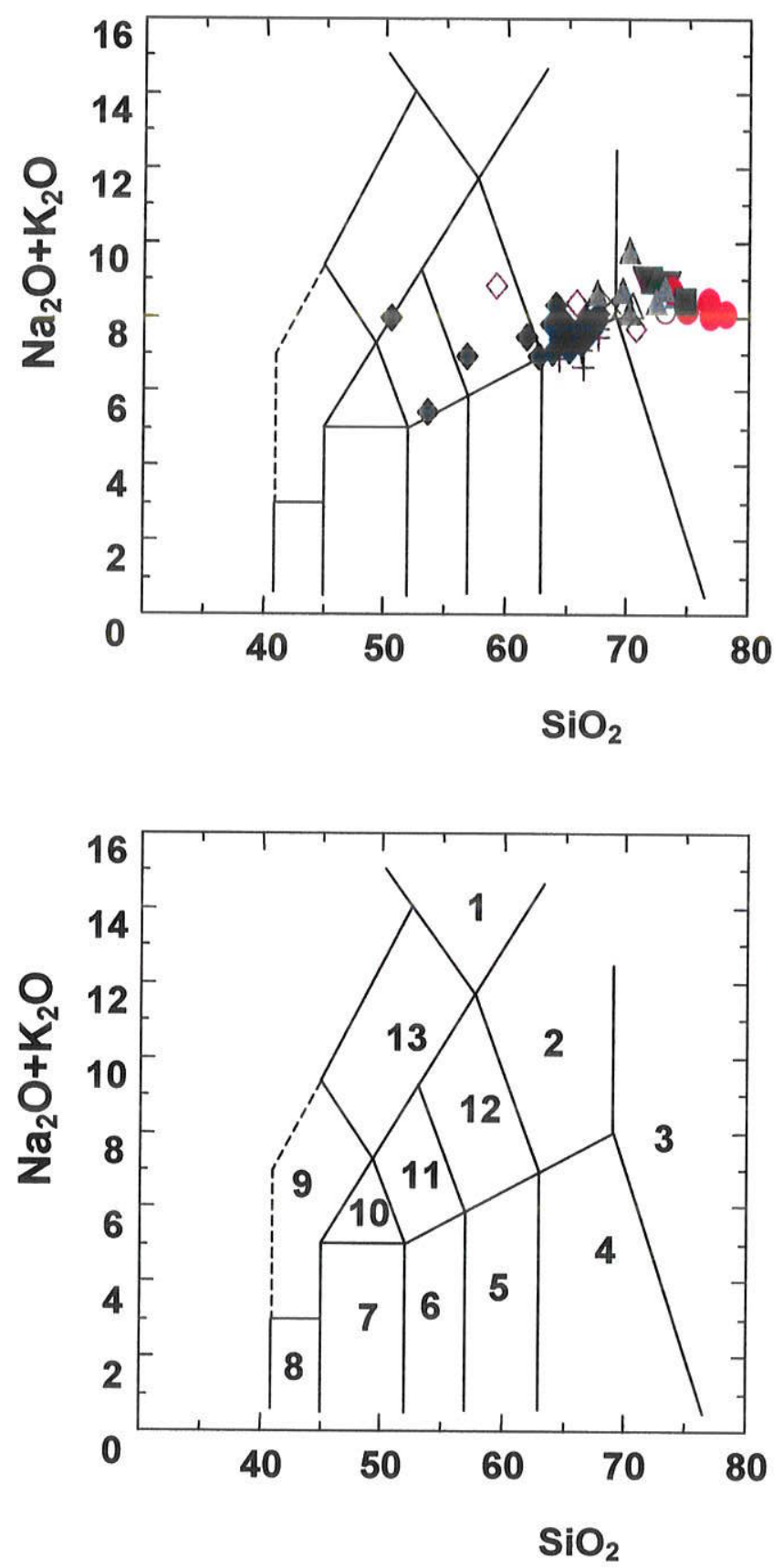

Figura 6.2B: Nomenclatura das rochas granitóides do Complexo Cunhaporanga, adaptada da proposição de Le Maitre et al. (1989) para rochas vulcânicas: 2 - quartzo monzonitos (Q quartzo normativo > 20\%); 3 - granitos; 4 granodioritos; 5 -dioritos; 6 - dioritos/gabros; 11 - monzodioritos/monzogabros; 12 monzodioritos. Símbolos como na Figura 6.1. Nos diagramas, valores em porcentagem em peso de óxidos. 


\section{COMPLEXO GRANÍTICO CUNHAPORANGA (geoquímica das rochas granitóides)}

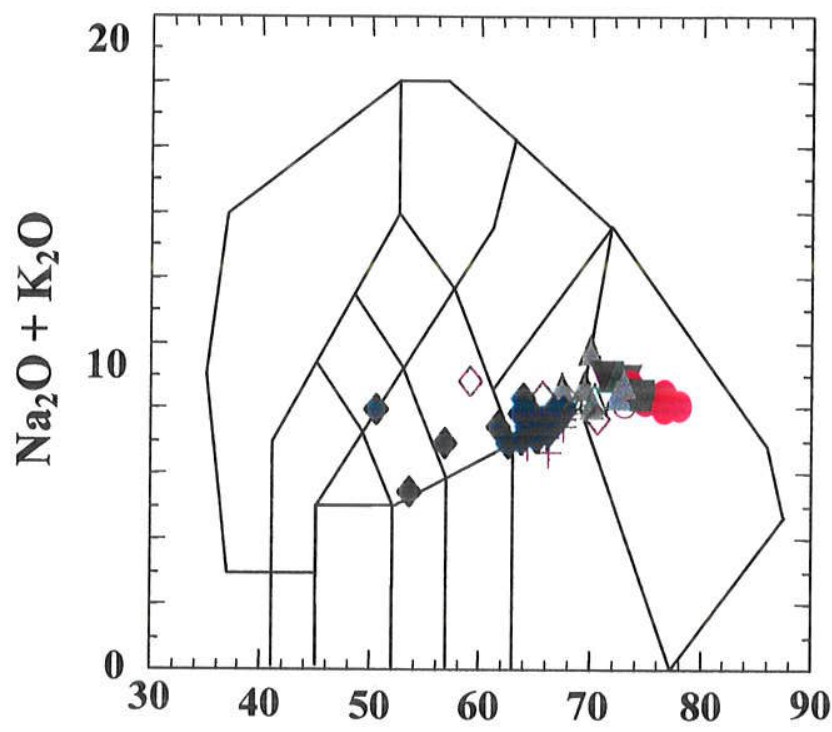

$\mathrm{SiO}_{2}$

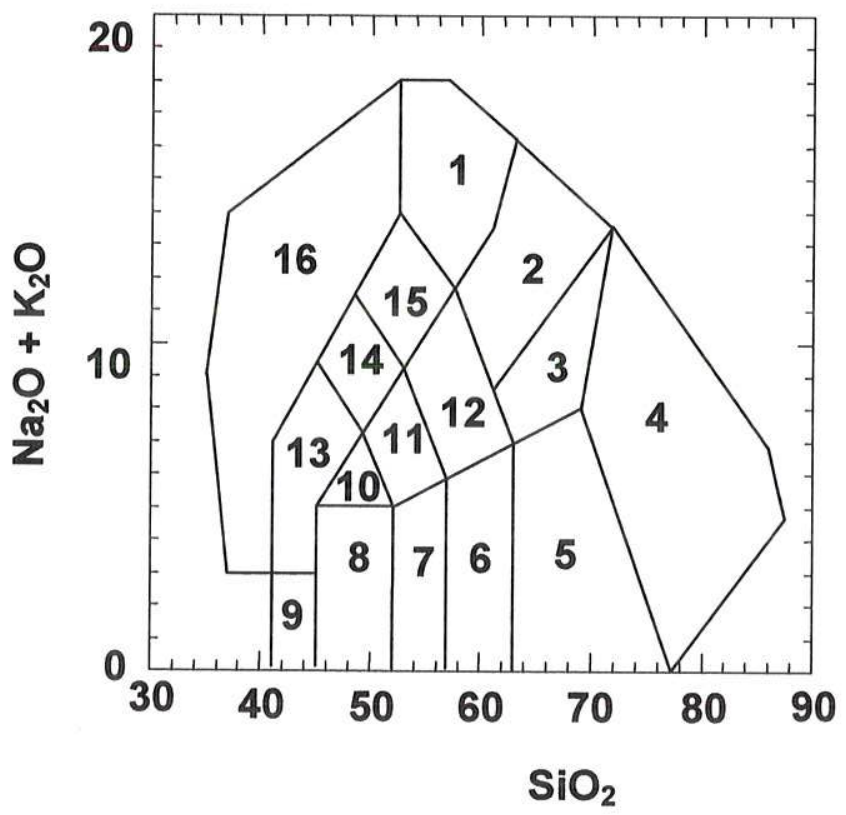

Figura 6.2C: Nomenclatura das rochas granitóides do Complexo Cunhaporanga, segundo a proposição de Middlemost (1994): 3 - quartzo monzonitos; 4 - granitos; 5 - granodioritos; 6 - dioritos; 7 - dioritos gabróicos; 11 - monzodioritos; 12 - monzonitos; 14 - feldspatóide monzodiorito. Símbolos como na Figura 6.1. Nos diagramas, valores em porcentagem de óxidos. 


\section{COMPLEXO GRANÍTICO CUNHAPORANGA (geoquímica das rochas granitóides)}
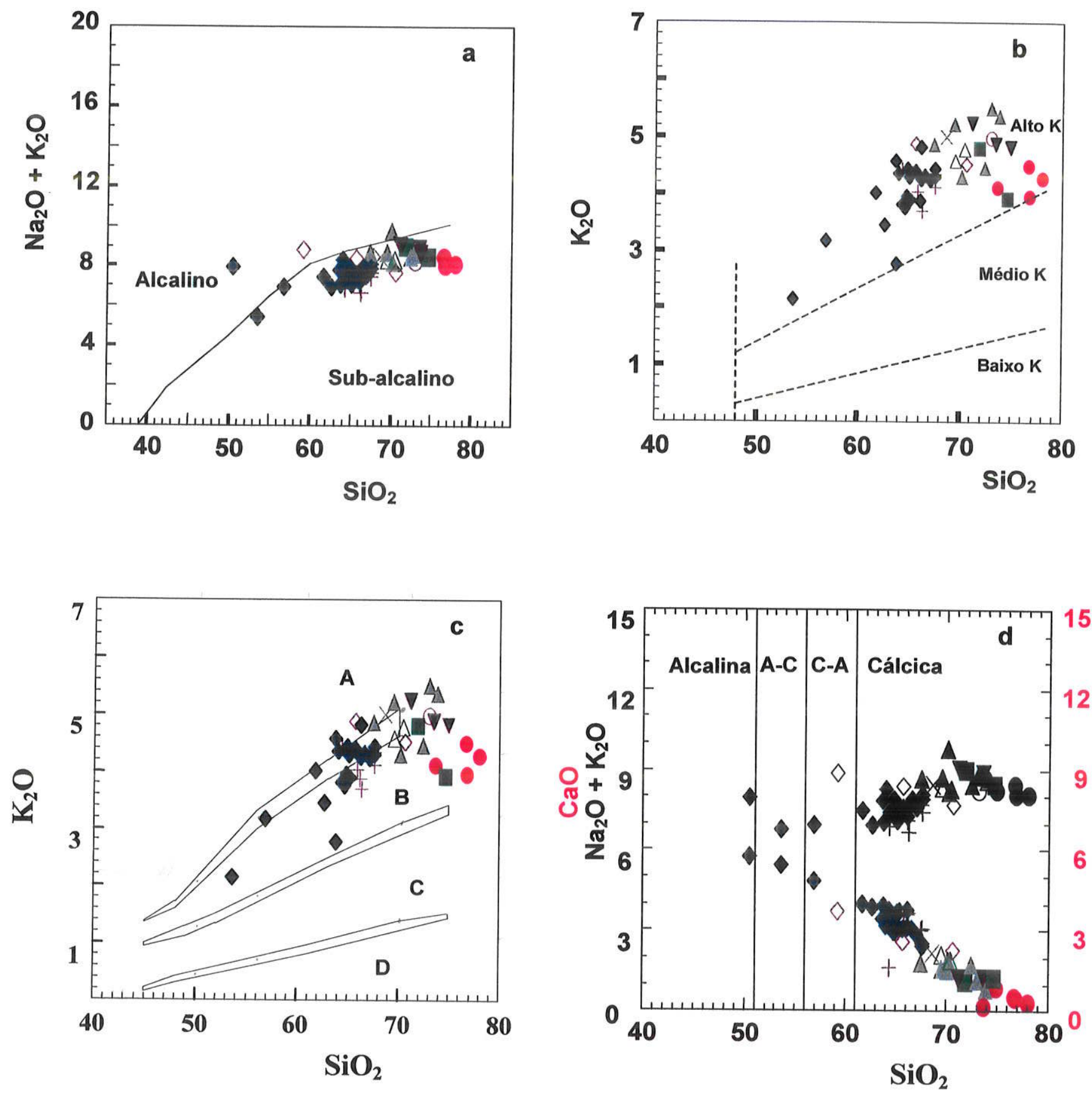

Figura 6.3: a - Discriminação entre rochas alcalinas e sub-alcalinas, utilizando-se a curva de Irvine \& Baragar (1971). b - Subdivisão das rochas sub-alcalinas, segundo Le Maitre et al. (1989). c Subdivisão das rochas sub-alcalinas de acordo com Rickwood (1989). Campo A - série shoshonítica; campo B - série cálcio-alcalina de alto potássio; campo C - série cálcio-alcalina; campo D - série tholeiítica. d - Diagrama $\mathrm{SiO}_{2}$ vs $\mathrm{CaO}$ (símbolos coloridos) e vs $\left(\mathrm{Na}_{2} \mathrm{O}+\mathrm{K}_{2} \mathrm{O}\right.$ ) (símbolos em negro), definindo um Índice de Peacock (porcentagem de sílica de uma série magmática em que os teores de $\mathrm{CaO}$ e $\mathrm{Na}_{2} \mathrm{O}+\mathrm{K}_{2} \mathrm{O}$ são iguais) dentro do campo das séries álcali-cálcicas (A-C) e não cálcio-alcalinas (C-A). Em todos os diagramas, valores em porcentagem em peso de óxido. 
$\mathrm{O}$ diagrama do $\mathrm{Zr}$ é complexo (Figura 6.1C). Aparece uma tendência geral de empobrecimento com o aumento da sílica, com exceção da major parte das amostras dos Granitos Serra do Carambeí e Joaquim Murtinho, detentoras dos maiores valores absolutos obtidos para o Complexo. Estes granitóides possuem também as maiores quantidades de $\mathrm{Rb}, \mathrm{Nb}, \mathrm{Ce}$ e $\mathrm{Y}$ (ver item 6.2.5, adiante).

As explicações mineralógico-químicas que podem ser aplicadas aos padrões exibidos nos diagramas de variação são:

a) É sintomática a variação nos teores de $\mathrm{Al}$, explicada pelo decréscimo no teor de An (relação catiônica Al:Si de 1:1) nos plagioclásios com o aumento em sílica. Adicionalmente, aumentam consideravelmente os teores de feldspato potássico e de albita (Al:Si de 1:3), junto com quartzo; mas não em proporções adequadas para contrapor-se à diminuição do teor de An.

b) as diminuições nos teores de $\mathrm{Fe}$ (total), $\mathrm{Mg}, \mathrm{Ti}$ e $\mathrm{V}$ estão ligadas ao empobrecimento em minerais máficos primários hornblenda, biotita, ilmenitamagnetita e titanita. Com efeito, os álcali-feldspato granitos, muscovita biotita granitóides e alguns dos biotita granitos, todos com baixo índice de cor, mostram teores mínimos de quase todos estes elementos;

c) o decréscimo nos teores de $P$ está ligado à redução das quantidades de apatita;

d) as diminuições nos teores de Ba (ver Tabela 5.3 e Figura 5.3) e Sr estão ligadas ao ingresso, em escala cada vez menor, no feldspato potássico $(\mathrm{Ba})$ e no plagioclásio (Sr, ligado ao Ca na anortita); dados de química mineral mostram que a biotita coexistente não contém quantidades apreciáveis de Ba (ver Tabela 5.7). A forte correlação negativa entre $\mathrm{Sr} \theta \mathrm{Si}$ tem a ver com a diminuição nos teores de $\mathrm{Ca}$, fortemente ligada à diminuição nos teores de An no plagioclásio, portanto com condições cada vez menores de incorporar Sr (e Ca) (ver comentários no item 5.1, Capítulo 5). O decréscimo em Ba, entretanto, deve estar controlado pela menor disponibilidade nos magmas mais evoluídos;

e) o decréscimo em $\mathrm{Zr}$ com o aumento de $\mathrm{SiO}_{2}$ é majoritariamente controlado pela diminuição nos teores modais de zircão. A explicação do incremento em Zr para os álcali-feldspato granitos, que apresentam zircões morfologicamente distintos 
COMPLEXO GRANÍTICO CUNHAPORANGA (geoquímica das rochas granitóides)
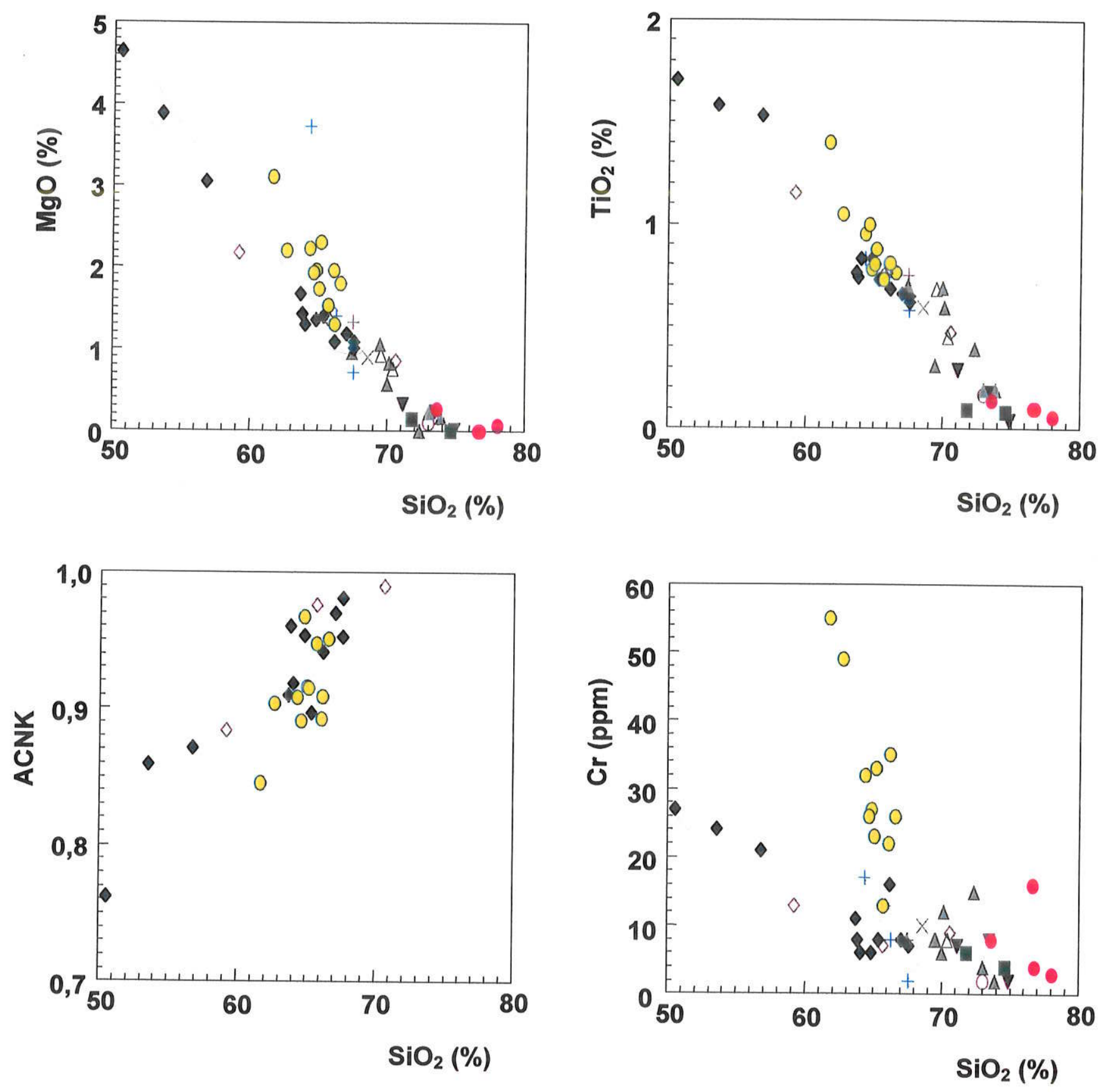

Figura 6.4: Comportamento diferenciado das rochas dos Domínios Petrográficos da porção S/SE do Complexo. Com respeito aos símbolos da Figura 6.1, os losangos dos titanita anfibólio biotita granitóides destes domínios foram substituídos por círculos amarelos, enquanto que as cruzes dos granitóides pórfiros com anfibólio tornaram-se azuis. Demais símbolos sem alterações. No diagrama $\mathrm{SiO}_{2}$ vs índice $A C N K$ estão representados apenas titanita anfibólio biotita granitóides. 
daqueles encontrados em outros tipos de granitóides do Complexo, deve estar relacionada a outras causas (ver item 6.2, adiante).

Os gráficos citados mostram claramente que as rochas menos evoluídas da porção sul/sudeste do Complexo desenham uma tendência que, dependendo do óxido/elemento considerado, é bem distinta daquela definida pelas rochas equivalentes das demais regiões (Figura 6.4). Este quadro, apenas sugerido nos diagramas de $\mathrm{SiO}_{2}$ vs $\mathrm{Sr}$ (Figura 6.1C), revela-se claramente nos gráficos do $\mathrm{MgO}, \mathrm{TiO}_{2}$, índice $\mathrm{ACNK}$ e $\mathrm{Cr}$ (Figura 6.4).

\subsubsection{Diagramas de variação multi-elementos ("aranhogramas")}

Nas Figuras 6.5A e B são mostrados os dados químicos dos granitóides do Complexo Cunhaporanga em aranhogramas, usando para comparação diagramas similares para rochas granitóides de regiōes já clássicas (ver Tabela 6.2). Nos diagramas a, b e c são lançados os valores dos granitóides com titanita-anfibóliobiotita, os com titanita e biotita e os pórfiros do Complexo. Nos três casos, o padrão de distribuição é muito semelhante, com "elevações" marcadas a fortes de Rb, U, Ce e Nd (exceto JGA-34 para o $\mathrm{Nd}$ ) e algo menor de $\mathrm{Y}$ e com "vales" mais ou menos ressaltados para o $\mathrm{Ba}, \mathrm{Nb}, \mathrm{P}$ e Ti.

As razões normalizadas nas Figuras $6.5 \mathrm{~A}$, em $\mathbf{a}$, $\mathbf{b}$ e $\mathbf{c}$, são parecidas até nos números (em especial a e c reforçando a idéia de consangüinidade entre os pórfiros e as rochas grosseiras), o que comprova a estreita afinidade entre estes tipos petrográficos. Percebe-se um empobrecimento em Sr, Ba e principalmente $\mathrm{P}$ quando da passagem das rochas com anfibólio (Figura 6.5A a) para os tipos apenas com titanita e biotita (Figura 6.5A b), mostrando a importância do fracionamento de apatita para esta série.

Na Figura 6.5A d estão representadas três rochas cálcio-alcalinas (linhagem "l") da área-tipo da Austrália oriental (White 1992), para efeitos de comparação. O desenho geral entre esta e as Figuras $6.5 \mathrm{~A}$ a, b e c é o mesmo, apenas mudando alguns valores. Assim, as rochas australianas mostram enriquecimento parelho de Th 

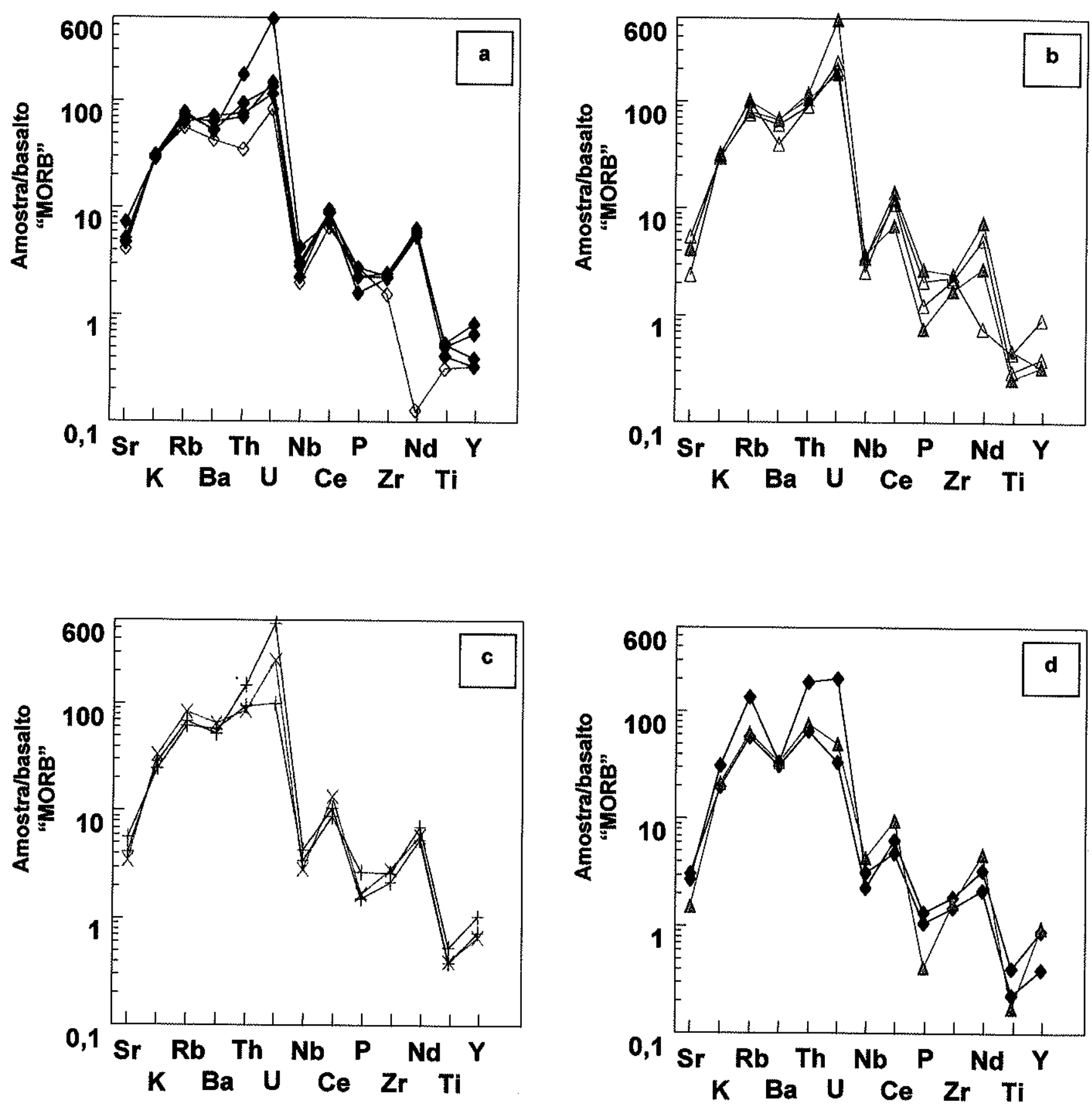

Figura 6.5A: Diagramas multi-elementos, normalizados em relação a um basalto de cadeia meso-oceânica. Dados para normalizaçăo segundo Pearce (1983), exceto Nd (Bevins et al. 1984) e U (U $=T h / 3,5)$. Símbolos como na Figura 6.1. a, b e c, rochas do Complexo Cunhaporanga. d, rochas do leste da Austrália (White 1992). Detalhes no texto e na Tabela 6.2. 


\section{COMPLEXO GRANÍTICO CUNHAPORANGA (geoquímica das rochas granitóides)}
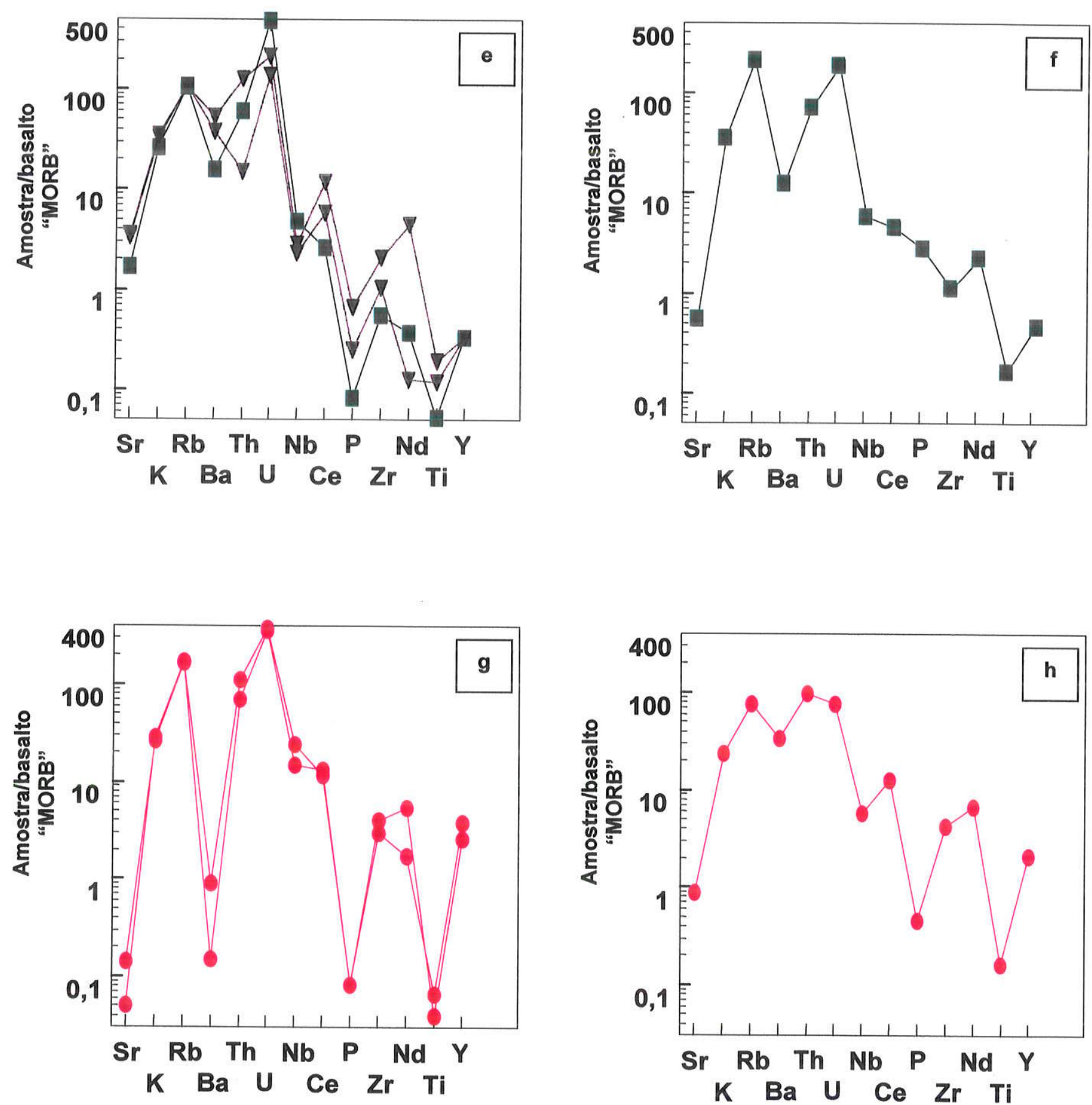

Figura 6.5B: Diagramas multi-elementos, normalizados em relação a um basalto de cadeia meso-oceânica. Dados para normalização segundo Pearce (1983), exceto Nd (Bevins et al. 1984) e U (U $=\mathrm{Th} / 3,5)$. Símbolos como na Figura 6.1. e e g, rochas do Complexo Cunhaporanga. $\mathbf{f}$ e $\mathbf{h}$, rochas do leste da Austrália (White 1992; Collins et al. 1982). Detalhes no texto e na Tabela 6.2. 
e $U$, enquanto que nos granitóides do Complexo as "elevações" para o $U$ são significativamente mais fortes que as do Th. Todavia, a forma desta parte do diagrama, mostrando as variações de Th e $U$, pode estar relacionada com problemas analíticos, pois os valores obtidos para estes elementos nas rochas do Complexo são muito baixos e próximos ao limite de deteç̧ão na metodologia empregada (FRX).

$\mathrm{Na}$ Figura 6.5B e, são vistos os padrões normalizados para biotita granitóides e um muscovita biotita granitóide, enquanto na Figura 6.5B g, tem-se os dados dos álcalifeldspato granitos. As anomalias negativas em $\mathrm{Sr}, \mathrm{Ba}, \mathrm{P}$ e Ti, já presentes nas Figuras $6.5 \mathrm{~A} \mathbf{a}, \mathbf{b}$ e c, aparecem ampliadas na Figura 6.5B e e g, em adaptação ao decréscimo progressivo destes elementos. Para as rochas dos Granitos Serra do Carambeí e Joaquim Murtinho, tem-se também o desaparecimento da anomalia negativa do $\mathrm{Nb}$ (Figura 6.5B e).

As Figuras $6.5 \mathrm{~B} \mathrm{f}$ e 6.5B $\mathrm{h}$ mostram, respectivamente, um muscovita granito " $\mathrm{S}$ " com sillimanita da área-tipo da Austrália oriental (White 1992) e a composição média de um granitóide do tipo " $A$ " (Collins et al. 1982). Nota-se que o granito " $S$ " dificilmente equivale às composições dos biotita ou muscovita biotita granitos do Complexo Cunhaporanga, ou então aos álcali-feldspato granitos.

Comparativamente ao muscovita biotita granitóide do Complexo, chama a atenção o $\mathrm{Sr}$ e principalmente o $\mathrm{P}$, respectivamente mais baixo e mais alto no granito "S" australiano. Segundo White (1992), os baixos teores de Sr estariam ligados ao baixo conteúdo de $\mathrm{Ca}$ da rocha, característica herdada dos metassedimentos que proporcionaram a geração dos magmas formadores destes granitóides.

enriquecimento em $\mathrm{P}$, ainda segundo este autor, seria resultado da alta solubilidade do fósforo em magmas fortemente aluminosos $(A C N K=1,27$ para $\circ$ Granito Granya, White 1992; ACNK 1,01-1,03 para os muscovita biotita granitóides do Complexo, Figura 6.6). Já para os biotita granitóides, as diferenças com o granito " $S$ " da Austrália estão tanto no $\mathrm{Sr}$ como no $\mathrm{Ba}$ (mais baixo no granito "S"), como também na ausência de uma anomalia negativa de $\mathrm{Nb}$. 
Os álcali-feldspato granitos das unidades Joaquim Murtinho e Serra do Carambeí (Figura 6.5B g), classificados como granitóides tipo "A" (e. g., Soares 1987) por serem "tardios" e de natureza "alasquítica", diferenciam-se também dos granitos " $\mathrm{A}$ " da Figura $6.5 \mathrm{~B}$ h. Nas rochas do Complexo destacam-se as fortes anomalias negativas de $\mathrm{Sr}, \mathrm{Ba}, \mathrm{P}$ e Ti, em parte condicionadas pelo enriquecimento relativamente alto dos elementos vizinhos ( $K, R b, U, T h$ e $Z r$ ) e que estão ausentes na Suíte Gabo de Collins et al. (1982; Figura 6.5B h).

É preciso lembrar, entretanto, que os corpos Carambeí e Joaquim Murtinho são muito mais diferenciados que os da Suíte Gabo (ver Tabela 6.3), prejudicando seriamente a comparação dos diagramas multi-elementos. Como será visto adiante (itens 6.2 .5 e 6.3.2), o padrão geoquímico dos álcali-feldspato granitóides é realmente semelhante ao dos granitos " $A$ ".

\subsubsection{Diagramas ACNK vs ANK}

São metaluminosas as rochas granitóides mais primitivas, com titanita e anfibólio, em geral, por força da composição química destes minerais. Os biotita granitóides, pelo contrário, são tipos litológicos mais evoluídos na maioria das "suítes" granitícas do mundo todo. Nestas rochas o caráter peraluminoso é adquirido pelo excesso em Al de suas biotitas, enriquecidas que são no componente siderofilita (ver item 5.5, Capítulo 5). Esta feição peraluminosa deve ser ainda mais enfatizada no caso dos muscovita biotita granitóides.

A situação acima descrita aparece claramente na Figura 6.6. Os tipos com titanita-anfibólio-biotita do Complexo Cunhaporanga são metaluminosos, enquanto que os com biotita e titanita estão situados no limite entre os dois campos (Figuras 6.6 a e b). Os pórfiros aparecem também no campo metaluminoso (com a exceção da amostra PS-103; influência de alteração incipiente, com remoção de álcalis e do Ca?).

Os tipos com biotita e com biotita e muscovita do Complexo situam-se no campo peraluminoso, como previsto pela mineralogia das rochas. $O$ índice $A C N K$ relativamente baixo para os muscovita biotita granitóides, até mesmo inferior ao de 


\section{COMPLEXO GRANIITICO CUNHAPORANGA (geoquímica das rochas granitóides)}
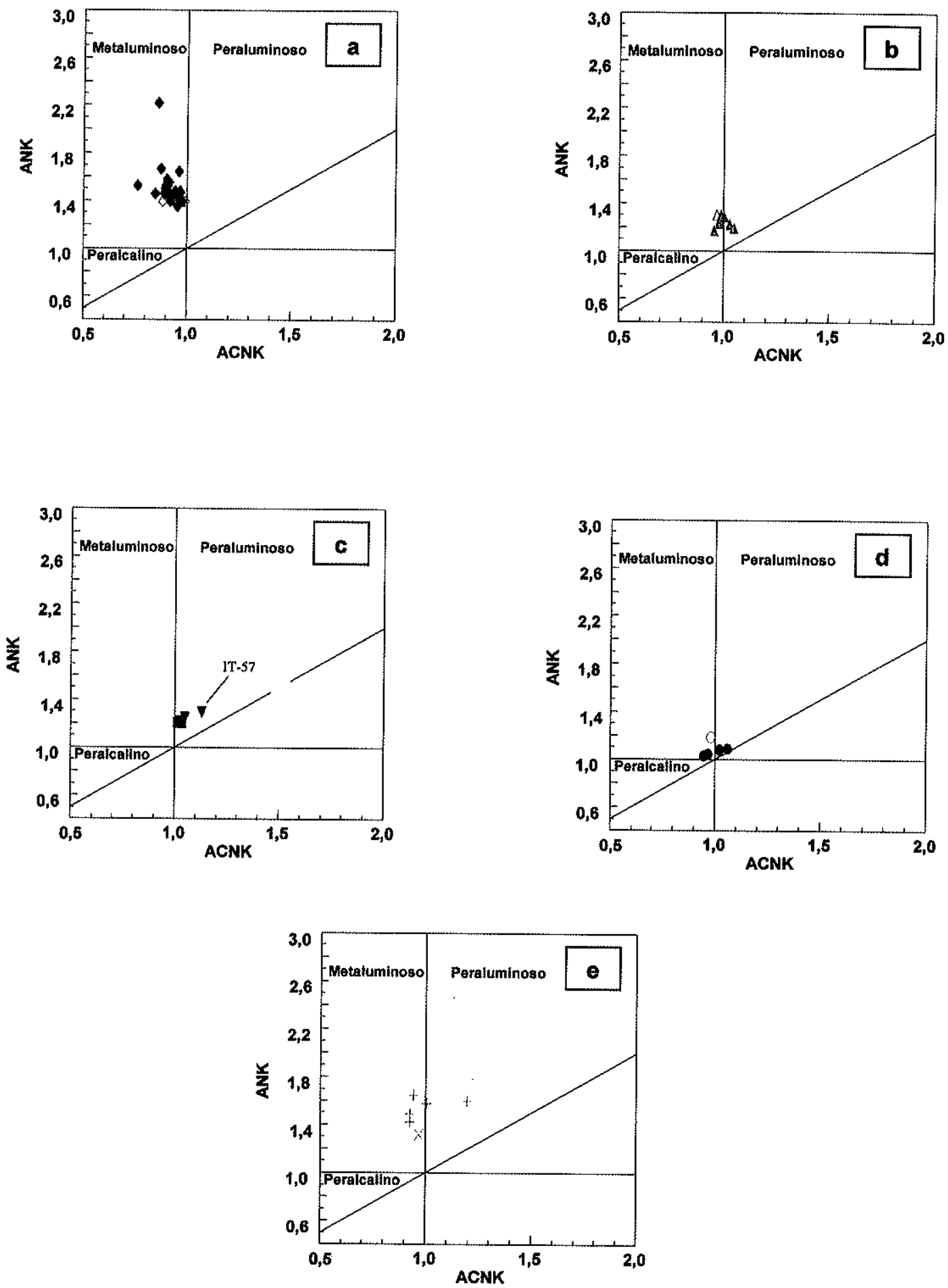

Figura 6.6: Diagramas ACNK $\times$ ANK de Maniar \& Piccoli (1989) para os diferentes tipos granitóides do Complexo Cunhaporanga (símbolos conforme Figura 6.1): a - titanita anfibólio biotita granitóides; b - titanita biotita granitóides; c - biotita granitóides e muscovita biotita granitóides; d álcali-feldspato granitóides ; e - granitóides pórfiros. $A C N K=\mathrm{Al}_{2} \mathrm{O}_{3}$ molecular $/\left(\mathrm{CaO}+\mathrm{Na}_{2} \mathrm{O}+\mathrm{K}_{2} \mathrm{O}\right)$ moleculares; $\mathrm{ANK}=\mathrm{Al}_{2} \mathrm{O}_{3}$ molecular $\left(\mathrm{Na}_{2} \mathrm{O}+\mathrm{K}_{2} \mathrm{O}\right)$ moleculares. 
alguns dos biotita granitóides, sugere que estas rochas poderiam ter-se formado a partir da contaminação de monzogranitos a granodioritos por material aluminoso, em concordância com as observações petrográficas e de campo citadas em capítulos anteriores. A assimilação de biotita-muscovita-quartzo xistos (a quartzitos) por rochas graníticas no Domínio Limeira (ver item 4.4.2, Capítulo 4) explicaria a peraluminosidade da amostra IT-57.

Nos álcali-feldspato granitos, o quartzo e os dois feldspatos são praticamente os únicos minerais presentes, explicando-se assim o seu posicionamento no diagrama da Figura $6.6 \mathbf{d}$ (ou seja, em volta do ponto que representa a composição dos feldspatos).

\subsection{A evolução dos granitóides Cunhaporanga por cristalização fracionada}

Um modelo de cristalização fracionada pode ser aplicado, em princípio, para tentar explicar as variações petrográficas e químicas detectadas nas rochas do Complexo Cunhaporanga. Este raciocínio pode ser melhor acompanhado tomando-se por base os granitóides da porção centro-norte do Complexo, uma vez que estas rochas possuem uma variação composicional, em termos de $\mathrm{SiO}_{2}$, mais ampla que a observada nos monzogranitos e granodioritos da porção sul/sudeste.

\subsubsection{Diagramas de variação: elementos maiores}

$\mathrm{O}$ decréscimo contínuo em $\mathrm{Al}_{2} \mathrm{O}_{3}$ deve-se, em primeiro lugar, ao fracionamento de plagioclásio mais cálcico (andesina ?, labradorita ?) e de hornblenda (possivelmente, também do piroxênio, que aparece como relicto em núcleos de hornblenda). O teor máximo de sílica dos tipos mais cálcio-alcalinos é da ordem de $68 \%$, sendo que os granitóides com titanita-biotita e biotita apresentam-se com teores maiores (Figura 6.1A). Nestes casos, a diminuição em Al deve estar controlada pelo fracionamento dos minerais aluminosos restantes, que são biotita e/ou oligoclásio e/ou feldspato potássico. 
A rápida descida nos teores de $\mathrm{Mg}$ está controlada pelo fracionamento, em primeiro lugar, de hornblenda (e/ou do piroxênio coexistente) e, outra vez a partir de $\sim 68 \% \mathrm{SiO}_{2}$, da biotita (Figura 6.1A). As rochas mais evoluídas, com mais de $70 \%$ $\mathrm{SiO}_{2}$, estão muito empobrecidas em $\mathrm{Mg}$ e os incrementos em Si são evidentemente controlados por outros processos (ver horizontalização da tendência no diagrama MgSi, Figura 6.1A).

A análise do diagrama Ca-Si confirma a importância do fracionamento da hornblenda (e/ou do piroxênio) nos estágios iniciais, junto com a remoção dos plagioclásios mais cálcicos (ver análise do diagrama Al-Si, acima). Uma evolução continuada (a partir de $\sim 68 \% \mathrm{SiO}_{2}$ ) deprime ainda mais o $\mathrm{Ca}$, agora apenas por fracionamento de plagioclásio (andesina ou oligoclásio? ).

O diagrama Fe-Si, mostrando queda muito brusca do primeiro elemento, é controlado pelo fracionamento de magnetita \pm ilmenita, juntamente com a separação da biotita e, em menor parte, da hornblenda e/ou piroxênio nos estágios iniciais (ambos minerais mais magnesianos que ferrosos, mostrando $\mathrm{mg}^{\#}$ médio > 0,6; ver Capítulo 5).

\subsubsection{Diagramas de variação: elementos menores e traços}

A análise qualitativa dos diagramas de variação de elementos maiores estabelece a possibilidade de um esquema de diferenciação magmática controlado por fracionamento de hornblenda ( \pm piroxênio) + magnetita ( \pm ilmenita) + biotita + plagioclásio cálcico (andesina e/ou labradorita), em teores variáveis. Passa-se assim desde os magmas "cálcio-alcalinos" mais "primitivos" $\left(\mathrm{SiO}_{2}\right.$ entre 55 e $\left.\sim 68 \%\right)$ para os tipos com titanita-biotita e os com biotita, mais evoluídos.

Esta evolução pode ser testada também com a avaliação dos diagramas que mostram elementos traços e os menores. O decréscimo no teor de $\mathrm{Sr}$ (coligado ao $\mathrm{Ca}$ ) com a sílica sugere fortemente que o plagioclásio é um dos minerais controladores da evolução, enquanto que a diminuição nos teores de Ti indica que tanto biotita como magnetita ( \pm ilmenita) e titanita também são minerais fracionados (Figuras $6.1 \mathrm{~B}$ e 6.1C); a separação dos óxidos opacos é confirmada pela queda nos teores do $\mathrm{V}$, 
localizado de preferência na magnetita (Figura 6.1C). A descida nos teores de $\mathrm{P}$ está diretamente associada à perda de apatita (Figura 6.1B). A contribuição para 0 decréscimo no teor de $\mathrm{Ca}$, no caso deste mineral, deve ter sido negligenciável.

O diagrama de variação do Ba mostra dados espalhados. O elemento hospedase, nestas rochas, principalmente nos feldspatos potássicos (ver Capítulo 5). A tendência, em geral, é de correlação negativa com a sílica, ainda que manifestada menos fortemente que em outros casos (e. g., Ti, P, ou V). Os álcali-feldspato granitos, em particular, mostram valores muito baixos de $\mathrm{Ba}$, tendo cristalizado a partir de magmas empobrecidos não só em $\mathrm{Ba}$, mas também em $\mathrm{Sr}$ (e $\mathrm{Ca}$ e $\mathrm{Mg}$ ), $\mathrm{V}, \mathrm{P}$ e Ti (Figuras 6.1A, 6.1B e 6.1C).

O comportamento do $\mathrm{Zr}$ é diferente especialmente para os álcali-feldspato granitos. Estes granitóides são rochas evoluídas, como indicado pelo comportamento da maioria dos elementos maiores, menores e traços (ver discuissão acima). São, neste sentido, rochas "exauridas", liberadas da maioria dos elementos que os minerais podem separar com eficiência durante o processo de fracionamento: $\mathrm{Ca}, \mathrm{Mg}, \mathrm{Fe}, \mathrm{Ti}, \mathrm{P}$, $\mathrm{V}$ e outros. Não é este o comportamento do $\mathrm{Zr}$, que mostra teores altos na maioria dos álcali-feldspato granitos analisados (Tabela 6.1, Figura 6.1C).

A explicação para $\circ$ incremento em $Z r$ neste litotipo deve estar relacionada a outras causas, possivelmente a fatores que impediram a cristalização de zircão nos magmas originais, através da formação de complexos tais como os de $\mathrm{F}$ com $\mathrm{Zr}$ (ver Collins et al. 1982). Realmente, estas rochas podem alcançar teores de $\mathrm{F}$ entre $2500 \mathrm{e}$ 7000 ppm, ao passo que os demais granitóides possuem quase sempre menos de $1400 \mathrm{ppm}$ de $\mathrm{F}$.

Observa-se neste tipo petrográfico uma presença constante de fluorita (intersticial, em veios, etc.), cavidades miarolíticas e marcante alteração deutéricahidrotermal (com enriquecimento em elementos como $U$ e Th; ver Capítulo 3), o que sugere enriquecimento em fluidos e elementos voláteis, principalmente $\mathrm{H}_{2} \mathrm{O}$ e $\mathrm{F}$. 


\subsubsection{Aranhogramas e a diferenciação magmática}

O aranhograma dos enclaves (Figura 6.7) é extremamente similar, em altos e baixos e nos respectivos valores, ao perfil observado nos tipos mais primitivos (Figura 6.5A a e também c). Quimicamente, os enclaves podem ser pouco a moderadamente evoluídos (e. g., $\mathrm{SiO}_{2}$ entre $\sim 50 \%$ e $\sim 70 \%$; ver Tabela 6.1). As relações geológicogeométricas (forma do enclave, mineralogia, textura, etc.) apontam a existência de fenômenos de "mistura parcial" ("commingling") entre magmas mais básicos e mais ácidos coexistentes. Os dados químicos mostrados nestes diagramas indicam uma vigorosa interação química entre ambos os magmas, com os enclaves sendo totalmente contaminados pelos magmas granitóides hospedeiros. Em alguns locais os enclaves devem representar "autólitos co-magmáticos", aparentados aos magmas "cálcio-alcalinos" predominantes, formados a partir da mistura em câmaras magmáticas sujeitas à cristalização fracionada (e. g., JGA-43 ?).

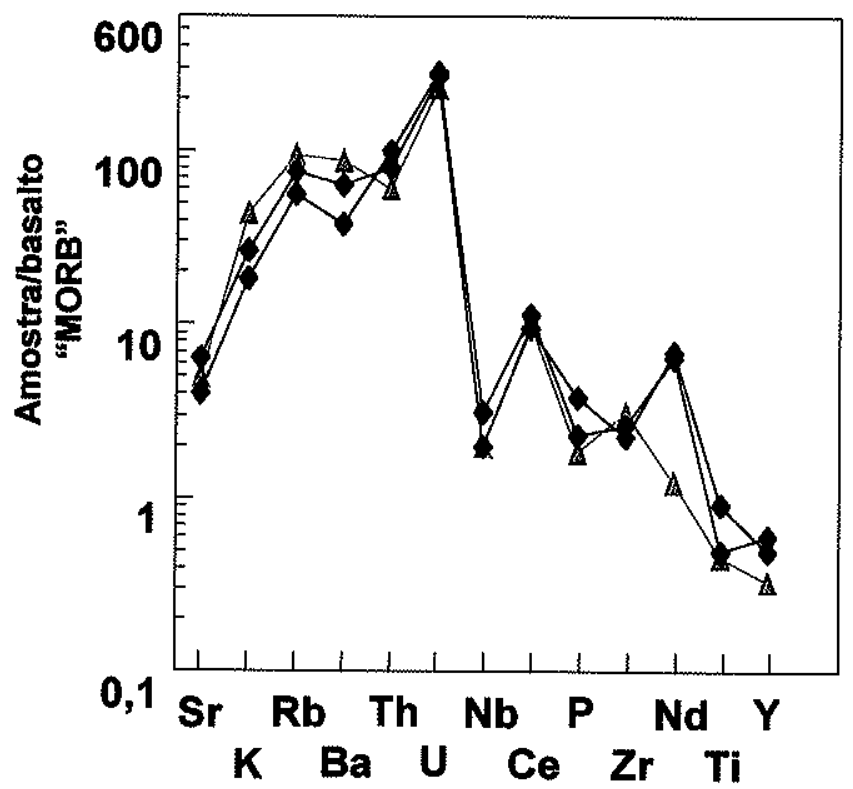

Figura 6.7: Diagrama multi-elementos, normalizado em relação a um basalto de cadeia meso-oceânica, para enclaves do Complexo Cunhaporanga (PS-79a, PS-93 e IT-95e). Dados para normalização segundo Pearce (1983), exceto Nd (Bevins et al. 1984) e $U(U=T h / 3,5)$. Símbolos como na Figura 6.1. 


\subsubsection{A origem dos muscovita-biotita granitóides}

Não resta dúvida que a separação de anfibólio, que se processa juntamente com - fracionamento de magnetita $\theta$ plagioclásio (e outros minerais), gera líquidos peraluminosos sistematicamente mais evoluídos (titanita-biotita e biotita granitóides), ao mesmo tempo mais ricos em $\mathrm{SiO}_{2}$ e em álcalis (ver discussão em White 1992). O passo seguinte na evolução, aparentemente, seria a geração de magmas ainda mais peraluminosos, o que não ocorre, pois os biotita granitóides aqui descritos são tão evoluídos como os com muscovita e biotita. Os álcali-feldspato granitos, que poderiam ser interpretados como os últimos resíduos líquidos, não podem ser aparentados aos tipos predominantes do Complexo (granitóides Cunhaporanga "normais"), formando uma linhagem distinta, como será discutido no próximo item.

Estes tipos com muscovita, em geral com enclaves micáceos ou quartzosos, aparecem freqüentemente junto à Faixa Itaiacoca e mostram sistematicamente valores baixos de susceptibilidade magnética (ver Anexos 3 e 5). Repete-se aqui o padrão identificado nos granitóides cálcio-alcalinos Piedade-Ibiúna, em São Paulo, no qual os biotita granitóides (sem titanita) são as rochas mais evoluídas, não as com muscovita e biotita (Leite 1997; Martins 1998).

Estas observações sugerem que os tipos a muscovita e biotita, também no Complexo Cunhaporanga, formam-se por assimilação parcial de rochas encaixantes. Assim sendo são proporcionadas as condições necessárias para a cristalização de muscovita primária (e biotita claramente peraluminosa, em parte já existente nos magmas sem contaminação) e também para o desaparecimento ou recristalização de magnetita, reduzindo drasticamente as susceptibilidades magnéticas.

\subsubsection{As linhagens geoquímicas-petrogenéticas nos granitóides do Complexo Cunhaporanga}

Os dados geoquímicos parecem indicar a existência de pelo menos três linhagens (ou séries) geoquímicas-petrogenéticas para as rochas granitóides do Complexo Cunhaporanga. Duas delas têm caráter cálcio-alcalino lato sensu (na 
verdade álcali-cálcico; ver Figura 6.3 d), provavelmente sendo controladas por processos contínuos ou intermitentes de fracionamento por separação de cristais. A terceira linhagem, representada pelos granitóides Serra do Carambeí e Joaquim Murtinho, é aqui denominada de alasquítica.

Estas séries ou linhagens encontram-se distribuídas no Complexo da seguinte maneira:

a) a primeira linhagem "cálcio-alcalina", aparentemente menos expandida, constitui-se dos granodioritos a monzogranitos dos Domínios Abapã-Santa Quitéria, Serra Abaixo-Alagados, Jotuba-Pitangui e inclui também os pórfiros com anfibólio, intrusivos em granitóides destes domínios;

b) entre os pórfiros intrusivos no Grupo Itaiacoca, ao menos o pórfiro PS-103 também deve pertencer a esta primeira linhagem;

c) a segunda linhagem "cálcio-alcalina" inclui as rochas dos Domínios Piraí do Sul, Biscaias-Boa Vista, Espigão Alto, Paredão da Santa, Varginha e Ouro VerdePatrimônio Santo Antônio;

d) nos Domínios Arroio das Pedrinhas, Passo da Anta-Água Clara, Francisco SimasVila Branca e Limeira são comuns os granitóides com muscovita primária, possíveis produto de assimilação entre magmas granitóides e rochas encaixantes da Faixa Itaiacoca;

e) as rochas do Domínio Santa Rita não têm clara afinidade com a primeira linhagem "cálcio-alcalina", apesar da proximidade geográfica (mesma situação do item d acima ?);

f) a linhagem alasquítica é formada pelos Granitos Serra do Carambeí e Joaquim Murtinho, além de um dique no norte do Complexo (ponto JGA-21).

Do ponto de vista geoquímico e até pelas características geológicas gerais, os granitóides das duas linhagens "cálcio-alcalinas" são similares aos tipos "l" citados na literatura (White 1992; Pitcher 1982; Chappel \& White 1974; dentre outros autores), derivados da fusão de protolitos ígneos --anfibolitos, gnaisses primitivos, etc.-- com ou sem participação de componentes crustais (ver discussão em Pearce 1983). Os aranhogramas da Figura 6.5 mostram que boa parte dos elementos listados à esquerda 
do diagrama ( $\mathrm{Sr}, \mathrm{K}, \mathrm{Rb}, \mathrm{Ba}$, Th e $\mathrm{U}$ ) estão fortemente enriquecidos, como é normal em rochas granitóides, indicando a contribuição crustal e/ou da zona de subducção eventualmente presente. Os elementos mais refratários (e. g., $\mathrm{Nb}, \mathrm{Zr}, \mathrm{Ti}, \mathrm{Y}$ ), que inicialmente seriam os componentes cedidos pelas fontes mantélicas, aparecem ora moderadamente enriquecidos (e. g., $\mathrm{Nb}, \mathrm{Zr}$ ), ora diminuídos (e. g., $\mathrm{Y}, \mathrm{Ti}$ ) (ver Figura $6.5 \mathrm{~A}$ a, b e $\mathrm{c} \in$ Figura $6.5 \mathrm{~B}$ e e g).

Os álcali-feldspato granitos, diferentes das linhagens anteriores, guardam algumas semelhanças com granitóides do tipo "A". Favoráveis a esta correlação, dentre outros aspectos, são os caracteres alasquítico e tardio destas rochas. No entanto, uma simples e pura comparação de análises dos Granitos Serra do Carambeí e Joaquim Murtinho com granitos tipo "A" australianos nem sempre é apropriada, como pôde ser visto na discussão dos aranhogramas (item 6.1.2).

Algumas das principais características geoquímicas dos granitos tipo " $A$ " (ver, dentre outros, Collins et al 1982; Whalen et al 1987; Eby 1990; Eby 1992) são compartilhadas pelos álcali-feldspato granitos do Complexo, como teores baixos de $\mathrm{CaO}$ e $\mathrm{MgO}$ e altos de $\mathrm{Fe}_{2} \mathrm{O}_{3}, \mathrm{Zr}, \mathrm{Ce}, \mathrm{Ga}, \mathrm{Nb}, \mathrm{Y}, \mathrm{F}$.

Uma possibilidade a ser explorada é a de que os álcali-feldspato granitos pudessem representar os termos mais fracionados das linhagens "cálcio-alcalinas". Entretanto, o exame das Figuras 6.5A e B (aranhogramas) e da Figura 6.8 não referenda este raciocínio.

Os diagramas da Figura 6.8 demonstram a discrepância destes granitóides com composições tipicamente fracionadas, além de apontar a afinidade com os granitos tipo "A" (tanto na Figura 6.8 A como na Figura 6.8 B, os granitos do tipo "A" posicionam-se à direita e acima dos campos 1 e 2; Whalen et al. 1987).

No caso do diagrama 6.8 $\mathrm{D}$ percebe-se claramente que os álcali-feldspato granitos não são semelhantes às rochas "l" e " $\mathrm{S}$ " fracionadas (são mais ricos em $\mathrm{Zr}, \mathrm{Ce}$ e Y), mas também diferem dos granitos "A" (e. g., os da suíte Topsails de Whalen et al. 


\section{COMPLEXO GRANÍTICO CUNHAPORANGA (geoquímica das rochas granitóides)}
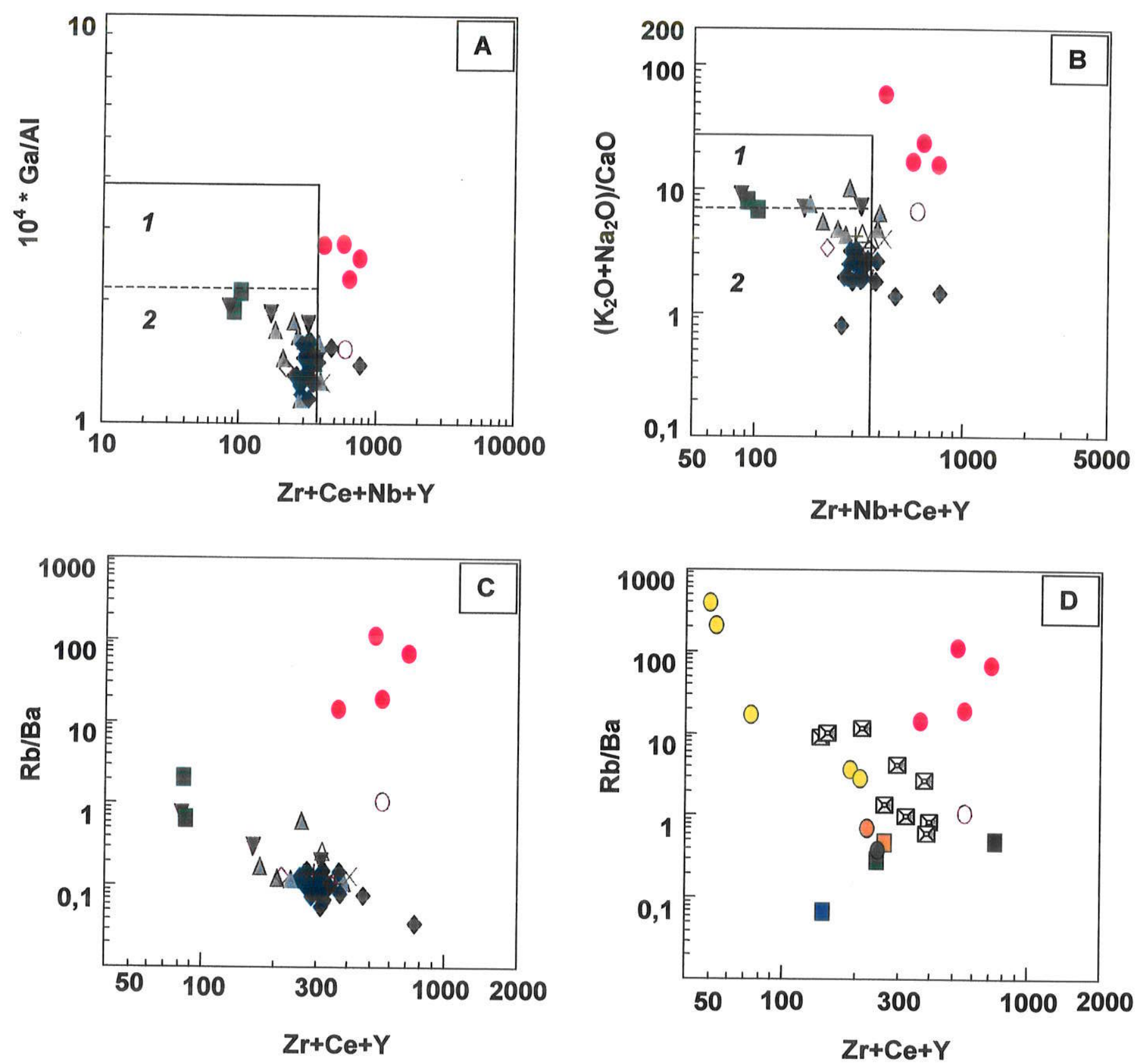

Figura 6.8: Diagramas A - $\mathrm{Zr}+\mathrm{Ce}+\mathrm{Nb}+\mathrm{Y}$ vs $10^{4} \mathrm{Ga} / \mathrm{Al} ; \mathbf{B}-\mathrm{Zr}+\mathrm{Ce}+\mathrm{Nb}+\mathrm{Y}$ vs $\left(\mathrm{K}_{2} \mathrm{O}+\mathrm{Na}_{2} \mathrm{O}\right) / \mathrm{CaO}$; C - $\mathrm{Zr}+\mathrm{Ce}+\mathrm{Y}$ vs $\mathrm{Rb} / \mathrm{Ba}$, para granitóides do Complexo Cunhaporanga (símbolos como na Figura 6.1). Em A e B, campo 1 para granitos félsicos fracionados, campo 2 para granitos $M, I$ e $S$ não fracionados. No diagrama $D$, além dos símbolos para álcali-feldspato granitos do Complexo, estão representados: composição média de granito $M$ (quadrado azul), granito I (quadrado verde), granito / félsico (círculo verde), granito $S$ (quadrado laranja), granito $S$ félsico (círculo laranja), granito $A$ (quadrado preto), além de granitos I fracionados (quadrados cinzas) e granitos $S$ fracionados (círculos amarelos). A, segundo Eby (1990); B, C e D, segundo Whalen et al. 1987. Valores das abscissas em ppm. 
1987), neste caso com razões mais altas de $\mathrm{Rb} / \mathrm{Ba}$ para a linhagem alasquítica do Complexo Cunhaporanga.

\subsection{O posicionamento dos dados geoquímicos em diagramas de caracterização geotectônica}

\subsubsection{Situação geotectônica do Complexo Cunhaporanga: informações geológicas}

Em termos regionais o Complexo Cunhaporanga insere-se em um contexto de amalgamação de diversos terrenos ao final do Ciclo Brasiliano (NeoproterozóicoEopaleozóico) e que culminaram na formação do supercontinente Gondwana (ver, dentre outros, Brito Neves et al. 1999). Esta aglutinação resultou da colisão dos blocos cratônicos Congo, São Francisco, Kalahari, Rio de La Plata, etc., onde o ajuste final destas grandes massas crustais deu-se através de importantes zonas de cisalhamento transcorrentes, como Lancinha-Taxaquara, Itapirapuã, etc.(ver, dentre outros, Sial et al. 1999).

Os mapeamentos realizados na região do Complexo Cunhaporanga e vizinhanças ainda são restritos, não existindo até o momento interpretações consensuais sobre os ambientes de deposição e deformação/metamorfismo de unidades como o Grupo Itaiacoca, a Formação Água Clara ou o "Quartzito Serra das Pedras". É portanto difícil estabelecer a paleogeografia e o ambiente geotectônico das rochas encaixantes dos granitos Cunhaporanga, ou as de seu vizinho a leste, o Complexo Três Córregos. Propostas iniciais utilizando esquemas gerais de interpretação (e. g., Soares 1987; Reis Neto 1994), em parte com suporte de estudos geológicos em áreas adjacentes, sugerem um ambiente geotectônico de "arco magmático" (do tipo andino ?) para estes granitóides.

As rochas granitóides do Complexo Cunhaporanga são nitidamente posteriores às duas primeiras fases tectônicas da Faixa Itaiacoca (evidências na forma de metamorfismo de contato, mega-xenólitos, etc.). Ainda não está completamente 
definida a época de intrusão destes granitos em relação à última fase deformacional (transcorrência NE-SW da Zona de Cisalhamento Itapirapuã, ZCl).

Provavelmente, as idades de intrusão das massas granitóides do Complexo não devem ter sido muito diferentes da época de máxima atuação da tectônica transcorrente, representada na área pela $\mathrm{ZCl}$. Favorecem esta hipótese a orientação da $\mathrm{ZCl}$ (paralela à orientação do batólito) e seu caráter dúctil-rúptil (compatível com as estimativas geobarométricas nos granitóides, ver item 6.4)

A estabilização final da região estaria representada também pelas bacias vulcano-sedimentares de natureza molássica, caracteristicamente distensionais, como as do Grupo Castro, Campo Alegre, Guaratubinha, etc. Conforme as interpretações da maioria dos autores (e. g., Soares 1987; Guimarães 1995), os Granitos Joaquim Murtinho e Serra do Carambeí, ambos de colocação rasa, seriam contemporâneos a este período.

Deste modo, com base nas evidências geológicas, o Complexo Cunhaporanga deve ter se originado ao final da orogênese brasiliana.

\subsubsection{Situação geotectônica do Complexo Cunhaporanga: diagramas de discriminação}

Segundo Liégeois (1998), a época de máxima convergência entre duas ou mais placas tectônicas ("colisão") corresponde a um momento desfavorável à ascensão de magmas. De acordo com este autor, o clímax da atividade magmática aconteceria imediatamente após a colisão, mas estando obviamente a ela relacionada, motivo pelo qual a expressão magmatismo pós-colisional representaria mais adequadamente o conjunto de processos responsáveis pela volumosa formação de corpos ígneos deste período.

As principais características do magmatismo pós-colisional seriam (Liégeois 1998): 
a) em termos volumétricos é predominantemente potássico, em particular cálcioalcalino de alto potássio, com quantidades subordinadas de rochas shoshoníticas;

b) está comumente ligado a grandes movimentos horizontais ao longo de importantes zonas de cisalhamento;

c) sua fonte teria uma importante componente juvenil (mantélica ou de crosta recémformada), gerada durante o período precedente de subducção ou colisão.

Levando-se em conta as considerações acima, foram selecionados dois dos mais difundidos e prestigiados conjuntos de diagramas para discriminação tectônica para testar os dados geoquímicos das rochas granitóides do Complexo Cunhaporanga. São eles o $R_{1}-R_{2}$ de Batchelor \& Bowden (1985) e o das relações entre $R b-(Y+N b)$ e $\mathrm{Nb}-\mathrm{Y}$ de Pearce et al. (1984).

Ressalte-se ainda que, segundo Pearce (1996), os granitos pós-colisionais são os mais difíceis de classificar através do uso de diagramas discriminantes, dada a diversidade de áreas-fonte envolvidas (ver comentários acima). Indica este autor que a geoquímica destes granitóides refletiria mais a composição de sua fonte do que o ambiente geotectônico: não sendo única a fonte, não seria possível individualizar um único ambiente tectônico.

Nos diagramas $R_{1}-R_{2}$ (Figura 6.9), as rochas mais primitivas cobrem os campos dos granitóides de "soerguimento pós-colisional" aos "tardi-orogênicos", com algum espalhamento para os "sincolisionais", enquanto que os com titanita e biotita seriam do tipo "tardi-orogênico" (a "sincolisional"), repetindo-se o posicionamento para os com biotita e com muscovita-biotita. Os pórfiros são similares aos tipos com titanita e anfibólio, enquanto que os álcali-feldspato granitos estão localizados na área das rochas "pós-orogênicas".

Nos diagramas de Pearce et al. (1984; Pearce 1996), percebe-se que as rochas das linhagens "cálcio-alcalinas" (e também os tipos com muscovita e biotita) situam-se no campo dos granitos de arco vulcânico, parte delas também na área reservada aos granitos pós-colisionais (Figuras 6.10A, 6.10B). As amostras da linhagem alasquítica são distintas, centrando-se no campo dos tipos "intraplaca", local ocupado pela maior 


\section{COMPLEXO GRANÍTICO CUNHAPORANGA (geoquímica das rochas granitóides)}

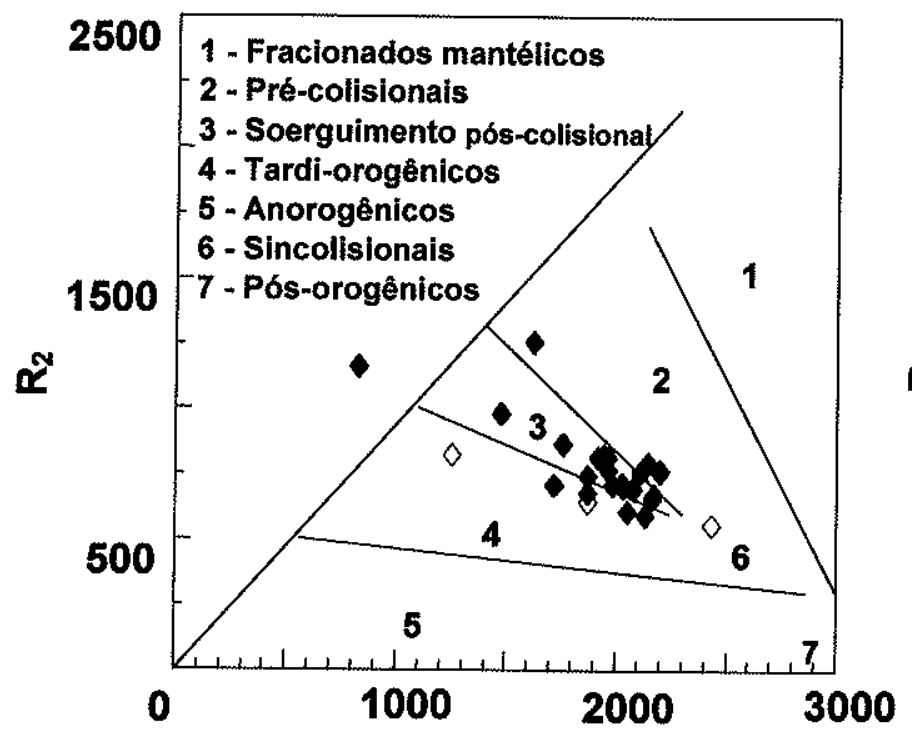

$\mathbf{R}_{\mathbf{1}}$

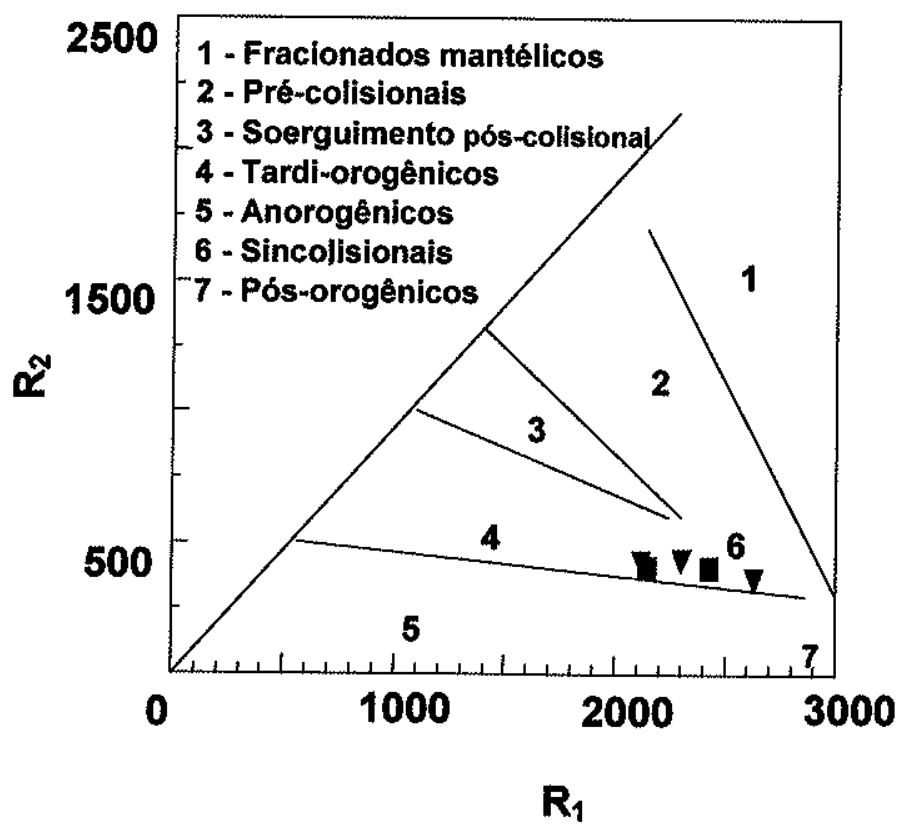

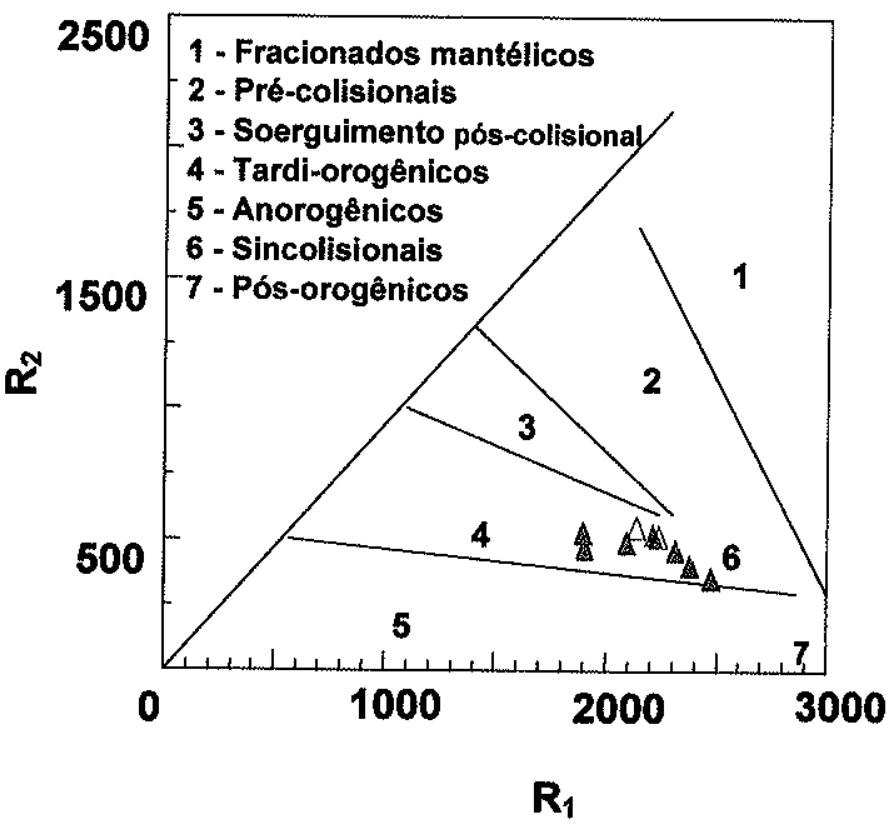

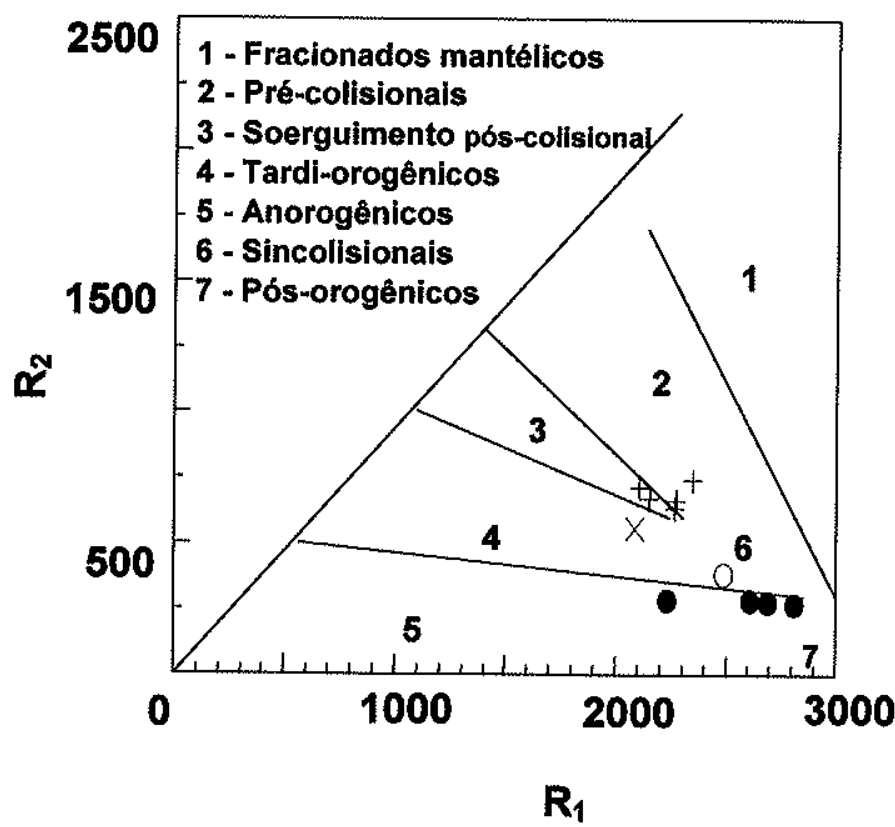

Figura 6.9: Diagramas discriminantes $R_{1} \times R_{2}$ (Batchelor \& Bowden 1985) para granitóides do Complexo Cunhaporanga (símbolos como na Figura 6.1). 


\section{COMPLEXO GRANÍTICO CUNHAPORANGA (geoquímica das rochas granitóides)}
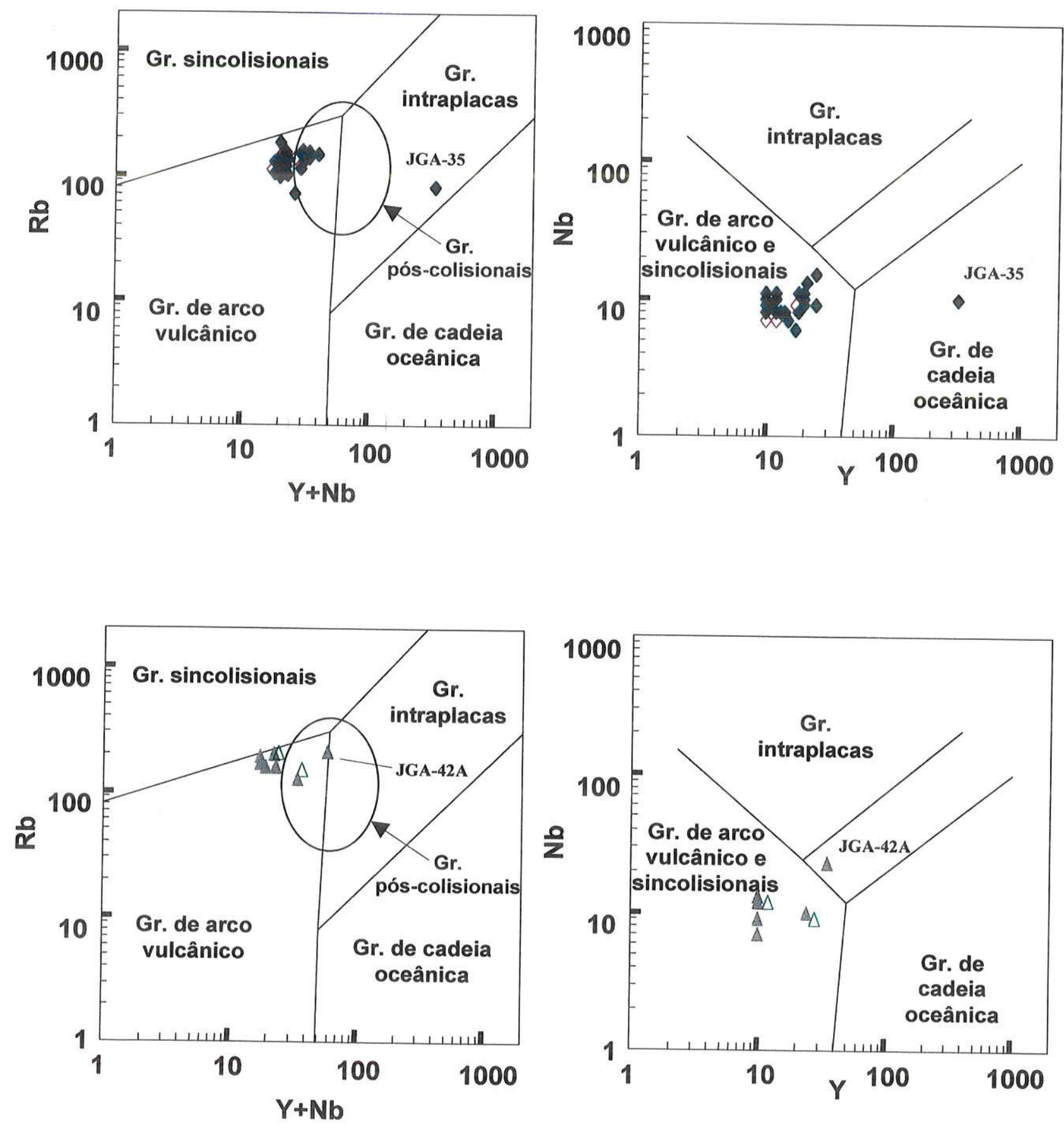

Figura 6.10A: Diagramas discriminantes $(\mathrm{Y}+\mathrm{Nb})$ vs $\mathrm{Rb}$ e $\mathrm{Y}$ vs Nb (Pearce et al. 1984; Pearce 1996) para rochas do Complexo Granítico Cunhaporanga (símbolos como na Figura 6.1). Teores em ppm. 
COMPLEXO GRANÍTICO CUNHAPORANGA (geoquímica das rochas granitóides)
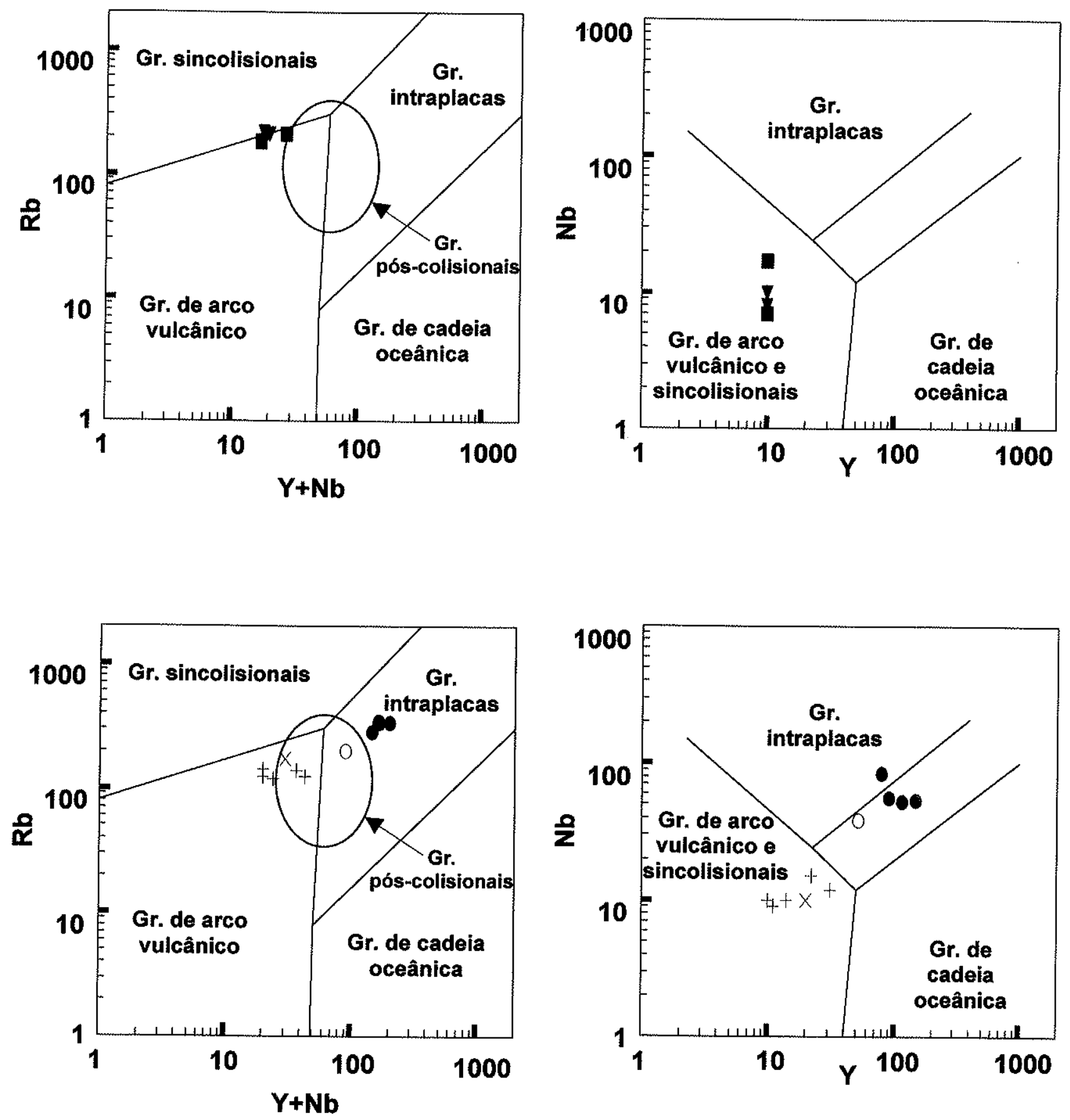

Figura 6.10B: Diagramas discriminantes $(\mathrm{Y}+\mathrm{Nb})$ vs $\mathrm{Rb}$ e $\mathrm{Y}$ vs $\mathrm{Nb}$ (Pearce et al. 1984; Pearce 1996) para rochas do Complexo Granítico Cunhaporanga (símbolos como na Figura 6.1). Teores em ppm. 
parte dos granitos tipo "A" da literatura (e. g., Eby 1990). Por motivos não compreendidos, a amostra JGA-35 posiciona-se de forma totalmente anômala.

Diversos autores reconheceram que a denominação "granito tipo-A" inclui dois grupos de rochas formados em situações geotectônicas diferentes, cada um com suas particularidades geoquímicas. Assim, existiriam os granitos " $A$ " de ambiente intra-placa (anorogênicos) e granitos "A" representando as últimas manifestações magmáticas de um ciclo orogênico (pós-orogênicos). Com base nos conteúdos de $\mathrm{Rb}, \mathrm{Nb}, \mathrm{Y}, \mathrm{Sc}$, Ga e $\mathrm{Ce}$, Eby (1992) propôs para o primeiro grupo a denominação de $A_{1}$ e para o segundo de $A_{2}$. A linhagem alasquítica do Complexo Cunhaporanga enquadra-se melhor no grupo químico $A_{2}$ de Eby (1992) (Figura 6.11).

Em síntese, o quadro apontado no item anterior (6.3.1) encontra respaldo nos diagramas discriminantes, uma vez que estes indicam uma assinatura geoquímica para as linhagens "cálcio-alcalinas" típica de um ambiente de arco magmático, provavelmente instalado na etapa final de um período colisional. A linhagem alasquítica, neste contexto, representaria as últimas manifestações magmáticas deste mesmo ciclo orogênico.

\subsection{Geotermobarometria}

As condições de pressão $(\mathbf{P})$, temperatura $(\mathbf{T})$ e fugacidade $(\boldsymbol{f})$ envolvidas durante a formação de rochas ígneas podem ser estimadas de várias formas. Na prática procura-se realizar uma avaliação integrada de todos os meios disponíveis, que foram:

a) comparação com as estimativas obtidas a partir das rochas encaixantes;

b) uso de geotermômetros de saturação (zircão e apatita);

c) emprego de geotermobarômetros de equilibrio para duas ou mais fases minerais;

d) presença/ausência de uma (ou mais) fase mineral;

e) utilização de indicadores geológicos (estruturas rúpteis vs dúcteis; stoping; presença de migmatitos; etc.). 


\section{COMPLEXO GRANÍTICO CUNHAPORANGA (geoquímica das rochas granitóides)}
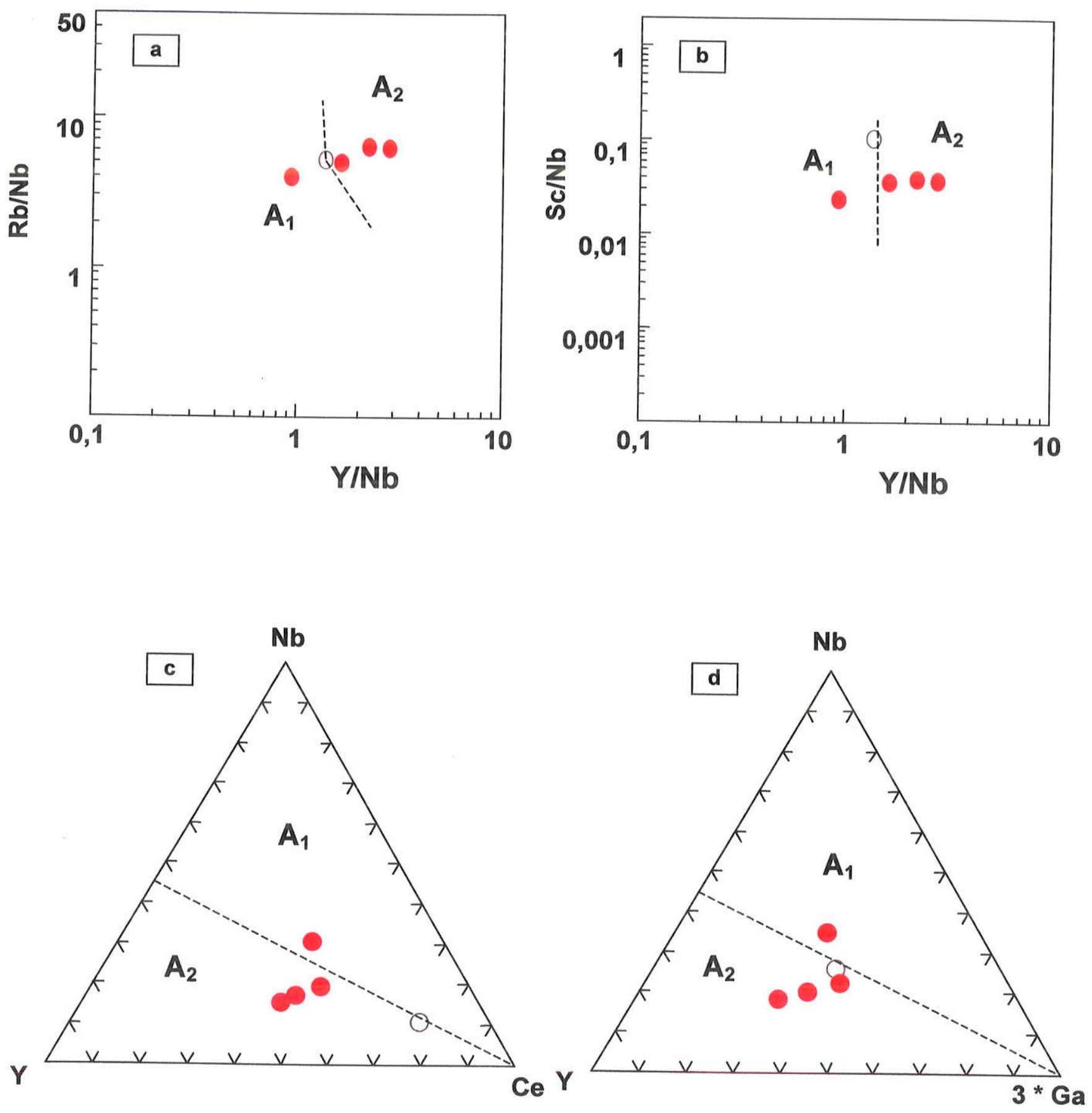

Figura 6.11: Diagramas Y/Nb vs Rb/Nb (a), Y/Nb vs Sc/Nb (b), Nb-Y-Ce (c) e Nb-Y-(3*Ga) (d), de Eby (1992), para rochas do Complexo Granítico Cunhaporanga (símbolos como na Figura 6.1). As linhas tracejadas separam os grupos químicos $\mathbf{A}_{1}$ e $\mathbf{A}_{2}$ dos granitos tipo-A (em a e b as linhas tracejadas são uma parte dos envoltórios dos campos $\mathbf{A}_{1}$ e $\mathbf{A}_{2}$ de Eby 1992; em $\mathbf{c}$ e d representam uma razão $\mathrm{Y} / \mathrm{Nb}$ igual a 1,2). 
É importante relembrar que, dadas as características dos sistemas magmáticos, podem ser obtidos parâmetros intensivos $(\mathbf{P}, \mathbf{T}, \emptyset)$ compatíveis com as diversas etapas de uma trajetória de cristalização. Deste modo são esperados valores referentes aos estágios liquidus, hypersolidus, solidus (ou quasi-solidus), assim como de reequilíbrio subsolidus.

Na Tabela 6.3 são apresentadas as estimativas de pressão e temperatura para granitóides do Complexo, obtidas com os geobarômetros de Al em hornblenda (Johnson \& Rutherford 1989, eq. 6.1; Schmidt 1992, eq. 6.2; Anderson \& Smith 1995, eq. 6.3), geotermômetro hornblenda-plagioclásio (Blundy \& Holland 1990, eq. 6.4; Holland \& Blundy 1994, eq. 6.5a e eq. 6.5b) e geotermômetros de saturação em zircão (Watson \& Harrison 1983, eq. 6.6) e apatita (Harrison \& Watson 1984, eq. 6.7) (ver equações no Anexo 7).

Nos casos em foram realizadas análises em microssonda eletrônica, utilizaramse apenas os dados obtidos nas zonas marginais dos minerais. Foram desprezadas as bordas albíticas dos plagioclásios e os anfibólios alterados e/ou excessivamente fragmentados.

Pressões calculadas a partir de geobarômetros de anfibólio que não tenham efetuado correções para os efeitos da temperatura (e. g., com as eqs. 6.1 e 6.2), foram colocadas em dúvida por Blundy \& Holland (1990), Anderson \& Smith (1995) e Anderson (1996). No trabalho de Anderson \& Smith (1995) o geotermômetro empregado foi o de Blundy \& Holland (1990), enquanto que Anderson (1996) considerou mais adequado o geotermômetro " $T_{B}$ " (edenita-richterita) de Holland \& Blundy (1994).

Os titanita anfibólio biotita granitóides do Complexo Cunhaporanga cumprem as exigências quanto às fases minerais que devem estar presentes para a utilização dos geobarômetros de $\mathrm{Al}$ em hornblenda. Estes minerais são anfibólio, quartzo, feldspato potássico, plagioclásio com $\mathrm{An}_{25-35}$, biotita, titanita e óxido de Fe-Ti. 
Segundo os autores acima citados, as pressões obtidas marcariam o período em que esta associação mineral esteve em equilíbrio com uma fase fluida (e. $\left.\mathrm{g}_{1}, \mathrm{H}_{2} \mathrm{O}\right)$ e com o líquido magmático residual. Em outras palavras, o método permitiria determinar a pressão existente no momento de colocação do corpo ígneo em arrefecimento.

Aparentemente o método Al em hornblenda não poderia ser aplicado em rochas cristalizadas sob fortes condições oxidantes, identificadas indiretamente por anfibólios com $m g^{\#}<0,35$ (Anderson 1996). Apesar das amostras do Complexo possuirem $m g^{\#}$ $>0,45$ (Tabela 5.6), estes valores estão quase sempre acima dos existentes nas condições experimentais em que foram definidas as eqs. 6.1, 6.2 e 6.3, sendo que a influência de proporções assim elevadas de $\mathrm{Mg} / \mathrm{Fe}$ sobre o geobarômetro permanece indefinida.

No caso da amostra SC-51, um granitóide pórfiro com anfibólio, não há feldspato alcalino isolado, aparecendo apenas intercrescido com quartzo em raros núcleos esferulíticos. Esta rocha também não possui titanita primária, o que em princípio tornaria a utilização do geobarômetro suspeita. Por outro lado, Anderson \& Smith (1995) consideraram negligenciáveis a influência do feldspato alcalino e da titanita.

Qual dos métodos seria mais realista ? Como visto acima, as pressões calculadas segundo Johnson \& Rutherford (1989) e Schmidt (1992) são pouco confiáveis, pois desconsideram o efeito da temperatura na repartição do Al nos sítios tetraédricos e octaédricos dos anfibólios. Assim, uma determinação barométrica adequada pressupõe uma boa estimativa da temperatura, o que significa uma escolha correta do geotermômetro a ser empregado.

O geotermômetro de Blundy \& Holland (1990) foi severamente criticado, a ponto dos autores proporem em 1994 um termômetro retificado (edenita-tremolita) e um totalmente novo (edenita-richterita) (ver discussões em Hammarstrom \& Zen 1992 , Rutherford \& Johnson 1992 e Poli \& Schmidt 1992, além das réplicas de Blundy \& Holland 1992 a, b). 
Nos testes feitos por Holland \& Blundy (1994) para seus termômetros, onde compararam-se as temperaturas de experimentos com aquelas obtidas matematicamente, os valores $T_{A}$ foram melhores que os $T_{B}$. De acordo com os autores, o principal problema de $T_{B}$ seria sua alta sensibilidade aos procedimentos de cálculo de $\mathrm{Fe}^{3+}$, os quais influenciam diretamente a alocação das diferentes posições estruturais no anfibólio. Na Tabela 6.3, no cálculo das temperaturas e pressões, efetuou-se a repartição de $\mathrm{Fe}^{3+}$ nas fórmulas estruturais de anfibólio de acordo com as sugestões originais dos autores, apesar de que o recálculo segundo Schumacher (1997, in Leake et al. 1997) conduziu a valores idênticos.

Especificamente no caso do Complexo Cunhaporanga, a utilização de valores $T_{B}$ proporciona pressões sempre mais altas que $T_{A}$, $\circ$ que está dentro do previsto (segundo Holland \& Blundy 1994, as temperaturas $T_{A}$ devem ser maiores que $T_{B}$ ). $O$ conjunto de pressões calculadas com $T_{A}$ parece ser mais razoável geologicamente, pois aproxima-se melhor do quadro previsto do estudo das paragêneses metamórficas dos metapelitos encaixantes (ver adiante).

Outro ponto em favor da utilização de $T_{A}$ é a pressão calculada para o pórfiro SC-51 (0,4 kbar, contra 2,7 kbar a partir de $\left.T_{B}\right)$, aparentemente mais realista para o contexto de uma rocha praticamente afanítica, alojada em um corpo de pequena dimensão. Lembre-se que a falta de feldspato alcalino isolado, como é o caso desta amostra, não impede a utilização dos geotermobarômetros (Anderson \& Smith 1995).

As pressões calculadas não são significativamente diferentes ao longo dos diversos setores do complexo, concentrando-se entre 2,5 e 4 kbar (ver coluna $\mathbf{P}$ $(A S)_{h b A}$ da Tabela 6.3), para um erro de $\pm 0,6$ kbar previsto na eq. 6.3. Estes valores são compatíveis com o contexto geológico local, em que as rochas encaixantes (Grupo Itaiacoca) estão pouco metamorfisadas (zona da clorita) e com diversas estruturas primárias preservadas.

Apesar da falta de trabalhos específicos sobre geotermobarometria do Grupo Itaiacoca, a existência de andalusita quiastolítica, tardi- a pós-tectônica, em metapelitos 
próximos ao contato com o Complexo, confirma um nível de colocação relativamente raso para os granitóides.

A observação de que granada e estaurolita estariam restritas a porções muito próximas ao contato com os granitóides do Complexo, além da presença comum de texturas nodulosas (cordierita ?) e porfiroblastos de muscovita, sugerem que estes metapelitos enquadrem-se na série facial 2, tipo 2a, de Pattison \& Tracy (1991).

As pressões desta série facial (Pattison \& Tracy 1991) oscilam entre 2 e $3 \mathrm{kbar}$, se forem consideradas as curvas de estabilidade para os polimorfos do sistema $\mathrm{Al}_{2} \mathrm{SiO}_{5}$ de Holdaway (1971), ou entre 3 e 4 kbar, se a opção for pelas linhas definidas por Pattison (1992).

De acordo com Anderson \& Smith (1995), a temperatura pode aumentar drasticamente as quantidades de $\mathrm{Al}^{\mathrm{IV}}$ dos anfibólios. Isto faz com que intrusões diferentes, uma mais "quente" que a outra e colocadas na mesma profundidade, possuam anfibólios com $A^{\text {tot }}$ distintos. Caso a pressão fosse investigada com, por exemplo, a eq. 6.2, alguém poderia interpretar erroneamente que se tratavam de intrusões que não se posicionaram em um mesmo nível estrutural.

Exemplos de situações em que aparentemente teores mais altos de A ${ }^{\text {tot }}$ estão relacionados a intrusões mais quentes, ao invés de mais profundas, são as amostras PS-54 e 76a (Domínio Abapã-Santa Quitéria) e IT-50b (Domínio Limeira; Tabela 6.3).

O caso da amostra IT-50 b é particularmente instrutivo, pois nela são observados cristais de epidoto interpretados como primários. O uso das eqs. 6.1 e 6.2 indica pressões entre 5 e $7 \mathrm{kbar}$, em concordância com a sugestão de Zen \& Hammarstrom (1984), para quem epidotos magmáticos seriam indicativos de pressões moderadamentes elevadas (> 6-8 kbar). No entanto, ao levar-se em conta a temperatura para esta rocha (eq. 6.3), chega-se a valores mais modestos de pressão, apenas marginalmente superiores às estimativas para outras rochas do Complexo. 
Esta aparente inconsistência do geobarômetro de Anderson \& Smith (1995), quando confrontada com as condições de estabilidade do epidoto, fica resolvida se forem considerados outros exemplos naturais (Tulloch 1986; Vyhnal et al. 1991) ou experimentais (Schmidt \& Thompson 1996). Para Vyhnal et al. (1991), por exemplo, o epidoto seria estável em magmas monzograníticos a granodioríticos (saturados em água e oxidantes) em pressões tão baixas quanto $2,8 \pm 0,5 \mathrm{kbar}$.

Segundo Schmidt \& Thompson (1996), o deslocamento das condições de $\mathrm{fO}_{2}$ do tampão Ni-NiO (NNO) para hematita-magnetita (HM) responde por reduções de até 2 kbar no limite mínimo do campo de estabilidade do epidoto em magmas tonalíticos. Um exemplo geológico equivalente (no qual se encaixa perfeitamente o granodiorito IT$50 b)$ ocorre nas bordas de intrusões, onde a interação com as rochas encaixantes em geral é acompanhada por uma elevação da $\mathrm{fO}_{2}$ do magma em cristalização.

Outro indicador barométrico para as rochas do Complexo é a presença de muscovita primária nos muscovita biotita granitóides, indicando uma $P_{\min } \sim 3,5 \mathrm{kbar}$ (White 1992) para magmas saturados em água (valores mais modestos são esperados em sistemas mais ricos em F)

A colocação bem próxima da superfície dos Granitos Serra do Carambeí e Joaquim Murtinho é confirmada pela existência de feldspatos hypersolvus $(<2,2 \mathrm{kbar}$; Smith 1974), texturas granofíricas, quartzo bipiramidal e cavidades miarolíticas (formadas a menos de 1 kbar; White 1992).

Considerando-se as pressões acima discutidas, as temperaturas (quasi-solidus) obtidas pelo par hornblenda-plagioclásio (eq. 6.5a) comprovam que estas rochas cristalizaram-se a partir de magmas normalmente insaturados em água (comparar os valores das Tabelas $6.3 \mathrm{com}$ a Figura 5.3 de White 1992, pg. 69).

Os limites previstos com 0 uso dos geotermômetros de saturação (Watson \& Harrison 1983; Harrison \& Watson 1984) são, para o zircão (eq. 6.6), temperaturas da ordem de $750^{\circ}-1000^{\circ} \mathrm{C}$ para $M$ entre 0,9 e 1,7 e, para a apatita (eq. 6.7), teores de $\mathrm{SiO}_{2}$ da rocha entre $45 \%$ e $75 \%$. 
deslocadas das condições experimentais de calibração do geotermômetro; Figura 6.12).

As estimativas das eqs. $6.5 a$ (geotermômetro hornblenda-plagioclásio) e 6.6 geotermômetro de saturação de zircão) para as rochas menos evoluídas, considerando-se seus erros intrínsecos, fornecem valores aproximadamente iguais (ver

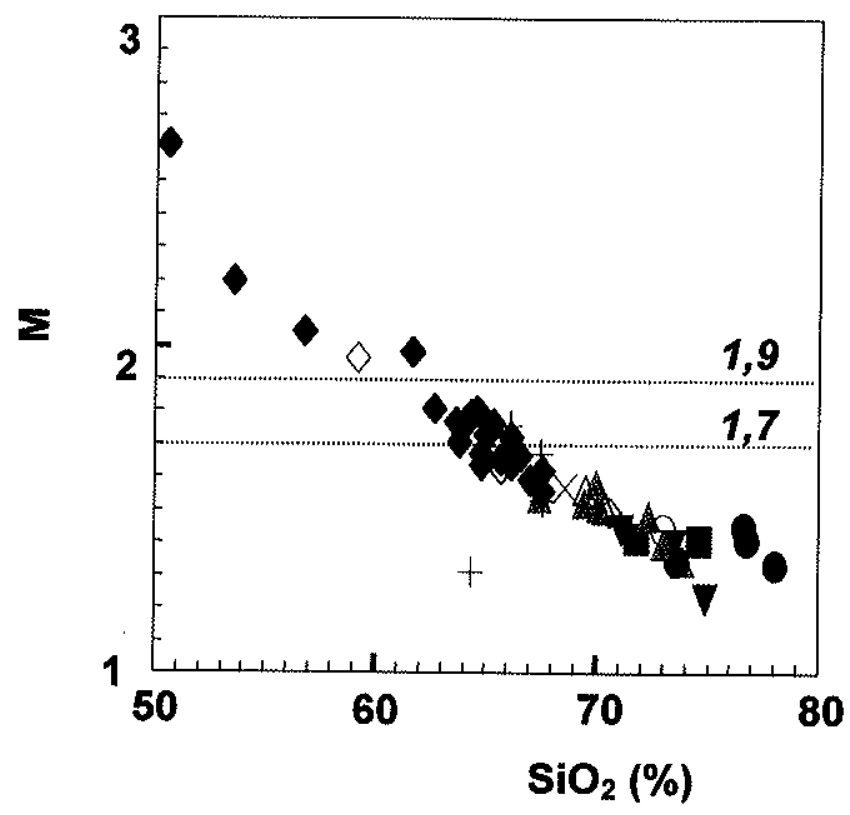

Figura 6.12: Índice $M$ de Watson \& Harrison (1983) para as rochas do Complexo Cunhaporanga (símbolos tais como na Figura 6.1). M é a razão atômica (Na $+\mathrm{K}+2 \mathrm{Ca}) /(\mathrm{Al} \times \mathrm{Si})$.

Tabela 6.3), o que permite afirmar que o ponto de saturação em zircônio foi alcançado apenas quando o resfriamento esteve próximo ao solidus.

Valores mais próximos do liquidus são encontrados apenas para as rochas da linhagem alasquítica (e. g., JGA-23 I e JM-96b). Estas temperaturas, da ordem de 830$870^{\circ} \mathrm{C}$ para os Granitos Serra do Carambeí e Joaquim Murtinho, estão em sintonia com o que está proposto na literatura para rochas similares. 
$870^{\circ} \mathrm{C}$ para os Granitos Serra do Carambeí e Joaquim Murtinho, estão em sintonia com o que está proposto na literatura para rochas similares.

Clemens et al. (1986), por exemplo, sugeriram que os magmas que originam granitos do tipo-A têm no mínimo $830^{\circ} \mathrm{C}$, podendo mesmo alcançar mais de $940^{\circ} \mathrm{C}$. Estes valores foram também confirmados por King et al. (1997), que indicaram uma temperatura média de $\sim 840^{\circ} \mathrm{C}$ para a saturação de zircão nos granitos " $A$ " do Cinturão Lachlan, Austrália (e. g., o Granito Watergums teria temperaturas de $893^{\circ} \pm 10^{\circ} \mathrm{C}$ ). É interessante assinalar que a média das temperaturas de saturação de zircão para os granitos tipo-I desta mesma região (King et al. 1997) são exatamente iguais a média para os titanita anfibólio biotita granitóides do Complexo Cunhaporanga $\left(781^{\circ} \mathrm{C}\right)$.

O geotermômetro de saturação em apatita não pôde ser aplicado para muitas das rochas extremamente evoluídas (álcali-feldspato granitos), ora pelo teor excessivo em sílica, ora pela ausência de fósforo na rocha.

Para os granitóides menos evoluídos as temperaturas conseguidas com esta metodologia são muito elevadas, principalmente entre $950-1000^{\circ} \mathrm{C}$ (contribuição de alguma apatita do protolito ?), enquanto que as rochas com muscovita primária (e alguns litotipos da linhagem alasquitica) mostram temperaturas bem mais baixas (750$800^{\circ} \mathrm{C}$ ). Estas altas temperaturas dos granitóides com anfibólio-titanita-biotita e titanitabiotita concordam com os valores estimados por Robert \& Clemens (1993) para magmas cálcio-alcalinos de alto $\mathrm{K}$ produzidos na interface manto-crosta $\left(900-950^{\circ} \mathrm{C}\right)$. 
Tabela 6.1: Teores para os elementos maiores, menores (em \% de óxido) e traços (ppm) para amostras de diferentes tipos granitóides do Complexo Granítico Cunhaporanga.

\begin{tabular}{|c|c|c|c|c|c|c|c|c|}
\hline & \multicolumn{8}{|c|}{$\begin{array}{c}\text { Domínios Petrográficos da porção S/SE do Complexo } \\
\text { DOMINIO ABAPÁ-SANTA QUITÉRIA }\end{array}$} \\
\hline & \multicolumn{8}{|c|}{ tit anf bio } \\
\hline & IIA-2-100 & ITA-4-36 & PS-21 & PS-54 & PS-76 & PS-78 & PS-79 & PS-79a \\
\hline $\mathrm{SiO}_{2}$ & 66,12 & 64,86 & 64,35 & 64,65 & 62,68 & 65,06 & 66,59 & 61,71 \\
\hline $\mathrm{TiO}_{2}$ & 0,81 & 0,78 & 0,95 & 1,00 & 1,05 & 0,80 & 0,75 & 1,40 \\
\hline $\mathrm{Al}_{2} \mathrm{O}_{3}$ & 14,35 & 14,90 & 15,37 & 14,86 & 14,99 & 14,69 & 14,64 & 14,62 \\
\hline $\mathrm{Fe}_{2} \mathrm{O}_{3}{ }^{\top}$ & 4,90 & 3,90 & 4,76 & 4,68 & 5,83 & 4,11 & 3,74 & 6,18 \\
\hline $\mathrm{MnO}$ & 0,08 & 0,06 & 0,06 & 0,06 & 0,08 & 0,06 & 0,06 & 0,09 \\
\hline $\mathrm{MgO}$ & 1,97 & 1,96 & 2,24 & 1,93 & 2,21 & 1,73 & 1,80 & 3,11 \\
\hline $\mathrm{CaO}$ & 3,60 & 2,95 & 3,77 & 3,58 & 3,90 & 3,17 & 3,07 & 4,01 \\
\hline $\mathrm{Na}_{2} \mathrm{O}$ & 3,24 & 3,19 & 3,61 & 3,71 & 3,51 & 3,42 & 3,61 & 3,44 \\
\hline $\mathrm{K}_{2} \mathrm{O}$ & 3,88 & 4,44 & 3,82 & 3,76 & 3,45 & 4,30 & 4,32 & 4,01 \\
\hline $\mathrm{P}_{2} \mathrm{O}_{5}$ & 0,24 & 0,28 & 0,33 & 0,31 & 0,34 & 0,27 & 0,25 & 0,46 \\
\hline P.F. & 1,38 & 1,67 & 1,12 & 1,09 & 0,95 & 0,79 & 0,92 & 1,31 \\
\hline $\mathrm{H}_{2} \mathrm{O}^{-}$ & 0,23 & 0,31 & 0,24 & 0,17 & 0,06 & 0,18 & 0,19 & 0,23 \\
\hline Total & 100,57 & 98,79 & 100,11 & 99,63 & 98,98 & 98,14 & 99,76 & 100,02 \\
\hline $\mathbf{V}$ & 67 & 72 & 80 & 74 & 110 & 70 & 58 & 105 \\
\hline $\mathrm{Zn}$ & 75 & 61 & 72 & 72 & - & 64 & 62 & 91 \\
\hline $\mathbf{S r}$ & 700 & 978 & 1.031 & 833 & 906 & 880 & 874 & 764 \\
\hline $\mathbf{Y}$ & 12 & 17 & 14 & $<10$ & $<10$ & 12 & $<10$ & 15 \\
\hline$\overline{Z r}$ & 191 & 195 & 216 & 210 & 191 & 204 & 193 & 203 \\
\hline $\mathrm{Ba}$ & 999 & 1.882 & 1.525 & 1.173 & 1.345 & 1.431 & 1.455 & 1.274 \\
\hline Sc & 11 & 9 & 10 & 9 & 8 & 9 & 9 & 12 \\
\hline $\mathrm{Cr}$ & 22 & 27 & 32 & 26 & 49 & 23 & 26 & 55 \\
\hline $\mathrm{Ni}$ & 4 & 13 & 12 & 12 & 26 & 11 & 12 & 24 \\
\hline $\mathrm{Ga}$ & 21 & 23 & 24 & 23 & 23 & 21 & 22 & 21 \\
\hline $\mathbf{R b}$ & 135 & 102 & 104 & 104 & 97 & 123 & 130 & 153 \\
\hline $\mathrm{Nb}$ & 7 & 6 & 8 & 8 & 10 & 8 & 8 & 7 \\
\hline La & 71 & 67 & 78 & 63 & 55 & 59 & 66 & 71 \\
\hline $\mathrm{Ce}$ & 101 & 100 & 129 & 94 & 84 & 95 & 87 & 96 \\
\hline Nd & 11 & 50 & 38 & 13 & 48 & 47 & 7 & 56 \\
\hline Th & 16 & 9 & 14 & 15 & 31 & 15 & 14 & 16 \\
\hline $\mathbf{U}$ & 15 & 13 & 12 & 10 & 28 & 7 & 5 & 16 \\
\hline$F$ & 574 & 652 & 749 & 831 & 1.255 & 495 & 751 & 1.111 \\
\hline
\end{tabular}


Tabela 6.1(cont.): Teores para os elementos maiores, menores (em \% de óxido) e traços (ppm) para amostras de diferentes tipos granitóides do Complexo Granítico Cunhaporanga.

\begin{tabular}{|c|c|c|c|c|c|c|c|c|}
\hline & \multicolumn{8}{|c|}{ Domínios Petrográficos da porção S/SE do Complexo } \\
\hline & \multicolumn{2}{|c|}{$\begin{array}{l}\text { DOMINIOSERRA } \\
\text { ABAIXO-ALAGADOS }\end{array}$} & \multirow{2}{*}{$\begin{array}{l}\text { DOMTIO } \\
\text { JOTUBA- } \\
\text { PITANGU }\end{array}$} & \multirow{2}{*}{$\begin{array}{c}\text { DOMINIO } \\
\text { SANTA } \\
\text { RITA } \\
\text { bio } \\
\end{array}$} & \multicolumn{3}{|c|}{$\begin{array}{l}\text { PORFIROSSINTRUSIVOS EM } \\
\text { GRANITOIDES DO COMPLEXO }\end{array}$} & \multirow{3}{*}{$\begin{array}{l}\text { POORF. } \\
\text { INTRUSIVO } \\
\text { NO GRUPO } \\
\text { ITAIACOCA } \\
\text { anf póffiro } \\
\end{array}$} \\
\hline & \multicolumn{2}{|c|}{ tit anf bio } & & & \multicolumn{3}{|c|}{ anf pórfiro } & \\
\hline & SC-34 & SC-77 & SC-79 & HP-01 & SC-51 & SC-74B & PS-23 & \\
\hline $\mathrm{SiO}_{2}$ & 65,72 & 66,19 & 65,17 & 73,49 & 67,56 & 66,31 & 65,82 & 64,37 \\
\hline $\mathrm{TiO}_{2}$ & 0,73 & 0,81 & 0,88 & 0,18 & 0,58 & 0,79 & 0,74 & 0,83 \\
\hline $\mathrm{Al}_{2} \mathrm{O}_{3}$ & 14,78 & 14,91 & 14,76 & 14,85 & 15,50 & 14,68 & 14,81 & 14,08 \\
\hline $\mathrm{Fe}_{2} \mathrm{O}_{3}{ }^{\top}$ & 4,41 & 4,95 & 4,64 & 1,10 & 3,79 & 5,02 & 4,33 & 3,81 \\
\hline $\mathrm{MnO}$ & 0,08 & 0,08 & 0,06 & 0,02 & 0,08 & 0,09 & 0,06 & 0,04 \\
\hline $\mathrm{MgO}$ & 1,54 & 1,31 & 2,31 & 0,24 & 0,72 & 1,40 & 1,50 & 3,73 \\
\hline $\mathrm{CaO}$ & 3,07 & 3,78 & 3,65 & 1,27 & 3,07 & 3,66 & 3,32 & 1,64 \\
\hline $\mathrm{Na}_{2} \mathrm{O}$ & 3,20 & 3,00 & 3,21 & 4,00 & 3,11 & 2,98 & 3,40 & 2,44 \\
\hline $\mathrm{K}_{2} \mathrm{O}$ & 4,40 & 4,26 & 3,90 & 4,88 & 4,33 & 3,70 & 4,03 & 4,42 \\
\hline $\mathrm{P}_{2} \mathrm{O}_{5}$ & 0,26 & 0,27 & 0,29 & 0,03 & 0,18 & 0,32 & 0,25 & 0,26 \\
\hline P.F. & 0,95 & 1,14 & 1,00 & 0,54 & 1,02 & 1,03 & 1,40 & 3,58 \\
\hline $\mathrm{H}_{2} \mathrm{O}^{-}$ & 0,17 & 0,15 & 0,19 & 0,15 & 0,10 & 0,17 & 0,11 & 0,38 \\
\hline Total & 98,92 & 100,71 & 99,51 & 100,59 & 99,93 & 99,72 & 99,66 & 99,21 \\
\hline V & 74 & 82 & 87 & 18 & 49 & 64 & 53 & 59 \\
\hline Zn & 61 & - & 44 & 44 & - & 78 & 70 & 49 \\
\hline $\mathrm{Sr}$ & 526 & 566 & 809 & 403 & 496 & 688 & 839 & 175 \\
\hline $\mathbf{Y}$ & 20 & 25 & 13 & $<10$ & 22 & 31 & 14 & 10 \\
\hline $\mathbf{Z r}$ & 180 & 220 & 185 & 95 & 194 & 234 & 208 & 196 \\
\hline $\mathbf{B a}$ & 977 & 1.060 & 1.256 & 745 & 1.035 & 1.157 & 1.290 & 1.005 \\
\hline & & & 0 & & & 14 & 0 & 10 \\
\hline Sc & 8 & 7 & 8 & 2 & 8 & 11 & 9 & 10 \\
\hline $\mathrm{Cr}$ & 13 & 35 & 33 & 8 & 2 & 8 & 13 & 17 \\
\hline $\mathrm{Ni}$ & 6 & 16 & 12 & 4 & 12 & 4 & 3 & 11 \\
\hline $\mathbf{G a}$ & 18 & 20 & 18 & 27 & 19 & 21 & 22 & 21 \\
\hline $\mathbf{R b}$ & 149 & 148 & 118 & 218 & 136 & 124 & 119 & 141 \\
\hline $\mathrm{Nb}$ & 9 & 15 & 8 & 8 & 15 & 12 & 10 & 10 \\
\hline La & 53 & 57 & 58 & 30 & 56 & 73 & 72 & 60 \\
\hline $\mathrm{Ce}$ & 73 & 72 & 75 & 58 & 107 & 90 & 114 & 85 \\
\hline $\mathrm{Nd}$ & 44 & 49 & 43 & $<1$ & 43 & 57 & 52 & 12 \\
\hline Th & 22 & 35 & 13 & $<3$ & 30 & 13 & 21 & 18 \\
\hline $\mathbf{U}$ & 18 & 61 & 13 & 11 & 33 & 13 & 24 & 33 \\
\hline$F$ & 391 & 806 & 581 & 992 & 615 & 589 & 662 & 604 \\
\hline
\end{tabular}


Tabela 6.1(cont.): Teores para os elementos maiores, menores (em \% de óxido) e traços (ppm) para amostras de diferentes tipos granitóides do Complexo Granítico Cunhaporanga.

\begin{tabular}{|c|c|c|c|c|c|c|c|}
\hline \multicolumn{8}{|c|}{ Domínios Petrográficos da porção centro-norte do Complexo } \\
\hline & \multirow{2}{*}{\multicolumn{2}{|c|}{$\frac{\text { DOWINIO PIRAIDO SUL }}{\text { tit anf bio }}$}} & \multicolumn{5}{|c|}{ DOMINIO BISCAIAS-BOA VISTA } \\
\hline & & & \multicolumn{4}{|c|}{ tit anf bio } & \multirow{2}{*}{$\begin{array}{l}\text { tit bio } \\
\text { JGA-32d }\end{array}$} \\
\hline & PS-5 & PS-32 & JGA-34 & JGA-35 & JGA-41 & $\Delta a A+11 B$ & \\
\hline $\mathrm{SiO}_{2}$ & 66,19 & 53,59 & 70,63 & 56,82 & 59,18 & 50,53 & 69,47 \\
\hline $\mathrm{TiO}_{2}$ & 0,68 & 1,58 & 0,47 & 1,53 & 1,15 & 1,71 & 0,31 \\
\hline $\mathrm{Al}_{2} \mathrm{O}_{3}$ & 14,53 & 17,23 & 14,09 & 16,05 & 16,26 & 15,96 & 14,01 \\
\hline $\mathrm{Fe}_{2} \mathrm{O}_{3} \mathrm{~T}$ & 4,26 & 9,21 & 2,66 & 7,45 & 5,37 & 9,09 & 2,65 \\
\hline MnO & 0,08 & 0,14 & 0,05 & 0,12 & 0,09 & 0,17 & 0,06 \\
\hline $\mathrm{MgO}$ & 1,09 & 1,30 & 0,86 & 3,05 & 2,18 & 4,64 & 1,06 \\
\hline $\mathrm{CaO}$ & 3,10 & 6,77 & 2,26 & 4,83 & 3,70 & 5,76 & 1,58 \\
\hline $\mathrm{Na}_{2} \mathrm{O}$ & 2,78 & 3,31 & 3,18 & 3,76 & 3,72 & 3,35 & 3,49 \\
\hline $\mathrm{K}_{2} \mathrm{O}$ & 4,81 & 2,14 & 4,52 & 3,18 & 5,13 & 4,61 & 5,21 \\
\hline $\mathrm{P}_{2} \mathrm{O}_{5}$ & 0,25 & 0,46 & 0,15 & 0,53 & 0,57 & 1,15 & 0,19 \\
\hline P.F. & 1,66 & 2,12 & 0,69 & 2,19 & 1,25 & 2,10 & 1,44 \\
\hline $\mathrm{H}_{2} \mathrm{O}^{-}$ & 0,13 & 0,33 & 0,17 & 0,20 & 0,25 & 0,28 & 0,19 \\
\hline Total & 99,43 & 100,43 & 99,55 & 99,52 & 98,60 & 99,06 & 99,48 \\
\hline V & 66 & 140 & 29 & 113 & 66 & 116 & 33 \\
\hline $\mathrm{Zn}$ & - & 109 & 43 & 128 & 87 & 155 & 51 \\
\hline $\mathrm{Sr}$ & 484 & 753 & 494 & 1.144 & 902 & 776 & 480 \\
\hline $\mathbf{Y}$ & 21 & 18 & $<10$ & 330 & 17 & 25 & $<10$ \\
\hline $\mathrm{Zr}$ & 194 & 148 & 139 & 275 & 180 & 312 & 148 \\
\hline $\mathbf{B a}$ & 990 & 605 & 862 & 2.356 & 2.224 & 1.807 & 1.356 \\
\hline Sc & 9 & 22 & 5 & 15 & 12 & 23 & 6 \\
\hline $\mathrm{Cr}$ & 8 & 24 & 9 & 21 & 13 & 27 & 8 \\
\hline $\mathrm{Ni}$ & 16 & 9 & 6 & 15 & 14 & 21 & 6 \\
\hline Ga & 19 & 25 & 19 & 22 & 22 & 24 & 20 \\
\hline $\mathbf{R b}$ & 131 & 72 & 111 & 81 & 138 & 138 & 168 \\
\hline $\mathrm{Nb}$ & 11 & 8 & 7 & 10 & 9 & 9 & 7 \\
\hline La & 53 & 81 & 48 & 142 & 96 & 123 & 39 \\
\hline $\mathrm{Ce}$ & 104 & 88 & 66 & 156 & 123 & 128 & 47 \\
\hline Nd & 54 & 27 & $<1$ & 130 & 31 & 49 & 27 \\
\hline Th & 25 & 22 & 7 & 9 & 18 & 29 & 7 \\
\hline $\mathbf{U}$ & 23 & 21 & 5 & 21 & 18 & 24 & 16 \\
\hline $\mathbf{F}$ & 502 & 907 & 727 & 129 & 1.201 & 1.213 & 732 \\
\hline
\end{tabular}


Tabela 6.1(cont.): Teores para os elementos maiores, menores (em $\%$ de óxido) e traços (ppm) para amostras de diferentes tipos granitóides do Complexo Granítico Cunhaporanga.

\begin{tabular}{|c|c|c|c|c|c|c|c|}
\hline \multirow{2}{*}{\multicolumn{8}{|c|}{$\frac{\text { Domínios Petrográficos da porção centro-norte do Complexo }}{\text { DOMINIO ESPIGÃO ALTO }}$}} \\
\hline & & & & & & & \\
\hline \multicolumn{8}{|c|}{$\begin{array}{cc} & \text { DOMINIO ESPIGÁOALTO } \\
\text { tit anf bio } & 1\end{array}$} \\
\hline & JGA-4C & JGA-20 & $J G A-42 B$ & JGA-43 & $\mathrm{JM}-39$ & PS.93 & PS-93A \\
\hline $\mathrm{SiO}_{2}$ & 63,68 & 67,60 & 64,02 & 65,36 & 67,60 & 63,83 & 67,08 \\
\hline $\mathrm{TIO}_{2}$ & 0,76 & 0,65 & 0,83 & 0,73 & 0,62 & 0,74 & 0,66 \\
\hline $\mathrm{Al}_{2} \mathrm{O}_{3}$ & 15,07 & 14,72 & 15,55 & 14,77 & 14,63 & 16,53 & 14,88 \\
\hline $\mathrm{Fe}_{2} \mathrm{O}_{3}$ & 4,85 & 3,46 & 4,24 & 5,11 & 3,35 & 5,44 & 3,77 \\
\hline MnO & 0,09 & 0,06 & 0,07 & 0,09 & 0,05 & 0,08 & 0,06 \\
\hline $\mathrm{MgO}$ & 1,68 & 1,09 & 1,30 & 1,41 & 1,02 & 1,43 & 1,19 \\
\hline $\mathrm{CaO}$ & 3,45 & 2,52 & 3,16 & 3,73 & 2,42 & 3,93 & 2,87 \\
\hline $\mathrm{Na}_{2} \mathrm{O}$ & 3,25 & 3,78 & 3,93 & 3,03 & 3,47 & 4,30 & 3,37 \\
\hline $\mathrm{K}_{2} \mathrm{O}$ & 4,58 & 4,30 & 4,36 & 4,35 & 4,44 & 2,77 & 4,24 \\
\hline $\mathbf{P}_{2} \mathbf{O}_{5}$ & 0,33 & 0,28 & 0,33 & 0,30 & 0,19 & 0,28 & 0,24 \\
\hline P.F. & 1,19 & 0,72 & 0,77 & 0,96 & 1,45 & 1,40 & 1,24 \\
\hline $\mathrm{H}_{2} \mathrm{O}^{-}$ & 0,18 & 0,14 & 0,15 & 0,07 & 0,18 & 0,24 & 0,11 \\
\hline Total & 98,93 & 99,19 & 98,57 & 99,84 & 99,22 & 100,44 & 99,61 \\
\hline & & & & & & & \\
\hline V & 69 & 48 & 51 & 76 & 42 & 62 & 56 \\
\hline $\mathrm{Zn}$ & 63 & 54 & 69 & - & 46 & 71 & 56 \\
\hline $\mathrm{Sr}$ & 615 & 730 & 864 & 588 & 564 & 486 & 523 \\
\hline $\mathbf{Y}$ & 20 & $<10$ & 12 & 20 & 10 & 18 & 11 \\
\hline $\mathrm{Zr}$ & 209 & 180 & 254 & 175 & 196 & 239 & 212 \\
\hline $\mathrm{Ba}$ & 1.048 & 1.189 & 1.708 & 1.011 & 1.271 & 759 & 1.253 \\
\hline & & & & & & & \\
\hline Sc & 11 & 8 & 9 & 12 & 7 & 10 & 8 \\
\hline $\mathrm{Cr}$ & 11 & 7 & 6 & 8 & 7 & 8 & 8 \\
\hline $\mathrm{Ni}$ & 6 & $<3$ & 4 & 16 & 2 & 6 & 2 \\
\hline $\mathrm{Ga}$ & 17 & 17 & 23 & 19 & 19 & 23 & 19 \\
\hline $\mathbf{R b}$ & 157 & 129 & 133 & 131 & 138 & 112 & 119 \\
\hline $\mathrm{Nb}$ & 10 & 9 & 11 & 11 & 11 & 11 & 9 \\
\hline La & 62 & 55 & 88 & 53 & 63 & 71 & 61 \\
\hline $\mathrm{Ce}$ & 90 & 87 & 110 & 62 & 91 & 113 & 94 \\
\hline Nd & 51 & 41 & 20 & 45 & 43 & 51 & 44 \\
\hline Th & 19 & 13 & 16 & 25 & 14 & 20 & 9 \\
\hline $\mathbf{U}$ & 8 & 7 & 5 & 23 & 9 & 17 & 15 \\
\hline$F$ & 1.065 & 166 & 1.224 & 502 & 921 & 910 & 998 \\
\hline
\end{tabular}


Tabela 6.1(cont.): Teores para os elementos maiores, menores (em \% de óxido) e traços (ppm) para amostras de diferentes tipos granitóides do Complexo Granítico Cunhaporanga.

\begin{tabular}{|c|c|c|c|c|c|c|c|}
\hline \multicolumn{8}{|c|}{ Domínios Petrográficos da porção centro-norte do Complexo } \\
\hline & \multicolumn{3}{|c|}{ Domínio Espigão Alto } & \multicolumn{2}{|c|}{$\begin{array}{l}\text { Dom. Paredão da } \\
\text { Santa }\end{array}$} & \multicolumn{2}{|c|}{$\begin{array}{l}\text { Dom. Passo da } \\
\text { Anta-Água Clara }\end{array}$} \\
\hline & tit anf blo & tit blo & af granito & tit anf blo & tht blo & mublo & blo \\
\hline & PS-96A & JGA-42A & JGA-21I & JGA-1 & JGA-44 & JGA-14 & PS-44 \\
\hline $\mathrm{SiO}_{2}$ & 65,69 & 73,86 & 73,04 & 64,83 & 67,44 & 71,84 & 71,14 \\
\hline $\mathrm{TiO}_{2}$ & 0,75 & 0,19 & 0,17 & 0,83 & 0,70 & 0,09 & 0,29 \\
\hline $\mathrm{Al}_{2} \mathrm{O}_{3}$ & 15,39 & 13,27 & 12,72 & 15,33 & 14,83 & 14,57 & 14,48 \\
\hline $\mathrm{Fe}_{2} \mathrm{O}_{3}^{\top}$ & 3,89 & 1,05 & 2,20 & 4,21 & 3,21 & 1,05 & 1,54 \\
\hline MnO & 0,06 & 0,04 & 0,04 & 0,07 & 0,06 & 0,02 & 0,02 \\
\hline $\mathrm{MgO}$ & 1,37 & 0,18 & 0,10 & 1,36 & 0,96 & 0,14 & 0,33 \\
\hline $\mathrm{CaO}$ & 2,59 & 0,83 & 1,24 & 2,94 & 1,79 & 1,11 & 1,25 \\
\hline $\mathrm{Na}_{2} \mathrm{O}$ & 3,52 & 3,24 & 3,25 & 3,93 & 3,83 & 4,18 & 3,79 \\
\hline $\mathrm{K}_{2} \mathrm{O}$ & 4,87 & 5,35 & 4,97 & 3,95 & 4,85 & 4,80 & 5,23 \\
\hline $\mathrm{P}_{2} \mathrm{O}_{5}$ & 0,31 & 0,03 & 0,02 & 0,33 & 0,32 & 0,01 & 0,08 \\
\hline P.F. & 1,21 & 0,65 & 1,61 & 1,04 & 0,81 & 0,94 & 0,80 \\
\hline $\mathrm{H}_{2} \mathrm{O}^{-}$ & 0,17 & 0,16 & 0,16 & 0,27 & 0,09 & 0,14 & 0,12 \\
\hline Total & 99,64 & 98,89 & 99,35 & 98,80 & 98,82 & 98,75 & 98,95 \\
\hline V & 44 & 25 & $<15$ & 53 & 40 & $<15$ & 18 \\
\hline $\mathrm{Zn}$ & 53 & 21 & 46 & 63 & 49 & 45 & 45 \\
\hline $\mathbf{S r}$ & 685 & 196 & 37 & 723 & 503 & 95 & 426 \\
\hline$Y$ & 11 & 35 & 52 & 12 & $<10$ & $<10$ & $<10$ \\
\hline $\mathrm{Zr}$ & 218 & 95 & 247 & 205 & 220 & 41 & 184 \\
\hline $\mathrm{Ba}$ & 1.459 & 337 & 191 & 1.206 & 1.370 & 87 & 1.067 \\
\hline Sc & 7 & 3 & 4 & 8 & 8 & 2 & 2 \\
\hline $\mathrm{Cr}$ & 7 & 2 & $<2$ & 6 & 8 & 6 & 7 \\
\hline $\mathrm{Ni}$ & 6 & 4 & 3 & 5 & $<3$ & $<3$ & $<3$ \\
\hline Ga & 19 & 15 & 19 & 19 & 23 & 27 & 25 \\
\hline $\mathbf{R b}$ & 153 & 208 & 200 & 119 & 197 & 178 & 208 \\
\hline$\overline{\mathrm{Nb}}$ & 10 & 23 & 38 & 10 & 12 & 7 & 10 \\
\hline La & 71 & 59 & 142 & 61 & 89 & $<7$ & 68 \\
\hline $\mathrm{Ce}$ & 114 & 129 & 259 & 122 & 144 & 33 & 117 \\
\hline Nd & 13 & 38 & 105 & 12 & 60 & $<1$ & 36 \\
\hline$T h$ & 12 & 47 & 25 & 13 & 21 & 5 & 25 \\
\hline $\bar{U}$ & 12 & 8 & 22 & 10 & 11 & 11 & 17 \\
\hline $\mathbf{F}$ & 1.008 & 506 & 4.725 & 714 & 793 & 388 & 940 \\
\hline
\end{tabular}


Tabela 6.1(cont.): Teores para os elementos maiores, menores (em $\%$ de óxido) e traços (ppm) para amostras de diferentes tipos granitóides do Complexo Granítico Cunhaporanga.

\begin{tabular}{|c|c|c|c|c|c|c|c|}
\hline & \multicolumn{3}{|c|}{$\begin{array}{l}\text { Dom. Petrogr. da porção } \\
\text { centro-N do Complexo }\end{array}$} & \multicolumn{4}{|c|}{$\begin{array}{l}\text { Dom. Petrogr. da porção NE do } \\
\text { Complexo }\end{array}$} \\
\hline & \multirow{2}{*}{$\begin{array}{l}\text { D. P. Alata- } \\
\text { A. Clara } \\
\text { tit bio }\end{array}$} & \multicolumn{2}{|c|}{$\begin{array}{l}\text { Domínio } \\
\text { Varginha }\end{array}$} & \multicolumn{4}{|c|}{$\begin{array}{l}\text { Domínio Ouro Verde-Patrimônio } \\
\text { Santo Antônio }\end{array}$} \\
\hline & & tit bio & bio pórf & ant pórf & & tit bio & \\
\hline & PS-57 & PS.66 & PS-48 & IT-96 & IT-95 & TT.95 E & $\mathrm{IT}-104$ \\
\hline $\mathrm{SiO}_{2}$ & 73,02 & 70,41 & $\overline{68,60}$ & 67,54 & $\overline{69,51}$ & 70,02 & 70,14 \\
\hline $\mathrm{TiO}_{2}$ & 0,19 & 0,45 & 0,59 & 0,75 & 0,68 & 0,69 & 0,59 \\
\hline $\mathrm{Al}_{2} \mathrm{O}_{3}$ & 13,84 & 14,22 & 14,55 & 14,63 & 14,42 & 14,48 & 14,27 \\
\hline $\mathrm{Fe}_{2} \mathrm{O}_{3}^{\top}$ & 1,28 & 2,62 & 3,13 & 4,01 & 2,96 & 2,62 & 2,66 \\
\hline Mno & 0,01 & & 0,05 & & & 0,03 & 0,05 \\
\hline $\mathrm{MgO}$ & 0,23 & 0,76 & 0,91 & 1,33 & 0,93 & 0,58 & 0,84 \\
\hline $\mathrm{CaO}$ & 1,16 & & 2,15 & & 2,09 & 1,52 & 1,89 \\
\hline $\mathrm{Na}_{2} \mathrm{O}$ & 3,27 & 3,52 & 3,44 & 3,55 & 3,74 & 3,18 & 3,85 \\
\hline $\mathrm{K}_{2} \mathrm{O}$ & 5,49 & & 5,00 & 4,1 & 4,57 & 6,60 & 4,30 \\
\hline $\mathrm{P}_{2} \mathrm{O}_{5}$ & 0,02 & 0,15 & 0,20 & 0,25 & 0,25 & 0,22 & 0,19 \\
\hline P.F. & 0,67 & 0,89 & 0,91 & 0,92 & 0,67 & 0,72 & 0,84 \\
\hline $\mathrm{H}_{2} \mathrm{O}^{\circ}$ & 0,14 & 0,13 & 0,13 & 0,09 & 0,19 & 0,14 & 0,12 \\
\hline Total & 99,18 & 99,73 & 99,54 & 100,19 & 99,86 & 100,66 & 99,61 \\
\hline V & 14 & 30 & 37 & 46 & 37 & 35 & 40 \\
\hline $\mathrm{Zn}$ & 21 & 46 & 67 & 66 & 60 & 41 & 58 \\
\hline $\mathrm{Sr}$ & 361 & 288 & 418 & 642 & 652 & 598 & 591 \\
\hline $\mathbf{Y}$ & 24 & 12 & 20 & 11 & 28 & $<10$ & $<10$ \\
\hline $\mathrm{Zr}$ & 94 & 192 & 253 & 210 & 203 & 280 & 170 \\
\hline $\mathrm{Ba}$ & 740 & 783 & 1.291 & 1.168 & 1.208 & 1.762 & 1.107 \\
\hline Sc & 3 & 5 & 7 & 9 & 6 & 3 & 6 \\
\hline $\mathrm{Cr}$ & 4 & 8 & 10 & 8 & 8 & 6 & 12 \\
\hline $\mathrm{Ni}$ & 3 & $<3$ & 7 & 3 & 3 & $<3$ & 5 \\
\hline Ga & 23 & 22 & 18 & 19 & 20 & 18 & 23 \\
\hline $\mathbf{R b}$ & 126 & 205 & 169 & 124 & 150 & 191 & 158 \\
\hline $\mathrm{Nb}$ & 10 & 12 & 10 & 9 & 9 & 7 & 9 \\
\hline La & 4 & 66 & 75 & 69 & 77 & 73 & 50 \\
\hline $\mathrm{Ce}$ & 56 & 110 & 135 & 90 & 124 & 100 & 84 \\
\hline Nd & $<1$ & 41 & 47 & 48 & 6 & 10 & 35 \\
\hline Th & 4 & 18 & 17 & 17 & 18 & 12 & 12 \\
\hline $\bar{U}$ & 4 & 12 & 15 & 15 & 14 & 14 & 15 \\
\hline$F$ & 124 & 1.787 & 1.976 & 529 & 1.813 & 1.042 & 1.421 \\
\hline
\end{tabular}


Tabela 6.1(cont.): Teores para os elementos maiores, menores (em \% de óxido) e traços (ppm) para amostras de diferentes tipos granitóides do Complexo Granítico Cunhaporanga.

\begin{tabular}{|c|c|c|c|c|c|c|c|}
\hline & \multicolumn{3}{|c|}{$\begin{array}{c}\text { Dom. Petrogr. da porção } \\
\text { NE do Complexo }\end{array}$} & \multicolumn{2}{|c|}{$\begin{array}{l}\text { Granito Serra } \\
\text { do Carambei }\end{array}$} & \multicolumn{2}{|c|}{$\begin{array}{c}\text { Granito Joaquim } \\
\text { Murtinho }\end{array}$} \\
\hline & \multirow{2}{*}{$\begin{array}{c}\begin{array}{c}\text { Dom. } \\
\text { Limeira }\end{array} \\
\text { bio }\end{array}$} & \multicolumn{2}{|c|}{$\begin{array}{l}\text { Dom. Fr. Simas- } \\
\text { V. Branca }\end{array}$} & & & & \\
\hline & & tit bio & mu bio & \multicolumn{2}{|c|}{ af granito } & \multicolumn{2}{|c|}{ af granito } \\
\hline & IT-57 & PS-63 & PS-130 & JGA-23I & $\mathrm{SC}-3$ & JM-96B & JM-96E \\
\hline $\mathrm{SiO}_{2}$ & 74,91 & 72,37 & 74,65 & 76,67 & 76,76 & 78,03 & 73,60 \\
\hline $\mathrm{TiO}_{2}$ & 0,04 & 0,39 & 0,08 & 0,10 & 0,10 & 0,06 & 0,14 \\
\hline $\mathrm{Al}_{2} \mathrm{O}_{3}$ & 14,03 & 14,27 & 14,10 & 11,66 & 11,49 & 11,74 & 13,03 \\
\hline $\mathrm{Fe}_{2} \mathrm{O}_{3}{ }^{\mathrm{T}}$ & 0,66 & 1,75 & 0,69 & 1,72 & 1,55 & 1,21 & 2,81 \\
\hline MnO & 0,01 & 0,02 & 0,02 & 0,03 & 0,02 & 0,02 & 0,03 \\
\hline $\mathrm{MgO}$ & 0,02 & $<0,01$ & $<0,01$ & $<0,01$ & 0,01 & 0,07 & 0,28 \\
\hline $\mathrm{CaO}$ & 0,85 & 1,74 & 1,23 & 0,53 & 0,48 & 0,34 & 0,15 \\
\hline $\mathrm{Na}_{2} \mathrm{O}$ & 3,42 & 3,97 & 4,52 & 3,94 & 4,10 & 3,82 & 4,59 \\
\hline $\mathrm{K}_{2} \mathrm{O}$ & 4,81 & 4,46 & 3,91 & 4,49 & 3,95 & 4,27 & 4,12 \\
\hline $\mathrm{P}_{2} \mathrm{O}_{5}$ & 0,00 & 0,09 & $<0,01$ & $<0,01$ & $<0,01$ & 0,01 & 0,01 \\
\hline P.F. & 1,03 & 0,59 & 0,65 & 0,71 & 0,72 & 1,04 & 1,15 \\
\hline $\mathrm{H}_{2} \mathrm{O}^{-}$ & 0,54 & 0,07 & 0,05 & 0,06 & 0,09 & 0,13 & 0,50 \\
\hline Total & 99,78 & 99,67 & 99,84 & 99,85 & 99,18 & 100,61 & 99,93 \\
\hline V & $<15$ & 24 & $<15$ & $<15$ & 8 & $<15$ & $<15$ \\
\hline $\mathbf{Z n}$ & 18 & - & - & 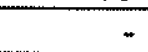 & 151 & 51 & 91 \\
\hline $\mathrm{Sr}$ & 185 & 499 & 202 & 13 & 17 & 6 & 13 \\
\hline $\mathbf{Y}$ & $<10$ & 10 & $<10$ & 109 & 115 & 79 & 91 \\
\hline $\mathrm{Zr}$ & 50 & 156 & 50 & 318 & 271 & 358 & 132 \\
\hline $\mathbf{B a}$ & 208 & 898 & 315 & 5 & 3 & 18 & 20 \\
\hline Sc & 2 & 2 & $<2$ & 2 & 2 & $<2$ & 2 \\
\hline $\mathrm{Cr}$ & $<2$ & 15 & 4 & 16 & 4 & 3 & 8 \\
\hline $\mathrm{Ni}$ & $<3$ & 10 & 5 & 9 & 5 & 6 & 3 \\
\hline $\mathbf{G a}$ & 27 & 25 & 29 & 29 & 31 & 26 & 35 \\
\hline $\mathbf{R b}$ & 181 & 158 & 208 & 336 & 338 & 340 & 280 \\
\hline $\mathrm{Nb}$ & 7 & 13 & 17 & 53 & 52 & 85 & 56 \\
\hline La & $<7$ & 37 & 6 & 57 & 64 & 42 & 57 \\
\hline $\mathrm{Ce}$ & 22 & 70 & 26 & 146 & 132 & 115 & 139 \\
\hline Nd & 2 & 22 & 3 & 56 & 14 & 44 & 65 \\
\hline Th & 4 & 24 & 12 & 37 & 14 & 22 & 14 \\
\hline $\mathbf{U}$ & 18 & 35 & 39 & 47 & 29 & 30 & $<2$ \\
\hline $\mathbf{F}$ & 140 & 873 & 676 & 6.702 & 4.700 & 2.720 & 1.036 \\
\hline
\end{tabular}

Observações: Rochas porfiríticas sublinhadas; enclaves microgranulares hachurados. Elementos maiores, menores e o primeiro conjunto de traços ( $\mathrm{V}-\mathrm{Ba}$ ) analisados por ICP-AES; traços do segundo conjunto (SC-F) analisados por fluorescência de raios $\mathrm{X}$. 
Tabela 6.2: Detalhes sobre as amostras utilizadas nos diagramas multi-elementos da Figura 6.5.

\begin{tabular}{|c|c|c|c|c|c|c|}
\hline Figura & Tipo & Amostra & $\% \mathrm{SiO}_{2}$ & $\begin{array}{c}\text { Unidade } \\
\end{array}$ & Classificação & Fonte \\
\hline $6.8 \mathrm{~A}$ & tit anf bio & $\begin{array}{l}\text { JGA-4C } \\
\text { JGA-34 } \\
\text { JM-39 } \\
\text { PS-78 } \\
\text { SC-77 }\end{array}$ & $\begin{array}{l}63,68 \\
70,63 \\
67,60 \\
65,06 \\
66,19 \\
\end{array}$ & $\begin{array}{c}\text { Espigão Alto } \\
\text { Biscaias-Boa Vista } \\
\text { Espigão Alto } \\
\text { Abapä-Santa Quitéria } \\
\text { Serra Abaixo-Alagados } \\
\end{array}$ & $\begin{array}{l}\text { Similares ao } \\
\text { tipo I }\end{array}$ & Este trabalho \\
\hline $6.8 \mathrm{~B}$ & tit bio & $\begin{array}{l}\text { JGA-44 } \\
\begin{array}{l}\text { IT-95 } \\
\text { PS-63 } \\
\text { PS-66 }\end{array}\end{array}$ & $\begin{array}{l}67,44 \\
70,04 \\
72,37 \\
70,41 \\
\end{array}$ & $\begin{array}{c}\text { Paredão da Santa } \\
\text { Patrimônio Santo Antônio-Ouro Verde } \\
\text { Francisco Simas-Vila Branca } \\
\text { Varginha }\end{array}$ & $\begin{array}{l}\text { Similares ao } \\
\text { tipo I }\end{array}$ & Este trabalho \\
\hline $6.8 \mathrm{C}$ & $\begin{array}{l}\text { anf pórfiro } \\
\text { anf pórfiro } \\
\text { bio pórfiro }\end{array}$ & $\frac{\frac{S C-51}{S C-74 B}}{P S-48}$ & $\begin{array}{l}67,56 \\
66,31 \\
68,60 \\
\end{array}$ & $\begin{array}{c}\text { Pórfiro intrusivo em outros granitóides do Complexo } \\
\text { Pórfiro intrusivo em outros granitóides do Complexo } \\
\text { Varginha }\end{array}$ & $\begin{array}{l}\text { Similares ao } \\
\text { tipo I }\end{array}$ & Este trabalho \\
\hline $6.8 \mathrm{D}$ & $\begin{array}{l}\text { tit anf bio } \\
\text { tit anf bio } \\
\text { tit bio }\end{array}$ & $\begin{array}{c}\text { AB299 } \\
\text { M51 } \\
\text { BB34 } \\
\end{array}$ & $\begin{array}{l}64,44 \\
70,96 \\
74,87 \\
\end{array}$ & $\begin{array}{l}\text { Granodiorito Braidwood - Batólito Bega } \\
\text { Monzogranito Moonbi - Batólito Bendemeer } \\
\text { Monzogranito Wullye - Batólito Berridale }\end{array}$ & Tipo I & White (1992) \\
\hline $6.8 E$ & $\begin{array}{c}\text { bio } \\
\text { bio } \\
\text { mu bio } \\
\end{array}$ & $\begin{array}{l}\text { PS-44 } \\
\text { HP-01 } \\
\text { PS-130 }\end{array}$ & $\begin{array}{l}71,14 \\
73,49 \\
74,65 \\
\end{array}$ & $\begin{array}{c}\text { Passo da Anta-Água Clara } \\
\text { Santa Rita } \\
\text { Francisco Simas-Vila Branca }\end{array}$ & $\begin{array}{l}\text { Similares ao } \\
\text { tipo I? }\end{array}$ & Este trabalho \\
\hline $6.8 \mathrm{~F}$ & mubio & VB-140 & 72,48 & Monzogranito Granya & Tipo S & White (1992) \\
\hline $6.8 \mathrm{G}$ & af granito & $\begin{array}{l}\mathrm{JM}-96 \mathrm{~b} \\
\mathrm{SC}-3\end{array}$ & $\begin{array}{l}78,03 \\
76,76\end{array}$ & $\begin{array}{l}\text { Granito Joaquim Murtinho } \\
\text { Granito Serra do Carambei }\end{array}$ & $\begin{array}{c}\text { Em parte } \\
\text { similares ao tipo } \\
\text { A } \\
\end{array}$ & Este trabalho \\
\hline $6.8 \mathrm{H}$ & $?$ & $\begin{array}{l}\text { Média de } 9 \\
\text { amostras }\end{array}$ & $\begin{array}{c}71,46 \\
a \\
73,71\end{array}$ & $\begin{array}{c}\text { Monzo- e sienogranitos Watergums, } \\
\text { Naghi, Nagha, Howe Range e } \\
\text { Gabo Island }\end{array}$ & Tipo A & $\begin{array}{c}\text { Collins et al. } \\
(1982)\end{array}$ \\
\hline
\end{tabular}

Observações: Amostras sublinhadas com textura porfirítica. 
Tabela 6.3: Estimativas de pressão e temperatura para rochas do Complexo Granítico Cunhaporanga.

\begin{tabular}{|c|c|c|c|c|c|c|c|c|c|c|c|}
\hline \multicolumn{12}{|c|}{ Domínios Petrográficos da porção S/SE do Complexo } \\
\hline & & & & MINIO AB & PÄ-SANI & A QUITER & & & & & \\
\hline Amostra & Tipo de granito & $\mathbf{P}(J R)$ & $\mathbf{P}(S)$ & $\mathbf{P}(A S)_{b h}$ & $\mathbf{T}(\mathrm{BH})$ & $\mathbf{P}(A S)_{h D A}$ & $T_{A}(H B)$ & $\mathbf{P}(A S)_{h D B}$ & $T_{B}(H B)$ & $\mathbf{T}(z r)$ & $\mathbf{T}(a p)$ \\
\hline ITA-2-100 & \multirow{8}{*}{ tit anf bio } & - & - & - & - & - & - & - & - & $775(*)$ & 959 \\
\hline ITA-4-36 & & 1,9 & 3,0 & 2,9 & 688 & 2,5 & 720 & 3,1 & 660 & 786()$\left.^{*}\right)$ & 965 \\
\hline PS-21 & & 3,3 & 4,6 & 3,6 & 747 & 3,7 & 740 & 4,3 & 730 & $783\left(^{*}\right)$ & 980 \\
\hline PS-54 & & 4,7 & 6,2 & 3,5 & 810 & 4,5 & 769 & 5,6 & 717 & 780()$\left.^{*}\right)$ & 975 \\
\hline PS-76 & & 3,8 & 5,1 & 2,6 & 809 & 3,7 & 762 & 4,3 & 730 & $771\left(^{*}\right)$ & 964 \\
\hline PS-78 & & 1,9 & 3,8 & 2,7 & 711 & 2,5 & 729 & 2,9 & 688 & $783\left(^{*}\right)$ & 962 \\
\hline PS-79 & & 2,6 & 3,8 & 3,1 & 730 & 2,9 & 740 & 3,5 & 698 & $783\left(^{*}\right)$ & 969 \\
\hline PS-79a & & 1,3 & 2,4 & 2,3 & 690 & 2,1 & 709 & 2,3 & 679 & 764 & 994 \\
\hline \multicolumn{12}{|c|}{ DOMÍNIO SERRA ABAIXO-ALAGADOS } \\
\hline Amostra & Tipo de granito & $\mathbf{P}(J R)$ & $P(S)$ & $\mathbf{P}(A S)_{b h}$ & $T(B H)$ & $\mathbf{P}(A S)_{h b A}$ & $\mathbf{T}_{\mathrm{A}}(H B)$ & $\mathbf{P}(A S)_{h b B}$ & $T_{B}(H B)$ & $\mathbf{T}(z r)$ & $\mathbf{T}(a p)$ \\
\hline SC-34 & \multirow[t]{2}{*}{ tit anf bio } & - & - & - & - & - & - & - & - & $777\left(^{*}\right)$ & 965 \\
\hline SC-77 & & 1,7 & 2,8 & 2,2 & 732 & 2,0 & 744 & 2,4 & 716 & $790(*)$ & 975 \\
\hline \multicolumn{12}{|c|}{ DOMINIO JOTUBA-PITANGUI } \\
\hline Amostra & Tipo de granito & $P(J R)$ & $\mathbf{P}(S)$ & $\mathbf{P}(A S)_{b h}$ & $\mathbf{T}(B H)$ & $\mathbf{P}(A S)_{h b A}$ & $T_{A}(H B)$ & $\mathbf{P}(A S)_{h b B}$ & $T_{B}(H B)$ & $T(z r)$ & $T(a p)$ \\
\hline SC-23 & \multirow[t]{2}{*}{ tit anf bio } & 3,8 & 5,2 & 3,2 & 787 & 3,7 & 766 & 4,5 & 723 & - & - \\
\hline SC-79 & & - & - & - & - & - & - & - & - & $773\left({ }^{*}\right)$ & 972 \\
\hline \multicolumn{12}{|c|}{ DOMINIO SANTA RITA } \\
\hline Amostra & Tipo de granito & $\mathbf{P}(J R)$ & $P(S)$ & $\mathbf{P}(A S)_{b h}$ & $\mathbf{T}(B H)$ & $\mathbf{P}(A S)_{h b A}$ & $\mathbf{T}_{\mathrm{A}}(H B)$ & $\mathrm{P}(A S)_{h b B}$ & $T_{B}(H B)$ & $T(z r)$ & $\mathbf{T}(a p)$ \\
\hline HP-01 & bio & $\mathrm{n}$ & $\mathrm{n}$ & $\mathrm{n}$ & $\mathrm{n}$ & $\mathrm{n}$ & $\mathrm{n}$ & $\mathrm{n}$ & $\mathrm{n}$ & 743 & 828 \\
\hline \multicolumn{12}{|c|}{ PÓRFIROS INTRUSIVOS EM GRANITÓIDES DO COMPLEXO } \\
\hline Amostra & Tipo de granito & $\mathbf{P}(J R)$ & $\mathbf{P}(S)$ & $\mathbf{P}(A S)_{b h}$ & $\mathbf{T}(\mathrm{BH})$ & $\mathbf{P}(A S)_{h b A}$ & $T_{A}(H B)$ & $\mathbf{P}(A S)_{h b B}$ & $\mathrm{~T}_{\mathrm{B}}(H B)$ & $\mathbf{T}(z r)$ & $\mathbf{T}(a p)$ \\
\hline PS-23 & \multirow{3}{*}{ anf porf } & - & - & - & - & - & - & - & - & 787 & 961 \\
\hline$\underline{\mathrm{SC}-51}$ & & 5,4 & 6,9 & $?$ & $?$ & 0,4 & 910 & 2,7 & 852 & 793 & 941 \\
\hline SC-74B & & - & - & - & - & - & - & - & - & 801 & 997 \\
\hline \multicolumn{12}{|c|}{ PORFIRO INTRUSIVO NO GRUPO ITAIACOCA } \\
\hline Amostra & Tipo de granito & $\mathbf{P}(J R)$ & $P(S)$ & $\mathbf{P}(A S)_{b h}$ & $T(B H)$ & $\mathbf{P}(A S)_{h b A}$ & $T_{A}(H B)$ & $\mathrm{P}(A S)_{h b B}$ & $T_{B}(H B)$ & $\mathrm{T}(z r)$ & $\mathbf{T}(a p)$ \\
\hline PS-103 & anf porf & - & - & - & - & - & - & - & - & 811 & 950 \\
\hline
\end{tabular}


Tabela 6.3 (cont.): Estimativas de pressão e temperatura para rochas do Complexo Granítico Cunhaporanga.

\begin{tabular}{|c|c|c|c|c|c|c|c|c|c|c|c|}
\hline \multicolumn{12}{|c|}{ Domínios Petrográficos da porção centro-norte do Complexo } \\
\hline \multicolumn{12}{|c|}{ DOMÍNIO PIRAÍ DO SUL } \\
\hline Amostra & Tipo de granito & $\mathrm{P}(J R)$ & $\mathbf{P}(S)$ & $\mathbf{P}(A S)_{b h}$ & $\mathbf{T}(\mathrm{BH})$ & $\mathbf{P}(A S)_{h b A}$ & $T_{A}(H B)$ & $\mathbf{P}(A S)_{h b B}$ & $T_{B}(H B)$ & $T(z r)$ & $\mathbf{T}(a p)$ \\
\hline PS-5 & \multirow[t]{2}{*}{ tit anf bio } & - & - & - & - & - & - & - & - & $785(*)$ & 965 \\
\hline PS-32 & & - & - & - & - & - & - & - & - & 724 & 886 \\
\hline \multicolumn{12}{|c|}{ DOMÍNIO BISCAIAS-BOA VISTA } \\
\hline Amostra & Tipo de granito & $\mathbf{P}(J R)$ & $\mathrm{P}(S)$ & $\mathbf{P}(A S)_{b h}$ & $T(B H)$ & $\mathbf{P}(A S)_{h b A}$ & $\mathbf{T}_{\mathrm{A}}(H B)$ & $\mathrm{P}(A S)_{h b B}$ & $T_{B}(H B)$ & $T(z r)$ & $T(a p)$ \\
\hline $\mathrm{JGA}-34$ & \multirow{5}{*}{ tit anf bio } & - & - & - & - & - & - & - & - & $767\left(^{*}\right)$ & 1045 \\
\hline JGA-35 & & 3,4 & 4,8 & 3,5 & 758 & 3,7 & 749 & 4,4 & 701 & $785\left(^{*}\right)$ & 953 \\
\hline JGA-41 & & 2,8 & 4,0 & 3,3 & 734 & 3,2 & 737 & 3,7 & 704 & $755(*)$ & 994 \\
\hline JGA-41E & & - & - & - & - & - & - & - & - & 753 & 989 \\
\hline PS-36 & & 3,1 & 4,4 & 3,5 & 742 & 3,5 & 740 & 4,1 & 702 & - & - \\
\hline JGA-32d & tit bio & $n$ & $\mathrm{n}$ & $n$ & $n$ & $\mathrm{n}$ & $n$ & $\mathrm{n}$ & $n$ & 770 & 967 \\
\hline \multicolumn{12}{|c|}{ DOMINIO ESPIGÃO ALTO } \\
\hline Amostra & Tipo de granito & $\mathbf{P}(J R)$ & $P(S)$ & $\mathbf{P}(A S)_{b h}$ & $\mathrm{~T}(\mathrm{BH})$ & $\mathbf{P}(A S)_{h D A}$ & $\mathrm{~T}_{\mathrm{A}}(H B)$ & $P(A S)_{h b B}$ & $T_{B}(H B)$ & $T(z r)$ & $\mathbf{T}(a p)$ \\
\hline JGA-4c & \multirow{9}{*}{ tit anf bio } & 3,2 & 4,5 & 2,8 & 779 & 2,7 & 785 & 3,7 & 736 & 782()$\left.^{*}\right)$ & 972 \\
\hline JGA-17 & & 2,7 & 3,9 & 3,2 & 735 & 2,9 & 749 & 3,6 & 702 & - & - \\
\hline JGA-20 & & - & - & - & - & $=$ & - & - & - & $780\left(^{*}\right)$ & 994 \\
\hline JGA-42B & & 1,9 & 3,0 & 2,6 & 713 & 2,2 & 739 & 2,8 & 699 & $800\left(^{*}\right)$ & 976 \\
\hline JGA-43 & & 3,6 & 4,9 & 4,6 & 705 & $?$ & $?$ & 4,3 & 723 & $767(*)$ & 979 \\
\hline $\mathrm{JM}-39$ & & - & - & - & - & - & - & - & - & $792\left(^{*}\right)$ & 948 \\
\hline PS-93 & & - & - & - & - & - & - & - & - & 798 & 953 \\
\hline PS-93A & & 3,0 & 4,2 & 3,1 & 755 & 3,1 & 754 & 3,5 & 731 & $796\left(^{*}\right)$ & 970 \\
\hline PS-96A & & - & - & - & - & - & - & - & - & $796\left(^{*}\right)$ & 986 \\
\hline JGA-42A & tit bio & $n$ & $n$ & $n$ & $n$ & $n$ & $n$ & $n$ & $n$ & 746 & 832 \\
\hline JGA-211 & af granito & $n$ & $n$ & $n$ & $\mathrm{n}$ & $\mathrm{n}$ & $n$ & $n$ & $n$ & 822 & 791 \\
\hline \multicolumn{12}{|c|}{ DOMÍNIO PAREDÃO DA SANTA } \\
\hline Amostra & Tipo de granito & $\mathbf{P}(J R)$ & $P(S)$ & $\mathbf{P}(A S)_{b h}$ & $\mathbf{T}(\mathrm{BH})$ & $\mathbf{P}(A S)_{h b A}$ & $\mathbf{T}_{\mathrm{A}}(H B)$ & $\mathbf{P}(A S)_{h b B}$ & $\mathrm{~T}_{\mathrm{B}}(H B)$ & $T(z r)$ & $\mathbf{T}(a p)$ \\
\hline JGA-1 & tit anf bio & 0,3 & 1,2 & 1,2 & 658 & 0,9 & 718 & 1,3 & 660 & $787(*)$ & 985 \\
\hline JGA-44 & tit bio & $\mathrm{n}$ & $n$ & $n$ & $\mathrm{n}$ & $n$ & $\mathrm{n}$ & $\mathrm{n}$ & $\mathrm{n}$ & 804 & 1009 \\
\hline
\end{tabular}


Tabela 6.3 (cont.): Estimativas de pressão e temperatura para rochas do Complexo Granítico Cunhaporanga.

\begin{tabular}{|c|c|c|c|c|c|c|c|c|c|c|c|}
\hline \multicolumn{12}{|c|}{ Domínios Petrográficos da porção centro-norte do Complexo } \\
\hline \multicolumn{12}{|c|}{ DOMINIO PASSO DA ANTA-ÁGUA CLARA } \\
\hline Amostra & Tipo de granito & $\mathrm{P}(J R)$ & $\mathbf{P}(S)$ & $\mathbf{P}(A S)_{b h}$ & $\mathbf{T}(\mathrm{BH})$ & $\mathbf{P}(A S)_{h b A}$ & $T_{A}(H B)$ & $P(A S)_{h D B}$ & $\mathbf{T}_{\mathrm{B}}(H B)$ & $\mathbf{T}(z r)$ & $\mathbf{T}(a p)$ \\
\hline PS-57 & tit bio & $n$ & $\mathrm{n}$ & $\mathrm{n}$ & $n$ & $\mathrm{n}$ & $n$ & $n$ & $n$ & 742 & 1059 \\
\hline PS-44 & bio & $n$ & $\mathrm{n}$ & $\bar{n}$ & $n$ & $n$ & $\mathrm{n}$ & $n$ & $n$ & 795 & 893 \\
\hline JGA-14 & mu bio & $n$ & $n$ & $\mathrm{n}$ & $n$ & $n$ & $n$ & $n$ & $n$ & 679 & $n$ \\
\hline \multicolumn{12}{|c|}{ DOMINIO VARGINHA } \\
\hline Amostra & Tipo de granito & $P(J R)$ & $P(S)$ & $\mathbf{P}(A S)_{b h}$ & $T(B H)$ & $\mathbf{P}(A S)_{h b A}$ & $T_{A}(H B)$ & $\mathbf{P}(A S)_{h b B}$ & $T_{B}(H B)$ & $\mathbf{T}(z r)$ & $\mathbf{T}(a p)$ \\
\hline PS-66 & tit bio & $n$ & $n$ & $n$ & $n$ & $n$ & $n$ & $n$ & $n$ & 794 & 950 \\
\hline PS-48 & bio porf & $n$ & $n$ & $n$ & $n$ & $n$ & $n$ & $n$ & $n$ & 814 & 964 \\
\hline \multicolumn{12}{|c|}{ Domínios Petrográficos da porção NE do Complexo } \\
\hline \multicolumn{12}{|c|}{ DOMINIO OURO VERDE-PATRIMÓNIO SANTO ANTÓNIO } \\
\hline Amostra & Tipo de granito & $\mathbf{P}(J R)$ & $\mathbf{P}(\mathcal{S})$ & $\mathbf{P}(A S)_{b h}$ & $\mathbf{T}(\mathrm{BH})$ & $\mathbf{P}(A S)_{h b A}$ & $\mathbf{T}_{\mathbf{A}}(H B)$ & $\mathbf{P}(A S)_{h b B}$ & $\mathrm{~T}_{B}(H B)$ & $T(z r)$ & $\mathbf{T}(a p)$ \\
\hline IT-95 & \multirow{3}{*}{ tit bio } & $n$ & $\mathrm{n}$ & $n$ & $n$ & $n$ & $n$ & $\mathrm{n}$ & $n$ & 795 & 1000 \\
\hline $1 \mathrm{~T}-95 \mathrm{E}$ & & $n$ & $n$ & $n$ & $n$ & $n$ & n & $n$ & $n$ & 822 & 990 \\
\hline IT-104 & & $\mathrm{n}$ & $n$ & $n$ & $n$ & $n$ & $n$ & $n$ & $n$ & 783 & 974 \\
\hline IT-96 & anf porf & 3,1 & 4,3 & 3,0 & 764 & 2,8 & 770 & 3,6 & 731 & 790 & 979 \\
\hline \multicolumn{12}{|c|}{ DOMINIO LIMEIRA } \\
\hline Amostra & Tipo de granito & $\mathbf{P}(J R)$ & $P(S)$ & $\mathbf{P}(A S)_{b h}$ & $\mathbf{T}(\mathrm{BH})$ & $\mathbf{P}(A S)_{h b A}$ & $\mathrm{~T}_{\mathrm{A}}(H B)$ & $\mathrm{P}(A S)_{h b B}$ & $\mathrm{~T}_{\mathrm{B}}(H B)$ & $T(z r)$ & $\mathbf{T}(a p)$ \\
\hline IT-50b & tit anf bio & 5,1 & 6,6 & 3,8 & 807 & 3,6 & 817 & 5,5 & 742 & - & - \\
\hline $1 T-57$ & bio & $n$ & $n$ & $n$ & $n$ & $n$ & $n$ & $n$ & $n$ & 703 & $n$ \\
\hline \multicolumn{12}{|c|}{ DOMINIO FRANCISCO SIMAS-VILA BRANCA } \\
\hline Amostra & Tipo de granito & $\mathbf{P}(J R)$ & $\mathbf{P}(S)$ & $\mathbf{P}(A S)_{b h}$ & $\mathbf{T}(\mathrm{BH})$ & $\mathbf{P}(A S)_{h D A}$ & $\mathbf{T}_{\mathrm{A}}(H B)$ & $\mathbf{P}(A S)_{h b B}$ & $T_{B}(H B)$ & $T(z r)$ & $T$ (ap) \\
\hline PS-63 & tit bio & $\mathrm{n}$ & $\mathrm{n}$ & $\mathrm{n}$ & $\mathrm{n}$ & $\mathrm{n}$ & $\mathrm{n}$ & $\mathrm{n}$ & $\mathrm{n}$ & 689 & 917 \\
\hline PS-130 & mu bio & $n$ & $n$ & $\mathrm{n}$ & $\mathrm{n}$ & $n$ & $n$ & $n$ & $n$ & 693 & 755 \\
\hline \multicolumn{12}{|c|}{ GRANITO SERRA DO CARAMBEI } \\
\hline Amostra & Tipo de granito & $\mathbf{P}(J R)$ & $\mathbf{P}(S)$ & $\mathbf{P}(A S)_{b h}$ & $\mathbf{T}(B H)$ & $\mathbf{P}(A S)_{h b A}$ & $\mathrm{~T}_{\mathrm{A}}(H B)$ & $\mathbf{P}(A S)_{h b B}$ & $\mathrm{~T}_{\mathrm{B}}(H B)$ & $T(z r)$ & $\mathbf{T}(a p)$ \\
\hline JGA-23I & \multirow[t]{2}{*}{ af granito } & $n$ & $\mathrm{n}$ & $\mathrm{n}$ & $n$ & $n$ & $n$ & $n$ & $n$ & 845 & $n$ \\
\hline SC-3 & & $\mathrm{n}$ & $\mathrm{n}$ & $\mathrm{n}$ & $\mathrm{n}$ & $\mathrm{n}$ & $n$ & $n$ & $n$ & 833 & $n$ \\
\hline
\end{tabular}


Tabela 6.3 (cont.): Estimativas de pressão e temperatura para rochas do Complexo Granítico Cunhaporanga.

\begin{tabular}{|c|c|c|c|c|c|c|c|c|c|c|c|}
\hline \multicolumn{12}{|c|}{ GRANITO JOAQUIM MURTINHO } \\
\hline JM-96e & & $n$ & $n$ & $n$ & $\mathrm{n}$ & $\mathrm{n}$ & $n$ & $\mathrm{n}$ & $n$ & 774 & 745 \\
\hline
\end{tabular}

Observações: Pressão (P), em kbar, estimada pelo método Al em hornblenda, a partir das equações de Johnson \& Rutherford $(1989 ; J R)$, Schmidt (1992; S) e Anderson \& Smith (1995; $A S)$. Temperatura $(\mathrm{T})$, em ${ }^{\circ} \mathrm{C}$, estimada para o equilíbrio entre hornblenda e plagioclásio, segundo os geotermômetros edenita-tremolita de Blundy \& Holland $(1990 ; B H)$ e de Holland \& Blundy (1994; $T_{A} H B$ ) e ainda pelo geotermômetro edenita-richterita de Holland \& Blundy (1994; $T_{B} H B$ ). Temperaturas de saturação de zircão (zr) de acordo com Watson \& Harrison (1983) e de saturação de apatita (ap) segundo Harrison \& Watson (1984). P $(A S)_{b h}$ - pressão calculada a partir da iteração algébrica com o geotermômetro de Blundy \& Holland (1990); P $(A S)_{h b A}$ - pressão obtida com base no geotermômetro $\mathrm{T}_{\mathrm{A}}$ de Holland \& Blundy (1994); P (AS)hbB - pressão calculada com a utilização do geotermômetro $T_{B}$ de Holland \& Blundy (1994). $n$ - pressão ou temperatura não obtida (amostras sem os atributos necessários para a aplicação dos geotermômetros e/ou geobarômetros); - pressão ou temperatura não obtida (não foram feitas análises químicas de minerais ou rochas); ? - pressão ou temperatura não obtida (não foi encontrada solução matemática para a iteração algébrica envolvendo as equações dos geobarômetros e geotermômetros). Código das rochas sublinhado: textura porfirítica; hachurado: enclaves. $\quad\left(^{\star}\right)$ - valores utilizados para o cálculo de uma $\mathbf{T}$ (zr) média dos tit anf bio granitóides (correspondente a $781^{\circ} \mathrm{C}$; excluídos enclaves e PS-32, com forte alteração deutérica). 


\section{CAPÍTULO 7}

\section{CONCLUSÕES}

Os trabalhos de mapeamento geológico, análise química de rochas e minerais selecionados, interpretação de mapas aerogeofísicos, além de uma revisão crítica dos estudos prévios sobre a geologia do Complexo Granítico Cunhaporanga permitiram concluir que:

- A unidade litoestratigráfica "Complexo Granítico Cunhaporanga" subdivide-se em unidades metamórficas (e. g., "Quartzito Serra das Pedras") e ígneas. O caráter ainda precário do conhecimento sobre a distribuição e constituição litológica da maior parte dos setores do Complexo não permitiu o amplo emprego de termos formais para as unidades ígneas, exceto nos casos dos Granitos Serra do Carambeí (Fuck 1967), Joaquim Murtinho (CCGP 1970 b) e São Domingos (Soares et al. 1987). O restante do Complexo foi separado em áreas de predomínio de tipos granitóides e foram denominadas de Domínios Petrográficos.

- Uma descrição dos granitóides do Complexo com base em critérios texturais e principalmente da natureza dos minerais máficos (mais muscovita) presentes, mostrou-se eficaz no tratamento dos dados de susceptibilidade magnética, geoquímica de rochas e química mineral, além de auxiliar na discriminação das unidades ígneas no mapa geológico.

- O contato entre o Grupo Itaiacoca e as rochas granitóides do Complexo Cunhaporanga é sempre intrusivo.

- As unidades metamórficas do Complexo correspondem a restos-de-teto ou fatias do Grupo Itaiacoca presenvadas entre as intrusões graníticas. Predominam 
metarenitos e metarcósios recristalizados por influência termal, não existindo gnaisses ou migmatitos "verdadeiros". Estas rochas quartzo-feldspáticas são facilmente identificáveis em mapas aerogamaespectrométricos (especialmente no canal da contagem total).

- Existem ao menos três linhagens magmáticas no Complexo, duas "cálcio-alcalinas" sensu latu (na verdade álcali-cálcicas) e uma alasquítica.

- Uma das linhagens cálcio-alcalinas é composta pelas rochas localizadas no centronorte e nordeste do Complexo, ou seja por dioritos, quartzomonzodioritos, granodioritos, monzogranitos e sienogranitos, pertencentes aos Domínios Piraí do Sul, Biscaias-Boa Vista, Espigão Alto, Espalha Brasa, Paredão da Santa, Ouro Verde-Patrimônio Santo Antônio e Varginha. Os granodioritos, monzogranitos e pórfiros localizados ao sul e englobados nos Domínios Abapã-Santa Quitéria, Serra Abaixo-Alagados e Jotuba-Pitangui, formam a outra linhagem "cálcio-alcalina".

- Monzogranitos e granodioritos com biotita e muscovita + biotita dos Domínios Passo da Anta-Água Clara, Francisco Simas-Vila Branca, Limeira e Arroio das Pedrinhas (também Santa Rita ?) são tipos especiais, formados por assimilação de rochas aluminosas do Grupo Itaiacoca.

- A linhagem alasquítica é representada pelos álcali-feldspato granitos hypersolvus dos Granitos Serra do Carambeí e Joaquim Murtinho.

- As rochas das linhagens "cálcio-alcalinas" evoluíram por cristalização fracionada, controlada em seus estágios iniciais principalmente pelo fracionamento de hornblenda ( \pm diopsídio) + labradorita/andesina + magnetita + apatita. Com a evolução do sistema magmático aumenta a importância da separação de biotita + oligoclásio ( \pm feldspato alcalino) + magnetita/ilmenita.

- Os granitóides das linhagens "cálcio-alcalinas" são enriquecidos mais fortemente em $\mathrm{K}$ e $\mathrm{Ba}$ e moderadamente em $\mathrm{Sr}$, apresentando um padrão típico das séries 
cálcio-alcalinas de alto $K$, em parte com afinidades shoshoníticas. Suas composições químicas, mineralógicas e modais os aproximam dos granitos tipo-l de Chappell \& White (1974).

- A linhagem "cálcio-alcalina" do sul/sudeste do Complexo possui um caráter mais primitivo que a linhagem do centro-norte e nordeste, como comprovado, entre outras evidências, pelos teores mais altos de $\mathrm{Cr}$ nas rochas, o índice $\boldsymbol{m g}^{\boldsymbol{*}}$ mais elevado para piroxênios e anfibólios e os núcleos mais cálcicos dos plagioclásios.

- A linhagem alasquítica possui granitóides fortemente exauridos em $\mathrm{Ca}, \mathrm{Mg}, \mathrm{Ba}, \mathrm{Sr}$ e $\mathrm{P}$, elevada proporção $\mathrm{Fe} /(\mathrm{Fe}+\mathrm{Mg})$ e altos teores de $\mathrm{SiO}_{2}, \mathrm{~F}, \mathrm{Nb}, \mathrm{Ga}, \mathrm{Y}, \mathrm{Zr}$ e $\mathrm{Rb}$. As evidências geológicas, petrográficas e químicas permitem considerá-la com estreita afinidade com os granitos tipo-A.

- A intrusão das rochas granitóides do Complexo se deu relativamente próxima à superfície. As pressões estimadas para os litotipos das linhagens "cálcio-alcalinas" encontram-se no intervalo de 2 a $4 \mathrm{kbar}$, enquanto que para a linhagem "alasquítica" seriam <2,2 kbar, provavelmente menos de 1 kbar.

- As temperturas calculadas para a cristalização dos magmas das três linhagens têm resultados idênticos aos propostos na literatura (por exemplo, temperatura liquidus $>830^{\circ} \mathrm{C}$ para a linhagem "alasquítica").

- O ambiente epizonal de intrusão proporcionou importante atividade deutéricahidrotermal nas rochas das três linhagens. A razão atômica $\mathrm{Ca} / \mathrm{Al}$ dos granitóides das linhagens "cálcio-alcalinas", normalmente $>0,25$, controlou o aparecimento em suas rochas de uma paragênese secundária constituída de prehnita \pm hidrogranada grossulária-andradita \pm pumpellyita $\pm\left(\mathrm{Fe}^{3+}\right)$ epidoto.

- A geração e intrusão dos granitóides do Complexo Cunhaporanga insere-se no contexto final de desenvolvimento do Ciclo Brasiliano, caracterizando um magmatismo pós-colisional (no sentido de Liégeois 1998). 
- Os dados geoquímicos sugerem para o quadro evolutivo do Complexo Cunhaporanga um ambiente de arco vulcânico para a formação dos granitóides "cálcio-alcalinos", mas um posicionamento tardio para os granitóides da linhagem alasquítica (pós-orogênico). 


\section{REFERÊNCIAS BIBLIOGRÁFICAS}

ALMEIDA, F. F. M. de - 1952 - Novas ocorrências de camadas supostas pliocênicas nos estados de São Paulo e Paraná. Boletim da Sociedade Brasileira de Geologia, 1(1): 53-58.

ALMEIDA, F. F. M. de - 1956 - Novas ocorrências de fósseis no Pré-Cambriano brasileiro. Anais Academia Brasileira Ciências, 28(4): XLIV-XLV.

ALMEIDA, F. F. M. de - 1957 - Novas ocorrências de fósseis no Pré-Cambriano brasileiro. Anais Academia Brasileira Ciências, 29(1): 63-72.

ANDERSON, J. L. - 1996 - Status of thermobarometry in granitic batholiths. Transactions of Royal Society of Edinburgh Earth Sciences, 87: 125-138.

ANDERSON, J. L. \& SMITH, D. R. - 1995 - The effect of temperature and oxygen fugacity on Al-in-hornblende barometry. American Mineralogist, 80: 549-559.

ASSINE, M. L. - 1996 - Aspectos da estratigrafia das seqüências pré-carboníferas da Bacia do Paraná no Brasil. Tese de Doutoramento (inédita). São Paulo, Instituto de Geociências-USP, 207 p.

BASTIN, G. F.; VAN LOO, F. J. J.; HEIJLIGERS, H. J. M. - 1984 - Evaluation and use of Gaussian $\phi\left(\begin{array}{l}\rho \\ \rho\end{array}\right)$ curves in quantitative eletron probe microanalysis: a new optimization. X-Ray Spectrometry, 13: 91-97.

BATCHELOR, R. A. \& BOWDEN, P. - 1985 - Petrogenetic interpretation of granitic rock series using multicationic parameters. Chemical Geology, 48: 43-55.

BEVINS, R. E.; KOKELAAR, B. P.; DUNKLEY, P. N. - 1984 - Petrology and geochemistry of lower to middle Ordovician igneous rocks in Wales: a volcanic arc to marginal basin transition. Proc. Geol. Ass., 95: 337-347.

BIGARELLA, J. J. - 1947 - Ocorrência de dolomito no município de Cêrro Azul, Paraná. Mineração e Metalurgia, XI(66): 323-326.

BIGARELLA, J. J.; SALAMUNI, R.; PINTO, V. M. (eds.) - 1967 - Geologia do PréDevoniano $e$ intrusivas subseqüentes da porção oriental do estado do Paraná. Boletim Paranaense Geociências, 23/25, 347 p.

BIONDI, J. C.; CAVA, L. T.; SOARES, P. C. - 1989 - Mapa Geológico do Estado do Paraná, 1: 650.000. Brasília, MME/DNPM/MINEROPAR. 
BLUNDY, J. D. \& HOLLAND, T. J. B. - 1990 - Calcic amphibole equilibria and a new amphibole-plagioclase geothermometer. Contributions to Mineralogy and Petrology, 104: 208-224.

BLUNDY, J. D. \& HOLLAND, T. J. B. - 1992 a - "Calcic amphibole equilibria and a new amphibole-plagioclase geothermometer": Reply to the comments of Hammarstrom and Zen, and Rutherford and Johnson. Contributions to Mineralogy and Petrology, 111: 269-272.

BLUNDY, J. D. \& HOLLAND, T. J. B. - 1992 b - "Calcic amphibole equilibria and a new amphibole-plagioclase geothermometer" - reply to the comment of Poli and Schmidt. Contributions to Mineralogy and Petrology, 111: 278-282.

BRITO NEVES, B. B. de; CAMPOS NETO, M. da C.; FUCK, R. A. - 1999 - From Rodinia to Western Gondwana: an approach to the Brasiliano-Pan African Cycle and orogenic collage. Episodes, 22(3): 155-166.

CCGP (Comissão da Carta Geológica do Paraná) - 1965 - Folha Geológica de Varzeão, 1:50.000. Curitiba, CCGP.

CCGP - 1966 a - Folha Geológica de Abapã, 1:50.000. Curitiba, CCGP.

CCGP - 1966 b - Folha Geológica de Castro, 1:50.000. Curitiba, CCGP.

CCGP - 1966 c - Folha Geológica de Piraí do Sul, 1:50.000. Curitiba, CCGP.

CCGP - 1970 a - Folha Geológica Jaguariaíva-Sul, 1:70.000. Curitiba, CCGP.

CCGP - 1970 b - Folha Geológica Joaquim Murtinho, 1:70.000. Curitiba, CCGP.

CCGP - 1970 c - Folha Geológica Serra das Antas, 1:70.000. Curitiba, CCGP.

CCGP - 1970 d - Folha Geológica Varzeão, 1:70.000. Curitiba, CCGP.

CHAPPELL, B. W. \& WHITE, A. J. R. - 1974 - Two contrasting granite types. Pacific Geology, 8: 173-174.

CHAYES, F. - 1949 - A simple point counter for thin-section analyses. American Mineralogist, 34: 1-11.

CLARKE, D.B. - 1992 - Granitoid Rocks. Chapman \& Hall, Londres, 283 p.

CLEMENS, J. D.; HOLLOWAY, J. R.; WHITE, A. J. R. - 1986 - Origin of an A-type granite: experimental constrains. American Mineralogist, 71: 317-324.

COIMBRA, A. M.; RICCOMINI, C.; SANT'ANNA, L. G.; VALARELLI, J. V. - 1996 Bacia de Curitiba: Estratigrafia e correlações regionais. In: Congr. Bras. Geol., 39, Salvador, 1996. Anais... Salvador, SBG, 1: 135-137. 
COLLINS, W. J., BEAMS, S. D., WHITE, A. J. R., CHAPPELL, B. W. - 1982 - Nature and origin of A-type granites with particular reference to southeastern Australia. Contributions to Mineralogy and Petrology, 80: 189-200.

CORDANI, U. G.; BASEI, M. A. S.; SIGA JR., O.; NUTMAN, A. - inédito - Idades U-Pb (SHRIMP) de rochas vulcânicas das bacias de Campo Alegre, Itajaí e Castro (SC e $\mathrm{PR})$.

COUTINHO, J. M. V. - 1955 - Geologia e Petrologia da região de Piraí do Sul, Paraná. Boletim da Sociedade Brasileira de Geologia, 4(1): 49-65.

COX, K. G.; BELL, J. D.; PANKHURST, R. J. - 1979 - The interpretation of igneous rocks. Allen \& Unwin, Londres, $450 \mathrm{p}$.

CPRM (Companhia de Pesquisa de Recursos Minerais) - 1972 a - Folha de Itararé. Relatório geológico preliminar. São Paulo, DNPM-CPRM, vol. I, 202 p.

CPRM - 1972 b - Folha de Itararé SG-22-X-B. Fichas de afloramentos - Análises. São Paulo, DNPM-CPRM, vol. II.

CPRM - 1977 a - Projeto Leste do Paraná. Folha Campo Largo, 1:100.000. São Paulo, DNPM-CPRM-BADEP.

CPRM - 1977 b - Projeto Leste do Paraná. Folha Cerro Azul, 1:100.000. Relatório final. São Paulo, DNPM-CPRM-BADEP, vol. I, 2 volumes.

CPRM - 1977 c - Projeto Leste do Paraná. Folha Piraí do Sul, 1:100.000. Relatório final. Anexos l e Il. São Paulo, DNPM-CPRM-BADEP, vol. I, $119 \mathrm{p}$.

CPRM - 1977 d - Projeto Leste do Paraná. Folha Piraí do Sul, 1:100.000. Relatório final. Anexos III, IV e V. São Paulo, DNPM-CPRM-BADEP, vol. II.

CPRM - 1977 e - Projeto Leste do Paraná. Folha Ponta Grossa, 1:50.000. São Paulo, DNPM-CPRM-BADEP.

CPRM - Serviço Geológico do Brasil. Página na INTERNET - http://www.cprm.gov.br DONATTI, L. M. - 1997 - Integração geológico-geofísica da região de Sengés (PR). Relatório de graduação (inédito). Curitiba, UFPr, $16 \mathrm{p}$ (16 anexos).

EBY, G. N. - 1990 - The A-type granitoids: a review of their occurrence and chemical characteristics and speculation on their petrogenesis. Lithos, 26: 115-134.

EBY, G. N. - 1992 - Chemical subdivision of the A-type granitoids: petrogenetic and tectonic implications. Geology, 20: 641-644. 
FOLHA DA MANHÃ S. A. - 1995 - Brasil - mapa rodoviário (parte integrante dos "Roteiros turísticos Fiat/Folha). São Paulo.

FRITZSONS JR., O. \& BIONDI, J. C. - 1983 - Relatório de compilação e síntese sobre as rochas graníticas do estado do Paraná - Fichas de compilação de dados (Granitos Agudos do Sul a Miringuava por ordem alfabética). Curitiba, MINEROPAR, vol. II, 3 volumes.

FUCK, R. A. - inédito - Notas preliminares sôbre a Geologia das Fôlhas de Jaguaricatu e Socavão.

FUCK, R. A. - 1966 - Nota explicativa da Fôlha Geológica de Quero-Quero. Boletim Universidade Federal Paraná, Geologia, 19, 21 p.

FUCK, R. A. - 1967 - Geologia da Fôlha Abapã. Boletim Universidade Federal Paraná, Geologia, 25, $34 \mathrm{p}$.

FUCK, R. A.; MARINI, O. J.; TREIN, E. - 1967 a - Contribuição ao estudo das rochas graníticas do Paraná. In: BIGARELLA, J. J.; SALAMUNI, R.; PINTO, V. M. (eds.) 1967 - Geologia do Pré-Devoniano e intrusivas subseqüentes da porção oriental do estado do Paraná. Boletim Paranaense Geociências, 23/25: 183-219.

FUCK, R. A.; TREIN, E.; MARINI, O. J. - 1967 b - Geologia e petrografia dos migmatitos do Paraná. In: BIGARELLA, J. J.; SALAMUNI, R.; PINTO, V. M. (eds.) 1967 - Geologia do Pré-Devoniano e intrusivas subseqüentes da porção oriental do estado do Paraná. Boletim Paranaense Geociências, 23/25: 5-41

GIMENEZ FILHO, A. - 1993 - Evolução do Complexo Granítico Três Córregos a noroeste de Apiaí - SP. Dissertação de Mestrado (inédita). São Paulo, Instituto de Geociências, USP, $118 \mathrm{p}$.

GOMES, C. B.; BITTENCOURT, I.; CORDANI, U. G.; DAMASCENO, E. C.; LELLIS, H.; MELCHER, G. C.; MELFI, A. J. - 1971 a - Geologia da Fôlha de Cerro Azul, SP e PR. In: Congr. Bras. Geol., 25, São Paulo, 1971. Anais... São Paulo, SBG, 1, 99.

GOMES, C. B.; BITTENCOURT, I.; CORDANI, U. G.; FÚlFARO, V. J.; MELFI, A. J.; PETRI, S. - 1971 b - Geologia da Fôlha de Itararé, SP e PR. In: Congr. Bras. Geol., 25, São Paulo, 1971. Anais... São Paulo, SBG, 1, 93. 
GOMES, C. B.; BERENHOLC, M.; HYPÓLITO, R.; ARRUDA, J. R. - 1975 a Geoquímica de maciços graníticos da região do Ribeira, parte 1: elementos principais. Anais Academia Brasileira Ciências, 47(1): 113-130.

GOMES, C. B.; ARRUDA, J. R.; BERENHOLC, M.; HYPÓLITO, R. - 1975 b Geoquímica de maciços graníticos da região do Ribeira, parte 2: elementos traços. Anais Academia Brasileira Ciências, 47(3/4): 459-476.

GRASTY, R. L.; SMITH, B. S. J.; MINTY, B. R. S. - 1997 - Developments in the standardization and analysis of airborne gamma ray data. In: Exploration 97, the $4^{\text {th }}$ Decennial International Conference on Mineral Exploration, Toronto, $15 \mathrm{p}$.

GUIMARÃES, G. B. - 1995 - O Complexo Granítico Cunhaporanga na região de Joaquim Murtinho, Piraí do Sul (PR): Caracterização faciológica das rochas granitóides. Dissertação de Mestrado (inédita). São Paulo, Instituto de Geociências, USP, 144 p.

GUIMARÃES, G. B. \& ULBRICH, H. H. G. J. - 1996 - Redefinição e tipologia do Granito Joaquim Murtinho, Piraí do Sul (PR). In: Congr. Bras. Geol., 39, Salvador, 1996. Anais... Salvador, SBG, 6: 367-369.

GUIMARÃES, G. B. \& ULBRICH, H. H. G. J. - 1999 - Aspectos geoquímicos das rochas granitóides do Complexo Granítico Cunhaporanga, sul do Brasil. In: Congr. Geoq. dos Países de Língua Portuguesa/Congr. Bras. Geoq., 5/7, Porto Seguro, 1999. Anais... Porto Seguro, SBGq, 522-524.

GUIMARÃES, G. B.; FERREIRA, F. J. F.; FORLIN, M.; ULBRICH, H. H. G. J. - 1997 a O Projeto Aerogeofísico Serra do Mar Sul e o Complexo Granítico Cunhaporanga (PR) e adjacências: análise preliminar dos dados magnetométricos. In: Congr. Intern. da Soc. Bras. de Geof., 5, São Paulo, 1997. Expanded Abstracts. São Paulo, SBGf, 1, 604-606.

GUIMARÄES, G. B.; FERREIRA, F. J. F.; ULBRICH, H. H. G. J. ; FORLIN, M. - 1997 b - O Projeto Aerogeofísico Serra do Mar Sul e o Complexo Granítico Cunhaporanga (PR) e adjacências: análise preliminar dos dados radiométricos. In: Congr. Intern. da Soc. Bras. de Geof., 5, São Paulo, 1997. Expanded Abstracts. São Paulo, SBGf, I, 607-609.

HAMMARSTROM, J. M. \& ZEN, E-an - 1992 - Discussion of Blundy and Holland's (1990) "Calcic amphibole equilibria and a new amphibole-plagioclase geothermometer". Contributions to Mineralogy and Petrology, 111: 264-266. 
HARRISON, T. M \& WATSON, E. B. - 1984 - The behavior of apatite during crustal anatexis: equilibrium and kinetic considerations. Geochimica and Cosmochimica Acta, 48: 1467-1477.

HASUI, Y.; CARNEIRO, C. D. R.; COIMBRA, A. M. - 1975 - The Ribeira folded belt. Revista Brasileira de Geociências, 5(4): 257-266.

HOLDAWAY, M. J. - 1971 - Stability of andalusite and aluminum silicate phase diagram. American Journal of Science, 271: 97-131.

HOLLAND, T. J. B. \& BLUNDY, J. D. - 1994 - Non-ideal interactions in calcic amphiboles and their bearing on amphibole-plagioclase thermometry. Contributions to Mineralogy and Petrology, 116: 433-447.

HORSFALL, K. R. - 1997 - Airborne magnetic and gamma-ray data acquisition. AGSO Journal of Australian Geology and Geophysics, 17(2): 23-30.

IAEA (International Atomic Energy Agency) - 1991 - Airborne gamma-ray spectrometer surveying. Technical Report Series, $n^{\circ} 323$, Vienna, IAEA, $97 \mathrm{p}$.

IPT (Instituto de Pesquisas Tecnológicas do Estado de São Paulo) - 1985 - Geologia das Folhas Barra do Chapéu (SG-22-X-B-I-4) e Araçaíba (SG-22-X-B-II-3), estado de São Paulo e Paraná. São Paulo, IPT (Relatório 22150).

IRVINE, T. N. \& BARAGAR, W. R. A. - 1971 - A guide to the chemical classification of the common volcanic rocks. Canadian Journal of Earth Sciences, 8: 523-548.

JANASI, V. A.; ANDRADE, S.; ULBRICH, H. H. G. J. - 1995 - A correção do drift instrumental em ICP-AES com espectrômetro seqüencial e a análise de elementos maiores, menores e traços em rochas. Bol. IG-USP, Série Científica., 26: 45-58.

JOHNSON, M. C. \& RUTHERFORD, M. J. - 1989 - Experimental calibration of an aluminum-in-hornblende geobarometer with application to Long Valley valdera (California) volcanic rocks. Geology, 17: 837-841.

KAEFER, L. Q. \& CUNHA, H. C. da S. - 1974 - Geologia da Folha de Castro (parcial). In: Congr. Bras. Geol., 28, Porto Alegre, 1974. Anais... Porto Alegre, SBG, 4, 189-206.

KING, P. L.; WHITE, A. J. R.; CHAPPELL, B. W.; ALLEN, C. M.- 1997 Characterization and origin of aluminous A-type granites from the Lachlan Fold Belt, Southeastern Australia. Journal of Petrology, 38(3): 371-391. 
LEAKE, B. E. (Chairman) - 1997 - Nomenclature of Amphiboles. Report of the Subcommittee on Amphiboles of the International Mineralogical Association Commission on New Minerals and Mineral Names. European Journal of Mineralogy, 9: 623-651.

LEITE, R. J. - 1997 - Geologia, petrografia e geoquímica dos granitóides da região de Piedade, SP. Dissertação de Mestrado (inédita), São Paulo, Instituto de Geociências, USP, 138 p.

Le MAITRE, R. W. (ed.) - 1989 - A classification of igneous rocks and glossary of terms. Grã-Bretanha, Blackwell, 193p.

LIÉGEOIS, J. P. - 1998 - Preface -- some words on the post-collisional magmatism. Lithos, 45: XV-xvii.

MANIAR, P. D. \& PICCOLI, P. M. - 1989 - Tectonic discrimination of granitoids. Geological Society of American Bulletin, 101: 635-643.

MARINI, O. J.; FUCK, R. A.; TREIN, E. - 1967 a - Intrusivas básicas jurássicocretácicas do primeiro planalto do Paraná. In: BIGARELLA, J. J.; SALAMUNI, R.; PINTO, V. M. (eds.) - 1967 - Geologia do Pré-Devoniano e intrusivas subseqüentes da porção oriental do estado do Paraná. Boletim Paranaense Geociências, 23/25: 307-324.

MARINI, O. J.; TREIN, E.; FUCK, R. A. - 1967 b - O Grupo Açungui no estado do Paraná. In: BIGARELLA, J. J.; SALAMUNI, R.; PINTO, V. M. (eds.) - 1967 Geologia do Pré-Devoniano e intrusivas subseqüentes da porção oriental do estado do Paraná. Boletim Paranaense Geociências, 23/25: 43-103.

MARTINS, L. - 1998 - Susceptibilidade magnética e o teor de minerais opacos como indicadores das condicões de cristalização magmática: o exemplo dos granitóides da região de Piedade-Ibiúna, SP. Relatório-FAPESP (inédito), São Paulo, 29 p.

MELCHER, G. C.; GOMES, C. B.; CORDANI, U. G.; BETTENCOURT, J. S.; DAMASCENO, E. C.; GIRARDI, V. A. V.; MELFI, A. J. - 1973 - Geologia e Petrologia das rochas metamórficas e graníticas associadas do Vale do rio Ribeira de Iguape, SP e PR. Revista Brasileira de Geociências, 3(2): 97-123.

MIDDLEMOST, E. A. K. - 1994 - Naming materials in the magma/igneous rock system. Earth-Science Reviews, 37: 215-224. 
MINTY, B. R. S.; LUYENDYK, A. P. J.; BRODIE, R. C. - 1997 - Calibration and data processing for airborne gamma-ray spectrometry. AGSO Journal of Australian Geology and Geophysics, 17(2): 51-62.

MISENER, D. J.; SINCLAIR, R.; MOURÃO, L. M. F. - 1997 - A new Brazil radiometric database generation and application. In: Congr. Intern. Soc. Bras. Geofísica, 5, São Paulo, 1997. Expanded Abstracts... São Paulo, SBGf, vol. 1: 564.

MORI, P.; REEVES, S.; CORREIA, C. T.; HAUKKA, M. - 1999 - Development of a fused glass disk XRF facility to complement the pressed powder pellet technique at the Instituto de Geociências, São Paulo University. Manuscrito, Laboratório de FRX, Instituto de Geociências, 12 p.

MORO, R. de P. X. M. - 1993 - A Bacia ordoviciana do Grupo Castro - PR. Dissertação de Mestrado (inédita). Rio Claro, Instituto de Geociências e Ciências Exatas, Unesp, $157 \mathrm{p}$.

MURATORI, A.; TREIN, E.; HAUSEN, J. P.; BERTOLDO, A.; RIVEREAU, J. C. - 1970 Geolgia do extremo norte do $1^{\circ}$ planalto e parte do $2^{\circ}$ planalto paranaense. In: Congr. Bras. Geol., Brasília, 1970. Resumo das conferências e comunicações. Brasília, SBG, Bol. Esp. 1, 201-203.

NOCKOLDS, S. R. - 1954 - Average chemical compositions of some igneous rocks. Bulletin of the Geological Society of America, 65(10): 1007-1032.

OLIVEIRA, E. P. de - 1916 - Geologia do Estado do Paraná. Rio de Janeiro, Boletim do Ministerio da Agricultura, Industria e Commercio, 5(1): 67-143.

OLIVEIRA, E. P. de - 1927 - Geologia e recursos mineraes do Estado do Paraná. Rio de Janeiro, Serviço Geológico e Mineralógico do Brasil, 172 p. (Monographia VI)

PATERSON, S. R.; VERNON, R. H.; FOWLER, Jr., T. K. - 1991 - Aureole tectonics. In: KERRICK, D.M. (ed.) - 1991 - Contact metamorphism. Reviews in Mineralogy, 26 (13): 673-722.

PATIÑO DOUCE, A. E. - 1993 - Titanium substitution in biotite: an empirical model with applications to thermometry, $\mathrm{O}_{2}$ and $\mathrm{H}_{2} \mathrm{O}$ barometries, and consequences for biotite stability. Chemical Geology, 108: 133-162.

PATTISON, D. R. M. - 1992 - Stability of andalusite and sillimanite and the $\mathrm{Al}_{2} \mathrm{SiO}_{5}$ triple point: constraints from the Ballachulish aureole, Scotland. Journal of Geology, 
PATTISON, D. R. M. \& TRACY, R. J. - 1991 - Phase equilibria and thermobarometry of metapelites. In: KERRICK, D.M. (ed.) - 1991 - Contact metamorphism. Reviews in Mineralogy, 26 (4): 105-206.

PEARCE, J. A. - 1983 - Role of the sub-continental lithosphere in magma genesis at active continental margins. In: HAWKESWORTH, C. J. \& NORRY, M. J.(eds.): Continental Basalts and Mantle Xenoliths. Shiva Publishing, Nantwich, 230-250.

PEARCE, J. A. - 1996 - Sources and settings of granitic rocks. Episodes, 19: 120-125. PEARCE, J. A., HARRIS, N. B. W., TINDLE, A. G. - 1984 - Trace element discrimination diagrams for the tectonic interpretation of granitic rocks. Journal of Petrology, 25: 956-983.

PINTO-COELHO, C. V. - 1986 - O Granito Serra do Carambeí - Paraná e as anomalias uraníferas associadas. Dissertação de Mestrado (inédita). Brasília, UnB, 309 p.

PINTO-COELHO, C. V. - 1987 - Petrografia e petroquímica do Granito Serra do Carambeí - Paraná. In: Simp. Sul-Bras. Geol., 3, Curitiba, 1987. Atas... Curitiba, SBG, 2: $551-570$.

PINTO-COELHO, C. V. - 1988 - Validade das classificações petroquímicas de rochas granitóides propostas com base em amostras de superfície - estudo preliminar do Granito Serra do Carambeí, Paraná. Ciência e Cultura, 40(8): 761-770.

PINTO-COELHO, C. V. \& MARINI, O. J. - 1986 - Assinatura em elementos terras-raras (ETR) do Granito Serra do Carambeí (Paraná) e das rochas ígneas associadas. In: Congr. Bras. Geol., 34, Goiânia, 1986. Anais... Goiânia, SBG, 3: 1311-1321.

PINTO-COELHO, C. V. \& SIEDLECKI, K. N. - 1988 - Distribuição de elementos radioativos no Granito Serra do Carambeí, Paraná, Brasil. Revista Brasileira de Geociências, 18(4): 433-440.

PINTO-COELHO, C. V.; SIEDLECKI, K. N.; ALANO, A. P. - 1988 - Caracterização do Granito Serra do Carambeí - Paraná com base no método tipológico do zircão. In: Congr. Bras. Geol., 35, Belém, 1988. Anais... Belém, SBG, 3: 1093-1103.

PITCHER, W. S. - 1982 - Granite type and tectonic environment. In: HSÜ, K.J. (ed.): Mountain Building Processes. Academic Press, London, 19-40.

POLI, S. \& SCHMIDT, M. W. - 1992 - A comment on "Calcic amphibole equilibria and a new amphibole - plagioclase geothermometer" by J.D. Blundy and T.J.B. Holland 
(Contrib Mineral Petrol (1990) 104: 208-224). Contributions to Mineralogy and Petrology, 111: 273-278.

PRAZERES FILHO, H. J.; GUIMARÃES, G. B.; BASEI, M. A. S.; SIGA JR., O.; REIS NETO, J. M.; CAMPANHA, G. A. C.; SALLUN FILHO, W. - 1998 - Mapa geológico 1:50.000 da porção centro-sul da Faixa Itaiacoca-PR. In: Congr. Bras. Geol., 40, Belo Horizonte, 1998. Anais... Belo Horizonte, SBG, 36.

REIS NETO, J. M. - 1994 - Faixa Itaiacoca: registro de uma colisão entre dois blocos continentais no Neoproterozóico. Tese de Doutoramento (inédita). São Paulo, Instituto de Geociências-USP, 255 p.

RIBAS, S. M. - 1981 - Reconhecimento geológico do "Complexo Granítico Cunhaporanga". Relatório de pesquisa (inédito). Curitiba, MINEROPAR, 2 volumes.

ROBERTS, M. P. \& CLEMENS, J. D. - 1993 - Origin of high-potassium, calc-alkaline, Itype granitoids. Geology, 21: 825-828.

RUTHERFORD, M. J. \& JOHNSON, M. C. - 1992 - Comment on Blundy and Holland's (1990) "Calcic amphibole equilibria and a new amphibole-plagioclase geothermometer". Contributions to Mineralogy and Petrology, 111: 266-268.

SCHMIDT, M. W. - 1992 - Amphibole composition in tonalite as a function of pressure: an experimental calibration of the Al-in-hornblende barometer. Contributions to Mineralogy and Petrology, 110: 304-310.

SCHMIDT, M. W. \& THOMPSON, A. B.- 1996 - Epidote in calc-alkaline magmas: an experimental study of stability, phase relationships, and role of epidote in magmatic evolution. American Mineralogist, 81: 462-474.

SIAL, A. N.; DALL'AGNOL, R.; FERREIRA, V. P.; NARDI, L. V. S.; PIMENTEL, M. M.; WIEDEMANN, C. M.- 1999 - Precambrian granitic magmatism in Brazil. Episodes, 22(3): 191-198.

SILVA, D. C. da \& MANTOVANI, M. S. M. - 1994 - Projeto aerogeofísico Serra do Mar Sul: uma abordagem semi-quantitativa. Revista Brasileira Geociências, 24 (2): 120-127.

SMITH, J. V. - 1974 - Feldspar minerals. Springer-Verlag, Berlin, 627 p. 
SOARES, P. C. - 1987 - Seqüências tecto-sedimentares e tectônica deformadora no centro-oeste do escudo paranaense. In: Simp. Sul-Bras. Geol., 3, Curitiba, 1987. Atas... Curitiba, SBG, 2: 743-771.

SOARES, P. C.; STEVANATTO, R.; CAMARGO, C. R. - 1987 - Geologia do noroeste da Faixa Itaiacoca - Paraná. In: Simp. Sul-Bras. Geol., 3, Curitiba, 1987. Atas... Curitiba, SBG, 1: 245-262.

SOUZA, A. - 1990 - Mapa Geológico na escala 1:50.000 e esboço da evolução tectônica e sedimentar do Grupo Itaiacoca, nas folhas Barra do Chapéu e Ouro Verde - SP/PR. Dissertação de Mestrado (inédita). São Paulo, Instituto de Geociências, USP, 200 p.

STEIGER, R. H. \& JAGER, E. - 1977 - Subcommission on Geochronology: convention on the use of decay constants in Geo and Cosmochronology. Earth and Planetary Science Letters, 36: 359-362.

STRECKEISEN, A. - 1976 - To each plutonic rock its proper name. Earth-Science Reviews, 12: 1-33.

TREIN, E. - inédito - Geologia da Fôlha de Itaiacoca.

TREIN, E. \& FUCK, R. A. - 1967 - O Grupo Castro. In: BIGARELLA, J. J.; SALAMUNI, R.; PINTO, V. M. (eds.) - 1967 - Geologia do Pré-Devoniano e intrusivas subseqüentes da porção oriental do estado do Paraná. Boletim Paranaense Geociências, 23/25: 257-305.

TULLOCH, A. J. - 1979 - Secondary Ca-Al silicates as low-grade alteration products of granitoid biotite. Contributions to Mineralogy and Petrology, 69(2): 105-117.

TULLOCH, A. J. - 1986 - Comment on "Implications of magmatic epidote-bearing plutons on crustal evolution in the accreted terranes of northwestern North America." and "Magmatic epidote and its petrologic significance." Geology, 14: 187-188.

ULBRICH, H. H. G. J. - 1984 - A petrografia, a estrutura e o quimismo de nefelina sienitos do maciço alcalino de Poços de Caldas, MG-SP. Tese de Livre Docência (inédita), São Paulo, Instituto de Geociências, USP, 477 p.

VLACH, S. R. F. - 1985 - Geologia, petrologia e geocronologia das partes meridional e oriental do Complexo de Morungaba, SP. Dissertação de Mestrado (inédita), São Paulo, Instituto de Geociências, USP, 252 p. 
VYHNAL, C. R.; McSWEEN JR., H. Y.; SPEER, J. A. - 1991 - Hornblende chemistry in southern Appalachian granitoids: implications for aluminum hornblende thermobarometry and magmatic epidote stability. American Mineralogist, 76: 176188.

WATSON, E. B. \& HARRISON, T. M - 1983 - Zircon saturation revisited: temperature and compositional effects in a variety of crustal magma types. Earth and Planetary Science Letters, 64: 295-304.

WATSON, E. B. \& HARRISON, T. M. - 1984 - Accessory minerals and the geochemical evolution of crustal magmatic systems: a summary and prospectus of experimental approaches. Physics of Earth and Planetary Sciences, 35: 19-30.

WERNICK, E.; RIGO JUNIOR, L.; GALEMBECK, T. M. B.; ARTUR, A. C.; WEBERDIEFENBACH, K. - 1990 a - Razão Sr:Ba:Rb e tipologia de zircão em granitóides dos estados de São Paulo, Paraná e Minas Gerais. Geociências, 9: 87-106.

WERNICK, E.; RIGO JUNIOR, L.; GALEMBECK, T. M. B.; WEBER-DIEFENBACH, K. - 1990 b - Os Complexos Granitóides Cunhaporanga e Três Córregos (PR): zoneamento magmático e implicações geotectônicas. Geociências, 9: 67-85.

WHALEN, J. B.; CURRIE, K. L.; CHAPPELL, B. W. - 1987 - A-type granites: geochemical characteristics, discrimination and petrogenesis. Contributions to Mineralogy and Petrology, 95: 407-419.

WHITE, A. J. R. - 1992 - Granite Handbook: description, genesis, some associated ore deposits. In: Congr. Bras. Geol., 37, São Paulo, 1992. Short Course São Paulo, SBG, $109 p$.

ZEN, E-an \& HAMMARSTROM, J. M. - 1984 - Magmatic epidote and its petrologic significance. Geology, 12: 515-518. 
ANEXOS 


\begin{abstract}
ANEXO 4
The airborne gamma-ray spectrometric survey of the Aerogeophysical Project Serra do Mar Sul in the region of the Cunhaporanga Granitic Complex, Paraná, southern Brazil
\end{abstract}

Gilson Burigo Guimarães', Francisco J. F. Ferreira' ${ }^{2}$, Horstpeter H. G. J. Ulbrich ${ }^{3}$ and Maximilian Forlin ${ }^{2}$

1. Departamento de Geociências, Universidade Estadual de Ponta Grossa, Paraná

2. Departamento de Geologia, Universidade Federal de Paraná, Curitiba, Paraná

3. Departamento de Mineralogia e Geotectônica, Instituto de Geociências, Universidade de São Paulo, São Paulo, Brazil

\title{
ABSTRACT
}

This paper analyses radiometric data of the Aerogeophysical Project Serra do Mar Sul (APSMS) in the Meso- to Neoproterozoic crystalline basement of eastern Paraná state, southern Brazil. Three main lithostratigraphic units are found, all with a N30-40E elongation. The easternmost is the Três Córregos Granitic Complex, constituted mainly by calc-alkaline granites and their mega-enclaves. The central unit is the low-grade metamorphic Itaiacoca Group. The western strip is occupied by the mostly calc-alkaline Cunhaporanga Granitic Complex, also showing large enclaves. Further west, the molassic volcano-sedimentary Eopaleozoic Castro Group, deposited within a graben structure, overlies unconformably the Cunhaporanga Complex. The Devonian sandstones of the Furnas Formation, to the west, are the main unit of the Paraná Basin in this region. The Cretaceous Banhadão alkaline massif $\left(8 \mathrm{~km}^{2}\right)$ intrudes Três Córregos granites. The heavily weathered central-northern area of the Cunhaporanga CComplex is in part covered by the alluvial deposits of the lapó drainage basin.

The cited units give different responses in the total count (TC), Th, $U$ and $K$ channels. Data were corrected with a cosine directional filter (degree 6), and presented as $\mathrm{cps}$, with no reduction to $\mathrm{eU}, \mathrm{eTh}$ and $\mathrm{K}(\mathrm{ppm}, \%)$ because of lack of reference data. 
$\mathrm{U}$ and $\mathrm{K}$ give answers that may be spurious, not always correlated with the ground geology.

Most Cunhaporanga intrusions present rather high Th- $\mathrm{U}$ and lower total and $\mathrm{K}$ counts, as opposed to the values found in theTrês Córregos rocks. High TC are found in some of the more evolved plutons within Cunhaporanga (such as the Serra do Carambeí Granite, a late A-type intrusion). The Três Córregos granites can be divided into two radiometric domains: one adjacent to the Itaiacoca belt and another to the south, corresponding to the São Sebastião Granite. The mega-enclaves in both granitic complexes show lower counts than the granites. The Itaiacoca belt is marked in all maps by low to medium counts. The Castro Group shows a complex pattern, sharply controlled by lithology. The Furnas sediments, outcropping as a scarp, also show overall low responses. The lapó river deposits stand out clearly by very low values of $\mathrm{K}$, Th, $U$ and TC.

Key words: airborne gamma-ray survey; geological mapping; Aerogeophysical Project Serra do Mar Sul; Cunhaporanga Granitic Complex.

\section{RESUMO}

Este trabalho analisa dados gama-espectrométricos do Projeto Aerogeofísico Serra do Mar Sul no embasamento cristalino meso- a neoproterozóico, leste do estado do Paraná, Brasil meridional. Três principais unidades litoestratigráficas são reconhecidas, todas com direção N30-40E. A ocorrência oriental é o Complexo Granítico Três Córregos, constituído por granitos cálcio-alcalinos e seus megaenclaves. A parte central é formada pela Faixa ou Grupo Itaiacoca, de baixo grau metamórfico. A porção ocidental é o Complexo Granítico Cunhaporanga, também com mega-enclaves. Para W, aparece ainda o Grupo vulcânico-sedimentar molássico Castro, do Eopaleozóico, depositado em estrutura de graben, discordantemente sobre - Complexo Cunhaporanga. São também encontradas as unidades basais dos arenitos devonianos da Formação Furnas. O maciço alcalino cretáceo Banhadão $\left(8 \mathrm{~km}^{2}\right)$ é intrusivo em granitos do Complexo Três Córregos. A parte central e setentrional do Complexo Cunhaporanga é coberta pela bacia hidrográfica do rio lapó, com abundantes depósitos aluviais. 
As unidades citadas mostram diferentes respostas nos canais radiométricos de TC (contagem total), Th, $\mathrm{U}$ e K. Os dados foram corrigidos com filtro co-seno direcional (grau 6) e apresentados como cps; a falta de dados comparativos torna impossível a redução a eU, eTh e $\mathrm{K}(\mathrm{ppm}, \%)$. As respostas de $\mathrm{U}$ e $\mathrm{K}$ são por vezes espúrias, não correlacionáveis com dados da geologia de superfície.

A maioria das intrusões do Complexo Cunhaporanga apresentam valores bastante altos de Th e $\mathrm{U}$, e mais baixos de TC e K; o contraste é menor nos granitos Três Córregos. Valores mais aitos na TC são encontrados em alguns dos plútons mais evoluídos do Complexo Cunhaporanga (como o Serra do Carambeí, um granito tipo A). Os granitos do Complexo Três Córregos podem ser divididos em dois domínios, um adjacente à Faixa ltaiacoca e outro mais ao $\mathrm{S}$, correspondendo à localização do Granito São Sebastião. Os mega-enclaves em ambos complexos são identificados por contagens mais baixas que as dos granitos. A Faixa Itaiacoca é mostrada, em todos os mapas, como região com contagens baixas a moderadas. $O$ Grupo Castro aparece com padrão radiométrico complexo, fortemente controlado por sua constituição litológica. Os arenitos Furnas, presentes como escarpa topográfica, mostram respostas em geral baixas. Os depósitos aluviais do lapó se destacam como faixas de valores muito baixos nos mapas de $\mathrm{K}$, Th, $\mathrm{U}$ e TC.

Palavras-chaves: projeto gamaespectrométrico aerotransportado; mapeamento geológico; Projeto Aerogeofísico Serra do Mar Sul; Complexo Granítico Cunhaporanga.

\section{INTRODUCTION}

The last decades witnessed an enormous increase in the use of aerogeophysical data (cf. comments in Grasty et al. 1997). Applications are not only in traditional fields such as ore prospecting and geologic mapping (e. g., Gunn 1997), but also in studies related with urban planning and recognition of potential health hazards.

The data obtained by the Aerogeophysical Project Serra do Mar Sul (APSMS) (e. g., Silva \& Mantovani 1994) are here explored as a tool in recognition and interpretation of geological structures in a basement area occupied mainly by the two large elongated Cunhaporanga and Três Córregos granitic complexes, separated by the metamorphic 
Itaiacoca belt, in Paraná state, southern Brazil (Figure 1). The main interest is to explore the presence of these large granitic belts, as well as variations within these units, to be compared with the known distribution of rock types, alteration patterns and structure.

Additionally, this paper is a first step of a more ambitious study, which wish to discuss the conversion of the absolute radiometric values by a back-calibration technique (cf. Grasty et al. 1997; Misener et al. 1997), perform ground surveys in selected areas and, finally, to compare the identified geophysical patterns with geochemical analyses of granitoid rocks of the Cunhaporanga Complex.

\section{METHODOLOGY}

\section{Gamma-spectrometric surveys}

The decay of radioactive elements generates alfa and beta particles, and gamma rays. The first ones show low energies and are absorbed by a few centimeters or decimeters of air, while the last ones can be registered up to heights of a few hundred meters. Even so, the response represents at the very most the composition of soil or rock down to a depth of no more than 30 or $40 \mathrm{~cm}$ (e. g., Minty 1997). The gamma rays registered in surveys are the ones from ${ }^{214} \mathrm{Bi}\left(U\right.$ decay chain) and ${ }^{208} \mathrm{TI}$ (Th decay), and from isotope ${ }^{40} \mathrm{~K}$ ( $\mathrm{K}$ decay). The window widths used in the APSMS were as follows: total count (TC): $1.00-2.90 \mathrm{MeV} ; \mathrm{K}: 1.35-1.65 \mathrm{MeV}$; U: $1.65-2.30 \mathrm{MeV}$; Th: $2.30-2.90$ $\mathrm{MeV}$ (Silva \& Mantovani 1994), somewhat different from the ones recommended by the IAEA (1991; TC: $0.41-2.81 \mathrm{MeV}$; K: 1.37-1.57 MeV; U: 1.66-1.86 MeV; Th: 2.41-2.81 $\mathrm{MeV})$.

The gamma emissions, under isotopic equilibrium conditions, are proportional to the contents of the emitting isotopes. The counted intensities (cps), however, depend strongly on environmental and instrumental conditions, and should be converted into elemental abundances (eU and eTh, "equivalent" ppm abundances; $K$, percentages), by calibration with selected samples at ground level and comparison with the obtained counts (cf. Minty et al. 1997). 
The gamma rays originate from a very thin upper layer of rock, soil or sediment (Wilford et al. 1997; Minty 1997, and bibliography therein). $U$ and Th, and especially $\mathrm{K}$, are mobile elements that can be leached during weathering, or alternatively concentrated in hydrothermally affected regions. Alluvial and colluvial cover, as well as stagnant water and humidity, also have an incidence on the readings.

The $K$ and Th decay sequences are relatively simple, and are mainly influenced by the behavior of the ${ }^{40} \mathrm{~K}$ and ${ }^{232} \mathrm{Th}$ isotopes. Uranium, with its two main isotopes ${ }^{235} \mathrm{U}$ and ${ }^{238} \mathrm{U}$, has a very complex decay scheme. Several of the daughter isotopes can be taken out of the original system, or added to them, leading to isotopic disequilibrium. Restauration of equilibrium conditions may take from a few days to up to a million years, depending on the fractionated isotope and its half life. Minty (1997) lists the main causes of isotopic disequilibrium in the $U$ chain:

-- selective leaching of ${ }^{238} U$ and/or of the ${ }^{234} U$ daughter isotope, in particular by adsorption on clay minerals;

-- selective leaching of ${ }^{230} \mathrm{Th}$;

-- selective fractionation of ${ }^{226} \mathrm{Ra}$;

-- loss to the atmosphere of the gas ${ }^{222} \mathrm{Rn}$.

$\mathrm{Ra}$ and $\mathrm{U}$ can be leached selectively in varying proportions, depending on oxidation-reduction in the environment. Loss of ${ }^{222} \mathrm{Rn}$ will reduce rapidly the contents of the ${ }^{214} \mathrm{~Pb}$ and ${ }^{214} \mathrm{Bi}$ daughter isotopes, both of which generate the most intense gamma emissions. Therefore, maps with $U$ counts have to be analysed with care. The $K$ and $T h$ maps, on the contrary, should register more faithfully the true contents of these elements present in the surficial layer.

\section{The Aerogeophysical Project Serra do Mar Sul}

The APSMS is a radiometric and magnetometric airborne survey conducted in the 70's for the Brazilian agency CPRM (Companhia de Pesquisa de Recursos Minerais). The covered area, about $50,000 \mathrm{~km}^{2}$, includes most of the crystalline basement in the states of Santa Catarina and Paraná as well as, to the W, the outcrops 
of the Castro Group and the eastern limit of the Paraná Basin sediments (Figure 2). Survey specifications were as follows (Silva \& Mantovani 1994): flight line-spacing between 750 and $1250 \mathrm{~m}$, with some local superpositions or blank strips of over $2 \mathrm{~km}$; medium flight height of $158 \mathrm{~m}$ (between 80 to about $300 \mathrm{~m}$ ); flight lines in the direction $\mathrm{N} 30 \mathrm{~W}$, not exactly perpendicular to the predominant N30-45E structural pattern; TC, $U$, Th and $K$ channels as specified before. The magnetic field was also registered.

Several shortcomings in the execution of this survey were noted: variations in the spacing of flight lines, errors in the localization of UTMS coordinates (sometimes over 4 $\mathrm{km}$ ), variability in the flight height, and differences in volume in the various detector crystals used in different airplanes (Silva \& Mantovani 1994). For practical purposes, the project has to be subdivided into two different surveys or populations, on account of topographic differences in the two used flight bases, Curitiba (altitude, $\sim 900 \mathrm{~m}$ ) and Florianópolis $(\sim 10 \mathrm{~m})$. The spacing of flight lines used in this survey of predominantly basement rocks allows representation on a scale not better than 1:250,000 (cf. Horsfall 1997). The results are represented as counts per second (cps), with no reduction to ppm (equivalent Th and $\mathrm{U}, \mathrm{eTh}, \mathrm{eU}$ ) or \% $(\mathrm{K})$; however, conversion of the original cps to absolute values by a back-calibration technique (cf. Grasty et al. 1997) was recently performed for this survey (Misener et al. 1997) but the results will be discussed in another paper.

\section{Data acquisition and handling}

The main objective is to compare the gamma-spectrometric cps results with the mapped geologic features. Data handling was realized using the GEOSOFT ${ }^{\mathrm{TM}}$ software, on maps with scales of $1: 250,000$ and 1:500,000, at the same time also plotting the outline of the main geologic units.

The uncorrected data show a distorted pattern, with artificially enhanced highs and lows along the N3OW flight direction, specially visible in the $K$ and $U$ channels. This effect was corrected by using a directional cosine filter (degree 6) along the flight direction, so that the distortions were cancelled or at least minimized; even existing more precise correction procedures (e. g., that proposed by Green 1987 or Minty 1991), 
the results obtained are satisfactory, considering the qualitative level of the discussions here detailed. Although based on a somewhat deficient data set, the cps-grids are still a good tool for general geologic interpretations.

\section{REGIONAL GEOLOGICAL OUTLINE}

The main geologic units in the studied area are the two large elongated Neoproterozoic Cunhaporanga and Três Córregos granitic Complexes and the Itaiacoca Belt of low-grade metamorphic rocks, together with the more restricted outcrops of the Eopaleozoic volcanic-molassic Castro Group and some Phanerozoic formations of the intracratonic Paraná Basin (Figure 1). Additional units are the small intrusive Cretaceous Banhadão alkaline massif $\left(\sim 8 \mathrm{~km}^{2}\right)$ and the prominent alluvial deposits of the lapó river.

The well-defined Itapirapuã shear zone (ISZ; CPRM, 1977), with a general N40E direction, divides the basement into two large tectonic blocks (Soares et al., 1998; Figure 1).

\section{The Itaiacoca Belt and related units}

The Itaiacoca Belt (e.g., Soares et al., 1987; Reis Neto, 1994; also, Itaiacoca Formation or Itaiacoca Group) shows a thick and complexly folded sequence of metamorphosed rocks, and a general N4OE elongation (Figure 1). There is still no agreement on its stratigraphic division; weathering is sometimes very heavy. Most geologists identify three main units, as confirmed by recent mapping in the central Itaiacoca Belt, between Abapã and Socavão (Prazeres et al., 1998). Here, the basal sequence is mainly formed by whitish arkosic rocks and more colored vesicular metavolcanic rocks (the Abapã Formation or Sequence of Trein et al., 1985; Lima et al., 1993). The intermediate unit is mainly dolomitic, to be replaced, to the $N$, by pelitic rocks, constituting the third and upper unit; these metadolomites and metapelites constitute the Tanque Grande Formation of Lima et al. (1993). All rocks are weakly metamorphosed (lower greenschist facies) and show preserved primary structures. The metamorphic $S_{1}$ surface is parallel to the original $S_{0}$ bedding. The whole sequence is 
folded by a NE/SW folding episode, accompanied by the formation of a slaty $S_{2}$ cleavage with $\mathrm{N} 30-45 E$ orientation.

A similar stratigraphic division is recognized in the southern region of the Itaiacoca belt, next to the locality of Itaiacoca (Marini et al., 1967b; Lima et al., 1993). In the northern part of the Itaiacoca Belt, weakly metamorphosed basal arenites and arkoses pass into the middle unit of metapelites, meta-arenites and metadolomites and, finally, into the uppermost metadolomites (Soares et al., 1987; Souza, 1990).

The "Serra das Pedras Quartzite" (SPQ; cf. Fuck, 1967) crops out as a large mega-enclave in the Cunhaporanga Complex (Figure 1), and shows, rather than true quartzites, mainly weathered white meta-arkoses and quartz-rich meta-arenites, with interbedded caolinitic layers (altered tuffs?). Some sheared Cunhaporanga granites also occur in this region (Guimarães, 1995), formerly mapped as "gneisses and migmatites". Similar "quartzites", possibly correlated with the SPQ, are found as smaller enclaves within the Cunhaporanga granites.

\section{The Três Córregos Granitic Complex}

The Três Córregos Complex (Fuck, 1966; Algarte \& Kaefer, 1972) comprises a NE-SW trending granitic batholith, with an area of about $3700 \mathrm{~km}^{2}$, extending to the $\mathrm{N}$ into São Paulo state (Figure 1). The ISZ defines to the $W$ the main contact with the Itaiacoca Belt; the eastern contact is intrusive, with the low-grade metamorphic rocks of the Água Clara Formation and the Açungui Group. Main rocks are both equigranular and porphyritic calc-alkaline granites, together with migmatites and anatexites, all cut by post-tectonic A-type granitic plutons of the so-called Itu granitic belt (e.g., Fuck et al., 1967; Gimenez Filho, 1993; Vlach et al., 1990). Mega-enclaves and roof pendants of the Água Clara Formation (medium grade schists, amphibolites, and meta-marls) and of other metamorphic rocks are frequently found (Fuck et al., 1967; Gimenez Filho 1993). The batholith, interpreted as the root zone of the "Três Córregos" magmatic arc, shows $\mathrm{Rb}-\mathrm{Sr}$ isochronic ages between 650 and $800 \mathrm{Ma}$, with late-magmatic intrusions appearing around 560-600 Ma (Gimenez Filho, 1993; Reis Neto, 1994). More recent 
concordia plots indicate U-Pb ages of $599 \pm 7.3$ and $604 \pm 3.5 \mathrm{Ma}$ for porphyritic coarsegrained Três Córregos granitic facies (M. Basei, 1999, pers. commun.).

\section{The Cunhaporanga Granitic Complex}

The Cunhaporanga "Granite" or Complex (Algarte \& Kaefer 1972, and bibliography therein) crops out over $2500 \mathrm{~km}^{2}$, entirely within Paraná state. Its orientation is N3OE. Contacts with the Itaiacoca belt are intrusive; to the W-NW, the complex is covered by the younger Castro Group and, in part, by the Furnas Formation to the NE and SW (Figure 1).

The granites are usually heavily weathered, and knowledge about its geology, structure and stratigraphic position is still very scant (cf. Fuck et al. 1967; Algarte \& Kaefer 1972; CPRM 1977; Ribas 1981). Predominant are calc-alkaline biotite ( \pm hornblende) granitoids. Less evolved rocks such as quartz diorites and diorites are restricted; microgranular enclaves of intermediate composition are plentiful. Some late "epizonal" alaskitic intrusions, corresponding to the so-called Itu granitoid belt, are locally observed (to the $N$, the Joaquim Murtinho Granite; to the $S$, the Serra do Carambei massif; Pinto-Coelho \& Marini 1986; Guimarães \& Ulbrich 1996; Guimarães 1995).

More recent geochemical and geochronologic work, although still very limited, considers the Complex the root zone of a Brasiliano magmatic arc (Soares 1987; Reis Neto 1994).

\section{The Banhadão alkaline massif}

This alkaline massif (about $8 \mathrm{~km}^{2}$; Algarte \& Kaefer 1972; Ruberti 1984) is intrusive in the Três Córregos granites. Predominant are nepheline syenites and phlogopite melteigites; several phonolite dikes are also observed. Fenitization seems to be widespread, although masked by deep weathering of the country rocks. Chemically, 
the rocks are rich in alkalies (e.g., $\mathrm{K}_{2} \mathrm{O}$ up to $10 \%$ ). Ages are around $100-110 \mathrm{Ma}$ (Ruberti 1984).

\section{Alluvial deposits}

The drainage basin of the lapó river covers areas underlain by the Castro Group and extends also over the rather flat northern-central region of the Cunhaporanga granites. This region is partly covered by water in the rainy summer months (September to March). Predominant are sandy-argilaceous and peat sediments. Some scattered outcrops of poorly consolidated sandstones and arkoses, probably of Cenozoic age, are found on top of the rocks of the Castro Group.

\section{DISCUSSION OF THE RADIOMETRIC DATA}

The several radiometric data are presented in Figures 3, 4, 5 and 6 (TC, total counts, and $\mathrm{Th}, \mathrm{U}$ and $\mathrm{K}$ counts, all in cps).

\section{The Itaiacoca belt and related units}

The radiometric maps reveal clearly the main outline of the Itaiacoca belt (e.g., $U$ and $\mathrm{K}$ counts, Figures 5 and 6 ). The areas with low to very low counts in the TC map (Figure 3) correspond to the metacarbonatic and metapsammitic unit, while medium (to locally high) values correlate with outcrops of the metapelitic formation (cf. geologic maps in CPRM 1977; Souza 1990; Prazeres et al. 1998). The convoluted pattern, observed especially in the TC map (Figure 3 ), reflects the folds found in the first two cited units. An unusual K-rich horizon, identified in Figure 6 by medium to high count values, corresponds in the field to the meta-arkosic/metavolcanic trachytic unit (Prazeres et al. 1998), referred to by Reis Neto (1994) as "feldspathic lamproites".

The Serra das Pedras Quartzite is characterized by low values in the TC and Th maps (Figures 3 and 4); low values also prevail in the $U$ map (Figure 5), but no contrast with the surrounding granites is observed. In the TC map, the areas corresponding to these "quartzites" appear as two divided spots, the largest one to the $\mathrm{N}$; this pattern is in 
contrast with the geologic maps (e.g., CCGP 1966; Biondi et al. 1989), where the SPQ is depicted as a single larger occurrence. The unit also appears in the Th and $K$ with low counts; thus, no $\mathrm{K}$ or Th has been adsorbed by the interstitial clays (cf. Wilford et al. 1997, for some discussion on the adsorption by clays). Several other regions (e.g., near the localities of Ouro Verde, Campina dos Elias and E.X. da Silva) register low to very low values (Figures 3, 4 and 5), and also correspond to outcrops of "quartzites" (i.e., weathered meta-arkoses, etc.).

\section{The Três Córregos Granitic Complex}

The cited Complex is especially well depicted in the TC and K maps (Figures 3 and 6), while the Th and $U$ counts show medium to low values; the anomaly with higher counts in these maps represent the location of the alkaline Banhadão massif. The Itapirapuã shear zone is only faintly registered in the TC map (Figure 3) as a discontinuous string, so that the limit with the Itaiacoca belt is poorly registered. High to very high counts in TC and $\mathrm{K}$, to the SE, determine the location, within Três Córregos, of the more evolved São Sebastião Granite (Figures 3 and 6; cf. also Figures 1 and 2). The low counts that are observed in the four radiometric maps, to the $N$ and $E$ of the São Sebastião Granite, register the presence of the Água Clara Formation separating this granitic unit from other Três Córregos granites. The Água Clara rocks are also seen as a mega-enclave near Abapã (low to very low counts in Figures 3 and 5).

\section{The Cunhaporanga Granitic Complex}

The rocks of this complex are depicted in the maps as several radiometric domains, each with a uniform radiometric pattern. The existence of the Cunhaporanga granitoid rocks, to the West of the SPQ outcrops, is confirmed by spots with high TC and Th values (Figures 3 and 4 ).

The central part, occupied by the lapó drainage basin, is heavily weathered and levelled (Figure 1). The presence of granites in this area is revealed by high Th counts, rapidly diminishing to the $\mathrm{N}$ and $\mathrm{E}$; this indicates that weathering concentrated Thbearing resistant minerals (e.g., zircon) in soils or allowed its retention by adsorption in 
supergene clays and Fe-Al hidroxides (e.g., Wilford et al. 1997). On the other hand, the alluvial deposits that cover the granites show low to very low Th values (Figure 4). A similar pattern is observed in the TC map (Figure 3); the variations in counts could be due to the presence of different facies of granites and/or of metamorphic enclaves, as well as different degrees of weathering.

The $U$ map (Figure 5) shows two very contrasted patterns, roughly coinciding with the regions that define the two different populations in the survey (Figure 2; Silva \& Mantovani 1994) and are, thus, a figment related to the flight pattern, in no way related to geologic factors (cf. above). The area of population 1 (to the SW; Figure 2) shows various sectors with very high $U$ values, while low to medium values are predominant in the areas belonging to population 2 (to the NE), with only a few spots showing high values.

In the $\mathrm{K}$ map (Figure 6), the Complex is shown as a strip with low to very low values, especially at its center. This virtual absence of the $\mathrm{K}$ radiation shows that the element was leached out of the surficial weathered blanket (cf. discussion in Wilford et al. 1997), a process that is controlled by the alteration of K-feldspar into kaolinite, and of biotite into hidroxides and clays.

In the Ouro Verde region, the TC, Th and $U$ maps (Figures 3, 4 and 5; also Figure 2) define a typical granitic oval domain ( $15 \times 10 \mathrm{~km}$, largest axis oriented N3OE) with high to very high values, surrounded by patches with low to very low counts, indicating the presence of rocks from the Itaiacoca belt (CCGP 1970a, 1970b; Figure 2).

The Serra do Carambei Granite is defined by high TC, Th and $U$ values, while $K$ counts are mostly low to very low, in strong contrast with geochemical-petrographic data and the reasonable outcrop pattern (e.g., $\mathrm{K}_{2} \mathrm{O}$ contents around $3-5 \%, \mathrm{~K}$ feldspar-rich granites; Pinto-Coelho \& Marini 1986). Again, this pattern probably reflects the surface alteration of K-feldspar and biotite into clays and hidroxides, very effectively leaching out $\mathrm{K}$; the scattered blocks of granites, found in this area, are not abundant enough to be registered by the survey, so as to offset the overwhelming influence of the alteration. 
Contrasted patterns in the Cunhaporanga and Três Córregos Complexes

Th and $U$ values are usually higher in the $C_{\gamma} C$, while the $C_{\gamma} T C$ is defined by higher $\mathrm{K}$ counts. This contrasted pattern between the two granitic complexes reflects, on the one hand, strong differences in weathering, much more enhanced in the $\mathrm{C} \gamma \mathrm{C}$, at the same time leaching out $\mathrm{K}$ and concentrating the residual accessory minerals (or Th and $U$ as elements) in the $\mathrm{C} \gamma \mathrm{C}$ soils. It may also, in part, represent true differences in mineralogy (e.g., somewhat higher amounts of zircon, allanite or monazite in $\mathrm{C}_{\gamma} \mathrm{C}$ ).

\section{The Castro Group}

The Group shows a very complex response in TC, Th and $U$ (Figures 3, 4 and 5), reflecting the lithologic variations. The $\mathrm{K}$ map for this area has to be interpreted with caution, since the adjacent topographic scarp of the Furnas sandstones may introduce a bias in the topographic correction, depressing (or increasing) the counted values to non-real figures. The Th map (Figure 4) registers the presence of the fault that separates, in the southern part, the Castro Group from the Cunhaporanga rocks. Rhyolitic domes in the Pirai do Sul region are identified by high Th counts. Alluvial deposits are also clearly identified by low to very low values (TC, Th, and U; Figures 3 , 4 and 5). These radiometric maps help to decide among different geologic intepretations. To the SW of the locality of Castro, two E-W trending domains are observed with low to very low TC values (Figure 3), a pattern that matches the two different horizons of porous sedimentary rocks mapped by Trein \& Fuck (1967), but is in disagreement with the single "basal sedimentary unit" presented in the map by Moro (1993).

\section{Sedimentary and volcanic formations of the Paraná Basin}

The limit of the Parana Basin formations is defined by the so-called Devonian Scarp, a very marked topographic feature, marked in the TC map by low to very low values, identifying the porous sedimentary rocks of the basal unit I (Figure 3). A parallel strip, with medium intensities, shows the outcrops of unit II, richer in clay minerals and 
characterized by higher radiometric counts (as documented from measurements in bore-hole samples; Assine 1996). The K map registers values that are incompatible with the known geology and may be a result of improper corrections (cf. Castro Group, above). The Th and $U$ maps (Figures 4 and 5 ) do not register clearly the limits of the Paraná Basin. The dike rocks are of limited extent and are not registered by gammaspectrometry.

\section{The Banhadão alkaline massif}

This massif is shown mainly in the Th and $U$ maps (Figures 4 and 5) as two separate areas or as an irregular patch, in both cases however covering an area over $20 \mathrm{~km}^{2}$, much larger than the outcrop pattern (e.g., Ruberti 1984), probably as a response to fenitization processes and/or the existence of dikes in the country rocks.

\section{Alluvial deposits}

These deposits appear very sharply, especially in the TC and Th maps, depicting the contrast between alluvium (TC, Figure 4) and the $\mathrm{C}_{\gamma} \mathrm{C}$ (Th, Figure 4; cf. also U, Figure 5). Partial flooding of the lapó alluvial flatlands during the rainy months, which do not dry out completely even during the dry season, will generate very low or nill responses for all radiometric channels; this may be the best explanation for the observed readings.

\section{FINAL COMMENTS AND CONCLUSIONS}

Airborne gamma-spectrometric surveys in the basement region in eastern Paraná state clearly recognize most major geologic units. The folded and weakly metamorphosed Itaiacoca belt is marked by low responses in TC, Th, $\mathrm{U}$ and $\mathrm{K}$ maps; horizons with unusual compositions, such as the K-trachytic unit, are clearly depicted in the K map. 
The two large granitic Cunhaporanga and Três Córregos complexes, on both sides of the Itaiacoca belt, show contrasted behavior (high Th and $U$ for the $\mathrm{C}_{\gamma} \mathrm{C}$; high values in the $\mathrm{K}$ map for the $\mathrm{TC} \gamma \mathrm{C}$ ); the pattern can be explained by differences in weathering, much stronger for the $\mathrm{C} \gamma \mathrm{C}$, and in part also by variations in the contents of accessory minerals, probably more concentrated in the soils overlying the $\mathrm{C}_{\gamma} \mathrm{C}$. An enhanced pattern in some maps depicts the presence of the more evolved late granite intrusions (e.g., Serra do Carambeí and São Sebastião granites). Large metasedimentary "quartzitic" enclaves in the two complexes clearly stand out, showing low to very low counts in all maps.

The Castro Group features a complex internal stratigraphy, giving rise to an equally complex variation in the radiometric maps.

Alluvial deposits show a strongly contrasted pattern of low to very low counts in all maps, thus indicating the absence of radiometric elements or, alternatively, environmental influences (isotopic disequilibrium, soil humidity, flooding of alluvial plains, etc.).

\section{ACKNOWLEDGMENTS}

G.B.Guimarães gratefully acknowledges scholarships from the Brazilian agency CAPES and the State University of Ponta Grossa. F.J.F.Ferreira and M.Forlin are thankful for help from the Federal University of Paraná. Field excursions and a part of the lab work was financed by grants from the São Paulo Science foundation FAPESP (to H. Ulbrich).

\section{REFERENCES}

ALGARTE, J. P. \& KAEFER, L. Q. - 1972 - Folha de Itararé. Preliminar Geological Report. São Paulo, DNPM-CPRM, vol. I, 202 p. 
ASSINE, M. L. - 1996 - Aspectos da estratigrafia das seqüências pré-carboníferas da Bacia do Paraná no Brasil. PhD Thesis (unpubl.). São Paulo, Instituto de Geociências-USP, $207 \mathrm{p}$.

BIONDI, J. C.; CAVA, L. T.; SOARES, P. C. - 1989 - Mapa Geológico do Estado do Paraná, 1: 650.000. Brasília, MME/DNPM/MINEROPAR.

CCGP (Comissão da Carta Geológica do Paraná) - 1966 - Folha Geológica de Piraí do Sul, 1:50.000. Curitiba, CCGP.

CCGP - 1970 a - Folha Geológica Jaguariaíva-Sul, 1:70.000. Curitiba, CCGP. CCGP - 1970 b - Folha Geológica de Serra das Antas, 1:70.000. Curitiba, CCGP. CPRM (Companhia de Pesquisa de Recursos Minerais) - 1977 - Projeto Leste do Paraná. Folha Piraí do Sul, 1:100.000. São Paulo, DNPM-CPRM-BADEP.

FUCK, R. A. - 1966 - Nota explicativa da Fôlha Geológica de Quero-Quero. Boletim Universidade Federal Paraná, Geologia, 19, 21 p.

FUCK, R. A. - 1967 - Geologia da Fôlha Abapã. Boletim Universidade Federal Paraná, Geologia, 25, $34 \mathrm{p}$.

FUCK, R. A.; MARINI, O. J.; TREIN, E. - 1967 - Contribuição ao estudo das rochas graníticas do Paraná. In: BIGARELLA, J. J.; SALAMUNI, R.; PINTO, V. M. (eds.) 1967 - Geologia do Pré-Devoniano e intrusivas subseqüentes da porção oriental do estado do Paraná. Boletim Paranaense Geociências, 23/25, 183-219.

GIMENEZ FILHO, A. - 1993 - Evolução do Complexo Granítico Três Córregos a noroeste de Apiaí, SP. MSc Thesis (unpubl.). São Paulo, Instituto de GeociênciasUSP, $118 \mathrm{p}$.

GRASTY, R. L.; SMITH, B. S. J.; MINTY, B. R. S. - 1997 - Developments in the standardization and analysis of airborne gamma ray data. In: Exploration 97, the $4^{\text {th }}$ Decennial International Conference on Mineral Exploration, Toronto, $15 \mathrm{p}$.

GREEN, A. A. - 1987 - Leveling airborne gamma-radiation data using between-channel correlation information. Geophysics, 52 (11): 1557-1562.

GUIMARÃES, G. B. - 1995 - O Complexo Granítico Cunhaporanga na região de Joaquim Murtinho, Piraí do Sul (PR): Caracterização faciológica das rochas granitóides. MSc Thesis (unpubl.). São Paulo, Instituto de Geociências-USP, 144 p. 
GUIMARÃES, G. B. \& ULBRICH, H. H. G. J. - 1996 - Redefinição e tipologia do Granito Joaquim Murtinho, Piraí do Sul (PR). In: Congr. Bras. Geol., 39, Salvador, 1996. Anais... Salvador, SBG, 6: 367-369.

GUNN, P. (ed.) - 1997 - Thematic issue: Airborne magnetic and radiometric surveys. AGSO Journal of Australian Geology and Geophysics, 17(2): $216 \mathrm{p}$.

HORSFALL, K. R. - 1997 - Airborne magnetic and gamma-ray data acquisition. AGSO Journal of Australian Geology and Geophysics, 17(2): 23-30.

IAEA (International Atomic Energy Agency) - 1991 - Airborne gamma-ray spectrometer surveying. Technical Report Series, $n^{\circ} 323$, Vienna, IAEA, $97 \mathrm{p}$.

LIMA, R. E.; REIS NETO, J. M.; MONASTIER, M. S. - 1993 - Geologia da Faixa Itaiacoca/PR: estratigrafia, litologia, depoósitos de talco e intrusivas associadas. In: Simpósio Sulbrasileiro de Geologia, 5, Curitiba, 1993. Excursion Guide. Curitiba, SBG.

MARINI, O. J.; FUCK, R. A.; TREIN, E. - 1967a - Intrusivas básicas jurássico-cretácicas do primeiro planalto do Paraná. In: BIGARELLA, J. J., SALAMUNI, R., \& PINTO, V. M. (eds.) - 1967 - Geologia do Pré-Devoniano e intrusivas subseqüentes da porção oriental do estado do Paraná. Boletim Paranaense Geociências, 23/25, 307 324.

MARINI, O. J.; TREIN, E.; FUCK, R. A. - 1967b - O Grupo Açungui no estado do Paraná. In: BIGARELLA, J. J., SALAMUNI, R., \& PINTO, V. M. (eds.) - 1967 Geologia do Pré-Devoniano e intrusivas subseqüentes da porção oriental do estado do Paraná. Boletim Paranaense Geociências, 23/25, 43-103.

MINTY, B. R. S. - 1991 - Simple micro-levelling for aeromagnetic data. Exploration Geophysics, 22, 591-592.

MINTY, B.R.S. - 1997 - Fundamentals of airborne gamma-ray spectrometry. AGSO Journal of Australian Geology and Geophysics, 17 (2): 30-50.

MINTY, B. R. S.; LUYENDYK, A. P. J.; BRODIE, R. C. - 1997 - Calibration and data processing for airborne gamma-ray spectrometry. AGSO Journal of Australian Geology and Geophysics, 17(2): 51-62.

MISENER, D. J.; SINCLAIR, R.; MOURÃO, L. M. F. - 1997 - A new Brazil radiometric database generation and application. In: Congr. Intern. Soc. Bras. Geofísica, 5, São Paulo, 1997. Expanded Abstracts... São Paulo, SBGf, vol. 1: 564. 
MORO, R. de P. X. M. - 1993 - A Bacia ordoviciana do Grupo Castro - PR. MSc Thesis (unpubl.). Rio Claro, Instituto de Geociências e Ciências Exatas-Unesp, 157 p.

PINTO-COELHO, C. V. \& MARINI, O. J. - 1986 - Assinatura em elementos terras-raras (ETR) do Granito Serra do Carambeí (Paraná) e das rochas ígneas associadas. In: Congr. Bras. Geol., 34, Goiânia, 1986. Anais... Goiânia, SBG, 3: 1311-1321.

PRAZERES FILHO, H. J.; GUIMARÃES, G. B.; BASEI, M. A. S.; SIGA JR., O.; REIS NETO, J. M.; CAMPANHA, G. A. C.; SALLUN FILHO, W. - 1998 - Mapa geológico 1:50.000 da porção centro-sul da Faixa Itaiacoca-PR. In: Congr. Bras. Geol., 40, Belo Horizonte, 1998. Anals... Belo Horizonte, SBG, 36.

REIS NETO, J. M. - 1994 - Faixa Itaiacoca: registro de uma colisão entre dois blocos continentais no Neoproterozóico. PhD Thesis (unpubl.). São Paulo, Instituto de Geociências-USP, 255 p.

RIBAS, S. M. - 1981 - Reconhecimento geológico do "Complexo Granítico Cunhaporanga". Technical report (unpubl.). Curitiba, MINEROPAR, 2 volumes. RUBERTI, E. - 1984 - Petrologia do Maciço Alcalino de Banhadão. PhD Thesis (unpubl.). São Paulo, Instituto de Geociências-USP, 248 p.

SILVA, D. C. da \& MANTOVANI, M. S. M. - 1994 - Projeto aerogeofísico Serra do Mar Sul: uma abordagem semi-quantitativa. Revista Brasileira Geociências, 24 (2): 120-127.

SOARES, P. C. - 1987 - Seqüências tecto-sedimentares e tectônica deformadora no centro-oeste do escudo paranaense. In: Simp. Sul-Bras. Geol., 3, Curitiba, 1987. Proceedings... Curitiba, SBG, 2: 743-771.

SOARES, P. C.; STEVANATTO, R.; CAMARGO, C. R. - 1987 - Geologia do noroeste da Faixa Itaiacoca - Paraná. In: Simp. Sul-Bras. Geol., 3, Curitiba, 1987. Proceedings... Curitiba, SBG, 1: 245-262.

SOARES, P. C.; FIORI, A. P.; ROSTIROLLA, S. P. - 1998 - Organização estratigráfica e estrutural dos terrenos alóctones no Cinturão Ribeira, no vale do Ribeira (PR-SP). In: Congr. Bras. Geol., 40, Belo Horizonte, 1998. Anals... Belo Horizonte, SBG, 41.

SOUZA, A. - 1990 - Mapa Geológico na escala 1:50.000 e esboço da evolução tectônica e sedimentar do Grupo Itaiacoca, nas folhas Barra do Chapéu e Ouro Verde - SP/PR. MSc Thesis (unpubl.). São Paulo, Instituto de Geociências-USP, 
$200 \mathrm{p}$.

TREIN, E. \& FUCK, R. A. - 1967 - O Grupo Castro. In: BIGARELLA, J. J.; SALAMUNI, R.; PINTO, V. M. (eds.) - 1967 - Geologia do Pré-Devoniano e intrusivas subseqüentes da porção oriental do estado do Paraná. Boletim Paranaense Geociências, 23/25, 257-305.

TREIN, E.; REIS NETO, J. M.; BIONDI, J. C.; MONASTIER, M. S. - 1985 - Revisão da Formação Itaiacoca: identificação de uma seqüência metavulcano-sedimentar em Abapã (PR). In: Simp. Reg. Geol., 5, São Paulo, 1985. Proceedings... São Paulo, SBG, 1: 169-182.

VLACH, S.R.F.; JANASI, V.A.; VASCONCELLOS, A.C.B.C. - 1990 - The Itu belt: associated calc-alkaline and aluminous A-type late Brasiliano granitoids in the states of São Paulo and Paraná, southern Brazil. In: Congr. Brasil. Geol., 36, Natal, RN, 1990. Anais...Natal, SBG, v.4, 1700-1711.

WILFORD, J. R.; BIERWIRTH, P. N.; CRAIG, M. A. - 1997 - Application of airborne gamma-ray spectrometry in soil/regolith mapping and applied geomorphology. AGSO Journal of Australian Geology and Geophysics, 17(2): 201-216.

ZALÁN, P.V.; WOLFF, S.; CONCEIÇÃO, J.C. de J.; VIEIRA, I.S.; ASTOLFI, M.A.M.; APPI, V.T.; ZANOTTO, O.A. - 1987 - A divisão tripartite do Siluariano da Bacia do Paraná. Revista Brasileira Geociências, 17, 242-252. 


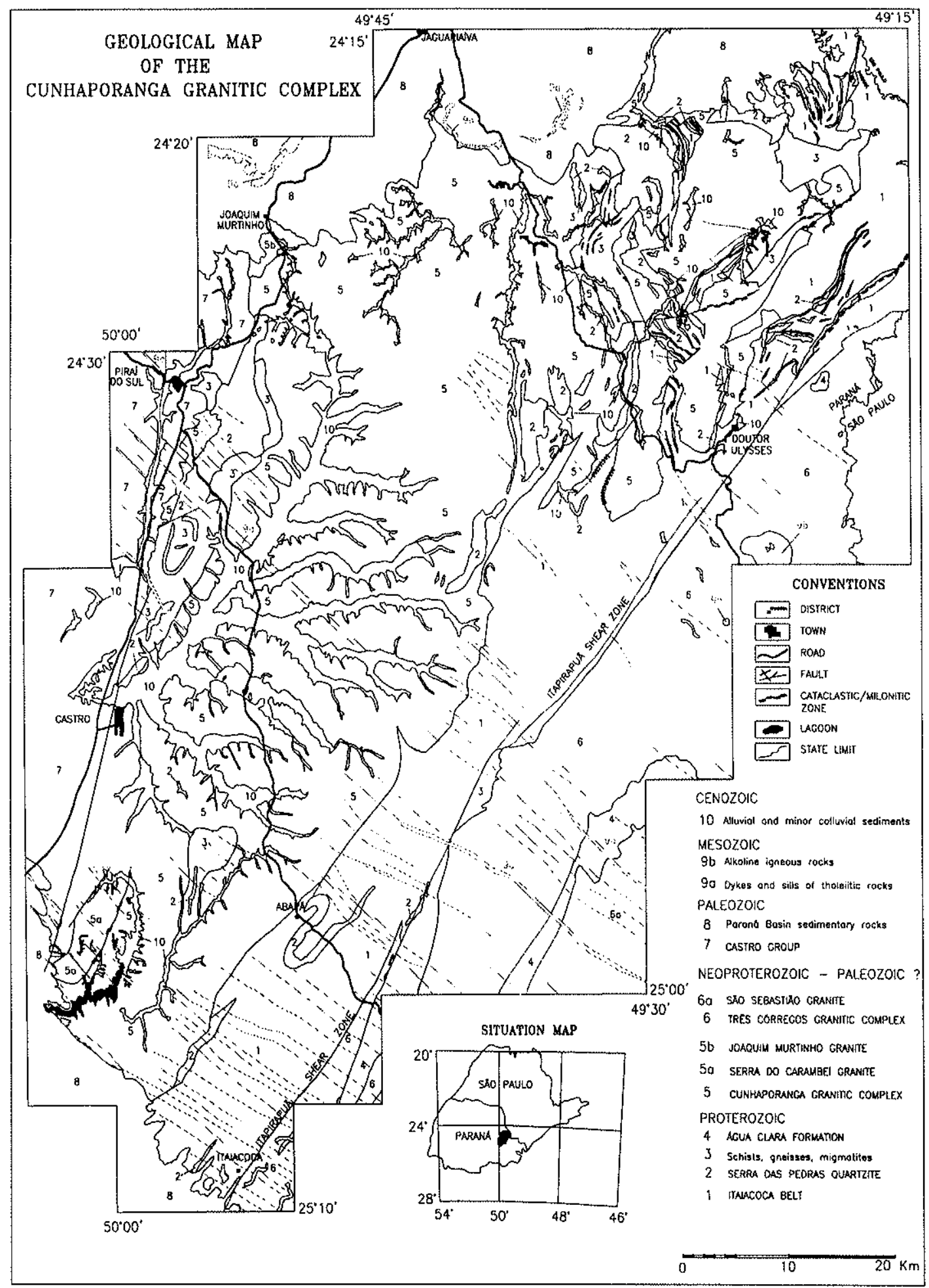

Figure 1. Regional geologic map of the basement area in Paraná state. 1. Itaiacoca Belt; 2: Serra das Pedras Quartzite; 3: Schists and migmatites; 4: Água Clara Formation; 5: Cunhaporanga Granitic Complex, 5a: Carambeí Granite, 5b: Joaquim Murtinho Granite; 6: Três Córregos Granitic Complex, 6a: São Sebastião Granite; 7: Castro Group; 7: sedimentary rocks of the Paraná Basin; 9: Banhadão alkaline massif; 10: alluvial deposits. Unpublished compilation, from several sources, by G.B. Guimarães. 
Figure 2. Limits of the Aereogeophysical Project Serra do Mar Sul. Geologic units as in Figure 1.

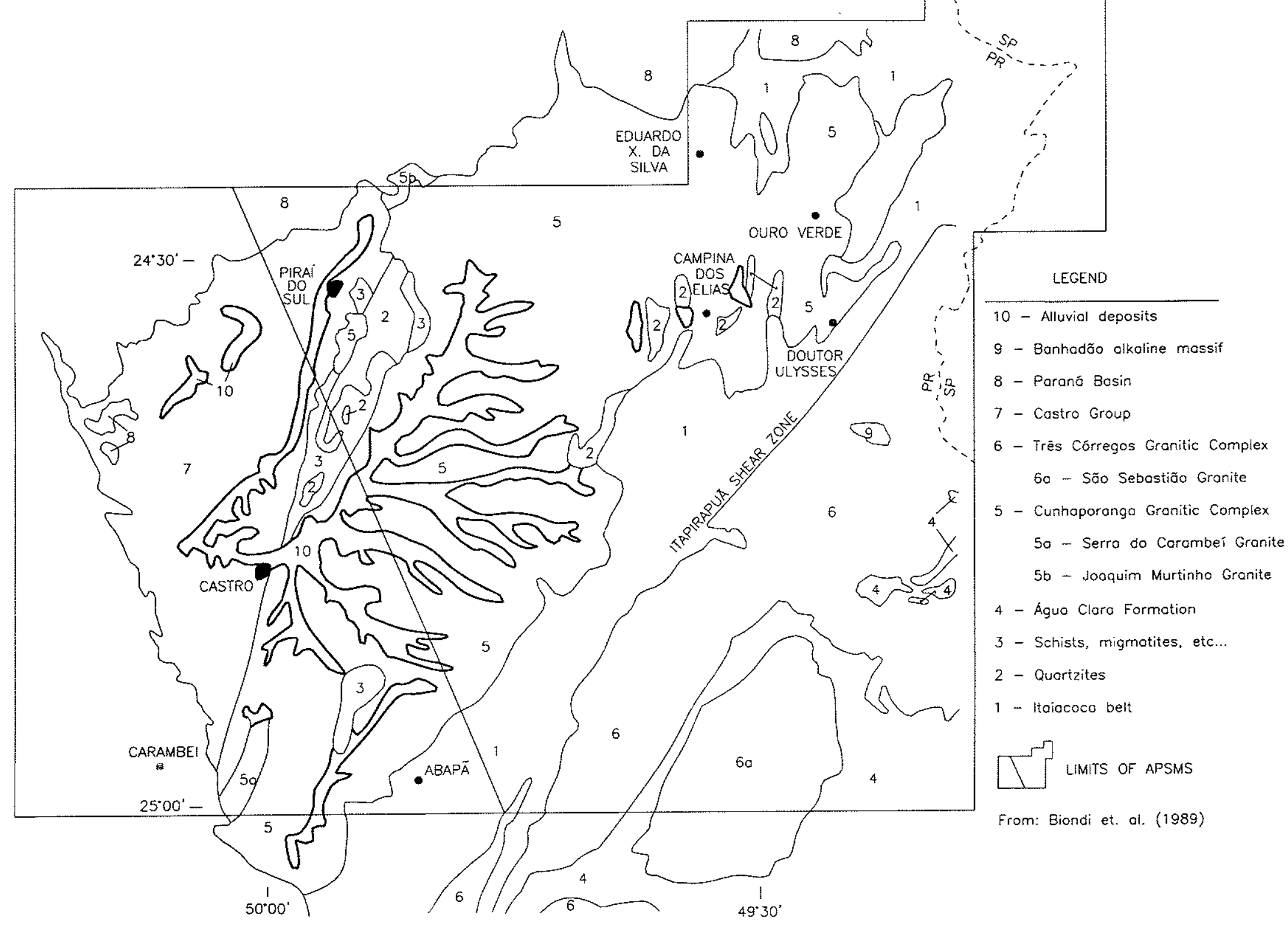




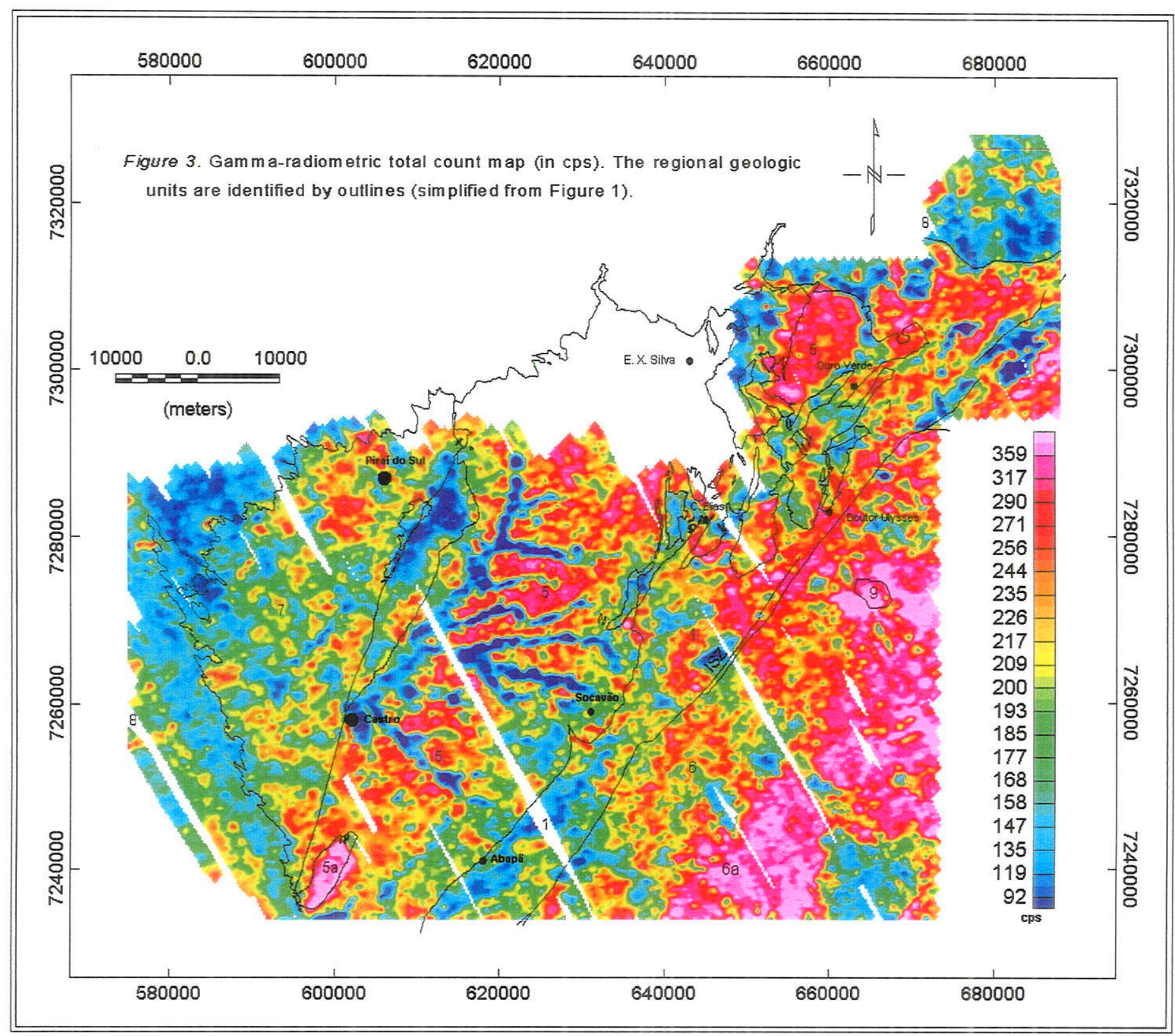




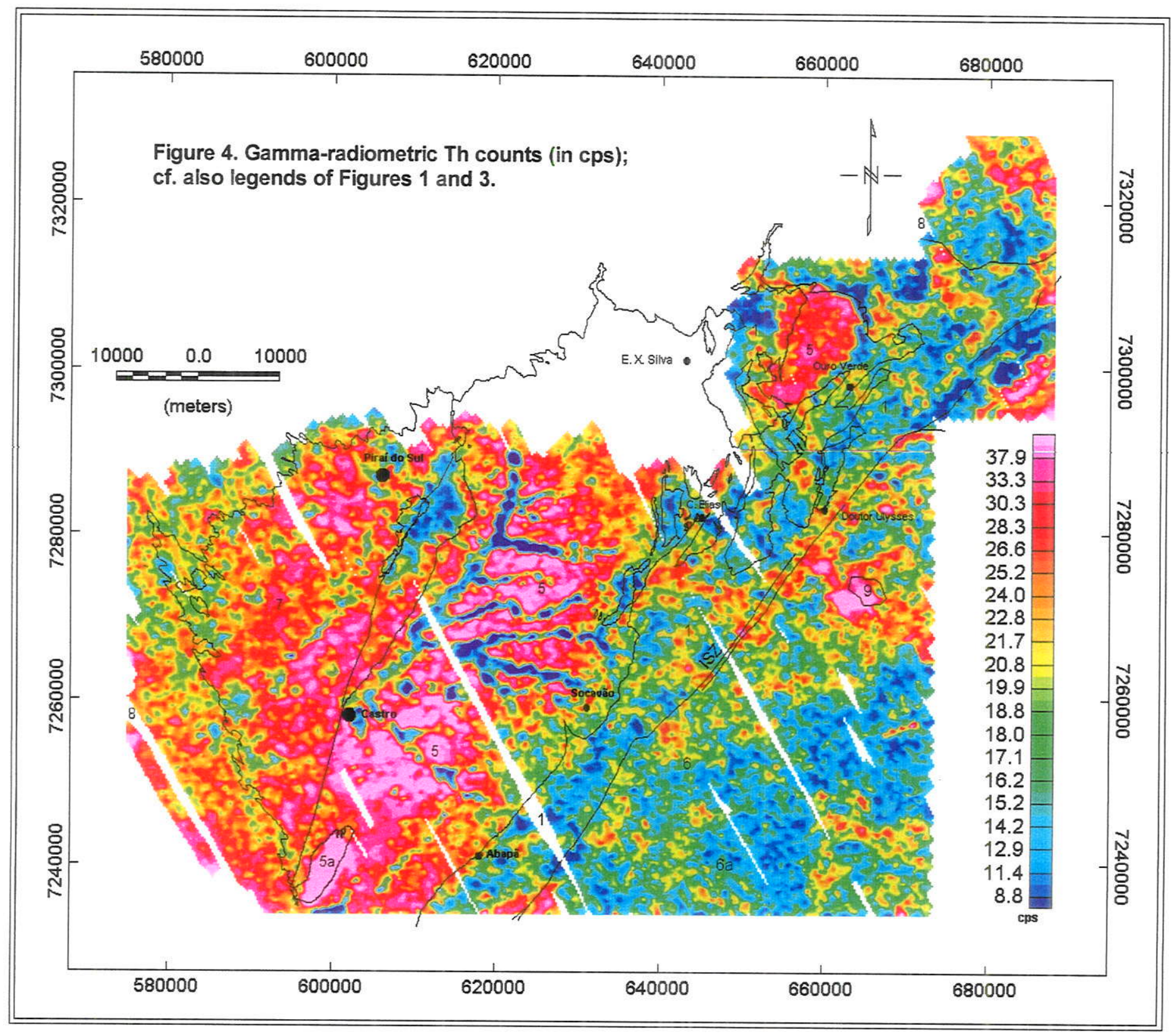




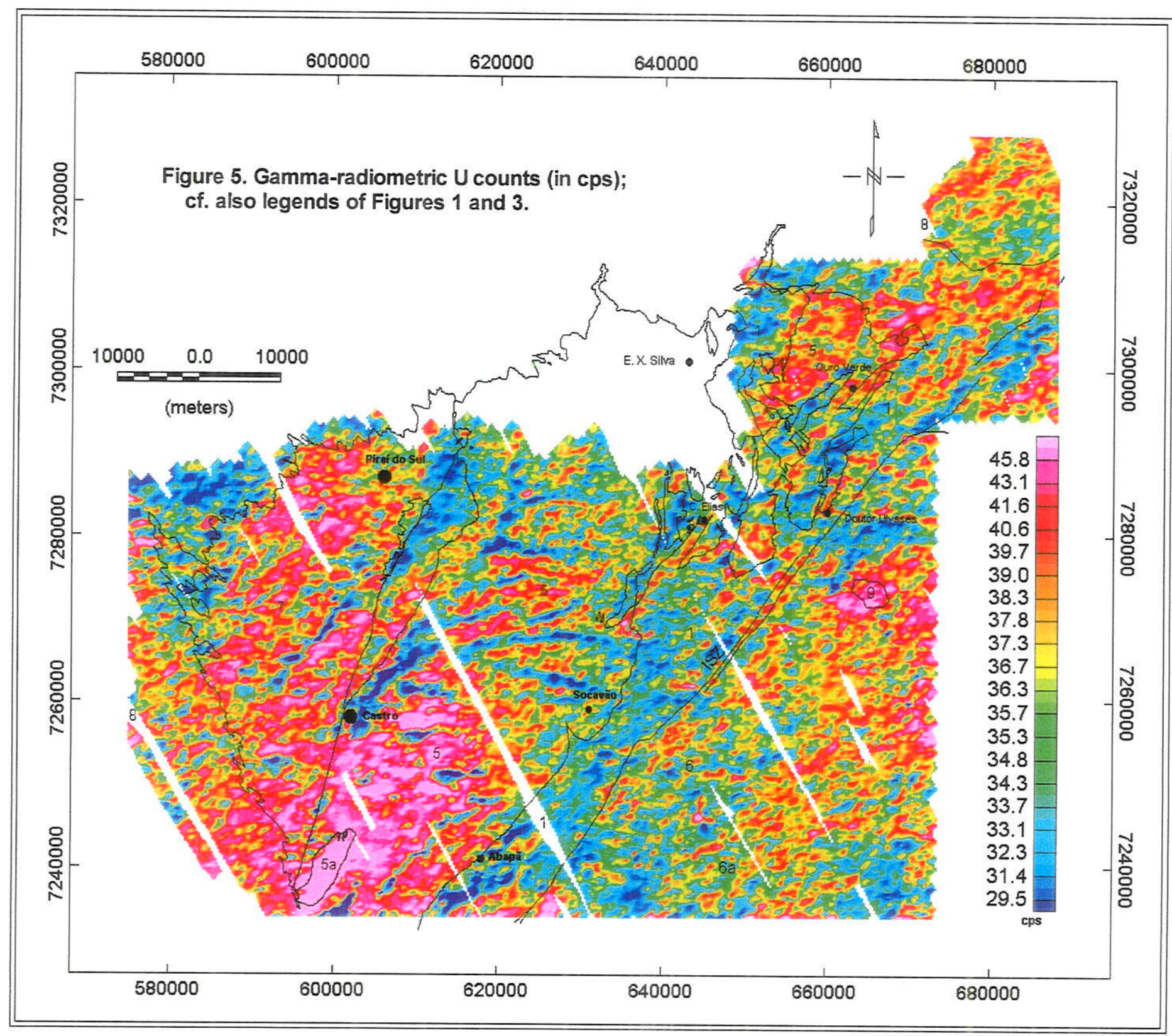




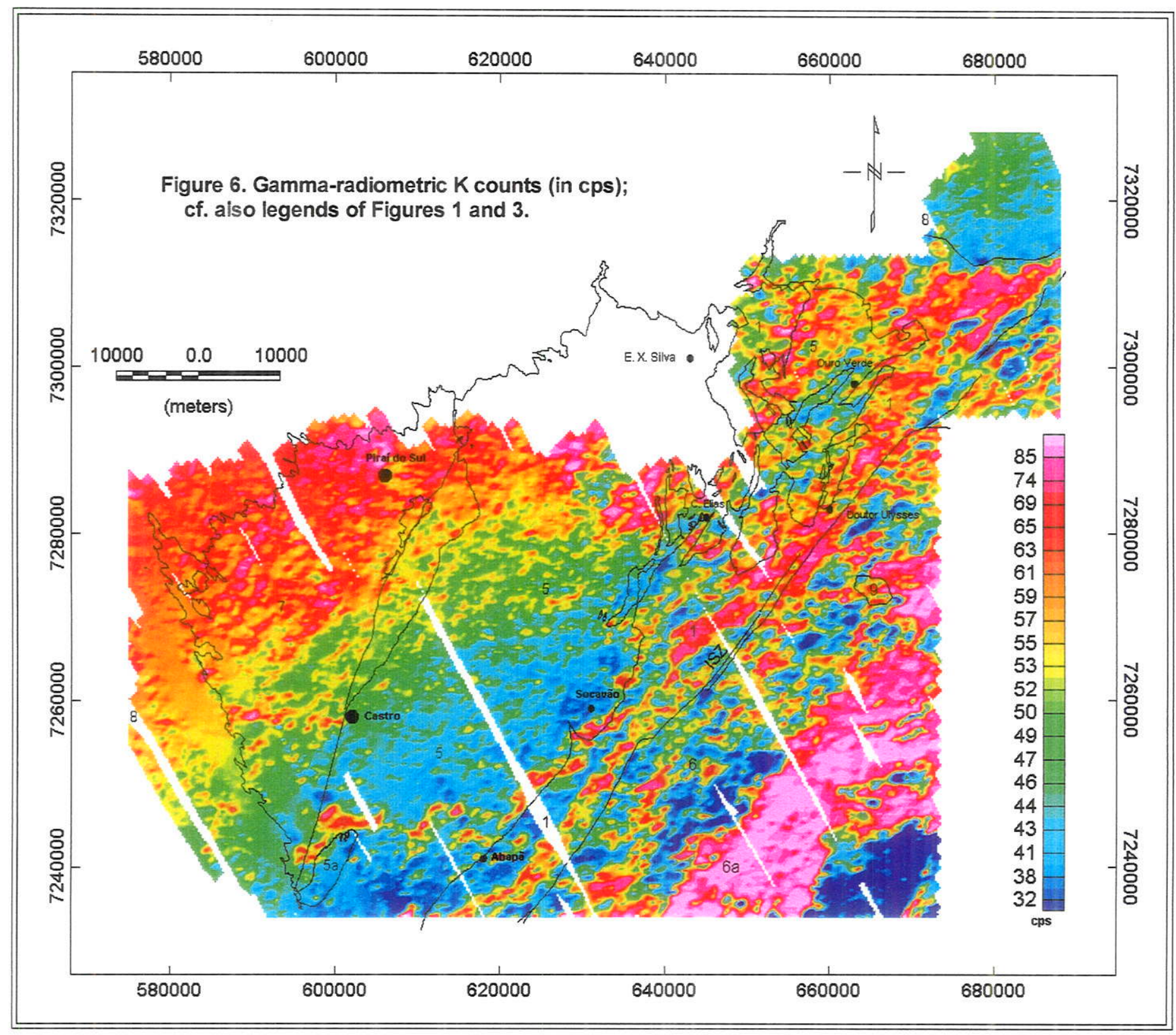




\section{ANEXO 5}

\section{The airborne Aerogeophysical Project Serra do Mar Sul in the region of the Cunhaporanga Granitic Complex, Paraná, southern Brazil: analyses of the magnetometric data}

Francisco J. F. Ferreira', Gilson Burigo Guimarães ${ }^{2}$, Maximilian Forlin $^{1}$ and Horstpeter H. G. J.Ulbrich ${ }^{3}$

1. Departamento de Geologia, Universidade Federal de Paraná, Curitiba, Paraná

2. Departamento de Geociências, Universidade Estadual de Ponta Grossa, Paraná

3. Departamento de Mineralogia e Geotectônica, Instituto de Geociências, Universidade de São Paulo, São Paulo, Brazil

\section{ABSTRACT}

The airborne Aerogeophysical Project Serra do Mar Sul provided aeromagnetic information about basement areas of Paraná and Santa Catarina states, covering about $50,000 \mathrm{~km}^{2}$. Object of this study are mainly the large Cunhaporanga Granitic Complex and other adjacent Proterozoic/Eopaleozoic geologic units: the Três Córregos Granitic Complex, the Itaiacoca metasedimentary-metavolcanic belt, the Água Clara Formation, several ill-defined quartzitic and gneiss-schist basement rocks and the molassic volcano-sedimentary Castro Group, as well as Cenozoic diabase dike swarms and the Devonian Furnas sandstones. Data reduction delivered several color and greyscale maps of the residual magnetic fields, including reduction to the pole and the equator, corrected with cosine filters to eliminate levelling errors and the influence of the NW-SE basalt dikes. The magnetic susceptibility $\boldsymbol{k}$ was measured on hand samples of Cunhaporanga granites, Castro Group rocks and some quartzites, schists and gneisses. Calc-alkaline granitoids are dominant in both granitoid complexes (large $k$ values); the maps, however, show irregular patterns for both, possibly due to a decrease in the amount of original magnetite, on account of hydrothermal and supergene alteration, pervasive cataclasis and incipient metamorphism (e.g., prehnite is present in many Cunhaporanga rocks). The Itaiacoca belt is represented mainly by negative anomalies; to the $S$, a convoluted positive pattern identifies the presence of the 
folded Itaiacoca metavolcanics. The Castro Group outcrops reproduce, in part, the irregular pattern of the basement rocks, suggesting that their total thickness may be limited. The Furnas sandstones and alluvial deposits are not registered. The alkaline Banhadão massif, with remanent magnetization, is shown as a circular pattern with a negative off-center anomaly (pole reduction), covering several times the size of the Banhadão outcrops.

Key words: airborne magnetometric survey, Aerogeophysical Project Serra do Mar Sul, Cunhaporanga Granitic Complex

\section{RESUMO}

O Projeto Aerogeofísico Serra do Mar Sul, com cobertura de $50.000 \mathrm{~km}^{2}$, forneceu informações aeromagnéticas de áreas do embasamento cristalino dos estados do Paraná e de Santa Catarina. O objetivo do trabalho é avaliar a resposta do Complexo Granítico Cunhaporanga e de outras unidades proterozóicas/eopaleozóicas vizinhas: o Complexo Granítico Três Córregos, a Faixa Itaiacoca de rochas metassedimentares-metavulcânicas, a Formação Água Clara, o Grupo Castro e quartzitos, xistos $\Theta$ gnaisses sem designação formal, além dos diques de rochas basálticas cretáceas correlacionados à Formação Serra Geral e os arenitos devonianos da Formação Furnas. $O$ tratamento dos dados resultou em vários mapas coloridos e em tons de cinza, onde os procedimentos de correção incluíram redução dos dados ao Pólo e ao Equador e a aplicação de filtros co-seno direcionais, estes visando eliminar ou diminuir erros de nivelamento $\Theta$ a influência magnética dos diques básicos. A susceptibilidade magnética $\boldsymbol{k}$ foi medida em amostras de granitóides Cunhaporanga, rochas do Grupo Castro e alguns quartzitos, xistos e gnaisses. Granitóides cálcioalcalinos (com altos valores de $k$ ) predominam nos dois complexos graníticos. Os mapas, entretanto, mostram padrões irregulares para esses complexos, em parte por redução dos teores originais de magnetita por influência da alteração superficial e hidrotermal, freqüente cataclase e metamorfismo incipiente (e.g., prehnita está presente em muitos granitos Cunhaporanga). A Faixa Itaiacoca é representada principalmente por um padrão alongado de anomalias negativas; na sua parte meridional, um padrão convoluto identifica a presença de metavulcânicas dobradas. $O$ Grupo Castro reproduz, em parte, o padrão irregular do embasamento, sugerindo que a sua espessura pode ser menor que a estimada. $O$ arenito Furnas e depósitos 
aluvionares do rio lapó não são registrados nestes mapas. O maciço alcalino de Banhadão, com magnetização remanescente, é observado como um padrão circular, exibindo um tamanho várias vezes superior à área dos afloramentos e com uma anomalia negativa central deslocada do centro (no mapa com redução ao Pólo).

Palavras chaves: levantamento aeromagnetométrico, Projeto Aerogeofísico Serra do Mar Sul, Complexo Granítico Cunhaporanga.

\section{INTRODUCTION}

The airborne Aerogeophysical Project Serra do Mar Sul was conducted in the 70's for the Companhia de Pesquisa de Recursos Minerais (CPRM), obtaining at the same time gamma-spectrometric data (TC, $\mathrm{U}, \mathrm{Th}$ and $\mathrm{K}$ channels) and aeromagnetic information. The covered area of about $50,000 \mathrm{~km}^{2}$ comprises a significant part of the basement complex of the states of Paraná and Santa Catarina (Figure 1). This information, made available to the general public, can be more fully explored to point out general correlations of magnetic data with major lithological units and structures. A second article is centered on the analysis of the gamma-ray spectrometric maps, which gives regional geologic information especially on the distribuiton of surface geologic units (cf. Guimarães et al. 1999). Magnetometric surveys, on the contrary, are able to show both rock distribution at depth and the general structural outline in the region under consideration.

\section{METHODOLOGY}

Airborne data acquisition. The Aerogeophysical Project Serra do Mar Sul was realized using a pattern with the general N30W flight direction, flight speed around 58 $\mathrm{m} / \mathrm{s}$, and a flight separation from 750 up to $1500 \mathrm{~m}$, locally showing superpositions, or separations, of up to $2 \mathrm{~km}$ (e.g., Barros 1984); readings were taken every $58 \mathrm{~m}$ in the flight direction. Control lines along the $\mathrm{N} 6 \mathrm{OW}$ direction were flown with a separation of $20 \mathrm{~km}$. Medium height was $158 \mathrm{~m}$, varying from 80 to somewhat over $300 \mathrm{~m}$. Navigation was realized with visual control. The airborne Geometrics G-803 magnetometer was used, with sensors mounted in the rear of an Islander-type airplain. A terrestrial G-826 magnetometer served for ground measurements. Several shortcomings of this survey 
were pointed out by Silva \& Mantovani (1994): variations in the spacing of flight lines, inconsistencies of up to $4 \mathrm{~km}$ in the recording of the UTM coordinates, and variability in the flight heights. In addition, the data set has to be separated into two different populations, since two different bases were used at that time for the survey, one at Curitiba (altitude of $\sim 900 \mathrm{~m}$ ), the other at Florianópolis $(\sim 10 \mathrm{~m})$ (cf. Figure 1).

Susceptibility measurements. A knowledge of the susceptibilities of rocks found in the study area help to understand the magnetometric pattern. The susceptibility $\boldsymbol{k}$ relates the magnetic moment per unit volume $\mathbf{J}$ to the intensity of the applied magnetic field $\mathbf{H}$, such that $\boldsymbol{k}=\mathbf{J} / \mathbf{H}$. A large number of hand samples, collected during a parallel geologic survey conducted in this area and mainly centered on the Cunhaporanga granites, is the basis for susceptibility measurements in the laboratory. No measurements were made for the Três Córregos granitoids and no published data are available, but it is assumed that the $\boldsymbol{k}$ values for these mostly calc-alkaline granites are similar to the ones found for the Cunhaporanga rocks. The measurements were performed with the portable Exploranium model KT-9 reader, using the pin-mode. A point reading is obtained by pressing the magnetometer's rubber pin against the sample, and repeating the readings at least 20 times on different points of a guide grid; the average value presumably represents adequately the magnetic susceptibility $\boldsymbol{k}$ of the sample. The Exploranium model gives results with an accuracy of about $1 \times 10^{-3} \mathrm{SI}$ units.

Data reduction and handling. The following sequence was observed during data reduction: handling of magnetometric, geologic and positional data with the GEOSOFT $^{\text {TM }}$ software (cell size $500 \times 500 \mathrm{~m}$ ), by means of the minimum curvature interpolation method; definition of the residual magnetic field grids, enhanced by different filters; printing of the geophysical-geologic maps (scales between 1: 250.000 and 1:500.000); comparison of the geomagnetic grids with the geologic and structural data. Values above $250 \mathrm{nT}$ were registered uniformly, with the same shade; they may go as high as $480 \mathrm{nT}$ in the region of Banhadão massif.

Distortions and/or strong magnetic influences in these maps can be removed or minimized with the use of a directional cosine filter (additional comments, cf. Guimarães 
et al. 1999); preliminary tests showed that grade- 6 filters were better suited than those with grade 1 or 2 , which tend to enhance too strongly the magnetic response in the orthogonal positions. Two directional grade-6 cosine filters were used, one in the N3OW direction to eliminate the "levelling erros" in the flight direction (e.g., Luyendyk 1997), the other in the N50W direction to reduce the strong magnetic pattern of the basaltic dikes.

The "reduction to the pole" is particularly suited for those regions with a magnetic inclination betweeen $20^{\circ}$ and $50^{\circ}$ ( $-31^{\circ}$ for the study area, at the time of the survey), and can remove the assimetry of the magnetic anomalies that are due to induction; this reduction places the magnetic anomalies directly above their sources (e.g., Gunn 1998; Liu \& Mackey 1998). Also applied was the "illumination" technique, placing the "sun" to the NW, which enhances structural or geologic details in the orthogonal direction.

The obtained results were printed in color and greyscale images, the first ones showing more clearly the overall patterns of the positive and negative anomalies, while the last ones are better suited to show finer structural and lithologic details.

\section{REGIONAL GEOLOGIC UNITS}

A summary of the main regional geologic units is given in Guimarães et al. (1999), with the listing of additional bibliography. The basement area mapped by this survey is part of the Ponta Grossa Arch, a structurally high basement region that was stripped of its sedimentary and basaltic cover. The apex of the Ponta Grossa Arch, as well as its northern and southern flanks, are marked by the invasion of NW-SE trending basaltic and intermediate dikes of the Cretaceous Serra Geral Formation and by some alkaline occurrences (e.g., the Banhadão, Jacupiranga and Juquiá silico-carbonatitic massifs, emplaced within the northern flank of the Arch). A simplified regional geologic map is presented in Figure 1.

The following summation points out mainly petrographic and mineralogical features that are important for the understanding and evaluation of the magnetometric maps, including available data on the magnetic susceptibility of the different rock types. 


\section{The Itaiacoca Belt and associated rocks}

Metasedimentary strata are predominant in this weakly metamorphosed belt, all showing low contents of mafic and opaque minerals. Folded and metamorphosed trachytes (?) and other volcanic types, founded in the southern part of the belt, present higher amounts of opaque and mafic silicate phases, and should therefore be registered as positive magnetic anomalies.

\section{The Serra das Pedras Quartzite}

Weakly metamorphosed quartz-rich sandstones and arkoses, the main constituents of this "quartzite" unit, occur mainly within the Cunhaporanga Complex, possibly as roof pendants, and along its borders; they are of very limited vertical thickness. The measured magnetic susceptibility $k$ is very low (e.g., between 0.08 and $0.31 \times 10^{-3} \mathrm{SI}$ units for quartz arenites) and even negative $\left(-1.0\right.$ to $-0.02 \times 10^{-3} \mathrm{Si}$ units in metagreywackes). These rocks should not show up, or only on a very local scale, in regional magnetometric surveys.

\section{The unit of gneisses, schists and migmatites}

This unnamed unit is found as mappable "enclaves" mainly within the Cunhaporanga granites (Figure 1; cf. also Guimarães et al. 1999), as thin partitions, with a general irregular to tabular shape. They probably represent roof pendants of limited vertical thickness. Most of these rocks are mica-rich, but devoid of oxide phases. The measured $\boldsymbol{k}$ are low (mica schists: around $0.18 \times 10^{-3} \mathrm{Si}$ units; phyllites: $0.10 \times 10^{-3}$ $\mathrm{SI}$; one quartz-plagioclase-biotite schist showed a moderate $\boldsymbol{k}$ value of $7.6 \times 10^{-3} \mathrm{SI}$ units. These rocks should not be recorded in the magnetometric survey.

\section{The Água Clara Formation}

Rocks of this metasedimentary formation crop out at the southeastern corner of the present survey (Figure 1). No susceptibility measurements were made on rocks from this formation. 
The Cunhaporanga Granitic Complex

Predominant in this Complex are calc-alkaline granites, either presenting an amphibole-biotite-sphene mafic association or showing only biotite (with or without sphene), always with visible or even significant amounts of magnetite as well as ilmenite. Differentiated granites, with little or no biotite, are present as circunscribed massifs, especially to the North, in the Joaquim Murtinho region, and to the South, around Carambeí (cf. Figure 1). Outcrops in the whole Complex are usually poor to nonexistent, especially in the levelled central part covered by the alluvial deposits of the lapó river. Better outcrops are seen in the northern and southern regions, even so mainly as scattered and frequently deformed blocks, often presenting hematite-bearing cataclastic or mylonitic bands and lenses; hematite-rich veins are sometimes observed (e.g., in the Serra do Carambeí Granite; Figure 1). Most of the granites are affected by deuteric or hydrothermal alteration, as attested by the strong reddish or very dark-grey color of their feldspars. Thus, magnetite may be partly or totally converted into secondary phases, as a response to the cited alteration and deformation.

A parallel survey on the petrography and mineralogy of the Cunhaporanga granites, conducted by one of the authors (G.B. Guimarães), disclosed a wide variety of granitic facies or types, each one defined by texture, structure and primary mineral phases. Similar rock types are found in most areas of the district, but distance from one of these districts to the next precludes any attempt at correlation, in terms of emplacement time or genetic ties.

The measured $\boldsymbol{k}$ values can be grouped in a few categories, identified by their main mafic association (Table 1): the calc-alkaline granites with sphene-hornblendebiotite (sphe-hbl-bio), the ones with sphene-biotite (sphe-bio) and with biotite devoid of sphene (bio), the peraluminous association with muscovite-biotite (musc-bio) and a few hololeucocratic (holo) granites. Another category is that of the differentiated (differ) types.

The largest $\boldsymbol{k}$ values are found in the fresh samples of the categories with sphene-hornblende-biotite and sphene-biotite (mean $\boldsymbol{k}$ of about 20 and $13 \times 10^{-3} \mathrm{SI}$ 
units, respectively; Table 1). In these rocks, the $k$ values diminish to about $9 \times 10^{-3} \mathrm{SI}$ units, with the onset of cataclastic deformation and weak metamorphism (as can be identified, for instance, by the presence of prehnite and/or orientation of biotites). A few apparently fresh samples of the sphe-hbl-bio category show low $k$ values, $<1 \times 10^{-3} \mathrm{SI}$ units, while samples with a visible imprint of hydrothermal alteration and/or weathering also present diminished $\boldsymbol{k}$ values, down to $<3 \times 10^{-3} \mathrm{SI}$ units. These lower values indicate a decrease in the amounts of magnetite, converted to hematite and/or Fehydroxides by deformation, hydrothermal alteration and incipient weathering.

The granites with only biotite have typically lower $\boldsymbol{k}$ figures $\left(5.7\right.$ to $7 \times 10^{-3} \mathrm{SI}$ units; Table 1), indicating lesser amounts and/or smaller sizes of the magnetite grains. A few granites with fresh biotite may actually belong to the sphene-hornblende-biotite association, since they present altered pseudomorphs of other mafic minerals; the corresponding $k$ values are high (e.g., $17 \times 10^{-3} \mathrm{SI}$ units), suggesting that the alteration did not affect magnetite.

The peraluminous muscovite-biotite granites, with low $\boldsymbol{k}$ values (Table 1), are mostly found in the vicinity of metasedimentary rocks (e.g., in the contact areas with the Itaiacoca Belt, to the East). Although these granites do not usually present conspicuous enclaves of metasedimentary rocks, the close and systematic relationship between them and the peraluminous metasediments suggests genetic interaction between the two, including assimilation and a corresponding decrease in the fugacity of $\mathrm{O}_{2}$. As a consequence, reduced oxides are crystallized instead of magnetite. In fact, the variation in the observed $k$ values --from almost zero to a maximum of $\sim 9.5 \times 10^{-3} \mathrm{SI}$ units in the muscovite granites-- may itself be a parameter that can roughly measure the amount of assimilation.

Hololeucocratic granites are found only as dike rocks, with few opaque grains (pyrite and magnetite). The maximum registered $k$ value is $2.5 \times 10^{-3} \mathrm{SI}$ units (Table 1).

The differentiated granites appear as restricted and localized bodies (e.g., the Joaquim Murtinho and Serra do Carambeí Granites; Figure 1). The rocks usually show strongly colored feldspars, possibly as a result of recrystallization (e.g., dispersed 
hematite platelets and/or increase in the amount of fluid inclusions in feldspars). A parallel conversion of magnetite into hematite, or into $\mathrm{Fe}$ hydroxides, may also occur. Measured values of $\boldsymbol{k}$ for Carambeí granites are close to zero (Table 1); similar figures may also hold for the Joaquim Murtinho samples.

The cited susceptibility values indicate that the Cunhaporanga Complex should be identified as a region with positive anomalies, since the most abundant granites are magnetite-bearing calc-alkaline types. On the other hand, the magnetometric response may be significantly reduced by the pervasive late to post-magmatic alteration, recrystallization and deformation registered in many of the observed outcrops. More differentiated granites should show a complex pattern, with weaker anomalies.

\section{The Três Córregos Complex}

Little is know about the petrography and geology of this complex, and no magnetic susceptibility measurements were realized up to now. Descriptions based on local studies indicate that this elongated granite unit is also mainly composed by calcalkaline granitoids, in part also affected by moderate to pronounced deformation. A complex magnetic pattern is therefore expected, with positive anomalies registering the presence of magnetite in the unaffected Três Córregos rocks, while moderate or even negative responses should pinpoint the location of enclaves and of deformed and/or altered granites (cf. comments on this subject in the paragraphs above).

Own observations show that foliated hornblende granodiorites and quartz-diorites are predominant in the Abapã region (Figure 1). In the area identified informally as the "São Sebastião Granite " (Figure 1), the predominant rocks are porphyritic biotitehornblende monzogranites, also showing large elongated enclaves of the Água Clara Formation.

\section{The Castro Group}

The latest map identifies three main lithostratigraphic units with a prevailing N4OE orientation (Moro 1993). Intermediate to acid volcanic rocks predominate in the 
central parts, associated with a mostly coeval sedimentary formation (arkoses, conglomerates and mudstones), to which a thickness of $6200 \mathrm{~m}$ is assigned (Moro 1993). Rhyolites are also registered in the marginal strips to the north and south. A few susceptibility measurements on volcanic rocks show a mean $k$ value of $0.4 \times 10^{-3} \mathrm{SI}$ units ( 3 samples); one measurement of a relatively fresh andesite yields $9.0 \times 10^{-3} \mathrm{SI}$ units. The sedimentary rocks, with little magnetite, should show low or negative $\boldsymbol{k}$ values. This limited data set suggests that the Castro Group should be characterized by a complex magnetic pattern, with the sedimentary units registered as negative anomalies.

\section{The sedimentary units of the Paraná Basin}

The quartz-rich sandstones of the Furnas Formation, to the west (Figure 1), overlie directly the basement rocks of the Ponta Grossa Arch and cover also the Castro Group. In this region, the outline of the Parana Basin is strongly marked by the so-called Devonian scarp, a topographic boundary with a vertical relief of 100 to $200 \mathrm{~m}$.

\section{The dike rocks of the Serra Geral Formation}

The Ponta Grossa Arch is cut by dike swarms of basaltic and intermediate rocks with a N45W trend. A concentration of up to 4 dikes per $\mathrm{km}$ was cited, especially in the apex area of the Arch (Marini et al. 1967), and their age is around 131.4-129.2 Ma (peak at $130.5 \mathrm{Ma}$; Renne et al. 1996). These rocks are associated with the flows of the basaltic Serra Geral Formation (age around 133-132 Ma; Renne et al. 1992). Only two wide dikes (widths of up to $700-800 \mathrm{~m}$ ) are registered in the available local geologic maps of the lapó drainage basin, an interpretation based on the aligned pattern of scattered blocks of dike rocks (Figure 1; CPRM 1977). Numerous thinner dikes were registered in the areas to the north and south (Figure 1; Pinto-Coelho 1986; CCGP 1970a, 1970b). Diabases are predominant, while diorites and quartz diorites to quartz monzonites are subordinate (own collected samples). Susceptibility values are high, measuring 29.5 and $\sim 15 \times 10^{-3} \mathrm{SI}$ units in a diabase and a diorite porphyry, respectively; the quartz-bearing rocks, part of the wider dikes in the center of this region, yield a mean $k$ value of $\sim 21 \times 10^{-3} \mathrm{SI}$ units (three samples; own measurements). 


\section{The Banhadão alkaline massif.}

This massif is mainly constituted by nepheline syenites and phlogopite melteigites, cropping out within Três Córregos granites along an ellipsoidal elevated area of $4.5 \times 3.5 \mathrm{~km}$. Phonolite dikes cut both the massif and basement rocks. The actual structure may be far larger: fenitization processes affected granites (Ruberti 1984), as also suggested by gamma-spectrometric maps (Guimarães 1999). This effect, and the presence of pyroxene-rich rocks, indicates that carbonatites (veins and/or plugs) may be present at depth. The emplacement age is around 108-110 Ma.

\section{Alluvial deposits.}

Alluvial deposits appear as mappable units only in the drainage basin of the lapó river, constituted by sands and sandy clays, with some silty and clayey lenses. Their thickness, however, is negligible.

\section{DISCUSSION OF THE AERO-MAGNETOMETRIC DATA}

The maps with the registered magnetic field intensity data are shown in Figures 2 to 5 . The represented area covers about 100 (E-W direction) by $80 \mathrm{Km}$ (N-S direction). The observed anomalies will now be discussed, based on a scheme recommended by Gunn (1998), consisting in the identification of several anomaly patterns and their possible interpretation as a function of the known regional geology (Table 2; cf. also Figure 1).

\section{Anomaly patterns}

The dikes of the Serra Geral Formation are clearly seen as a dike pattern in Figure 2, with a general N40-45W trend; the "beading" effect is due to the almost coincident flight direction. The dike streaks continue to the NW, into the basement of the Paraná Basin, and to the SE, into the granites of the Três Córregos Complex. 
The dike effect has been removed from Figures 3, 4 and 5. These maps show clearly a centrally located area of common texure, marked by predominant low to very low negative anomalies, flanked by two wide strips with a complex pattern (positive anomalies intermingled with negative areas, the first ones prominent in the strip located to the NW). All three patterns show the general regional N4OE alignment; prominent streaks with the same direction represent at least in part true geologic features (e.g., presence of granite wedges, with a N40E orientation, within the Itaiacoca belt; cf. Figure $5)$.

Some changes in the pattern are observed in the various figures. In Figure 5, the area with a negative anomaly is clearly superposed upon the outcrops of the mainly metasedimentary Itaiacoca belt, with low magnetic susceptibilities, but considerably shifted to the NW in Figures 3 and 4 . The last two maps represent the Cunhaporanga rocks as negative anomalies, a result that is not to be expected; the extension of the positive anomalies that depict the outcrops of granites, clearly observed in the Ouro Verde region, to the NW, are considerably reduced or even converted into negative anomalies in the cited Figures (compare with Figure 5). In Figure 5, the only clearly negative anomalies observed within the Cunhaporanga Complex appear as an irregular strip at the contact with the Itaiacoca Belt, pointing to the existence of granitic rocks with lower susceptibilities. This pattern points out the the presence of the peraluminous granites, supposedly generated by assimilation of Itaiacoca country rocks.

The granites of the Três Córregos Complex are again represented by a complex pattern. The positive magnetic anomalies, as well as the correct position of the more differentiated "São Sebastião Granite", are clearly shown in Figure 5, but undisclosed or hidden in Figures 3 and 4.

The prominent Itapirapuã shear zone separates tectonically the Itaiacoca Belt from the Três Córregos Complex. Therefore, no interactions are to be expected between the original Três Córregos magmas and the metasedimentary units, such as assimilation. The presence of this shear zone is not marked by a sharp linear anomaly, but rather by a change in the type of pattern, going from the very negative anomaly to positive regions (cf. Figures 2, 3 and 4); no shear zone can be recognized in Figure 5. 
It is worth noting that the pattern that represents the Cunhaporanga Complex continues into the triangular area covered by the Castro Group, suggesting that the Castro cover may not be as thick as cited in the literature. The magnetic orientation of the basement rocks continues into the Paraná Basin, since the beds of the Furnas sandstones, as is to be expected, are not registered by this survey (e.g., Figures 3 and $5)$.

An elongated positive circular pattern, with a negative off-center core, signals the position of the Banhadão massif (e.g., Figure 5). Geologic observations show a wide aureole of fenitization around this massif (Ruberti 1984), probably also accompanied by crystalization of magnetite. The magnetic anomaly is several times larger than the mapped outcrop area, perhaps as a response to the wide aureole of fenitization around this massif (Ruberti 1984) or even an increase in size, at depth.

\section{The Itaiacoca Belt.}

The Itapirapuã shear zone, registered by a break in the magnetic pattern, appears as a rather continuous feature with low field intensities, especially in the central and northern regions (Figure 3); it is not visible in Figure 5, except very locally (e.g., near the locality of Dr. Ulysses). The Itaiacoca Belt shows a varying pattern, usually with low to very low intensities. The exception is a convoluted strip with moderate to high values, near Abapã, indicating the presence of the folded metavolcanic units (e.g., Figure 5; cf. also Figure 1).

\section{The Serra das Pedras Quartzite and the unit of schists and gneisses.}

The Serra das Pedras Quartzite, together with intermingled schists and gneisses (Figure 1) is only observed near the locality of E.X. Silva, marked by low intensities (Figures 3 and 5). The numerous "quartzite" outcrops within Cunhaporanga rocks are not registered, as well as the mappable "megaenclaves" of schists and gneisses, bolstering the interpretation that they represent roof pendants with a shallow root zone. 


\section{The Água Clara Formation}

Rocks of this formation are observed at the SE corner of the surveyed area, to the $E$ of the São Sebastião Granite, in Figure 5 (compare with Figure 2). The magnetic response suggests that this unit is not very thick.

\section{The Cunhaporanga Granitic Complex}

This Complex should stand out in the survey as positive anomalies, given the predominance of calc-alkaline granites. In Figure 3, however, most of the outcrop area of the Cunhaporanga Complex is covered by rather low intensity values. Some strips with high values are observed at the northern limit and between the localities of Castro and the differentiated Serra do Carambeí Granite, the last one is itself characterized by a striped pattern of high and low responses (Figure 3). In Figure 5, the Cunhaporanga Complex stands out as an area with high intensities, with the exception of low values to the north and an eastern irregular strip that runs parallel to the Itaiacoca belt, near Socavão; this strip is also characterized by low TC and Th values in the gammaradiometric survey (Guimarães et al. 1999). The Cunhaporanga granitoids that crop out to the north of Ouro Verde are identified by high intensity counts in Figure 5, in contrast to the low values found in Figure 3.

\section{The Três Córregos Granitic Complex}

This granitic complex should feature rather high intensity values, on account of its predominantly calc-alkaline nature. However, the magnetic responses are usually rather low, especially in the region that borders with the Itapirapuã shear zone (Figures 3 and 6), possibly because deformation transformed the primary magnetite into secondary minerals with low $\boldsymbol{k}$ values. Septa of the Água Clara Formation, included within the Três Córregos granites, may show up as isolated strips with low intensity. The hornblende-biotite porphyritic granitoids of the São Sebastião Granite are identified by moderate to high intensity values (Figures 3 and 5). A north-south wedge of the Três Córregos Complex within the Itaiacoca belt, bounded by faults on both sides (Figure 1), is pointed out in the magnetic survey by higher intensity (near Abapã; Figure 5). 


\section{The Castro Group}

An anomaly pattern with a N40E distribution is observed, with lower intensities to the $\mathrm{N}$ and $\mathrm{S}$, and higher values in the central part (Figures 3 and 5). The intermediate volcanic rocks, which should stand out as positive anomalies, are not registered. The observed magnetic pattern, on the other hand, is very similar to the Cunhaporanga responses, indicating that the Castro rocks may be present only as a rather thin cover.

\section{The sandstones of the Furnas Formation}

This formation shows, at the contact with basement rocks, a thickness of no more than $\sim 200 \mathrm{~m}$. As a result, the outline of the Paraná Basin is not visible in the maps of this survey. The registered pattern (Figures 3 and 5) indicates the structure and lithologies of the underlying basement rocks.

\section{The dikes of the Serra Geral Formation}

The uncorrected field intensity map (Figure 2) clearly shows a series of discontinuous streaks, aligned as 12 (or even more) discontinuous linear structures within the Cunhaporanga Complex. This pattern represents the location of uniformly distributed dikes (or dike swarms), with a common N45W orientation (very similar to that of the N3OW flight directions, hence the discontinuous pattern of the magnetic response). These features continue into the Itaiacoca belt and the Três Córregos rocks. To the NW, they cut rocks of the Castro Group, and extend well into the Paraná Basin (Figure 2). The numerous dikes, or dike swarms, shown in the magnetic map were not registered as such in geologic maps (Figure 1), especially in the lapó drainage basin, possibly on account of poor outcrops.

\section{The Banhadão alkaline massif}

A circular positive anomaly with an inner negative region, somewhat elongated to the NE, is observed close to the Banhadão massif, with an off-center negative core (RP, Figure 5). The cited elongation is the result of the cosine filter correction, enhancing the 
NE-streaking. It should be noted that the circular pattern is incomplete, being cut off by the eastern edge of the survey; a spurious pattern may emerge in such circumstances. On the other hand, in the reduction to the equator (Figure 6) the circular elongated pattern is still preserved, but now showing a negative rim and a positive off-center core. Under normal circunstances, this reversion in pattern should indicate the existence of an intrusive body with remanent magnetization (V. Shukowsky, pers. commun.). These observations suggest that the described pattern is really related to the presence of the Banhadão massif. The off-center position of the core in the RP and RE (Figures 5 and 6) can be explained either by positioning errors in the flight lines (cf. Methodology) and/or by an irregular distribution of magnetite- bearing rocks in the Banhadão stock. The structure, as a whole, should be two or three times as large as the outcrop pattern (Ruberti 1984; cf. also Guimarães et al. 1999).

\section{SUMMARY AND CONCLUDING REMARKS}

The prevailing NE-SW structural trend in the basement areas of the Ponta Grossa Arch dominates the magnetic anomaly pattern. The large Cunhaporanga and Três Córregos Granites, mainly constituted by magnetite-bearing calc-alkaline granitoids, should register as strong positive anomalies. Both granitic units, however, are characterized by a complex magnetic pattern, with positive anomalies intermingled with negative ones. In the Cunhaporanga granitoids, the reduction of the original high magnetic susceptibilities of the primary mineral assemblage to lower and sometimes even negative values can be explained by conversion of magnetite into hematite and/or Fe hydroxides. The causes are factors such as incipient metamorphism, deformation and deuteric-hydrothermal alteration, as attested by the unevenly distributed but very frequent occurrence of cataclastic to mylonitic bands, mica orientation, presence of prehnite, reddish to dark-grey colors of $K$ feldspars, and alteration of biotite and hornblende. The Três Córregos magnetic pattern is more complex (e.g., larger areas with negative anomalies in RP figures); even so, a similar explanation as for Cunhaporanga may be applied, although detailed petrographic-mineralogical data are still missing for Três Córregos. 
The Cunhaporanga peraluminous granitoids with muscovite and biotite show usually low susceptibility values and may have crystallized from magmas that assimilated peraluminous metasediments; they are mainly restricted to the intrusive contact with the mostly metasedimentary Itaiacoca Belt, appearing on the magnetic maps as a localized strip with low intensity values. Several mappable "quartzite" and schist-gneiss megaenclaves, within Cunhaporanga, are interpreted as roof-pendants with shallow roots; they are usually not registered as negative anomalies in the granites.

A marked break in the general magnetic pattern defines the presence of the regionally significant Itapirapuã shear belt, which separates Três Córregos granites from the Itaiacoca Belt. This belt, as expected, shows a uniform negative anomaly, with the exception of a convoluted positive pattern, to the $S$, indicating the presence of folded metavolcanic rocks with higher susceptibilities.

The Castro Group rocks present a striped magnetic pattern with a general N4OE orientation, that probably corresponds to that of the underlying Cunhaporanga granitic basement. Accordingly, the rocks of this Group may be far thinner than the total thickness cited in the literature $(>6000 \mathrm{~m})$, at the same doubling the size of the Cunhaporanga complex (e.g., Figure 5).

The dikes (or dike swarms) that appear at the apex and both flanks of the Ponta Grossa Arch are marked as a dozen linear "beaded" streaks in the uncorrected magnetic maps with the original response. These magnetic maps are compatible with the reported dike density (several per $\mathrm{km}$ ), both on the apex and flanks of the Ponta Grossa Arch.

A circular pattern, with an elongated circular positive ring and a negative offcenter core, marks the presence of the Banhadão alkaline massif (RP, Figure 5), and is reversed in the RE map (Figure 6), probably as a result of remanence. As also shown in gamma-radiometric maps, the size of the anomaly suggests that the intrusive body, at depth, must be much larger, an effect that may also originate on account of the observed fenite aureole surrounding the massif. 


\section{Acknowledgments}

F.F.J. F., G.B.G. and M.F. are thankful for the support given by the Federal University of Paraná (Curitiba). G.B.G. also thanks the Brazilian agency CAPES for a graduate scholarship. Financial support for field and, in part, laboratory work was given by FAPESP (to H.H.G.J.U.). Discussions with V.Schukowsky (IAG-USP) on the Banhadão pattern are gratefully acknowledged.

\section{REFERENCES}

BIONDI, J. C.; CAVA, L. T.; SOARES, P. C. - 1989 - Mapa Geológico do Estado do Paraná, 1: 650.000 . Brasília, MME/DNPM/MINEROPAR.

CCGP (Comissão da Carta Geológica do Paraná) - 1970 a - Folha Geológica Jaguariaíva-Sul, 1:70.000. Curitiba, CCGP.

CCGP - 1970 b - Folha Geológica de Serra das Antas, 1:70.000. Curitiba, CCGP.

CPRM (Companhia de Pesquisa de Recursos Minerais) - 1977 - Projeto Leste do

Paraná. Folha Piraí do Sul, 1:100.000. São Paulo, DNPM-CPRM-BADEP.

FERREIRA, F. J. F. \& ALGARTE, J. P. - 1979 - O comportamento aeromagnéticocintilométrico das principais rochas alcalinas dos Estados de São Paulo e Paraná. In: Simpósio Regional de Geologia, 2, Rio Claro, 1979. Atas... Rio Claro, SBG, 2: 195-208.

GIMENEZ FILHO, A. - 1993 - Evolução do Complexo Granítico Três Córregos a noroeste de Apiai, SP. MSc Thesis (unpubl.). São Paulo, Instituto de GeociênciasUSP, $118 p$.

GUIMARÃES, G. B. - 1995 - O Complexo Granítico Cunhaporanga na região de Joaquim Murtinho, Piraí do Sul (PR): Caracterização faciológica das rochas granitóides. MSc Thesis (unpubl.). São Paulo, Instituto de Geociências-USP, 144 p.

GUIMARÃES, G. B. \& ULBRICH, H. H. G. J. - 1996 - Redefinição e tipologia do Granito Joaquim Murtinho, Piraí do Sul (PR). In: Congr. Bras. Geol., 39, Salvador, 1996. Anais... Salvador, SBG, 6: 367-369.

GUIMARÃES, G. B.; FERREIRA, F. J. F.; ULBRICH, H. H. G. J.; FORLIN, M. - 1999 The airborne gamma-ray spectrometric survey of the Aerogeophysical Project Serra 
do Mar Sul in the region of the Cunhaporanga Granitic Complex, Paraná, southern Brazil. (Manuscript, submitted).

GUNN, P. - 1998 - Interpretation of airborne magnetic and radiometric surveys. Airborne Geophysics Group, Australian Geological Survey Organization, unpublished course notes.

LIU, S. \& MACKEY, T. - 1998 - Using images in a geological interpretation of magnetic data. Research Newsletters, Australian Geological Organization, 28: 17-19.

LUYENDYK, A. P. J. - 1997 - Processing of airborne magnetic data. AGSO Journal of Australian Geology \& Geophysics, 17: 31-38.

MARINI, O. J.; FUCK, R. A.; TREIN, E. - 1967 - Intrusivas básicas jurássico-cretácicas do primeiro planalto do Paraná. In: BIGARELLA, J. J., SALAMUNI, R., \& PINTO, V. M. (eds.) - 1967 - Geologia do Pré-Devoniano e intrusivas subseqüentes da porção oriental do estado do Paraná. Boletim Paranaense Geociências, 23/25, 307324.

MORO, R. de P. X. M. - 1993 - A Bacia ordoviciana do Grupo Castro - PR. MSc Thesis (unpubl.). Rio Claro, Instituto de Geociências e Ciências Exatas-Unesp, 157 p.

PINTO-COELHO, C. V. \& MARINI, O. J. - 1986 - Assinatura em elementos terras-raras (ETR) do Granito Serra do Carambeí (Paraná) e das rochas ígneas associadas. In: Congr. Bras. Geol., 34, Goiânia, 1986. Anais... Goiânia, SBG, 3: 1311-1321.

RENNE, P. M.; ERNESTO, M.; PACCA, I. G.; COE, R. S.; GLEN, J. M.; PREVOT, M.; PERRIN, M. - 1992 - The age of the Paraná flood volcanism, rifting of Gondwanaland, and the Jurassic-Cretaceous boundary. Science, 258: 975-979.

RENNE, P. M.; DECKART, K.; ERNESTO, M.; FÉRAUD, G.; PICCIRILLO, E. M. - 1996 - Age of the Ponta Grossa dike swarm (Brazil), and implications to Paraná flood volcanism. Earth Planetary Sciences Letters, 144: 199-211.

ROSALES, M. J. T. - 1999 - Caracterização geofísica do Complexo intrusivo ultrabásico-alcalino de Jacupiranga (SP). MSc. Thesis (unpublished). Instituto Astronômico e Geofísico-USP, $120 \mathrm{p}$.

RUBERTI, E. - 1984 - Petrologia do Maciço Alcalino de Banhadão. PhD Thesis (unpubl.). São Paulo, Instituto de Geociências-USP, 248 p. 
SILVA, D. C. da \& MANTOVANI, M. S. M. - 1994 - Projeto aerogeofísicó Serra do Mar Sul: uma abordagem semi-quantitativa. Revista Brasileira Geociências, 24 (2): 120-127.

TREIN, E. \& FUCK, R. A. - 1967 - O Grupo Castro. In: BIGARELLA, J. J.; SALAMUNI, R.; PINTO, V. M. (eds.) - 1967 - Geologia do Pré-Devoniano e intrusivas subseqüentes da porção oriental do estado do Paraná. Boletim Paranaense Geociências, 23/25, 257-305.

Table 1. Magnetic susceptibility $\boldsymbol{k}$ in Cunhaporanga granites

\begin{tabular}{|l|c|c|c|}
\hline \multicolumn{1}{|c|}{ Category } & $\boldsymbol{k}_{\min }$ & $\boldsymbol{k}_{\max }$ & $\boldsymbol{k}_{\text {mean }}$ \\
\hline & & & $19.8(80)$ \\
\hline Sphe-hbl-bio & 7.63 & 34.0 & $12.9(33)$ \\
\hline Sphe-bio & 5.57 & 23.4 & $7.10(15)$ \\
\hline Bio & 1.94 & 16.7 & $5.73(14)$ \\
\hline Musc-bio & 1.94 & 8.17 & $2.85(6)$ \\
\hline Holo & -0.00 & 9.55 & $0.77(6)$ \\
\hline Differ & 0.05 & 2.55 & $0.09(8)$ \\
\hline
\end{tabular}

Obs.: $\boldsymbol{k}$ values in $10^{-3} \mathrm{SI}$ units; minimum, maximum and mean $\boldsymbol{k}$ values are shown; in parenthesis, number of measured hand samples. 
Table 2. Geometric and intensity patterns of magnetic anomalies

\begin{tabular}{|c|c|c|c|}
\hline Anomaly type & Configuration & Variations & Geologic features \\
\hline $\operatorname{Dike}(s)^{\star}$ & Linear, $\mathrm{P}$ or $\mathrm{N}$ & "Beading" & $\begin{array}{l}\text { Dikes or dike } \\
\text { swarms (diabase, } \\
\text { basalt, etc.) }\end{array}$ \\
\hline Vertical prism* & $\begin{array}{l}\mathrm{P} \text {, round to } \\
\text { ellipsoidal shape }\end{array}$ & $\begin{array}{l}\text { Well-defined to } \\
\text { irregular borders }\end{array}$ & $\begin{array}{l}\text { Igneous felsic to } \\
\text { mafic plugs, stocks, } \\
\text { etc. }\end{array}$ \\
\hline Point-source ${ }^{*}$ & P, point-like & & $\begin{array}{l}\text { Small plugs, necks, } \\
\text { etc. }\end{array}$ \\
\hline $\begin{array}{l}\text { Areas of common } \\
\text { texture }\end{array}$ & $\begin{array}{l}\text { Irregular pattern } \\
\text { (streaks, areas, } \\
\text { etc.), either } \mathrm{P} \text { or } \mathrm{N} \text {, } \\
\text { or both }\end{array}$ & & $\begin{array}{l}\text { Flows, batholiths, } \\
\text { large stocks, etc.: } \\
\text { fractured, sheared, } \\
\text { many intrusions, } \\
\text { etc. }\end{array}$ \\
\hline $\begin{array}{l}\text { Narrow to sinuous } \\
\text { band }\end{array}$ & $\begin{array}{l}\text { Linear, convoluted, } \\
\text { folded, etc.; P or N, } \\
\text { or both }\end{array}$ & & $\begin{array}{l}\text { Paleochannels with } \\
\text { magnetic minerals; } \\
\text { folded rocks; etc. }\end{array}$ \\
\hline Faults & Linear, $\mathrm{P}$ or $\mathrm{N}$ & & $\begin{array}{l}\text { Enhanced by } \\
\text { presence of } \mathrm{Fe} \\
\text { minerals in fault } \\
\text { plane }\end{array}$ \\
\hline $\begin{array}{l}\text { Effects of } \\
\text { remanence }\end{array}$ & $\begin{array}{l}\mathrm{N}(\text { or } \mathrm{P} \text { ) circles or } \\
\text { areas, with } \mathrm{P} \text { (or } \mathrm{N} \text { ) } \\
\text { core }\end{array}$ & & $\begin{array}{l}\text { Stocks, plugs } \\
\text { (alkaline rocks, } \\
\text { carbonatites, etc.) }\end{array}$ \\
\hline $\begin{array}{l}\text { Regional } \\
\text { metamorphism }\end{array}$ & $\begin{array}{l}\text { Large (usually } \mathrm{P} \text { ) } \\
\text { irregular areas, } \\
\text { strips, etc. }\end{array}$ & & $\begin{array}{l}\text { Magnetisation } \\
\text { enhanced by } \\
\text { regional } \\
\text { metamorphism: } \\
\text { metasediments }\end{array}$ \\
\hline
\end{tabular}

Obs: P, N: positive or negative anomalies. Source: Gunn (1998). 
Figure 1. Regional geologic map of the basement of the Ponta Grossa Arch; the limits show the area covered by the Aerogeophysical Project Serra do Mar Sul. 1: Itaiacoca belt; 2: units of schists, gneisses and migmatites; 3: Serra das Pedras Quartzite; 4: Água Clara Formation; 5: Cunhaporanga Granitic Complex; 5a: Serra do Carambeí Granite; 5b: Joaquim Murtinho Granite; 6: Três Córregos Granitic Complex; 6a: São Sebastião Granite; 7: Castro Group;

8: Paraná Basin; 9: Banhadão alkaline massif; 10: alluvial deposits (based on an unpublished compilation by Guimarães 1997; simplified).
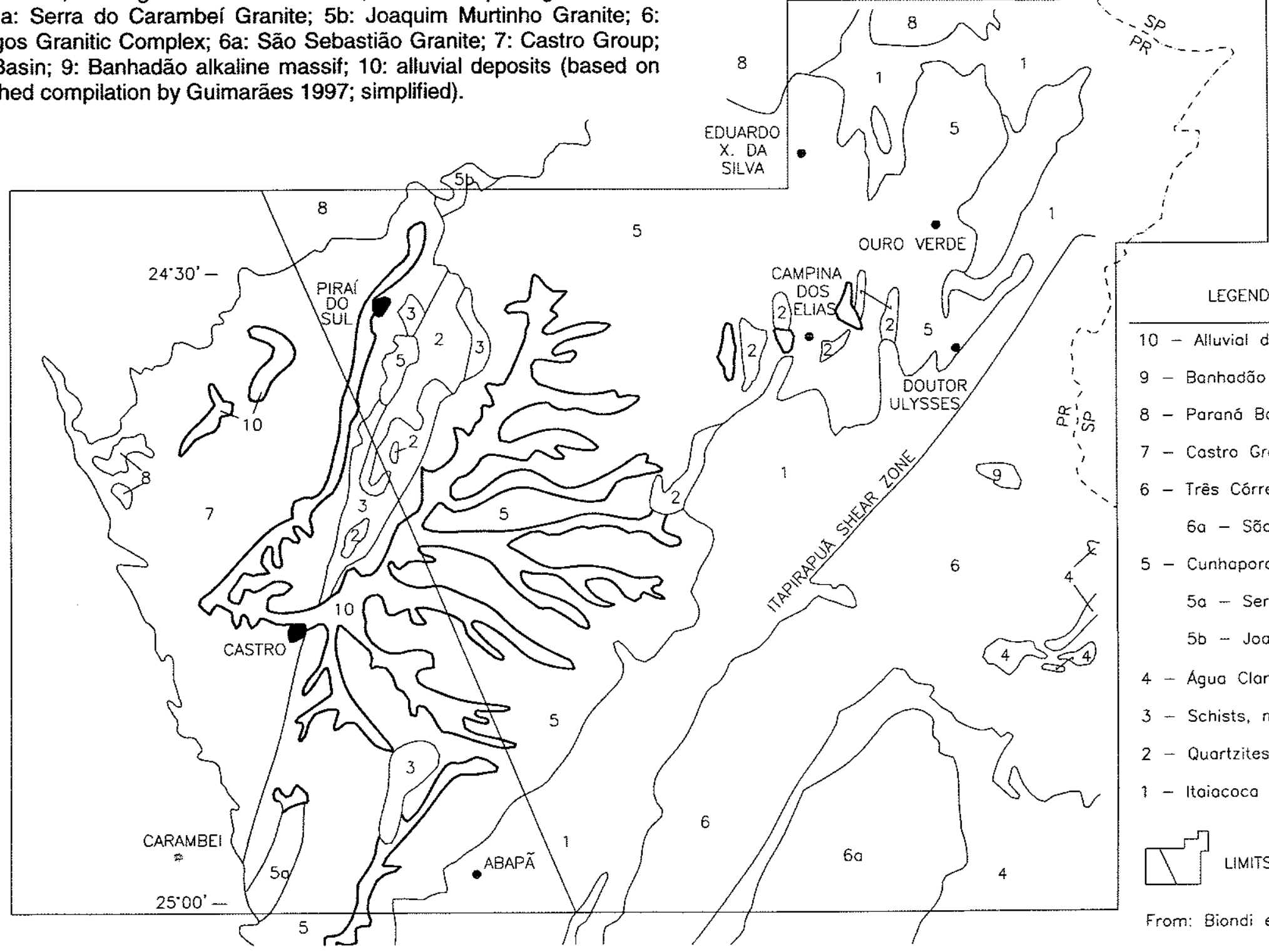

10 - Alluvial deposits

9 - Banhadão olkaline massif

8 - Paranó Basin

7 - Costro Group

6 - Três Córregos Granitic Complex

6a - São Sebastião Gronite

5 - Cunhoporango Gronitic Complex

5 a - Serra do Corambeí Granite

$5 b$ - Joaquim Murtinho Granite

4 - Água Clara Formation

3 - Schists, migmotites, etc...

2 - Quartzites

1 - Itaiacoca belt

]

IMITS OF APSMS

From: Biondi et. al. (1989) 


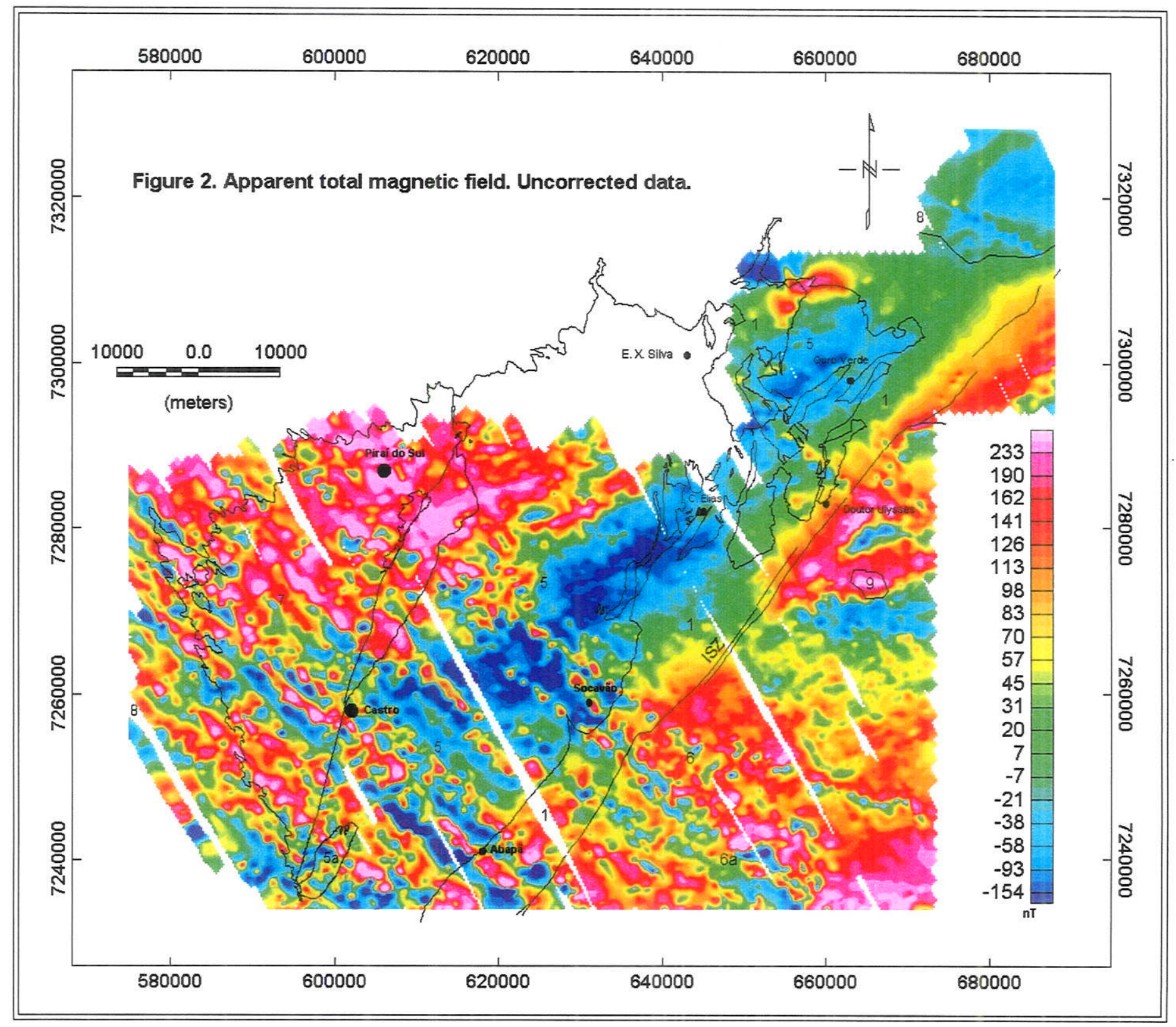




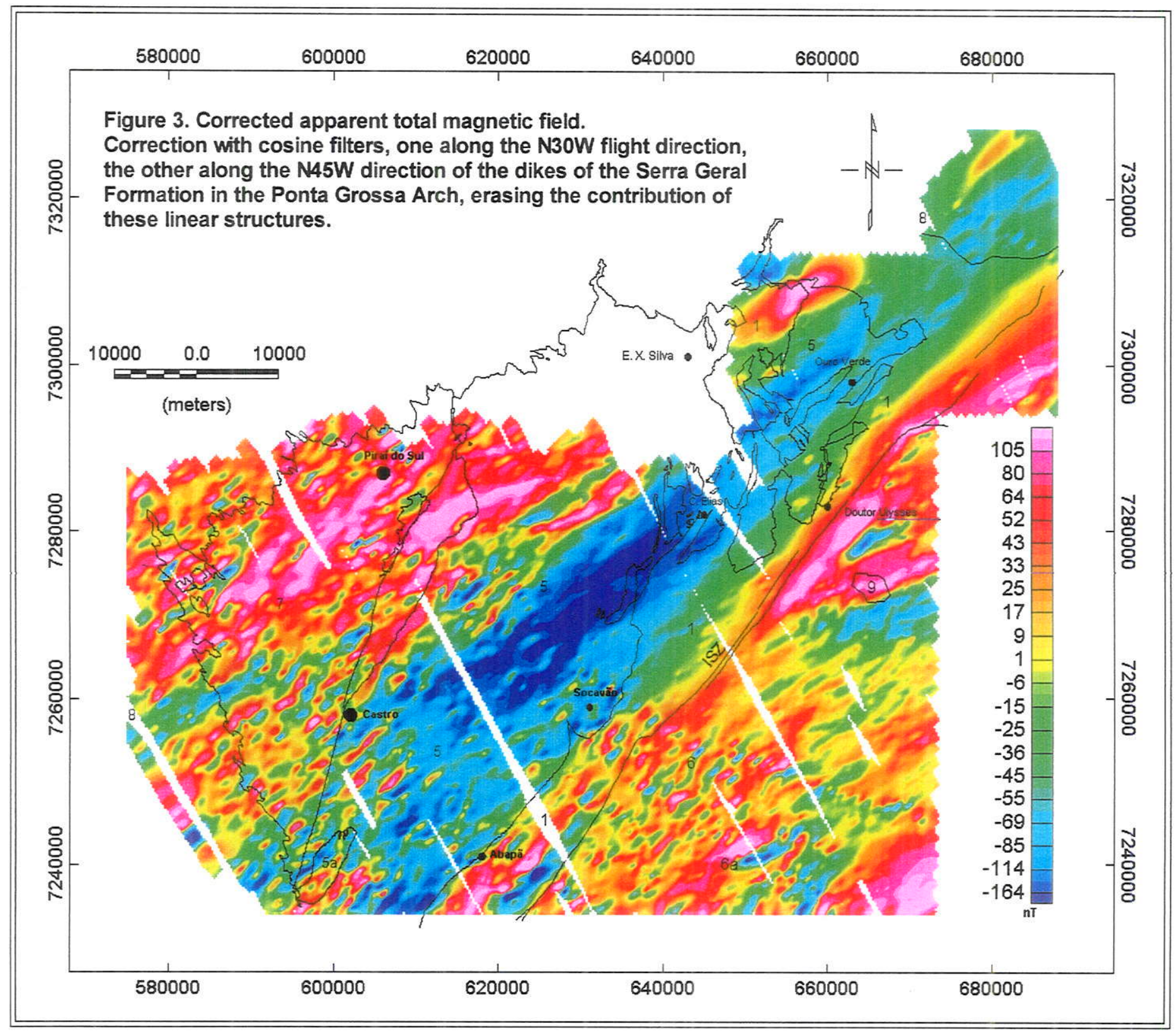




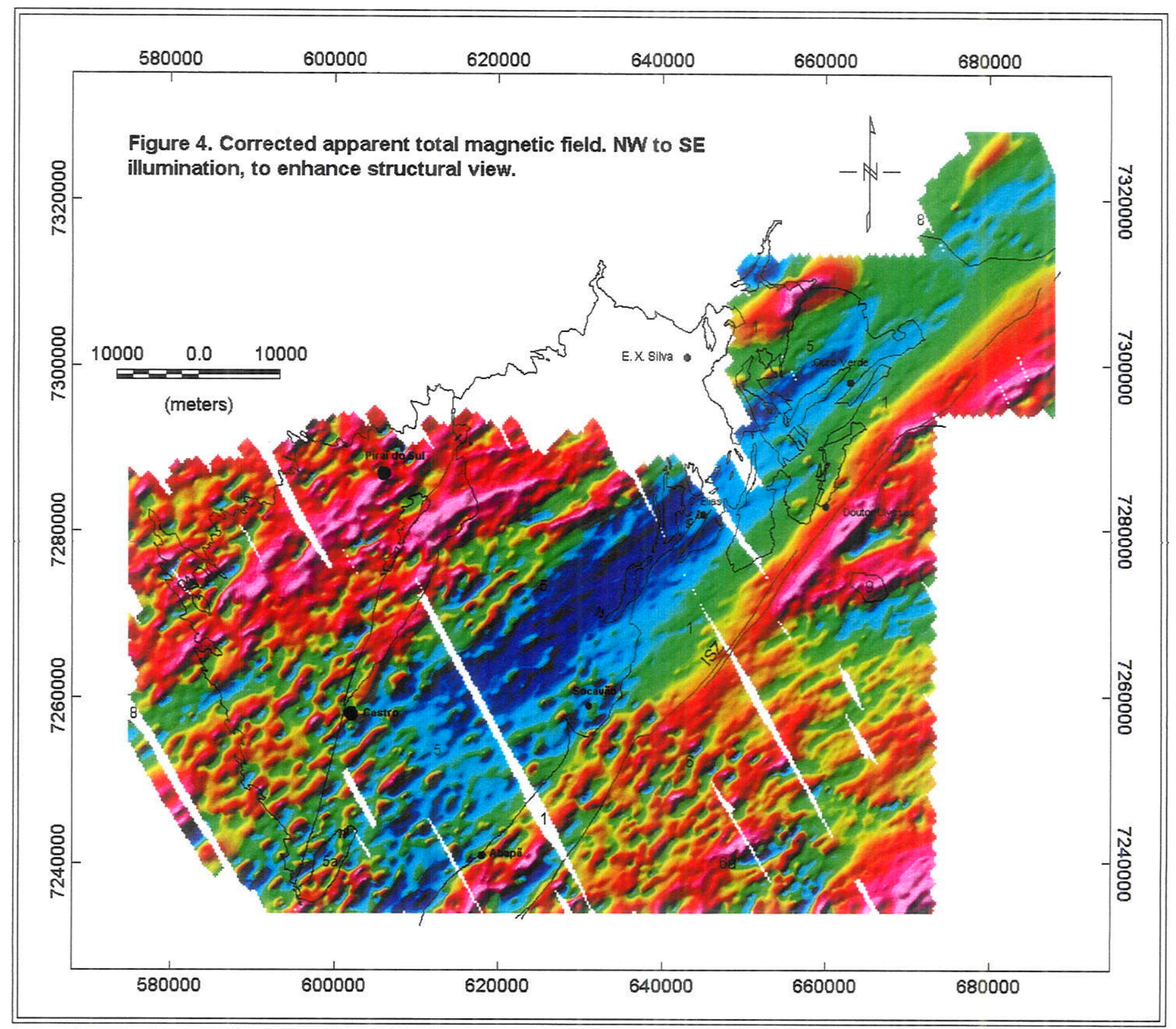




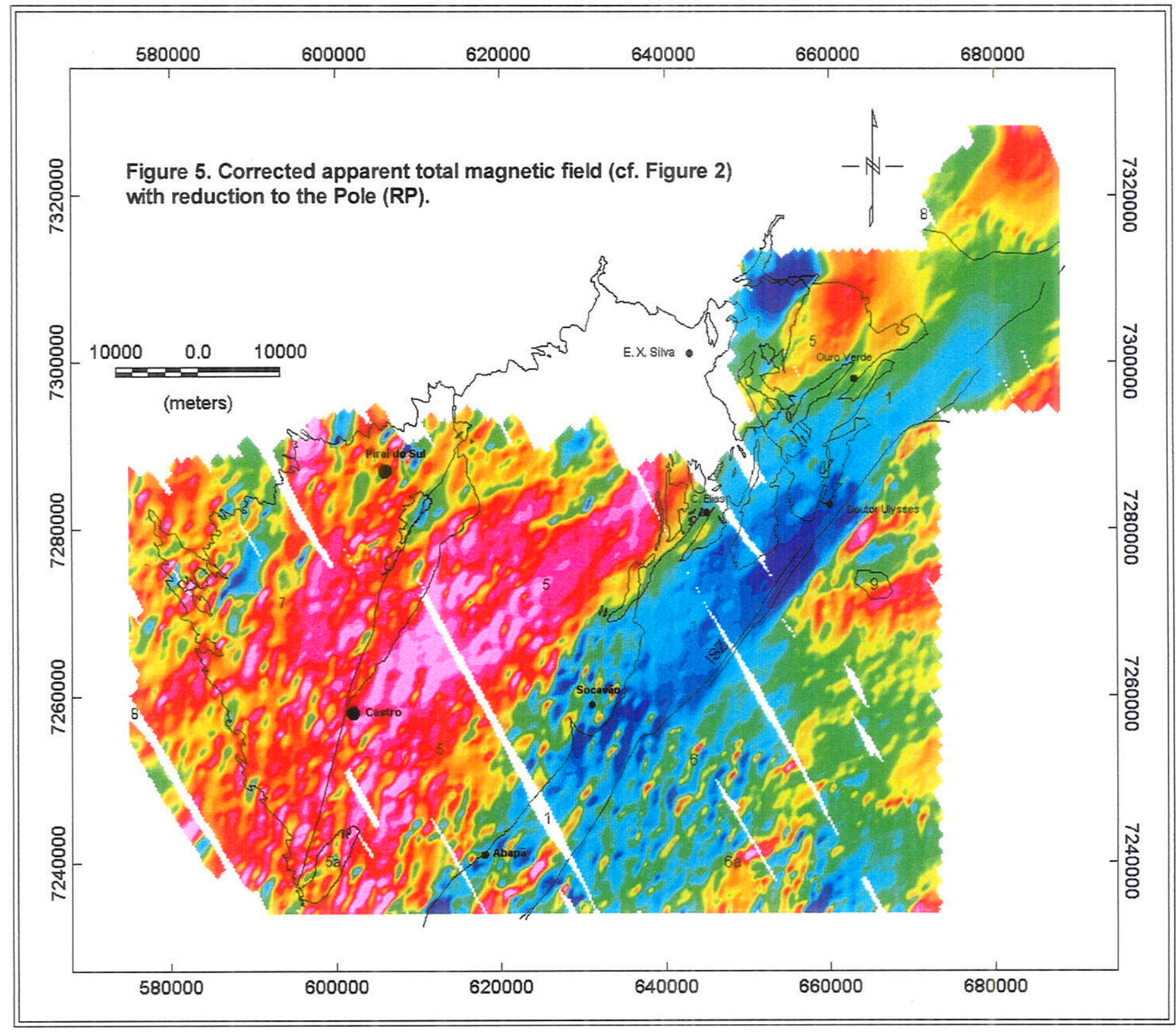




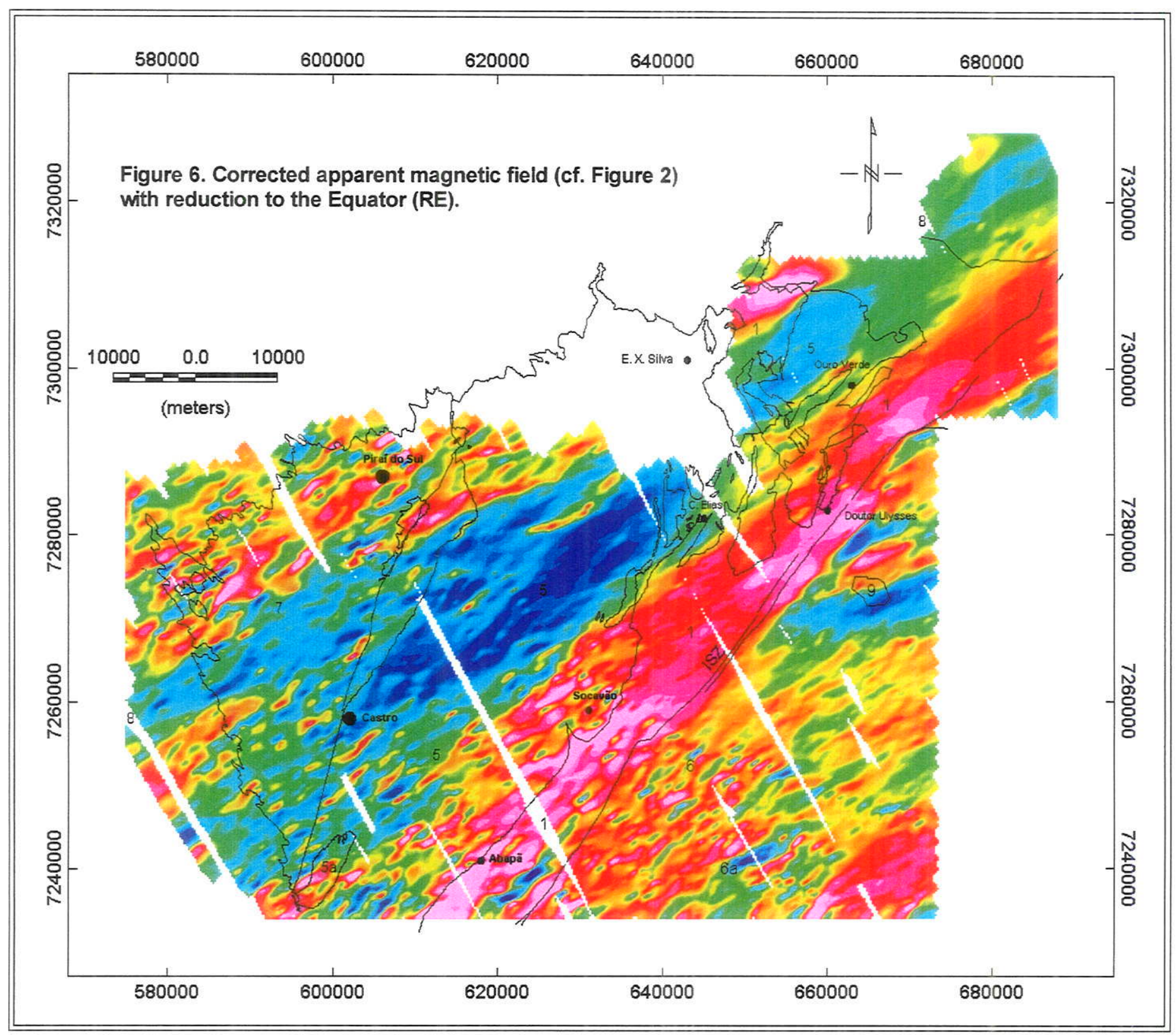




\title{
ANEXO 6
}

\section{Prehnita e outros silicatos secundários de Ca e Al em rochas granitóides do Complexo Granítico Cunhaporanga (PR)}

\author{
Gilson Burigo Guimarães ${ }^{1}$ e Horstpeter H. G. J. Ulbrich ${ }^{2}$
}

1. Departamento de Geociências, Universidade Estadual de Ponta Grossa, Paraná

2. Departamento de Mineralogia e Geotectônica, Instituto de Geociências, Universidade de São Paulo, São Paulo, Brasil

\section{ABSTRACT}

The Cunhaporanga Granitic Complex is a shallow-level batholith of the Neoproterozoic Ribeira Fold Belt, southern Brazil. Granitoid rocks comprise a dominant high-K calc-alkaline suite, including hornblende-biotite monzogranites and granodiorites, biotite monzo- (to syeno-) granites, and some equivalent dike porhyries. Minor amounts of muscovite-biotite monzogranites and granodiorites are related to local assimilation of country rocks. A distinctive group is made up of late minor intrusions of alkali feldspar granites (the Joaquim Murtinho and Serra do Carambei Granites).

Many Ca-rich granitoids present late $\mathrm{Ca}-\mathrm{Al}$ silicates: prehnite $\left(\sim 5.3 \% \mathrm{Fe}_{2} \mathrm{O}_{3}{ }^{\top}\right)$, hydrogarnet (grandite composition, with $\sim 1.6 \% \mathrm{~F}$ ), pumpellyite $\left(\sim 14.9 \% \mathrm{FeO}^{\top}\right)$ and epidote $\left(\sim 21.5 \% \mathrm{Fe}_{2} \mathrm{O}_{3}{ }^{\top}\right)$, either as single grains or intergrown with biotite (or chlorite); $\mathrm{Fe}^{3+}$ is predominant in these minerals.

The host granitoids have normally $>2 \%$ wt. $\mathrm{CaO}$ and $\mathrm{Ca} / \mathrm{Al}$ ratio $>0.25$. No CaAl silicates are found in Ca-poor more evolved rocks.

$\mathrm{Ca}-\mathrm{Al}$ silicates are produced by burial-like metamorphic conditions (involving reactions with $\mathrm{Ca}, \mathrm{Al}$ and $\mathrm{Fe}^{3+}$ from biotite and plagioclase), probably at $\mathrm{T}<300^{\circ} \mathrm{C}, \mathrm{P} \sim$ 2-3 kbar, and hydrous oxidizing conditions (no significant $\mathrm{CO}_{2}$ is present), prevailing during the near-surface cooling of granitoid rocks. 


\section{RESUMO}

O Complexo Granítico Cunhaporanga trata-se de um batólito neoproterozóico do Cinturão de Dobramentos Ribeira, sul do Brasil, cuja colocação ocorreu próxima da superfície. As rochas granitóides incluem uma suíte predominante de natureza cálcioalcalina de alto-K, formada por hornblenda biotita monzogranitos e granodioritos, biotita monzo- (a sieno)granitos, além de pórfiros de composição similar. Muscovita biotita monzogranitos a granodioritos subordinados estão relacionados à assimilação local de rochas encaixantes. Um grupo distinto de granitóides é dado por intrusões localizadas, tardias, de álcali-feldspato granitos (Granitos Joaquim Murtinho e Serra do Carambeí).

A maior parte dos granitóides mais ricos em $\mathrm{Ca}$ apresentam $\mathrm{Ca}-\mathrm{Al}$ silicatos secundários, com $\mathrm{Fe}^{3+}$ predominante: prehnita $\left(\sim 5,3 \% \mathrm{Fe}_{2} \mathrm{O}_{3}{ }^{\top}\right)$, hidrogranada (granditas com até $\sim 1,6 \% \mathrm{~F}$ ), pumpellyita $\left(\sim 14,9 \% \mathrm{FeO}^{\top}\right)$ e epidoto $\left(\sim 21,5 \% \mathrm{Fe}_{2} \mathrm{O}_{3}{ }^{\top}\right)$. Estes podem aparecer como grãos isolados ou intercrescidos com biotita e/ou clorita.

Os granitóides hospedeiros destes minerais secundários têm normalmente $>2 \%$ $\mathrm{CaO}$ e $\mathrm{Ca} / \mathrm{Al}$ mol. $>0,25$, não se encontrando $\mathrm{Ca}-\mathrm{Al}$ silicatos secundários em rochas mais evoluídas (empobrecidas em $\mathrm{Ca}$ ).

Os $\mathrm{Ca}$-Al silicatos secundários foram produzidos em condições equivalentes as do metamorfismo de carga, a partir de reações em que tomaram parte $\circ \mathrm{Ca}, \circ \mathrm{Al}$ e o $\mathrm{Fe}^{3+}$ da biotita e do plagioclásio. Estas reações provavelmente aconteceram durante 0 resfriamento das rochas granitóides próximo da superfície, sob condições de elevada fugacidade de $\mathrm{H}_{2} \mathrm{O}$ e $\mathrm{O}_{2}\left(T<300^{\circ} \mathrm{C}, \mathrm{P} \sim 2-3 \mathrm{kbar}\right.$ e com quantidades insignificantes de $\mathrm{CO}_{2}$ ).

\section{INTRODUÇÃo}

A prehnita, $\mathrm{Ca}_{2} \mathrm{Al}\left(\mathrm{AlSi}_{3} \mathrm{O}_{10}\right)(\mathrm{OH})_{2}$, normalmente ocorre como míneral índice no metamorfismo de carga de baixo grau, em rochas grauváquicas ou vulcânicas intermediárias a básicas, ou ainda como produto de cristalização hidrotermal em rochas ígneas básicas (e. g., Deer et al. 1992; Winkler 1991). Nas últimas décadas vários autores descreveram a presença de prehnita, junto com outros silicatos de $\mathrm{Ca}$ e $\mathrm{Al}$, em rochas granitóides, todos derivados da alteração de biotitas primárias (Wrucke 1965; Zeck 1971; Philips \& Rickwood 1975; Tulloch 1979; AIDahan 1989). Entre estes outros 
silicatos secundários, destacam-se a pumpellyita, a hidrogrossulária (ou hidrogranada) e minerais do grupo clinozoisita-epidoto (e. g., Tulloch 1979).

Neste trabalho são apresentados dados sobre a ocorrência de silicatos secundários de $\mathrm{Ca}$ e $\mathrm{Al}$ em rochas granitóides do Complexo Granítico Cunhaporanga. Este Complexo (Oliveira 1916; Fuck 1967; CPRM 1972) é constituído por rochas granitóides variadas, com intercalações e "roof pendants" de xistos e principalmente metarenitos/metarcósios do chamado "Quartzito Serra das Pedras". A unidade situa-se integralmente no estado do Paraná, sul do Brasil, ocupando uma superfície aflorante da ordem de $2500-3000 \mathrm{~km}^{2}$ (Figura 1). Orientada segundo $\mathrm{N} 30 \mathrm{E}$, aparece limitada a $E$ pelas rochas metassedimentares e metavulcânicas do Grupo Itaiacoca, no qual é intrusivo. Para $\mathrm{N}$ e SW, o Complexo é coberto pelos arenitos da Formação Furnas e, mais ao W, pela bacia vulcano-sedimentar molássica do Grupo Castro.

O conhecimento sobre o Complexo Cunhaporanga é precário, fundamentado em trabalhos gerais de reconhecimento. Os dados geocronológicos, ainda não definitivos, sugerem uma idade neoproterozóica do conjunto, que representaria a raiz de um arco magmático gerado durante o ciclo Brasiliano (e. g., Soares 1987; Reis Neto 1994).

\section{METODOLOGIA}

As observações a seguir estão baseadas em trabalhos de campo, incluindo uma coleta sistemática de amostras na maioria dos setores do Complexo Cunhaporanga e trabalhos de laboratório (estudo de lâminas petrográficas e análises químicas de rochas e minerais). As determinações analíticas dos minerais primários e secundários foram realizadas com a microssonda eletrônica Jeol JXA-8600S, do Departamento de Mineralogia e Geotectônica do IG-USP, aparelhada ainda com sistema EDS da NORAN e automatizada com o sistema NORAN-Voyager 4, incluindo o software PROZA para correções várias e o cálculo das proporções em peso e as catiônicas. Em análises de rotina são aplicados $15 \mathrm{KV}$ e $20 \mathrm{nA}$ de aceleração e corrente de feixe, com diâmetro de feixe de 1 a 5 micra para os minerais máficos e tempo de contagem geralmente de $20 \mathrm{~s}$. Os padrões utilizados foram a Albita Amelia para $\mathrm{Na}$, microclínio para $\mathrm{K}$, diopsídio sintético para $\mathrm{Si}, \mathrm{Ca}$ e $\mathrm{Mg}$; hornblenda Arenal para Al, olivina-Mn para 
Fe e Mn; fluorita e rutilo sintéticos respectivamente para $\mathrm{F}$ e Ti. As determinações em rochas dos elementos maiores, menores e de alguns traços foram realizadas em amostras moídas e abertas por fusão alcalina, no equipamento ICP-AES, do mesmo Departamento. A metodologia ICP-AES utilizada, bem como as correções para o efeito do "driff" instrumental, estão detalhadas em Janasi et al. (1995).

\section{PETROGRAFIA DAS ROCHAS GRANITÓIDES.}

Os trabalhos de campo permitiram identificar no Complexo Cunhaporanga um grande conjunto de fácies petrográficas intrusivas, geralmente monzogranitos e granodioritos, com quartzo monzodioritos e quartzo monzonitos subordinados; algumas rochas de dique são granito pórfiros a dacito ou riolito pórfiros, com matrizes freqüentemente finas até afaníticas. As rochas granitóides são ainda caracterizadas por variações na estrutura, textura e teores dos minerais máficos. Estas variedades podem ser reunidas em "tipos" ou linhagens petrográficas, definidas claramente pela associação de minerais máficos principais e acessórios. Assim, são definidos os "tipos" granitóides tipicamente cálcio-alcalinos, com hornblenda-biotita-titanita ou com titanitabiotita, os tipos meta- a peraluminosos com biotita (sem titanita) e com muscovitabiotita, além dos granitóides mais evoluídos, hololeucocráticos ("alasquíticos").

As rochas tipicamente cálcio-alcalinas são monzogranitos e granodioritos, em menor propoção quartzo monzonitos e quartzo monzodioritos, com estruturas primárias maciças e equigranulares médias ou grossas, com ou sem megacristais de feldspatos, apresentando freqüentes enclaves microgranulares intermediários ou básicos. Do ponto de vista geoquímico, estas rochas mostram-se normalmente com valores intermediários de $\mathrm{SiO}_{2}$ (até 67-68\%) e entre 14 e $17 \%$ de $\mathrm{Al}_{2} \mathrm{O}_{3}$, com $\mathrm{CaO}>2 \%$ e $\mathrm{MgO}$ ao redor de 1 a $3 \%$; são bastante ricas em $\mathrm{Na}_{2} \mathrm{O}$ (acima de $3 \%$ ) e estão também enriquecidas em $\mathrm{K}_{2} \mathrm{O}$, pertencendo à série de rochas de "alto potássio" (valores do óxido em geral $\geq 3 \%$ ). Entre os traços, destacam-se os valores relativamente altos do $\mathrm{Sr}$, do $\mathrm{Rb}$ e principalmente os do $\mathrm{Ba}$, preferencialmente contido nos feldspatos alcalinos (teor de celsiana de até $3 \%$ ). Algumas análises destes granitóides cálcioalcalinos são listadas na Tabela 1. 
As rochas mais evoluídas, incluindo as com biotita e sem titanita, são monzogranitos, granodioritos e quartzo monzonitos; a estrutura primária é maciça a levemente foliada, com granulação fina a média, com enclaves biotíticos freqüentes.

Os silicatos secundários de $\mathrm{Ca}$ e $\mathrm{Al}$ aparecem restritos aos tipos petrográficos relativamente ricos em $\mathrm{Ca}(\mathrm{CaO}>2 \%$ e Ca/Al $>0,25)$, estando ausentes nos granitóides mais evoluídos.

\section{MINERAIS DE ALTERAÇÃO.}

Os minerais primários mais importantes são os feldspatos e o quartzo e, em proporções variáveis, os minerais máficos hornblenda (em parte, com núcleos de clinopiroxênio), biotita e titanita, junto com apatita, zircão e fases opacas (magnetita e ilmenita). Estas rochas estão quase sempre alteradas em grau variável, em função da atuação de processos deutéricos e/ou hidrotermais e em parte mostrando sinais de deformação (em amostras de mão: presença de faixas cataclásticas ou miloníticas e orientação incipiente de biotitas; ao microscópio, moagem e quebra de fases primárias, exsoluções frequentes em feldspatos, etc.). A alteração não é homogênea, variando em escala de amostra de mão ou até na superfície da lâmina petrográfica observada.

As feições de alteração mais comumente observadas são a sericitização dos plagioclásios, marcada a forte, particularmente nas regiões mais cálcicas do núcleo e a cloritização de biotita primária, parcial ou até total. A clorita, em particular, aparece tipicamente como lâminas localizadas intersticialmente entre as clivagens das biotitas. Os silicatos secundários de Ca e Al também ocorrem entre as clivagens das biotitas, geralmente como cristais pouco desenvolvidos. A prehnita, em particular, forma agregados muto finos com hábito prismático, fusiforme, de "bow-tie" ou de "relógio de areia", tidos como típicos do mineral (e. g., Deer et al. 1992; Tröeger 1979); a biotita hospedeira (ou, no caso de alteração, a clorita secundária) aparece freqüentemente com as suas clivagens deformadas, adaptando-se ao contorno da prehnita. Os outros silicatos de $\mathrm{Ca}$ e $\mathrm{Al}$ aparecem como fases separadas, não associadas à prehnita: epidoto microgranular a prismático, pumpellyita granular-irregular e hidrogrossulária irregular a equidimensional. 
A prehnita, ortorrômbica, é incolor e mostra relevo positivo marcado, birrefringência de segunda ordem (por vezes com cores anômalas), clivagens em duas direções ortogonais e, eventualmente, geminação múltipla; a elongação, quando é possível a observação, é positiva. O epidoto, monoclínico, mostra cores suaves (em tons de amarelado ou esverdeado, com algum pleocroísmo, tanto mais forte quanto maior o teor de $\mathrm{Fe}$ ), relevo marcado, birrefringência baixa e freqüentemente anômala, com cores brilhantes; a extinção é reta (em seções prismáticas) e a elongação é ora positiva, ora negativa, sendo que o eixo óptico $\beta$ coincide com a máxima elongação dos prismas. A pumpellyita é monoclínica, com marcado relevo positivo e birrefringência baixa a forte, ambas propriedades incrementadas com o aumento no teor de $\mathrm{Fe}$; em lâmina é incolor a levemente esverdeada ou verde-azulada, podendo neste último caso mostrar ainda pleocroísmo moderado (ver Deer et al. 1992; Tröeger 1979). A hidrogranada mostra hábitos em geral não equidimensionais, relevo marcado $e$ geralmente birrefringência muito baixa; geminações do tipo setorial ou complexo são inexistentes.

O tamanho de grão destes minerais de alteração é em geral diminuto, de maneira que estas propriedades ópticas não podem ser sempre identificadas em lâmina; pelo mesmo motivo, dificilmente podem ser utilizadas, para fins de identificação, as diferenças existentes no sinal óptico e no valor do ângulo $2 \mathrm{~V}$ da prehnita, do epidoto e da pumpellyita.

\section{COMPOSIÇÃO QUÍMICA DOS MINERAIS SECUNDÁRIOS.}

As Tabelas 2 a 5 contêm os resultados analíticos e a fórmula estrutural dos silicatos secundários de $\mathrm{Ca}$ e Al dos granitóides do Complexo Cunhaporanga. Estes minerais ocorrem espalhados em todas as áreas do Complexo Cunhaporanga, sempre localizadas em granitóides tipicamente cálcio-alcalinos, mas faltando como minerais de alteração nas amostras de granitóides evoluídos.

Prehnitas. Para efeitos do cálculo estrutural das prehnitas, foi adotada a distribuição proposta por Zunic et al. (1990), que se baseia em refinamento no grupo ortorrômbico $P 2 \mathrm{~cm}$, apresentando três posições tetraédricas, $\mathrm{Si}(1), \mathrm{Si}(2)$ e $\mathrm{Al}(1)$, com distâncias 
médias $\mathrm{Si}$-O e Al-O de 1,60 $\AA, 1,63 \AA$ e $1,74 \AA$, respectivamente. O Al neste mineral, portanto, deve estar totalmente ordenado, confinado inteiramente (principalmente?) à posição $\mathrm{Al}(1)$. O alumínio octaédrico aparece contido na posição $\mathrm{Al}(2)$ (distâncias cátion-O em torno de 1,92 a $1,93 \AA$ ), enquanto que os cátions maiores estão na posição $\mathrm{Ca}$. As prehnitas mostram correlação inversa entre $\mathrm{Al}^{\mathrm{V} /}$ e $\mathrm{Fe}^{3+}$, comprovandose então que estes dois cátions ocupam a mesma posição $\mathrm{Al}(2)$. Segundo Deer et al. (1992), a posição do Al octaédrico deve aceitar até $\sim 16 \%$ de $\mathrm{Fe}^{3+}$ e deve também ser receptora do pouco $\mathrm{Ti}, \mathrm{Mn}$ e $\mathrm{Mg}$, da ordem de $<0,05 \%$, eventualmente encontrados nas prehnitas. As análises de prehnitas estão em geral prejudicadas pelo íntimo intercrescimento entre estas e as biotitas (e/ou cloritas) hospedeiras; por este motivo, valores maiores de $\mathrm{Mg}$, por vezes citados em determinações químicas, são devidos a "efeitos de matriz" por registrar o feixe da microssonda também a presença destes minerais, enquanto que teores mais elevados de Ti devem representar inclusões de ilmenita e/ou titanita (e. g., Tulloch 1979). Os cátions $\mathrm{K}$ e $\mathrm{Na}$ que são referidos em análises de prehnitas por microssonda (ver Tabela 2) provavelmente também representam "contaminação" por efeitos de matriz e devem ser descartados.

Com base na proposta de Zunic et al. (1990), a fórmula estrutural da prehnita é escrita como $X_{4} Y_{2}\left(Z_{8} \mathrm{O}_{20}\right)(\mathrm{OH})_{4}$, onde $X=4=\mathrm{Ca}, Y=2=\mathrm{Al}{ }^{\mathrm{VI}}+\mathrm{Fe}^{3+}+\mathrm{Mg}+\mathrm{Ti}+\mathrm{Mn}$, $Z=6 \mathrm{Si}+2 \mathrm{~A}^{\mathrm{IV}}=8$ (base de cálculo anidra: $22 \mathrm{O}$ ). Na Tabela 1 são mostrados os resultados para as prehnitas do Complexo Cunhaporanga. O cátion Si mostra valores com déficit, entre 5,75 e 5,99, que pode ser equilibrado com a inclusão de algum $A l^{\mathrm{IV}}$. Por este motivo, o $\mathrm{Al}^{\mathrm{IV}}$ mostra valores entre 2,01 e 2,25, algo maiores que os que deveriam caracterizar a ocupação na posição $\mathrm{Al}(1)=2$. $\quad \mathrm{OCa}$ ocupa sozinho praticamente toda a posição $X$ (valores entre 3,84 e 4,00). Fica também comprovado que, em prehnitas, $\mathrm{Fe}$ aparece totalmente como $\mathrm{Fe}^{3+}$, presente apenas na posição $Y$ (colunas 1 a 8; Tabela 2). A única exceção é a prehnita da coluna 9 , onde a posição $Y$ mostra um excesso de $\sim 0,50$ cátions e a $X$ um defeito equivalente. Portanto, parte do $\mathrm{Fe}^{3+}$ desta prehnita deve ser retirado da posição $Y$, para equilibrar, como $\mathrm{Fe}^{2+}, a$ posição $X$. Os resultados analíticos de Tulloch (1979) são, em geral, similares aos registrados para as prehnitas do Complexo (Tabela 2). 
Granadas. As granadas têm a fórmula estrutural geral $X_{3} Y_{2}\left(Z_{4}\right)_{3}$, onde $X$ são os cátions divalentes $\left(\mathrm{Fe}^{2+}, \mathrm{Mn}, \mathrm{Ca}, \mathrm{Mg}\right), Y$ os trivalentes $\left(\mathrm{Al}, \mathrm{Fe}^{3+}, \mathrm{Cr}^{3+}\right)$ e $Z$ os que ocupam posições tetraédricas (principalmente $\mathrm{Si}$, eventualmente também algum $\mathrm{Ti}$; Deer at al. 1992). Nestes minerais, o Al deveria estar ocupando unicamente posições octaédricas. As hidrogranadas, por outra parte, representariam, em geral, um termo composicional intermediário entre a grossulária, $3 \mathrm{CaO} \cdot \mathrm{Al}_{2} \mathrm{O}_{3} \cdot 3 \mathrm{SiO}_{2}$ e a hibschita ou plazolita, $3 \mathrm{CaO} \cdot \mathrm{Al}_{2} \mathrm{O}_{3} \cdot 2 \mathrm{SiO}_{2} \cdot 2 \mathrm{H}_{2} \mathrm{O}$. A fórmula proposta é escrita como $X_{3} \mathrm{Y}_{2}\left(\mathrm{ZO}_{4}\right)_{3}$ ${ }_{m}(\mathrm{OH})_{4 m}$, onde $X, Y$ e $Z$ representam os cátions da fórmula convencional (cf. Deer et al. 1992).

O cálculo da fórmula estrutural convencional das granadas deveria resultar em $\mathrm{Si}=6$ (para $\mathrm{O}=24$ ), mas nas hidrogranadas sempre aparece um déficit, que deve ser compensado em parte com $\mathrm{Ti}^{4+}$ em posição tetraédrica e por $4 \mathrm{H}$, puramente para efeitos de balanço de carga (e. g., Coombs, et al. 1977; ver Tabela 3). A maioria das hidrogranadas mostra $\mathrm{Fe}^{3+}$ substituindo $\mathrm{Al}$, formando portanto em parte a molécula da andradita. Na Tabela 3 são mostradas as determinações químicas de hidrogranadas dos granitóides Cunhaporanga e suas fórmulas estruturais, fazendo que $\mathrm{Si}+\mathrm{Ti}+\mathrm{H}_{4}=$ 6 e com $\circ \mathrm{Fe}^{3+}$ substituindo parcialmente o Al, com o eventual excesso calculado como $\mathrm{Fe}^{2+}$.

As fórmulas estruturais mostram sistematicamente um déficit em $\mathrm{Si}$, compensado com $\mathrm{Ti}_{\text {e }} \mathrm{H}_{4}$. O elevado teor de $\mathrm{Ti}$ detectado em algumas amostras do Complexo e da literatura deve-se provavelmente ao "efeito matriz", já citado, com o qual o mineral analisado incorpora sinais espúrios provindos de fases opacas, biotita, etc.: estas "hidrogranadas" com teores elevados de Ti teriam pouca $\mathrm{H}_{2} \mathrm{O}$, uma conclusão que é certamente errada (ver Tabela 3, colunas 5 e 7). Da mesma forma, as posições $X$ mostram também excessos sistemáticos, em boa parte devido ao elevado número de cátions $\mathrm{Ca}$ (ou perto de 6,0, ou com valores superiores a 6,0; Tabela 3). Estes resultados, mais que mostrar erros analíticos e/ou do "efeito matriz" da microssonda, devem-se provavelmente à falta de adequação da fórmula utilizada no cálculo para as hidrogranadas. $\mathrm{Na}$ e $\mathrm{K}$, freqüentemente registrados em pequenas quantidades em análises de microssonda, devem ser eliminados, já que não existem motivos cristaloquímicos para incorporar esses cátions na fórmula das granadas. 
Pumpellyitas. $\mathrm{Na}$ fórmula geral das pumpellyitas, $W_{8} X_{4} Y_{8} Z_{12} O_{56-n}(O H)_{n}$, W é uma posição, com coordenação 7, ocupada principalmente (unicamente?) por $\mathrm{Ca}, X$ e $Y$ são duas posições octaédricas independentes com cátions di-e trivalentes ( $\mathrm{Mg}, \mathrm{Al}, \mathrm{Fe}, \mathrm{Cr}$ e $\mathrm{Mn}$ ), e $Z$ é a posição tetraédrica com Si (e. g., Artioli \& Geiger 1994). O cátion predominante na posição $Y$ determina o nome do mineral: pumpellyita quando é Al, julgoldita quando $\mathrm{Fe}$, okhotskita quando $\mathrm{Mn}$ e shuikita quando $\mathrm{Cr}$. Ficou também estabelecido que $\mathrm{Mn}^{2+}$ e $\mathrm{Fe}^{2+}$ preferem a posição $X$, maior e mais simétrica, e $\mathrm{Mn}^{3+}$ e $\mathrm{Fe}^{3+}$ a posição $Y$ (Artioli \& Geiger 1994; Artioli et al. 1996). As fórmulas estruturais do mineral são em geral calculadas na base de 16 cátions, já que o número de oxigênios presente é variável (e. g., Artioli \& Geiger 1994; Artioli et al. 1996; referências na Tabela 4).

As determinações analíticas e fórmula estrutural de apenas uma pumpellyita, encontrada em granitóide de Cunhaporanga, junto com várias outras determinações da literatura, aparecem listadas na Tabela 4. Em pumpellyitas metamórficas, muito ricas em inclusões de outros minerais, encontra-se sistematicamente um excesso de Si na posição $Z$ (e. g., coluna 6 , Tabela 4), indicando contaminação, na contagem, por inclusões de quartzo (e. g., Coombs, et al. 1996); este excesso, desaparece, ou fica muito reduzido, nas análises de pumpellyitas encontradas em granitóides (e. g., colunas 1 até 5,7 até 9 ). Da mesma maneira que em prehnita e em granadas, o $\mathrm{Na} e$ o $\mathrm{K}$ detectados em análises de microssonda devem representar contaminação (e. g., da biotita hospedeira, ou inclusões de feldspatos, etc.). Nas análises listadas, aparecem apenas pequenas proporções de $\mathrm{Ti}$, sugerindo-se com isto que os grãos analisados não apresentavam inclusões de titanita, ilmenita, etc.

Epidotos. Os epidotos e clinozoisitas presentes como alteração em granitóides mostram composições entre os dois membros extremos clinozoisita, $\mathrm{Ca}_{2} \mathrm{Al}_{2} \mathrm{O}$.AlOH. $\left(\mathrm{Si}_{2} \mathrm{O}_{7}\right)\left(\mathrm{SiO}_{4}\right)$ e pistacita, $\mathrm{Ca}_{2} \mathrm{Al}_{2} \mathrm{O}$. $\left(\mathrm{Fe}^{3+}\right) \mathrm{OH} .\left(\mathrm{Si}_{2} \mathrm{O}_{7}\right)\left(\mathrm{SiO}_{4}\right)$. O silício aparece distribuído em grupos simples $\left(\mathrm{SiO}_{4}\right)$ e duplos $\left(\mathrm{Si}_{2} \mathrm{O}_{7}\right)$. Os outros cátions estão posicionados nas três posições octaédricas $M 1, M 2$ e $M 3$, com os octaedros $M 1$ e $M 2$ formando cadeias, os $\mathrm{M} 1$ também acompanhados pelos octaedros M3. Na clinozoisita, $\mathrm{Al}$ ocupa todas as posições octaédricas, enquanto que nos epidotos o Al ocupa preferencialmente $\mathrm{M} 1$ e $\mathrm{M} 2$, enquanto que a posição $\mathrm{M} 3$, com maior espaço e mais 
distorcida, é preferida por $\mathrm{Fe}^{3+}$ e $\mathrm{Mn}^{3+}$, além do $\mathrm{Al}$ restante. As posições $\mathrm{A} 1$ e $\mathrm{A} 2$, com coordenação 9 e 10, ocupam as largas cavidades deixadas pelas cadeias octaédricas $e$ os grupos tetraédricos, alojando o Ca (ver Dollase 1971; Deer et al. 1992). A passagem para allanita é marcada peloa substituição $\mathrm{Ca}+\mathrm{Fe}^{3+}=\mathrm{ETR}^{3+}+\mathrm{Fe}^{2+}$, onde os ETR ocupam principalmente as posições A2 (Deer et al. 1992). Com o incremento nos teores de $\mathrm{Mn}^{3+}$, o epidoto passa para piemontita. $\mathrm{K} \in \mathrm{Na}$ são normalmente indicados em análises de epidoto, mas devem corresponder, pelo menos em parte, a inclusões e/ou efeito de matriz, registrados pelo feixe de elétrons da microssonda.

As fórmulas estruturais são normalmente calculadas na base de $12,5 \mathrm{O}$, que correspondem à fórmula indicada acima. A distribuição dos cátions nos epidotos "normais" é realizada, na maioria das publicações, da seguinte maneira (e. g., Tulloch 1979). As posições tetraédricas $Z$ somam 3 , com um eventual defeito geralmente equilibrado pelo ingresso de $\mathrm{Al}^{\mathrm{lV}}$ (ver também Deer et al. 1992). As posições do Al e do $\mathrm{Fe}^{3+}$, aos quais é acrescentado o $\mathrm{Ti}$, são identificadas por $Z=3$. Nas posições $\mathrm{A} 1$ e $\mathrm{A} 2$, que hospedam $\circ \mathrm{Ca}$, inclue-se também $\circ \mathrm{Mn}, \mathrm{Mg}, \mathrm{Fe}^{2+}$ e outros cátions. Esta distribuição foi adotada na Tabela 5 , onde aparece listado apenas uma análise de epidoto de granitóides Cunhaporanga.

\section{AS REAÇÕES METAMÓRFICAS QUE ORIGINAM OS SILICATOS SECUNDÁRIOS DE Ca E AI.}

A prehnita, a pumpellyita, as hidrogranadas e 0 epidoto observados nos granitóides do Complexo Cunhaporanga aparecem como minerais não relacionados entre si, sistematicamente inclusos em biotitas, ora frescas, ora parcial ou totalmente cloritizadas. Por outra parte, são encontrados preferencialmente em granodioritos e monzogranitos e também em alguns pórfiros com anfibólio, caracterizados pela associação máfica titanita-anfibólio-biotita, que constituem em geral as rochas granitóides mais primitivas do conjunto e que mostram teores de $\mathrm{CaO}$ iguais ou superiores a $3 \%$ e $\mathrm{Al}_{2} \mathrm{O}_{3}$ em geral superiores a $14,5 \%$ (Tabela 1). Esses minerais de alteração não são encontrados nos granitóides mais evoluídos, os tipos com biotita ou com muscovita-biotita e os álcali-feldspato granitos, nos quais os teores de $\mathrm{CaO}$ são muito inferiores, sendo também menores os conteúdos de $\mathrm{Al}_{2} \mathrm{O}_{3}$. Estas observações, 
bem como as relações texturais, em parte mostradas nas Fotomicrografias 1 até 4 , permitem estabelecer alguns parâmetros para identificar as reações que geram em especial a prehnita e a pumpellyita, confirmando em geral as indicações da literatura:

1) As fugacidades de $\mathrm{H}_{2} \mathrm{O}$ e do $\mathrm{O}_{2}$ devem ser relativamente elevadas, já que os minerais citados são hidratados e com $\mathrm{Fe}^{3+}$;

2) não é possivel estabelecer, nos casos estudados, se clorita e prehnita coexistentes cristalizam ao mesmo tempo, ou se existe relação de reação entre elas;

3) em alguns casos, a prehnita e os silicatos congêneres, geram-se diretamente a partir da biotita;

4) não existem sinais macro- ou microscópicos de deformação, nem nos granitóides Cunhaporanga, nem nas unidades vizinhas posteriores (Grupo Castro).

Observações similares são citadas na literatura, formando a base para as propostas de reações que gerariam estes minerais em rochas graníticas, gnáissicas e dioríticas (e. g., Hall 1965; Zeck 1971; Phillips \& Rickwood 1975; Tulloch 1979; AIDahan 1989), parcialmente adaptadas da observação de reações em rochas vulcânicas básicas e similares (e. g., Papezik 1974; Nyström 1983; Jenkins \& Offler 1996; Coombs et al. 1996; dentre outros).

Estas feições indicam claramente que as reações metamórficas ocorrem em ambiente de pressão de carga (e não deformante), na presença de fluidos hidrotermais metassomatizantes, oxidantes e ricos em $\mathrm{H}_{2} \mathrm{O}$, carregados de $\mathrm{Ca}$ e que também se encarregam de transportar os cátions sobrantes, em particular $\mathrm{Mg}, \mathrm{Fe}, \mathrm{K}$ e eventualmente $\mathrm{Na}$. A presença desta alteração tão somente em rochas granitóides mais ricas em Ca (ver também Tulloch 1979) indica que o Ca é de origem local, provindo da alteração e/ou recristalização, principalmente, do plagioclásio da rocha hospedeira. Portanto, as equações que descrevem estas reações devem ser escritas considerando reagente (a biotita ou a clorita, dela derivada) e produto (a prehnita, etc.), 
porém com a participação de soluções hidrotermais, até porque elas ocorrem no interior do mineral sob alteração.

São pertinentes as observações petrográficas de AIDahan (1989) que relaciona a coexistência de prehnita e pumpellyita em granitóides pós-orogênicos (coexistência não observada em Cunhaporanga), à reação entre clorita e ilmenita:

1,2 Fe-Mg-Al-Ti clorita + ilmenita + $7 \mathrm{Ca}^{2+}+6,4 \mathrm{H}_{4} \mathrm{SiO}_{4}+3,1 \mathrm{O}_{2}=\mathrm{Ca}-\mathrm{Fe}-\mathrm{Mg}-\mathrm{Al}$ pumpellyita + prehnita + titanita $+0,12$ rutilo $+1,5 \mathrm{Fe}^{2+}+0,9 \mathrm{Mg}^{2+}+9,2 \mathrm{H}^{+}+6,1 \mathrm{H}_{2} \mathrm{O}$

onde a sílica é transportada em solução como ácido silicíco. Cátions como $\mathrm{Ca}$ e $\mathrm{Si}$ provém da alteração dos plagioclásios vizinhos, enquanto que $\mathrm{Fe}$ e Mg liberados são redistribuídos pela rocha. Uma reação similar ocorre nos granitóides pós-orogênicos estudados. A presença de pumpellyita em biotita, nesses mesmos granitóides pósorogênicos, é explicada pela seguinte reação:

3 biotita $+2 \mathrm{Ca}^{2+}+12,8 \mathrm{H}^{+}+1,9 \mathrm{O}_{2}=\mathrm{Ca}-\mathrm{Fe}-\mathrm{Mg}-\mathrm{Al}$ pumpellyita $+3 \mathrm{~K}^{+}+1,55 \mathrm{Fe}^{2+}+$ $3,55 \mathrm{Mg}^{2+}+0,9 \mathrm{Ti}^{4+} 3 \mathrm{H}_{4} \mathrm{SiO}_{4}+5,9 \mathrm{H}_{2} \mathrm{O}$

onde, outra vez, os cátions presentes na reação migram em soluções hidrotermais, percorrendo apenas distâncias muito pequenas (da ordem de micra até $\mathrm{mm}$ ou $\mathrm{cm}$ ); a interpretação de reações metamórficas por mecanismos como estes explicam porque estes minerais aparecem com variações extremas nas suas composições (e. g., teores de 3,6 até $10,1 \% \mathrm{Fe}_{2} \mathrm{O}_{3}$ num único grão de prehnita, não zonado; ver Nyström 1983).

A pumpellyita, por sua vez, passa rapidamente para epidoto com o aumento na fugacidade de $\mathrm{O}_{2}$ (AIDahan 1989).

Em rochas vulcânicas básicas-intermediárias, a seqüência no metamorfismo de carga é, com pressões ascendentes, da associação ou fácies com prehnita-pumpellyita a de pumpellyita-actinolita até a fácies xisto-verde (e. g., Papezik 1974; Turner 1981; Nyström 1983); freqüentemente, não ocorrem rochas com zeólitas, de grau metamórfico imediatamente inferior ao da fácies prehnita-pumpellyita. 
As temperaturas mínimas de cristalização de prehnitas são extremamente baixas, da ordem $\sim 100^{\circ} \mathrm{C}$ e os da pumpellyita algo maiores, em torno de $\sim 150^{\circ} \mathrm{C}$, para pressões de carga $\left(e\right.$ de $\mathrm{H}_{2} \mathrm{O}$ ) de 2 a $3 \mathrm{~Kb}$; provavelmente, as temperaturas de cristalização para a associação de prehnita-pumpellyita em rochas pelíticas e vulcânicas sejam da ordem de $250 \pm 50^{\circ} \mathrm{C}$ (e. g., Liou 1979; Liou et al. 1983; Nyström 1983; Coombs et al. 1996) chegando-se ao intervalo de $160-260^{\circ} \mathrm{C}$ com medições de reflectância da vitrinita (Jenkins \& Offler 1996).

Os estudos teóricos realizados por Digel \& Ghent (1994), com a construção de diagramas de fases de baixa temperatura para o sistema CaO-MgO- $\mathrm{Al}_{2} \mathrm{O}_{3}-\mathrm{SiO}_{2}-\mathrm{H}_{2} \mathrm{O}$ $\mathrm{CO}_{2}$, incluem os minerais de $\mathrm{Ca}$ e $\mathrm{Al}$ aqui citados e mostram que pumpellyita e em especial prehnita, tão somente são estáveis com pouca ou nenhuma participação do $\mathrm{CO}_{2}$ no fluido hidrotermal intersticial, com frações molares inferiores a 0,002 ! Estabiliza-se, com teores maiores de $\mathrm{CO}_{2}$, a associação epidoto-calcita-clorita, em detrimento da prehnita e da pumpellyita.

Condicões qualitativamente similares devem também ser aplicadas para os sistemas granitóides. Ou seja, prehnita deve ser estável em rochas feldspáticas e quartzo-feldspáticas a temperaturas baixas, sob pressões de fluidos hidrotermais intersticiais constituídos essencialmente por $\mathrm{H}_{2} \mathrm{O}$, da ordem de 2 a $3 \mathrm{Kbar}$, enquanto que pumpellyita deve ser um indicador de temperaturas ligeiramente maiores, provavelmente não superiores a 300 ou $350^{\circ} \mathrm{C}$. Nestas rochas, a presença de epidoto (+ calcita + clorita + quartzo + sericita) é indicativa de temperaturas também baixas, mas cristalizadas na presença de fluidos intersticiais algo mais ricos em $\mathrm{CO}_{2}$.

\section{O CONTEXTO GEOLÓGICO}

Os granitóides do estado de São Paulo invadem rochas metamórficas de grau médio a alto e neles são muito raros, ou eventualmente inexistentes, as alterações para prehnita e pumpellyita. O Complexo Cunhaporanga, pelo contrário, invade para $\mathrm{E} O$ Grupo Itaiacoca, com metassedimentos deformados, mas com estrutuas preservadas e 
ainda muito pouco metamorfoseados. No teto das intrusões são encontradas as rochas do "Quartzito Serra das Pedras", onde predominam metarcósios e metarenitos de grau muito baixo, também com as suas estruturas sedimentares preservadas. As considerações sobre as reações metamórficas, acima, mostram que a geração de prehnita e pumpellyita ocorre apenas quando água, quase sem $\mathrm{CO}_{2}$, circula como fluido intersticial e redistribui cátions, ingressando na biotita com $\mathrm{Ca}^{2+}$ e levando os sobrantes na forma de $\mathrm{K}^{+} e \mathrm{Mg}^{2+}$, sob condições de alta fugacidade de oxigênio. Eventualmente, o fluido intersticial também afasta $\circ \mathrm{Fe}^{2+}$ (ou $\mathrm{Fe}^{3+}$ ?) não utilizado nas reações.

O contexto geológico propício para estas condições deve ser o da parte final do "emplacemenf" do Complexo (provavelmente, uma colisão continental; e. g., Soares 1987, e vários outros autores), com a aparição no seu interior de feições cataclásticas e miloníticas, que acompanham o desenvolvimento, em regiões vizinhas, de zonas de cisalhamento (e. g., a de Itapirapuã). A profundidade atingida pelas invasões magmáticas não deve ter ultrapassado 5 a $7 \mathrm{~km}$, como evidenciado pelos dados das reações acima indicadas $\theta$, principalmente, pela aparição no próprio Complexo de granitóides de "epizona", de colocação rasa (e. g., os com texturas granofíricas, cavidades miarolíticas, etc.) e do baixo grau metamórfico mostrado pela Faixa invadida Itaiacoca. Neste caso, as águas intersticiais presentes são aquecidas, passando a formar parte do sistema de conveç̧ão que deve ser o mecanismo mais atuante e importante para resfriar a anomalia térmica representada pelo Complexo invasor. 


\section{REFERÊNCIAS BIBLIOGRÁFICAS}

ALDAHAN, A. A. - 1989 - The paragenesis of pumpellyite in granitic rocks from the Siljan area, central Sweden. Neues Jahrbuch für Mineralogie Monatshefte, 8: 367383.

ARTIOLI, G. \& GEIGER, C. A. - 1994 - The crystal chemistry of pumpellyite: an X-ray Rietveld refinement and ${ }^{57} \mathrm{Fe}$ Mössbauer study. Physics and Chemistry of Minerals, 20(7): 443-453.

ARTIOLI, G.; PAVESE, A.; BELLOTTO, M.; COLLINS, S. P.; LUCCHETTI, G. - 1996 Mn crystal chemistry in pumpellyite: a resonant scattering powder diffraction Rietveld study using synchrotron radiation. American Mineralogist, 81(5-6): 603-610.

COOMBS, D. S.; KAWACHI, Y.; FORD, P. B. -1996 - Porphyroblastic manganaxinite metapelagites with incipient garnet in prehnite-pumpellyite facies, near Meyers Pass, Torlesse Terrane, New Zealand. Journal of Metamorphic Geology, 14(2): 125-142.

COOMBS, D. S.; KAWACHI, Y.; HOUGHTON, B. F.; HYDEN, G.; PRINGLE, I. J.; WILLIAMS, J. G. - 1977 - Andradite and andradite-grossular solid solutions in very low-grade regionally metamorphosed rocks in southern New Zealand. Contributions to Mineralogy and Petrology, 63(3): 229-246.

CPRM (Companhia de Pesquisa de Recursos Minerais) - 1972 - Folha de Itararé.

Relatório geológico preliminar. São Paulo, DNPM-CPRM, vol. I, 202 p.

DEER, W. A.; HOWIE, R. A.; ZUSSMAN, J. - 1992 - An Introduction to the Rock-DIGEL, S. \& GHENT, E. D. - 1994 - Fluid-mineral equilibria in prehnite-pumpelleyite to greenschist facies metabasites near Flin Flon, Manitoba, Canada: implications for petrographic grids. Journal of Metamorphic Geology, 12: 467-477.

DOLLASE, W. A. - 1971 - Refinement of the crystal structures of epidote, allanite and hancockite. American Mineralogist, 56(3-4): 447-464.

FUCK, R. A. - 1967 - Geologia da Fôlha Abapã. Boletim Universidade Federal Paraná, Geologia, 25, $34 \mathrm{p}$.

GUIMARÃES, G. B. - 1995 - O Complexo Granítico Cunhaporanga na região de Joaquim Murtinho, Piraí do Sul (PR): Caracterização faciológica das rochas granitóides. Dissertação de Mestrado (inédita). São Paulo, Instituto de Geociências, USP, $144 \mathrm{p}$. 
HALL, A. - 1965 - The occurrence of prehnite in appinitic rocks from Donegal, Ireland. Mineralogical Magazine, 35(269): 234-236.

JANASI, V. A.; ANDRADE, S.; ULBRICH, H. H. G. J. - 1995 - A correção do drift instrumental em ICP-AES com espectrômetro seqüencial e a análise de elementos maiores, menores e traços em rochas. Bol. IG-USP, Série Científica., 26: 45-58.

JENKINS, R. B. \& OFFLER, R. - 1996 - Metamorphism and deformation of an Early Permian extensional basin sequence: the Manning Group, southern New England Orogen. Australian Journal of Earth Sciences, 43(4): 423-436.

LIOU, J. G. - 1971 - Synthesis and stability relations of prehnite, $\mathrm{Ca}_{2} \mathrm{Al}_{2} \mathrm{Si}_{3} \mathrm{O}_{10}(\mathrm{OH})_{2}$. American Mineralogist, 56(3-4): 507-531.

LIOU, J. G.; KIM, H. S.; MARUYAMA, S. - 1983 - Prehnite-epidote equilibria and their petrologic applications. Journal of Petrology, 24(4): 321-342.

NYSTRÖM, J. O. - 1983 - Pumpellyite-bearing rocks in central Sweden and extent of host rock alteration as a control of pumpellyite composition. Contributions to Mineralogy and Petrology, 83(1-2): 159-168.

OLIVEIRA, E. P. de - 1916 - Geologia do Estado do Paraná. Rio de Janeiro, Boletim do Ministerio da Agricultura, Industria e Commercio, 5(1): 67-143.

PAPEZIK, V. S. - 1974 - Prehnite-pumpellyite facies metamorphism of Late Precambrian rocks of the Avalon Peninsula, Newfoundland. Canadian Mineralogist, 12(7): 463-468.

PASSAGLIA, E. \& GOTTARDI, G. - 1973 - Crystal chemistry and nomenclature of pumpelleyites and julgoldites. Canadian Mineralogist, 12(3): 219-223.

PHILLIPS, E. R. \& RICKWOOD, P. C. - 1975 - The biotite-prehnite association. Lithos, 8(4): 275-281.

REIS NETO, J. M. - 1994 - Faixa Itaiacoca: registro de uma colisão entre dois blocos continentais no Neoproterozóico. Tese de Doutoramento (inédita). São Paulo, Instituto de Geociências-USP, 255 p.

SOARES, P. C. - 1987 - Seqüências tecto-sedimentares e tectônica deformadora no centro-oeste do escudo paranaense. In: Simp. Sul-Bras. Geol., 3, Curitiba, 1987. Atas... Curitiba, SBG, 2: 743-771.

TRÖEGER, W. E. - 1979 - Optical Determination of Rock-Forming Minerals. Schweizerbart'sche, Stuttgart, $188 \mathrm{p}$. 
TULLOCH, A. J. - 1979 - Secondary Ca-Al silicates as low-grade alteration products of granitoid biotite. Contributions to Mineralogy and Petrology, 69(2): 105-117.

TURNER, F. J. - 1981 - Metamorphic Petrology. McGraw-Hill, New York, 524 p.

WINKLER, H. G. F. - 1991 - Petrogenesis of Metamorphic Rocks. $6^{a}$. edição, revisão completa por K. Bucher \& M. Frey. Springer, New York, $318 \mathrm{p}$.

WRUCKE, C. T. - 1965 - Prehnite and hydrogarnet (?) in Precambrian rocks near Boulder, Colorado. U. S. Geological Survey Professional Paper, 525D: D55-D58.

ZECK, H. P. - 1971 - Prehnite-pumpellyite facies metamorphism in Precambrian basement rocks of $S$ Sweden. Contributions to Mineralogy and Petrology, 32(4): 307-314.

ZUNIC, T. B.; SCAVNICAR, S.; MOLIN, G. - 1990 - Crystal structure of prehnite from Komiza. European Journal of Mineralogy, 2(5): 731-734. 
Tabela 1: Análises químicas de algumas rochas cálcio-alcalinas do Complexo Cunhaporanga.

\begin{tabular}{|c|c|c|c|c|c|c|}
\hline Amostra & JGA-1 & $\mathrm{JGA}-4 \mathrm{c}$ & ITA-4-36 & PS-78 & ITA-2-100 & SC-77 \\
\hline $\mathrm{SiO}_{2}$ & 64,83 & 63,68 & 64,86 & 65,06 & 66,12 & 66,10 \\
\hline $\mathrm{Al}_{2} \mathrm{O}_{3}$ & 15,33 & 15,07 & 14,90 & 14,69 & 14,35 & 14,91 \\
\hline $\mathrm{TiO} 2$ & 0,83 & 0,76 & 0,78 & 0,80 & 0,81 & 0,81 \\
\hline $\mathrm{FeO}^{*}$ & & & & 2,28 & & \\
\hline $\mathrm{Fe}_{2} \mathrm{O}_{3}$ & & & & 1,58 & & \\
\hline $\mathrm{Fe}_{2} \mathrm{O}_{3}{ }^{\mathrm{T}}$ & 4,21 & 4,85 & 3,90 & 4,11 & 4,90 & 4,95 \\
\hline $\mathrm{MnO}$ & 0,07 & 0,09 & 0,06 & 0,06 & 0,08 & 0,08 \\
\hline $\mathrm{MgO}$ & 1,36 & 1,68 & 1,96 & 1,73 & 1,97 & 1,31 \\
\hline $\mathrm{CaO}$ & 2,94 & 3,45 & 2,95 & 3,17 & 3,60 & 3,78 \\
\hline $\mathrm{Na}_{2} \mathrm{O}$ & 3,93 & 3,25 & 3,19 & 3,42 & 3,24 & 3,00 \\
\hline $\mathrm{K}_{2} \mathrm{O}$ & 3,95 & 4,58 & 4,44 & 4,30 & 3,88 & 4,26 \\
\hline $\mathrm{P}_{2} \mathrm{O}_{5}$ & 0,33 & 0,33 & 0,28 & 0,27 & 0,24 & 0,27 \\
\hline PF & 1,04 & 1,19 & 1,67 & 0,79 & 1,38 & 1,14 \\
\hline Total & 98,80 & 98,83 & 98,79 & 98,14 & 100,57 & 100,17 \\
\hline $\mathrm{H}_{2} \mathrm{O}^{-}$ & 0,27 & 0,18 & 0,31 & 0,18 & 0,23 & 0,15 \\
\hline$\overline{\mathrm{Sr}}$ & 723 & 615 & 978 & 880 & 700 & 566 \\
\hline $\mathrm{Ba}$ & 1206 & 1048 & 1882 & 1431 & 999 & 1060 \\
\hline $\mathrm{Rb}$ & 119 & 157 & 102 & 123 & 135 & 148 \\
\hline
\end{tabular}

Obs.: $\mathrm{FeO}^{*}$ determinado por titração; $\mathrm{Fe}_{2} \mathrm{O}_{3}{ }^{\top}$ por espectrometria ICP-AES. Rochas são monzogranitos a granodioritos (modas). Ver Capítulo 6. 
Tabela 2: Prehnitas: determinações analíticas e fórmulas estruturais.

\begin{tabular}{|c|c|c|c|c|c|c|c|c|c|c|c|c|}
\hline & $\begin{array}{l}\text { ITA- } \\
2-100\end{array}$ & $\begin{array}{l}\text { ITA- } \\
2-100\end{array}$ & $\begin{array}{l}\text { ITA- } \\
2-100\end{array}$ & $\begin{array}{l}\text { ITA- } \\
2-100\end{array}$ & $\begin{array}{l}\text { ITA- } \\
2-100\end{array}$ & $\begin{array}{l}\text { ITA- } \\
2-100\end{array}$ & $\begin{array}{c}\text { JGA- } \\
1\end{array}$ & $\begin{array}{c}\text { JGA- } \\
4 \mathrm{c}\end{array}$ & $\begin{array}{l}\text { JGA- } \\
4 \mathrm{c}\end{array}$ & 45007 & 45006 & 45003 \\
\hline & 1 & 2 & 3 & 4 & 5 & 6 & 7 & 8 & 9 & 10 & 11 & 12 \\
\hline $\mathrm{SiO}_{2}$ & 42,92 & 41,64 & 41,95 & 42,90 & 42,29 & 42,39 & 42,74 & 42,19 & 40,85 & 41,82 & 42,75 & 40,76 \\
\hline $\mathrm{Al}_{2} \mathrm{O}_{3}$ & 21,77 & 22,01 & 19,93 & 22,23 & 21,46 & 20,91 & 22,47 & 21,07 & 21,59 & 23,03 & 21,68 & 19,59 \\
\hline $\mathrm{TiO}_{2}$ & 0,00 & 1,00 & 1,46 & 0,42 & 0,39 & 0,82 & 0,05 & 0,23 & 0,37 & 0,44 & 0,18 & 1,18 \\
\hline $\mathrm{Fe}_{2} \mathrm{O}_{3}$ & 5,12 & 4,76 & 6,20 & 4,52 & 5,79 & 5,44 & 2,76 & 6,15 & 6,63 & 1,69 & 4,41 & 6,85 \\
\hline $\mathrm{MnO}$ & 0,00 & 0,07 & 0,06 & 0,01 & 0,05 & 0,04 & 0,03 & 0,04 & 0,05 & 0,03 & 0,03 & 0,04 \\
\hline $\mathrm{MgO}$ & 0,01 & 0,31 & 0,10 & 0,01 & 0,21 & 0,01 & 0,05 & 0,48 & 2,04 & 0,08 & 0,01 & 0,01 \\
\hline $\mathrm{CaO}$ & 26,80 & 25,57 & 26,67 & 26,93 & 25,66 & 26,99 & 26,46 & 26,03 & 23,63 & 27,11 & 26,77 & 25,96 \\
\hline $\mathrm{Na}_{2} \mathrm{O}$ & 0,01 & 0,00 & 0,00 & 0,01 & 0,01 & 0,01 & 0,03 & 0,01 & 0,02 & 0,01 & 0,04 & 0,06 \\
\hline $\mathrm{K}_{2} \mathrm{O}$ & 0,02 & 0,03 & 0,03 & 0,00 & 0,02 & 0,01 & 0,12 & 0,00 & 0,09 & 0,01 & 0,01 & 0,01 \\
\hline$\Sigma$ & 96,65 & 95,39 & 96,40 & 97,03 & 95,88 & 96,62 & 94,74 & 96,20 & 95,27 & 94,21 & 95,87 & 95,23 \\
\hline$\widehat{\mathrm{Si}}$ & 5,94 & 5,83 & 5,87 & 5,91 & 5,91 & 5,90 & 5,99 & 5,89 & 5,75 & 5,89 & 5,96 & 5,83 \\
\hline $\mathrm{Al}^{\mathrm{N}}$ & 2,06 & 2,17 & 2,13 & 2,09 & 2,09 & 2,10 & 2,01 & 2,11 & 2,25 & 2,11 & 2,04 & 2,17 \\
\hline \multicolumn{13}{|l|}{$Z=8$} \\
\hline $\mathrm{Al}^{\mathrm{VI}}$ & 1,49 & 1,46 & 1,16 & 1,52 & 1,44 & 1,33 & 1,70 & 1,35 & 1,33 & 1,71 & 1,61 & 1,14 \\
\hline $\mathrm{Fe}^{3+}$ & 0,53 & 0,50 & 0,65 & 0,47 & 0,61 & 0,57 & 0,29 & 0,65 & 0,70 & 0,18 & 0,46 & 0,74 \\
\hline $\mathrm{Ti}$ & 0,00 & 0,11 & 0,15 & 0,04 & 0,04 & 0,09 & 0,01 & 0,02 & 0,04 & 0,05 & 0,02 & 0,13 \\
\hline $\mathrm{Mn}$ & 0,00 & 0,01 & 0,01 & 0,00 & 0,01 & 0,00 & 0,00 & 0,00 & 0,01 & 0,00 & 0,00 & 0,01 \\
\hline $\mathrm{Mg}$ & 0,00 & 0,06 & 0,02 & 0,00 & 0,00 & 0,04 & 0,01 & 0,10 & 0,43 & 0,02 & 0,00 & 0,02 \\
\hline$Y=2$ & 2,02 & 2,14 & 1,99 & 2,03 & 2,10 & 2,03 & 2,01 & 2,12 & 2,51 & 1,96 & 2,09 & 2,04 \\
\hline $\mathrm{Ca}$ & 3,98 & 3,84 & 4,00 & 3,97 & 3,84 & 4,02 & 3,97 & 3,89 & 3,56 & 4,09 & 3,99 & 4,03 \\
\hline$x=4$ & 3,98 & 3,84 & 4,00 & 3,97 & 3,84 & 4,02 & 3,97 & 3,89 & 3,56 & 4,09 & 3,99 & 4,03 \\
\hline$\Sigma$ & 14,00 & 13,98 & 13,99 & 14,00 & 13,94 & 14,05 & 13,98 & 14,01 & 14,07 & 14,05 & 14,08 & 14,07 \\
\hline
\end{tabular}

Base de cálculo: 22 O. Colunas 1 a 9: prehnitas de granitóides do Complexo Cunhaporanga; 10 a 12: prehnitas em granodioritos paleozóicos do batólito Karamea, ilha S da Nova Zelândia (Tulloch 1979). 
Tabela 3: Hidrogranadas: determinações analíticas e fórmulas estruturais.

\begin{tabular}{|c|c|c|c|c|c|c|c|c|c|}
\hline & PS-36 & PS-36 & PS-78 & $\mathrm{SC}-77$ & SC-77 & SC-77 & 45004 & 45003 & A \\
\hline & 1 & 2 & 3 & 4 & 5 & 6 & 7 & 8 & 9 \\
\hline $\mathrm{SiO}_{2}$ & 33,58 & 32,25 & 35,18 & 34,06 & 33,99 & 33,80 & 34,17 & 34,07 & 35,67 \\
\hline $\mathrm{Al}_{2} \mathrm{O}_{3}$ & 7,44 & 7,68 & 9,07 & 8,52 & 8,49 & 7,66 & 8,65 & 8,97 & 20,46 \\
\hline $\mathrm{TiO}_{2}$ & 0,73 & 0,14 & 0,63 & 1,30 & 2,15 & 1,11 & 2,11 & 0,65 & 0,30 \\
\hline $\mathrm{Fe}_{2} \mathrm{O}_{3}{ }^{*}$ & 19,82 & 20,17 & 18,04 & 18,48 & 17,06 & 19,05 & 16,18 & 18,17 & \\
\hline $\mathrm{Fe}_{2} \mathrm{O}_{3}{ }^{* *}$ & 19,40 & 18,59 & 17,90 & 18,27 & 17,06 & 19,05 & 16,18 & 17,55 & 1,53 \\
\hline $\mathrm{FeO}^{*+2}$ & 0,42 & 1,44 & 0,14 & $0,0,21$ & 0,00 & 0,00 & 0,00 & 0,57 & 0,30 \\
\hline $\mathrm{MnO}$ & 0,28 & 0,32 & 0,41 & 0,25 & 0,26 & 0,25 & 2,01 & 0,36 & 27,04 \\
\hline $\mathrm{MgO}$ & 0,19 & 0,04 & 0,56 & 0,72 & 0,95 & 0,02 & 0,07 & 0,25 & $\cdots$ \\
\hline $\mathrm{CaO}$ & 33,21 & 34,07 & 33,53 & 32,93 & 32,97 & 34,23 & 34,18 & 34,04 & 13,78 \\
\hline $\mathrm{Na}_{2} \mathrm{O}$ & 0,00 & 0,03 & 0,00 & 0,00 & 0,04 & 0,02 & 0,07 & 0,10 & $\ldots$ \\
\hline $\mathrm{K}_{2} \mathrm{O}$ & 0,07 & 0,02 & $\overline{0,02}$ & 0,03 & 0,04 & 0,00 & 0,04 & 0,05 & $\ldots$ \\
\hline $\mathrm{H}_{2} \mathrm{O}^{* *}$ & 0,52 & 1,28 & 0,32 & 0,39 & $\overline{0,40}$ & 0,44 & 0,40 & 0,68 & 1,22 \\
\hline$\sum^{*}$ & 95,32 & 94,72 & 97,44 & 96,29 & 95,95 & 96,14 & 97,55 & 96,66 & \\
\hline$\sum^{* *}$ & 95,84 & 95,86 & 97,76 & 96,68 & 96,35 & 96,58 & 97,88 & 97,29 & 100,30 \\
\hline $\mathrm{Si}$ & 5,76 & 5,61 & 5,83 & 5,73 & 5,72 & 5,74 & 5,71 & 5,73 & 5,64 \\
\hline $\mathrm{Ti}$ & 0,09 & 0,02 & 0,08 & 0,16 & 0,27 & 0,14 & 0,27 & 0,08 & 0,04 \\
\hline $\mathrm{H}_{4}$ & 0,15 & 0,37 & 0,09 & 0,11 & 0,01 & 0,12 & 0,01 & 0,19 & 0,32 \\
\hline \multicolumn{10}{|l|}{$Z=6$} \\
\hline $\mathrm{Al}^{\mathrm{VI}}$ & 1,50 & 1,57 & 1,77 & 1,69 & 1,68 & 1,53 & 1,71 & 1,78 & 3,82 \\
\hline $\mathrm{Fe}^{3+}$ & 2,50 & 2,43 & 2,23 & 2,31 & 2,16 & 2,43 & 2,03 & 2,22 & 0,18 \\
\hline$Y=4$ & 4,00 & 4,00 & 4,00 & 4,00 & 3,84 & 3,96 & 3,74 & 4,00 & 4,00 \\
\hline $\mathrm{Fe}^{2+}$ & 0,06 & 0,21 & 0,02 & 0,03 & $\ldots$ & --. & $\ldots$ & 0,08 & 0,04 \\
\hline $\mathrm{Mn}$ & 0,04 & 0,05 & 0,06 & 0,04 & 0,04 & 0,04 & 0,28 & 0,05 & 3,62 \\
\hline $\mathrm{Mg}$ & 0,05 & 0,01 & 0,14 & 0,18 & 0,24 & 0,01 & 0,02 & 0,06 & \\
\hline $\mathrm{Ca}$ & 6,10 & 6,35 & 5,95 & 5,94 & 5,95 & 6,23 & 6,12 & 6,13 & 2,34 \\
\hline$X=6$ & 6,25 & 6,62 & 6,15 & 6,19 & 6,23 & 6,28 & 6,42 & 6,32 & 6,00 \\
\hline$\sum=16$ & 16,12 & 16,26 & 16,08 & 16,09 & 16,08 & 16,13 & 16,17 & 16,17 & 16,00 \\
\hline
\end{tabular}

Base: 24 O. Colunas 1 a 6: granadas de granitóides do Complexo; 7 e 8: granadas em granodioritos, batólito Karamea, itha S da Nova Zelândia (Tulloch 1979); 9: Mn-hidrogranada em metassedimento pelágico, Meyers Pass, ilha $S$ da Nova Zelândia (Coombs et al. 1996). *: teores originais; **: valores calculados a partir da fórmula estrutural. 
Tabela 4: Pumpellyitas: determinações analíticas e fórmulas estruturais.

\begin{tabular}{|c|c|c|c|c|c|c|c|c|c|}
\hline & SC-77 & 54008 & $\begin{array}{c}\text { OJE- } \\
\text { HG 6B }\end{array}$ & $\begin{array}{c}\text { A462- } \\
\text { C1 }\end{array}$ & $\begin{array}{c}\text { A601- } \\
\text { A2 }\end{array}$ & 62091 & Srg 1 & G4341 & G5695 \\
\hline & 1 & 2 & 3 & 4 & 5 & 6 & 7 & 8 & 9 \\
\hline $\mathrm{SiO}_{2}$ & 35,52 & 35,12 & 35,75 & 36,24 & 36,40 & 39,50 & 34,91 & 36,30 & 35,11 \\
\hline $\mathrm{Al}_{2} \mathrm{O}_{3}$ & 16,12 & 14,65 & 16,96 & 22,73 & 25,02 & 24,70 & 8,80 & 15,81 & 13,58 \\
\hline $\mathrm{TiO}_{2}$ & 0,21 & 0,03 & 0,05 & 0,00 & 0,06 & 0,29 & 0,34 & 0,56 & 0,12 \\
\hline $\mathrm{Fe}_{2} \mathrm{O}_{3}$ & 14,39 & 19,12 & & & & & & & \\
\hline $\mathrm{FeO}$ & & & 15,92 & 7,57 & 4,87 & 3,56 & 26,42 & 15,96 & 19,43 \\
\hline $\mathrm{MnO}$ & 0,06 & 0,11 & 0,19 & 0,15 & 0,07 & 0,11 & 0,03 & 0,13 & 0,09 \\
\hline $\mathrm{MgO}$ & 2,37 & 2,02 & 1,70 & 2,66 & 3,52 & 2,67 & 0,65 & 2,20 & 2,05 \\
\hline $\mathrm{CaO}$ & 21,66 & 22,42 & 21,47 & 22,09 & 21,83 & 22,27 & 21,80 & 22,33 & 22,16 \\
\hline $\mathrm{Na}_{2} \mathrm{O}$ & 0,05 & 0,03 & 0,01 & 0,03 & 0,04 & 0,06 & & & \\
\hline $\mathrm{K}_{2} \mathrm{O}$ & 0,00 & 0,00 & 0,00 & 0,00 & 0,01 & 0,08 & & & \\
\hline$\Sigma$ & 90,38 & 93,49 & 92,05 & 91,47 & 91,82 & 93,24 & 93,05 & 93,27 & 92,54 \\
\hline $\mathrm{Si}$ & 6,08 & 5,88 & 6,03 & 5,97 & 5,90 & 6,34 & 6,06 & 6,12 & 6,03 \\
\hline $\mathrm{Al}^{\mathrm{N}}$ & & 0,12 & & 0,03 & 0,10 & & & & \\
\hline$Z=6$ & 6,08 & 6,00 & 6,03 & 6,00 & 6,00 & 6,34 & 6,06 & 6,12 & 6,03 \\
\hline $\mathrm{Al}^{\mathrm{VI}}$ & 3,25 & 2,77 & 3,37 & 4,00 & 3,99 & 3,98 & 1,83 & 3,14 & 2,69 \\
\hline $\mathrm{Ti}$ & 0,03 & 0,00 & 0,01 & $\cdots$ & 0,01 & 0,03 & 0,04 & & 0,01 \\
\hline $\mathrm{Fe}^{3+}$ & 0,72 & 1,23 & 0,62 & -- & & & 2,18 & 0,88 & 1,26 \\
\hline$Y=4$ & 4,01 & 4,00 & 4,00 & 4,00 & 4,00 & 4,01 & 4,05 & 4,02 & 3,96 \\
\hline $\mathrm{Al}$ & & & 0,00 & 0,38 & 0,79 & 0,69 & & & \\
\hline $\mathrm{Fe}^{2+}$ & 1,34 & 1,45 & 1,63 & 1,04 & 0,66 & 0,48 & 1,66 & 1,34 & 1,47 \\
\hline $\mathrm{Mg}$ & $.0,60$ & 0,50 & 0,43 & 0,65 & 0,85 & 0,64 & 0,17 & 0,51 & 0,50 \\
\hline $\mathrm{Mn}$ & 0,01 & 0,02 & 0,03 & 0,02 & 0,01 & 0,01 & & 0,01 & 0,02 \\
\hline$X=2$ & 1,95 & 1,97 & 2,09 & 2,09 & 2,31 & 1,82 & 1,83 & 1,86 & 1,99 \\
\hline $\mathrm{Ca}$ & 3,98 & 4,02 & 3,88 & 3,91 & 3,79 & 3,83 & 4,06 & 4,00 & 4,02 \\
\hline$W=4$ & 3,98 & 4,02 & 3,88 & 3,91 & 3,79 & 3,83 & 4,06 & 4,00 & 4,02 \\
\hline$\sum=16$ & 16,00 & 16,00 & 16,00 & 16,00 & 16,00 & 16,00 & 16,00 & 16,002 & 16,00 \\
\hline
\end{tabular}

Base: 16 cátions. $\mathrm{FeO}$ ou $\mathrm{Fe}_{2} \mathrm{O}_{3}$ : total. Coluna 1: pumpellyita em granitóides Complexo; 2: em granodioritos, batólito Karamea, itha S da Nova Zelândia (Tulloch 1979); 3, 4 e 5: em rochas vulcânicas básicas a intermediárias, Proterozóico da Suécia central (Nyström, 1983); 6: em metargilito e metagrauvaca, com inclusões de quartzo; Meyers Pass, ilha $S$ da Nova Zelândia (Coombs et al. 1996); 7, 8 e 9: em granitóides proterozóicos tardi (Srg) a pós-tectônicos (amostras G), Suécia central (AIDahan 1989). 
Tabela 5. Epidoto: determinações analíticas e fórmulas estruturais.

\begin{tabular}{|c|c|c|c|c|}
\hline & ITA-4-36 & 45003 & 45004 & 45016 \\
\hline & 1 & 2 & 3 & 4 \\
\hline $\mathrm{SiO}_{2}$ & 35,87 & 36,07 & 36,95 & 36,96 \\
\hline $\mathrm{Al}_{2} \mathrm{O}_{3}$ & 16,24 & 18,93 & 17,91 & 16,08 \\
\hline $\mathrm{TiO}_{2}$ & 0,10 & 2,01 & 0,18 & 0,50 \\
\hline $\mathrm{Fe}_{2} \mathrm{O}_{3}(\mathrm{t})$ & 21,46 & 17,39 & 20,37 & 23,06 \\
\hline $\mathrm{MnO}$ & 0,02 & 0,41 & 0,13 & 0,10 \\
\hline $\mathrm{MgO}$ & 0,03 & 0,09 & 0,01 & 0,03 \\
\hline $\mathrm{CaO}$ & 21,73 & 22,38 & 22,41 & 22,02 \\
\hline $\mathrm{Na}_{2} \mathrm{O}$ & 0,00 & 0,10 & 0,00 & 0,02 \\
\hline $\mathrm{K}_{2} \mathrm{O}$ & 0,01 & 0,08 & 0,01 & 0,02 \\
\hline$\Sigma$ & 95,52 & 97,47 & 97,97 & 98,79 \\
\hline $\mathrm{Si}$ & 3,03 & 2,95 & 3,02 & 3,02 \\
\hline $\mathrm{Al}^{\mathrm{IV}}$ & & 0,05 & & \\
\hline$Z=\mathbf{3}$ & 3,03 & 3,00 & 3,02 & 3,02 \\
\hline $\mathrm{Al}^{\mathrm{VI}}$ & 1,61 & 1,76 & 1,72 & 1,55 \\
\hline $\mathrm{Ti}$ & 0,01 & 0,12 & 0,01 & 0,03 \\
\hline $\mathrm{Fe}^{3+}$ & 1,36 & 1,07 & 1,25 & 1,42 \\
\hline$Y=3$ & 2,98 & 2,95 & 2,98 & 3,00 \\
\hline $\mathrm{Mn}$ & 0,00 & 0,03 & 0,01 & 0,01 \\
\hline $\mathrm{Mg}$ & 0,00 & 0,01 & 0,00 & 0,00 \\
\hline $\mathrm{Ca}$ & 1,97 & 1,96 & 1,96 & 1,93 \\
\hline$X, W=2$ & 1,97 & 2.00 & 1,97 & 1,94 \\
\hline$\Sigma=8$ & 7,98 & 7,95 & 7,97 & 7,96 \\
\hline
\end{tabular}

Base: 12.5 O. Coluna 1: epidoto em granitóides do Complexo Cunhaporanga; 3,4 e 5 : em granodioritos, batólito Karamea, N. Zelândia (Tulloch 1979). 


\section{ANEXO 7}

Equações utilizadas para as estimativas de pressão $(\boldsymbol{P})$ e temperatura $(\boldsymbol{T})$ do item 6.4, do Capítulo 6

$$
P( \pm 0,5 \mathrm{kbar})=-3,46+4,23 A^{\text {lot }} \quad(\text { eq. 6.1) }
$$

$$
P( \pm 0,6 \mathrm{kbar})=-3,01+4,76 A^{\text {fot }} \quad \text { (eq. 6.2) }
$$

$\boldsymbol{P}( \pm 0,6 \mathrm{kbar})=-3,01+4,76 \mathrm{~A}^{\prime \text { ot }}-\left\{\left[T\left({ }^{\circ} \mathrm{C}\right)-675\right] / 85\right\} \times\left\{0,530 \mathrm{~A}^{\text {(ot }}+0,005294\left[\boldsymbol{T}\left({ }^{\circ} \mathrm{C}\right)-675\right]\right\} \quad$ (eq. 6.3)

$$
T( \pm 75 \mathrm{~K})=\frac{0,677 P-48,98+Y}{-0,0429-0,008314 \ln K} \quad \text { (eq. 6.4) }
$$

$K=\underline{S i-4} X_{A b}$

8-Si

se $X_{A b}>0,5$ então $Y=0$

se $X_{A B}<0,5$ então $Y=-8,06+25,5\left(1-X_{A B}\right)^{2}$

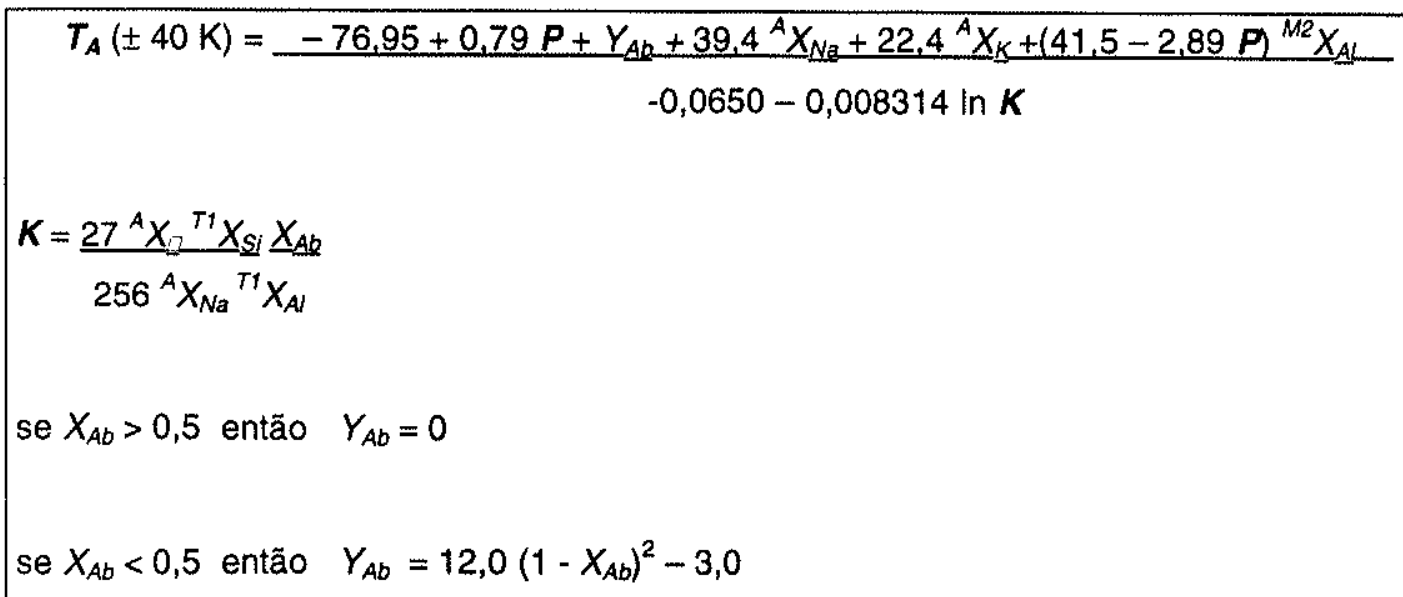




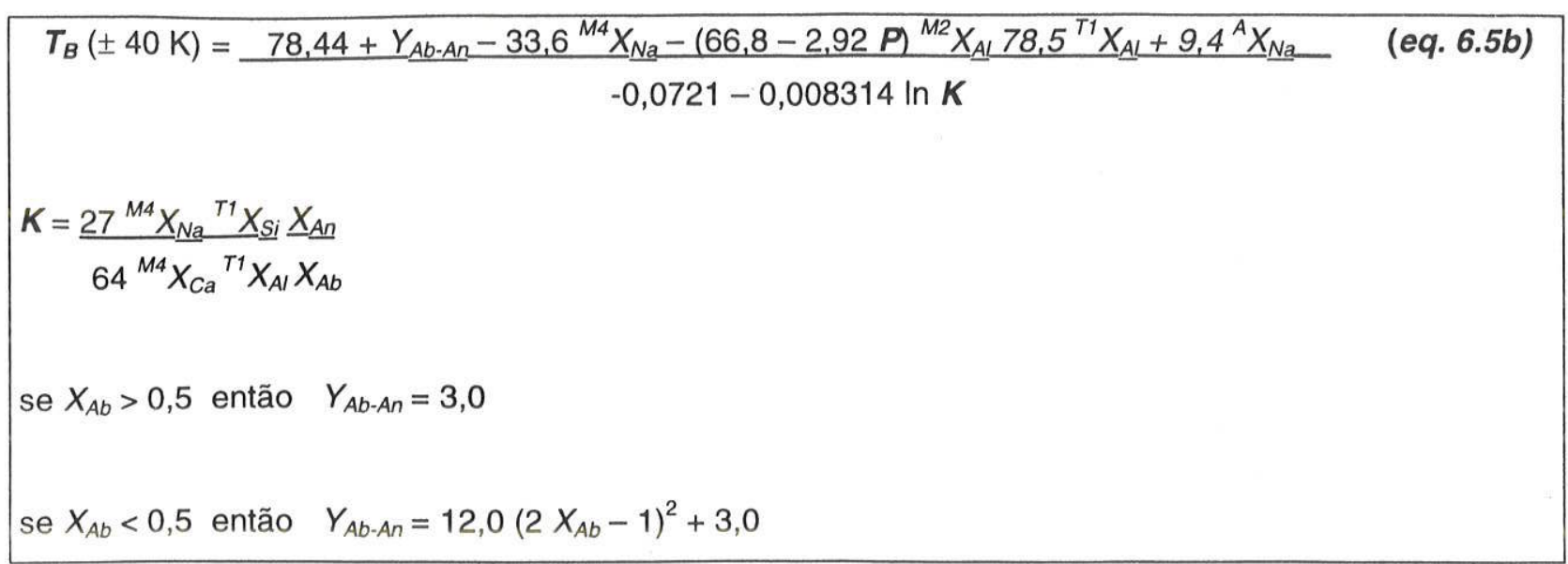

$$
\ln D_{z r}=\{-3,80-[0,85(M-1)]\}+12900 / T(K) \quad M=(N a+K+2 C a) /(A / \times S I) \quad \text { (eq. 6.6) }
$$

$$
\ln D_{P}=\left(\left\{8400+\left[2,64 \times 10^{4}\left(\mathrm{SiO}_{2}-0,5\right)\right]\right\} / T(\mathrm{~K})\right)-\left(3,1+\left\{12,4\left[\mathrm{SiO}_{2}-0,5\right]\right\}\right) \quad \text { (eq. 6.7) }
$$

onde os símbolos para cada equação, além de $\boldsymbol{T}$ para temperatuta e $\boldsymbol{P}$ para pressão, são:

eqs. 6.1, 6.2 e 6.3: $A t^{\text {tot }}$ é a quantidade total de alumínio por fórmula estrutural (p.f.e.) de anfibólio

eq. 6.4: Si é o silício p.f.e. de anfibólio; $X_{A b}$ é a fração molar da molécula albita em plagioclásio

eq. 6.5: $T_{A}$ é o geotermômetro edenita-tremolita; $T_{B}$ é o geotermômetro edenitarichterita; ${ }^{T 1} X_{S i}=(S i-4) / 4 ;{ }^{T 1} X_{A l}=(8-S i) / 4 ;{ }^{M 2} X_{A l}=(A l+S i-8) / 2 ;{ }^{A} X_{K}=K$; ${ }^{A} X_{-3}=3-\mathrm{Na}-\mathrm{K}-\mathrm{cm} ;{ }^{A} X_{\mathrm{Na}}=\mathrm{Ca}+\mathrm{Na}+\mathrm{cm}-2 ;{ }^{M 4} X_{\mathrm{Na}}=(2-\mathrm{Ca}-\mathrm{cm}) / 2 ;$ ${ }^{M 4} X_{C a}=C a / 2 ; \mathrm{cm}=\mathrm{Si}+\mathrm{Al}+\mathrm{Ti}+\mathrm{Fe}^{3+}+\mathrm{Mg}+\mathrm{Mn}-13,0 ; \mathrm{Si}, \mathrm{Al}, \mathrm{Ti}, \mathrm{Fe}^{3+}, \mathrm{Mg}$, $\mathrm{Mn}, \mathrm{Ca}, \mathrm{Na}$ e $\mathrm{K}$ são as quantidades destes elementos p.f.e de anfibólio; $X_{A b}$ é a fração molar da molécula albita em plagioclásio; $X_{A n}$ é a fração molar da molécula anortita em plagioclásio

eq. 6.6: $D_{Z r}$ é o coeficiente de partição do zircônio entre o zircão e o magma; $\mathrm{Na}, \mathrm{K}, \mathrm{Ca}$ e $A$ l representam as quantidades atômicas de sódio, potássio, cálcio e alumínio na rocha

eq. 6.7: $D_{P}$ é o coeficiente de partição do fósforo entre a apatita e o líquido magmático; $\mathrm{SiO}_{2}$ é o teor de óxido de silício na rocha 
- Os dados geoquímicos sugerem para o quadro evolutivo do Complexo Cunhaporanga um ambiente de arco vulcânico para a formação dos granitóides "cálcio-alcalinos", mas um posicionamento tardio para os granitóides da linhagem alasquítica (pós-orogênico). 


\section{ANEXO 3: UNIDADES LITOESTRATIGRÁFICAS} DO COMPLEXO GRANÍTICO

CUNHAPORANGA

0.12345

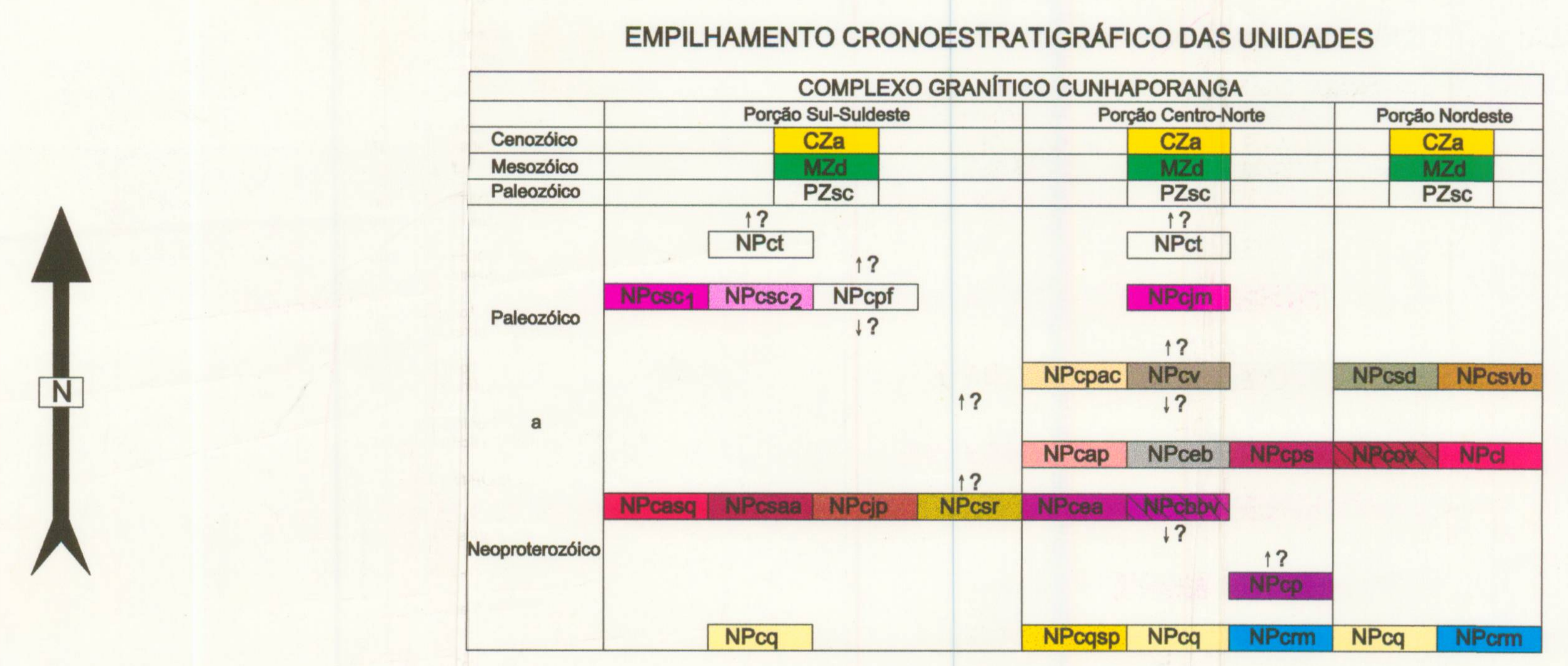

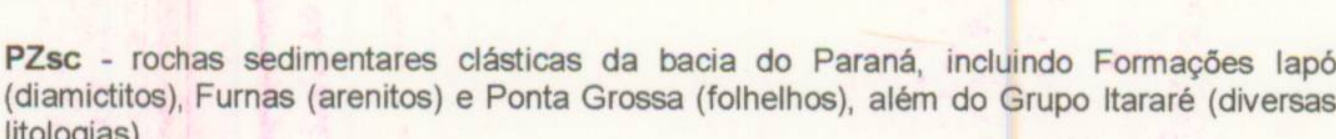

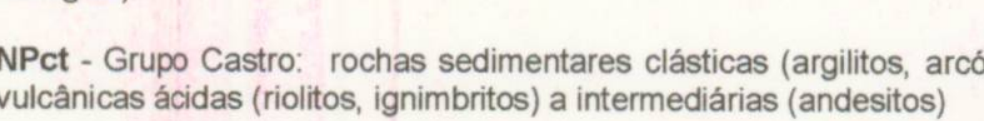

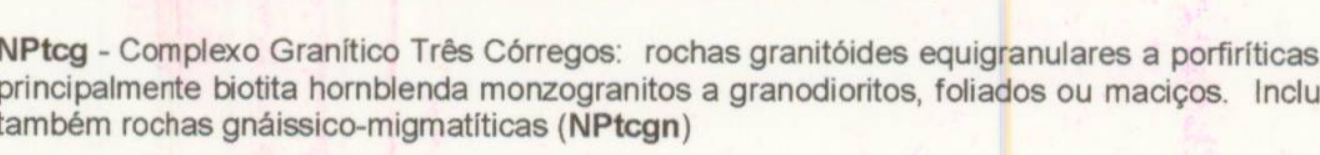

Smplexo G Grantitico Cunnaporarat

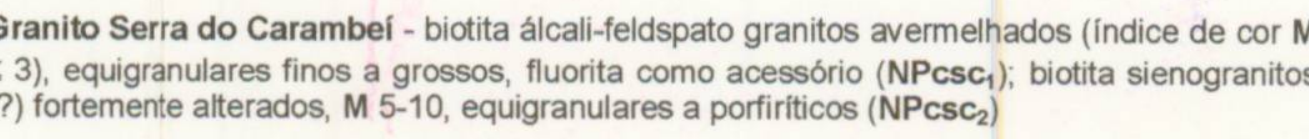

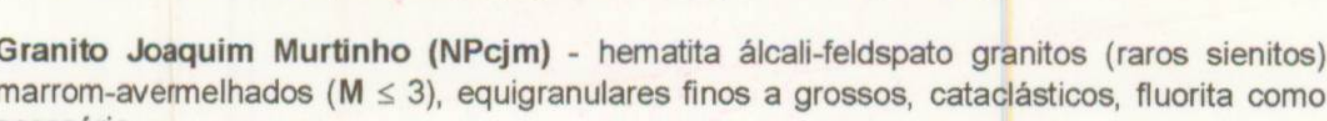

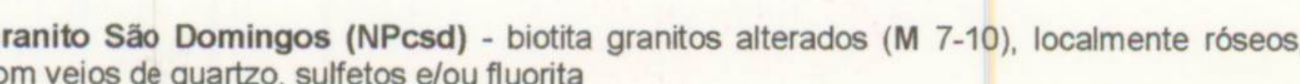

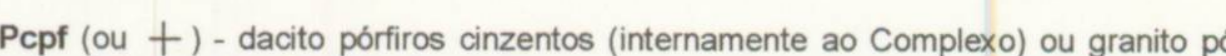

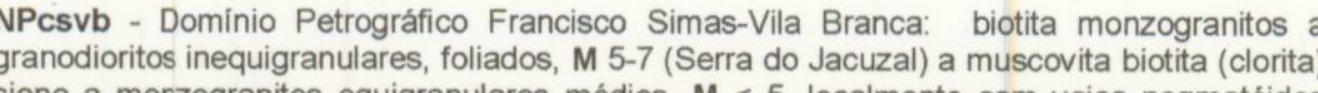

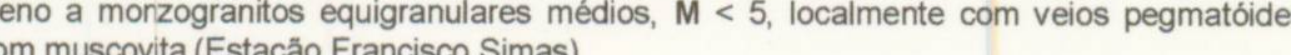

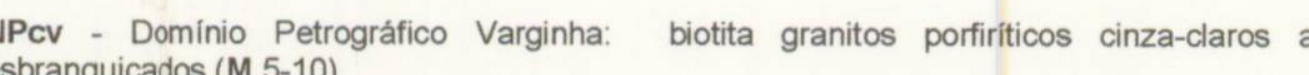

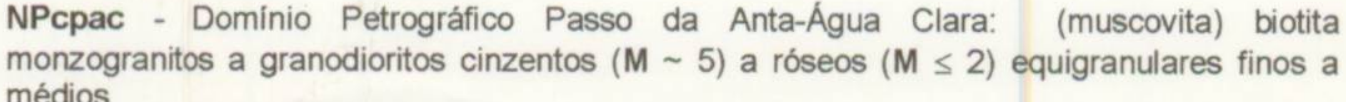

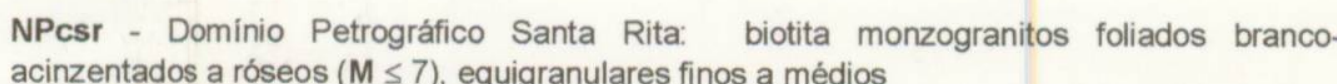

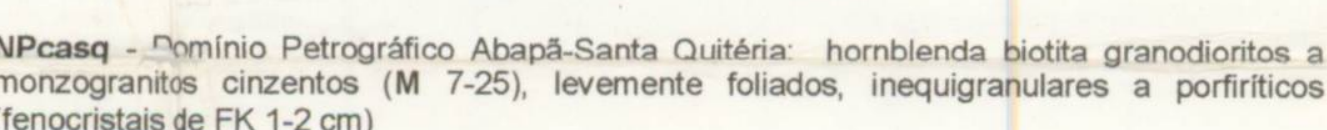

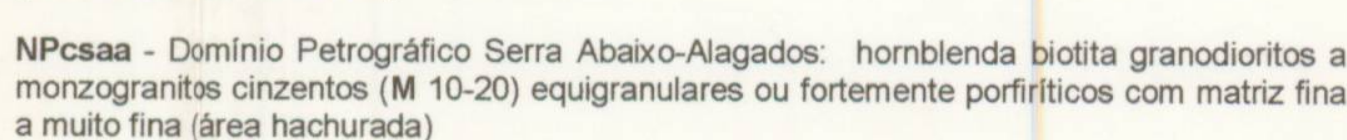

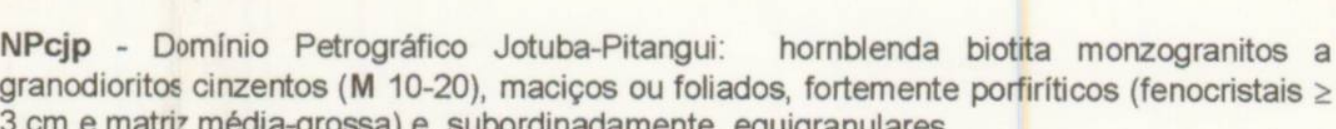

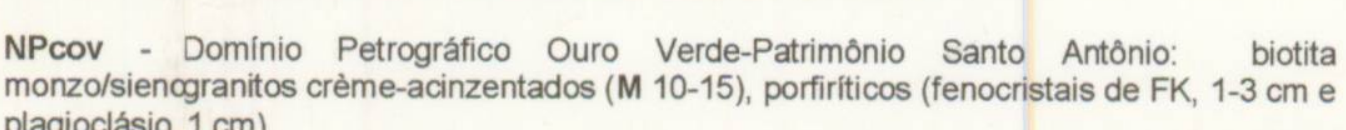

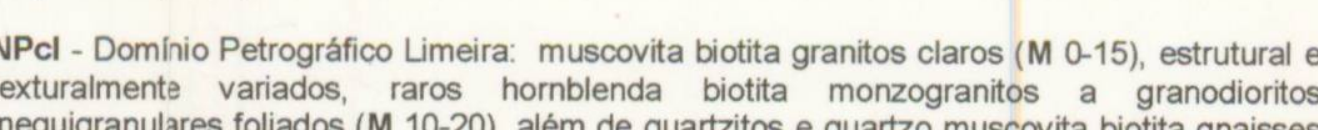

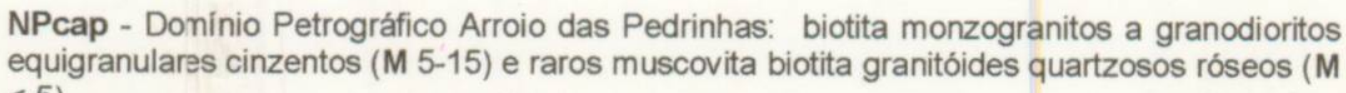

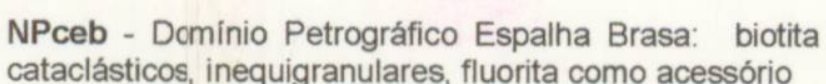

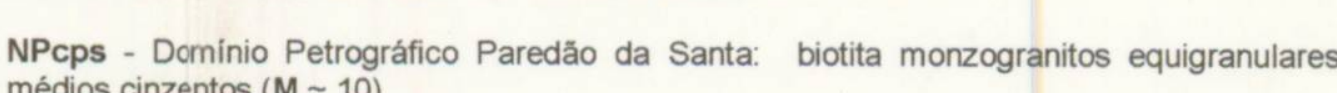

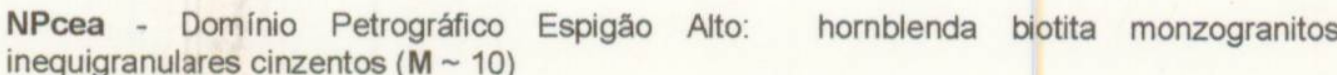

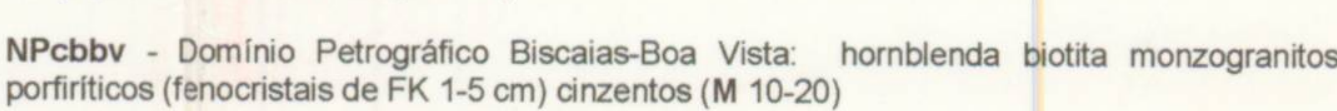

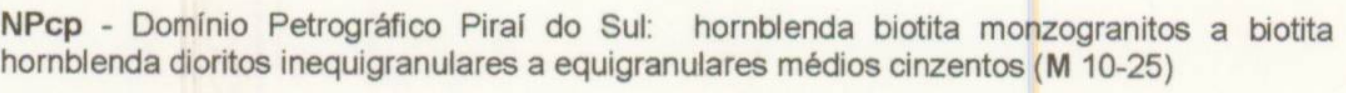

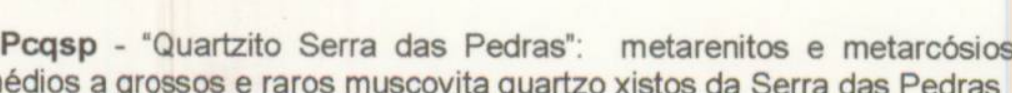
NPcq (ou of outros metarentios e me 


\section{ANEXO 2: MAPA DE PONTOS}
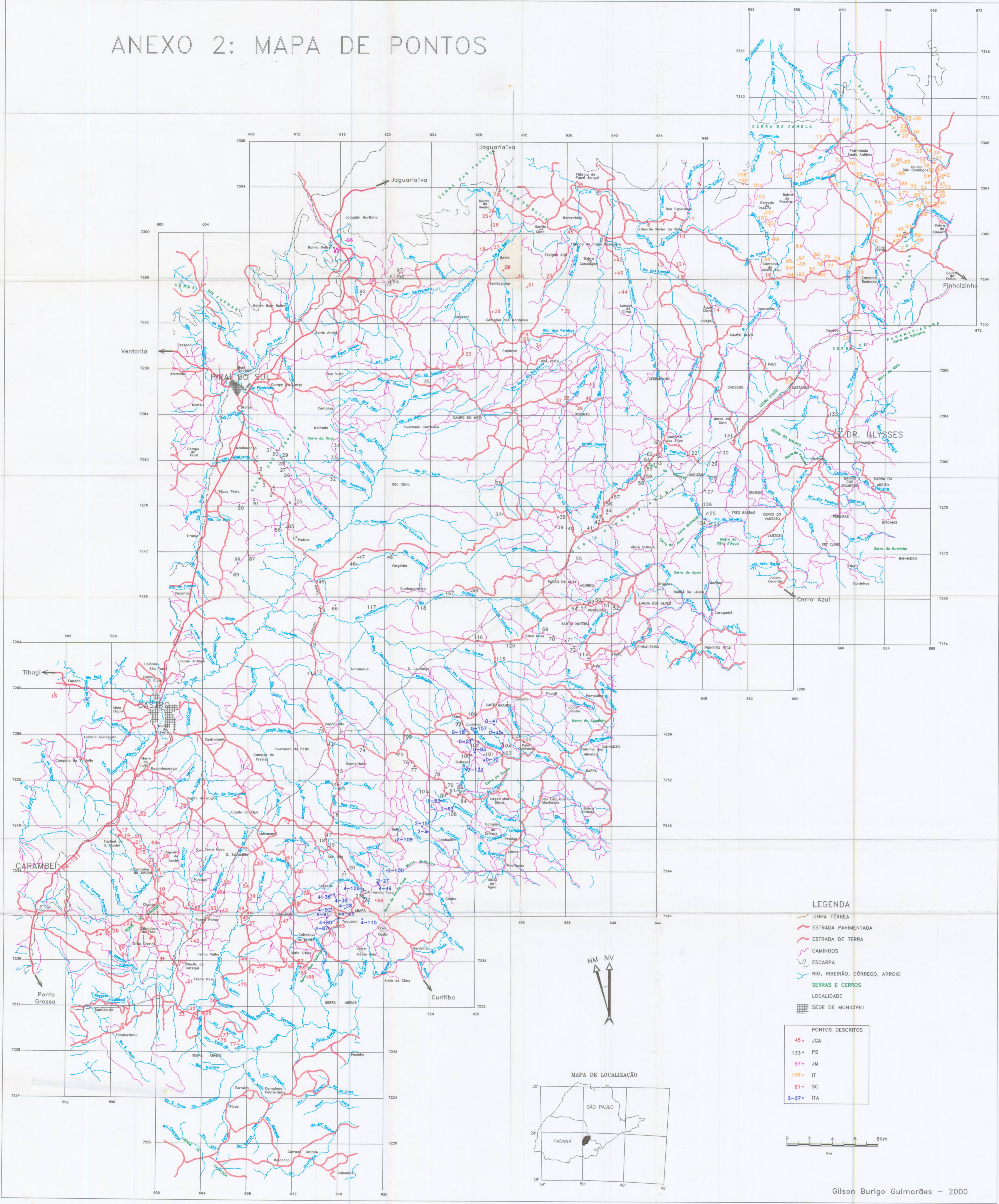
ANEXO 1: MAPA GEOLÓGICO DE

COMPILAÇÃO DA REGIÃO

DO COMPLEXO GRANITICO CUNHAPORANGA

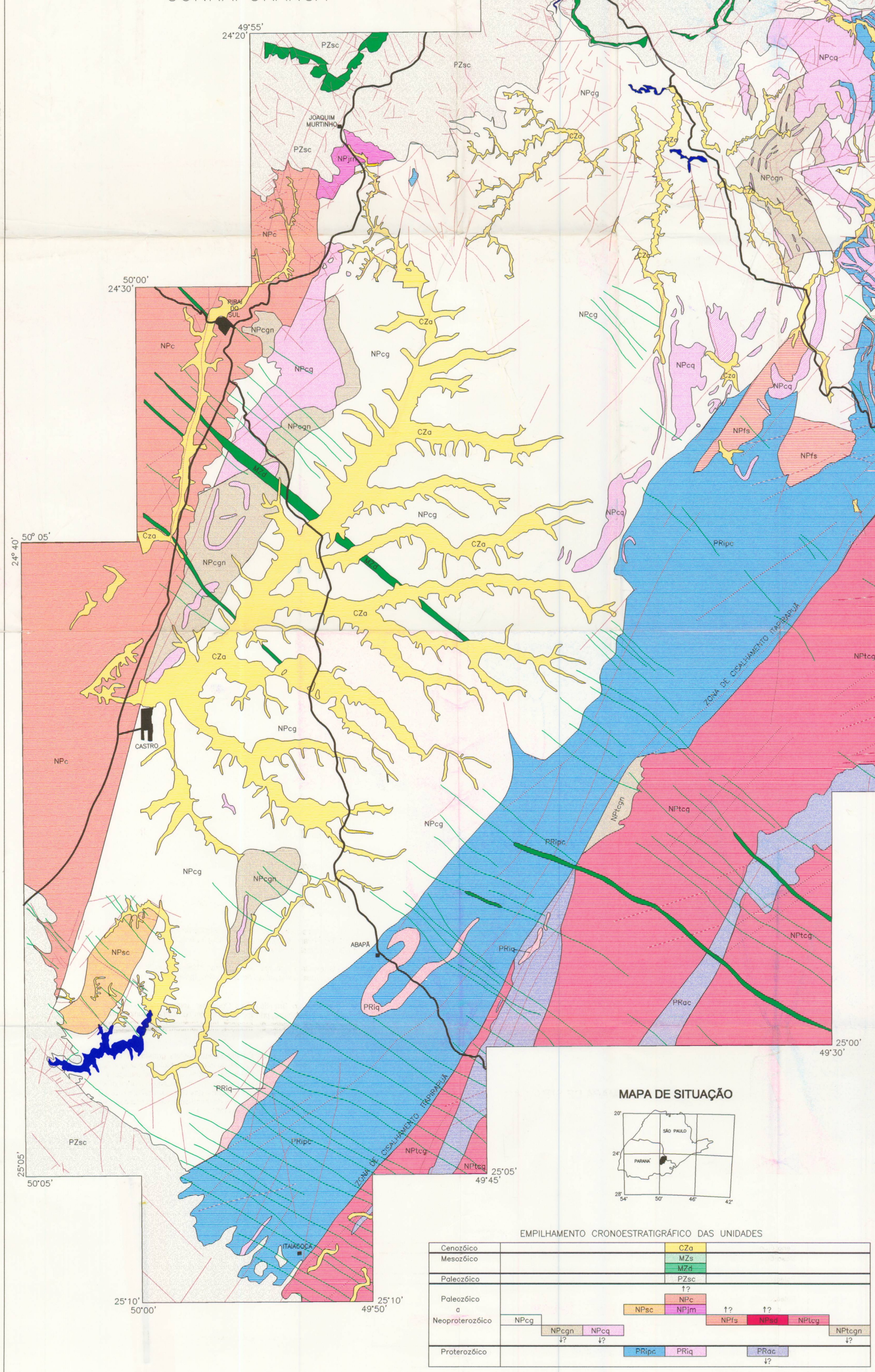

\section{CONVENÇÕES}

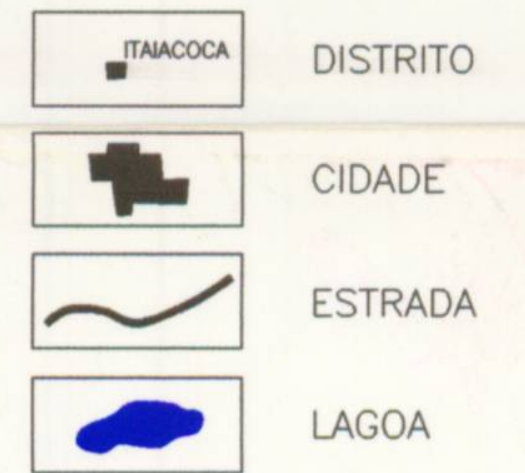

GEOLOGIA

X FALHA

CONSTITUÇÃO LITOLOGGICA DAS UNIDADES

CZa - sedimentos aluvionares e, em parte, coluvionares

MZs - rochas Igneas alcalinas, principalmente sienitos e nefellina sienitos PZsc - diabásios e, localmente, diontos, e gabros, correlatos à Formaçăo
Serra Geral

PZsc - rochas sedimentares clásticas da bacia do Paraná, incluindo Formacaoes lapo (diamictitos), Furnas (arenitos) e Ponta Grossa (folhelhos), al
do Grupo Itararé (diversas Iitologias) $\mathrm{NPC}$ - Grupo Castro: rochas sedimentares clásticas (argilitos, arcósios, (andesitos)

NPtcg - Complexo Granlitico Três Corregos: rochas granitóides equigranodiontitos, folliados ou maciẹos. Inclui também rochas gnáissico-

NPcg - Complexo Granltico Cunhaporanga: rochas granittides equigranodionitos, macicos a levemente foliados. Inclui ála lali-fildspato (Nanitos Serra do Carambel (NPsc) e Joaquim murtinho(NPj (NPfs) e Săo Domingos (NPsd), além de mega-enclaves de rochas quartzit

PRiq - Grupo Itaiacoca: quartzitos, metarenitos e metarcossios (rochas

PRipc-Grupo Itaiacoca: rochas metapelliticas, carbonaticas e PRac - Fomação Agua Clara: margas, quartzitos, xistos e anfibolitos de

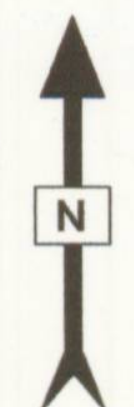

ESCALA 1:150.000 